\title{
REMOÇÃO DE SUBSTÂNCIAS HÚMICAS EM TRATAMENTO DE ÁGUA POR MEIO DE PRÉ-OXIDAÇÃO E DUPLA FILTRAÇÃO
}

Giovana Kátie Wiecheteck

Tese apresentada à Escola de Engenharia de São Carlos, da Universidade de São Paulo, como parte dos requisitos para obtenção do título de Doutor em Hidráulica e Saneamento

ORIENTADOR: Prof. Dr. Luiz Di Bernardo

São Carlos

2005 
Dedico este trabalho às pessoas que mais amo, meus pais Gilson e Regina, meus irmãos Carlos, Gilcélia e Rubens, e meus sobrinhos Maria Helena, Marina, Eduardo, Leonardo, Gabriel e ...

... Gustavo (in memoriam). 
"Algo superior e poderoso que torna os homens diferentes dos animais e que os faz resistir além de suas forças, alcançar limites acima do possível: A VONTADE!" 


\section{AGRADECIMENTOS}

A Deus, por infinitas bênçãos alcançadas.

Ao Prof. Luiz Di Bernardo pela orientação precisa e pelos ensinamentos adquiridos.

Aos meus familiares, que compartilharam comigo as alegrias e as tristezas e sempre estiveram ao meu lado.

Ao Hélio, pelo companheirismo e carinho, estando sempre presente durante este período de minha vida.

Aos amigos Bianca e André, por dividirem comigo as horas de trabalho durante os ensaios experimentais na instalação piloto.

A minha querida amiga Cristina, além do companheirismo, participou ativamente neste trabalho, estando sempre disposta a ajudar.

Ao Neyson Mendonça pelo auxílio no ensaio para determinação dos tempos de contato na coluna de ozonização.

Ao Sandro Xavier de Campos pela caracterização das substâncias húmicas.

À Prof ${ }^{a}$ Eny Maria Vieira do Instituto de Química de São Carlos, pela contribuição fundamental à realização deste trabalho, e sugestões propostas no exame de qualificação.

Aos colegas de doutorado, Edson, Edumar, Ângela, Sérgio, Marcelo, Sávia e Karina pela amizade e contribuição dada para a realização deste trabalho.

Aos técnicos do Laboratório de Saneamento, Júlio, Cidinha e Paulo, pela amizade e disposição para auxiliar nas análises de água realizadas neste laboratório.

Ao Chico, técnico do Laboratório de Instalações Piloto, pela montagem da instalação piloto e auxílio na solução dos problemas hidráulicos que surgiram durante a realização dos ensaios experimentais. 
Aos colegas do Departamento de Engenharia Civil da Universidade Estadual de Ponta Grossa, especialmente ao Prof. Alceu, pelo incentivo, apoio e confiança depositada em mim.

Aos professores do Departamento de Hidráulica e Saneamento da Escola de Engenharia de São Carlos pelos ensinamentos adquiridos durante a fase de conclusão de créditos.

Ao Serviço Autônomo de Água e Esgoto de São Carlos (SAAE) pela concessão do espaço para a montagem da instalação piloto e execução dos ensaios experimentais, nas dependências da ETA II de São Carlos. Aos amigos do SAAE, pela companhia nos intervalos das análises de água.

À Coordenadoria de Aperfeiçoamento de Pessoal de Ensino Superior (CAPES) pela bolsa de estudos de doutorado pelo Programa Institucional de Capacitação Docente e Técnica (PICDT).

À FINEP / PROSAB pelo auxílio financeiro para a montagem da instalação piloto e compra de materiais e equipamentos.

À FAPESP Processo 02/04622-1, pela concessão de auxílio financeiro para a execução dos ensaios experimentais.

A todos os meus amigos que participaram do meu dia a dia e que de uma forma ou de outra ajudaram na conclusão deste trabalho. 



\section{SUMÁRIO}

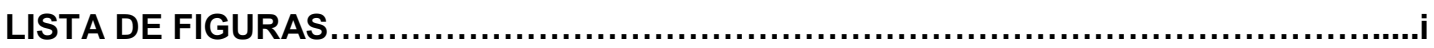

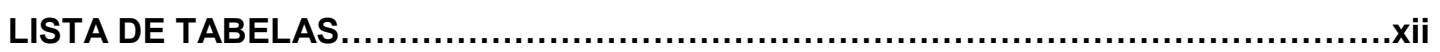

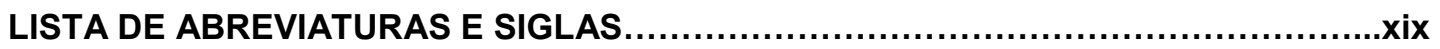

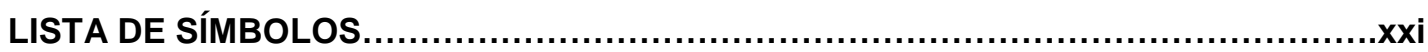

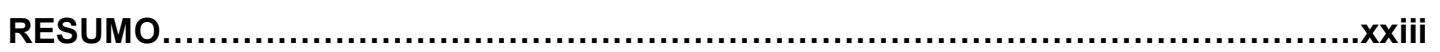

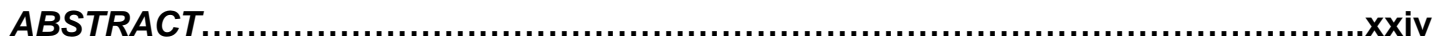

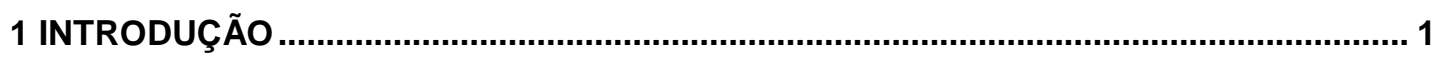

2. OBJETIVOS

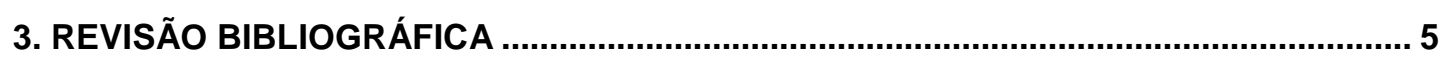

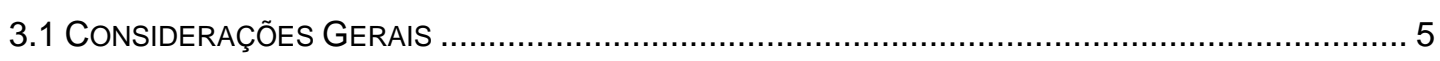

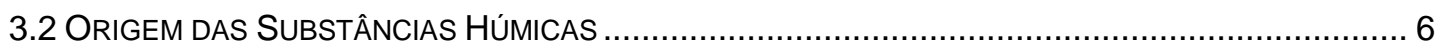

3.2.1 Características das Substâncias Húmicas …........................................................... 8

3.3 Processos Utilizados Para RemoÇÃo de SubStânCIas Húmicas ................................... 11

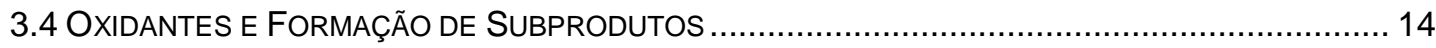

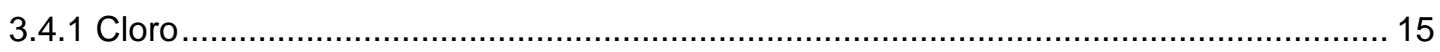

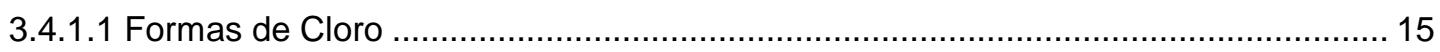

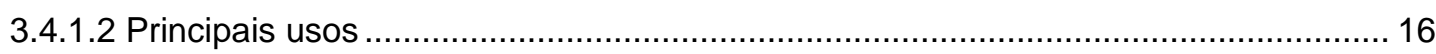

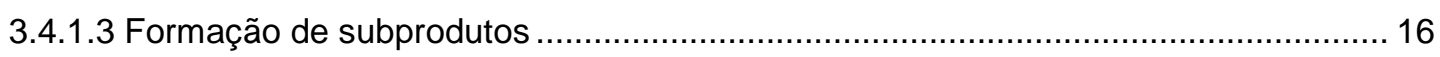

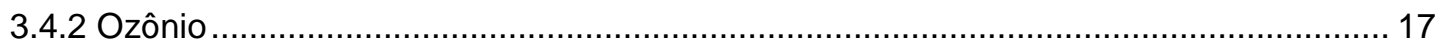

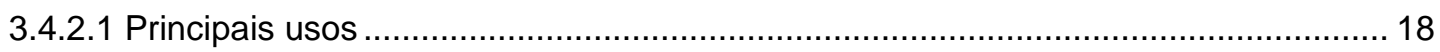

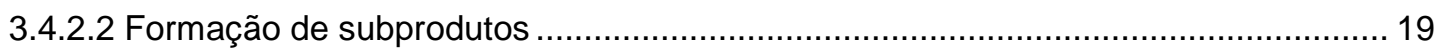

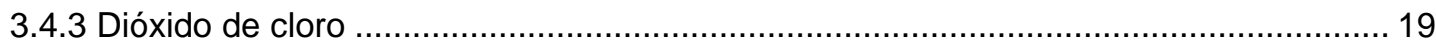

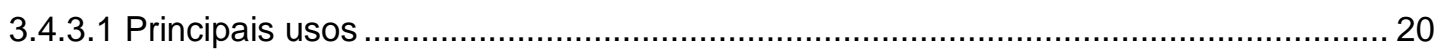

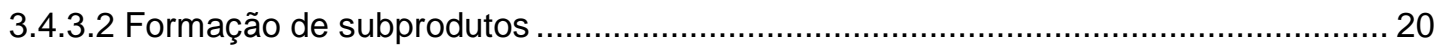

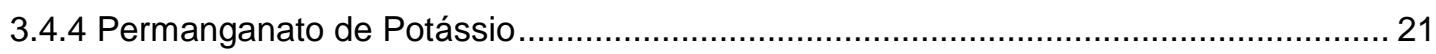

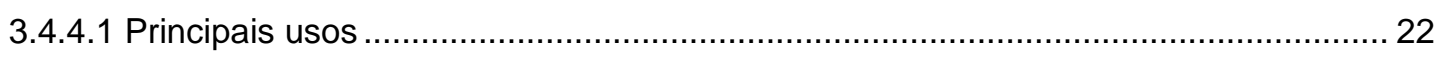

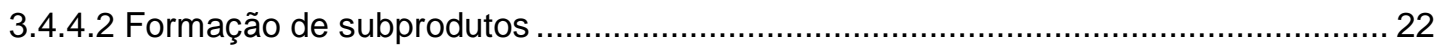

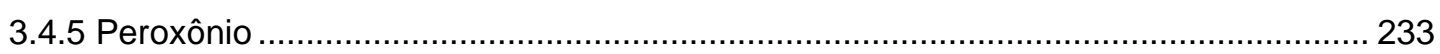

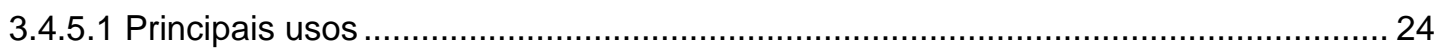

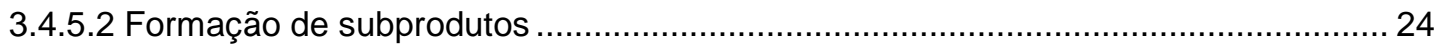

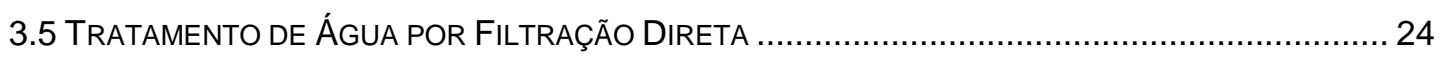

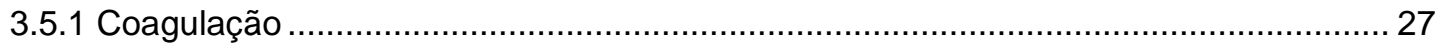

3.5.2 Filtração Direta Ascendente.......................................................................... 31

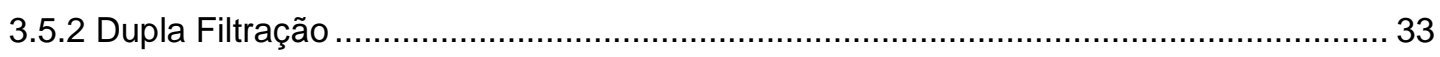

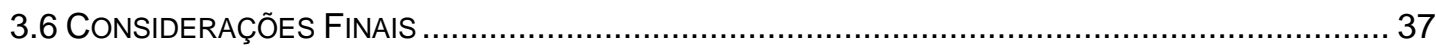


4. MATERIAIS E MÉTODOS 39

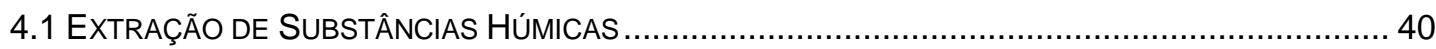

4.1.1 Caracterização do extrato das substâncias húmicas ............................................. 40

4.1.2 Variação da cor verdadeira da água em relação ao $\mathrm{pH}$...................................... 42

4.2 ENSAIOS EM REATORES ESTÁTICOS ................................................................. 42

4.2.1 Escolha da granulometria da areia utilizada nos FLAs ....................................... 43

4.2.2 Determinação da dosagem de coagulante e pH de coagulação e definição das

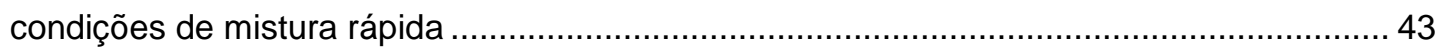

4.3 EnSAiOS nA INSTALAÇÃO PILOTO EM ESCOAMENTO CONTíNUO ..................................... 43

4.3.1 Descrição Geral da Instalação Piloto ......................................................... 43

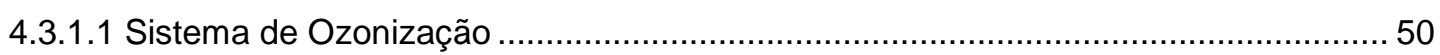

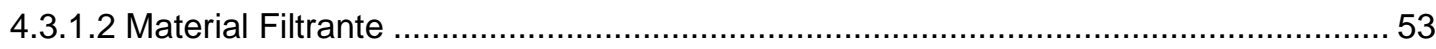

4.3.1.3 Funcionamento dos Filtros Ascendente e Descendente ........................................5 56

4.3.1.4 Limpeza e Lavagem dos Filtros ............................................................. 56

4.3.2 Produtos Químicos Utilizados ................................................................ 57

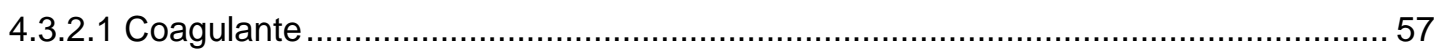

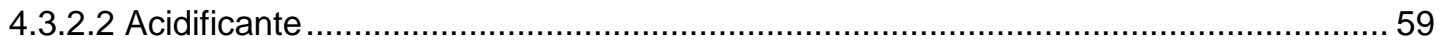

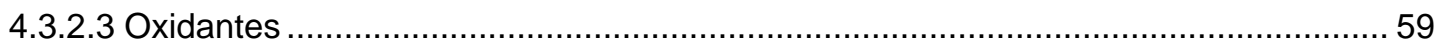

4.3.3 Características da Água, Métodos e Equipamentos...............................................6 63

4.3.4 Ensaios sem Pré-Oxidação e com Variação das Taxas de Filtração.......................... 64

4.3.5 Ensaios sem e com Pré-Oxidação e com Taxas de Filtração Fixas .......................... 65

4.3.5.1 Determinação da dosagem de oxidantes, coagulante e $\mathrm{pH}$ de coagulação ............. 66

4.3.5.2 Determinação do tempo de contato para os ensaios com pré-oxidação ................. 68

4.3.5.3 Coleta de amostra e verificação da formação de subprodutos ................................ 68

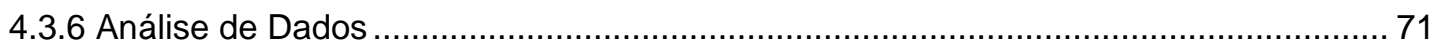

4.3.6.1 Correção da perda de carga em função da temperatura da água .......................... 72

4.3.6.2 Determinação da produção efetiva de água filtrada ......................................... 74

4.3.6.3 Remoção de substâncias húmicas e eficiência global do sistema de dupla filtração 76

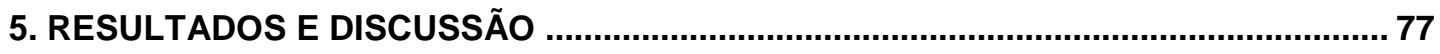

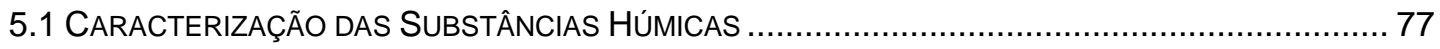

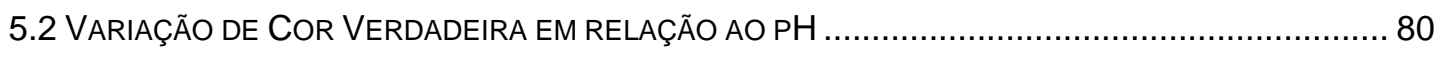

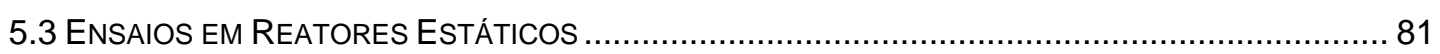

5.3.1 Escolha da Granulometria da Areia Utilizada nos FLAs ................................... 81

5.3.2 Determinação da Dosagem de Coagulante e pH de Coagulação e Definição das

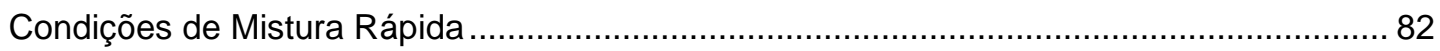

5.4 ENSAIOS NA INSTALAÇÃO PILOTO EM ESCOAMENTO CONTÍNUO ...................................... 84

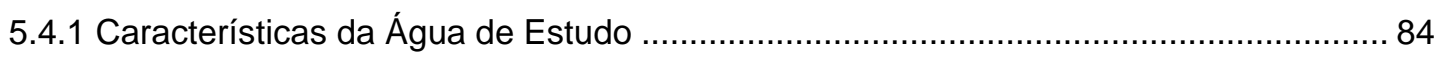

5.4.2 Ensaios sem pré-oxidação e com variação de taxas de filtração no FAAG e FRD ..... 85 


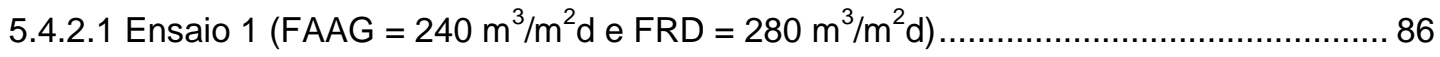

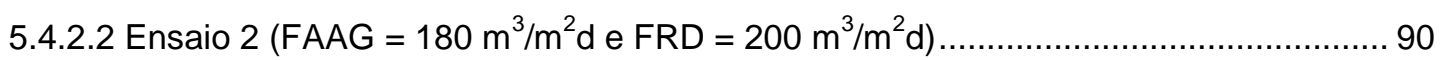

5.4.2.3 Ensaio $3\left(F A A G=180 \mathrm{~m}^{3} / \mathrm{m}^{2} \mathrm{~d}\right.$ e FRD $\left.=240 \mathrm{~m}^{3} / \mathrm{m}^{2} \mathrm{~d}\right)$..................................... 94

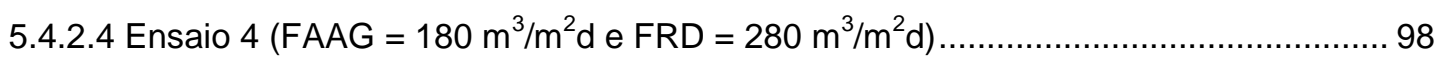

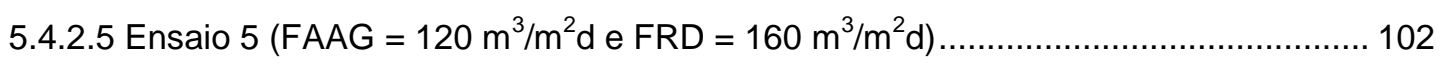

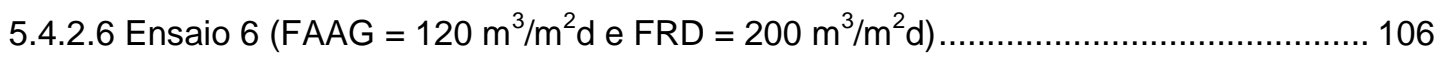

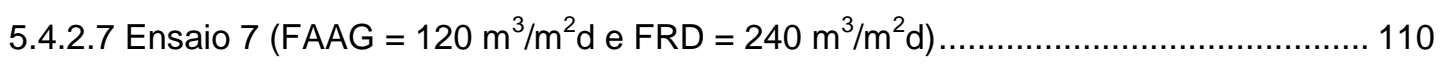

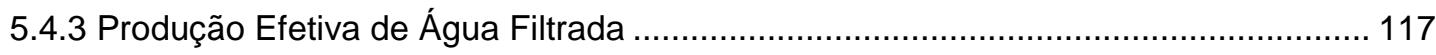

5.4.4 ENSAIOS SEM E COM PRÉ-OXIDAÇÃO COM TAXAS DE FILTRAÇÃO FIXAS NO FAAG E NO FRD

5.4.4.1 Determinação dos tempos de contato dos oxidantes para os ensaios com préoxidação 118

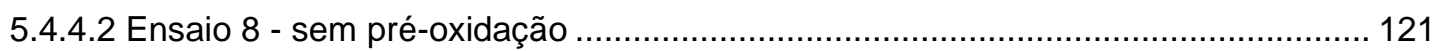

5.4.4.3 Ensaio 9 - Pré-oxidação com Ozônio ................................................................ 124

5.4.4.4 Ensaio 10 - Pré-oxidação com Peróxido de Hidrogênio ....................................... 131

5.4.4.5 Ensaio 11 - Pré-oxidação com Tricloro-s-triazina-triona......................................... 136

5.4.4.6 Ensaio 12 - Pré-oxidação com Dióxido de Cloro …………................................ 141

5.4.4.7 Ensaio 13 - Pré-oxidação com Permanganato de Potássio .................................... 145

5.4.4.8 Ensaio 14 - Pré-oxidação com Peroxônio .............................................................. 149

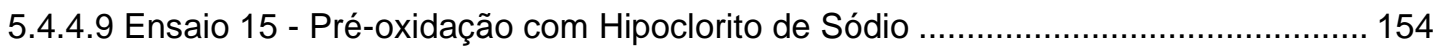

5.4.5 Formação de Subprodutos da Pré-Oxidação e Pós-Cloração .................................... 163

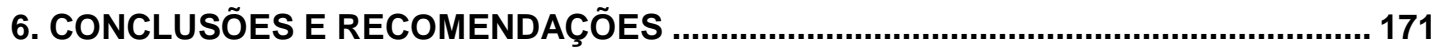

ANEXOS

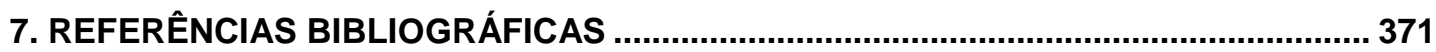




\section{LISTA DE FIGURAS}

Figura 3.1 - Principais vias propostas para a formação das substâncias húmicas pela decomposição de resíduos animais e vegetais no solo. Fonte: ROCHA \& ROSA, 2003. ...... 7

Figura 3.2 - Configurações dos sistemas de filtração direta............................................. 26

Figura 3.3 - Diagrama de coagulação com sulfato de alumínio............................................ 30

Figura 4.1 - Fluxograma geral das etapas do trabalho experimental. ................................. 39

Figura 4.2 - Sacos de celofane amarrados com elástico, contendo o extrato de substâncias

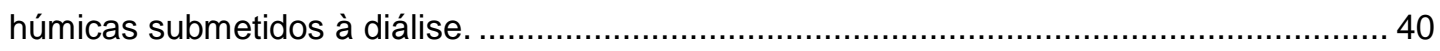

Figura 4.3 - Foto do equipamento de jarteste e filtros de laboratório de areia (FLAs). ........ 42

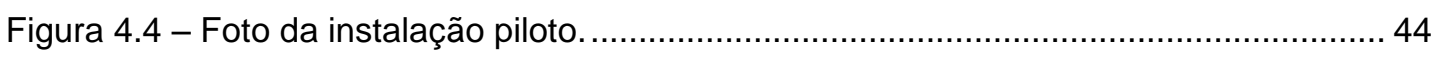

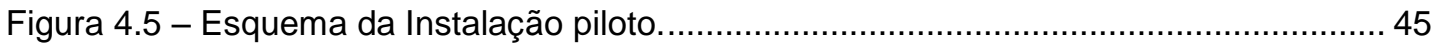

Figura 4.6 - Tanques com agitador para o preparo das soluções de coagulante, de extrato de substâncias húmicas, de acidificante e de oxidantes. ....................................................... 46

Figura 4.7 - Turbidímetros de escoamento contínuo (modelo $1720 \mathrm{C}$ - HACH) .................... 46

Figura 4.8 - Esquema da caixa de nível constante ........................................................ 47

Figura 4.9 - Foto da caixa de nível constante e da caixa de homogeneização de substâncias

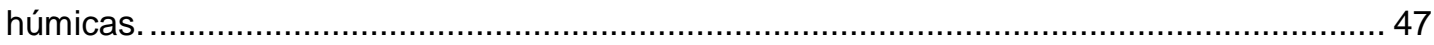

Figura 4.10 - Caixa de homogeneização da solução diluída de extrato de substâncias

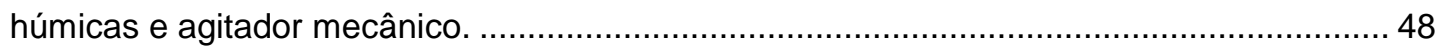

Figura 4.11 - Vista lateral da caixa de mistura rápida................................................... 49

Figura 4.12 - Sistema de ajuste de vazão de água coagulada........................................... 49

Figura 4.13 - Detalhes da entrada de água na interface pedregulho-areia no FAAG, da saída de água no FRD e da derivação do efluente do FRD para o turbidímetro de escoamento contínuo. 50

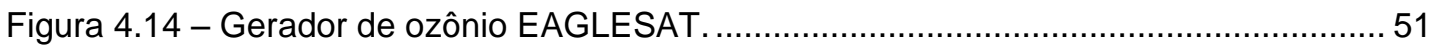

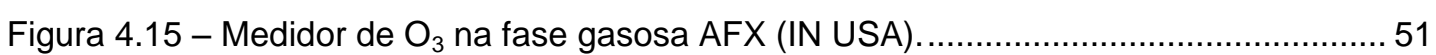

Figura 4.16 - Sensor instalado em linha para a medida de $\mathrm{O}_{3}$ na fase líquida. ................... 51

Figura 4.17 - Medidor de $\mathrm{O}_{3}$ na fase líquida (Dulcometer - ProMinent)............................... 51

Figura 4.18 - Destruidor de ozônio.................................................................................. 52

Figura 4.19 - Entrada de água de estudo no topo da coluna de ozonização. ...................... 52

Figura 4.20 - Pedra difusora para a distribuição de ozônio, localizada na parte inferior da coluna de ozonização. 52

Figura 4.21 - Distribuição do ozônio da parte inferior para o meio da coluna de ozonização.

Figura 4.22 - Distribuição de ozônio do meio para a parte superior da coluna de ozonização. 
Figura 4.24 - Esquema do FAAG e do FRD, com detalhes das subcamadas de material granular e das tomadas piezométricas (DE PAULA, 2003)............................................... 55

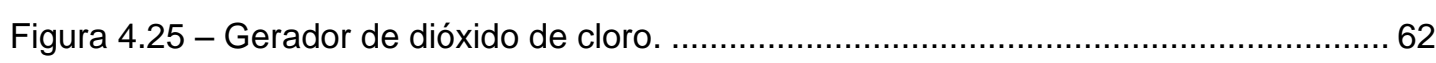

Figura 4.26 - Frascos utilizados para armazenamento das amostras de água pós cloradas

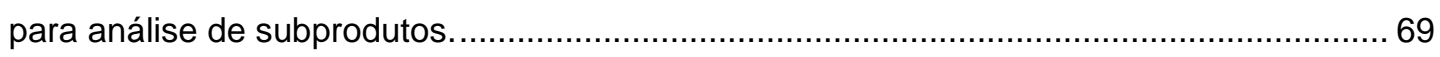

Figura 4.27 - Massa específica da água em função da temperatura. ................................ 74

Figura 4.28 - Viscosidade absoluta da água em função da temperatura. ........................... 74

Figura 5.1 - Espectro da região do infravermelho das substâncias húmicas. ....................... 78

Figura 5.2 - Espectro de UV-Vísivel na região de 400 a 800 nm para a amostra de

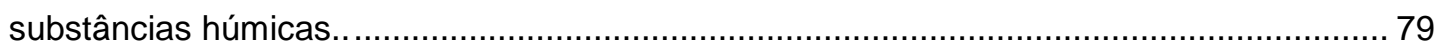

Figura 5.3 - Curvas de variação da cor verdadeira em função da absorvância ( $\lambda=455 \mathrm{~nm}$ ) em relação ao $\mathrm{pH}$.

Figura 5.4 - Evolução da perda de carga no FAAG $\left(240 \mathrm{~m}^{3} / \mathrm{m}^{2} \mathrm{~d}\right)$ e FRD $\left(280 \mathrm{~m}^{3} / \mathrm{m}^{2} \mathrm{~d}\right)$ durante o ensaio 1, para $T=20^{\circ} \mathrm{C}$, com execução de DFIs no FAAG. Fonte: Tabela B 1.3 do ANEXO B. .88

Figura 5.5 - Variação de cor aparente na $A B, A E$ e efluentes do $F A A G$ e do $F R D$, e cor verdadeira na $A B$ de 12 a $29 \mathrm{uH}$ e na $A E$ de 76 a $133 \mathrm{uH}$, durante o ensaio 1 (FAAG $=240$ $\mathrm{m}^{3} / \mathrm{m}^{2} \mathrm{~d}$ e FRD $=280 \mathrm{~m}^{3} / \mathrm{m}^{2} \mathrm{~d}$ ). Fonte: Tabela B 1.1 do ANEXO B. 88 Figura 5.6 - Variação de turbidez na $A B$ e efluentes do FAAG e do FRD durante o ensaio 1 $\left(F A A G=240 \mathrm{~m}^{3} / \mathrm{m}^{2} \mathrm{~d}\right.$ e $\left.\mathrm{FRD}=280 \mathrm{~m}^{3} / \mathrm{m}^{2} \mathrm{~d}\right)$. 89 Figura 5.7 - Variação de absorvância $254 \mathrm{~nm}$ na $A B, A E$ e nos efluentes do FAAG e do FRD durante o ensaio $1\left(F A A G=240 \mathrm{~m}^{3} / \mathrm{m}^{2} \mathrm{~d}\right.$ e $\left.F R D=280 \mathrm{~m}^{3} / \mathrm{m}^{2} \mathrm{~d}\right)$. Fonte: Tabela $B 1.2$ do ANEXO B. 89

Figura 5.8 - Variação de $C O D$ na $A B, A E$ e nos efluentes do FAAG e do FRD durante o ensaio $1\left(F A A G=240 \mathrm{~m}^{3} / \mathrm{m}^{2} \mathrm{~d}\right.$ e FRD $=280 \mathrm{~m}^{3} / \mathrm{m}^{2} \mathrm{~d}$ ). Fonte: Tabela B 1.2 do ANEXO B. .. 90 Figura 5.9 - Evolução da perda de carga no FAAG $\left(180 \mathrm{~m}^{3} / \mathrm{m}^{2} \mathrm{~d}\right)$ e FRD $\left(200 \mathrm{~m}^{3} / \mathrm{m}^{2} \mathrm{~d}\right)$ durante o ensaio 2, para $T=20^{\circ} \mathrm{C}$, com execução de DFIs no FAAG. Fonte: Tabela B 2.3 no ANEXO B. 91

Figura 5.10 - Variação da cor aparente na $A B, A E$ e efluentes do FAAG e do FRD, e cor verdadeira na $A B$ de 10 a $26 \mathrm{uH}$ e na $A E$ de 78 a $121 \mathrm{uH}$, durante o ensaio 2 (FAAG = 180 $\mathrm{m}^{3} / \mathrm{m}^{2} \mathrm{~d}$ e $\mathrm{FRD}=200 \mathrm{~m}^{3} / \mathrm{m}^{2} \mathrm{~d}$ ). Fonte: Tabela B 2.1 do ANEXO B. .93

Figura 5.11 - Variação de turbidez na $A B$ e efluentes do FAAG e do FRD durante o ensaio 2 $\left(F A A G=180 \mathrm{~m}^{3} / \mathrm{m}^{2} \mathrm{~d}\right.$ e FRD $=200 \mathrm{~m}^{3} / \mathrm{m}^{2} \mathrm{~d}$ ). .93 Figura 5.12 - Variação de absorvância $254 \mathrm{~nm}$ na $A B, A E$ e nos efluentes do FAAG e do FRD durante o ensaio $2\left(F A A G=180 \mathrm{~m}^{3} / \mathrm{m}^{2} \mathrm{~d}\right.$ e FRD $\left.=200 \mathrm{~m}^{3} / \mathrm{m}^{2} \mathrm{~d}\right)$. Fonte: Tabela $B 2.2$ do ANEXO B. 94

Figura 5.13 - Variação de $C O D$ na $A B, A E$ e nos efluentes do FAAG e do FRD durante o ensaio $2\left(F A A G=180 \mathrm{~m}^{3} / \mathrm{m}^{2} \mathrm{~d}\right.$ e FRD $\left.=200 \mathrm{~m}^{3} / \mathrm{m}^{2} \mathrm{~d}\right)$. Fonte: Tabela B 2.2 do ANEXO B. .. 94 
Figura 5.14 - Evolução da perda de carga no FAAG $\left(180 \mathrm{~m}^{3} / \mathrm{m}^{2} \mathrm{~d}\right)$ e FRD $\left(240 \mathrm{~m}^{3} / \mathrm{m}^{2} \mathrm{~d}\right)$ durante o ensaio 3 , para $T=20^{\circ} \mathrm{C}$, com execução de DFls no FAAG. Fonte: Tabela B 3.3 do ANEXO B.

Figura 5.15 - Variação da cor aparente na $A B, A E$ e efluentes do FAAG e do FRD, e cor verdadeira na $A B$ de 21 a $33 \mathrm{uH}$ e na $A E$ de 83 a $120 \mathrm{uH}$, durante o ensaio 3 (FAAG $=180$ $\mathrm{m}^{3} / \mathrm{m}^{2} \mathrm{~d}$ e $\mathrm{FRD}=240 \mathrm{~m}^{3} / \mathrm{m}^{2} \mathrm{~d}$ ). Fonte: Tabela B 3.1 do ANEXO B. .. 97

Figura 5.16 - Variação de turbidez na $A B$ e efluentes do FAAG e do FRD durante o ensaio 3 $\left(F A A G=180 \mathrm{~m}^{3} / \mathrm{m}^{2} \mathrm{~d}\right.$ e FRD $\left.=240 \mathrm{~m}^{3} / \mathrm{m}^{2} \mathrm{~d}\right)$.

Figura 5.17 - Variação de absorvância $254 \mathrm{~nm}$ na $A B, A E$ e nos efluentes do FAAG e do FRD durante o ensaio $3\left(F A A G=180 \mathrm{~m}^{3} / \mathrm{m}^{2} \mathrm{~d}\right.$ e FRD $=240 \mathrm{~m}^{3} / \mathrm{m}^{2} \mathrm{~d}$ ). Fonte: Tabela 3.2 do ANEXO B.

Figura 5.18 - Variação de $C O D$ na $A B, A E$ e nos efluentes do $F A A G$ e do FRD durante o ensaio $3\left(F A A G=180 \mathrm{~m}^{3} / \mathrm{m}^{2} \mathrm{~d}\right.$ e FRD $=240 \mathrm{~m}^{3} / \mathrm{m}^{2} \mathrm{~d}$ ). Fonte: Tabela B 3.2 do ANEXO B. .. 98 Figura 5.19 - Evolução da perda de carga no FAAG $\left(180 \mathrm{~m}^{3} / \mathrm{m}^{2} \mathrm{~d}\right)$ e FRD $\left(280 \mathrm{~m}^{3} / \mathrm{m}^{2} \mathrm{~d}\right)$ durante o ensaio 4 , para $T=20^{\circ} \mathrm{C}$, com execução de DFls no FAAG. Fonte: Tabela B 4.3 do ANEXO B. 100

Figura 5.20 - Variação da cor aparente na $A B, A E$ e efluentes do FAAG e do FRD, e cor verdadeira na $A B$ de 14 a $25 \mathrm{uH}$ e na $A E$ de 82 a $112 \mathrm{uH}$, durante o ensaio 4 (FAAG = 180 $\mathrm{m}^{3} / \mathrm{m}^{2} \mathrm{~d}$ e FRD $=280 \mathrm{~m}^{3} / \mathrm{m}^{2} \mathrm{~d}$ ). Fonte: Tabela B 4.1 do ANEXO B. 101

Figura 5.21 - Variação de absorvância $254 \mathrm{~nm}$ na $A E$ e nos efluentes do FAAG e do FRD durante 0 ensaio $4\left(F A A G=180 \mathrm{~m}^{3} / \mathrm{m}^{2} \mathrm{~d}\right.$ e FRD $\left.=280 \mathrm{~m}^{3} / \mathrm{m}^{2} \mathrm{~d}\right)$. Fonte: Tabela $B 4.2$ do ANEXO B. 101

Figura 5.22 - Variação de $C O D$ da $A B, A E$ e nos efluentes do FAAG e do FRD durante o ensaio $4\left(F A A G=180 \mathrm{~m}^{3} / \mathrm{m}^{2} \mathrm{~d}\right.$ e FRD $\left.=280 \mathrm{~m}^{3} / \mathrm{m}^{2} \mathrm{~d}\right)$. Fonte: Tabela B 4.2 do ANEXO B. 102 Figura 5.23 - Evolução da perda de carga no FAAG $\left(120 \mathrm{~m}^{3} / \mathrm{m}^{2} \mathrm{~d}\right)$ e FRD $\left(160 \mathrm{~m}^{3} / \mathrm{m}^{2} \mathrm{~d}\right)$ durante o ensaio 5 , para $T=20^{\circ} \mathrm{C}$, com execução de DFls no FAAG. Fonte: Tabela B 5.3 do ANEXO B. 104

Figura 5.24 - Variação da cor aparente na $A B, A E$ e efluentes do FAAG e do FRD, e cor verdadeira na $A B$ de 18 a $28 \mathrm{uH}$ e na $A E$ de 85 a $116 \mathrm{uH}$, durante o ensaio 5 (FAAG = 120 $\mathrm{m}^{3} / \mathrm{m}^{2} \mathrm{~d}$ e FRD $=160 \mathrm{~m}^{3} / \mathrm{m}^{2} \mathrm{~d}$ ). Fonte: Tabela B 5.1 do ANEXO B. 104

Figura 5.25 - Variação da turbidez na $A B$ e efluentes do FAAG e do FRD durante o ensaio 5 $\left(F A A G=120 \mathrm{~m}^{3} / \mathrm{m}^{2} \mathrm{~d}\right.$ e FRD $=160 \mathrm{~m}^{3} / \mathrm{m}^{2} \mathrm{~d}$ ). 105

Figura 5.26 - Variação de absorvância $254 \mathrm{~nm}$ na $A B, A E$ e nos efluentes do FAAG e do FRD durante o ensaio $5\left(F A A G=120 \mathrm{~m}^{3} / \mathrm{m}^{2} \mathrm{~d}\right.$ e $\left.F R D=160 \mathrm{~m}^{3} / \mathrm{m}^{2} \mathrm{~d}\right)$. Fonte: Tabela $B 5.2$ do ANEXO B. 105

Figura 5.27 - Variação de $C O D$ na $A B, A E$ e nos efluentes do FAAG e do FRD durante o ensaio $5\left(F A A G=120 \mathrm{~m}^{3} / \mathrm{m}^{2} \mathrm{~d}\right.$ e FRD $\left.=160 \mathrm{~m}^{3} / \mathrm{m}^{2} \mathrm{~d}\right)$. Fonte: Tabela B 5.2 do ANEXO B. 106 
Figura 5.28 - Evolução da perda de carga no FAAG $\left(120 \mathrm{~m}^{3} / \mathrm{m}^{2} \mathrm{~d}\right)$ e FRD $\left(200 \mathrm{~m}^{3} / \mathrm{m}^{2} \mathrm{~d}\right)$ durante o ensaio 6 , para $T=20^{\circ} \mathrm{C}$, com execução de DFls no FAAG. Fonte: Tabela B 6.3 do ANEXO B.

Figura 5.29 - Variação da cor aparente na $A B, A E$ e efluentes do $F A A G$ e do $F R D$, e cor verdadeira na $A B$ de 14 a $33 \mathrm{uH}$ e na $A E$ de 76 a $119 \mathrm{uH}$, durante o ensaio 6 (FAAG $=120$ $\mathrm{m}^{3} / \mathrm{m}^{2} \mathrm{~d}$ e FRD $=200 \mathrm{~m}^{3} / \mathrm{m}^{2} \mathrm{~d}$ ). Fonte: Tabela B 6.1 do ANEXO B. 108

Figura 5.30 - Variação da turbidez na $A B$ e efluentes do FAAG e do FRD durante o ensaio 6 $\left(F A A G=120 \mathrm{~m}^{3} / \mathrm{m}^{2} \mathrm{~d}\right.$ e FRD $=200 \mathrm{~m}^{3} / \mathrm{m}^{2} \mathrm{~d}$ ). 109

Figura 5.31 - Variação de absorvância $254 \mathrm{~nm}$ na $A B, A E$ e nos efluentes do FAAG e do FRD durante o ensaio $6\left(F A A G=120 \mathrm{~m}^{3} / \mathrm{m}^{2} \mathrm{~d}\right.$ e FRD $\left.=200 \mathrm{~m}^{3} / \mathrm{m}^{2} \mathrm{~d}\right)$. Fonte: Tabela $B 6.2$ do ANEXO B. 109

Figura 5.32 - Variação de $C O D$ na $A B, A E$ e nos efluentes do FAAG e do FRD durante o ensaio $6\left(F A A G=120 \mathrm{~m}^{3} / \mathrm{m}^{2} \mathrm{~d}\right.$ e FRD $\left.=200 \mathrm{~m}^{3} / \mathrm{m}^{2} \mathrm{~d}\right)$. Fonte: Tabela B 6.2 do ANEXO B. 110 Figura 5.33 - Evolução da perda de carga no FAAG $\left(120 \mathrm{~m}^{3} / \mathrm{m}^{2} \mathrm{~d}\right)$ e FRD $\left(240 \mathrm{~m}^{3} / \mathrm{m}^{2} \mathrm{~d}\right)$ durante o ensaio 7 , para $T=20^{\circ} \mathrm{C}$, com execução de DFIs no FAAG. Fonte: Tabela B 7.3 do ANEXO B.

Figura 5.34 - Variação da cor aparente na $A B, A E$ e efluentes do FAAG e do FRD, e cor verdadeira na $A B$ de 15 a $23 \mathrm{uH}$ e na $A E$ de 86 a $120 \mathrm{uH}$, durante o ensaio 7 (FAAG $=120$ $\mathrm{m}^{3} / \mathrm{m}^{2} \mathrm{~d}$ e FRD $=240 \mathrm{~m}^{3} / \mathrm{m}^{2} \mathrm{~d}$ ). Fonte: Tabela 7.1 do ANEXO B 112

Figura 5.35 - Variação da turbidez na $A B$ e efluentes do FAAG e do FRD durante o ensaio 7 $\left(F A A G=120 \mathrm{~m}^{3} / \mathrm{m}^{2} \mathrm{~d}\right.$ e $\mathrm{FRD}=240 \mathrm{~m}^{3} / \mathrm{m}^{2} \mathrm{~d}$ ).

Figura 5.36 - Variação de absorvância $254 \mathrm{~nm}$ na $A B, A E$ e nos efluentes do FAAG e do FRD durante o ensaio $7\left(F A A G=120 \mathrm{~m}^{3} / \mathrm{m}^{2} \mathrm{~d}\right.$ e $\left.F R D=240 \mathrm{~m}^{3} / \mathrm{m}^{2} \mathrm{~d}\right)$. Fonte: Tabela $B 7.2$ do ANEXO B.

Figura 5.37 - Variação de $C O D$ na $A B, A E$ e nos efluentes do $F A A G$ e do $F R D$ durante o ensaio $7\left(F A A G=120 \mathrm{~m}^{3} / \mathrm{m}^{2} \mathrm{~d}\right.$ e FRD $\left.=240 \mathrm{~m}^{3} / \mathrm{m}^{2} \mathrm{~d}\right)$. Fonte: Tabela B 7.2 do ANEXO B. 114 Figura 5.38 - Tempo de detenção do traçador na coluna de ozonização, sem introdução de ar. 119

Figura 5.39 - Tempo de detenção do traçador na coluna de ozonização, com introdução de ar. 120

Figura 5.40 - Evolução da perda de carga no FAAG $\left(180 \mathrm{~m}^{3} / \mathrm{m}^{2} \mathrm{~d}\right)$ e no FRD $\left(280 \mathrm{~m}^{2} / \mathrm{m}^{3} \mathrm{~d}\right)$ para $T=20^{\circ} \mathrm{C}$ durante o ensaio 8 , sem pré-oxidação e sem DFls no FAAG. Fonte: Tabela $\mathrm{C}$ 1.3 do ANEXO C. 122

Figura 5.41 - Variação de cor aparente na $A B, A E$ e efluentes do FAAG e FRD, e cor verdadeira na $A B$ de 21 a $27 \mathrm{uH}$ e na $A E$ de 93 a $105 \mathrm{uH}$, durante o ensaio 8 - sem préoxidação $\left(F A A G=180 \mathrm{~m}^{3} / \mathrm{m}^{2} \mathrm{~d}\right.$ e $\left.\mathrm{FRD}=280 \mathrm{~m}^{3} / \mathrm{m}^{2} \mathrm{~d}\right)$. Fonte: Tabela C 1.1 do ANEXO C. 123 Figura 5.42 - Variação da turbidez na $A B$ e nos efluentes do FAAG $\left(180 \mathrm{~m}^{3} / \mathrm{m}^{2} \mathrm{~d}\right)$ e FRD $\left(280 \mathrm{~m}^{2} / \mathrm{m}^{3} \mathrm{~d}\right)$ durante o ensaio 8 - sem pré-oxidação e sem DFls no FAAG. 123 
Figura 5.43 - Variação de absorvância $254 \mathrm{~nm}$ na $A B, A E$ e nos efluentes do FAAG e do FRD durante o ensaio 8 , sem pré-oxidação e sem DFls no FAAG (FAAG $=180 \mathrm{~m} 3 / \mathrm{m} 2 \mathrm{~d}$ e $\mathrm{FRD}=280 \mathrm{~m} 3 / \mathrm{m} 2 \mathrm{~d}$ ). Fonte: Tabela C 1.2 do ANEXO C.

Figura 5.44 - Variação de COD na $A B, A E$ e nos efluentes do FAAG e do FRD durante o ensaio 8 , sem pré-oxidação e sem DFls no FAAG (FAAG $=180 \mathrm{~m}^{3} / \mathrm{m}^{2} \mathrm{~d}$ e FRD $=280$ $\mathrm{m}^{3} / \mathrm{m}^{2} \mathrm{~d}$ ). Fonte: Tabela C 1.2 do ANEXO C. 124

Figura 5.45 - Evolução da perda de carga no FAAG $\left(180 \mathrm{~m}^{3} / \mathrm{m}^{2} \mathrm{~d}\right)$ e no FRD $\left(280 \mathrm{~m}^{2} / \mathrm{m}^{3} \mathrm{~d}\right)$ para $T=20^{\circ} \mathrm{C}$ durante o ensaio 9, pré-oxidação com ozônio e sem DFls no FAAG. Fonte: Tabela C 2.3 do ANEXO C. 128

Figura 5.46 - Variação de cor aparente na $A B, A E, A P O$ e efluentes do FAAG e FRD, e cor verdadeira na $A B$ de 14 a $28 \mathrm{uH}$, na $A E$ de 83 a $106 \mathrm{uH}$ e na APO de 23 a $91 \mathrm{uH}$, durante o ensaio 9 - pré-oxidação com ozônio ( $F A A G=180 \mathrm{~m}^{3} / \mathrm{m}^{2} \mathrm{~d}$ e $\mathrm{FRD}=280 \mathrm{~m}^{3} / \mathrm{m}^{2} \mathrm{~d}$ ). Fonte: Tabela C 2.1 do ANEXO C.

Figura 5.47 - Variação da turbidez na $A B$ e nos efluentes do FAAG $\left(180 \mathrm{~m}^{3} / \mathrm{m}^{2} \mathrm{~d}\right)$ e $F R D$ $\left(280 \mathrm{~m}^{2} / \mathrm{m}^{3} \mathrm{~d}\right)$ durante o ensaio 9 - pré-oxidação com ozônio e sem DFls no FAAG. 130 Figura 5.48 - Variação de absorvância $254 \mathrm{~nm}$ na $A B, A E, A P O$ e nos efluentes do FAAG e do FRD durante o ensaio 9, pré-oxidação com ozônio e sem DFls no FAAG (FAAG $=180$ $\mathrm{m}^{3} / \mathrm{m}^{2} \mathrm{~d}$ e $\mathrm{FRD}=280 \mathrm{~m}^{3} / \mathrm{m}^{2} \mathrm{~d}$ ). Fonte: Tabela C 2.2 do ANEXO C 131 Figura 5.49 - Variação de $C O D$ na $A B, A E, A P O$ e nos efluentes do FAAG e do FRD durante o ensaio 9, pré-oxidação com ozônio e sem DFls no FAAG (FAAG $=180 \mathrm{~m}^{3} / \mathrm{m}^{2} \mathrm{~d}$ e $\mathrm{FRD}=280 \mathrm{~m}^{3} / \mathrm{m}^{2} \mathrm{~d}$ ). Fonte: Tabela C 2.2 do ANEXO C 131

Figura 5.50 - Evolução da perda de carga no FAAG $\left(180 \mathrm{~m}^{3} / \mathrm{m}^{2} \mathrm{~d}\right)$ e no FRD $\left(280 \mathrm{~m}^{2} / \mathrm{m}^{3} \mathrm{~d}\right)$ para $\mathrm{T}=20^{\circ} \mathrm{C}$ durante o ensaio 10 - pré-oxidação com peróxido de hidrogênio e sem DFls no FAAG. Fonte: Tabela C 3.3 do ANEXO C 132

Figura 5.51 - Variação de cor aparente na $A B, A E, A P O$ e efluentes do FAAG e FRD, e cor verdadeira na $A B$ de 18 a $31 \mathrm{uH}$, na $A E$ de 90 a $121 \mathrm{uH}$ e na $A P O$ de 91 a $117 \mathrm{uH}$, durante o ensaio 10 - pré-oxidação com peróxido de hidrogênio (FAAG $=180 \mathrm{~m}^{3} / \mathrm{m}^{2} \mathrm{~d}$ e $\mathrm{FRD}=280$ $\mathrm{m}^{3} / \mathrm{m}^{2} \mathrm{~d}$ ). Fonte: Tabela C 3.1 do ANEXO C. 134

Figura 5.52 - Variação da turbidez na $A B$ e nos efluentes do FAAG $\left(180 \mathrm{~m}^{3} / \mathrm{m}^{2} \mathrm{~d}\right)$ e FRD $\left(280 \mathrm{~m}^{2} / \mathrm{m}^{3} \mathrm{~d}\right)$ durante o ensaio 10 - pré-oxidação com peróxido de hidrogênio e sem DFls no FAAG. 135

Figura 5.53 - Variação de absorvância $254 \mathrm{~nm}$ na $A B, A E, A P O$ e nos efluentes do FAAG e do FRD durante o ensaio 10, pré-oxidação com peróxido de hidrogênio e sem DFls no FAAG $\left(F A A G=180 \mathrm{~m}^{3} / \mathrm{m}^{2} \mathrm{~d}\right.$ e FRD $\left.=280 \mathrm{~m}^{3} / \mathrm{m}^{2} \mathrm{~d}\right)$. Fonte: Tabela C 3.2 do ANEXO C..... 135 Figura 5.54 - Variação de $C O D$ na $A B, A E, A P O$ e nos efluentes do FAAG e do FRD durante o ensaio 10, pré-oxidação com peróxido de hidrogênio e sem DFIs no FAAG (FAAG $=180 \mathrm{~m}^{3} / \mathrm{m}^{2} \mathrm{~d}$ e FRD $=280 \mathrm{~m}^{3} / \mathrm{m}^{2} \mathrm{~d}$ ). Fonte: Tabela C 3.2 do ANEXO C. 136 
Figura 5.55 - Evolução da perda de carga no FAAG $\left(180 \mathrm{~m}^{3} / \mathrm{m}^{2} \mathrm{~d}\right)$ e no FRD $\left(280 \mathrm{~m}^{2} / \mathrm{m}^{3} \mathrm{~d}\right)$ para $\mathrm{T}=20^{\circ} \mathrm{C}$ durante o ensaio 11 - pré-oxidação com tricloro-s-triazina-triona e sem DFls no FAAG. Fonte: Tabela C 4.3 do ANEXO C. 138

Figura 5.56 - Variação de cor aparente na $A B, A E, A P O$ e efluentes do FAAG e FRD, e cor verdadeira na $A B$ de 12 a $16 \mathrm{uH}$, na $A E$ de 92 a $102 \mathrm{uH}$ e na APO de 83 a $96 \mathrm{uH}$, durante o ensaio 11 - pré-oxidação com tricloro-s-triazina-triona ( $F A A G=180 \mathrm{~m}^{3} / \mathrm{m}^{2} \mathrm{~d}$ e $\mathrm{FRD}=280$ $\mathrm{m}^{2} / \mathrm{m}^{3} \mathrm{~d}$ ). Fonte: Tabela C 4.1 do ANEXO C. 138

Figura 5.57 - Variação da turbidez na $A B$ e nos efluentes do FAAG $\left(180 \mathrm{~m}^{3} / \mathrm{m}^{2} \mathrm{~d}\right)$ e FRD $\left(280 \mathrm{~m}^{2} / \mathrm{m}^{3} \mathrm{~d}\right)$ durante o ensaio 11 - pré-oxidação com tricloro-s-triazina-triona e sem DFls no FAAG. 139

Figura 5.58 - Variação de absorvância $254 \mathrm{~nm}$ na $A B, A E, A P O$ e nos efluentes do FAAG e do FRD durante o ensaio 11, pré-oxidação com tricloro-s-triazina-triona e sem DFls no FAAG $\left(F A A G=180 \mathrm{~m}^{3} / \mathrm{m}^{2} \mathrm{~d}\right.$ e FRD $\left.=280 \mathrm{~m}^{3} / \mathrm{m}^{2} \mathrm{~d}\right)$. Fonte: Tabela C 4.2 do ANEXO C..... 140 Figura 5.59 - Variação de $C O D$ na $A B, A E, A P O$ e nos efluentes do FAAG e do FRD durante o ensaio 11, pré-oxidação com tricloro-s-triazia-triona e sem DFIs no FAAG (FAAG $=180 \mathrm{~m}^{3} / \mathrm{m}^{2} \mathrm{~d}$ e FRD $=280 \mathrm{~m}^{3} / \mathrm{m}^{2} \mathrm{~d}$ ). Fonte: Tabela C 4.2 do ANEXO C. 140 Figura 5.60 - Evolução da perda de carga no FAAG $\left(180 \mathrm{~m}^{3} / \mathrm{m}^{2} \mathrm{~d}\right)$ e no FRD $\left(280 \mathrm{~m}^{3} / \mathrm{m}^{2} \mathrm{~d}\right)$ para $\mathrm{T}=20^{\circ} \mathrm{C}$ durante $\mathrm{o}$ ensaio 12 , pré-oxidação com dióxido de cloro e sem DFls no FAAG. Fonte: Tabela C 5.3 do ANEXO C. 141

Figura 5.61 - Variação de cor aparente na $A B, A E, A P O$ e efluentes do FAAG e FRD, e cor verdadeira na $A B$ de 12 a $16 \mathrm{uH}$, na AE de 94 a $107 \mathrm{uH}$ e na APO de 88 a $102 \mathrm{uH}$, durante o ensaio 12 - pré-oxidação com dióxido de cloro (FAAG $=180 \mathrm{~m}^{2} / \mathrm{m}^{3} \mathrm{~d}$ e $\mathrm{FRD}=280$ $\left.\mathrm{m}^{2} / \mathrm{m}^{3} \mathrm{~d}\right)$.......

Figura 5.62 - Variação da turbidez na $A B$ e nos efluentes do FAAG $\left(180 \mathrm{~m}^{3} / \mathrm{m}^{2} \mathrm{~d}\right)$ e FRD $\left(280 \mathrm{~m}^{2} / \mathrm{m}^{3} \mathrm{~d}\right)$ durante o ensaio 12 - pré-oxidação com dióxido de cloro e sem DFls no FAAG. 144

Figura 5.63 - Variação de absorvância 254 nm na AB, AE, APO e nos efluentes do FAAG e do FRD durante o ensaio 12, pré-oxidação com dióxido de cloro e sem DFls no FAAG $\left(F A A G=180 \mathrm{~m}^{3} / \mathrm{m}^{2} \mathrm{~d}\right.$ e $\left.\mathrm{FRD}=280 \mathrm{~m}^{3} / \mathrm{m}^{2} \mathrm{~d}\right)$. Fonte: Tabela C 5.2 do ANEXO C 144 Figura 5.64 - Variação de $C O D$ na $A B, A E, A P O$ e nos efluentes do FAAG e do FRD durante o ensaio 12, pré-oxidação com dióxido de cloro e sem DFIs no FAAG (FAAG $=180$ $\mathrm{m}^{3} / \mathrm{m}^{2} \mathrm{~d}$ e FRD $=280 \mathrm{~m}^{3} / \mathrm{m}^{2} \mathrm{~d}$ ). Fonte: Tabela C 5.2 do ANEXO C. 145 Figura 5.65 - Evolução da perda de carga no FAAG $\left(180 \mathrm{~m}^{3} / \mathrm{m}^{2} \mathrm{~d}\right)$ e no FRD $\left(280 \mathrm{~m}^{2} / \mathrm{m}^{3} \mathrm{~d}\right)$ para $\mathrm{T}=20^{\circ} \mathrm{C}$ durante o ensaio 13 , pré-oxidação com permanganato de potássio e sem DFIs no FAAG. Fonte: Tabela C 6.3 do ANEXO C. 146 Figura 5.66 - Variação de cor aparente na $A B, A E, A P O$ e efluentes do FAAG e FRD, e cor verdadeira a $A B$ de 12 a $14 \mathrm{uH}$, na $A E$ de 96 a $111 \mathrm{uH}$ e na APO de 124 a $144 \mathrm{uH}$, durante o ensaio 13 - pré-oxidação com permanganato de potássio. Fonte: Tabela C 6.1 do ANEXO C. 148 
Figura 5.67 - Variação da turbidez na $A B$ e nos efluentes do FAAG $\left(180 \mathrm{~m}^{3} / \mathrm{m}^{2} \mathrm{~d}\right)$ e FRD $\left(280 \mathrm{~m}^{2} / \mathrm{m}^{3} \mathrm{~d}\right)$ durante o ensaio 13 - pré-oxidação com permanganato de potássio e sem DFIs no FAAG. 148

Figura 5.68 - Variação de absorvância $254 \mathrm{~nm}$ na $A B, A E, A P O$ e nos efluentes do FAAG e do FRD durante o ensaio 13, pré-oxidação com permanganato de potássio e sem DFls no FAAG $\left(F A A G=180 \mathrm{~m}^{3} / \mathrm{m}^{2} \mathrm{~d}\right.$ e FRD $\left.=280 \mathrm{~m}^{3} / \mathrm{m}^{2} \mathrm{~d}\right)$. Fonte: Tabela C 6.2 do ANEXO C..... 149 Figura 5.69 - Variação de $C O D$ na $A B, A E, A P O$ e nos efluentes do FAAG e do FRD durante o ensaio 13 , pré-oxidação com permanganato de potássio e sem DFls no FAAG $\left(F A A G=180 \mathrm{~m}^{3} / \mathrm{m}^{2} \mathrm{~d}\right.$ e FRD $\left.=280 \mathrm{~m}^{3} / \mathrm{m}^{2} \mathrm{~d}\right)$. Fonte: Tabela C 6.2 do ANEXO C 149 Figura 5.70 - Evolução da perda de carga no FAAG $\left(180 \mathrm{~m}^{3} / \mathrm{m}^{2} \mathrm{~d}\right)$ e no FRD $\left(280 \mathrm{~m}^{2} / \mathrm{m}^{3} \mathrm{~d}\right)$ para $T=20^{\circ} \mathrm{C}$ durante o ensaio 14 , pré-oxidação com peroxônio e sem DFIs no FAAG. Fonte: Tabela C 7.3 do ANEXO C. 150

Figura 5.71 - Variação de cor aparente na $A B, A E, A P O$ e efluentes do FAAG e FRD, e cor verdadeira na $A B$ de 17 a $22 \mathrm{uH}$, na $A E$ de 94 a $109 \mathrm{uH}$ e na $A P O$ de 51 a $71 \mathrm{uH}$, durante o ensaio 14 - pré-oxidação com peroxônio. Fonte: Tabela C 7.1 do ANEXO C. 152

Figura 5.72 - Variação da turbidez na $A B$ e nos efluentes do FAAG $\left(180 \mathrm{~m}^{3} / \mathrm{m}^{2} \mathrm{~d}\right)$ e $F R D$ $\left(280 \mathrm{~m}^{2} / \mathrm{m}^{3} \mathrm{~d}\right)$ durante o ensaio 14 - pré-oxidação com peroxônio e sem DFIs no FAAG. 152 Figura 5.73 - Variação de absorvância $254 \mathrm{~nm}$ da $A B, A E, A P O$ e dos efluentes do FAAG e do FRD durante o ensaio 14, pré-oxidação com peroxônio e sem DFls no FAAG (FAAG = $180 \mathrm{~m}^{3} / \mathrm{m}^{2} \mathrm{~d}$ e FRD $=280 \mathrm{~m}^{3} / \mathrm{m}^{2} \mathrm{~d}$ ). Fonte: Tabela C 7.2 do ANEXO C.

Figura 5.74 - Variação de $C O D$ na $A B, A E, A P O$ e nos efluentes do FAAG e do FRD durante o ensaio 14, pré-oxidação com peroxônio e sem DFls no FAAG (FAAG $=180$ $\mathrm{m}^{3} / \mathrm{m}^{2} \mathrm{~d}$ e FRD $=280 \mathrm{~m}^{3} / \mathrm{m}^{2} \mathrm{~d}$ ). Fonte: Tabela C 7.2 do ANEXO C.................................... 153 Figura 5.75 - Evolução da perda de carga no FAAG $\left(180 \mathrm{~m}^{3} / \mathrm{m}^{2} \mathrm{~d}\right)$ e no FRD $\left(280 \mathrm{~m}^{2} / \mathrm{m}^{3} \mathrm{~d}\right)$ para $T=20^{\circ} \mathrm{C}$ durante o ensaio 15 , pré-oxidação com hipoclorito de sódio e sem DFls no FAAG. Fonte: Tabela C 8.3 do ANEXO C. 154

Figura 5.77 - Variação da turbidez na $A B$ e dos efluentes do FAAG $\left(180 \mathrm{~m}^{3} / \mathrm{m}^{2} \mathrm{~d}\right)$ e FRD $\left(280 \mathrm{~m}^{2} / \mathrm{m}^{3} \mathrm{~d}\right)$ durante o ensaio 15 - pré-oxidação com hipoclorito de sódio e sem DFls no FAAG.

Figura 5.78 - Variação de absorvância 254 nm na AB, AE, APO e nos efluentes do FAAG e do FRD durante o ensaio 15 , pré-oxidação com hipoclorito de sódio e sem DFls no FAAG $\left(F A A G=180 \mathrm{~m}^{3} / \mathrm{m}^{2} \mathrm{~d}\right.$ e $\left.\mathrm{FRD}=280 \mathrm{~m}^{3} / \mathrm{m}^{2} \mathrm{~d}\right)$. Fonte: Tabela C 8.2 do ANEXO C 157 Figura 5.79 - Variação de $C O D$ da $A B, A E, A P O$ e dos efluentes do FAAG e do FRD durante o ensaio 15, pré-oxidação com hipoclorito de sódio e sem DFls no FAAG (FAAG = $180 \mathrm{~m}^{3} / \mathrm{m}^{2} \mathrm{~d}$ e FRD $=280 \mathrm{~m}^{3} / \mathrm{m}^{2} \mathrm{~d}$ ). Fonte: Tabela C 8.2 do ANEXO C. 157 Figura 5.80 - Formação de trialometanos nas amostras de APO (pH de 5,7 a 6,5) e no efluente do FRD ( $\mathrm{pH}$ de 4,9 a 5,2) pós-cloradas com dosagem de cloro de 4 a $6 \mathrm{mg} / \mathrm{L} \mathrm{e}$ tempo de contato de 24 horas, coletadas após 6 horas de funcionamento dos filtros nos ensaios na instalação piloto em escoamento contínuo com pré-oxidação e taxas de filtração 
de $180 \mathrm{~m}^{3} / \mathrm{m}^{2} \mathrm{~d}$ (FAAG) e $280 \mathrm{~m}^{3} / \mathrm{m}^{2} \mathrm{~d}$ (FRD). Fonte: Tabelas D 1.1 a D 1.4 e cromatogramas

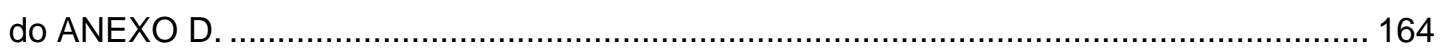

Figura 5.81 - Formação de trialometanos nas amostras de APO (pH de 5,7 a 6,5) e no efluente do FRD ( $\mathrm{pH}$ de 7,0 a 8,6) pós-cloradas com dosagem de cloro de 4 a $6 \mathrm{mg} / \mathrm{L} \mathrm{e}$ tempo de contato de 24 horas, coletadas após 6 horas de funcionamento dos filtros nos ensaios na instalação piloto em escoamento contínuo com pré-oxidação e taxas de filtração de $180 \mathrm{~m}^{3} / \mathrm{m}^{2} \mathrm{~d}$ (FAAG) e $280 \mathrm{~m}^{3} / \mathrm{m}^{2} \mathrm{~d}$ (FRD). Fonte: Tabelas $\mathrm{D} 1.1$ a $\mathrm{D} 1.4$ e cromatogramas do ANEXO D. 165

Figura 5.82 - Formação de trialometanos nas amostras de APO (pH de 5,7 a 6,5) e do efluente do FRD ( $\mathrm{pH}$ de 9,0 a 10,5) pós-cloradas com dosagem de cloro de 4 a $6 \mathrm{mg} / \mathrm{L} \mathrm{e}$ tempo de contato de 24 horas, coletadas após 6 horas de funcionamento dos filtros nos ensaios na instalação piloto em escoamento contínuo com pré-oxidação e taxas de filtração de $180 \mathrm{~m}^{3} / \mathrm{m}^{2} \mathrm{~d}$ (FAAG) e $280 \mathrm{~m}^{3} / \mathrm{m}^{2} \mathrm{~d}$ (FRD). Fonte: Tabelas $\mathrm{D} 1.1$ a $\mathrm{D} 1.4$ e cromatogramas do ANEXO D. 165

Figura 5.83 - Formação de haloacetonitrilas, halocetonas e halopicrinas nas amostras de APO ( $\mathrm{pH}$ de 5,7 a 6,5 ) e no efluente do FRD (pH de 4,9 a 5,2) pós-cloradas com dosagem de cloro de 4 a $6 \mathrm{mg} / \mathrm{L}$ e tempo de contato de 24 horas, coletadas após 6 horas de funcionamento dos filtros nos ensaios na instalação piloto em escoamento contínuo com pré-oxidação e taxas de filtração de $180 \mathrm{~m}^{3} / \mathrm{m}^{2} \mathrm{~d}$ (FAAG) e $280 \mathrm{~m}^{3} / \mathrm{m}^{2} \mathrm{~d}$ (FRD). Fonte: Tabelas D 1.1 a D 1.4 e cromatogramas do ANEXO D. 166 Figura 5.84 - Formação de haloacetonitrilas, halocetonas e halopicrinas nas amostras de APO ( $\mathrm{pH}$ de 5,7 a 6,5 ) e no efluente do FRD ( $\mathrm{pH}$ de 7,0 a 8,6) pós-cloradas com dosagem de cloro de 4 a $6 \mathrm{mg} / \mathrm{L}$ e tempo de contato de 24 horas, coletadas após 6 horas de funcionamento dos filtros nos ensaios na instalação piloto em escoamento contínuo com pré-oxidação e taxas de filtração de $180 \mathrm{~m}^{3} / \mathrm{m}^{2} \mathrm{~d}$ (FAAG) e $280 \mathrm{~m}^{3} / \mathrm{m}^{2} \mathrm{~d}$ (FRD). Fonte: Tabelas D 1.1 a D 1.4 e cromatogramas do ANEXO D................................................... 166 Figura 5.85 - Formação de haloacetonitrilas, halocetonas e halopicrinas nas amostras de APO ( $\mathrm{pH}$ de 5,7 a 6,5) e no efluente do FRD ( $\mathrm{pH}$ de 9,0 a 10,5) pós-cloradas com dosagem de cloro de 4 a $6 \mathrm{mg} / \mathrm{L}$ e tempo de contato de 24 horas, coletadas após 6 horas de funcionamento dos filtros nos ensaios na instalação piloto em escoamento contínuo com pré-oxidação e taxas de filtração de $180 \mathrm{~m}^{3} / \mathrm{m}^{2} \mathrm{~d}$ (FAAG) e $280 \mathrm{~m}^{3} / \mathrm{m}^{2} \mathrm{~d}$ (FRD). Fonte: Tabelas D 1.1 a D 1.4 e cromatogramas do ANEXO D.

Figura 5.86 - Formação de ácidos haloacéticos nas amostras de APO (pH de 5,7 a 6,5) e no efluente do FRD ( $\mathrm{pH}$ de 4,9 a 5,2) pós-cloradas com dosagem de cloro de 4 a $6 \mathrm{mg} / \mathrm{L} \mathrm{e}$ tempo de contato de 24 horas, coletadas após 6 horas de funcionamento dos filtros nos ensaios na instalação piloto em escoamento contínuo com pré-oxidação e taxas de filtração de $180 \mathrm{~m}^{3} / \mathrm{m}^{2} \mathrm{~d}$ (FAAG) e $280 \mathrm{~m}^{3} / \mathrm{m}^{2} \mathrm{~d}$ (FRD). Fonte: Tabelas $\mathrm{D} 1.1$ a $\mathrm{D} 1.4$ e cromatogramas do ANEXO D. 167 
Figura 5.87 - Formação de ácidos haloacéticos nas amostras de APO (pH de 5,7 a 6,5) e no efluente do FRD ( $\mathrm{pH}$ de 7,0 a 8,6) pós-cloradas com dosagem de cloro de 4 a $6 \mathrm{mg} / \mathrm{L}$ e tempo de contato de 24 horas, coletadas após 6 horas de funcionamento dos filtros nos ensaios na instalação piloto em escoamento contínuo com pré-oxidação e taxas de filtração de $180 \mathrm{~m}^{3} / \mathrm{m}^{2} \mathrm{~d}$ (FAAG) e $280 \mathrm{~m}^{3} / \mathrm{m}^{2} \mathrm{~d}$ (FRD). Fonte: Tabelas $\mathrm{D} 1.1$ a $\mathrm{D} 1.4$ e cromatogramas do ANEXO D. 168

Figura 5.88 - Formação de ácidos haloacéticos nas amostras de APO (pH de 5,7 a 6,5) e no efluente do FRD ( $\mathrm{pH}$ de 9,0 a 10,5) pós-cloradas com dosagem de cloro de 4 a $6 \mathrm{mg} / \mathrm{L} \mathrm{e}$ tempo de contato de 24 horas, coletadas após 6 horas de funcionamento dos filtros nos ensaios na instalação piloto em escoamento contínuo com pré-oxidação e taxas de filtração de $180 \mathrm{~m}^{3} / \mathrm{m}^{2} \mathrm{~d}$ (FAAG) e $280 \mathrm{~m}^{3} / \mathrm{m}^{2} \mathrm{~d}$ (FRD). Fonte: Tabelas D 1.1 a D 1.4 e cromatogramas do ANEXO D. 168

Figura B 1.1 - Perda de carga ao longo do meio filtrante do FRD durante o ensaio 1 (FAAG $=240 \mathrm{~m}^{3} / \mathrm{m}^{2} \mathrm{~d}$ e FRD $=280 \mathrm{~m}^{3} / \mathrm{m}^{2} \mathrm{~d}$ ). Fonte: Tabela B $1.3-$ ANEXO B. 177 Figura $B 1.2$ - Perda de carga ao longo do meio filtrante do FAAG durante o ensaio 1 $\left(F A A G=240 \mathrm{~m}^{3} / \mathrm{m}^{2} \mathrm{~d}\right.$ e $\left.\mathrm{FRD}=280 \mathrm{~m}^{3} / \mathrm{m}^{2} \mathrm{~d}\right)$. Fonte: Tabela B $1.3-$ ANEXO B. 177 Figura B 2.1 - Perda de carga na camada suporte e camada de areia grossa no FAAG durante o ensaio 2 - sem pré-oxidação e com DFls no FAAG (FAAG $=180 \mathrm{~m}^{3} / \mathrm{m}^{2} \mathrm{~d}$ e FRD = $200 \mathrm{~m}^{3} / \mathrm{m}^{2} \mathrm{~d}$ ). Fonte: Tabela B 2.3 - ANEXO B. 186

Figura B 2.2 - Perda de carga ao longo do meio filtrante do FRD durante o ensaio 2 - sem pré-oxidação e com DFls no FAAG (FAAG $=180 \mathrm{~m}^{3} / \mathrm{m}^{2} \mathrm{~d}$ e $\mathrm{FRD}=200 \mathrm{~m}^{3} / \mathrm{m}^{2} \mathrm{~d}$ ). Fonte: Tabela B 2.3 - ANEXO B. 186 Figura B 3.1 - Perda de carga na camada suporte e camada de areia grossa no FAAG durante o ensaio 3 - sem pré-oxidação e com DFls no FAAG (FAAG $=180 \mathrm{~m}^{3} / \mathrm{m}^{2} \mathrm{~d}$ e FRD = $240 \mathrm{~m}^{3} / \mathrm{m}^{2} \mathrm{~d}$ ). Fonte: Tabela B 3.3 - ANEXO B. 196

Figura B 3.2 - Perda de carga ao longo do meio filtrante do FRD durante o ensaio 3 - sem pré-oxidação e com DFls no FAAG (FAAG $=180 \mathrm{~m}^{3} / \mathrm{m}^{2} \mathrm{~d}$ e $\mathrm{FRD}=240 \mathrm{~m}^{3} / \mathrm{m}^{2} \mathrm{~d}$ ). Fonte: Tabela B 3.3 - ANEXO B. 196

Figura B 4.1 - Perda de carga na camada suporte e camada de areia grossa no FAAG durante o ensaio 4 - sem pré-oxidação e com DFIs no FAAG (FAAG $=180 \mathrm{~m}^{3} / \mathrm{m}^{2} \mathrm{~d}$ e FRD = $280 \mathrm{~m}^{3} / \mathrm{m}^{2} \mathrm{~d}$ ). Fonte: Tabela B 4.3 - ANEXO B. 205 Figura B 4.2 - Perda de carga ao longo do meio filtrante do FRD durante o ensaio 4 - sem pré-oxidação e com DFls no FAAG (FAAG $=180 \mathrm{~m}^{3} / \mathrm{m}^{2} \mathrm{~d}$ e $\mathrm{FRD}=280 \mathrm{~m}^{3} / \mathrm{m}^{2} \mathrm{~d}$ ). Fonte: Tabela B 4.3 - ANEXO B. 205

Figura B 5.1 - Perda de carga na camada suporte e camada de areia grossa no FAAG durante o ensaio 5 - sem pré-oxidação e com DFls no FAAG (FAAG $=120 \mathrm{~m}^{3} / \mathrm{m}^{2} \mathrm{~d}$ e FRD = $160 \mathrm{~m}^{3} / \mathrm{m}^{2} \mathrm{~d}$ ). Fonte: Tabela B 5.3 - ANEXO B. 
Figura B 5.2 - Perda de carga ao longo do meio filtrante do FRD durante o ensaio 5 - sem pré-oxidação e com DFls no FAAG (FAAG $=120 \mathrm{~m}^{3} / \mathrm{m}^{2} \mathrm{~d}$ e FRD $\left.=160 \mathrm{~m}^{3} / \mathrm{m}^{2} \mathrm{~d}\right)$. Fonte: Tabela B 5.3 - ANEXO B.

Figura B 6.1 - Perda de carga na camada suporte e camada de areia grossa no FAAG durante o ensaio 6 - sem pré-oxidação e com DFIs no FAAG (FAAG $=120 \mathrm{~m}^{3} / \mathrm{m}^{2} \mathrm{~d}$ e FRD = $200 \mathrm{~m}^{3} / \mathrm{m}^{2} \mathrm{~d}$ ). Fonte: Tabela B 6.3 - ANEXO B. 223

Figura B 6.2 - Perda de carga ao longo do meio filtrante do FRD durante o ensaio 6 - sem pré-oxidação e com DFls no FAAG (FAAG $=120 \mathrm{~m}^{3} / \mathrm{m}^{2} \mathrm{~d}$ e FRD $\left.=200 \mathrm{~m}^{3} / \mathrm{m}^{2} \mathrm{~d}\right)$. Fonte: Tabela B 6.3 - ANEXO B. 223

Figura B 7.1 - Perda de carga na camada suporte e camada de areia grossa no FAAG durante o ensaio 7 sem pré-oxidação e com DFIs no FAAG (FAAG $=120 \mathrm{~m}^{3} / \mathrm{m}^{2} \mathrm{~d}$ e FRD = $240 \mathrm{~m}^{3} / \mathrm{m}^{2} \mathrm{~d}$ ). Fonte: Tabela B 7.3 - ANEXO B. 236

Figura $B 7.2$ - Perda de carga ao longo do meio filtrante do FRD durante o ensaio 7 sem pré-oxidação e com DFls no FAAG (FAAG $=120 \mathrm{~m}^{3} / \mathrm{m}^{2} \mathrm{~d}$ e $\mathrm{FRD}=240 \mathrm{~m}^{3} / \mathrm{m}^{2} \mathrm{~d}$ ). Fonte: Tabela B 7.3 - ANEXO B.

Figura C 1.1 - Perda de carga na camada suporte e camada de areia grossa no FAAG durante o ensaio 8 - sem pré-oxidação ( $F A A G=180 \mathrm{~m}^{3} / \mathrm{m}^{2} \mathrm{~d}$ e $\mathrm{FRD}=280 \mathrm{~m}^{3} / \mathrm{m}^{2} \mathrm{~d}$ ). Fonte: Tabela C 1.3 - ANEXO C. 245

Figura C 1.2 - Perda de carga ao longo do meio filtrante do FRD durante o ensaio 8 - sem pré-oxidação $\left(F A A G=180 \mathrm{~m}^{3} / \mathrm{m}^{2} \mathrm{~d}\right.$ e $\left.\mathrm{FRD}=280 \mathrm{~m}^{3} / \mathrm{m}^{2} \mathrm{~d}\right)$. Fonte: Tabela C $1.3-$ ANEXO C.

Figura C 2.1 - Perda de carga na camada suporte e camada de areia grossa no FAAG durante o ensaio 9 - pré-oxidação com ozônio ( $F A A G=180 \mathrm{~m}^{3} / \mathrm{m}^{2} \mathrm{~d}$ e FRD $=280 \mathrm{~m}^{3} / \mathrm{m}^{2} \mathrm{~d}$ ). Fonte: Tabela C 2.3 - ANEXO C. 251

Figura C 2.2 - Perda de carga ao longo do meio filtrante do FRD durante o ensaio 9 - préoxidação com ozônio (FAAG $=180 \mathrm{~m}^{3} / \mathrm{m}^{2} \mathrm{~d}$ e $\mathrm{FRD}=280 \mathrm{~m}^{3} / \mathrm{m}^{2} \mathrm{~d}$ ). Fonte: Tabela C $2.3-$ ANEXO C 251

Figura C 3.1 - Perda de carga na camada suporte e camada de areia grossa no FAAG durante o ensaio 10 - pré-oxidação com peróxido de hidrogênio ( $F A A G=180 \mathrm{~m}^{3} / \mathrm{m}^{2} \mathrm{~d}$ e $\mathrm{FRD}=280 \mathrm{~m}^{3} / \mathrm{m}^{2} \mathrm{~d}$ ). Fonte: Tabela C $3.3-$ ANEXO C. 257

Figura C 3.2 - Perda de carga ao longo do meio filtrante do FRD durante o ensaio 10 - préoxidação com peróxido de hidrogênio ( $F A A G=180 \mathrm{~m}^{3} / \mathrm{m}^{2} \mathrm{~d}$ e $\mathrm{FRD}=280 \mathrm{~m}^{3} / \mathrm{m}^{2} \mathrm{~d}$ ). Fonte: Tabela C 3.3 - ANEXO C. 257

Figura C 4.1 - Perda de carga na camada suporte e camada de areia grossa no FAAG durante o ensaio 11 - pré-oxidação com tricloro-s-triazina-triona (FAAG $=180 \mathrm{~m}^{3} / \mathrm{m}^{2} \mathrm{~d}$ e $\mathrm{FRD}=280 \mathrm{~m}^{3} / \mathrm{m}^{2} \mathrm{~d}$ ). Fonte: Tabela C $4.3-$ ANEXO C.

Figura C 4.2 - Perda de carga ao longo do meio filtrante do FRD durante o ensaio 11 - préoxidação com tricloro-s-triazina-triona ( $F A A G=180 \mathrm{~m}^{3} / \mathrm{m}^{2} \mathrm{~d}$ e $\mathrm{FRD}=280 \mathrm{~m}^{3} / \mathrm{m}^{2} \mathrm{~d}$ ). Fonte: Tabela C 4.3 - ANEXO C. 
Figura C 5.1 - Perda de carga na camada suporte e camada de areia grossa no FAAG durante o ensaio 12 - pré-oxidação com dióxido de cloro $\left(F A A G=180 \mathrm{~m}^{3} / \mathrm{m}^{2} \mathrm{~d}\right.$ e $\mathrm{FRD}=280$ $\mathrm{m}^{3} / \mathrm{m}^{2} \mathrm{~d}$ ). Fonte: Tabela C 5.3 - ANEXO C. 269

Figura C 5.2 - Perda de carga ao longo do meio filtrante do FRD durante o ensaio 12 - préoxidação com dióxido de cloro $\left(F A A G=180 \mathrm{~m}^{3} / \mathrm{m}^{2} \mathrm{~d}\right.$ e $\left.\mathrm{FRD}=280 \mathrm{~m}^{3} / \mathrm{m}^{2} \mathrm{~d}\right)$. Fonte: Tabela C 5.3 - ANEXO C 269

Figura C 6.1 - Perda de carga na camada suporte e camada de areia grossa no FAAG durante o ensaio 13 - pré-oxidação com permanganato de potássio $\left(F A A G=180 \mathrm{~m}^{3} / \mathrm{m}^{2} \mathrm{~d}\right.$ e $\mathrm{FRD}=280 \mathrm{~m}^{3} / \mathrm{m}^{2} \mathrm{~d}$ ). Fonte: Tabela C $6.3-$ ANEXO C. 275

Figura C 6.2 - Perda de carga ao longo do meio filtrante do FRD durante o ensaio 13 - préoxidação com permanganato de potássio ( $F A A G=180 \mathrm{~m}^{3} / \mathrm{m}^{2} \mathrm{~d}$ e $F R D=280 \mathrm{~m}^{3} / \mathrm{m}^{2} \mathrm{~d}$ ). Fonte: Tabela C 6.3 - ANEXO C 275

Figura C 7.1 - Perda de carga na camada suporte e camada de areia grossa no FAAG durante o ensaio 14 - pré-oxidação com peroxônio ( $F A A G=180 \mathrm{~m}^{3} / \mathrm{m}^{2} \mathrm{~d}$ e $\mathrm{FRD}=280$ $\mathrm{m}^{3} / \mathrm{m}^{2} \mathrm{~d}$ ). Fonte: Tabela C 7.3 - ANEXO C. 281

Figura C 7.2 - Perda de carga ao longo do meio filtrante do FRD durante o ensaio 14 - préoxidação com peroxônio ( $F A A G=180 \mathrm{~m}^{3} / \mathrm{m}^{2} \mathrm{~d}$ e $\mathrm{FRD}=280 \mathrm{~m}^{3} / \mathrm{m}^{2} \mathrm{~d}$ ). Fonte: Tabela C $7.3-$ ANEXO C 281

Figura C 8.1 - Perda de carga na camada suporte e camada de areia grossa no FAAG durante o ensaio 15 - pré-oxidação com hipoclorito de sódio (FAAG $=180 \mathrm{~m}^{3} / \mathrm{m}^{2} \mathrm{~d}$ e FRD = $280 \mathrm{~m}^{3} / \mathrm{m}^{2} \mathrm{~d}$ ). Fonte: Tabela C 8.3 - ANEXO C.

Figura C 8.2 - Perda de carga ao longo do meio filtrante do FRD durante o ensaio 15 - préoxidação com hipoclorito de sódio ( $F A A G=180 \mathrm{~m}^{3} / \mathrm{m}^{2} \mathrm{~d}$ e $\mathrm{FRD}=280 \mathrm{~m}^{3} / \mathrm{m}^{2} \mathrm{~d}$ ). Fonte: Tabela C 8.3 - ANEXO C. 236 


\section{LISTA DE TABELAS}

Tabela 3.1 - Comparação da composição elementar típica de substâncias húmicas aquáticas e composição elementar média das substâncias húmicas extraídas de solo. ....... 9 Tabela 3.2 - Principais características estruturais das substâncias húmicas aquáticas (LANGLAIS et al., 1991). 10

3.3 Processos Utilizados para Remoção de Substâncias Húmicas 11

Tabela 3.3 - Parâmetros sugeridos para projeto e operação da Filtração Direta Ascendente.

Tabela 3.4 - Parâmetros sugeridos para projeto e operação da Dupla Filtração.

Tabela 4.1 - Composição do meio granular utilizado no FAAG e no FRD, recomendado por DI BERNARDO (1993) e utilizado por DE PAULA (2003).

Tabela 4.2 - Características da água, amostra, método e equipamento

Tabela 4.3 - Taxas de filtração utilizadas nos ensaios na instalação piloto em escoamento contínuo sem pré-oxidação.

Tabela 4.4 - Ensaios realizados na instalação piloto em escoamento contínuo sem e com pré-oxidação com taxas de filtração fixas no FAAG de $180 \mathrm{~m}^{3} / \mathrm{m}^{2} \mathrm{~d}$ e no FRD de $280 \mathrm{~m}^{3} / \mathrm{m}^{2} \mathrm{~d}$.

Tabela 4.5 - Resumo da curva analítica para trialometanos, haloacetonitrilas, halocetonas e halopicrinas (em $\mu \mathrm{g} / \mathrm{L})$.

Tabela 4.6 - Resumo da curva analítica para os ácidos haloacéticos (em $\mu \mathrm{g} / \mathrm{L}$ ).

Tabela 4.7 - Variações da massa específica e viscosidade absoluta da água em função da temperatura. .73

Tabela 5.1 - Composição elementar das substâncias húmicas e as razões atômicas. ........ 77

Tabela 5.2 - Resultados das análises de metais no extrato de substâncias húmicas. ......... 80

Tabela 5.3 - Resultados dos ensaios em reatores estáticos para a escolha do tipo de areia utilizada nos filtros de laboratório de areia (FLAs).

Tabela 5.4 - Resultados dos ensaios em reatores estáticos com variação do volume de $\mathrm{HCl}$ $(0,07 \mathrm{M})$ adicionado em cada jarro para a escolha do $\mathrm{pH}$ de coagulação.

Tabela 5.5 - Resultados dos ensaios em reatores estáticos para a escolha do gradiente de velocidade de mistura rápida $\left(G_{m r}\right)$.

Tabela 5.6 - Características da água bruta e da água de estudo durante a execução dos ensaios na instalação piloto em escoamento contínuo.

Tabela 5.7 - Resumo dos resultados obtidos no ensaio 1 realizado na instalação piloto em escoamento contínuo sem pré-oxidação.

Tabela 5.8 - Resumo dos resultados obtidos no ensaio 2 realizado na instalação piloto em escoamento contínuo sem pré-oxidação. 
Tabela 5.9 - Resumo dos resultados obtidos no ensaio 3 realizado na instalação piloto em escoamento contínuo sem pré-oxidação.

Tabela 5.10 - Resumo dos resultados obtidos no ensaio 4 realizado na instalação piloto em escoamento contínuo sem pré-oxidação. .99

Tabela 5.11 - Resumo dos resultados obtidos no ensaio 5 realizado na instalação piloto em escoamento contínuo sem pré-oxidação. 103

Tabela 5.12 - Resumo dos resultados obtidos no ensaio 6 realizado na instalação piloto em escoamento contínuo sem pré-oxidação. 107

Tabela 5.13 - Resumo dos resultados obtidos no ensaio 7 realizado na instalação piloto em escoamento contínuo sem pré-oxidação.

Tabela 5.14 - Resumo geral dos resultados obtidos nos ensaios 1, 2, 3 e 4 na instalação piloto em escoamento contínuo sem pré-oxidação, durante a Fase 1. 115

Tabela 5.15 - Resumo geral dos resultados obtidos nos ensaios 5, 6 e 7 na instalação piloto em escoamento contínuo sem pré-oxidação, durante a Fase 1 116

Tabela 5.16 - Resultados de eficiência na produção de água filtrada para as diferentes taxas de filtração utilizadas.

Tabela 5.17 - Resumo dos resultados obtidos no ensaio 8 realizado na instalação piloto em escoamento contínuo sem pré-oxidação.

Tabela 5.18 - Características da água de estudo e da água pré-oxidada com ozônio durante os ensaios em reatores estáticos (RE). 125

Tabela 5.19 - Resultados obtidos nos ensaios RE1, RE2, RE3 e RE4 em reatores estáticos. 126

Tabela 5.20 - Variação da dosagem de coagulante, do pH de coagulação e do alumínio residual durante o ensaio 9 - pré-oxidação com ozônio.

Tabela 5.21 - Resumo dos resultados obtidos no ensaio 9 (pré-oxidação com ozônio). ... 129 Tabela 5.22 - Resumo dos resultados obtidos no ensaio 10 - pré-oxidação com peróxido de hidrogênio. 133

Tabela 5.23 - Resumo dos resultados obtidos no ensaio 11 - pré-oxidação com tricloro-striazina-triona.

Tabela 5.24 - Valores de COT para amostras de água destilada com extrato de substâncias húmicas (ESH), não cloradas e cloradas com $\mathrm{NaClO}$ e tricloro-s-triazina-triona....... 139 Tabela 5.25 - Resumo dos resultados obtidos no ensaio 12 - pré-oxidação com dióxido de cloro. 142

Tabela 5.26 - Resumo dos resultados obtidos no ensaio 13 - pré-oxidação com permanganato de potássio. 147

Tabela 5.27 - Resumo dos resultados obtidos no ensaio 14, pré-oxidação com peroxônio. 151

Tabela 5.28 - Resumo dos resultados obtidos no ensaio 15, pré-oxidação com hipoclorito de sódio. 155 
Tabela 5.29 - Resumo geral dos resultados obtidos nos ensaios 8 e 9 na instalação piloto em escoamento contínuo sem e com pré-oxidação, durante a Fase 2 .

Tabela 5.30 - Resumo geral dos resultados obtidos nos ensaios 10 e 11 na instalação piloto em escoamento contínuo sem e com pré-oxidação, durante a Fase 2. 160

Tabela 5.31 - Resumo geral dos resultados obtidos nos ensaios 12 e 13 na instalação piloto em escoamento contínuo sem e com pré-oxidação, durante a Fase 2. 161

Tabela 5.32 - Resumo geral dos resultados obtidos nos ensaios 14 e 15 na instalação piloto em escoamento contínuo sem e com pré-oxidação, durante a Fase 2.

Tabela B 1.1 - Características físicas da AB, AE e efluentes do FAAG e do FRD durante o ensaio 1 - sem pré-oxidação e com DFIs no FAAG (FAAG $=240 \mathrm{~m}^{3} / \mathrm{m}^{2} \mathrm{~d}$; FRD $=280$ $\left.\mathrm{m}^{3} / \mathrm{m}^{2} \mathrm{~d}\right)$. 178

Tabela B 1.2 - Características químicas da $A B, A E$ e efluentes do FAAG e do FRD durante o ensaio 1 - sem pré-oxidação e com DFls no FAAG (FAAG $=240 \mathrm{~m}^{3} / \mathrm{m}^{2} \mathrm{~d}$; FRD $=280$ $\left.\mathrm{m}^{3} / \mathrm{m}^{2} \mathrm{~d}\right)$ 179

Tabela B 1.3 - Perda de carga no FAAG $\left(240 \mathrm{~m}^{3} / \mathrm{m}^{2} \mathrm{~d}\right)$ e no FRD $\left(280 \mathrm{~m}^{3} / \mathrm{m}^{2} \mathrm{~d}\right)$ durante o ensaio 1, sem pré-oxidação e com DFls no FAAG para a temperatura $T$ e para $T=20^{\circ} \mathrm{C} .180$ Tabela B 1.4 - Variação de vazões e taxas de filtração do FAAG e do FRD durante o ensaio 1 - sem pré-oxidação e com DFIs (FAAG $=240 \mathrm{~m}^{3} / \mathrm{m}^{2} \mathrm{~d}$; FRD $=280 \mathrm{~m}^{3} / \mathrm{m}^{2} \mathrm{~d}$ ). 178 Tabela B 2.1 - Características físicas da AB, AE e efluentes do FAAG e do FRD durante o ensaio 2 - sem pré-oxidação e com DFls no FAAG (FAAG $=180 \mathrm{~m}^{3} / \mathrm{m}^{2} \mathrm{~d} ; \mathrm{FRD}=200$ $\mathrm{m}^{3} / \mathrm{m}^{2} \mathrm{~d}$ ).

Tabela B 2.2 - Características químicas da $A B, A E$ e efluentes do FAAG e do FRD durante o ensaio 2 - sem pré-oxidação e com DFls no FAAG (FAAG $=180 \mathrm{~m}^{3} / \mathrm{m}^{2} \mathrm{~d}$; FRD = 200 $\left.\mathrm{m}^{3} / \mathrm{m}^{2} \mathrm{~d}\right)$.

Tabela B 2.3 - Perda de carga no FAAG $\left(180 \mathrm{~m}^{3} / \mathrm{m}^{2} \mathrm{~d}\right)$ e no FRD $\left(200 \mathrm{~m}^{3} / \mathrm{m}^{2} \mathrm{~d}\right)$ durante o ensaio 2, sem pré-oxidação e com DFls no FAAG para a temperatura $T$ e para $T=20^{\circ} \mathrm{C} .183$ Tabela B 2.4 - Variação de vazões e taxas de filtração do FAAG e do FRD durante o ensaio 2 - sem pré-oxidação e com DFIs no FAAG $\left(F A A G=180 \mathrm{~m}^{3} / \mathrm{m}^{2} \mathrm{~d}\right.$; FRD $\left.=200 \mathrm{~m}^{3} / \mathrm{m}^{2} \mathrm{~d}\right) \ldots 187$ Tabela B 3.1 - Características físicas da $A B, A E$ e efluentes do FAAG e do FRD durante o ensaio 3 - sem pré-oxidação e com DFls no FAAG (FAAG $=180 \mathrm{~m}^{3} / \mathrm{m}^{2} \mathrm{~d}$; FRD $=240$ $\mathrm{m}^{3} / \mathrm{m}^{2} \mathrm{~d}$ )

Tabela B 3.2 - Características químicas da AB, AE e efluentes do FAAG e do FRD durante o ensaio 3 - sem pré-oxidação e com DFls no FAAG (FAAG $=180 \mathrm{~m}^{3} / \mathrm{m}^{2} \mathrm{~d}$; FRD $=240$ $\mathrm{m}^{3} / \mathrm{m}^{2} \mathrm{~d}$ ).

Tabela B 3.3 - Perda de carga no FAAG $\left(180 \mathrm{~m}^{3} / \mathrm{m}^{2} \mathrm{~d}\right)$ e no FRD $\left(240 \mathrm{~m}^{3} / \mathrm{m}^{2} \mathrm{~d}\right)$ durante o ensaio 3, sem pré-oxidação e com DFls no FAAG para a temperatura $T$ e para $T=20^{\circ} \mathrm{C} .192$ Tabela B 3.4 - Variação de vazões e taxas de filtração do FAAG e do FRD durante o ensaio 3 - sem pré-oxidação e com DFIs no FAAG $\left(F A A G=180 \mathrm{~m}^{3} / \mathrm{m}^{2} \mathrm{~d}\right.$; FRD $\left.=240 \mathrm{~m}^{3} / \mathrm{m}^{2} \mathrm{~d}\right) \ldots 197$ 
Tabela B 4.1 - Características físicas da $A B, A E$ e efluentes do FAAG e do FRD durante o ensaio 4 - sem pré-oxidação e com DFIs no FAAG (FAAG $=180 \mathrm{~m}^{3} / \mathrm{m}^{2} \mathrm{~d}$; FRD $=240$ $\left.\mathrm{m}^{3} / \mathrm{m}^{2} \mathrm{~d}\right)$.

Tabela B 4.2 - Características químicas da $A B, A E$ e efluentes do FAAG e do FRD durante o ensaio 4 - sem pré-oxidação e com DFls no FAAG (FAAG $=180 \mathrm{~m}^{3} / \mathrm{m}^{2} \mathrm{~d}$; FRD $=280$ $\left.\mathrm{m}^{3} / \mathrm{m}^{2} \mathrm{~d}\right)$. 200

Tabela B 4.3 - Perda de carga no FAAG $\left(180 \mathrm{~m}^{3} / \mathrm{m}^{2} \mathrm{~d}\right)$ e no FRD $\left(280 \mathrm{~m}^{3} / \mathrm{m}^{2} \mathrm{~d}\right)$ durante o ensaio 4, sem pré-oxidação e com DFIs no FAAG para a temperatura $T$ e para $T=20^{\circ} \mathrm{C} .202$ Tabela B 4.4 - Variação de vazões e taxas de filtração do FAAG e do FRD durante o ensaio 4 - sem pré-oxidação e com DFIs no FAAG (FAAG $=180 \mathrm{~m}^{3} / \mathrm{m}^{2} \mathrm{~d}$; FRD $=280 \mathrm{~m}^{3} / \mathrm{m}^{2} \mathrm{~d}$ ) $\ldots 206$ Tabela B 5.1 - Características físicas da AB, AE e efluentes do FAAG e do FRD durante o ensaio 5 - sem pré-oxidação e com DFls no FAAG (FAAG $=120 \mathrm{~m}^{3} / \mathrm{m}^{2} \mathrm{~d} ; \mathrm{FRD}=160$ $\left.\mathrm{m}^{3} / \mathrm{m}^{2} \mathrm{~d}\right)$. 208

Tabela B 5.2 - Características químicas da $A B, A E$ e efluentes do FAAG e do FRD durante o ensaio 5 - sem pré-oxidação e com DFIs no FAAG (FAAG $=120 \mathrm{~m}^{3} / \mathrm{m}^{2} \mathrm{~d}$; FRD $=160$ $\left.\mathrm{m}^{3} / \mathrm{m}^{2} \mathrm{~d}\right)$.

Tabela B 5.3 - Perda de carga no FAAG $\left(120 \mathrm{~m}^{3} / \mathrm{m}^{2} \mathrm{~d}\right)$ e no FRD $\left(160 \mathrm{~m}^{3} / \mathrm{m}^{2} \mathrm{~d}\right)$ durante o ensaio 5 , sem pré-oxidação e com DFls no FAAG para a temperatura $T$ e para $T=20^{\circ} \mathrm{C} .211$ Tabela B 5.4 - Variação de vazões e taxas de filtração do FAAG e do FRD durante o ensaio 5 - sem pré-oxidação e com DFls no FAAG (FAAG $=120 \mathrm{~m}^{3} / \mathrm{m}^{2} \mathrm{~d}$; FRD $\left.=160 \mathrm{~m}^{3} / \mathrm{m}^{2} \mathrm{~d}\right) \ldots 215$ Tabela B 6.1 - Características físicas da $A B, A E$ e efluentes do FAAG e do FRD durante o ensaio 6 - sem pré-oxidação e com DFls no FAAG (FAAG $=120 \mathrm{~m}^{3} / \mathrm{m}^{2} \mathrm{~d}$; FRD $=200$ $\mathrm{m}^{3} / \mathrm{m}^{2} \mathrm{~d}$ )

Tabela B 6.2 - Características químicas da AB, AE e efluentes do FAAG e do FRD durante o ensaio 6 - sem pré-oxidação e com DFls no FAAG (FAAG $=120 \mathrm{~m}^{3} / \mathrm{m}^{2} \mathrm{~d}$; FRD $=200$ $\left.\mathrm{m}^{3} / \mathrm{m}^{2} \mathrm{~d}\right)$...... 218

Tabela B 6.3 - Perda de carga no FAAG $\left(120 \mathrm{~m}^{3} / \mathrm{m}^{2} \mathrm{~d}\right)$ e no FRD $\left(200 \mathrm{~m}^{3} / \mathrm{m}^{2} \mathrm{~d}\right)$ durante 0 ensaio 6, sem pré-oxidação e com DFIs no FAAG para a temperatura $T$ e para $T=20^{\circ} \mathrm{C} .220$ Tabela B 6.4 - Variação de vazões e taxas de filtração do FAAG e do FRD durante o ensaio 6 - sem pré-oxidação e com DFls no FAAG (FAAG $=120 \mathrm{~m}^{3} / \mathrm{m}^{2} \mathrm{~d}$; FRD $=200 \mathrm{~m}^{3} / \mathrm{m}^{2} \mathrm{~d}$ ) ... 224 Tabela B 7.1 - Características físicas da $A B, A E$ e efluentes do FAAG e do FRD durante o ensaio 7 - sem pré-oxidação e com DFls no FAAG (FAAG $=120 \mathrm{~m}^{3} / \mathrm{m}^{2} \mathrm{~d}$; FRD $=240$ $\mathrm{m}^{3} / \mathrm{m}^{2} \mathrm{~d}$ ) 226

Tabela B 7.2 - Características químicas da AB, AE e efluentes do FAAG e do FRD durante o ensaio 7 - sem pré-oxidação e com DFIs no FAAG (FAAG $=120 \mathrm{~m}^{3} / \mathrm{m}^{2} \mathrm{~d}$; FRD $=240$ $\left.\mathrm{m}^{3} / \mathrm{m}^{2} \mathrm{~d}\right)$. 227

Tabela B 7.3 - Perda de carga no FAAG $\left(120 \mathrm{~m}^{3} / \mathrm{m}^{2} \mathrm{~d}\right)$ e no FRD $\left(240 \mathrm{~m}^{3} / \mathrm{m}^{2} \mathrm{~d}\right)$ durante o ensaio 7 , sem pré-oxidação e com DFIs no FAAG para a temperatura $T$ e para $T=20^{\circ} \mathrm{C} .229$ 
Tabela B 7.4 - Variação de vazões e taxas de filtração do FAAG e do FRD durante o ensaio 7 - sem pré-oxidação e com DFIs no FAAG (FAAG $=120 \mathrm{~m}^{3} / \mathrm{m}^{2} \mathrm{~d}$; FRD $=240 \mathrm{~m}^{3} / \mathrm{m}^{2} \mathrm{~d}$ ) $\ldots 237$ Tabela B 8.1 - Resultados de produção efetiva de água filtrada para os ensaios na instalação piloto em escoamento contínuo - Fase 1

Tabela C 1.1 - Características físicas da $A B, A E$ e efluentes do FAAG e do FRD durante o ensaio 8 - sem pré-oxidação ( $F A A G=180 \mathrm{~m}^{3} / \mathrm{m}^{2} \mathrm{~d}$; $F R D=280 \mathrm{~m}^{3} / \mathrm{m}^{2} \mathrm{~d}$ ).

Tabela C 1.2 - Características químicas da $A B, A E$ e efluentes do FAAG e do FRD durante o ensaio 8 - sem pré-oxidação ( $\left.F A A G=180 \mathrm{~m}^{3} / \mathrm{m}^{2} \mathrm{~d} ; \mathrm{FRD}=280 \mathrm{~m}^{3} / \mathrm{m}^{2} \mathrm{~d}\right)$.

Tabela C 1.3 - Perda de carga no FAAG $\left(180 \mathrm{~m}^{3} / \mathrm{m}^{2} \mathrm{~d}\right)$ e no FRD $\left(280 \mathrm{~m}^{3} / \mathrm{m}^{2} \mathrm{~d}\right)$ durante o ensaio 8, sem pré-oxidação e sem DFIs no FAAG para a temperatura $T$ e para $T=20^{\circ} \mathrm{C} .243$ Tabela C 1.4 - Variação de vazões e taxas de filtração do FAAG e do FRD durante o ensaio 8 - sem pré-oxidação ( $\left.F A A G=180 \mathrm{~m}^{3} / \mathrm{m}^{2} \mathrm{~d} ; \mathrm{FRD}=280 \mathrm{~m}^{3} / \mathrm{m}^{2} \mathrm{~d}\right)$. 246

Tabela C 2.1 - Características físicas da AB, AE, APO e efluentes do FAAG e do FRD durante o ensaio 9 - pré-oxidação com ozônio (FAAG $=180 \mathrm{~m}^{3} / \mathrm{m}^{2} \mathrm{~d}$; FRD $=280 \mathrm{~m}^{3} / \mathrm{m}^{2} \mathrm{~d}$ ).

Tabela C 2.2 - Características químicas da AB, AE, APO e efluentes do FAAG e do FRD durante o ensaio 9 - pré-oxidação com ozônio ( FAAG $=180 \mathrm{~m}^{3} / \mathrm{m}^{2} \mathrm{~d}$; FRD $=280 \mathrm{~m}^{3} / \mathrm{m}^{2} \mathrm{~d}$ ).

Tabela C 2.3 - Perda de carga no FAAG $\left(180 \mathrm{~m}^{3} / \mathrm{m}^{2} \mathrm{~d}\right)$ e no FRD $\left(280 \mathrm{~m}^{3} / \mathrm{m}^{2} \mathrm{~d}\right)$ durante o ensaio 9, pré-oxidação com ozônio e sem DFIs no FAAG para a temperatura $T$ e para $T=$ $20^{\circ} \mathrm{C}$.

Tabela C 2.4 - Variação de vazões e taxas de filtração do FAAG e do FRD durante o ensaio 9 - pré-oxidação com ozônio ( $F A A G=180 \mathrm{~m}^{3} / \mathrm{m}^{2} \mathrm{~d}$; $F R D=280 \mathrm{~m}^{3} / \mathrm{m}^{2} \mathrm{~d}$ ).

Tabela C 3.1 - Características físicas da AB, AE, APO e efluentes do FAAG e do FRD durante o ensaio 10 - pré-oxidação com peróxido de hidrogênio ( $F A A G=180 \mathrm{~m}^{3} / \mathrm{m}^{2} \mathrm{~d}$; FRD $=280 \mathrm{~m}^{3} / \mathrm{m}^{2} \mathrm{~d}$ ).

Tabela C 3.2 - Características químicas da AB, AE, APO e efluentes do FAAG e do FRD durante o ensaio 10 - pré-oxidação com peróxido de hidrogênio ( $F A A G=180 \mathrm{~m}^{3} / \mathrm{m}^{2} \mathrm{~d}$; FRD $=280 \mathrm{~m}^{3} / \mathrm{m}^{2} \mathrm{~d}$ ).

Tabela C 3.3 - Perda de carga no FAAG $\left(180 \mathrm{~m}^{3} / \mathrm{m}^{2} \mathrm{~d}\right)$ e no FRD $\left(280 \mathrm{~m}^{3} / \mathrm{m}^{2} \mathrm{~d}\right)$ durante 0 ensaio 10, pré-oxidação com peróxido de hidrogênio e sem DFls no FAAG para a temperatura $\mathrm{T}$ e para $\mathrm{T}=20^{\circ} \mathrm{C}$.

Tabela C 3.4 - Variação de vazões e taxas de filtração do FAAG e do FRD durante o ensaio 10 - pré-oxidação com peróxido de hidrogênio ( $F A A G=180 \mathrm{~m}^{3} / \mathrm{m}^{2} \mathrm{~d} ; \mathrm{FRD}=280 \mathrm{~m}^{3} / \mathrm{m}^{2} \mathrm{~d}$ ).

Tabela C 4.1 - Características físicas da AB, AE, APO e efluentes do FAAG e do FRD durante o ensaio 11 - pré-oxidação com tricloro-s-triazina-triona ( $F A A G=180 \mathrm{~m}^{3} / \mathrm{m}^{2} \mathrm{~d}$; FRD $\left.=280 \mathrm{~m}^{3} / \mathrm{m}^{2} \mathrm{~d}\right)$. 259 
Tabela C 4.2 - Características químicas da AB, AE, APO e efluentes do FAAG e do FRD durante o ensaio 11 - pré-oxidação com tricloro-s-trizina-triona $\left(F A A G=180 \mathrm{~m}^{3} / \mathrm{m}^{2} \mathrm{~d}\right.$; $F R D=$ $280 \mathrm{~m}^{3} / \mathrm{m}^{2} \mathrm{~d}$ ).

Tabela C 4.3 - Perda de carga no FAAG $\left(180 \mathrm{~m}^{3} / \mathrm{m}^{2} \mathrm{~d}\right)$ e no FRD $\left(280 \mathrm{~m}^{3} / \mathrm{m}^{2} \mathrm{~d}\right)$ durante o ensaio 11, pré-oxidação com tricloro-s-triazina-triona e sem DFls no FAAG para a temperatura $\mathrm{T}$ e para $\mathrm{T}=20^{\circ} \mathrm{C}$

Tabela C 4.4 - Variação de vazões e taxas de filtração do FAAG e do FRD durante o ensaio 11 - pré-oxidação com tricloro-s-triazina-triona ( FAAG $=180 \mathrm{~m}^{3} / \mathrm{m}^{2} \mathrm{~d} ; \mathrm{FRD}=280 \mathrm{~m}^{3} / \mathrm{m}^{2} \mathrm{~d}$ ).

Tabela C 5.1 - Características físicas da AB, AE, APO e efluentes do FAAG e do FRD durante o ensaio 12 - pré-oxidação com dióxido de cloro (FAAG $=180 \mathrm{~m}^{3} / \mathrm{m}^{2} \mathrm{~d} ; \mathrm{FRD}=280$ $\left.\mathrm{m}^{3} / \mathrm{m}^{2} \mathrm{~d}\right)$. 265

Tabela C 5.2 - Características químicas da AB, AE, APO e efluentes do FAAG e do FRD durante o ensaio 12 - pré-oxidação com dióxido de cloro $\left(F A A G=180 \mathrm{~m}^{3} / \mathrm{m}^{2} \mathrm{~d} ; \mathrm{FRD}=280\right.$ $\mathrm{m}^{3} / \mathrm{m}^{2} \mathrm{~d}$ ). 266

Tabela C 5.3 - Perda de carga no FAAG $\left(180 \mathrm{~m}^{3} / \mathrm{m}^{2} \mathrm{~d}\right)$ e no FRD $\left(280 \mathrm{~m}^{3} / \mathrm{m}^{2} \mathrm{~d}\right)$ durante o ensaio 12, pré-oxidação com dióxido de cloro e sem DFls no FAAG para a temperatura T e para $\mathrm{T}=20^{\circ} \mathrm{C}$.

Tabela C 5.4 - Variação de vazões e taxas de filtração do FAAG e do FRD durante o ensaio 12 - pré-oxidação com dióxido de cloro ( $F A A G=180 \mathrm{~m}^{3} / \mathrm{m}^{2} \mathrm{~d} ; \mathrm{FRD}=280 \mathrm{~m}^{3} / \mathrm{m}^{2} \mathrm{~d}$ ). 270 Tabela C 6.1 - Características físicas da AB, AE, APO e efluentes do FAAG e do FRD durante o ensaio 13 - pré-oxidação com permanganato de potássio ( $F A A G=180 \mathrm{~m}^{3} / \mathrm{m}^{2} \mathrm{~d}$; $\mathrm{FRD}=280 \mathrm{~m}^{3} / \mathrm{m}^{2} \mathrm{~d}$ ).

Tabela C 6.2 - Características químicas da AB, AE, APO e efluentes do FAAG e do FRD durante o ensaio 13 - pré-oxidação com permanganato de potássio ( $F A A G=180 \mathrm{~m}^{3} / \mathrm{m}^{2} \mathrm{~d}$; $\mathrm{FRD}=280 \mathrm{~m}^{3} / \mathrm{m}^{2} \mathrm{~d}$ ).

Tabela C 6.3 - Perda de carga no FAAG $\left(180 \mathrm{~m}^{3} / \mathrm{m}^{2} \mathrm{~d}\right)$ e no FRD $\left(280 \mathrm{~m}^{3} / \mathrm{m}^{2} \mathrm{~d}\right)$ durante o ensaio 13, pré-oxidação com permanganato de potássio e sem DFls no FAAG para a temperatura $\mathrm{T}$ e para $\mathrm{T}=20^{\circ} \mathrm{C}$

Tabela C 6.4 - Variação de vazões e taxas de filtração do FAAG e do FRD durante o ensaio 13 - pré-oxidação com permanganato de potássio (FAAG $=180 \mathrm{~m}^{3} / \mathrm{m}^{2} \mathrm{~d} ; \mathrm{FRD}=280$ $\left.\mathrm{m}^{3} / \mathrm{m}^{2} \mathrm{~d}\right)$. 276

Tabela C 7.1 - Características físicas da AB, AE, APO e efluentes do FAAG e do FRD durante o ensaio 14 - pré-oxidação com peroxônio (FAAG $=180 \mathrm{~m}^{3} / \mathrm{m}^{2} \mathrm{~d}$; FRD $=280$ $\left.\mathrm{m}^{3} / \mathrm{m}^{2} \mathrm{~d}\right)$. 277

Tabela C 7.2 - Características químicas da AB, AE, APO e efluentes do FAAG e do FRD durante o ensaio 14 - pré-oxidação com peroxônio (FAAG $=180 \mathrm{~m}^{3} / \mathrm{m}^{2} \mathrm{~d}$; FRD $=280$ $\left.\mathrm{m}^{3} / \mathrm{m}^{2} \mathrm{~d}\right)$. 278 
Tabela C 7.3 - Perda de carga no FAAG $\left(180 \mathrm{~m}^{3} / \mathrm{m}^{2} \mathrm{~d}\right)$ e no FRD $\left(280 \mathrm{~m}^{3} / \mathrm{m}^{2} \mathrm{~d}\right)$ durante o ensaio 14, pré-oxidação com peroxônio e sem DFIs no FAAG para a temperatura T e para $T$ $=20^{\circ} \mathrm{C}$.

Tabela C 7.4 - Variação de vazões e taxas de filtração do FAAG e do FRD durante o ensaio 14 - pré-oxidação com peroxônio ( $F A A G=180 \mathrm{~m}^{3} / \mathrm{m}^{2} \mathrm{~d}$; $\mathrm{FRD}=280 \mathrm{~m}^{3} / \mathrm{m}^{2} \mathrm{~d}$ ). 282 Tabela C 8.1 - Características físicas da AB, AE, APO e efluentes do FAAG e do FRD durante o ensaio 15 - pré-oxidação com hipoclorito de sódio $\left(F A A G=180 \mathrm{~m}^{3} / \mathrm{m}^{2} \mathrm{~d}\right.$; FRD = $280 \mathrm{~m}^{3} / \mathrm{m}^{2} \mathrm{~d}$ ).

Tabela C 8.2 - Características químicas da AB, AE, APO e efluentes do FAAG e do FRD durante o ensaio 15 - pré-oxidação com hipoclorito de sódio $\left(F A A G=180 \mathrm{~m}^{3} / \mathrm{m}^{2} \mathrm{~d}\right.$; FRD = $280 \mathrm{~m}^{3} / \mathrm{m}^{2} \mathrm{~d}$ ). 284

Tabela C 8.3 - Perda de carga no FAAG $\left(180 \mathrm{~m}^{3} / \mathrm{m}^{2} \mathrm{~d}\right)$ e no FRD $\left(280 \mathrm{~m}^{3} / \mathrm{m}^{2} \mathrm{~d}\right)$ durante o ensaio 15 , pré-oxidação com cloro (hipoclorito de sódio) e sem DFIs no FAAG para a temperatura $\mathrm{T}$ e para $\mathrm{T}=20^{\circ} \mathrm{C}$ 285

Tabela D 1.1 - Resumo dos resultados da formação de subprodutos das amostras de APO utilizando diferentes oxidantes e pós-cloração com dosagem de 4 a $6 \mathrm{mg} / \mathrm{L}$ e tempo de contato de $24 \mathrm{~h}$, e das amostras do efluente do FRD com variação do pH - ENSAIOS 8 e 9.

Tabela D 1.2 - Resumo dos resultados da formação de subprodutos das amostras de APO utilizando diferentes oxidantes e pós-cloração com dosagem de 4 a $6 \mathrm{mg} / \mathrm{L}$ e tempo de contato de $24 \mathrm{~h}$, e das amostras do efluente do FRD com variação do pH- ENSAIOS $10 \mathrm{e}$ 11. 239

Tabela D 1.3 - Resumo dos resultados da formação de subprodutos das amostras de APO utilizando diferentes oxidantes e pós-cloração com dosagem de 4 a $6 \mathrm{mg} / \mathrm{L}$ e tempo de contato de $24 \mathrm{~h}$, e das amostras do efluente do FRD com variação do pH - ENSAIOS 12 e 13.

Tabela D 1.4 - Resumo dos resultados da formação de subprodutos das amostras de APO utilizando diferentes oxidantes e pós-cloração com dosagem de 4 a $6 \mathrm{mg} / \mathrm{L}$ e tempo de contato de $24 \mathrm{~h}$, e das amostras do efluente do FRD com variação do pH - ENSAIOS $14 \mathrm{e}$ 15. 


\section{LISTA DE ABREVIATURAS E SIGLAS}

\begin{tabular}{|c|c|}
\hline$A B$ & - Água Bruta \\
\hline $\mathrm{AE}$ & - Água de Estudo \\
\hline $\mathrm{AH}$ & - Ácido Húmico \\
\hline AHAs & - Ácidos Haloacéticos \\
\hline AF & - Ácido Fúlvico \\
\hline APO & - Água Pré-oxidada \\
\hline COA & - Carbono Orgânico Assimilável \\
\hline COD & - Carbono Orgânico Dissolvido \\
\hline CODB & - Carbono Orgânico Dissolvido Biodegradável \\
\hline COT & - Carbono Orgânico Total \\
\hline CT & - Concentração de Desinfetante e Tempo de Contato \\
\hline EESC & - Escola de Engenharia de São Carlos \\
\hline EPA & - Environmental Protection Agency \\
\hline ETA II & - Estação de Tratamento de Água II \\
\hline $\mathrm{ESH}$ & - Extrato de Substância Húmica \\
\hline FAAG & - Filtro Ascendente de Areia Grossa \\
\hline FLAs & - Filtros de Laboratório de Areia \\
\hline FRD & - Filtro Rápido Descendente \\
\hline $\mathrm{G}_{\mathrm{mr}}$ & - Gradiente de Mistura Rápida \\
\hline HANs & - Haloacetonitrilas \\
\hline HCs & - Halocetonas \\
\hline HP & - Halopicrinas \\
\hline IV & - Infravermelho \\
\hline MON & - Matéria Orgânica Natural \\
\hline MTBE & - Metil-terc-butírico-éter \\
\hline ND & - Não Detectado \\
\hline NMP & - Número Mais Provável \\
\hline NR & - Não Realizado \\
\hline $\mathrm{RMN}-{ }^{13} \mathrm{C}$ & - Ressonância Magnética Nuclear - Carbono 13 \\
\hline SR & - Sem Referência \\
\hline $\mathrm{T}_{\mathrm{mr}}$ & - Tempo de Mistura Rápida \\
\hline TAMs & - Trialometanos \\
\hline UA & - Unidade de Absorvância \\
\hline
\end{tabular}


UFC - Unidade Formadora de Colônia

UNAERP - Universidade de Ribeirão Preto

USP - Universidade de São Paulo

UV - Ultravioleta 


\section{LISTA DE SÍMBOLOS}

\begin{tabular}{|c|c|}
\hline$A_{F A A G}$ & - Área do FAAG \\
\hline$A_{F R D}$ & - Área do FRD \\
\hline $\mathrm{Al}_{2}\left(\mathrm{SO}_{4}\right)_{3} \cdot \mathrm{n} \mathrm{H}_{2} \mathrm{O}$ & - Solução comercial de sulfato de alumínio \\
\hline C & - Concentração de oxidante aplicada \\
\hline $\mathrm{C}_{\mathrm{ab}}$ & - Concentração de oxidante na água bruta \\
\hline $\mathrm{C}_{\mathrm{SE}}$ & - Concentração da solução estoque do oxidante \\
\hline $\mathrm{ClO}_{2}$ & - Dióxido de cloro \\
\hline DDF & - Duração da descarga de fundo \\
\hline DCF & - Duração da carreira de filtração \\
\hline DFs & - Descargas de fundo \\
\hline DFIs & - Descargas de fundo intermediárias \\
\hline $\begin{array}{l}\mathrm{DFI}_{\mathrm{C} 50} \\
\text { aparente do eflue }\end{array}$ & $\begin{array}{l}\text { - Descarga de fundo intermediária executada quando a cor } \\
\text { do FAAG atingia valor } \geq 50 \mathrm{uH}\end{array}$ \\
\hline $\begin{array}{l}\mathrm{DFI}_{\mathrm{PC}} \\
\text { carga }\end{array}$ & - Descarga de fundo intermediária executada por perda de \\
\hline$D L_{F A A G}$ & - Duração da lavagem do FAAG \\
\hline$D L_{F R D}$ & - Duração da lavagem do FRD \\
\hline $\mathrm{D}_{\mathrm{SA}}$ & - Dosagem de sulfato de alumínio \\
\hline $\mathrm{h}_{20}$ & - Perda de carga corrigida para a temperatura de $20^{\circ} \mathrm{C}$ \\
\hline$h_{t}$ & - Perda de carga na temperatura t \\
\hline $\mathrm{HCl}$ & - Ácido clorídrico \\
\hline $\mathrm{H}_{2} \mathrm{O}_{2}$ & - Peróxido de hidrogênio \\
\hline $\mathrm{KMnO}_{4}$ & - Permanganato de potássio \\
\hline Lav.FRDPC & - Lavagem do FRD quando atingiu a perda de carga limite \\
\hline Lav.FRD $D_{\text {transpasse }}$ & - Lavagem do FRD quando ocorreu o transpasse \\
\hline $\mathrm{NaCl}$ & - Cloreto de sódio \\
\hline $\mathrm{NaClO}$ & - Hipoclorito de Sódio \\
\hline $\mathrm{NaOH}$ & - Hidróxido de Sódio \\
\hline $\mathrm{N}^{0}$ DFIs $\mathrm{FAAG}$ & - Número de DFIs executadas no FAAG \\
\hline $\mathrm{NL}_{\text {FAAG }}$ & - Número de lavagens executadas no FAAG \\
\hline $\mathrm{NL}_{\text {FRD }}$ & - Número de lavagens executadas no FRD \\
\hline $\mathrm{O}_{3}$ & - Ozônio \\
\hline PE & - Produção efetiva de água filtrada \\
\hline
\end{tabular}




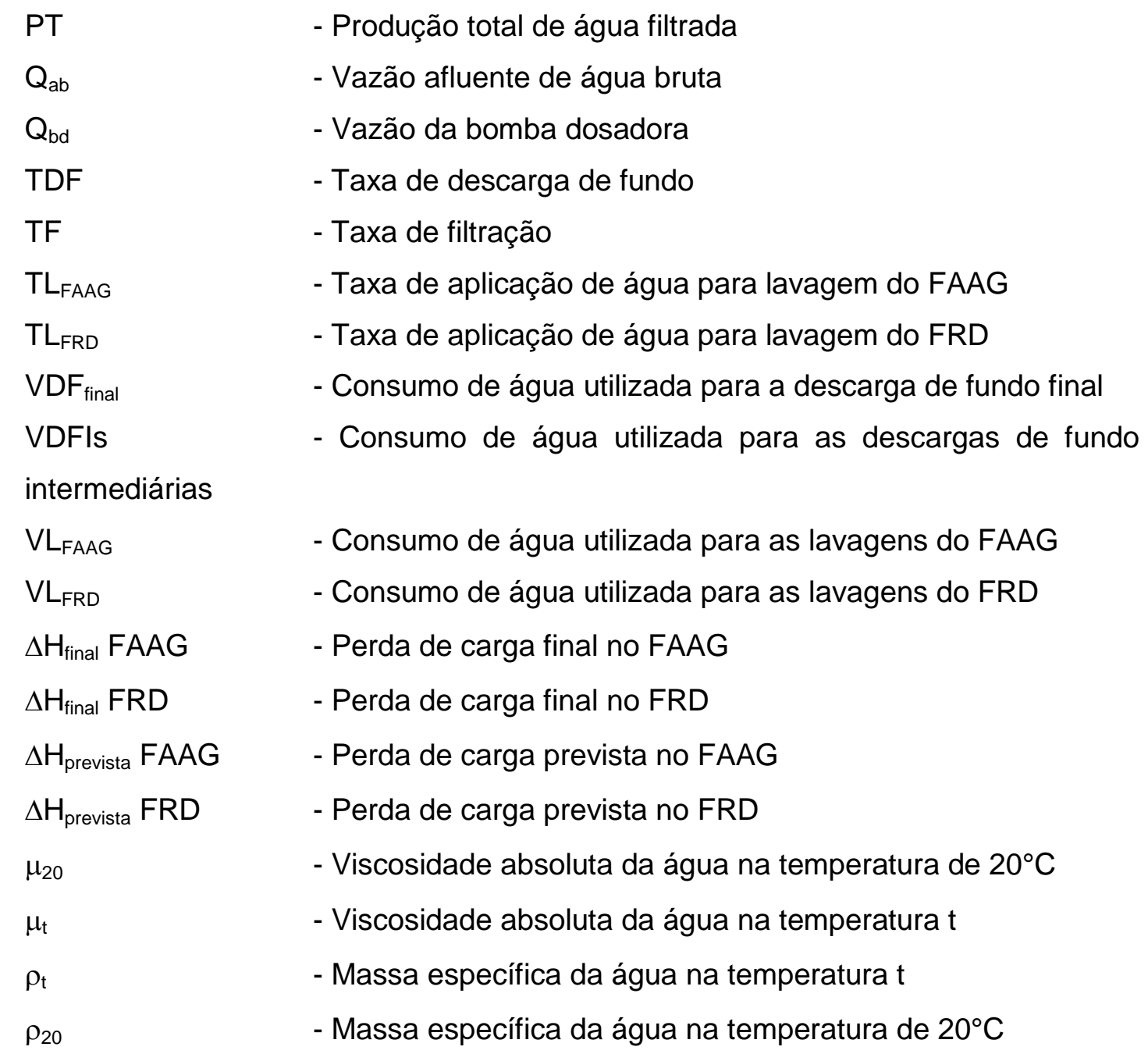




\section{RESUMO}

WIECHETECK, G. K. (2005). Remoção de Substâncias Húmicas em Tratamento de Água por Meio de Pré-Oxidação e Dupla Filtração. São Carlos, 376 p. Tese (Doutorado) - Escola de Engenharia de São Carlos, Universidade de São Paulo.

Para estudar a remoção de substâncias húmicas da água, foi utilizada uma instalação piloto de pré-oxidação e dupla filtração com filtro ascendente de areia grossa (FAAG) e filtro rápido descendente (FRD). Ozônio, peróxido de hidrogênio, peroxônio, tricloro-s-triazina-triona, dióxido de cloro, permanganato de potássio e hipoclorito de sódio foram utilizados como pré-oxidantes. A água de estudo era proveniente do Ribeirão do Feijão (São Carlos - SP) com adição de extrato de substâncias húmicas até cor verdadeira de 90 a $110 \mathrm{uH}$. O trabalho experimental foi realizado em quatro etapas: i) extração de substâncias húmicas; ii) ensaios em reatores estáticos; iii) ensaios na instalação piloto em escoamento contínuo sem pré-oxidação com taxas de filtração no FAAG entre 120 e $240 \mathrm{~m}^{3} / \mathrm{m}^{2} \mathrm{~d}$ e no FRD entre 160 e $280 \mathrm{~m}^{3} / \mathrm{m}^{2} \mathrm{~d}$ e; iv) ensaios na instalação piloto em escoamento contínuo sem e com pré-oxidação com taxas de filtração de $180 \mathrm{~m}^{3} / \mathrm{m}^{2} \mathrm{~d}$ no FAAG e 280 $\mathrm{m}^{3} / \mathrm{m}^{2} \mathrm{~d}$ no FRD. Houve eficiência de remoção de substâncias húmicas nos ensaios sem pré-oxidação e com variação de taxas de filtração, eventualmente, observouse residual de alumínio maior que $0,2 \mathrm{mg} / \mathrm{L}$ no efluente do FRD. Nos ensaios com pré-oxidação obteve-se redução de $50 \%$ na dosagem de coagulante, resultando em menores concentrações de alumínio residual nos filtros, e redução de 43 a $63 \%$ na perda de carga final do FAAG, comparando-se com o ensaio sem pré-oxidação. As amostras pré-oxidadas com ozônio apresentaram maiores concentrações de ácidos haloacéticos. No efluente do FRD, observou-se aumento das concentrações de trialometanos com o aumento do $\mathrm{pH}$. Nos ensaios com dióxido de cloro e permanganato de potássio observaram-se menores concentrações de subprodutos.

Palavras-chave: Tratamento de Água, Dupla Filtração, Pré-Oxidação, Oxidantes, Remoção de Substâncias Húmicas, Formação de Subprodutos. 


\begin{abstract}
WIECHETECK, G. K. (2005). Removal of Humic Substances in Water Treatment through Preoxidation and Double Filtration. São Carlos, 376 p. Tese (Doutorado)

- Escola de Engenharia de São Carlos, Universidade de São Paulo.
\end{abstract}

A pilot plant of preoxidation and double filtration with coarse sand upflow filter (CSUF) and downflow filter (DF) was used with the purpose of removing humic substances of the water. Ozone, hydrogen peroxide, peroxone, chlorine, chlorine dioxide and potassium permanganate were used as preoxidants. The water of study was originating from Ribeirão Feijão (São Carlos - SP) with addition of extract of humic substances until true color from 90 to $110 \mathrm{uH}$. The experimental work was accomplished in four stages: i) extraction of humic substances; ii) tests in static reactors; iii) runs in the pilot plant in continuous flow without preoxidation with filtration rates in the upflow filter between 120 and $240 \mathrm{~m}^{3} / \mathrm{m}^{2} \mathrm{~d}$ and in the downflow filter between 160 and $280 \mathrm{~m}^{3} / \mathrm{m}^{2} \mathrm{~d}$ and; iv) runs in the pilot plant in continuous flow with and without preoxidation with filtration rates of $180 \mathrm{~m}^{3} / \mathrm{m}^{2} \mathrm{~d}$ in the upflow filter and $280 \mathrm{~m}^{3} / \mathrm{m}^{2} \mathrm{~d}$ in the downflow filter. There was efficiency of removal of humic substances in the runs without preoxidation with variation of filtration rates, but the effluent of the downflow filter presented aluminum residual larger than 0,2 $\mathrm{mg} / \mathrm{L}$. In the runs with preoxidation a reduction in the coagulant dosage of $50 \%$ was observed and consequently smaller concentration of aluminum residual in the effluent of the downflow filter, and reduction of 43 to $63 \%$ in the final load loss in the upflow filter, compared with the run without preoxidation. The preoxidaded water with ozone was verified higher concentration of haloacetic acids. In the effluent of the downflow filter was observed increase of trihalomethane concentrations with the increase of the $\mathrm{pH}$. In the runs with chlorine dioxide and potassium permanganate were observed lower concentrations of byproducts.

Keywords: Water Treatment, Double Filtration, Preoxidation, Oxidants, Removal of Humic Substances, Byproduct Formation. 


\section{INTRODUÇÃO}

A maioria dos compostos de natureza orgânica presente em mananciais de abastecimento é proveniente da decomposição da matéria orgânica natural (MON) e são chamados de substâncias húmicas, sendo a causa principal da presença de cor em águas naturais. Substâncias húmicas são macromoléculas com caráter predominantemente aromático e de grande massa molecular.

De acordo com OWEN et al. (1995), MON é um termo usado para descrever a complexa matriz de material orgânico presente em águas naturais, a qual influencia significativamente o desempenho das unidades de tratamento de água (oxidação, coagulação, adsorção), a aplicação de desinfetantes, e a estabilidade biológica. Além disso, a MON interfere na qualidade da água tratada com a formação de subprodutos da desinfecção, aumento de cor, sabor e odor, e do crescimento de microrganismos no sistema de distribuição.

Novas tecnologias e processos de tratamento para a remoção de MON vêm sendo estudados, objetivando a redução ou eliminação de substâncias húmicas.

De acordo com BOLTO et al. (1999), a eficiência dos processos de tratamento de água na remoção de MON varia com a natureza, tamanho molecular e polaridade da MON, e com as características da água bruta, tais como turbidez e dureza. Em alguns casos, o tratamento em ciclo completo com sulfato de alumínio é ineficiente. EIKEBROKK (1999) relata que a otimização do processo de coagulação seguida da filtração direta tem apresentado valores da ordem de 75 a 90\% e 40 a $70 \%$ de remoção de cor e carbono orgânico, respectivamente.

A filtração direta ascendente pode ser considerada como uma das principais tecnologias de tratamento de água, sendo utilizada com sucesso em diversos países. Segundo DI BERNARDO (1993), a filtração direta ascendente foi aplicada pela primeira vez no Brasil, nas cidades de Colatina (ES) e Ponta Grossa (PR). A estação de tratamento de água de Ponta Grossa apresentou custo de implantação correspondente a cerca de $40 \%$ do custo de uma estação de tratamento em ciclo completo. 
Com a necessidade de se melhorar a qualidade da água filtrada, surgiram estudos aplicando-se a filtração rápida descendente precedida da filtração direta ascendente, originando a dupla filtração, apresentando também menor custo comparado ao do tratamento em ciclo completo. A dupla filtração permite o tratamento de água com pior qualidade, possibilita o uso de taxas de filtração mais elevadas no filtro ascendente, oferece maior segurança do ponto de vista operacional em relação às variações bruscas de qualidade da água bruta, apresenta melhor remoção de microrganismos aumentando a segurança em relação à desinfecção final, além de outras vantagens com relação à filtração direta ascendente (DI BERNARDO, 2003).

O uso de oxidantes químicos tais como cloro, dióxido de cloro, ozônio, permanganato de potássio, peróxido de hidrogênio ou a combinação deles no pré e pós-tratamento de água tem apresentado benefícios à qualidade da água tratada. $A$ pré-oxidação apresenta vantagens como remoção de cor, controle de sabor e odor, redução de poluentes orgânicos específicos, precipitação de metais, redução na dosagem de coagulante e melhoria no processo de coagulação.

No entanto, quando o cloro é adicionado à água bruta, ele reage com a MON e pode produzir clorofórmio $\left(\mathrm{CHCl}_{3}\right)$, ácidos mono-, di- e tricloroacético, e outros subprodutos clorados provenientes da desinfecção. Se a água contém apreciável quantidade de bromo, o cloro oxidará o bromo a ácido hipobromoso ( $\mathrm{HBrO})$, o qual por sua vez reagirá com a $\mathrm{MON}$ e produzirá bromofórmio $\left(\mathrm{CHBr}_{3}\right)$ e ácidos acéticos bromados e outros subprodutos da desinfecção (SINGER, 1999).

Os principais fatores que influenciam na formação de subprodutos da desinfecção são: $\mathrm{pH}$, tempo de contato, temperatura, natureza e concentração da MON, dosagem de cloro aplicada, residual de cloro livre e concentração de brometos (DI BERNARDO, 1993). O consumo de cloro e a produção de subprodutos da desinfecção são proporcionais principalmente à concentração de carbono orgânico contido na MON.

A aplicação de oxidantes alternativos como o ozônio, dióxido de cloro, peróxido de hidrogênio associado ao ozônio (peroxônio), permanganato de potássio, são eficientes na remoção de matéria orgânica e na minimização do potencial de formação de subprodutos indesejados. No entanto, alguns destes oxidantes apresentam custo elevado, sendo necessários mais estudos com relação ao seu custo-benefício. 
A ação do ozônio sobre substâncias húmicas em pH neutro pode conduzir à redução dos compostos que dão origem à cor, à diminuição na fração de maior massa molecular e ao aumento na fração de menor massa molecular e nos grupos funcionais carboxílicos.

De acordo com FREESE et al. (1999), o uso combinado de ozônio e peróxido de hidrogênio proporciona maior reatividade, com o peróxido de hidrogênio promovendo o máximo efeito do ozônio, reduzindo a sua dosagem.

No Brasil, a maioria das estações de tratamento de água utiliza o cloro como oxidante ou desinfetante, sem a preocupação das conseqüências de seu uso. Portanto, é necessário o estudo de diferentes oxidantes para a produção de água tratada de melhor qualidade. 


\section{OBJETIVOS}

O objetivo principal deste trabalho foi estudar a eficiência da pré-oxidação e da dupla filtração com filtro ascendente de areia grossa (FAAG) e filtro rápido descendente (FRD) na remoção de substâncias húmicas de água com cor verdadeira de 90 a $110 \mathrm{uH}$.

Os objetivos específicos foram:

- verificar a eficiência da dupla filtração sem pré-oxidação na remoção de substâncias húmicas da água, com taxas de filtração de 120, 180 e 240 $\mathrm{m}^{3} / \mathrm{m}^{2} \mathrm{~d}$ no FAAG e de $160,200,240$ e $280 \mathrm{~m}^{3} / \mathrm{m}^{2} \mathrm{~d}$ no FRD, utilizando sulfato de alumínio como coagulante;

- comparar a eficiência da dupla filtração sem e com pré-oxidação utilizando diferentes oxidantes (ozônio, peróxido de hidrogênio, cloro, dióxido de cloro, permanganato de potássio e peroxônio) na remoção de substâncias húmicas, com taxas de filtração de $180 \mathrm{~m}^{3} / \mathrm{m}^{2} \mathrm{~d}$ no $F A A G$ e de $280 \mathrm{~m}^{3} / \mathrm{m}^{2} \mathrm{~d}$ no FRD;

- identificar e quantificar os subprodutos formados (trialometanos, haloacetonitrilas, halocetonas, halopicrinas e ácidos haloacéticos) decorrentes da pré-oxidação e pós-cloração. 


\section{REVISÃO BIBLIOGRÁFICA}

\subsection{Considerações Gerais}

O desenvolvimento de tecnologias de tratamento de água, ocorrido na segunda metade do século 20 , levou à aceitação da idéia de que os mananciais que recebem efluentes industriais contendo micropoluentes sintéticos, orgânicos e inorgânicos, poderiam ser convenientemente tratados, permitindo a produção de água com qualidade segura. Independentemente dos níveis de poluição desses mananciais, acreditava-se que os processos e operações unitárias de coagulação, floculação, sedimentação, filtração e desinfecção, seriam suficientes para tornar a água segura para abastecimento doméstico, eliminando os agentes etiológicos causadores das doenças de veiculação hídrica, que eram naquela época, a principal preocupação de saúde pública associada ao abastecimento de água (HESPANHOL, 1999).

Com a evolução industrial, introduziram-se na sociedade, no meio ambiente e nos corpos de água superficiais e subterrâneos, milhares de compostos orgânicos e inorgânicos sintéticos, surgindo os riscos de doenças crônicas, associadas às concentrações muito baixas de micropoluentes, orgânicos e inorgânicos, que podem não ser removidos em sistemas convencionais de tratamento de água.

Com o aumento rápido da urbanização e a crescente demanda por recursos hídricos disponíveis em lagos, rios e águas subterrâneas, os riscos do consumo de água contaminada aumentaram e com isso, novas tecnologias de tratamento de água e a utilização de novos produtos químicos oxidantes (ozônio, peróxido de hidrogênio, dióxido de cloro, permanganato de potássio, etc) tem sido proposta para a remoção de metais pesados e compostos orgânicos sintéticos e naturais, como os ácidos húmicos e fúlvicos.

Os ácidos húmicos e fúlvicos compreendem a fração húmica proveniente da decomposição da matéria orgânica natural (MON) em águas superficiais, com característica hidrofílica e alta massa molecular, conferindo cor à água. A fração não-húmica corresponde às proteínas, aos aminoácidos, aos carboidratos e aos ácidos orgânicos de baixa massa molecular. Em termos de propriedades químicas 
e implicações para o tratamento de água, a fração da MON designada como substância húmica é considerada mais importante.

\subsection{Origem das Substâncias Húmicas}

A matéria orgânica presente em solos, turfas e sedimentos consiste em uma mistura de compostos orgânicos provenientes de plantas, animais e microrganismos, física e quimicamente heterogênea e em diferentes estágios de decomposição. Essa matéria é chamada de húmus, substâncias húmicas e substâncias não húmicas. A base de diferenciação é que as substâncias não húmicas são de estrutura definida como aminoácidos, carboidratos, proteínas e ácidos orgânicos, ao passo que as substâncias húmicas são de estrutura química complexa, compondo um grupo de compostos heterogêneos (SARGENTINI JÚNIOR et al., 2001; CANELLAS et al., 2001; RAUEN et al., 2002; ROCHA \& ROSA, 2003).

Substâncias húmicas são formadas pela transformação de biomoléculas durante a decomposição de resíduos vegetais e animais presentes no ambiente. $O$ principal processo é a oxidação de substratos hidrolisados monoméricos, para conduzir a polímeros macromoleculares de cor mais ou menos escura e massa molecular elevada. As quatro vias, mostrada na Figura 3.1, podem ocorrer simultaneamente no solo, porém não com a mesma extensão e importância (ROCHA \& ROSA, 2003).

De acordo com ROCHA \& ROSA (2003), o mecanismo 1 propõe a formação do húmus a partir da polimerização não enzimática por condensação entre aminoácidos e açúcares formados como subprodutos da atividade microbiana. Os mecanismos 2 e 3 envolvem a participação de quinonas e, no mecanismo 4, as substâncias húmicas seriam derivadas de ligninas modificadas. Os mecanismos baseados na condensação polimérica de polifenóis e quinonas têm sido os mais aceitos por pesquisadores e pela Sociedade Internacional de Substâncias Húmicas. 


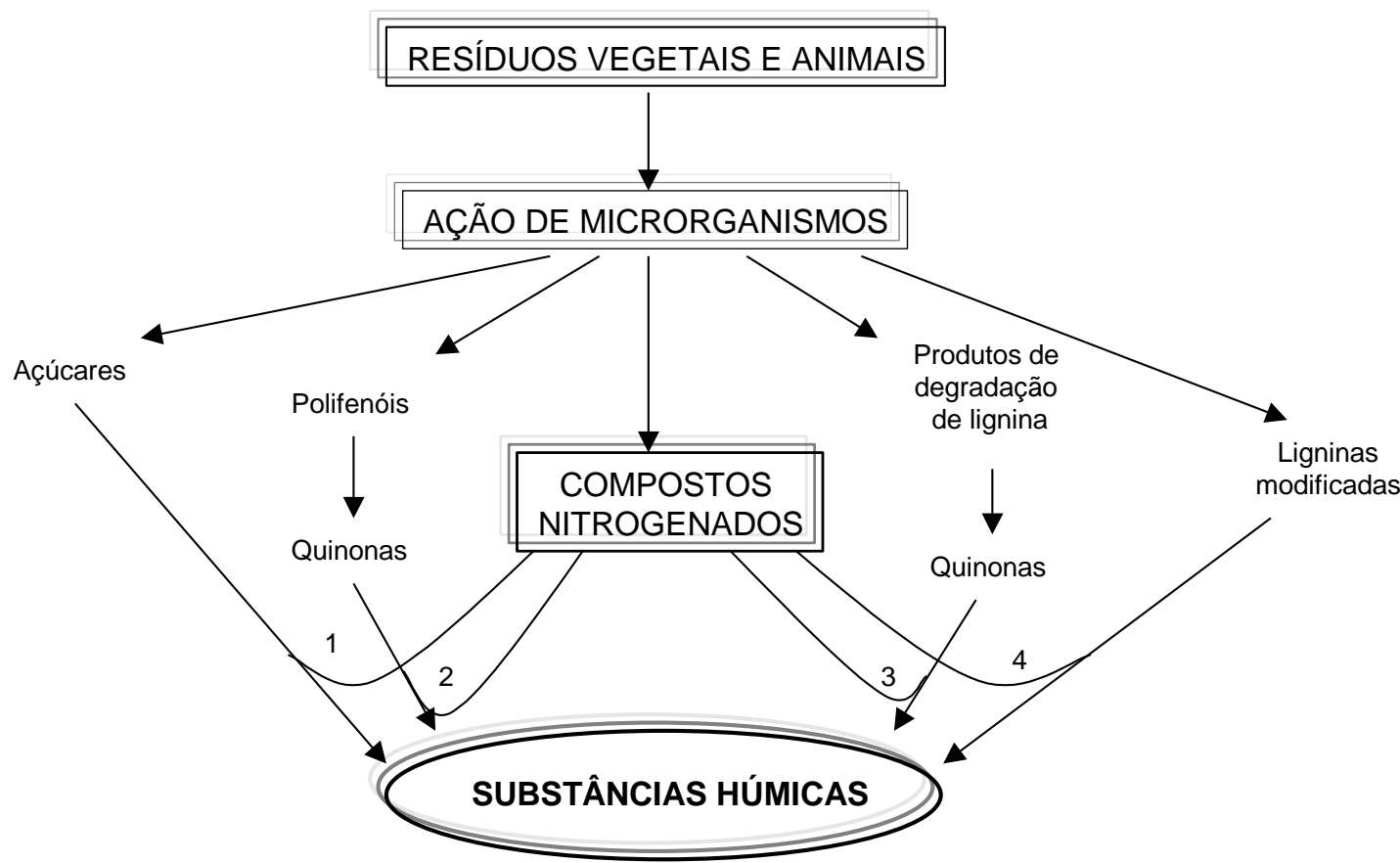

Figura 3.1 - Principais vias propostas para a formação das substâncias húmicas pela decomposição de resíduos animais e vegetais no solo. Fonte: ROCHA \& ROSA, 2003.

Devido à natureza heterogênea e complexa das substâncias húmicas, pouco se sabe sobre sua estrutura química, elas apresentam-se como misturas heterogêneas de moléculas polidispersas, unidas entre si principalmente por interações hidrofóbicas, e com elevada massa molecular. Possuem alto teor de grupos funcionais contendo oxigênio na forma de carboxilas, hidroxilas fenólicas e carbonilas. Devido as suas características estruturais, as substâncias húmicas podem interagir com metais e compostos orgânicos como, por exemplo, pesticidas e herbicidas. Com base nas suas respectivas solubilidades, as substâncias húmicas podem ser classificadas em: humina (insolúvel em qualquer $\mathrm{pH}$ ), ácidos fúlvicos (solúveis em meio ácido e meio alcalino) e ácidos húmicos (solúveis em meio alcalino) (SARGENTINI JÚNIOR et al., 2001; CANELLAS et al., 2001; RAUEN et al., 2002).

A presença de substâncias húmicas em águas superficiais resulta das reações microbiológicas, químicas e fotoquímicas que ocorrem durante a degradação e polimerização da matéria vegetal, conferindo cor à água.

THURMAN \& MALCOLM (1981) definiram substâncias húmicas aquáticas como uma porção não específica, amorfa, constituída de carbono orgânico dissolvido (COD) em pH 2 e adsorvente em coluna de resina XAD 8, não iônica, 
com altos valores de coeficiente de distribuição. As substâncias húmicas aquáticas compreendem cerca de um terço ou metade do COD na água e são constituídas em sua maior parte por ácidos hidrofóbicos.

Grande parte do COD em sistemas aquáticos tropicais com coloração escura, por exemplo, o Rio Negro (AM), apresenta-se como substâncias húmicas aquáticas. Em geral, a concentração de substâncias húmicas em águas é baixa, por isso, são requeridos grandes volumes de amostra para se obter quantidades satisfatórias de substâncias húmicas aquáticas.

As substâncias húmicas aquáticas podem ser de origem alóctone, levadas por lixiviação e/ou erosão dos solos e transportadas aos lagos, rios e oceanos pelas águas das chuvas, pequenos cursos de água e águas subterrâneas, ou autóctones, derivadas dos constituintes celulares e da degradação de organismos aquáticos nativos. Embora haja alguma similaridade entre substâncias húmicas presentes no solo e na água, a diversidade no ambiente de formação e nos compostos de origem faz elas apresentarem diferenças peculiares. Entretanto, as similaridades entre diferentes substâncias húmicas aquáticas são mais significativas que suas diferenças. A natureza da água, lagos, rios ou mar, e a estação do ano também são fatores determinantes nos processos de formação das substâncias húmicas aquáticas (ROCHA \& ROSA, 2003).

\subsubsection{Características das Substâncias Húmicas}

Geralmente $90 \%$ das substâncias húmicas aquáticas dissolvidas em águas são constituídas de ácidos fúlvicos e o restante (10\%) correspondem aos ácidos húmicos (ROCHA \& ROSA, 2003). Os ácidos húmicos diferem dos ácidos fúlvicos pela composição elementar, teor de grupos funcionais, intervalo de massa molecular e outras características.

Na Tabela 3.1 está apresentada uma comparação da composição elementar típica das substâncias húmicas aquáticas, fornecida pela International Humic Substances Society e citada por LANGLAIS et al (1991), e da composição média de substâncias húmicas extraídas de solo citada por ROCHA \& ROSA (2003). 
Tabela 3.1 - Comparação da composição elementar típica de substâncias húmicas aquáticas e composição elementar média das substâncias húmicas extraídas de solo.

\begin{tabular}{c|c|c|c|c|c|c|c|c}
\hline $\begin{array}{c}\text { Substâncias } \\
\text { Húmicas }\end{array}$ & Ácido & $\% \mathrm{C}$ & $\% \mathrm{H}$ & $\% \mathrm{O}$ & $\% \mathrm{~N}$ & $\% \mathrm{~S}$ & $\% \mathrm{P}$ & Total \\
\hline \hline \multirow{2}{*}{ Aquáticas } & fúlvico & 53,75 & 4,29 & 40,48 & 0,68 & 0,50 & 0,01 & 99,71 \\
\cline { 2 - 9 } & Húmico & 54,22 & 4,14 & 39,00 & 1,21 & 0,82 & 0,01 & 99,40 \\
\hline \multirow{2}{*}{ De solo } & Fúlvico & $40,7-50,6$ & $3,8-7,0$ & $39,7-49,8$ & $0,9-3,3$ & $0,1-3,6$ & - & - \\
\cline { 2 - 9 } & Húmico & $53,8-58,7$ & $3,2-6,2$ & $32,8-38,3$ & $0,8-4,3$ & $0,1-1,5$ & - & - \\
\hline \hline
\end{tabular}

Fonte: adaptado de LANGLAIS et al. (1991) e ROCHA \& ROSA (2003).

Observa-se na Tabela 3.1 que o ácido húmico $(\mathrm{AH})$ tem maior teor de carbono e menor teor de oxigênio que o ácido fúlvico ( $A F)$, tanto para as substâncias húmicas de origem aquática quanto para as extraídas de solo. A razão $\mathrm{C} / \mathrm{H}$ é maior para o $\mathrm{AH}$ indicando maior aromaticidade e uma estrutura mais condensada. A razão $\mathrm{C} / \mathrm{N}$, associada ao grau de decomposição do material, não apresenta grande variação para os ácidos.

De acordo com ROCHA \& ROSA (2003), substâncias húmicas com maiores teores de oxigênio possuem maiores concentrações de grupos funcionais, tornando-as com características mais hidrofílicas e diminuindo o acúmulo de compostos orgânicos não iônicos. Entretanto, a maior concentração de grupos oxigenados torna as substâncias húmicas com características mais ácidas, favorecendo a complexação com metais.

Muitas moléculas responsáveis pela cor da água contêm um ou mais anéis aromáticos que absorvem luz a $254 \mathrm{~nm}$. Muitos pesquisadores têm demonstrado correlações entre medidas de cor em espectrofotômetro no comprimento de onda de 400 a $500 \mathrm{~nm}$ com a absorção UV a $254 \mathrm{~nm}$. Embora nem todos os anéis aromáticos produzam cor, há certamente uma correlação entre cor e aromaticidade quando a cor é atribuída principalmente a ácidos húmicos (LANGLAIS et al., 1991).

As substâncias húmicas possuem muitas propriedades químicas que surgem da presença de vários grupos funcionais em sua estrutura complexa pouco conhecida. $\mathrm{Na}$ Tabela 3.2 estão listadas algumas das características das substâncias húmicas aquáticas, com suas respectivas referências citadas por LANGLAIS et al. (1991). 
Tabela 3.2 - Principais características estruturais das substâncias húmicas aquáticas (LANGLAIS et al., 1991).

\begin{tabular}{|c|c|c|}
\hline Característica estrutural & Valores citados na literatura & Referência \\
\hline $\begin{array}{l}\text { Massa } \\
\text { aparente }\end{array}$ & $\begin{array}{l}\text { Depende do método analítico (UF, } \\
\text { gel, raio } X): A H=2-5 \mathrm{kD} \text { e } \\
\mathrm{AF}=0,5-2 \mathrm{kD}\end{array}$ & Thurman $(1985)^{1}$ \\
\hline Absorção UV & $\begin{array}{l}\text { Nenhuma faixa característica de } \\
\text { AH absorve mais que AF. } \\
\text { Para } 11 \text { AF }(\lambda=254 \mathrm{~nm}) \text { : } \\
0,025-0,040 \mathrm{UA} / \mathrm{mg} \mathrm{C}\end{array}$ & $\begin{array}{l}\text { Oliver \& Thurman }(1983)^{2} ; \\
\text { Legube et al. }(1989 a)^{3}\end{array}$ \\
\hline Carbono aromático & $\begin{array}{l}\text { Por } \mathrm{RMN}-{ }^{13} \mathrm{C}: \\
20-40 \% \text { de carbono total }\end{array}$ & Thurman (1985) \\
\hline Funções carboxílicas & $\begin{array}{l}\text { Por titulometria ou } \mathrm{RMN}-{ }^{13} \mathrm{C}: \\
1-7 \mathrm{meq} / \mathrm{g} \text { AH ou AF. } \\
\text { Por titulometria para } 11 \mathrm{AF}: \text { média } \\
\text { de } 12 \mathrm{meq} / \mathrm{g} \mathrm{C}\end{array}$ & $\begin{array}{c}\text { Thurman (1985); } \\
\text { Thurman \& Malcolm (1983) } \\
\text { Legube et al. (1989a) }\end{array}$ \\
\hline Funções OH-fenólicas & $\begin{array}{l}\text { Por titulometria ou } \mathrm{RMN}-{ }^{13} \mathrm{C} \text { : } \\
1-4 \mathrm{meq} / \mathrm{g} \mathrm{AH} \text { ou } \mathrm{AF}\end{array}$ & $\begin{array}{c}\text { Thurman (1985); } \\
\text { Thurman \& Malcolm (1983) }\end{array}$ \\
\hline Carboidratos & $2-4 \%$ de carbono total & Thurman (1985) \\
\hline Aminoácidos & $0,5-1 \%$ de carbono total & SR \\
\hline
\end{tabular}

Nota: $\mathrm{AH}=$ ácidos húmicos; $\mathrm{AF}=$ ácidos fúlvicos; $\mathrm{UA}=$ unidade de absorvância; $\mathrm{RMN}-{ }^{13} \mathrm{C}=$ ressonância magnética nuclear - carbono $13 . \mathrm{SR}=$ sem referência; $\mathrm{kD}=$ quilo Dalton.

Além das características estruturais, LANGLAIS et al. (1991) apresentam as principais propriedades físicas e químicas das substâncias húmicas que interferem no tratamento de água, que são:

- forte reatividade com compostos halogenados, levando a um alto consumo de cloro no tratamento de água e produção de vários compostos halogenados voláteis e não voláteis, alguns de natureza fortemente mutagênica;

- possível complexação com metais tornando-os mais insolúveis, ou uma possível complexação com coagulantes, induzindo a precipitação das substâncias húmicas durante o processo de clarificação;

- possível combinação com micropoluentes orgânicos, incluindo alguns pesticidas.

\footnotetext{
${ }^{1}$ THURMAN, E.M. (1985) Developments in Biogeochemistry: Organic Geochemistry of Natural Waters. N. Nijhoff and Dr. W. Junk Publishers, Dordrecht, The Netherlands.

${ }^{2}$ OLIVER, B. G. \& THURMAN, E. M. (1983) Influence of Aquatic Humic Substances in Trihalomethane Potential. In Water Chlorination: Environmental Impact and Health Effects, vol.4, Edited by R. L. Jolley et al. Ann Arbor Science Publishers, Ann Arbor, Mich.

${ }^{3}$ LEGUBE, B. et al. (1989a) Estude sur lês Acides Fulviques Extraits d'Eaux Superficielles Françaises: Extraction, Carcatérisation et Réactivité avec lê Chlore. Revue Français Sci. De l'Eau, à paraître.

${ }^{4}$ THURMAN, E. M. \& MALCOLM, R. L. (1983) Structural Study of Humic Substances: New Approaches and Methods. Edited by R. F. Christman and E. T. Gjessing. Ann Arbor Science Publishers, Ann Arbor, Mich.
} 
A massa molar de ácidos fúlvicos geralmente varia entre 200 e $2.000 \mathrm{Da}$, enquanto a de ácidos húmicos é maior que 2.000 Da, sendo $\mathrm{Da}=$ Dalton, unidade de massa atômica, igual a $1,66 \times 10^{-24} \mathrm{~g}$. Assim, mesmo que as características usualmente medidas de duas águas sejam aproximadamente iguais, incluindo-se cor verdadeira, concentração de COT, etc., a coagulação de uma pode ser conseguida com sucesso, enquanto da outra não, resultado que pode estar relacionado ao tamanho das moléculas (DI BERNARDO, 2003).

De acordo com CROZES et al. (1995), as substâncias húmicas são caracterizadas pela sua solubilidade em água a um determinado $\mathrm{pH}$. Os ácidos húmicos e os ácidos fúlvicos são polieletrólitos aniônicos com grau de ionização dependente do $\mathrm{pH}$. Os autores relatam que pesquisadores realizaram uma titulação potenciométrica em soluções de ácidos húmicos e ácidos fúlvicos e observaram dois pontos de inflexão, características dos grupos fenólicos ( $\mathrm{pH} 8,0$ a 8,2) e dos grupos carboxílicos ( $\mathrm{pH} 4,6$ a 4,9).

\subsection{Processos Utilizados para Remoção de Substâncias Húmicas}

A caracterização das substâncias húmicas inclui a distribuição de massa molecular aparente e a composição de grupos funcionais e aromáticos. As moléculas de ácidos húmicos e fúlvicos podem ser removidas por processos tais como coagulação química, adsorção em carvão ativado e filtração em membranas. Estas moléculas também podem ser transformadas, utilizando o processo de oxidação (pré-ozonização, processos avançados de oxidação), em subprodutos de menor massa molecular que podem ser menos reativos com cloro e que produzam menores valores de cor.

Segundo LANGLAIS et al. (1991), até $70 \%$ da cor verdadeira presente em águas superficiais pode ser removida por meio de filtração direta ou tratamento em ciclo completo que compreende as etapas de coagulação com sais de alumínio ou ferro, floculação, sedimentação e filtração.

LEMARCHAND et al. (1981) ${ }^{5}$ apud LANGLAIS et al. (1991) afirmaram que a eficiência de remoção de substâncias húmicas e cor da água se dá por adsorção em carvão ativado. Entretanto, o carvão ativado pode ter vida útil curta, dependendo do nível inicial de cor e da natureza dos compostos orgânicos na água.

\footnotetext{
${ }^{5}$ LEMARCHAND et al (1981) Charbon Actif et Matières Organiques dans le Traitement de l'Eau Potable. TSM l'Eau
} 
As substâncias húmicas podem ser removidas da água utilizando-se diferentes processos de tratamento, pois são moléculas orgânicas de grande massa molecular transportando carga negativa, com comportamento similar ao dos colóides. Além do tratamento em ciclo completo utilizando-se coagulação e floculação, os processos de troca iônica e de adsorção em carvão ativado, bem como os processos de membrana filtrante e de oxidação/biofiltração, apresentamse eficientes na remoção de substâncias húmicas (ODEGAARD et al., 1999).

De acordo com a AWWA (1990), os agentes oxidantes atacam parte das moléculas das substâncias húmicas que absorvem luz visível, convertendo-as em formas químicas que não absorvem luz visível. Por exemplo, o cloro e o ozônio atacam as ligações de carbono, oxidam metais e rompem os quelatos, os quais podem contribuir para absorção de luz visível. A pré-oxidação combinada com coagulação química, floculação, sedimentação e filtração são usualmente os métodos adequados para a remoção de cor da água. Dos oxidantes comumente utilizados, o cloro, o ozônio e o dióxido de cloro são mais eficientes.

A ozonização de águas contendo substâncias húmicas reduz a cor da água, e pode promover a formação de produtos que são mais susceptíveis à degradação microbiológica do que as próprias substâncias húmicas.

O efeito da ozonização sobre as substâncias húmicas propicia a formação de grupos hidroxila, carbonila e carboxila, aumentando sua polaridade e hidrofilicidade, e diminuindo a adsorbabilidade (GOEL et al., 1995).

Conforme SINGER (1999), as substâncias húmicas também reagem com ozônio para produzir aldeídos, aldo- e acetoácidos, e ácidos carboxílicos que contribuem para a fração de carbono orgânico biodegradável da água ozonizada. Se não forem controlados, estes subprodutos da oxidação podem levar à formação de biofilmes que podem interferir na qualidade da água tratada e no crescimento microbiano em sistemas de distribuição de água.

DALSASSO (1999) estudou a pré-ozonização de águas contendo carbofuran (pesticida) seguida de filtração direta, e afirma que a pré-ozonização apresentou benefícios quanto à remoção de cor aparente e absorvância UV 254 $\mathrm{nm}$, quando submetida ao processo de filtração direta. A eficiência na remoção do carbofuran cresce com o aumento da dosagem de ozônio para um dado valor de carbono orgânico total (COT) da água bruta. Foi possível eliminar de 90 a 95\% do carbofuran, com concentração da ordem de 70 a $80 \mu \mathrm{g} / \mathrm{L}$ na água bruta, com uma relação ozônio/COT de 0,6. 
De acordo com O'MELIA et al. (1999), o ozônio pode beneficiar ou retardar a coagulação, dependendo do tipo de coagulante utilizado e da qualidade da água bruta. Para água bruta contendo concentração de COT maior que 4,0 mg/L, a dosagem de coagulante é determinada pela MON. Neste caso, a ozonização aumenta a dosagem ótima de coagulante ou reduz a remoção de COD. Para a água contendo baixa concentração de COT, menor que 4,0 mg/L, a dosagem ótima de coagulante é determinada pela turbidez. Neste caso, a ozonização reduz a dosagem ótima de coagulante.

A função do coagulante é neutralizar as cargas negativas das substâncias húmicas para a formação dos flocos, e também assegurar que estes flocos sejam retidos no meio filtrante. Os dois fatores mais importantes para se obter uma boa eficiência no processo de coagulação são a dosagem de coagulante e $\circ \mathrm{pH}$ de coagulação. Para que ocorra bom desempenho dos filtros, é necessário que se obtenha eficiência na etapa de coagulação.

De acordo com SINGER $(1992)^{6}$ apud USEPA (1999) sais de alumínio e ferro podem remover quantidades variáveis de MON. Quando utiliza-se sulfato de alumínio, o pH ótimo de remoção de MON geralmente é de 5,5 a 6,0. Com a adição de sulfato de alumínio, o pH da água diminui, o que permite, em alguns casos, atingir esta faixa de pH sem a adição de ácido. No entanto, águas com alcalinidade muito alta ou muito baixa requerem a adição de acidificante ou alcalinizante para atingir a pH de coagulação ótimo para remoção de MON.

Em média, aproximadamente $90 \%$ do COT é dissolvido. O COD é definido como o COT que passa na membrana filtrante de 0,45 $\mu \mathrm{m}$. A absorvância UV é uma boa técnica para avaliar a presença de COD, porque o COD consiste principalmente de substâncias húmicas, que contêm estruturas aromáticas que absorvem luz no espectro UV. A oxidação de COD reduz a absorvância UV da água, devido à oxidação de compostos orgânicos que absorvem luz no espectro UV (USEPA, 1999)

Portanto, as técnicas analíticas indiretas como UV $254 \mathrm{~nm}$, COT e COD, potencial de formação de trialometanos (PFTAM), etc, podem ser medidas de controle dos processos na remoção de compostos orgânicos. Para a quantificação de orgânicos sintéticos, que representam uma fração muito pequena quando avaliados através das medidas citadas, são utilizadas técnicas analíticas,

${ }^{6}$ SIINGER, P.C. (1992) Formation and Characterization of Disinfection Byproducts. Presented at the First International Conference on the Safety of Water Disinfection: Balancing Chemical and Microbial Risks. 
cromatografia líquida e gasosa e, na identificação de compostos orgânicos para concentrações muito baixas, estas técnicas devem estar associadas à espectrometria de massas (OWEN et al., 1995).

\subsection{Oxidantes e Formação de Subprodutos}

Os oxidantes mais utilizados no tratamento de água são cloro, dióxido de cloro, ozônio, peróxido de hidrogênio e permanganato de potássio. Embora a inativação de organismos patogênicos seja sua função primária, os desinfetantes também são oxidantes utilizados no tratamento de águas de abastecimento para oxidar o ferro e o manganês, manter a estabilidade biológica e evitar que ocorra o crescimento de microrganismos no sistema de distribuição, remover sabor e odor, melhorar a eficiência da coagulação e filtração, impedir o crescimento de algas no decantador e nos filtros, remover cor, entre outros (AWWA, 1990).

Quanto à aplicação da oxidação química na remoção de substâncias húmicas, acredita-se que o tamanho das moléculas das substâncias húmicas influencia os tipos de subprodutos formados pela oxidação com cloro, ozônio, dióxido de cloro, peróxido de hidrogênio, radiação ultravioleta, etc. Por isso, atualmente, há muito interesse de, na caracterização das substâncias húmicas, separar e quantificar as frações com diferentes massas molares, as quais, nas águas naturais, podem variar desde 200 Da até cerca de 100 kDa (DI BERNARDO, 2003).

O desempenho da oxidação química é influenciado pelo $\mathrm{pH}$, temperatura, dosagem de oxidante, tempo de reação, e pela presença de substâncias que interferem com a desejada reação redox. Muitas vezes, o pH interfere na taxa de oxidação. Geralmente, as taxas de oxidação química aumentam com o aumento da temperatura e da dosagem de oxidante. O tempo de reação deve ser suficiente para permitir que as reações de oxidação química sejam eficientes e benéficas ao tratamento. Além disso, a utilização da oxidação química dependerá de sua economia comparada a outros métodos de remoção de contaminantes, da formação de subprodutos e seus efeitos à saúde, e todos os benefícios que ela proporcionará ao sistema de tratamento (AWWA, 1990).

A seguir estão descritas algumas considerações sobre os oxidantes utilizados em tratamento de água. 


\subsubsection{Cloro}

O cloro é o oxidante mais comumente utilizado em tratamento de água por apresentar algumas características atrativas, como: i) é eficiente na inativação de muitos organismos patogênicos comumente presentes na água; ii) deixa residual na água facilmente medido e controlado; iii) é econômico; iv) possibilita melhoria no desempenho das unidades de tratamento de água. Há entretanto, alguns problemas com relação ao uso de cloro tais como: i) o cloro reage com muitos compostos orgânicos e inorgânicos na água formando subprodutos indesejáveis da desinfecção; ii) perigos associados com o uso de cloro, especificamente cloro gasoso, requerem cuidados especiais de segurança; iii) altas dosagens de cloro podem causar problemas de sabor e odor (USEPA, 1999).

\subsubsection{Formas de Cloro}

O cloro é fornecido na forma gasosa ou líquida, como uma solução aquosa concentrada (hipoclorito de sódio) ou um sólido (hipoclorito de cálcio). O cloro gasoso se hidrolisa rapidamente na água e forma o ácido hipocloroso $(\mathrm{HOCl})$. $\mathrm{O}$ cloro também pode ser fornecido como cloro estabilizado em tabletes, mais utilizados para a desinfecção de piscinas, o ingrediente ativo é o tricloro-s-triazinatriona, com teor de cloro disponível de 90\%.

A equação (3.1) apresenta a reação de hidrólise com cloro gasoso:

$$
\mathrm{Cl}_{2(\mathrm{~g})}+\mathrm{H}_{2} \mathrm{O} \Rightarrow \mathrm{HOCl}+\mathrm{H}^{+}+\mathrm{Cl}^{-}
$$

A adição de cloro gasoso na água reduz o pH da água devido à produção do íon $\mathrm{H}^{+}$. O ácido hipocloroso é um ácido fraco $\left(\mathrm{pK}_{\mathrm{a}} \cong 7,5\right)$, que se dissocia em íons de hidrogênio e hipoclorito, como mostrado na equação (3.2):

$\mathrm{HOCl} \Leftrightarrow \mathrm{H}^{+}+\mathrm{OCl}^{-}$

O hipoclorito de sódio é produzido quando o cloro gasoso é dissolvido em solução de hidróxido de sódio. A solução de hipoclorito de sódio contém aproximadamente $12,5 \%$ de cloro disponível (USEPA, 1999). A reação entre o hipoclorito de sódio e a água é mostrada na equação (3.3): 
$\mathrm{NaOCl}+\mathrm{H}_{2} \mathrm{O} \Rightarrow \mathrm{HOCl}+\mathrm{Na}^{+}+\mathrm{OH}^{-}$

A equação (3.3) mostra que a aplicação de hipoclorito de sódio na água produz ácido hipocloroso, da mesma forma que a reação com cloro gasoso (eq. 3.1). Entretanto, a adição de hipoclorito de sódio na água produz o radical livre hidroxila $\left(\mathrm{OH}^{-}\right)$que aumenta o $\mathrm{pH}$ da água.

O hipoclorito de cálcio é formado do precipitado que resulta do cloro gasoso dissolvido em uma solução de óxido de cálcio e hidróxido de sódio. O produto comercial de hipoclorito de cálcio granular contém 65\% de cloro disponível (USEPA, 1999). A equação (3.4) mostra a reação do hipoclorito de cálcio na água:

$$
\mathrm{Ca}(\mathrm{OCl})_{2}+2 \mathrm{H}_{2} \mathrm{O} \Rightarrow 2 \mathrm{HOCl}^{-}+\mathrm{Ca}^{++}+2 \mathrm{OH}^{-}
$$

A aplicação de hipoclorito de cálcio na água também produz ácido hipocloroso e íons hidroxila, que aumentam o pH da água.

\subsubsection{Principais usos}

O cloro é utilizado principalmente na desinfecção para a inativação de vírus, bactérias e protozoários. Também é utilizado como oxidante para controle de sabor e odor, prevenção do crescimento algal, remoção de ferro e manganês, remoção de cor, manutenção da qualidade da água no sistema de distribuição, e melhorar o processo de coagulação.

Sendo o cloro um forte oxidante e extremamente corrosivo, deve-se tomar muito cuidado com o armazenamento e manuseio do produto.

\subsubsection{Formação de subprodutos}

Quando o cloro livre reage com a MON são formados compostos orgânicos halogenados. Alguns fatores como o tipo e a concentração da MON, dosagem e forma de cloro aplicada, concentração de nitrogênio orgânico, $\mathrm{pH}$, temperatura e outros, influem na formação de subprodutos halogenados. O nitrogênio orgânico influencia significativamente a formação de subprodutos como haloacetonitrilas e halopicrinas. 
De acordo com a USEPA (1999) a formação de trialometanos aumenta com o aumento do $\mathrm{pH}$ da água clorada, ao contrário de alguns subprodutos como 0 ácido tricloroacético, o dicloroacetonitrila e o tricloropropanona que diminuem com o aumento do pH. STEVENS et al. (1989) relataram que há maior formação de trialometanos em $\mathrm{pH}=9,4$ do que em $\mathrm{pH}=5,0$. A formação de trialometanos e ácidos haloacéticos está relacionada com o teor de carbono orgânico total e com a concentração de bromo na água, bem como o pH durante a cloração.

\subsubsection{Ozônio}

O ozônio é um forte oxidante, capaz de oxidar muitos compostos orgânicos e inorgânicos presentes na água. O ozônio se decompõe espontaneamente durante o tratamento de água por um mecanismo complexo que envolve a geração de radicais livres hidroxila. Estes radicais hidroxila são os mais reativos agentes oxidantes na água.

O ozônio pode reagir em solução aquosa de duas maneiras: oxidação direta por ozônio molecular $\left(\mathrm{O}_{3}(\mathrm{aq})\right.$ ) e/ou oxidação por radicais livres hidroxila formados durante a decomposição do ozônio.

Por ser uma molécula instável, o ozônio deverá ser gerado no ponto de aplicação para o uso em tratamento de água. A geração in loco economiza muito espaço de armazenagem. É formado pela combinação de um átomo de oxigênio com uma molécula de oxigênio $\left(\mathrm{O}_{2}\right)$, como mostrado na equação (3.5):

$3 \mathrm{O}_{2} \Leftrightarrow 2 \mathrm{O}_{3}$

$\mathrm{O}$ ozônio pode ser gerado do $\mathrm{O}_{2}$ presente no ar ou de $\mathrm{O}_{2}$ com alto grau de pureza. Por ser um gás tóxico, sua produção e instalações de aplicação deverão ser projetadas para gerar, aplicar e controlar o gás. É importante o uso de equipamentos de proteção individual para os operadores. Os níveis de ozônio devem ser monitorados continuamente na estação de tratamento de água.

De acordo com a USEPA (1999), a utilização de ozônio apresenta algumas vantagens e desvantagens com relação aos demais oxidantes, como vantagens podem-se citar: i) é mais eficiente que o cloro, cloraminas e dióxido de cloro para a inativação de vírus, Cryptosporidium e Giardia; ii) oxida ferro e manganês; iii) pode algumas vezes melhorar o processo de clarificação e remoção de turbidez; iv) oxida compostos que conferem cor, sabor e odor na água; v) é um dos mais eficientes 
desinfetantes, e requer pouco tempo de contato; vi) na ausência de bromo, não são formados subprodutos halogenados; vii) sob decomposição, forma oxigênio dissolvido como residual; viii) a atividade biocida não é influenciada pelo $\mathrm{pH}$. Como desvantagens, o uso de ozônio pode apresentar: i) formação de subprodutos da desinfecção, particularmente na presença de bromo, aldeídos e cetonas; ii) o custo inicial do equipamento de ozonização é alto; iii) sua geração requer energia e deverá ser gerado in loco; iv) é altamente corrosivo e tóxico; v) são necessários filtros ativados biologicamente para remover carbono orgânico assimilável e subprodutos biodegradáveis da desinfecção; vi) ele se decompõe rapidamente a alto $\mathrm{pH}$ e temperaturas amenas; vii) não fornece residual; viii) requer altos níveis de habilidade e manutenção dos operadores.

A demanda de ozônio está associada com (USEPA, 1999):

- reações com a MON presente na água. A oxidação de MON leva à formação de aldeídos e ácidos orgânicos;

- subprodutos de oxidação orgânica, que são geralmente mais biodegradáveis e podem ser medidos como carbono orgânico assimilável (COA) ou carbono orgânico dissolvido biodegradável (CODB);

- compostos orgânicos sintéticos, que podem ser oxidados e mineralizados sob condições favoráveis. Para atingir a total mineralização, a oxidação por radical hidroxila deverá ser dominante, tais como nos processos de oxidação avançada (peroxônio);

- oxidação de íon $\mathrm{Br}^{-}$, que leva à formação de ácido hipobromoso, íon hipobromito, íon bromato, orgânicos bromados, bromoaminas;

- íons bicarbonato e carbonato, comumente medidos como alcalinidade, que agem como seqüestradores dos radicais hidroxila e formam carbonatos. Estas reações são importantes nos processos de oxidação avançada onde a oxidação por radicais hidroxila é predominante.

\subsubsection{Principais usos}

O ozônio é usado principalmente na desinfecção e oxidação química. Como agente oxidante, pode ser usado para remover cor, aumentar a biodegradabilidade de compostos orgânicos, oxidar os compostos que conferem sabor e odor à água, reduzir os níveis de precursores de subprodutos da cloração, oxidar poluentes 
inorgânicos, incluindo ferro e manganês, oxidar poluentes fenólicos e alguns pesticidas e reduzir a demanda de cloro.

\subsubsection{Formação de subprodutos}

Segundo a USEPA (1999), as variáveis que influem na eficiência do ozônio são: dosagem, $\mathrm{pH}$, alcalinidade e principalmente a natureza dos compostos orgânicos. Para a maioria das substâncias húmicas, o pH crítico é 7,5, no qual a decomposição de ozônio a radicais livres hidroxila aumenta rapidamente, e as taxas de oxidação orgânica também aumentam. Portanto, as implicações a pH mais baixos $(6,0$ a 7,0), em que ozônio molecular predomina sobre os radicais livres hidroxila, os subprodutos precursores de trialometanos apresentam natureza diferente daqueles formados pelos radicais livres hidroxila, oxidados a níveis de $\mathrm{pH}$ mais altos.

Em pH neutro e níveis moderados de alcalinidade o potencial de formação de trialometanos é reduzido de 3 a $20 \%$, com dosagens de 0,2 a 1,6 $\mathrm{mg} \mathrm{O}_{3} / \mathrm{mg} \mathrm{C}$ (SINGER et al, 19897; GEORGESON \& KARIMI, $1988^{8}$ apud USEPA, 1999).

A aplicação de ozônio com a presença de bromo na água, ou se o cloro for adicionado como desinfetante secundário, podem ser formados subprodutos halogenados. Os ácidos orgânicos e aldeídos são também subprodutos da ozonização (USEPA, 1999).

\subsubsection{Dióxido de cloro}

O dióxido de cloro $\left(\mathrm{ClO}_{2}\right)$ é um forte oxidante e sua geração é feita no local de aplicação. Na geração de dióxido de cloro, o clorito de sódio reage com cloro gasoso, ácido hipocloroso $(\mathrm{HOCl})$ ou ácido clorídrico $(\mathrm{HCl})$. Estas reações estão representadas pelas equações (3.6), (3.7) e (3.8):

$2 \mathrm{NaClO}_{2}+\mathrm{Cl}_{2(\mathrm{~g})} \Rightarrow 2 \mathrm{ClO}_{2(\mathrm{~g})}+2 \mathrm{NaCl}$

$2 \mathrm{NaClO}_{2}+\mathrm{HOCl} \Rightarrow 2 \mathrm{ClO}_{2}(\mathrm{~g})+\mathrm{NaCl}+\mathrm{NaOH}$

\footnotetext{
${ }^{7}$ SINGER, P.C. et al. (1989) Ozonation at Belle Glade, Florida: A Case History. Conference proceeding. IOA Ninth Ozone World Conference.

${ }^{8}$ GEORGESON, D. L. \& KARIMI, A. A. (1988) Water Quality Improvements with the Use of Ozone at the Los Angeles Water Treatment Plant. Ozone Sci. Engrg. 10(3): 225-276.
} 
$5 \mathrm{NaClO}_{2}+4 \mathrm{HCl} \Rightarrow 4 \mathrm{ClO}_{2}(\mathrm{~g})+5 \mathrm{NaCl}+2 \mathrm{H}_{2} \mathrm{O}$

O dióxido de cloro é um gás estável em água na ausência de luz e elevadas temperaturas. Ele apresenta algumas vantagens como: i) é mais eficiente que o cloro para a inativação de vírus, Cryptosporidium e Giardia; ii) oxida ferro, manganês e sulfito; iii) pode melhorar o processo de clarificação; iv) oxida os compostos que conferem cor, sabor e odor na água; v) é facilmente gerado; vi) não são formados subprodutos halogenados sob condições de geração controladas (por exemplo, sem excesso de cloro); vii) sua capacidade como agente desinfetante não é influenciada pelo $\mathrm{pH}$; viii) fornece residual. Como desvantagens, o uso de dióxido de cloro pode apresentar: i) formação de subprodutos específicos indesejados como clorito e clorato; ii) dificuldade na otimização e na eficiência do gerador podem causar excesso de cloro a ser alimentado no ponto de aplicação, que potencializa a formação de subprodutos halogenados; iii) os custos associados ao treinamento, amostragem e ensaios em laboratório para análises de clorito e clorato são altos; iv) o custo de clorito de sódio é alto; v) deve ser gerado in loco; vi) se decompõe na presença de luz; vii) pode produzir odores nocivos em alguns sistemas (USEPA, 1999).

\subsubsection{Principais usos}

É usado como desinfetante principalmente para a inativação de vírus, bactérias e protozoários, controle de sabor e odor, redução de trialometanos totais e ácidos haloacéticos, oxidação de ferro e manganês, remoção de cor, destruição de compostos fenólicos.

\subsubsection{Formação de subprodutos}

De acordo com a USEPA (1999), AWWA (1990) e GATES (1998), o dióxido de cloro não produz trialometanos, ele reduz a formação de trialometanos e ácidos haloacéticos pela oxidação dos precursores destes subprodutos.

Quando adicionado na água, o dióxido de cloro reage com compostos orgânicos e inorgânicos e produz clorito $\left(\mathrm{ClO}_{2}{ }^{-}\right)$e clorato $\left(\mathrm{ClO}_{3}{ }^{-}\right)$como produtos finais, compostos responsáveis por efeitos prejudiciais à saúde humana, como a anemia hemolítica. De acordo com WERDEHOFF \& SINGER (1987), o $\mathrm{ClO}_{2}^{-}$é o 
produto final da reação predominante, com aproximadamente 50 a $70 \%$ de dióxido de cloro convertido em $\mathrm{ClO}_{2}{ }^{-}$e $30 \%$ em $\mathrm{ClO}_{3}{ }^{-}$e $\mathrm{Cl}^{-}$.

O clorito e o clorato são produzidos durante o tratamento com dióxido de cloro como produtos finais em proporções variadas. Os principais fatores que influem nas concentrações finais de dióxido de cloro, clorito e clorato são (USEPA, 1999): dosagem aplicada e demanda de oxidante; proporção dos produtos químicos utilizados na geração do dióxido de cloro; exposição da água contendo dióxido de cloro ao sol; reações entre cloro e clorito se o cloro livre é utilizado para manter o residual no sistema de distribuição; níveis de clorato no clorito de sódio armazenado para geração de dióxido de cloro.

De acordo com SINGER $(1992)^{6}$ apud USEPA (1999), a dosagem aplicada de $2 \mathrm{mg} / \mathrm{L}$ de dióxido de cloro pode produzir de 1 a $1,4 \mathrm{mg} / \mathrm{L}$ de clorito. Portanto, deverá ser feito um estudo de demanda de dióxido de cloro para determinar a sua dosagem para obter o valor requerido de CT como desinfetante. Nos Estados Unidos, a dosagem de dióxido de cloro não poderá exceder 1,4 mg/L para limitar a concentração combinada total de $\mathrm{ClO}_{2}, \mathrm{ClO}_{2}^{-}$, e $\mathrm{ClO}_{3}{ }^{-}$, de no máximo $1,0 \mathrm{mg} / \mathrm{L}$. No Brasil, a Portaria 518/2004 limita este valor em 0,2 mg/L, restringindo desta forma, o uso de dióxido de cloro.

\subsubsection{Permanganato de Potássio}

De acordo com a USEPA (1999), no processo de oxidação com permanganato de potássio $\left(\mathrm{KMnO}_{4}\right)$ é reduzido a dióxido de manganês $\left(\mathrm{MnO}_{2}\right) \mathrm{O}$ qual precipita. Todas as reações são exotérmicas. As equações (3.9) e (3.10) mostram como ocorrem as reações de oxidação, em meio ácido.

$$
\begin{array}{ll}
\mathrm{MnO}_{4}^{-}+4 \mathrm{H}^{+}+3 e^{-} \Rightarrow \mathrm{MnO}_{2}+\mathrm{H}_{2} \mathrm{O} & \mathrm{E}^{\circ}=1,68 \mathrm{~V} \\
\mathrm{MnO}_{4}^{-}+8 \mathrm{H}^{+}+5 e^{-} \Rightarrow \mathrm{Mn}^{2+}+4 \mathrm{H}_{2} \mathrm{O} & \mathrm{E}^{\circ}=1,51 \mathrm{~V}
\end{array}
$$

Em meio alcalino, a reação é mostrada na equação (3.11):

$$
\mathrm{MnO}_{4}^{-}+2 \mathrm{H}_{2} \mathrm{O}+3 e^{-} \Rightarrow \mathrm{MnO}_{2}+4 \mathrm{OH}^{-} \quad \mathrm{E}^{\circ}=0,60 \mathrm{~V}
$$

${ }^{6}$ SIINGER, P.C. (1992) Formation and Characterization of Disinfection Byproducts. Presented at the First International Conference on the Safety of Water Disinfection: Balancing Chemical and Microbial Risks. 
As taxas de reações para a oxidação de compostos presentes em águas naturais são relativamente rápidas e dependem da temperatura, $\mathrm{pH}$ e dosagem do oxidante. Não é desejável manter residual de permanganato de potássio na água, por conferir cor rosa à mesma.

O permanganato de potássio é fornecido em pó e a solução concentrada é preparada no local de aplicação.

O permanganato de potássio apresenta vantagens, dentre elas pode-se citar: oxida ferro e manganês; é fácil de transportar, estocar e aplicar; é útil no controle da formação de trialometanos e outros subprodutos. Como desvantagens: requer longo tempo de contato; tende a conferir cor rosa à água; é tóxico e pode irritar a pele e as mucosas; quando aplicadas dosagens muito altas pode causar problemas de saúde tais como icterícia química e baixa pressão sanguínea (USEPA, 1999).

\subsubsection{Principais usos}

O permanganato de potássio é utilizado como oxidante para o controle de sabor e odor, remoção de cor, controle do crescimento de microrganismos em estações de tratamento de água e remoção de ferro e manganês. Também pode ser útil no controle da formação de trialometanos e outros subprodutos, oxidando seus precursores e reduzindo a demanda de outros desinfetantes (USEPA, 1999). Embora o permanganato de potássio seja bastante utilizado como oxidante, como desinfetante ele é menos utilizado.

\subsubsection{Formação de subprodutos}

Não há na literatura confirmação da formação de subprodutos com a utilização de permanganato de potássio como oxidante. A pré-oxidação com $\mathrm{KMnO}_{4}$ combinada com a pós-cloração resultará em concentrações mais baixas de subprodutos comparadas às concentrações formadas utilizando-se pré-oxidação com cloro (USEPA,1999). 


\subsubsection{Peroxônio}

Processos avançados de oxidação geram radicais livres hidroxila altamente reativos, para oxidar vários compostos presentes na água. Os radicais hidroxila são produzidos durante a decomposição espontânea de ozônio. Com o aumento da taxa de decomposição do ozônio, eleva-se a concentração de radicais hidroxila, ocasionando o aumento da taxa de oxidação. Muitos métodos têm sido usados para aumentar a decomposição do ozônio e produzir altas concentrações de radicais hidroxila. Um dos mais comuns envolve a adição de peróxido de hidrogênio à água ozonizada (USEPA, 1999).

O bom desempenho da ação oxidante do peroxônio depende da proporção peróxido de hidrogênio:ozônio, que deve ser menor ou igual a 0,3 (USEPA, 1999). No entanto, na otimização desta proporção devem ser considerados o tempo de contato e a finalidade do uso deste oxidante. TANGERINO (2003), que estudou a remoção de substâncias húmicas utilizando oxidação com peroxônio e filtração lenta, afirma que a proporção de $\mathrm{H}_{2} \mathrm{O}_{2}: \mathrm{O}_{3}$ não deve ser menor que 0,2 .

O processo de oxidação com peroxônio depende principalmente da oxidação com o radical hidroxila. Nos processos com peroxônio, o ozônio residual tem "vida curta" porque a adição de peróxido de hidrogênio acelera a decomposição de ozônio. O processo de oxidação é mais reativo e muito mais rápido no processo com peroxônio comparado ao processo com ozônio molecular.

As reações e o potencial de oxidação do radical hidroxila e o ozônio são apresentados nas equações (3.12), (3.13) e (3.14):

$$
\begin{array}{ll}
\mathrm{OH}+e^{-} \Rightarrow \mathrm{OH}^{-} & \mathrm{E}^{\circ}=+2,8 \mathrm{~V} \\
\mathrm{O}_{3}+2 \mathrm{H}^{-}+2 e^{-} \Rightarrow \mathrm{O}_{2}+\mathrm{H}_{2} \mathrm{O} & \mathrm{E}^{\circ}=+2,07 \mathrm{~V} \\
\mathrm{O}_{3}+\mathrm{H}_{2} \mathrm{O}+2 e^{-} \Rightarrow \mathrm{O}_{2}+2 \mathrm{OH}^{-} & \mathrm{E}^{\circ}=+1,24 \mathrm{~V}
\end{array}
$$

O processo de oxidação com peroxônio apresenta algumas vantagens, podendo-se citar: é mais reativo e muito mais rápido comparado ao processo de oxidação com ozônio molecular; é eficiente na remoção de compostos orgânicos, tais como os que conferem sabor e odor à água; é eficiente em oxidar compostos halogenados. Dentre as desvantagens, têm-se: o peróxido é um forte oxidante e extremamente perigoso, pode ser armazenado in loco, mas deteriora gradualmente 
mesmo quando armazenado corretamente; não fornece residual mensurável, não sendo possível calcular os valores CT (concentração de desinfetante e tempo de contato); a capacidade do peroxônio oxidar ferro e manganês é menos efetiva do que a aplicação de ozônio isoladamente (USEPA, 1999).

\subsubsection{Principais usos}

Com uso primário, a oxidação. Como agente oxidante o peroxônio pode ser usado para remover poluentes orgânicos sintéticos e aumentar a biodegradabilidade de compostos orgânicos. Não pode ser utilizado como desinfetante secundário porque é altamente reativo e não mantém residual no sistema de distribuição.

\subsubsection{Formação de subprodutos}

O peroxônio não forma subprodutos halogenados quando reage com a MON, entretanto, se houver bromo presente na água bruta, poderão ser formados compostos halogenados. Como no processo de oxidação com o ozônio, o principal benefício do uso de peroxônio é controlar a formação de trialometanos, com a redução da dosagem do desinfetante secundário, geralmente o cloro ou cloraminas.

Em estudo realizado por FERGUSON et. al (1990) para avaliar a utilização do peroxônio quanto à formação de subprodutos, foi feita a pré-oxidação com peroxônio e utilizado cloro e cloraminas como desinfetantes secundários. Quando o cloro foi o desinfetante secundário, as concentrações de trialometanos variaram de 67 a $160 \mu \mathrm{g} / \mathrm{L}$, quando utilizou-se cloraminas, as concentrações de trialometanos apresentaram-se menores que $3,5 \mu \mathrm{g} / \mathrm{L}$.

\subsection{Tratamento de Água por Filtração Direta}

Basicamente a filtração consiste na remoção de partículas suspensas e coloidais e de microrganismos presentes na água que escoa através de um meio permeável. Após um determinado tempo de funcionamento do filtro, com a retenção das partículas no meio poroso, há a necessidade da lavagem do filtro, geralmente feita pela introdução de água no sentido ascensional com velocidade relativamente 
alta para promover a fluidificação do meio granular com liberação das partículas retidas nos seus poros.

Segundo DI BERNARDO (2003) os mecanismos responsáveis pela remoção de partículas durante a filtração com ação de profundidade são complexos e influenciados principalmente pelas características físicas e químicas das partículas, presentes na água e no meio filtrante, da taxa de filtração e do método de operação dos filtros. Considera-se a filtração o resultado da ação de três mecanismos distintos: transporte, aderência e desprendimento.

Os mecanismos de transporte são responsáveis por conduzir as partículas suspensas para as proximidades da superfície dos coletores (material granular), as quais podem permanecer aderidas a estes por meio de forças superficiais, que resistem às forças de cisalhamento resultantes das características do escoamento ao longo do meio filtrante. Quando essas forças superam as forças de aderência, tem-se o desprendimento. Se a taxa de filtração, que é a vazão afluente ao filtro dividida pela área do filtro em planta, ou velocidade de aproximação, permanecer constante, a velocidade de escoamento nos poros, denominada de velocidade instersticial, aumenta em decorrência das partículas retidas e causa o arraste das partículas para as subcamadas inferiores (filtro descendente) ou superiores (filtro ascendente) do meio filtrante, podendo ocasionar o fenômeno conhecido como transpasse (DI BERNARDO, 2003).

De acordo com DI BERNARDO (2003) a filtração direta pode ser empregada para o tratamento de águas para abastecimento em três configurações básicas, apresentadas na Figura 3.2. 


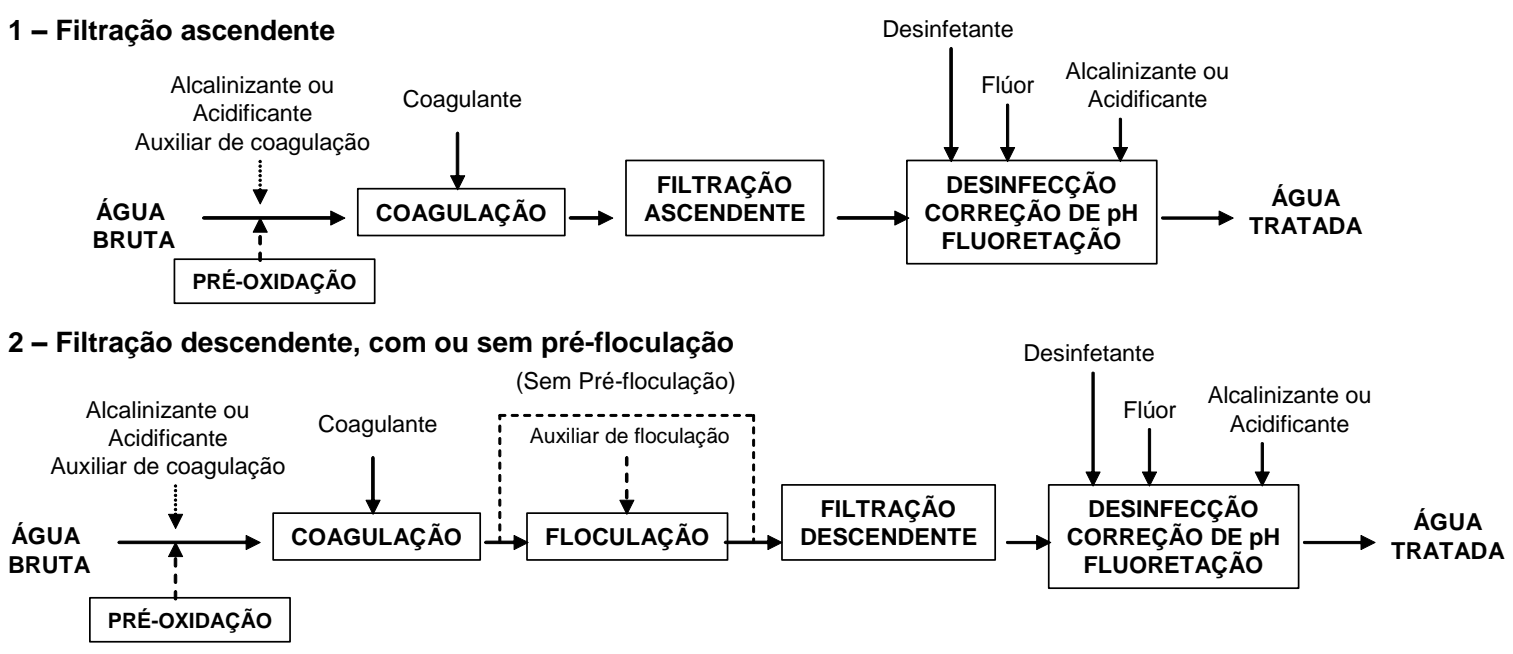

3 - Dupla Filtração

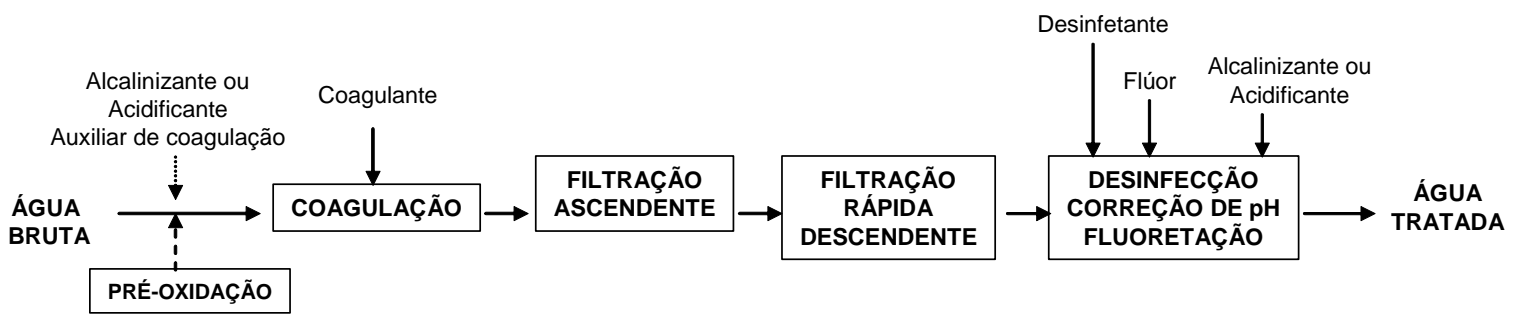

Figura 3.2 - Configurações dos sistemas de filtração direta. Fonte: adaptado de DI BERNARDO, 2003.

A filtração pode se dar por ação de profundidade e por ação superficial. $\mathrm{Na}$ filtração rápida descendente, com ação de profundidade, as impurezas são retidas ao longo do meio filtrante. Em contraposição, na filtração de ação superficial a retenção das partículas é significativa apenas no topo do meio filtrante.

Segundo DI BERNARDO (2003), a filtração ascendente tem sido comumente considerada com ação de profundidade, embora, dependendo das características do meio granular e da taxa de filtração, a retenção de impurezas seja mais significativa na camada de pedregulho e subcamadas iniciais de areia. A filtração com ação de profundidade pode ser entendida como o resultado de uma sucessão de estágios relativos à colmatação das subcamadas que compõe o meio filtrante.

Nas três configurações de filtração direta apresentadas na Figura 3.2 é imprescindível que o processo de coagulação seja eficiente, para que 0 desempenho das unidades subseqüentes não seja prejudicado.

A remoção de impurezas da água bruta em estações de tratamento de água que empregam a coagulação química geralmente é feita utilizando-se sais de ferro 
ou de alumínio como coagulante primário e, eventualmente, polímeros. A escolha do tipo de coagulante deve levar em consideração o custo, sua eficiência na estabilização das partículas presentes na água bruta, sua capacidade de atenuar flutuações na qualidade da água sem afetar a eficiência da coagulação, o volume de lodo produzido e sua influência sobre a duração das carreiras de filtração, sendo desejado que o coagulante reduza a perda de carga na unidade de filtração e o risco de ocorrência de transpasse (DI BERNARDO, 2003).

\subsubsection{Coagulação}

A dosagem de coagulante, $\mathrm{o} \mathrm{pH}$ de coagulação e as características químicas da água bruta definem o mecanismo de coagulação predominante em cada processo. Os mecanismos de coagulação podem ser denominados de: compressão da camada difusa, adsorção-neutralização de cargas, varredura e adsorção-formação de pontes. Apresenta-se a seguir, uma breve descrição dos quatro mecanismos de coagulação citados.

\section{a) Compressão da camada difusa}

De acordo com DI BERNARDO (1993), desde o final do século XIX sabe-se que um sistema coloidal pode ser desestabilizado pela adição de íons com carga contrária à das partículas coloidais. Sais simples, cloreto de sódio, são considerados "eletrólitos indiferentes" e não têm características de hidrólise ou de adsorção, como ocorre com sais de ferro e alumínio. A introdução de um eletrólito indiferente num sistema coloidal irá causar aumento na densidade de cargas na camada difusa e diminuir a "esfera" de influência de partículas, ocorrendo a coagulação por compressão da camada difusa.

Neste mecanismo de coagulação a quantidade de eletrólitos necessários para conseguir a coagulação é praticamente independente da concentração de colóides na água, e não é possível causar a reversão de carga dos colóides (reestabilização), independentemente da quantidade de eletrólitos adicionada.

\section{b) Adsorção-Neutralização de Cargas}

Existem algumas espécies químicas capazes de serem adsorvidas na superfície das partículas coloidais. Se estas espécies possuírem carga contrária à da superfície dos colóides, haverá desestabilização dos mesmos. A atração entre a 
superfície e a espécie adsorvida resulta, provavelmente, de interações tais como ligação de hidrogênio, ligações covalentes e reações de troca iônica. É importante observar que a intensidade de tais fenômenos é superior aos efeitos eletrostáticos obtidos pela compressão da camada difusa, o que de certa forma esclarece a possibilidade de reestabilização da solução coloidal por reversão da carga superficial, quando ocorrer super dosagem de coagulante (DI BERNARDO, 1993).

São três as principais diferenças existentes entre os mecanismos de compressão da camada difusa e adsorção-neutralização de cargas: i) as espécies adsorvíveis são capazes de desestabilizar os colóides em dosagens muito inferiores às necessárias para a compressão da camada difusa; ii) a relação existente entre a concentração dos colóides e a quantidade necessária de espécies desestabilizadas por adsorção-neutralização de cargas segue uma relação estequiométrica; iii) no mecanismo de adsorção-neutralização de cargas é possível ocorrer a reversão da carga superficial das partículas coloidais por meio da dosagem excessiva de espécies adsorvíveis (DI BERNARDO, 1993).

O mecanismo de adsorção-neutralização de cargas é adequado às tecnologias de tratamento que empregam a filtração direta, por não serem formados flocos grandes, mas partículas desestabilizadas que são retidas no filtro. Nesse mecanismo, a dosagem de coagulante geralmente é inferior à necessária quando a água é coagulada no mecanismo de varredura.

\section{c) Varredura}

De acordo com DI BERNARDO (1993), dependendo principalmente da dosagem de coagulante, do $\mathrm{pH}$ de mistura e da concentração de alguns tipos de íons na água, poderá ocorrer a formação de precipitados. As partículas coloidais presentes comportam-se como núcleos de condensação para estes precipitados que, desta forma, são removidas por sedimentação. Com sais de ferro e alumínio, podem ser formados os precipitados $\mathrm{Al}(\mathrm{OH})_{3(\mathrm{p})}$ e $\mathrm{Fe}(\mathrm{OH})_{3(\mathrm{p})}$.

O mecanismo de varredura é muito utilizado nas ETAs nas quais se tem floculação e sedimentação antecedendo a filtração, pois os flocos resultantes são de maior tamanho e apresentam velocidades de sedimentação relativamente altas, quando comparados às dos flocos obtidos com a coagulação no mecanismo de adsorção-neutralização de cargas. Este mecanismo é caracterizado por altas dosagens de coagulante, necessária para a formação de precipitado de hidróxido de alumínio ou de ferro, quando são utilizados sais destes metais como coagulante. 


\section{d) Adsorção e Formação de Pontes}

Existe uma variedade de compostos naturais e sintéticos caracterizados por grande cadeia molecular, com a propriedade de apresentarem grupos com carga ao longo da cadeia e capazes de agirem como coagulantes eficientes. Tais compostos, denominados polieletrólitos, podem ser classificados como aniônicos, catiônicos, não iônicos. Pesquisas sobre o comportamento destes compostos têm mostrado que é possível a desestabilização de colóides carregados negativamente por ambos tipos de polímeros, catiônico e aniônico. Desta forma, nem o mecanismo de compressão da camada difusa e nem o de adsorção-neutralização podem ser considerados para caracterizar este mecanismo (DI BERNARDO, 1993).

AMIRTHARAJAH \& MILLS (1982) desenvolveram um diagrama de coagulação com sulfato de alumínio, apresentado na Figura 3.3, no qual são delimitadas as regiões em que ocorrem os três mecanismos de coagulação (compressão da camada difusa, adsorção-neutralização de cargas e varredura). Pode-se observar a influência do $\mathrm{pH}$ e da dosagem de coagulante na formação de espécies hidrolisadas de alumínio na definição do mecanismo de coagulação, ressaltando-se que a qualidade da água bruta exerce grande influência na delimitação destas regiões.

Quando utiliza-se um coagulante a base de ferro, o comportamento é bastante distinto comparado ao de alumínio, por exemplo, o cloreto férrico apresenta faixa de $\mathrm{pH}$ de coagulação mais ampla do que a do sulfato de alumínio (DI BERNARDO, 2003). 


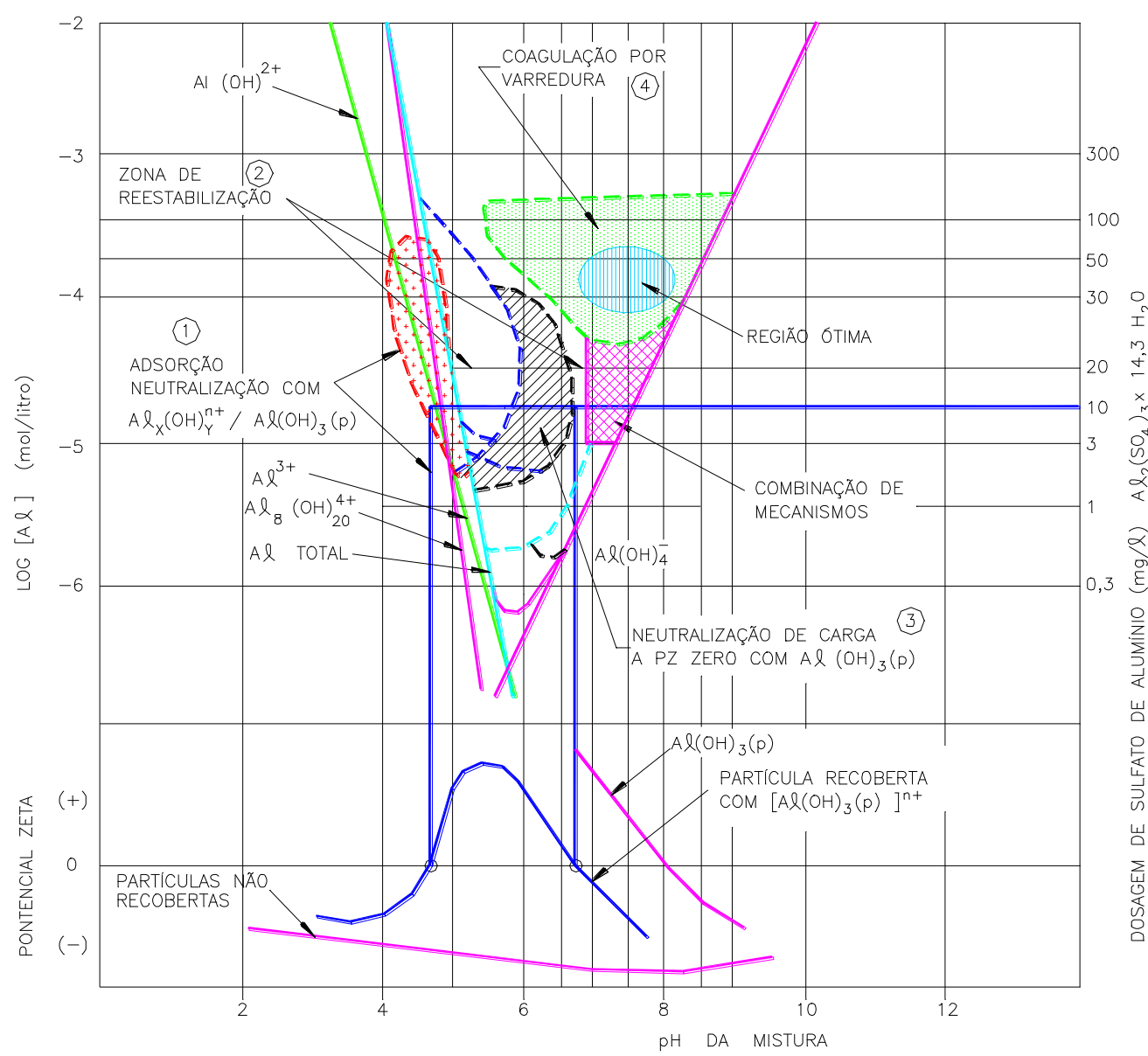

Figura 3.3 - Diagrama de coagulação com sulfato de alumínio. Fonte: AMIRTHARAJAH \& MILLS (1982).

Grande ênfase tem sido dada à remoção de matéria orgânica natural por coagulação química, uma vez que ela pode ser precursora da formação de subprodutos indesejáveis da desinfecção. Desta maneira, deve-se conciliar a remoção de turbidez, que constitui objetivo tradicional da coagulação realizada nas estações de tratamento de água, com a remoção de matéria orgânica natural, o que exige o emprego de maiores dosagens de coagulante, podendo inviabilizar o uso da filtração direta.

Quando a água bruta apresenta cor elevada, o tratamento por coagulação pode ser auxiliado pelo processo de oxidação química, o que deve permitir a redução da dosagem de coagulante empregada na ETA. No entanto, deve-se evitar o uso de cloro para oxidar a cor decorrente de matéria orgânica natural, pois os compostos resultantes podem ser potencialmente prejudiciais à saúde. O cloro pode ser utilizado em combinação com amônia (amoniocloração) ou na forma de 
dióxido de cloro, os quais reduzem o risco de formação de subprodutos indesejados. Em todas as situações deve-se monitorar a formação de subprodutos (DI BERNARDO, 2003).

\subsubsection{Filtração Direta Ascendente}

Quando as características da água bruta forem favoráveis ao uso de filtração direta ascendente, ela apresenta vantagens em relação ao tratamento em ciclo completo utilizado na maioria das estações de tratamento de água no Brasil, destacando-se: redução das dimensões da estação de tratamento com a eliminação das unidades de floculação e decantação; redução da quantidade de coagulante utilizado; filtração no sentido do grão maior para o menor, em camada simples de areia, utilizando a altura total da camada para a retenção de impurezas, ao contrário do que acontece nos filtros convencionais de escoamento descendente; redução na perda de carga durante a filtração devido à remoção de uma quantidade substancial de impurezas na porção do meio filtrante de maior granulometria (DI BERNARDO, 1993).

Com o desenvolvimento de pesquisas realizadas utilizando-se a filtração direta ascendente, constatou-se que grande quantidade de impurezas era retida na camada suporte, de difícil remoção durante a lavagem, portanto optou-se por fazer a drenagem do filtro por meio de descargas de fundo, antes do início da lavagem. Essa situação que a princípio, configurava um problema, deu origem a uma das mais importantes alterações nessa tecnologia de tratamento, que é a filtração direta ascendente com descargas de fundo intermediárias (DI BERNARDO, 1993).

A camada suporte desempenha um papel de grande importância na filtração direta ascendente, sendo responsável pelo processo de floculação e pela remoção de grande parte dos sólidos presentes no afluente (MENDES (1985); PATERNIANI (1986); TEIXEIRA (1986); CRUZ VELEZ (1993); LARA PINTO (1994); ISAAC (1997); CASTILLA MIRANDA (1997)).

PATERNIANI (1986) estudou a influência de descargas de fundo na eficiência da remoção de microrganismos e concluiu que, quanto maior for 0 número mais provável (NMP) de coliformes totais por $100 \mathrm{~mL}$ do afluente, pior resulta a qualidade bacteriológica do efluente produzido, independente da realização das descargas de fundo. O autor recomenda que, quando houver descargas de fundo, a água filtrada seja descartada imediatamente após a 
realização das mesmas, por um período de pelo menos 30 minutos, devido à grande quantidade de microrganismos presentes.

A produção de efluente com turbidez ou cor verdadeira baixa, depende da eficiência da coagulação. Quanto maior a turbidez ou a cor verdadeira da água bruta, maior será a dosagem de coagulante e, portanto, mais acentuada a taxa de crescimento de perda de carga, com menor duração da carreira de filtração.

Segundo MENDES (1985), para otimizar o desempenho do processo de filtração direta ascendente é necessário reduzir em pelo menos $25 \%$ a dosagem ótima de sulfato de alumínio utilizada em estações de tratamento convencional.

Para a determinação das dosagens de coagulante em reatores estáticos, GUSMÃO (2001) utilizou filtros de laboratório de areia, sendo mais apropriados do que os filtros de papel, uma vez que o meio filtrante apresentou maior sensibilidade à variação da dosagem do coagulante permitindo indicação mais precisa da melhor dosagem do coagulante.

Muitos trabalhos foram desenvolvidos nos últimos vinte anos, na Escola de Engenharia de São Carlos - Universidade de São Paulo (EESC - USP), sobre a filtração direta ascendente. Baseando-se nestes trabalhos DI BERNARDO \& ISAAC (2001) sugerem alguns parâmetros de projeto e operação para a filtração direta ascendente, apresentados na Tabela 3.3.

Tabela 3.3 - Parâmetros sugeridos para projeto e operação da Filtração Direta Ascendente.

\begin{tabular}{|c|c|}
\hline \multicolumn{2}{|c|}{ Características da Água Bruta } \\
\hline Parâmetro & Condição \\
\hline Turbidez (uT) & $\begin{array}{r}90 \% \text { do tempo menor que } 25 \\
95 \% \text { do tempo menor que } 50 \\
100 \% \text { do tempo menor que } 100 \\
\end{array}$ \\
\hline Cor Verdadeira $(\mathrm{uH})$ & $\begin{array}{r}90 \% \text { do tempo menor que } 20 \\
95 \% \text { do tempo menor que } 50 \\
100 \% \text { do tempo menor que } 100 \\
\end{array}$ \\
\hline $\mathrm{DBO}_{5}(\mathrm{mg} / \mathrm{L})$ & $<5$ \\
\hline Coliformes totais (UFC/100 mL) & $<5000$ \\
\hline E. coli (UFC/100 mL) & $<1000$ \\
\hline Carbono orgânico total (mg/L) & $<2$ \\
\hline Concentração algal (UPA/mL) & $<500$ \\
\hline \multicolumn{2}{|c|}{ Parâmetros de Projeto e Operação } \\
\hline $\begin{array}{l}\text { Taxa de filtração }\left(\mathrm{m}^{3} / \mathrm{m}^{2} \mathrm{~d}\right) \\
\text { Número de descargas de fundo intermediárias (DFIs) } \\
\text { durante a carreira de filtração }\end{array}$ & $\begin{array}{c}120-240 \\
\geq 1\end{array}$ \\
\hline $\begin{array}{l}\text { Taxa de aplicação de água na interface areia } \\
\text { pedregulho durante as DFIs }\left(\mathrm{m}^{3} / \mathrm{m}^{2} \mathrm{~d}\right)\end{array}$ & $\geq 600$ \\
\hline
\end{tabular}

Fonte: adaptado de DI BERNARDO \& ISAAC (2001). 


\subsubsection{Dupla Filtração}

A dupla filtração consiste na filtração direta ascendente, recebendo água coagulada no mecanismo de neutralização de cargas, seguida da filtração descendente, cuja finalidade é reter as impurezas presentes no efluente da primeira etapa. Como o efluente do filtro ascendente não necessita apresentar turbidez inferior a 1 uT, a espessura da camada de areia pode ser menor, e a granulometria e a taxa de filtração podem ser maiores que as utilizadas na tecnologia de filtração direta ascendente. DI BERNARDO (1993) recomenda que tais unidades sejam projetadas de modo a possibilitar a realização de descargas de fundo intermediárias com introdução de água na interface pedregulho-areia.

O emprego do filtro com escoamento descendente após a filtração ascendente pode ser a solução adequada quando a qualidade microbiológica da água bruta não for apropriada ou quando houver suspeita da presença de outros organismos como o vibrião da cólera, a cercária da esquistossomose, protozoários e outros organismos.

Ao estudar a filtração direta ascendente em pedregulho como prétratamento à filtração rápida descendente, MEGDA (1999) concluiu que a eficiência global da instalação de dupla filtração foi relativamente alta quanto à remoção de turbidez, cor aparente, ferro e coliformes totais - em geral, a turbidez do efluente final foi sempre inferior a $1 \mathrm{uT}$, a cor aparente menor que $5 \mathrm{uH}$, o teor de ferro inferior a $0,1 \mathrm{mg} / \mathrm{L}$ e o NMP de coliformes totais menor que $5 \mathrm{ufc} / 100 \mathrm{~mL}$.

Segundo DI BERNARDO (1993), existem no norte e nordeste do Brasil estações de tratamento de água utilizando a filtração direta ascendente que encontram-se funcionando satisfatoriamente. Apesar disso, seria recomendável a dupla filtração sempre que a qualidade da água bruta não atenda às condições sugeridas na Tabela 3.3, mas sim à Tabela 3.4, onde estão indicados os parâmetros de projeto para a dupla filtração. 
Tabela 3.4 - Parâmetros sugeridos para projeto e operação da Dupla Filtração.

\begin{tabular}{|c|c|c|}
\hline \multicolumn{3}{|c|}{ Características da Água Bruta } \\
\hline \multirow[t]{2}{*}{ Parâmetro } & \multicolumn{2}{|c|}{ Condição } \\
\hline & Areia grossa & Pedregulho \\
\hline Turbidez (uT) & $\begin{array}{c}90 \% \text { do tempo }<50 \\
95 \% \text { do tempo }<100 \\
100 \% \text { do tempo }<150 \\
\end{array}$ & $\begin{array}{r}90 \% \text { do tempo }<100 \\
95 \% \text { do tempo }<150 \\
100 \% \text { do tempo }<200\end{array}$ \\
\hline Cor Verdadeira $(\mathrm{uH})$ & $\begin{array}{c}90 \% \text { do tempo }<50 \\
95 \% \text { do tempo }<100 \\
100 \% \text { do tempo }<150 \\
\end{array}$ & $\begin{array}{c}90 \% \text { do tempo }<100 \\
95 \% \text { do tempo }<150 \\
100 \% \text { do tempo }<200\end{array}$ \\
\hline $\mathrm{DBO}_{5}(\mathrm{mg} / \mathrm{L})$ & $<10$ & $<10$ \\
\hline Coliformes totais (UFC/100 mL) & $<20000$ & $<20000$ \\
\hline E. coli (UFC/100 mL) & $<5000$ & $<5000$ \\
\hline Carbono orgânico total (mg/L) & $<5$ & $<52$ \\
\hline Concentração algal (UPA/mL) & $<2000$ & $<2000$ \\
\hline \multicolumn{3}{|c|}{ Parâmetros de Projeto e Operação } \\
\hline $\begin{array}{l}\text { Taxa de filtração no filtro ascendente } \\
\left(\mathrm{m}^{3} / \mathrm{m}^{2} \mathrm{~d}\right)\end{array}$ & $120-240$ & $24-144$ \\
\hline $\begin{array}{l}\text { Taxa de filtração no filtro ascendente } \\
\left(\mathrm{m}^{3} / \mathrm{m}^{2} \mathrm{~d}\right)\end{array}$ & $200-400$ & $200-400$ \\
\hline $\begin{array}{l}\text { Número de descargas de fundo } \\
\text { intermediárias (DFIs) durante a } \\
\text { carreira de filtração }\end{array}$ & $\geq 4$ & $\geq 4$ \\
\hline $\begin{array}{l}\text { Taxa de aplicação de água na } \\
\text { interface areia pedregulho durante as } \\
\text { DFls }\left(\mathrm{m}^{3} / \mathrm{m}^{2} \mathrm{~d}\right)\end{array}$ & $\geq 600$ & $\geq 600$ \\
\hline
\end{tabular}

Fonte: adaptado de DI BERNARDO \& ISAAC (2001), DI BERNARDO (2003).

GUSMÃO (2001) avaliou dois sistemas de dupla filtração, um de filtração direta ascendente em areia seguida de filtração rápida descendente (sistema 01), e outro de filtração direta ascendente em pedregulho seguida de filtração rápida descendente (sistema 02), variando as taxas na filtração ascendente, de 200 a 360 $\mathrm{m}^{3} / \mathrm{m}^{2}$ dia (em areia) e de 80 a $190 \mathrm{~m}^{3} / \mathrm{m}^{2}$ dia (em pedregulho) e na filtração rápida descendente de 115 a $480 \mathrm{~m}^{3} / \mathrm{m}^{2}$ dia. No sistema 02 , o crescimento da perda de carga no meio granular foi menos intenso na unidade de filtração ascendente do que no filtro rápido descendente, ocorrendo o inverso no sistema 01 , no qual, em alguns ensaios, o filtro rápido descendente mostrou-se desnecessário em função da qualidade da água efluente do filtro ascendente. Em alguns casos, a floculação predominou na unidade de filtração direta ascendente em pedregulho, prejudicando a qualidade do seu efluente.

SALDANHA (2002) avaliou um sistema de dupla filtração em escala real, Estação de Tratamento de Água de São Carlos (ETA II), composta de três unidades de dupla filtração que funcionam em paralelo, a qual trata água bruta proveniente 
do Ribeirão do Feijão. O material filtrante foi caracterizado e foram verificadas as condições operacionais da ETA II, definindo-se e acompanhando-se os principais problemas. Após esta etapa, foi realizada uma comparação da ETA em escala real com a escala piloto. Os resultados mostraram que a ETA II apresentou baixa produção efetiva de água e qualidade do efluente muitas vezes insatisfatória decorrente principalmente da existência de caminhos preferenciais e falta de material filtrante, confirmando, portanto, a importância da distribuição e da dosagem adequada de coagulante, bem como, a necessidade da qualificação dos operadores, evitando a ocorrência de problemas operacionais.

DE PAULA (2003) estudou em instalação piloto de dupla filtração com filtro ascendente em areia grossa e filtro descendente em areia, combinações de taxas de filtração variando de 120 a $360 \mathrm{~m}^{3} / \mathrm{m}^{2} \mathrm{~d}$ no ascendente e de 200 a $400 \mathrm{~m}^{3} / \mathrm{m}^{2} \mathrm{~d}$ no descendente, com simulação de um pico de turbidez de curta duração da ordem de 380 uT para as taxas de filtração de $160 \mathrm{~m}^{3} / \mathrm{m}^{2} \mathrm{~d}$ no filtro ascendente e de 300 $\mathrm{m}^{3} / \mathrm{m}^{2} \mathrm{~d}$ no filtro descendente. A turbidez resultante nos efluentes dos filtros apresentou-se menor que 1,0 uT nas 19 horas de duração da carreira de filtração. Um sistema de dupla filtração, com filtro ascendente de pedregulho e filtro descendente de areia foi operado em paralelo a este sistema, por KURODA (2002), com variações de taxas de filtração no filtro ascendente de 60 a $240 \mathrm{~m}^{3} / \mathrm{m}^{2} \mathrm{~d}$ e no filtro descendente de 100 a $240 \mathrm{~m}^{3} / \mathrm{m}^{2} \mathrm{~d}$. O método de descargas de fundo intermediárias com esvaziamento total do filtro apresentou mais eficiência na recuperação da carga hidráulica, comparado ao método em que o esvaziamento se dava até o topo do meio filtrante. Para os dois sistemas, o efluente final apresentou valores dentro dos limites de potabilidade permissíveis pela Portaria 1469/2000.

BENINI (2003) utilizou a mesma instalação piloto de dupla filtração de KURODA (2002) para estudar a remoção de substâncias húmicas de água com cor verdadeira de 90 a $110 \mathrm{uH}$, turbidez $\leq 15 \mathrm{uT}, \mathrm{pH} \cong 6,5$; alcalinidade $\cong 9 \mathrm{mg} / \mathrm{LCaCO}_{3}$. Os resultados obtidos, em termos de absorvância 254 nm (89,1 a 93,6\%), cor aparente no efluente do filtro descendente (na maioria dos ensaios, apresentou valor $\leq 1 \mathrm{uH})$ e remoção de COD (27,5 a 48,7\%), foram satisfatórios.

WIECHETECK et al. (2004) compararam a eficiência de remoção de substâncias húmicas de água proveniente de manancial superficial com adição de extrato de substâncias húmicas (água de estudo), utilizando dois sistemas de dupla filtração em paralelo, um com filtro ascendente de areia grossa (sistema 1) e outro com filtro ascendente de pedregulho (sistema 2), ambos com filtros descendentes 
de areia independentes. Os dois sistemas foram comparados com relação à produção efetiva de água filtrada utilizando taxas de filtração que variaram de 80 , 120 e $180 \mathrm{~m}^{3} / \mathrm{m}^{2} \mathrm{~d}$ nos filtros ascendentes e de 80,120,150,160, 180, 200, 240 e $280 \mathrm{~m} / \mathrm{m}^{2} \mathrm{~d}$ nos filtros descendentes. A água de estudo apresentou as seguintes características: $\mathrm{pH}=6,14$ a 7,45; temperatura $=17$ a $26^{\circ} \mathrm{C}$; alcalinidade $=7,04 \mathrm{a}$ $19,36 \mathrm{mg} / \mathrm{L} \mathrm{CaCO}_{3}$; cor verdadeira = 76 a $133 \mathrm{uH}$, cor aparente = 168 a $366 \mathrm{uH}$; turbidez = 8,8 a 25 uT, absorvância $254 \mathrm{~nm}=0,144$ a 0,225 $\mathrm{cm}^{-1}$ e COD =2,808 a 5,375 mg/L. A remoção de substâncias húmicas em termos de absorvância 254 nm foi eficiente, em média de $93 \%$ nos dois sistemas, quanto ao COD, as melhores eficiências obtidas foram de $53,7 \%$ no sistema 1 e de $48,7 \%$ no sistema 2 . As melhores produções efetivas obtidas foram de $95,4 \%$ no sistema 1 , para a combinação de taxas de filtração de 120 e $240 \mathrm{~m}^{3} / \mathrm{m}^{2} \mathrm{~d}$; e de $97,4 \%$ no sistema 2 , para as taxas de filtração de 80 e $150 \mathrm{~m}^{3} / \mathrm{m}^{2} \mathrm{~d}$, nos filtros ascendentes e descendentes respectivamente.

DI BERNARDO (2004) estudou o desempenho de dois sistemas de dupla filtração, sendo um constituído de filtro ascendente de areia grossa e filtro descendente de areia (sistema 1) e outro de filtro ascendente de pedregulho e filtro descendente de areia (sistema 2), nos quais foi realizada investigação experimental com águas de estudo preparadas com caulinita, dois tipos de água, água tipo I com turbidez em torno de 100 uT e água tipo II com turbidez em torno de 300 uT. O coagulante utilizado foi o sulfato de alumínio, não necessitando o uso de acidificante ou alcalinizante. Foram variadas as taxas de filtração nos filtros ascendentes e descendentes, em 120 a $240 \mathrm{~m}^{3} / \mathrm{m}^{2} \mathrm{~d}$ e 180 a $300 \mathrm{~m}^{3} / \mathrm{m}^{2} \mathrm{~d}$, respectivamente. Os ensaios foram feitos com e sem descargas de fundo intermediárias (DFIs) nos filtros ascendentes. A principal conclusão do trabalho foi que os dois sistemas foram capazes de produzir água filtrada com turbidez consistentemente menor que 0,5 uT e que a produção efetiva de água depende da turbidez da água de estudo, das taxas de filtração, da execução das DFls e da carga hidráulica disponível para a retenção de sólidos. 


\subsection{Considerações Finais}

A revisão bibliográfica evidenciou que o entendimento dos mecanismos pelos quais as substâncias húmicas interferem nos processos de tratamento de água, e suas propriedades associadas ao transporte, labilidade e complexação de íons metálicos no sistema aquático são relevantes do ponto de vista ambiental. No tratamento de água, as substâncias húmicas podem reagir com o cloro, produzindo compostos orgânicos halogenados. É necessária a remoção de substâncias húmicas da água para que não ocorra a formação destes compostos orgânicos halogenados.

A utilização de diferentes oxidantes como ozônio, peróxido de hidrogênio, peroxônio, dióxido de cloro, permanganato de potássio e outros, pode ser uma alternativa benéfica à saúde humana, com a redução ou não-formação destes compostos orgânicos.

Algumas considerações técnicas associadas ao uso de oxidantes devem ser avaliadas na escolha do oxidante mais apropriado, além é claro do tipo de manancial de abastecimento, superficial ou subterrâneo, que interfere na qualidade da água bruta, e na tecnologia de tratamento de água:

- Formação de trialometanos, compostos orgânicos halogenados: a formação de subprodutos da oxidação depende da concentração e dos tipos de precursores presentes na água;

- Formação de subprodutos inorgânicos: clorato, clorito e brometo associados com dióxido de cloro e ozônio;

- Necessidade de qualificação e habilidade dos operadores com relação ao manuseio e à aplicação dos oxidantes.

Os avanços obtidos sobre a aplicabilidade da dupla filtração, com os estudos realizados na EESC - USP com relação à remoção de turbidez, apresentados por MEGDA (1999), GUSMÃO (2001), KURODA (2002), DE PAULA (2003), DI BERNARDO (2004) confirma a potencialidade desta tecnologia de tratamento. No entanto, devem ser conduzidos estudos a respeito da remoção de substâncias húmicas utilizando-se a dupla filtração com a variação do meio fitrante no filtro ascendente, o que foi feito no presente trabalho. BENINI (2003) obteve resultados satisfatórios quanto à eficiência de remoção de substâncias húmicas em instalação piloto de dupla filtração com filtro ascendente de pedregulho. A utilização 
da dupla filtração com filtro ascendente de areia grossa na remoção de substâncias húmicas, a aplicação da pré-oxidação e a formação de subprodutos decorrentes das reações dos oxidantes com a matéria orgânica natural presente na água são avaliados neste trabalho. 


\section{MATERIAIS E MÉTODOS}

Neste capítulo estão descritas as três etapas que compreenderam o trabalho experimental, sendo que cada etapa foi dividida em duas fases, conforme fluxograma da Figura 4.1. São apresentados também uma descrição da instalação piloto utilizada nos ensaios em escoamento contínuo, o funcionamento das unidades componentes do sistema de tratamento de água, as características da água, as freqüências de amostragem, os equipamentos utilizados $e$ as metodologias adotadas, e a forma da análise de dados para cada fase correspondente aos ensaios na instalação piloto.

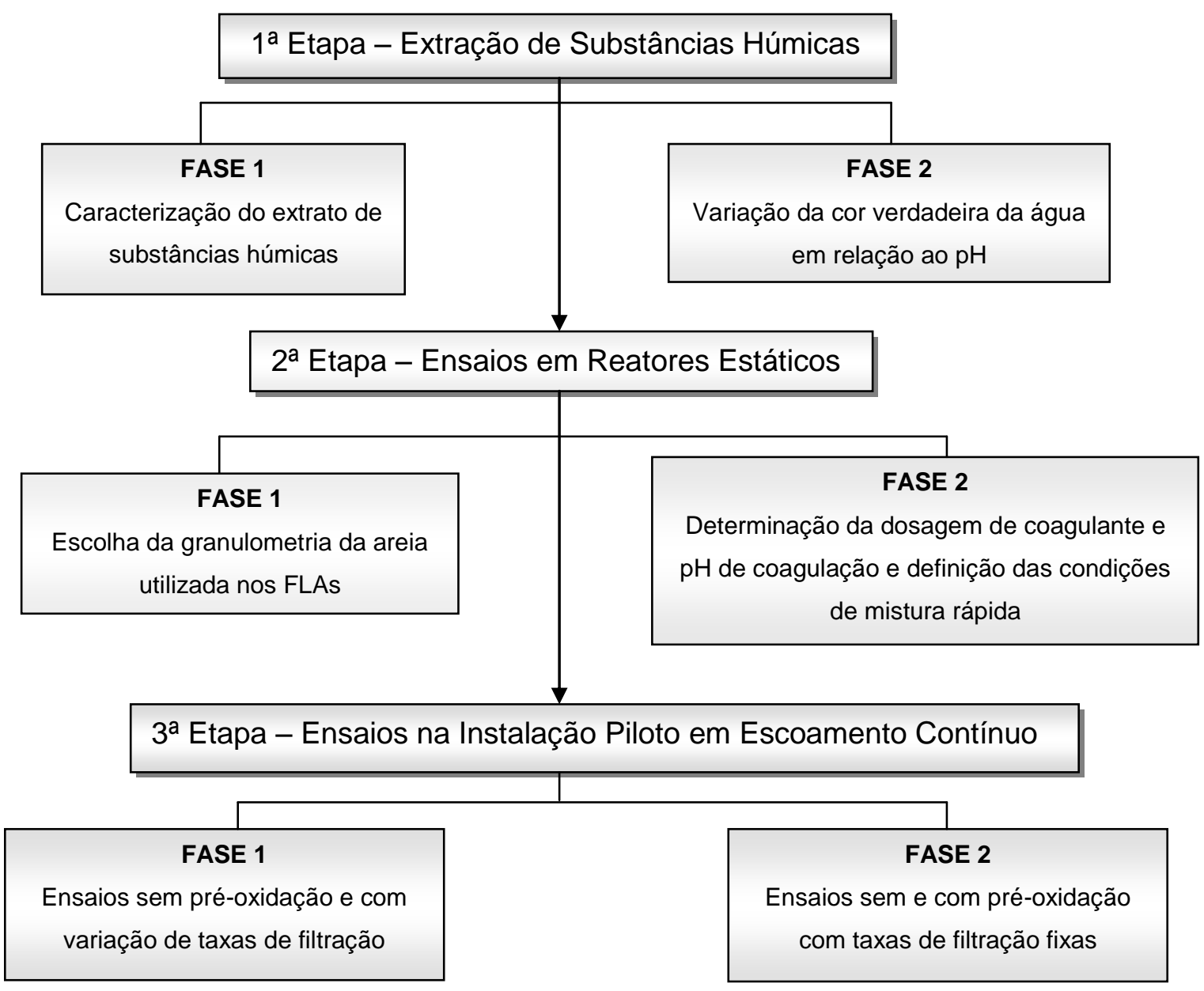

Figura 4.1 - Fluxograma geral das etapas do trabalho experimental. 


\subsection{Extração de Substâncias Húmicas}

As substâncias húmicas foram extraídas de solo turfoso coletado próximo ao Rio Mogi-Guaçu, no município de Luís Antônio (SP). A turfa foi seca à temperatura ambiente, triturada e peneirada.

As extrações foram feitas com soluções de $\mathrm{NaOH}$ na concentração de 0,5 $\mathrm{mol} / \mathrm{L}$, por 4 horas com agitação mecânica e na proporção turfa/extrator 1:20 (m/v), como recomendado por ROSA et al. (2000).

Após a extração, deixava-se a solução em repouso por 48 horas para que os sólidos sedimentassem. O sobrenadante era colocado em papel celofane e amarrado com elástico para submeter à diálise em água proveniente do poço artesiano da EESC-USP, com adição de ácido clorídrico até $\mathrm{pH} \leq 2$, a qual era substituída 3 vezes ao dia, durante 2 dias (ver Figura 4.2).

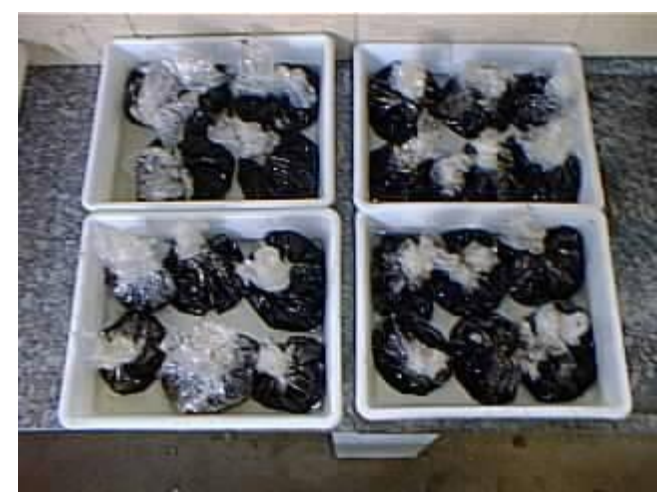

Figura 4.2 - Sacos de celofane amarrados com elástico, contendo o extrato de substâncias húmicas submetidos à diálise.

Para a eliminação de cloretos, o extrato de substâncias húmicas era transferido para a diálise em água do poço da EESC-USP, até que o teste com solução de nitrato de prata apresentasse negativo. Após a extração das substâncias húmicas armazenava-se o extrato em bombonas de $200 \mathrm{~L}$.

\subsubsection{Caracterização do extrato das substâncias húmicas}

Para a caracterização das substâncias húmicas foram liofilizados $200 \mathrm{~mL}$ do extrato em um liofilizador da marca Edwards, modelo F101-02-000. Foram feitas análises elementar, de infravermelho e de ultravioleta visível. Estas análises foram 
feitas por CAMPOS (2004) no Instituto de Química de São Carlos (IQSC). Além destas análises, fez-se também a determinação de metais.

\section{a) Análise Elementar}

As análises químicas elementares das substâncias húmicas foram feitas utilizando-se um aparelho CHNS-O da marca Fisons, EA 1108. As porcentagens dos elementos carbono $(C)$, hidrogênio $(H)$, nitrogênio $(N)$ foram obtidas diretamente e o elemento oxigênio $(O)$ foi obtido por diferença.

\section{b) Análises de Infravermelho (IV)}

O espectrômetro de IV, por transformada de Fourier, utilizado foi da marca Bomem MB-102. Para a análise foram feitas pastilhas do material liofilizado na proporção aproximada de 1:100 (1 mg de amostra e $100 \mathrm{mg} \mathrm{de} \mathrm{KBr}$ ). Foram realizadas 16 varreduras com $4 \mathrm{~cm}^{-1}$ de resolução nos espectros obtidos.

\section{c) Análises de Ultravioleta Visível (UV/Vis)}

Para as análises de UV/Vis foi utilizado um equipamento Hitachi modelo U3501. Foi dissolvida uma pequena quantidade de substâncias húmicas em $10 \mathrm{~mL}$ de solução de $\mathrm{NaHCO}_{3} \quad 0,05 \mathrm{~mol} / \mathrm{L}$ e determinou-se as razões entre as absorvâncias lidas nos comprimentos de onda de 465 e $665 \mathrm{~nm}\left(\mathrm{E}_{4} / \mathrm{E}_{6}\right)$.

\section{d) Análises de Metais}

Estas análises foram feitas no Laboratório de Recursos Hídricos da UNAERP, e o método utilizado foi de espectrofotometria por absorção atômica (APHA et al., 1998), sendo empregado o gerador de hidreto com vapor frio para determinação de arsênio. Para estas análises foi utilizado um equipamento de absorção atômica AA Analist 700, marca Perkin Elmer.

Um volume de $50 \mathrm{~mL}$ de amostra do extrato de substâncias húmicas foi previamente digerido com a adição de porções iguais de ácido nítrico e ácido clorídrico com aquecimento seguido de filtração. O extrato digerido obtido foi aspirado no equipamento de absorção atômica. 


\subsubsection{Variação da cor verdadeira da água em relação ao pH}

Para as leituras de cor verdadeira e cor aparente das amostras da água de estudo foi necessário obter uma curva de leitura no espectrofotômetro UV DR 4000, a partir de soluções diluídas com o extrato de substâncias húmicas. Com o extrato de substâncias húmicas preparou-se uma "solução-mãe" com cor verdadeira equivalente a $500 \mathrm{mg}$ Pt-Co. Esta "solução-mãe" foi diluída até que se obtivessem soluções com cor verdadeira variando de 5; 10;15;20; 30; 40; 50; 75; 100 e 120 uH. Para verificar a variação da cor verdadeira em relação ao $\mathrm{pH}$, estas soluções foram ajustadas para valores de $\mathrm{pH}$ de 4,5; 5,0; 5,5; 6,0; 6,5 e 7,0. Para cada variação de cor e pH foram feitas as leituras de absorvância correspondentes ao comprimento de onda do pico de melhor absorção, após varredura de 400 a 700 $\mathrm{nm}$. Foram obtidas as curvas que relacionam absorvância com cor verdadeira para cada valor de $\mathrm{pH}$.

\subsection{Ensaios em Reatores Estáticos}

Estes ensaios foram realizados em equipamento de jarteste e filtros de laboratório de areia (FLAs) como mostrado na Figura 4.3, e compreendem duas fases nas quais a temperatura da água foi mantida em $20 \pm 1^{\circ} \mathrm{C}$. A água utilizada nestes ensaios era proveniente do Ribeirão do Feijão com adição de extrato de substâncias húmicas até cor verdadeira de 90 a 110 uH.

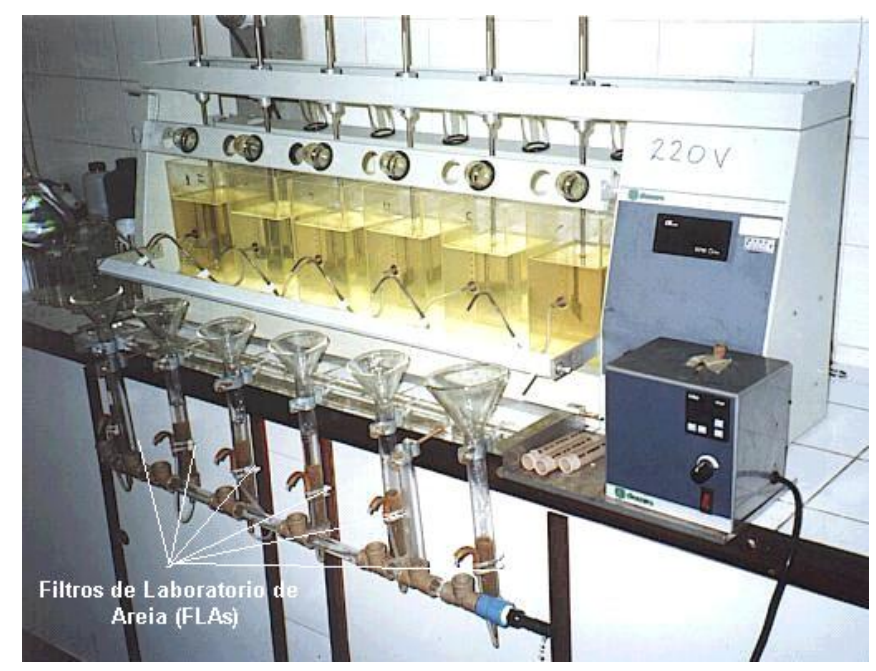

Figura 4.3 - Foto do equipamento de jarteste e filtros de laboratório de areia (FLAs). 


\subsubsection{Escolha da granulometria da areia utilizada nos FLAs}

Para a escolha da granulometria da areia dos FLAs foram utilizados três tipos de areia variando-se a faixa granulométrica de 0,30 a 0,59 mm (Tipo 1); 0,42 a 0,84 mm (Tipo 2) e 0,59 a 1,41 mm (Tipo 3). Nestes ensaios fixou-se o gradiente de velocidade $\left(G_{m r}\right)$ em $1000 \mathrm{~s}^{-1}$ e o tempo de mistura rápida $\left(T_{\mathrm{mr}}\right)$ em $25 \mathrm{~s}$ e variou-se a dosagem de coagulante $\left(\mathrm{Al}_{2}\left(\mathrm{SO}_{4}\right)_{3} .14,3 \mathrm{H}_{2} \mathrm{O}\right)$ em 5, 10, 15, 20, 25 e $30 \mathrm{mg} / \mathrm{L}$, o pH de coagulação de 6,36 a 6,99 e o tipo de areia dos FLAs. Após a escolha da granulometria da areia dos FLAs em que obteve-se menores resultados de cor aparente remanescente, procedeu-se aos ensaios para a determinação da dosagem do coagulante e pH de coagulação.

\subsubsection{Determinação da dosagem de coagulante e pH de coagulação e definição das condições de mistura rápida}

Nesta fase, foi fixada a dosagem de coagulante e variado $\mathrm{o} \mathrm{pH}$ de coagulação e vice-versa, até que se obtivesse um par de valores que apresentasse menores resultados de cor remanescente nos FLAs.

A definição das condições de mistura rápida foi feita variando-se o gradiente de velocidade $\left(500,750\right.$ e $\left.1000 \mathrm{~s}^{-1}\right)$ e o tempo de mistura rápida $(15,20,25,30,35$ e 40 s), até que se obtivesse um gradiente de velocidade que apresentasse menor variação na remoção de cor remanescente nos FLAs, em relação ao tempo de mistura rápida. Esta determinação foi importante devido às diferentes taxas de filtração que foram utilizadas nos ensaios na instalação piloto em escoamento contínuo, que alteravam o tempo de mistura rápida resultante nos diferentes ensaios em função da taxa de filtração adotada.

\subsection{Ensaios na Instalação Piloto em Escoamento Contínuo}

\subsubsection{Descrição Geral da Instalação Piloto}

A instalação piloto utilizada nos ensaios experimentais foi montada nas dependências da Estação de Tratamento de Água de São Carlos II (ETA II). A água de estudo era proveniente do Ribeirão do Feijão com adição de extrato de substâncias húmicas. Na Figura 4.4 está a foto da instalação piloto. 


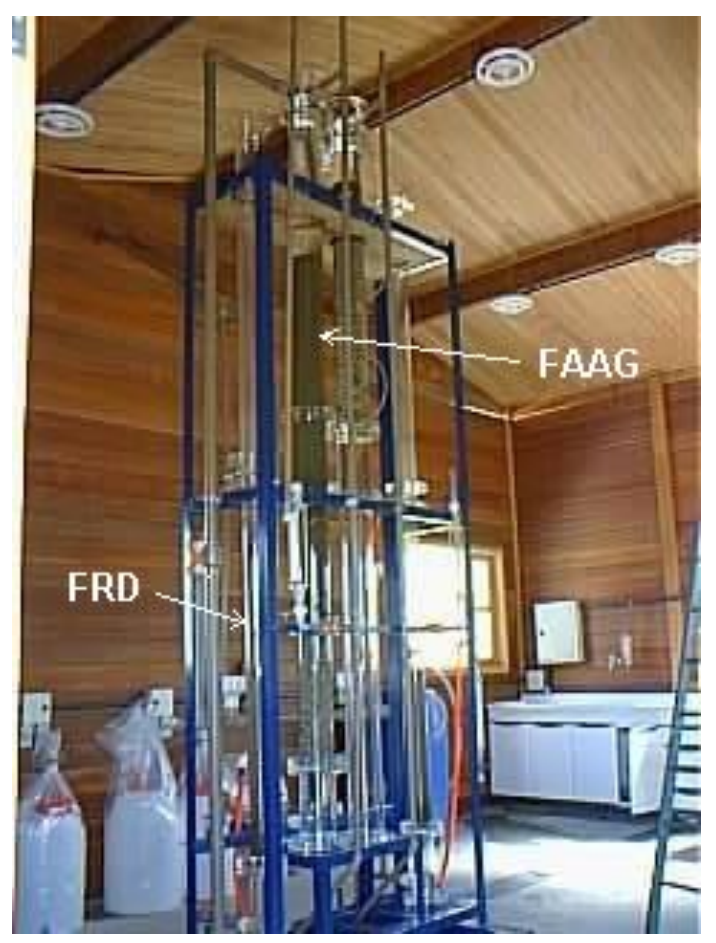

Figura 4.4 - Foto da instalação piloto.

Basicamente, a instalação piloto era constituída de: sistema de dupla filtração, com filtro ascendente de areia grossa (FAAG) e filtro descendente (FRD) com camada única de areia; bomba centrífuga instalada no reservatório de armazenamento de água bruta da ETA II; caixa de nível constante; caixa de homogeneização com agitador para mistura da solução diluída do extrato de substâncias húmicas (Figura 4.10); caixa de mistura rápida; tacômetro digital com sensor acoplado na paleta do agitador mecânico, para controle do gradiente de velocidade da mistura rápida; gerador de ozônio; coluna de ozonização; tanques providos de bomba dosadora e agitador para dosagem e mistura das soluções de coagulante, do extrato de substâncias húmicas, de acidificante e oxidantes; tubulações individuais para alimentação do sistema de dupla filtração; medidores de vazão (rotâmetros); filtro de laboratório de areia (FLA) para ajuste da dosagem de coagulante e pH de coagulação; turbidímetros de escoamento contínuo (Figura 4.7) e placa de aquisição de dados em microcomputador; quadros de piezômetros para medidas de perda de carga ao longo do meio granular dos filtros ascendente e descendente; sistema de lavagem de filtros incluindo reservatório de armazenamento de água, bomba centrífuga e compressor de ar. Na Figura 4.5 está apresentado um esquema da instalação piloto. 


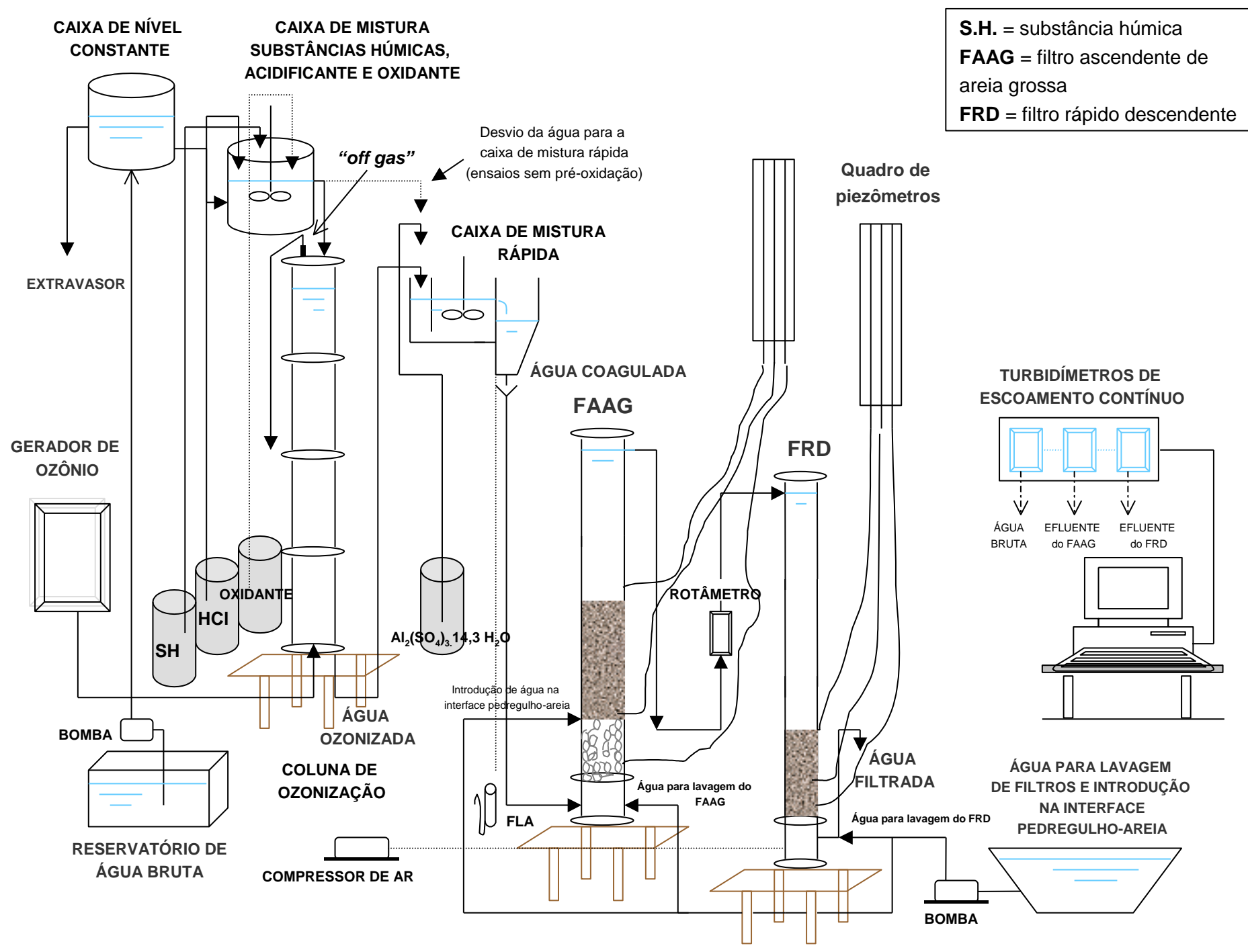

Figura 4.5 - Esquema da Instalação piloto. 
A água bruta era bombeada do reservatório de armazenamento para a caixa de nível constante, em seguida, para a caixa de homogeneização com agitador, na qual eram adicionados o extrato de substâncias húmicas, as soluções do acidificante $(\mathrm{HCl})$ e dos oxidantes (quando utilizados). Após a caixa de homogeneização, a água era encaminhada para a câmara de mistura rápida onde era adicionada a solução de coagulante. Nos ensaios com pré-oxidação, antes da caixa de mistura rápida, a água passava pela coluna de ozonização, que servia como câmara de contato. Finalmente a água de estudo (com cor verdadeira de $90 \mathrm{a}$ $110 \mathrm{uH}$ ), pré-oxidada (quando utilizada a pré-oxidação) e coagulada era encaminhada ao sistema de dupla filtração.

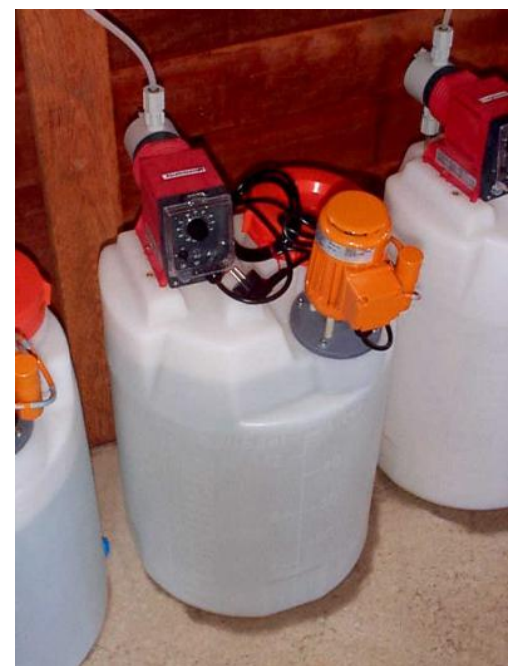

Figura 4.6 - Tanques com agitador para o preparo das soluções de coagulante, de extrato de substâncias húmicas, de acidificante e de oxidantes.

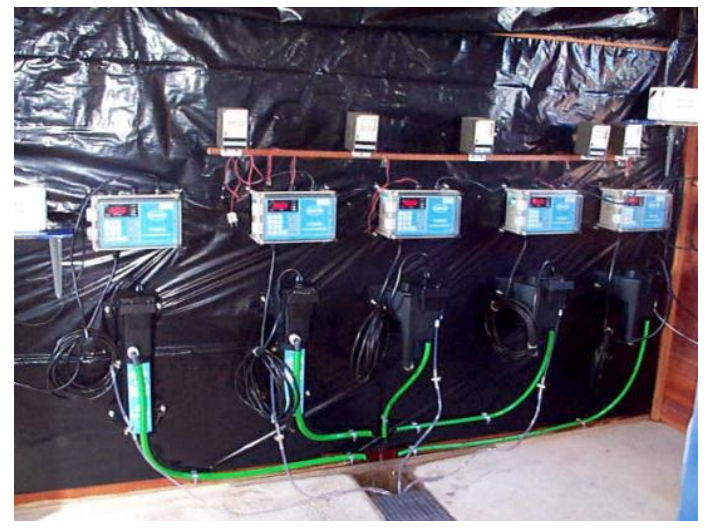

Figura $4.7-$ Turbidímetros de escoamento contínuo (modelo $1720 \mathrm{C}-$ $\mathrm{HACH}$ ) 
A caixa de nível constante era de PVC e constituída de tubulação de entrada da água bruta, extravasor de água central, o qual mantinha o nível de água constante na caixa, e tubulação roscável de saída da água bruta para a caixa de homogeneização de substâncias húmicas com vazão ajustada por meio de um "cap" com orifício central. Conhecendo-se o diâmetro do orifício do "cap" e a vazão de água necessária, determinava-se a altura da lâmina d'água sobre o orifício, pela equação (4.1):

$Q=C d^{*} A * \sqrt{2 * g * h} \Rightarrow h=\frac{Q^{2}}{C d^{2 *} A^{2 *} 2^{*} g}$

em que:

$\mathrm{Q}=$ vazão desejada $\left(\mathrm{m}^{3} / \mathrm{s}\right)$;

$\mathrm{Cd}=$ coeficiente de descarga $(\mathrm{Cd}=0,60)$;

$A=$ área do orifício $\left(\mathrm{m}^{2}\right)$;

$\mathrm{g}=$ aceleração da gravidade $\left(\mathrm{g}=9,81 \mathrm{~m} / \mathrm{s}^{2}\right)$;

$\mathrm{h}=$ altura da lâmina líquida sobre o orifício $(\mathrm{m})$.

Nas Figuras 4.8 e 4.9 estão apresentados respectivamente, o esquema e a foto da caixa de nível constante.

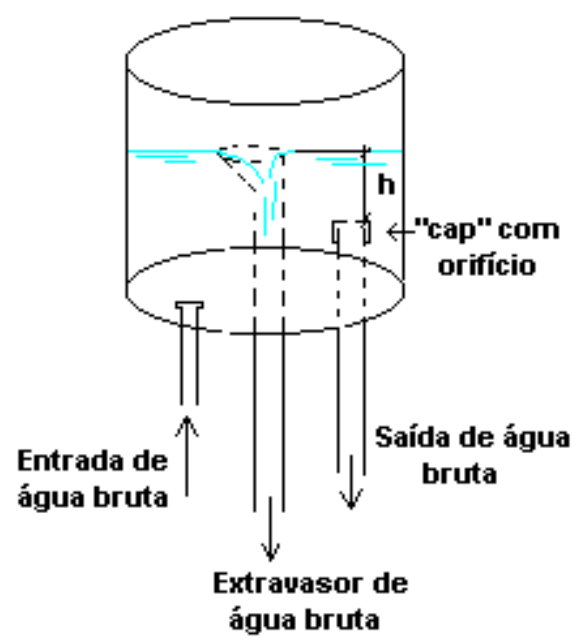

Figura 4.8 - Esquema da caixa de nível constante

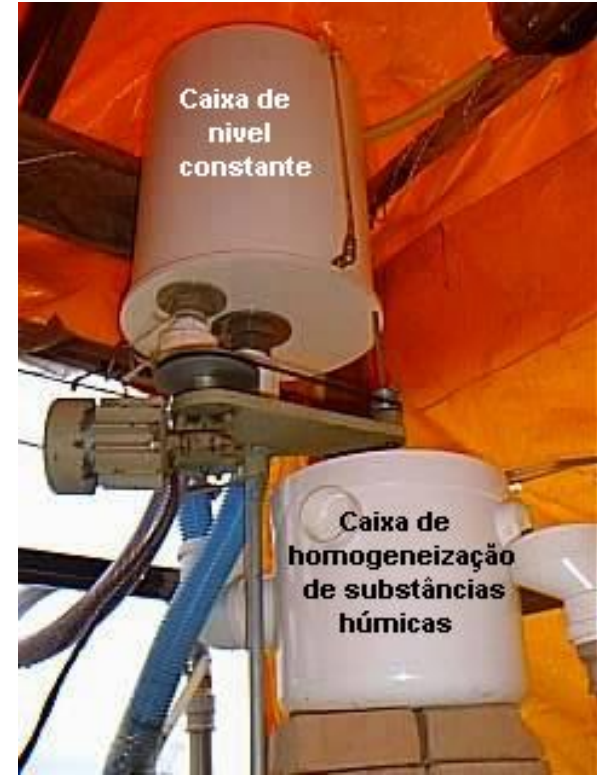

Figura 4.9 - Foto da caixa de nível constante e da caixa de homogeneização de substâncias húmicas. 
A caixa de homogeneização de substâncias húmicas era de PVC e constituída de entrada de água bruta (proveniente da caixa de nível constante), saída da água de estudo (água bruta + extrato de substâncias húmicas) e agitador mecânico com paleta giratória com dois braços. O extrato de substâncias húmicas era adicionado por meio de mangueira e bomba dosadora. Na Figura 4.10 está mostrada uma foto da caixa de homogeneização.

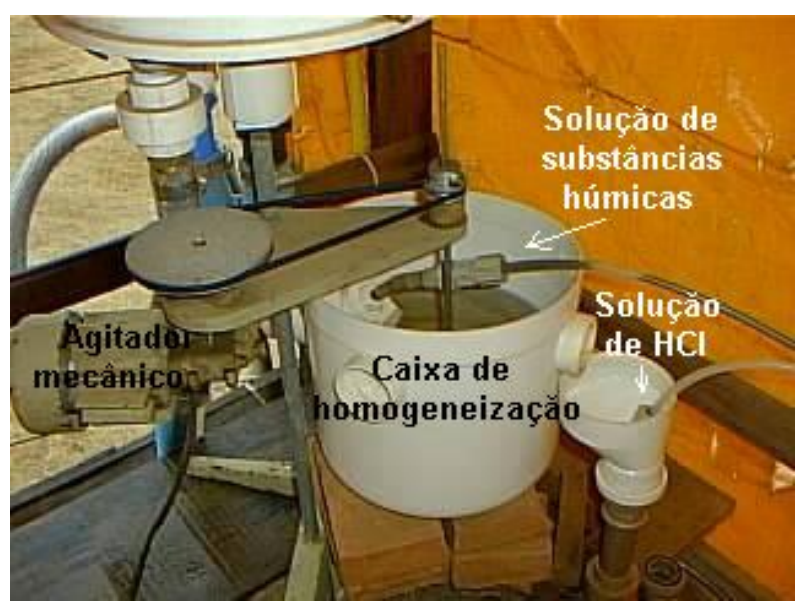

Figura 4.10 - Caixa de homogeneização da solução diluída de extrato de substâncias húmicas e agitador mecânico.

Na saída da caixa de homogeneização era adicionada a solução de acidificante ( $\mathrm{HCl}$ 0,07 M) e de oxidante (quando utilizado).

A caixa de mistura rápida era de acrílico e possuía as mesmas dimensões do jarro do equipamento de jarteste. Era dividida em dois compartimentos por uma placa de acrílico com orifícios. No primeiro compartimento, era adicionada a solução de coagulante por meio de mangueira e bomba dosadora, a mistura era feita com um agitador mecânico com paleta giratória. Junto à paleta havia um sensor que transmitia a rotação por minuto para um tacômetro digital, para controle do gradiente de velocidade na mistura rápida. O segundo compartimento era constituído de extravasor central, o qual mantinha o nível de água constante, e tubulação roscável de saída de água para o sistema de dupla filtração. No topo da tubulação de saída de água foi colocado um "cap" com orifício no qual era ajustada a lâmina d'água sobre o orifício e conseqüentemente a vazão requerida, da mesma forma como na caixa de nível constante. Nas Figuras 4.11 e 4.12 estão mostradas as fotos da caixa de mistura rápida (vista lateral) e do sistema de ajuste de vazão. 


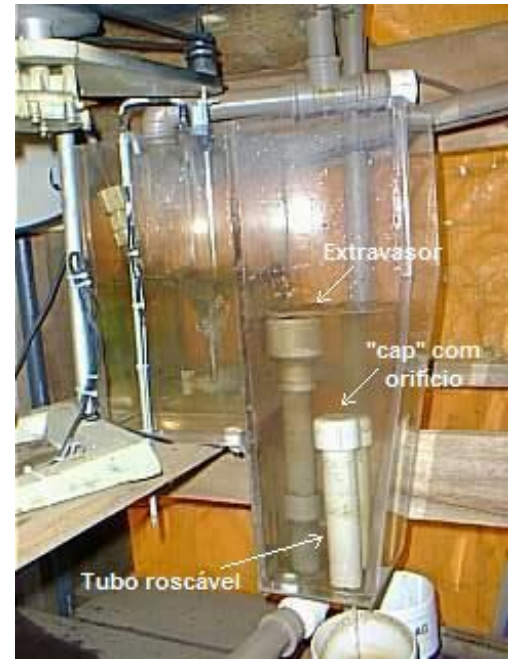

Figura 4.11 - Vista lateral da caixa de mistura rápida.

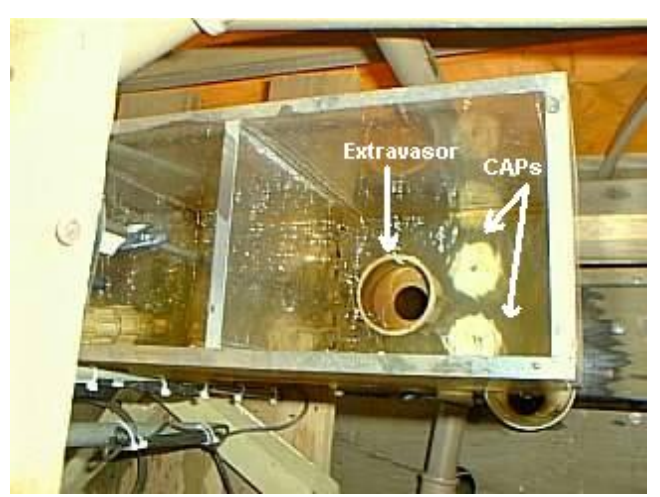

Figura 4.12 - Sistema de ajuste de vazão de água coagulada.

O FAAG possuía diâmetro externo de $153 \mathrm{~mm}$ e interno de $141 \mathrm{~mm}$ e o FRD possuía diâmetro externo de $100 \mathrm{~mm}$ e interno de $91,4 \mathrm{~mm}$, ambos construídos em acrílico transparente. A tubulação de alimentação do FAAG possuía desvio da água coagulada para o FLA, para os ajustes da dosagem de coagulante e do $\mathrm{pH}$ de coagulação. Uma vez constatada a condição desejável de coagulação, a água coagulada entrava pela parte inferior do FAAG e a água clarificada era coletada na sua parte superior e conduzida para o FRD. A vazão de água na entrada do FRD era ajustada em um rotâmetro com capacidade máxima de $600 \mathrm{~L} / \mathrm{h}$.

O FAAG possuía entrada de água na interface pedregulho-areia para a injeção de água por ocasião da execução de descargas de fundo intermediárias (DFIs). O FRD tinha saída de água filtrada posicionada um pouco acima da cota do topo do meio filtrante. Na Figura 4.13 podem ser observados estes detalhes nos filtros ascendente e descendente. 


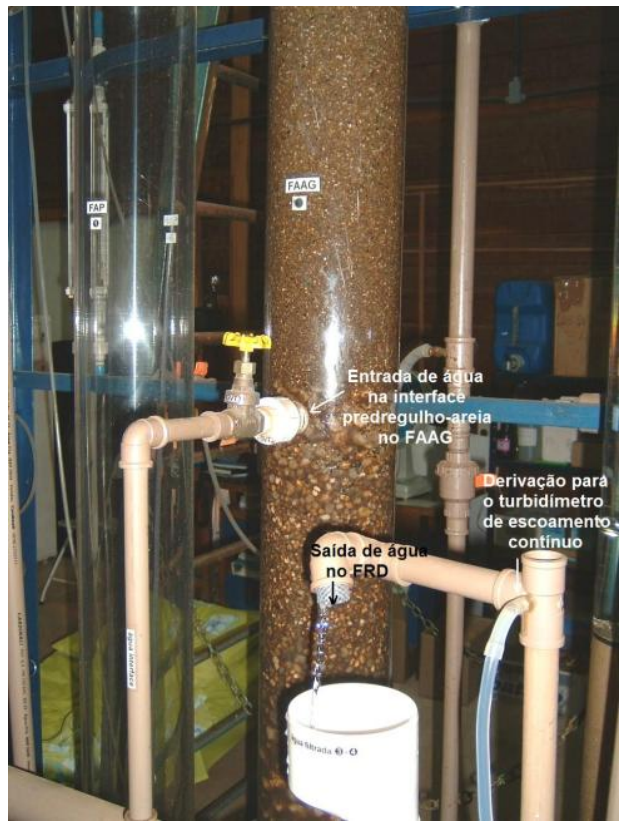

Figura 4.13 - Detalhes da entrada de água na interface pedregulho-areia no FAAG, da saída de água no FRD e da derivação do efluente do FRD para o turbidímetro de escoamento contínuo.

\subsubsection{Sistema de Ozonização}

O ozônio era gerado in loco, a partir do ar atmosférico por descarga elétrica (efeito corona). O sistema de ozonização era constituído de: coluna de ozonização; gerador de ozônio; medidor de ozônio na fase gasosa; medidor de ozônio na fase líquida; rotâmetro de gás com vazão máxima de $60 \mathrm{~L} / \mathrm{h}$; destruidor de ozônio e válvulas reguladoras de vazão.

O gerador de ozônio era da marca EAGLESAT, modelo OZ-7, com capacidade de produção de $7 \mathrm{~g} / \mathrm{h}$ (ver Figura 4.14). O equipamento era dotado de válvulas reguladoras de vazão e pressão, permitindo a variação na concentração de ozônio, que era controlada por um medidor de ozônio na fase gasosa modelo AFX - IN USA, apresentado na Figura 4.15.

A determinação de ozônio gasoso era contínua e feita por absorção UV, com compensação automática de pressão, de temperatura e de massa molecular, no próprio equipamento.

O ozônio na fase líquida era medido continuamente por um equipamento Dulcometer, marca ProMinent, com sensor e válvula solenóide em linha o qual transmitia o sinal para o medidor, cuja faixa de medida era de 0 a $2 \mathrm{mg} / \mathrm{L}$ de ozônio (ver Figuras 4.16 e 4.17). 


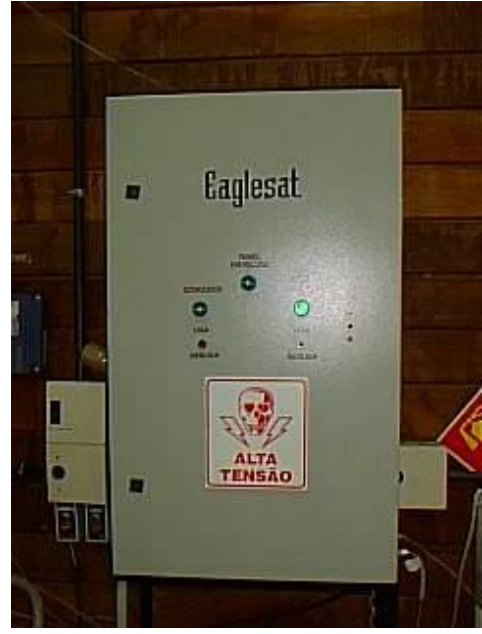

Figura 4.14 - Gerador de ozônio EAGLESAT.

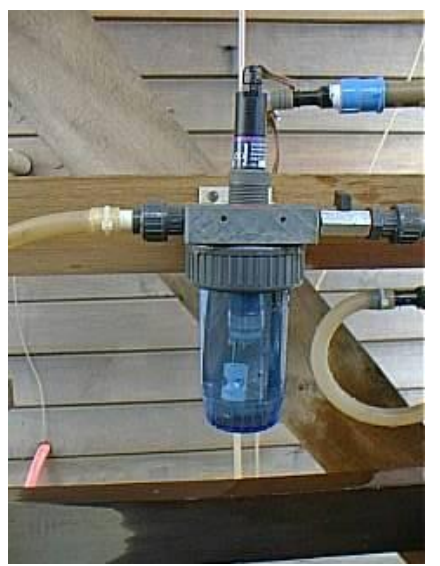

Figura 4.16 - Sensor instalado em linha para a medida de $\mathrm{O}_{3}$ na fase líquida.

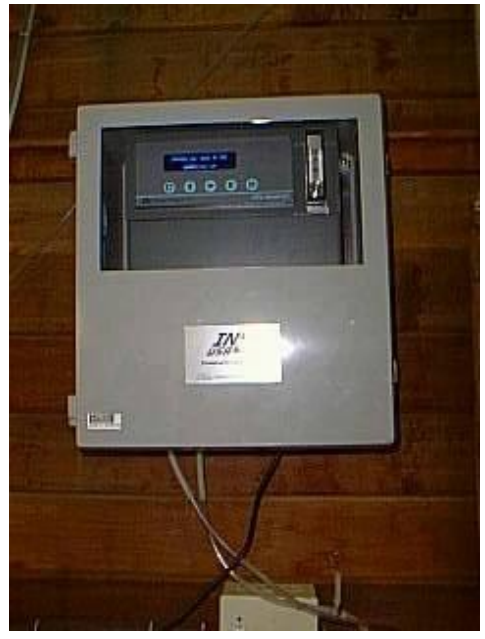

Figura 4.15 - Medidor de $\mathrm{O}_{3}$ na fase gasosa AFX (IN USA).

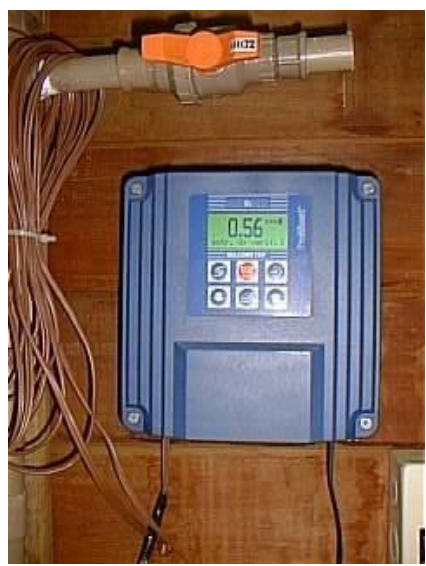

Figura 4.17 - Medidor de $\mathrm{O}_{3}$ na fase líquida (Dulcometer - ProMinent).

Na saída do gerador de ozônio foi instalado um rotâmetro, no qual era regulada a vazão necessária para a distribuição de $\mathrm{O}_{3}$ na coluna de ozonização. Por meio de uma válvula de agulha regulava-se a vazão de $\mathrm{O}_{3}$ para a coluna de ozonização, para o medidor de $\mathrm{O}_{3}$ na fase gasosa, onde era controlada a concentração de $\mathrm{O}_{3}$, e o excesso era encaminhado ao destruidor de $\mathrm{O}_{3}$ (ver Figura 4.18). 


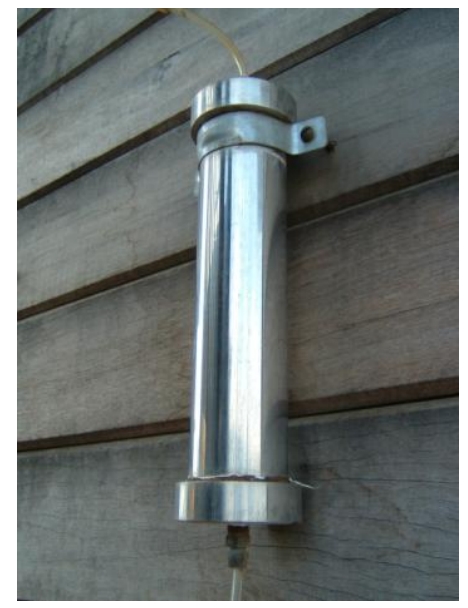

Figura 4.18 - Destruidor de ozônio.

A coluna de ozonização era de acrílico transparente, com diâmetro externo de $153 \mathrm{~mm}$ e interno de $141 \mathrm{~mm}$ e $6 \mathrm{~m}$ de altura. A distribuição de ozônio na coluna era feita por meio de uma pedra difusora, em contra-corrente. A entrada da água de estudo estava localizada na parte superior da coluna, o ozônio era aplicado na parte inferior da coluna e a água ozonizada era coletada na parte inferior e encaminhada para a caixa de mistura rápida. Nas Figuras 4.19 e 4.20 estão mostrados alguns detalhes do topo e do fundo da coluna de ozonização.

O medidor de ozônio na fase líquida foi calibrado utilizando-se o método iodométrico e o excesso de ozônio também foi medido pelo método iodométrico (APHA et al., 1998).

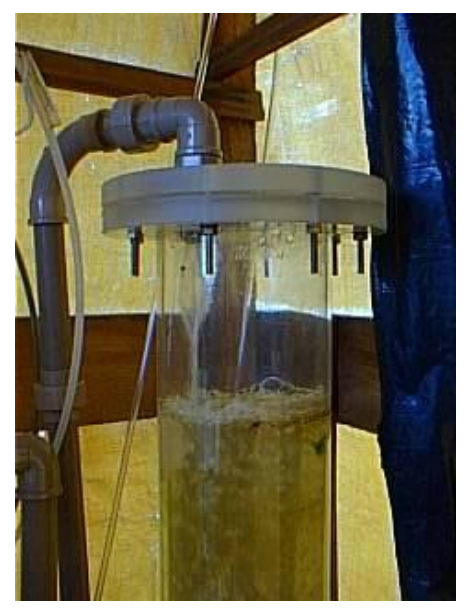

Figura 4.19 - Entrada de água de estudo no topo da coluna de ozonização.

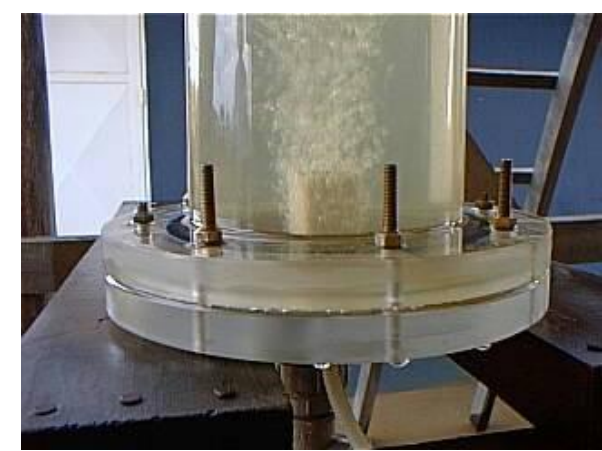

Figura 4.20 - Pedra difusora para a distribuição de ozônio, localizada na parte inferior da coluna de ozonização. 
$\mathrm{Na}$ Figura 4.20 observa-se a formação de caminhos preferenciais na distribuição do ozônio, ocorrendo somente neste local da coluna de ozonização, sendo que ao longo da coluna a distribuição de ozônio foi uniforme, como pode ser observado nas Figuras 4.21 e 4.22.

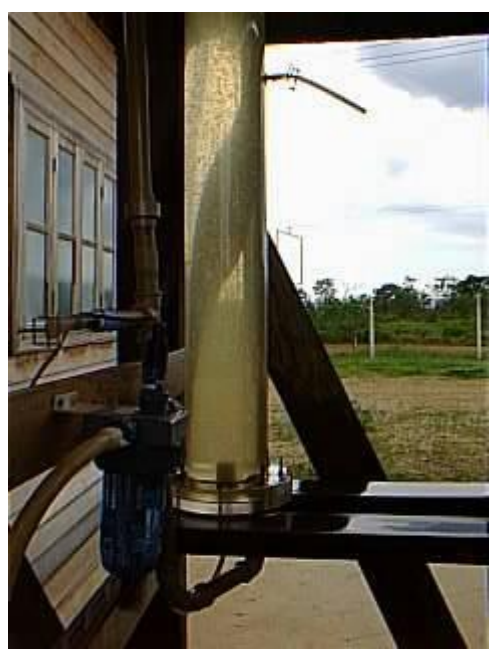

Figura 4.21 - Distribuição do ozônio da parte inferior para o meio da coluna de ozonização.

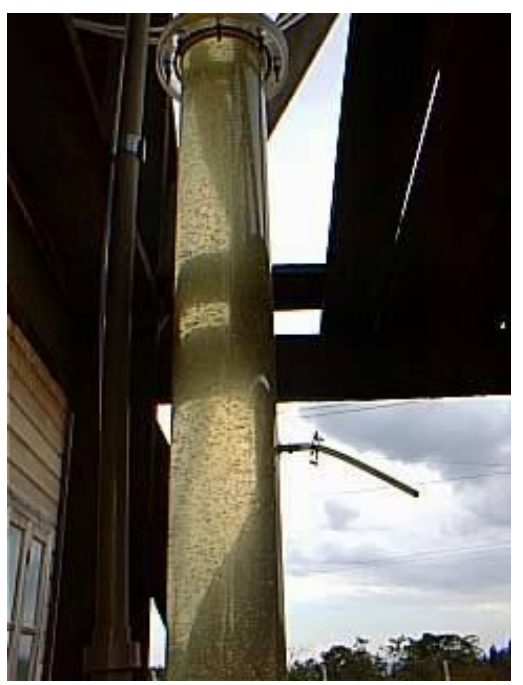

Figura 4.22 - Distribuição de ozônio do meio para a parte superior da coluna de ozonização.

\subsubsection{Material Filtrante}

O material filtrante utilizado nos filtros ascendente e descendente foi 0 mesmo utilizado por DE PAULA (2003). Na Tabela 4.1 está apresentada a composição do material filtrante no FAAG e no FRD e na Figura 4.23 está a curva granulométrica da areia utilizada no FAAG e no FRD. O FRD possuía placa perfurada no fundo, sobre a qual estava disposta uma tela metálica onde foi colocado o material filtrante.

Tabela 4.1 - Composição do meio granular utilizado no FAAG e no FRD, recomendado por DI BERNARDO (1993) e utilizado por DE PAULA (2003).

\begin{tabular}{|c|c|c|c|c|}
\hline Filtro & Material & Subcamada & Tamanho dos grãos $(\mathrm{mm})$ & Espessura (cm) \\
\hline \multirow{7}{*}{ FAAG } & \multirow{6}{*}{$\begin{array}{l}\text { PEDREGULHO } \\
\text { (camada suporte) }\end{array}$} & fundo & $25,4-19,0$ & 10 \\
\hline & & primeira & $12,7-19,0$ & 10 \\
\hline & & segunda & $6,4-12,7$ & 10 \\
\hline & & terceira & $3,2-6,4$ & 15 \\
\hline & & quarta & $6,4-12,7$ & 7,5 \\
\hline & & superior & $12,7-19,0$ & 7,5 \\
\hline & \multicolumn{4}{|c|}{$\begin{array}{l}\text { AREIA: tamanho dos grãos }=1,0-2,4 \mathrm{~mm} \text {; tamanho efetivo }=1,4 \mathrm{~mm} \text {; espessura da } \\
\text { camada }=1,6 \mathrm{~m}\end{array}$} \\
\hline FRD & \multicolumn{4}{|c|}{$\begin{array}{l}\text { AREIA: tamanho dos grãos }=0,30-1,41 \mathrm{~mm} \text {; tamanho efetivo }=0,43 \mathrm{~mm} \text {; espessura da } \\
\text { camada }=0,7 \mathrm{~m}\end{array}$} \\
\hline
\end{tabular}




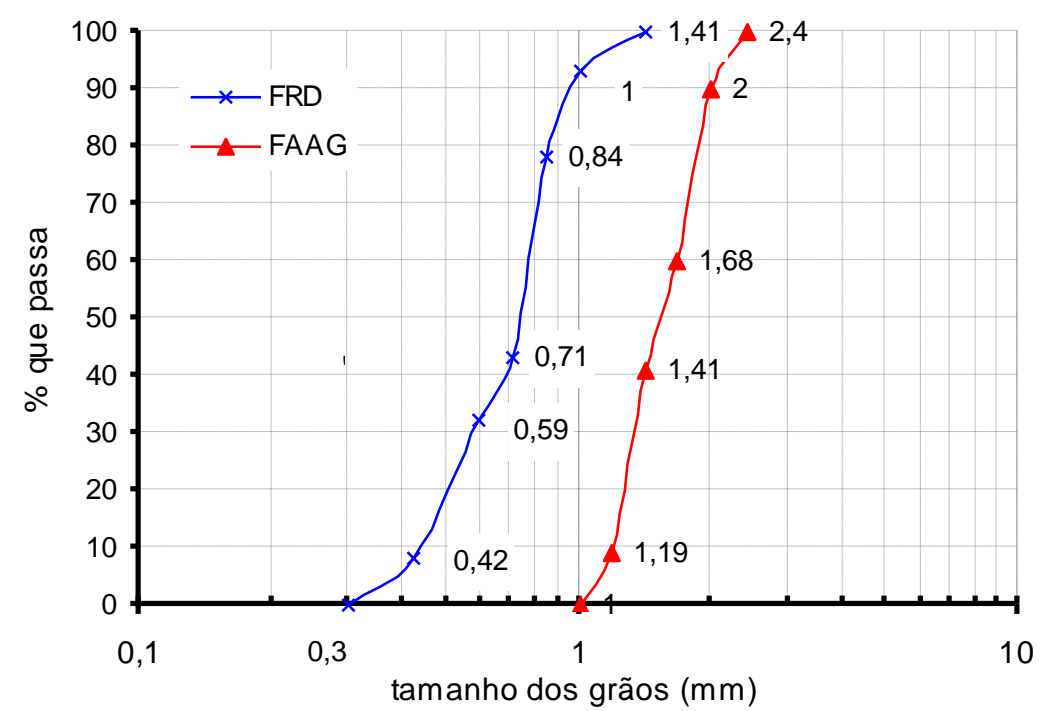

Figura 4.23 - Curva granulométrica da areia utilizada no FAAG e no FRD. Fonte: DE PAULA, 2003.

Na Figura 4.24 é mostrado o esquema dos filtros ascendente e descendente com as espessuras das subcamadas e suas respectivas faixas granulométricas. Estão indicados os pontos onde foram instaladas as tomadas piezométricas ao longo do meio filtrante, sendo três no FAAG e quatro no FRD. 


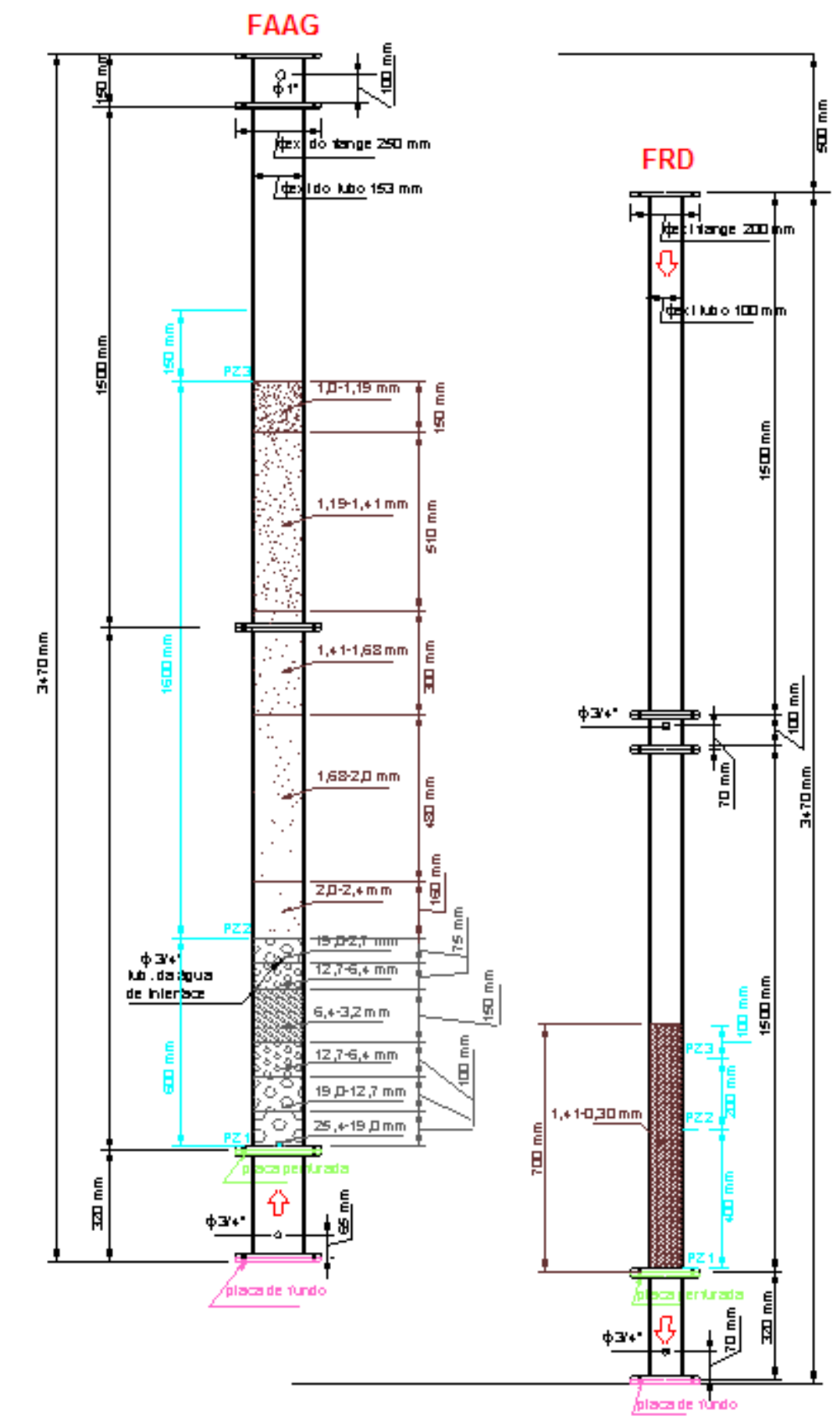

Tomadas piezométricas em azul

Material filtrante em marrom

Figura 4.24 - Esquema do FAAG e do FRD, com detalhes das subcamadas de material granular e das tomadas piezométricas (DE PAULA, 2003). 


\subsubsection{Funcionamento dos Filtros Ascendente e Descendente}

Nos ensaios na instalação piloto em escoamento contínuo correspondentes à Fase 1 foram executadas descargas de fundo intermediárias (DFIs) no FAAG, e na Fase 2 não foram realizadas DFls no FAAG. A execução ou não de DFls foi determinada pelo fato de que na Fase 1 não utilizou-se a pré-oxidação e houve variação nas taxas de filtração no FAAG e no FRD; na Fase 2, o objetivo foi avaliar e comparar a eficiência da pré-oxidação com diferentes oxidantes sem a variação de taxas de filtração nos filtros, portanto não foram realizadas as DFIs no FAAG.

Os critérios para a execução das DFIs foram estabelecidos conforme duas situações distintas:

- com base nos resultados obtidos por DE PAULA (2003) foram definidas 4 DFIs no FAAG adotando-se o seguinte procedimento: subtraía-se o valor da perda de carga inicial da perda de carga final $(2,20 \mathrm{~m})$ e o valor obtido era dividido por 5 pelo fato de serem 4 DFls;

- quando a cor aparente do efluente do FAAG atingia valor maior ou igual a $50 \mathrm{uH}$.

A taxa de aplicação das DFls e da descarga de fundo final no FAAG era de 1000 a $1200 \mathrm{~m}^{3} / \mathrm{m}^{2} \mathrm{~d}$, durante 2 minutos com introdução de água na interface pedregulho-areia.

O encerramento da carreira de filtração era definido quando:

- atingia a perda de carga limite no meio granular, de 2,20 m no FAAG ou 2,10 m no FRD ou;

- a turbidez do efluente do filtro descendente extrapolava 1 UT ou;

- atingia 72 horas de funcionamento na Fase 1 e 36 horas de funcionamento na Fase 2.

\subsubsection{Limpeza e Lavagem dos Filtros}

No FAAG após a descarga de fundo final, introduzia-se água para lavagem com velocidade ascensional de $1,8 \mathrm{~m} / \mathrm{min}$, promovendo expansão no meio filtrante de 20 a $30 \%$, durante o período necessário para que a turbidez do efluente resultasse inferior a $5 \mathrm{uT}$. 
A lavagem do FRD era efetuada por meio de insuflação de ar durante 3 minutos, com taxa de aplicação de $15 \mathrm{~L} / \mathrm{s} . \mathrm{m}^{2}$, seguida de água para promover expansão de $30 \%$ na camada de areia, com velocidade ascensional de $0,6 \mathrm{~m} / \mathrm{min}$, durante 7 minutos.

A água utilizada na lavagem dos filtros e para introdução na interface pedregulho-areia durante as DFs, era água filtrada da ETA II, armazenada previamente em caixa de polietileno.

Para a insuflação de ar durante a lavagem do FRD foi utilizado um compressor de ar de 1/2 HP, marca DOUAT, modelo MC - 3,5. A vazão de ar era ajustada em um rotâmetro com capacidade de $400 \mathrm{~L} / \mathrm{h}$, por meio de válvula agulha.

\subsubsection{Produtos Químicos Utilizados}

\subsubsection{Coagulante}

O coagulante utilizado foi o sulfato de alumínio líquido, fornecido pela Nheel Química Ltda (Rio Claro - SP), na forma de solução comercial. Esta solução é produzida a partir de sulfato de alumínio sólido contendo $17 \%$ de $\mathrm{Al}_{2} \mathrm{O}_{3}$. Considerando que o sulfato de alumínio comercial sólido tem a fórmula geral $\mathrm{Al}_{2}\left(\mathrm{SO}_{4}\right)_{3} \cdot \mathrm{n} \mathrm{H}_{2} \mathrm{O}$, foi estimado em 14,3 o número (n) de moléculas de $\mathrm{H}_{2} \mathrm{O}$ nessa fórmula.

Para o preparo da solução estoque de $\mathrm{Al}_{2}\left(\mathrm{SO}_{4}\right)_{3} \cdot 14,3 \mathrm{H}_{2} \mathrm{O}$, foi determinada a massa específica que corresponde a uma determinada concentração de sulfato de alumínio. Esta correlação entre a massa específica e a concentração de sulfato de alumínio foi fornecida pelo fabricante do produto e está apresentada na Tabela A1 do ANEXO A. Sabendo-se a concentração da solução comercial e a concentração da solução estoque, preparava-se a solução estoque com a diluição da solução comercial de sulfato de alumínio em determinado volume de água filtrada da ETA II (água de diluição), baseando-se no cálculo da equação (4.2).

$\mathrm{C}_{\mathrm{SA}}{ }^{*} \mathrm{~V}_{\mathrm{SA}}=\mathrm{C}_{\mathrm{SE}}{ }^{*} \mathrm{~V}_{\mathrm{SE}}$

em que:

$\mathrm{C}_{\mathrm{SA}}=$ concentração de $\mathrm{Al}_{2}\left(\mathrm{SO}_{4}\right)_{3} \cdot 14,3 \mathrm{H}_{2} \mathrm{O} / \mathrm{L}$ solução comercial (mg/L);

$\mathrm{V}_{\mathrm{SA}}=$ volume de $\mathrm{Al}_{2}\left(\mathrm{SO}_{4}\right)_{3} .14,3 \mathrm{H}_{2} \mathrm{O}$ da solução comercial $(\mathrm{L})$; 
$\mathrm{C}_{\mathrm{SE}}=$ concentração da solução estoque $(\mathrm{mg} / \mathrm{L})$;

$\mathrm{V}_{\mathrm{SE}}=$ volume da solução estoque $(\mathrm{L})$.

O volume total da solução estoque correspondia ao volume de água de diluição, no máximo 50 L, que era a capacidade do tanque de mistura (Figura 4.6), menos o volume de sulfato de alumínio determinado.

As massas específicas da solução comercial de sulfato de alumínio obtidas, com suas respectivas concentrações foram de:

- Ensaios na Instalação Piloto - Fase 1:

$\rho=1332 \mathrm{~g} / \mathrm{L} \Rightarrow \mathrm{C}=683,2 \mathrm{~g} \mathrm{Al}_{2}\left(\mathrm{SO}_{4}\right)_{3} .14,3 \mathrm{H}_{2} \mathrm{O} / \mathrm{L}$ solução comercial.

- Ensaios na Instalação Piloto - Fase 2:

$\rho=1315 \mathrm{~g} / \mathrm{L} \Rightarrow \mathrm{C}=637,8 \mathrm{~g} \mathrm{Al}_{2}\left(\mathrm{SO}_{4}\right)_{3} .14,3 \mathrm{H}_{2} \mathrm{O} / \mathrm{L}$ solução comercial.

Por exemplo, para o preparo de uma solução estoque de sulfato de alumínio com concentração de $6000 \mathrm{mg} / \mathrm{L}$ e volume de $40 \mathrm{~L}$, considerando a concentração da solução comercial de sulfato de alumínio de 683,2 g/L, calculava-se o volume da solução comercial de sulfato de alumínio:

$683200 \mathrm{mg} / \mathrm{L} * \mathrm{~V}_{\mathrm{SA}}(\mathrm{L})=6000 \mathrm{mg} / \mathrm{L}$ * $40 \mathrm{~L} \therefore \mathrm{V}_{\mathrm{SA}}=0,351 \mathrm{~L}=351 \mathrm{~mL}$

O volume total de água de diluição era igual a $40 \mathrm{~L}-0,351 \mathrm{~L}=39,649 \mathrm{~L}$.

As dosagens de coagulante foram calculadas utilizando-se a equação (4.3):

$D_{S A}=D_{S C} * \frac{C_{S A}}{\rho}$

em que:

$D_{\mathrm{SA}}=$ dosagem de sulfato de alumínio aplicada $(\mathrm{mg} / \mathrm{L})$;

$\mathrm{D}_{\mathrm{SC}}=$ dosagem da solução comercial de sulfato de alumínio (mg/L);

$\rho=$ massa específica da solução comercial de sulfato de alumínio (mg/L).

Conhecendo-se a dosagem de sulfato de alumínio a ser aplicada, determinava-se a dosagem da solução comercial. Calculava-se a vazão na bomba dosadora aplicando-se a equação (4.4):

$D_{S C}=\frac{Q_{b d}{ }^{*} C_{S E}}{Q_{b d}+Q_{a b}}$

em que: 
$\mathrm{Q}_{\mathrm{bd}}=$ vazão na bomba dosadora $(\mathrm{L} / \mathrm{h})$;

$\mathrm{Q}_{\mathrm{ab}}=$ vazão da água bruta $(\mathrm{L} / \mathrm{h})$.

Aplicando-se as equações (4.3) e (4.4), por exemplo, em um ensaio em que a $D_{S A} \cong 8 \mathrm{mg} / \mathrm{L}$, a $C_{S E} \cong 6000 \mathrm{mg} / \mathrm{L}$ e a $Q_{a b}=170 \mathrm{~L} / \mathrm{h}$, obtinha-se a $Q_{b d}$ : $8=D_{S C} * \frac{0,6832}{1,332} \Rightarrow D_{S C}=15,6 m g / L \quad \therefore 15,6=\frac{Q_{b d}{ }^{*} 6000}{Q_{b d}+170} \Rightarrow Q_{b d}=0,44 L / h$

\subsubsection{Acidificante}

O acidificante utilizado foi o ácido clorídrico $(\mathrm{HCl})$ comercial, da Synth. A solução estoque era preparada no tanque de mistura (Figura 4.6), com concentração de $0,07 \mathrm{M}$. A água de diluição utilizada para o preparo da solução estoque era água filtrada da ETA II. A solução era agitada por 10 minutos e em seguida iniciava-se a adição de $\mathrm{HCl}(0,07 \mathrm{M})$ para ajuste do $\mathrm{pH}$ de coagulação. $\mathrm{A}$ vazão da bomba dosadora variava para cada ensaio, e era dependente da taxa de filtração aplicada no FAAG e do pH de coagulação desejado.

\subsubsection{Oxidantes}

Além do ozônio gerado in loco, conforme descrito no item 4.3.1.1, foram utilizados peróxido de hidrogênio, cloro nas formas de tricloro-s-triazina-triona e hipoclorito de sódio, dióxido de cloro, permanganato de potássio e peroxônio, os quais eram preparados em soluções estoque com diferentes concentrações, homogeneizadas no tanque de mistura (Figura 4.6) e dosadas com bomba dosadora cuja vazão era calculada utilizando-se a equação (4.5).

$C=\frac{C_{a b}{ }^{*} Q_{a b}+C_{S E}{ }^{*} Q_{b d}}{Q_{a b}+Q_{b d}}$

em que:

$\mathrm{C}=$ concentração de oxidante aplicada $(\mathrm{mg} / \mathrm{L})$;

$\mathrm{C}_{\mathrm{ab}}=$ concentração de oxidante na água bruta $(\mathrm{mg} / \mathrm{L})$;

$\mathrm{Q}_{\mathrm{ab}}=$ vazão afluente de água bruta = vazão afluente ao $F A A G$ + vazão de água pré-oxidada e coagulada desviada para o FLA (L/h);

$\mathrm{C}_{\mathrm{SE}}=$ concentração da solução estoque do oxidante $(\mathrm{mg} / \mathrm{L})$;

$\mathrm{Q}_{\mathrm{bd}}=$ vazão da bomba dosadora $(\mathrm{L} / \mathrm{h})$. 
Com exceção do ozônio em que as dosagens foram determinadas em reatores estáticos, as dosagens dos demais oxidantes aplicadas nos ensaios foi determinada em ensaio preliminar na instalação piloto em escoamento contínuo variando-se a dosagem de oxidante, dosagem de coagulante e $0 \mathrm{pH}$ de coagulação. Além da cor aparente remanescente no efluente do FRD, o residual de oxidante foi determinante na dosagem de oxidante.

\section{a) Peróxido de Hidrogênio $\left(\mathrm{H}_{2} \mathrm{O}_{2}\right)$}

Foi utilizada solução comercial de peróxido de hidrogênio Clamarim 503 da Degussa-Hüls, armazenada em bombona de 50 litros.

A concentração da solução comercial foi determinada pelo método recomendado por MASSCHELEN (1977), que consiste na adição de $5 \mathrm{~mL}$ de $\mathrm{H}_{2} \mathrm{SO}_{4} 20 \%$ em $10 \mathrm{~mL}$ da solução de $\mathrm{H}_{2} \mathrm{O}_{2}$ e titulometria com $\mathrm{KMnO}_{4}(0,1 \mathrm{~N})$ até obter a cor rosa. O cálculo foi feito utilizando-se a equação (4.6).

$\mathrm{mg} / \mathrm{L} \mathrm{H}_{2} \mathrm{O}_{2}=\left(\mathrm{mL}\right.$ gastos de $\left.\mathrm{KMnO}_{4} 0,1 \mathrm{~N}\right){ }^{*} 170,1 \mathrm{ou}$

$\% \mathrm{H}_{2} \mathrm{O}_{2}=\left(\mathrm{mL}\right.$ gastos de $\left.\mathrm{KMnO}_{4} 0,1 \mathrm{~N}\right){ }^{*} 0,017$

Em seguida preparou-se a solução estoque de $\mathrm{H}_{2} \mathrm{O}_{2}$ diluída com água filtrada da ETA II, com concentração determinada pelo mesmo método descrito anteriormente, e calculava-se a vazão da bomba dosadora utilizando-se a equação (4.5).

As medidas do residual de $\mathrm{H}_{2} \mathrm{O}_{2}$ foram feitas utilizando-se o método espectrofotométrico UV $(\lambda=260 \mathrm{~nm})$ com cobalto e bicarbonato para a faixa de leitura de 0,02 a 0,2 mg/L, recomendado por MASSCHELEN (1977) e utilizado por COELHO (2002) e TANGERINO (2003). O método consiste na adição sucessiva de $1 \mathrm{~mL}$ de solução de hexametafosfato e $1 \mathrm{~mL}$ de solução de cobalto em $80 \mathrm{~mL}$ de amostra em balão volumétrico de $100 \mathrm{~mL}$. Completava-se o volume com solução de bicarbonato de sódio saturada. Fez-se uma curva de calibração, com concentrações variando de 0,03 a $0,180 \mathrm{mg} / \mathrm{L}$ no espectrofotômetro UV $(\lambda=260$ nm) para realizar as leituras do residual de $\mathrm{H}_{2} \mathrm{O}_{2}$ das amostras. 


\section{b) Cloro}

Foram utilizados cloro sólido (tricloro-s-triazina-triona), e cloro em solução de hipoclorito de sódio ( $\mathrm{NaClO}$ ). O tricloro-s-triazina-triona foi utilizado pela facilidade de obtenção e quando aplicado à água não provoca alterações bruscas no $\mathrm{pH}$, o hipoclorito de sódio foi utilizado para comparar com os resultados obtidos com tricloro-s-triazia-triona.

O cloro sólido é fornecido em tabletes de $200 \mathrm{~g}$, da marca GENCO, usado para desinfecção de piscinas, cujo ingrediente ativo é o tricloro-s-triazina-triona, com teor de cloro ativo disponível de 90\%. Este produto foi colocado em 1 litro de água destilada em frasco com tampa e coberto com papel alumínio para evitar a incidência de luz, e deixado em repouso durante três dias dentro da geladeira, pois ele dissolve-se lentamente.

Com a solução concentrada de cloro, preparou-se a solução estoque no tanque de mistura, com água de diluição (água filtrada da ETA II) com concentração conhecida. Utilizando-se a equação (4.5) foi possível determinar a vazão na bomba dosadora.

No ensaio com hipoclorito de sódio, a solução estoque de cloro foi preparada com a diluição de $\mathrm{NaClO}$ em água filtrada da ETA II, no tanque de mistura (Figura 4.6).

O residual de cloro foi determinado utilizando-se o método colorimétrico DPD, e as leituras eram feitas no espectrofotômetro UV DR 4000, no comprimento de onda de $530 \mathrm{~nm}$ e faixa de leitura de 0 a $2 \mathrm{mg} / \mathrm{L}$.

\section{c) Dióxido de cloro $\left(\mathrm{ClO}_{2}\right)$}

A solução de dióxido de cloro foi gerada no laboratório de instalações piloto da EESC - USP, em um gerador da marca ProMinent com capacidade de $50 \mathrm{~g} / \mathrm{h}$ (ver Figura 4.25), a partir de soluções diluídas de clorito de sódio e ácido clorídrico.

Como a solução de dióxido de cloro gerada já era diluída, foi gerada uma quantidade suficiente de dióxido de cloro para a execução do ensaio, não sendo necessária outra diluição. Tendo-se o conhecimento da concentração da solução estoque, a dosagem de dióxido de cloro a ser aplicada e a vazão afluente ao sistema, a vazão da bomba dosadora foi determinada pela equação (4.5).

O residual de dióxido de cloro foi medido pelo método colorimétrico DPD, no espectrofotômetro UV DR 4000, em que se determinava o teor de cloro livre e o resultado era multiplicado por 1,9 (correção estequiométrica). 
Não foram feitas determinações de clorito e clorato por não haver equipamento para a execução destas análises.

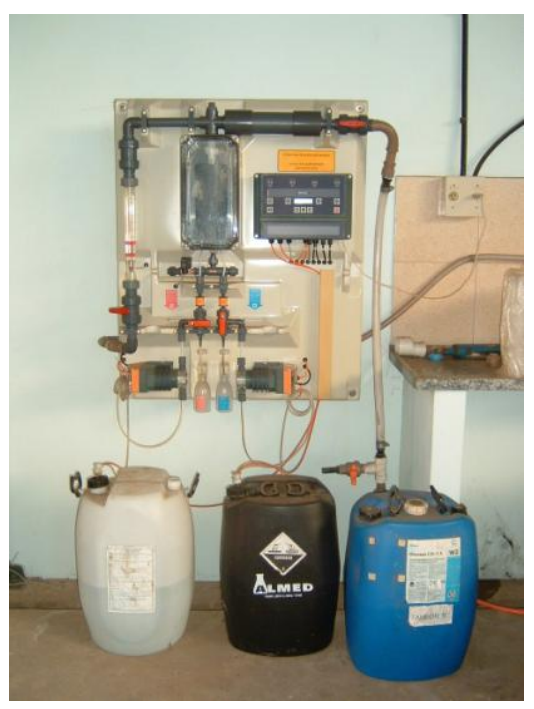

Figura 4.25 - Gerador de dióxido de cloro.

\section{d) Permanganato de potássio $\left(\mathrm{KMnO}_{4}\right)$}

Foi utilizado $\mathrm{KMnO}_{4}$ em pó, da Synth, com teor de pureza de $99 \%$, o qual foi diluído em água filtrada da ETA II para preparo da solução estoque com concentração conhecida. Com a determinação da dosagem de permanganato de potássio a ser aplicada, em ensaio preliminar na instalação piloto em escoamento contínuo, com a concentração da solução estoque e a vazão afluente ao sistema, foi possível calcular a vazão na bomba dosadora utilizando-se a equação (4.5).

As medidas do residual de permanganato de potássio foram feitas em espectrofotômetro UV DR 4000 no comprimento de onda de $530 \mathrm{~nm}$, utilizando-se uma curva de calibração preparada com concentrações de 0 a 5 mg/L de $\mathrm{KMnO}_{4}$.

\section{e) Peroxônio $\left(\mathrm{H}_{2} \mathrm{O}_{2}+\mathrm{O}_{3}\right)$}

Foi preparada uma solução estoque de $\mathrm{H}_{2} \mathrm{O}_{2}$ com concentração conhecida. Adicionava-se $\mathrm{H}_{2} \mathrm{O}_{2}$ na saída da caixa de homogeneização de substâncias húmicas e aplicava-se $\mathrm{O}_{3}$ na coluna de ozonização. A relação de $\mathrm{H}_{2} \mathrm{O}_{2}: \mathrm{O}_{3}$ utilizada foi de 0,5. Devido às instabilidades observadas no gerador de $\mathrm{O}_{3}$, provocando variações na dosagem de $\mathrm{O}_{3}$, ajustava-se a vazão da bomba dosadora da solução estoque de $\mathrm{H}_{2} \mathrm{O}_{2}$ mantendo-se a relação $\mathrm{H}_{2} \mathrm{O}_{2}: \mathrm{O}_{3}$ em 0,5 .

Medidas de $\mathrm{O}_{3}$ na fase líquida e gasosa eram controladas nos respectivos medidores, e o off gas era determinado pelo método iodométrico (APHA et al., 
1998). O residual de $\mathrm{H}_{2} \mathrm{O}_{2}$ era medido pelo método espectrofotométrico cobalto bicarbonato $(\lambda=260 \mathrm{~nm})$, recomendado por MASSCHELEN (1977).

\subsubsection{Características da Água, Métodos e Equipamentos}

A coleta, a conservação e a determinação das características físicas e químicas das amostras de água foram feitas de acordo com a APHA et al. (1998). As principais características da água, os pontos de amostragem e os métodos e equipamentos utilizados estão apresentados na Tabela 4.2.

Tabela 4.2 - Características da água, amostra, método e equipamento.

\begin{tabular}{|c|c|c|c|}
\hline Característica & Amostra & Método & Equipamento \\
\hline Turbidez (uT) & $\begin{array}{c}A B \text {, efluentes do FAAG } \\
\text { e FRD }\end{array}$ & Nefelométrico & $\begin{array}{c}\text { Turbidímetro de } \\
\text { escoamento contínuo } \\
\text { (1720 C }-\mathrm{HACH})\end{array}$ \\
\hline Cor aparente $(\mathrm{uH})$ & $\begin{array}{c}\mathrm{AB}, \mathrm{AE}, \mathrm{APO} \mathrm{(}^{(*)} \\
\text { efluentes FAAG e FRD }\end{array}$ & $\begin{array}{c}\text { Espectrofotométrico } \\
(\lambda=455 \mathrm{~nm})\end{array}$ & $\begin{array}{l}\text { Espectrofotômetro } \\
\text { DR } 4000(\mathrm{HACH})\end{array}$ \\
\hline Cor verdadeira $(\mathrm{uH})$ & $\mathrm{AB}, \mathrm{AE}, \mathrm{APO} \mathrm{O}^{(*)}$ & $\begin{array}{c}\text { Espectrofotométrico } \\
(\lambda=455 \mathrm{~nm})\end{array}$ & $\begin{array}{l}\text { Espectrofotômetro } \\
\text { DR } 4000(\mathrm{HACH})\end{array}$ \\
\hline $\mathrm{pH}$ & $\mathrm{AC}, \mathrm{AE}, \mathrm{AB}, \mathrm{APO} \mathrm{O}^{(*)}$ & Potenciométrico & $\begin{array}{c}\text { Potenciômetro de } \\
\text { bancada } 230 \text { A (Orion) }\end{array}$ \\
\hline Temperatura $\left({ }^{\circ} \mathrm{C}\right)$ & $\mathrm{AE}$ & Leitura direta & Termômetro de mercúrio \\
\hline $\begin{array}{l}\text { Alcalinidade } \\
\left.(\mathrm{mg} / \mathrm{L} \mathrm{CaCO})_{3}\right)\end{array}$ & $\mathrm{AB}, \mathrm{AE}, \mathrm{APO}^{(*)}$ & $\begin{array}{c}\text { Titulação } \\
\text { poteciométrica }\end{array}$ & $\begin{array}{c}\text { Bureta digital e } \\
\text { potenciômetro de } \\
\text { bancada }\end{array}$ \\
\hline $\begin{array}{ll}\begin{array}{l}\text { Alumínio } \\
(\mathrm{mg} / \mathrm{L})\end{array} & \text { residual } \\
\end{array}$ & $\begin{array}{c}A B, A E, \text { efluentes FAAG } \\
\text { e FRD }\end{array}$ & $\begin{array}{c}\text { Espectrofotométrico } \\
(\lambda=535 \mathrm{~nm})\end{array}$ & $\begin{array}{l}\text { Espectrofotômetro } \\
\text { DR } 4000(\mathrm{HACH})\end{array}$ \\
\hline Absorvância 254 nm & $\begin{array}{c}\mathrm{AB}, \mathrm{AE}, \mathrm{APO} \mathrm{(*)}^{(*)} \\
\text { efluentes } \mathrm{FAAG} \text { e FRD }\end{array}$ & $\begin{array}{c}\text { Espectrofotométrico } \\
(\lambda=254 \mathrm{~nm})\end{array}$ & $\begin{array}{l}\text { Espectrofotômetro } \\
\text { DR } 4000(\mathrm{HACH})\end{array}$ \\
\hline $\begin{array}{l}\text { Carbono orgânico } \\
\text { dissolvido }(\mathrm{mg} / \mathrm{L})\end{array}$ & $\begin{array}{c}\mathrm{AB}, \mathrm{AE}, \mathrm{APO} \mathrm{(}^{(*)} \\
\text { efluentes FAAG e FRD }\end{array}$ & $\begin{array}{l}\text { Analisador de gás } \\
\text { infravermelho }\end{array}$ & $\begin{array}{c}\text { Total Organic Carbon } \\
\text { Analyser } 5000 \mathrm{~A} \\
\text { (Schimadzu) }\end{array}$ \\
\hline Ferro $(\mathrm{mg} / \mathrm{L})^{(*)}$ & $\begin{array}{c}\text { AB, AE, APO, efluentes } \\
\text { FAAG e FRD }\end{array}$ & Absorção atômica & $\begin{array}{l}\text { AA Analist } 700 \\
\text { (Perkin Elmer) }\end{array}$ \\
\hline Manganês $(\mathrm{mg} / \mathrm{L})^{(*)}$ & $\begin{array}{c}\mathrm{AB}, \mathrm{AE}, \mathrm{APO} \text {, efluentes } \\
\text { FAAG e FRD }\end{array}$ & Absorção atômica & $\begin{array}{l}\text { AA Analist } 700 \\
\text { (Perkin Elmer) }\end{array}$ \\
\hline $\begin{array}{l}\text { Residual de oxidantes } \\
(\mathrm{mg} / \mathrm{L})^{\left({ }^{*}\right)}\end{array}$ & Efluentes FAAG e FRD & $\begin{array}{c}\text { Iodométrico }\left(\mathrm{O}_{3}\right) \\
\text { Espectrofotométrico } \\
\text { (demais oxidantes) }\end{array}$ & $\begin{array}{c}\text { Bureta manual } \\
\text { Espectrofotômetro } \\
\text { DR } 4000(\mathrm{HACH})\end{array}$ \\
\hline 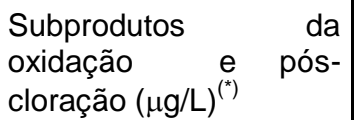 & APO e efluente FRD & $\begin{array}{l}\text { EPA } 551.1 \\
\text { EPA } 552.2\end{array}$ & $\begin{array}{l}\text { Cromatógrafo gasoso } \\
3600 \mathrm{CX} \text { (Varian) }\end{array}$ \\
\hline
\end{tabular}

A cor aparente, cor verdadeira, $\mathrm{pH}$ e temperatura da água de estudo e dos efluentes dos filtros ascendente e descendente foram medidos a cada 2 horas. $A$ 
alcalinidade e a absorvância $254 \mathrm{~nm}$ foram analisadas a cada 6 horas, e o alumínio e carbono orgânico dissolvido uma vez por dia, nos ensaios correspondentes à Fase 1 , ou a cada 12 horas, nos ensaios correspondentes à Fase 2. As análises de ferro e manganês foram feitas no Laboratório de Recursos Hídricos da UNAERP, com as amostras previamente digeridas com adição de porções iguais de ácido nítrico e ácido clorídrico, com aquecimento seguido de filtração, foram feitas duas coletas por ensaio (a cada 18 horas). O residual de oxidantes foi medido a cada 9 horas, e os subprodutos da pré-oxidação e pós-cloração, 1 vez por ensaio. As vazões dos filtros ascendente e descendente e dos turbidímetros de escoamento contínuo eram medidas volumetricamente com auxílio de cronômetro e proveta, e as leituras piezométricas eram feitas a cada 1 hora.

As leituras de cor aparente e cor verdadeira eram feitas no espectrofotômetro UV DR - 4000 utilizando-se a curva de calibração feita com a "solução-mãe" de extrato de substâncias húmicas, a cor verdadeira era obtida após filtração das amostras em membrana de 0,45 $\mu \mathrm{m}$.

\subsubsection{Ensaios sem Pré-Oxidação e com Variação das Taxas de Filtração}

Nesta etapa do trabalho experimental foram realizados sete ensaios com variação nas taxas de filtração utilizadas nos filtros ascendente e descendente, e com execução de DFls no FAAG. Durante esta etapa do trabalho experimental, BENINI (2003) operou um sistema de dupla filtração instalado em paralelo, utilizando filtro ascendente de pedregulho para remoção de substâncias húmicas, possibilitando desta maneira a operação dos dois sistemas com duração de 72 horas. Na Tabela 4.3 estão apresentadas as taxas de filtração utilizadas no FAAG e FRD para cada ensaio.

Tabela 4.3 - Taxas de filtração utilizadas nos ensaios na instalação piloto em escoamento contínuo sem pré-oxidação.

\begin{tabular}{c|c|c}
\hline \multirow{2}{*}{ Ensaio } & \multicolumn{2}{|c}{ Taxas de filtração $\left(\mathbf{m}^{3} / \mathbf{m}^{2} \mathbf{d}\right)$} \\
\cline { 2 - 3 } & FAAG & FRD \\
\hline \hline 2 & 240 & 280 \\
3 & 180 & 200 \\
4 & 180 & 240 \\
5 & 180 & 280 \\
6 & 120 & 160 \\
7 & 120 & 200 \\
\hline \hline
\end{tabular}


Antes do início da carreira de filtração, preparavam-se as soluções de $\mathrm{Al}_{2}\left(\mathrm{SO}_{4}\right)_{3} \cdot 14,3 \mathrm{H}_{2} \mathrm{O}$, ácido clorídrico $(0,07 \mathrm{M})$ e extrato de substâncias húmicas. $\mathrm{A}$ solução estoque de substâncias húmicas era preparada no tanque de mistura (Figura 4.6), com água de diluição (água filtrada da ETA II) e extrato de substâncias húmicas, na proporção de $n+1: n$ (volume:volume), esta foi a concentração requerida para se trabalhar dentro da faixa de vazão da bomba dosadora ( 0 a 1,2 $\mathrm{L} / \mathrm{h}$ ) até que se atingisse cor verdadeira de 90 a $110 \mathrm{uH}$. Agitava-se a solução por 10 minutos e dosava-se o extrato de substâncias húmicas na água bruta. Em seguida, iniciava-se a dosagem do acidificante e do coagulante e realizava-se um ensaio no FLA para verificar se as condições de coagulação apresentavam eficiência de remoção de cor aparente e turbidez. Uma vez constatada a condição desejável de coagulação, a água coagulada entrava pela parte inferior do FAAG e a água clarificada era coletada na parte superior e conduzida para o FRD.

No início da carreira de filtração ajustavam-se as vazões dos filtros e as de saída dos turbidímetros de escoamento contínuo, coletavam-se amostras da água bruta, da água de estudo e dos efluentes do FAAG e do FRD, e faziam-se as leituras nos piezômetros para obter a perda de carga inicial nos filtros.

Para avaliar o desempenho do sistema de dupla filtração e comparar os resultados obtidos nos ensaios na instalação piloto em escoamento contínuo com variação das taxas de filtração no FAAG e no FRD, fez-se a correção da perda de carga em função da temperatura e calculou-se a produção efetiva de água filtrada para cada ensaio, conforme descrito nos itens 4.3.6.1 e 4.3.6.2.

\subsubsection{Ensaios sem e com Pré-Oxidação e com Taxas de Filtração Fixas}

Foram realizados oito ensaios, com as taxas de filtração fixas no FAAG e no FRD em 180 e $280 \mathrm{~m}^{3} / \mathrm{m}^{2} \mathrm{~d}$ respectivamente, e não foram executadas DFls no FAAG. Foram utilizados como oxidantes: ozônio, peróxido de hidrogênio, cloro na forma de tricloro-s-triazina-triona e hipoclorito de sódio, dióxido de cloro, permanganato de potássio e peroxônio. Na Tabela 4.4 está apresentada a ordem de execução dos ensaios e os oxidantes utilizados.

A duração da carreira de filtração, na maioria dos ensaios foi de 36 horas, com exceção do ensaio 15 , em que foi utilizado hipoclorito de sódio, que teve duração de 16 horas devido a problemas ocorridos com a água afluente à ETA II, e consequentemente à instalação piloto, que estava sendo pré-oxidada com 
hipoclorito de sódio. Com o funcionamento intermitente da ETA II, quando interrompia-se o funcionamento da ETA II, o pH da água bruta aumentava devido à concentração de hipoclorito de sódio, prejudicando a operação da instalação piloto.

Tabela 4.4 - Ensaios realizados na instalação piloto em escoamento contínuo sem e com pré-oxidação com taxas de filtração fixas no FAAG de $180 \mathrm{~m}^{3} / \mathrm{m}^{2} \mathrm{~d}$ e no FRD de $280 \mathrm{~m}^{3} / \mathrm{m}^{2} \mathrm{~d}$.

\begin{tabular}{c|c}
\hline Ensaio & Variável \\
\hline \hline 8 & Sem pré-oxidação \\
9 & Pré-oxidação com ozônio \\
10 & Pré-oxidação com peróxido de hidrogênio \\
11 & Pré-oxidação com tricloro-s-triazina-triona \\
12 & Pré-oxidação com dióxido de cloro \\
13 & Pré-oxidação com permanganato de potássio \\
14 & Pré-oxidação com peroxônio \\
15 & Pré-oxidação com hipoclorito de sódio \\
\hline \hline
\end{tabular}

\subsubsection{Determinação da dosagem de oxidantes, coagulante e pH de coagulação}

No ensaio 8 foram determinados a dosagem de coagulante e $0 \mathrm{pH}$ de coagulação na instalação piloto em escoamento contínuo. Variava-se a dosagem de coagulante e o pH de coagulação e vice-versa, a água coagulada era desviada para o FLA e realizava-se o ensaio de filtração até que se obtivesse cor aparente remanescente $\leq 5 \mathrm{uH}$.

No ensaio 9 a determinação da dosagem de coagulante e pH de coagulação foi feita na instalação piloto em escoamento contínuo com a água de estudo, adotando-se o seguinte procedimento:

- iniciava-se a geração de ozônio, esperava-se o tempo necessário para a estabilização do gerador e determinava-se a concentração necessária para sua aplicação, com auxílio da equação (4.7):

$\mathrm{C}=\frac{\mathrm{C}_{\text {água }} \cdot \mathrm{Q}_{\text {água }}+\mathrm{C}_{\text {oxidante }} \cdot \mathrm{Q}_{\text {oxidante }}}{\mathrm{Q}_{\text {água }}+\mathrm{Q}_{\text {oxidante }}}$

em que:

$\mathrm{C}=$ concentração de $\mathrm{O}_{3}$ aplicada $(\mathrm{mg} / \mathrm{L})$;

$\mathrm{C}_{\text {água }}=$ concentração de $\mathrm{O}_{3}$ na água afluente à coluna de ozonização $(\mathrm{mg} / \mathrm{L})$;

$Q_{\text {água }}=$ vazão de água afluente à coluna de ozonização, dependente da taxa de filtração no FAAG (L/h); 
$\mathrm{C}_{\text {oxidante }}=$ concentração de $\mathrm{O}_{3}$, dada pelo medidor de $\mathrm{O}_{3}$ na fase gasosa $(\mathrm{mg} / \mathrm{L})$;

$\mathrm{Q}_{\text {oxidante }}=$ vazão de ozônio aplicada na coluna de ozonização e ajustada no rotâmetro instalado na saída do gerador de $\mathrm{O}_{3}(\mathrm{~L} / \mathrm{h})$.

- aplicava-se $\mathrm{O}_{3}$ na coluna de ozonização e a água pré-oxidada era coletada em um balde, após o tempo de contato de aproximadamente 10 minutos, determinado preliminarmente com ensaio de traçador;

- a água pré-oxidada era transferida aos jarros do jarteste, nos quais eram variadas as dosagens de coagulante e procedia-se ao ensaio nos reatores estáticos e FLAs.

Nos ensaios 10 a 15, a determinação das dosagens de oxidante e coagulante e do pH de coagulação foi feita preliminarmente, na instalação piloto em escoamento contínuo, variando-se a dosagem do oxidante e de coagulante e ajustando-se o pH de coagulação, até que se obtivesse cor aparente remanescente $\leq 5 \mathrm{uH}$ e turbidez $\leq 1 \mathrm{uT}$ no efluente do FRD. Para cada variação nas dosagens de oxidante e coagulante e ajustes no pH de coagulação, esperava-se o tempo de aproximadamente 1 hora para a coleta de amostras de água no efluente do FRD. Após a determinação das dosagens de oxidante e coagulante e ajuste do pH de coagulação, interrompia-se este ensaio preliminar, lavavam-se os filtros, compactavam-se os meios filtrantes e iniciavam-se os ensaios sem interrupções.

No período de execução do ensaio 8, a água bruta afluente à ETA II e à instalação piloto estava sendo pré-oxidada com hipoclorito de sódio. A dosagem de $\mathrm{NaClO}$ na instalação piloto era ajustada com base na dosagem aplicada na água bruta da ETA II. Este ensaio ficou prejudicado, devido ao funcionamento intermitente da ETA II, que era interrompido das 19:00 às 22:00 h, sendo observado um aumento no teor de cloro na água bruta e conseqüentemente aumento de $\mathrm{pH}$ da água pelo uso de $\mathrm{NaClO}$. Com o aumento do $\mathrm{pH}$ da água bruta foi necessário um acréscimo excessivo de acidificante, além disso, ocorreu a interrupção na adição de extrato de substâncias húmicas devido a um vazamento na mangueira. Este problema não pôde ser solucionado devido à dificuldade de acesso em que se localizava o furo, ocorrendo a interrupção deste ensaio com 16 horas de funcionamento. 


\subsubsection{Determinação do tempo de contato para os ensaios com pré-oxidação}

A coluna de ozonização foi utilizada como câmara de contato para todos os ensaios com pré-oxidação. Devido ao fato do ozônio ser um oxidante gasoso, e os demais oxidantes eram em solução, foi necessário determinar tempos de contato diferentes. O escoamento na coluna de ozonização era em contra-corrente quando utilizou-se o ozônio como pré-oxidante, com entrada de água na parte superior, introdução de ozônio na parte inferior por meio de pedra difusora, e saída de água pré-oxidada na parte inferior.

Após o ajuste da vazão de entrada de água na coluna de ozonização, considerando a taxa de filtração de $180 \mathrm{~m}^{3} / \mathrm{m}^{2} \mathrm{~d}$ utilizada no $\mathrm{FAAG}$, que resulta em uma vazão aproximada de 117 L/h, e a vazão do desvio de água coagulada de aproximadamente $50 \mathrm{~L} / \mathrm{h}$, deu-se início aos ensaios para determinação dos tempos de contato na coluna de ozonização.

Os ensaios para determinar os tempos de contato basearam-se na introdução de uma solução de cloreto de sódio com concentrações de 20 e 40 mg/L (traçador) na entrada de água na coluna de ozonização (topo) e com auxílio de um medidor de condutividade, instalado em linha na tubulação de saída da água préoxidada, obtiveram-se as concentrações de cloreto em diferentes tempos. O equipamento de medida de condutividade utilizado era da marca Texas Instrumentation, o qual armazenava os dados obtidos.

Para o ozônio, introduziu-se ar com vazão de 60 L/h na parte inferior da coluna de ozonização, que era distribuído pela pedra difusora, e procedeu-se o ensaio da mesma maneira.

\subsubsection{Coleta de amostra e verificação da formação de subprodutos}

Após 6 horas de funcionamento de cada ensaio, amostras de 1 litro da água pré-oxidada e do efluente do FRD foram coletadas, separadas e armazenadas em frascos âmbar (ver Figura 4.26) e cloradas com cloro na forma de tricloro-s-triazinatriona com dosagem de 2 vezes o valor do COD da amostra (BECKER et al., 2001), durante o tempo de contato de 24 horas, para verificar a formação de subprodutos decorrentes da pré-oxidação. Foram coletados 3 litros do efluente do FRD, sendo variado $0 \mathrm{pH}$ das amostras, a primeira era clorada sem alteração do $\mathrm{pH}$ e nas outras duas era adicionado algumas gotas de solução de hidróxido de sódio $(0,5 \mathrm{~N})$ até $\mathrm{pH}$ de aproximadamente 7 e 9, as quais eram cloradas e armazenadas em 
frascos âmbar até que completasse o tempo de contato de 24 horas. Após este tempo, coletava-se $100 \mathrm{~mL}$ da amostra clorada e adicionava-se aproximadamente 1 g de ácido ascórbico para cessar a reação do cloro.

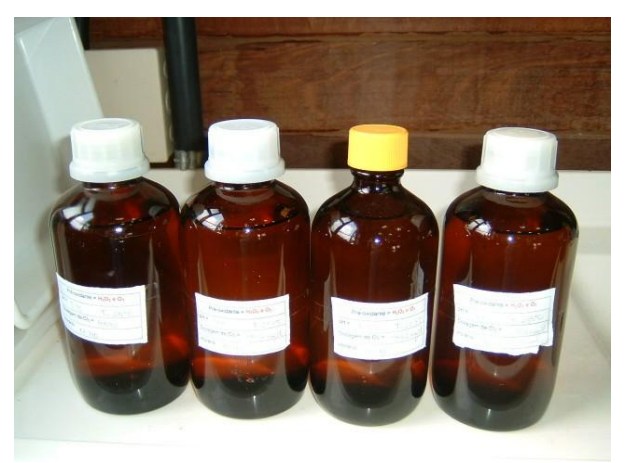

Figura 4.26 - Frascos utilizados para armazenamento das amostras de água pós cloradas para análise de subprodutos.

As análises de trialometanos, haloacetonitrilas, halocetonas, halopicrinas e ácidos haloacéticos foram feitas no Laboratório de Cromatografia da Universidade de Ribeirão Preto (UNAERP), utilizando-se um cromatógrafo a gás da marca VARIAN, modelo $3600 \mathrm{CX}$, com detector de captura de elétrons (DCE). Para estas análises foram utilizados os métodos 551.1 e 552.2 (USEPA, 1995), desenvolvidos por PASCHOALATO et al. (2004).

\section{- Método EPA 551.1:}

Extração de subprodutos: foi utilizada a extração líquido-líquido com adição de $20 \mu \mathrm{L}$ de padrão interno (diclorometano) e de $4 \mathrm{~mL}$ de metil-terc-butírico-éter (MTBE), em $10 \mathrm{~mL}$ de amostra e aproximadamente $1 \mathrm{~g}$ de sulfato de sódio como agente secante. Agitou-se vigorosamente por 1 minuto seguido de repouso por 2 minutos em $4^{\circ} \mathrm{C}$. Em seguida, $1 \mu \mathrm{L}$ do extrato da fase orgânica de MTBE foi injetado no cromatógrafo gasoso.

Condições cromatográficas: utilizou-se uma coluna capilar de sílica fundida DB - 1 com $0,32 \mathrm{~mm}$ de diâmetro interno $\times 30 \mathrm{~m}$ e $0,5 \mu \mathrm{m}$ de micro filme. $O$ gás de arraste foi o nitrogênio com fluxo de $3,4 \mathrm{~mL} / \mathrm{min}$ e pressão de $15 \mathrm{Psi}$. A temperatura isoterma foi de $40^{\circ} \mathrm{C}$ por 1 minuto, com rampa de aquecimento até $125^{\circ} \mathrm{C}$ por 2 minutos, em uma razão de $5^{\circ} \mathrm{C} / \mathrm{min}$, e aquecimento a $150^{\circ} \mathrm{C}$ numa razão de $20^{\circ} \mathrm{C} / \mathrm{min}$ por $2 \mathrm{~min}$. A temperatura do injetor era de $160^{\circ} \mathrm{C}$ e a do detector de $290^{\circ} \mathrm{C}$. Cada análise durava 25 minutos. Os padrões cromatográficos utilizados foram da marca Supelco (EPA 551A, 4-8045 e EPA 551B, 4-8046), em meio 
acetona. Foi feita uma curva analítica com concentrações de 25, 50, 75, 100 e 150 $\mu \mathrm{g} / \mathrm{L}$, conforme apresentada na Tabela 4.5.

Com este método foram identificados os seguintes subprodutos:

Trialometanos (TAMs): Clorofórmio, bromofórmio, bromodiclorometano, dibromoclorometano.

Haloacetonitrilas (HANs): dicloroacetonitrila, tricloroacetonitrila, dibromoacetonitrila e bromocloroacetonitrila.

Halocetonas (HCs): 1,1-dicloropropanona, 1,1,1-tricloropropanona.

Halopicrinas (HP): cloropicrinas.

$\mathrm{Na}$ Tabela 4.5 está apresentado um resumo da curva de calibração dos subprodutos listados anteriormente.

Tabela 4.5 - Resumo da curva analítica para trialometanos, haloacetonitrilas, halocetonas e halopicrinas (em $\mu \mathrm{g} / \mathrm{L})$.

\begin{tabular}{l|c|c|c|c|c}
\multicolumn{1}{c|}{ Compostos } & Ponto 1 & Ponto 2 & Ponto 3 & Ponto 4 & Ponto 5 \\
\hline \hline Padrão interno & 20 & 20 & 20 & 20 & 20 \\
\hline Clorofórmio & 25 & 50 & 75 & 100 & 150 \\
\hline Tricloroacetonitrila & 25 & 50 & 75 & 100 & 150 \\
\hline Dicloroacetonitrila & 25 & 50 & 75 & 100 & 150 \\
\hline Bromodiclorometano & 25 & 50 & 75 & 100 & 150 \\
\hline 1,1-dicloropropanona & 25 & 50 & 75 & 100 & 150 \\
\hline Cloropicrina & 25 & 50 & 75 & 100 & 150 \\
\hline Dibromoclorometano & 25 & 50 & 75 & 100 & 150 \\
\hline 1,1,1-tricloropropanona & 25 & 50 & 75 & 100 & 150 \\
\hline Bromocloroacetonitrila & 25 & 50 & 75 & 100 & 150 \\
\hline Dibromoacetonitrila & 25 & 50 & 75 & 100 & 150 \\
\hline Bromofórmio & 25 & 50 & 75 & 100 & 150 \\
\hline \hline
\end{tabular}

\section{- Método EPA 552.2:}

Extração de subprodutos: foi feita uma derivatização por metilação ácida seguida de extração líquido-líquido com MTBE. Foi colocado $50 \mathrm{~mL}$ da amostra resfriada a $4^{\circ} \mathrm{C}$ em balão volumétrico, adicionados $50 \mu \mathrm{L}$ de padrão interno $(2,3$ ácido dibromopropiônico - solução com concentração de 20 mg/L), aproximadamente $2 \mathrm{~g}$ de $\mathrm{CuSO}_{4}$ e $16 \mathrm{~g}$ de $\mathrm{Na}_{2} \mathrm{SO}_{4}$, e $1 \mathrm{~mL}$ de $\mathrm{H}_{2} \mathrm{SO}_{4}$ concentrado e agitou-se. Foram adicionados $5 \mathrm{~mL}$ de MTBE na solução gelada, agitou-se novamente o balão volumétrico durante 10 minutos e a solução foi colocada na geladeira. Foi retirado $3 \mathrm{~mL}$ da fase orgânica e transferido para um frasco de 10 $\mathrm{mL}$, no qual foi adicionado $1 \mathrm{~mL}$ de solução ácida de metanol (10\%). O frasco com o extrato foi deixado em banho a $50^{\circ} \mathrm{C}$ por 2 horas, depois de resfriado, adicionou- 
se $4 \mathrm{~mL}$ de solução saturada de bicarbonato de sódio em incrementos de $1 \mathrm{~mL}$. Após este procedimento, $1 \mu \mathrm{L}$ do extrato foi injetado no cromatógrafo a gás.

Condições cromatográficas: utilizou-se uma coluna capilar de sílica fundida

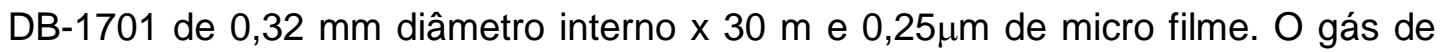
arraste foi o nitrogênio com fluxo de $1,4 \mathrm{~mL} / \mathrm{min}$ e pressão de 6 Psi. A temperatura isoterma foi de $40^{\circ} \mathrm{C}$ por 3 minutos com rampa de aquecimento até $180^{\circ} \mathrm{C}$ por 3 minutos. A temperatura do injetor era de $250^{\circ} \mathrm{C}$ e a do detector de $300^{\circ} \mathrm{C}$. O padrão cromatográfico utilizado foi da marca Supelco (EPA 552.2, 4-7787) em meio MTBE, com padrão interno (2,3 dibromopropiônico) adicionado aos padrões, branco e amostras. Foi feita uma curva analítica com as concentrações apresentadas na Tabela 4.6.

Com este método foram identificados os seguintes subprodutos:

Ácidos Haloacéticos (AHAs): ácido cloroácetico, ácido dicloroacético, ácido tricloroacético, ácido bromoacético, ácido dibromoacético, ácido tribromoacético, ácido bromocloroacético, ácido bromodicloroacético, ácido clorodibromoacético.

Tabela 4.6 - Resumo da curva analítica para os ácidos haloacéticos (em $\mu \mathrm{g} / \mathrm{L})$.

\begin{tabular}{|c|c|c|c|c|c|c|}
\hline \multirow[b]{2}{*}{ Compostos } & \multirow{2}{*}{$\begin{array}{c}\text { Concentração } \\
(\mathrm{mg} / \mathrm{L})\end{array}$} & \multicolumn{5}{|c|}{ Pontos da curva analítica } \\
\hline & & 1 & 2 & 3 & 4 & 5 \\
\hline ácido cloroácetico & 600 & 6 & 12 & 18 & 24 & 30 \\
\hline ácido bromoacético & 400 & 4 & 8 & 12 & 16 & 20 \\
\hline ácido dicloroacético & 600 & 6 & 12 & 18 & 24 & 30 \\
\hline ácido tricloroacético & 200 & 2 & 4 & 6 & 8 & 10 \\
\hline ácido bromocloroacético & 400 & 4 & 8 & 12 & 16 & 20 \\
\hline ácido bromodicloroacético & 400 & 4 & 8 & 12 & 16 & 20 \\
\hline ácido dibromoacético & 200 & 2 & 4 & 6 & 8 & 10 \\
\hline ácido clorodibromoacético & 1000 & 10 & 20 & 30 & 40 & 50 \\
\hline ácido tribromoacético & 2000 & 20 & 40 & 60 & 80 & 100 \\
\hline padrão interno & 20 & 50 & 50 & 50 & 50 & 50 \\
\hline
\end{tabular}

\subsubsection{Análise de Dados}

Os resultados obtidos nos ensaios na instalação piloto em escoamento contínuo foram analisados conforme os objetivos propostos pelo trabalho, com necessidade de alguns ajustes, como por exemplo, a correção da perda de carga para a temperatura de $20^{\circ} \mathrm{C}$ para uma comparação mais real dos resultados. Além 
da remoção de substâncias húmicas, foi avaliada a produção efetiva de água filtrada para cada ensaio correspondente à Fase 1, considerando as condições de operação. E para os ensaios com pré-oxidação foi avaliada a formação de subprodutos utilizando-se os métodos descritos no item 4.3.5.3. A seguir estão descritas as formas de análise de dados para comparação e discussão dos resultados.

\subsubsection{Correção da perda de carga em função da temperatura da água}

Para comparar a evolução da perda de carga no FAAG e no FRD durante os ensaios experimentais na instalação piloto em escoamento contínuo nas fases 1 e 2, e devido a variação da temperatura da água, foi feita a correção da perda de carga em função da temperatura, considerando a variação da massa específica e da viscosidade da água, utilizando a equação (4.8).

Como a temperatura da água variou de 16 a $26^{\circ} \mathrm{C}$ em todos os ensaios, optou-se por corrigir a perda de carga dos filtros para a temperatura de $20^{\circ} \mathrm{C}$.

$$
\mathrm{h}_{20}=\frac{\mathrm{h}_{\mathrm{t}}{ }^{*} \rho_{\mathrm{t}}{ }^{*} \mu_{20}}{\rho_{20}{ }^{*} \mu_{\mathrm{t}}}
$$

em que:

$\mathrm{h}_{20}=$ perda de carga corrigida para a temperatura de $20^{\circ} \mathrm{C}(\mathrm{m})$;

$h_{t}=$ perda de carga na temperatura $t(m)$;

$\rho_{\mathrm{t}}=$ massa específica da água na temperatura $\mathrm{t}\left(\mathrm{kg} / \mathrm{m}^{3}\right)$;

$\mu_{20}=$ viscosidade absoluta da água na temperatura de $20^{\circ} \mathrm{C}\left(\mathrm{N} . \mathrm{s} / \mathrm{m}^{2}\right)$;

$\rho_{20}=$ massa específica da água na temperatura de $20^{\circ} \mathrm{C}\left(\mathrm{kg} / \mathrm{m}^{3}\right)$;

$\mu_{\mathrm{t}}=$ viscosidade absoluta da água na temperatura $\mathrm{t}\left(\mathrm{N} . \mathrm{s} / \mathrm{m}^{2}\right)$.

$\mathrm{Na}$ Tabela 4.7 estão apresentadas as variações da massa específica e viscosidade absoluta da água em função da temperatura. 
Tabela 4.7 - Variações da massa específica e viscosidade absoluta da água em função da temperatura.

\begin{tabular}{c|c|c}
\hline $\begin{array}{c}\text { Temperatura } \\
\left({ }^{\circ} \mathrm{C}\right)\end{array}$ & $\begin{array}{c}\text { Massa específica } \\
\left(\mathrm{kg} / \mathrm{m}^{3}\right)\end{array}$ & $\begin{array}{c}\text { Viscosidade absoluta } \\
\times 10^{-3}\left(\mathrm{~N} \cdot \mathrm{s} / \mathrm{m}^{2}\right)\end{array}$ \\
\hline \hline 10 & 999,702 & 1,308 \\
\hline 11 & 999,607 & 1,271 \\
\hline 12 & 999,500 & 1,236 \\
\hline 13 & 999,379 & 1,203 \\
\hline 14 & 999,246 & 1,171 \\
\hline 15 & 999,102 & 1,140 \\
\hline 16 & 998,945 & 1,111 \\
\hline 17 & 998,777 & 1,083 \\
\hline 18 & 998,598 & 1,056 \\
\hline 19 & 998,407 & 1,030 \\
\hline 20 & 998,206 & 1,005 \\
\hline 21 & 997,995 & 0,981 \\
\hline 22 & 997,773 & 0,958 \\
\hline 23 & 997,541 & 0,936 \\
\hline 24 & 997,299 & 0,914 \\
\hline 25 & 997,048 & 0,894 \\
\hline 26 & 996,787 & 0,874 \\
\hline 27 & 996,517 & 0,855 \\
\hline 28 & 996,237 & 0,836 \\
\hline 29 & 995,949 & 0,818 \\
\hline 30 & 995,651 & 0,801 \\
\hline \hline
\end{tabular}

Fonte: DI BERNARDO (2004).

Com os dados da Tabela 4.7 foram ajustadas as curvas relacionando a temperatura com a massa específica e a viscosidade absoluta da água, obtendo-se as equações e os respectivos coeficientes de correlação, conforme apresentados nas Figuras 4.27 e 4.28. Com as equações das curvas ajustadas foi possível calcular a massa específica e a viscosidade absoluta da água na temperatura t lida durante os ensaios. 


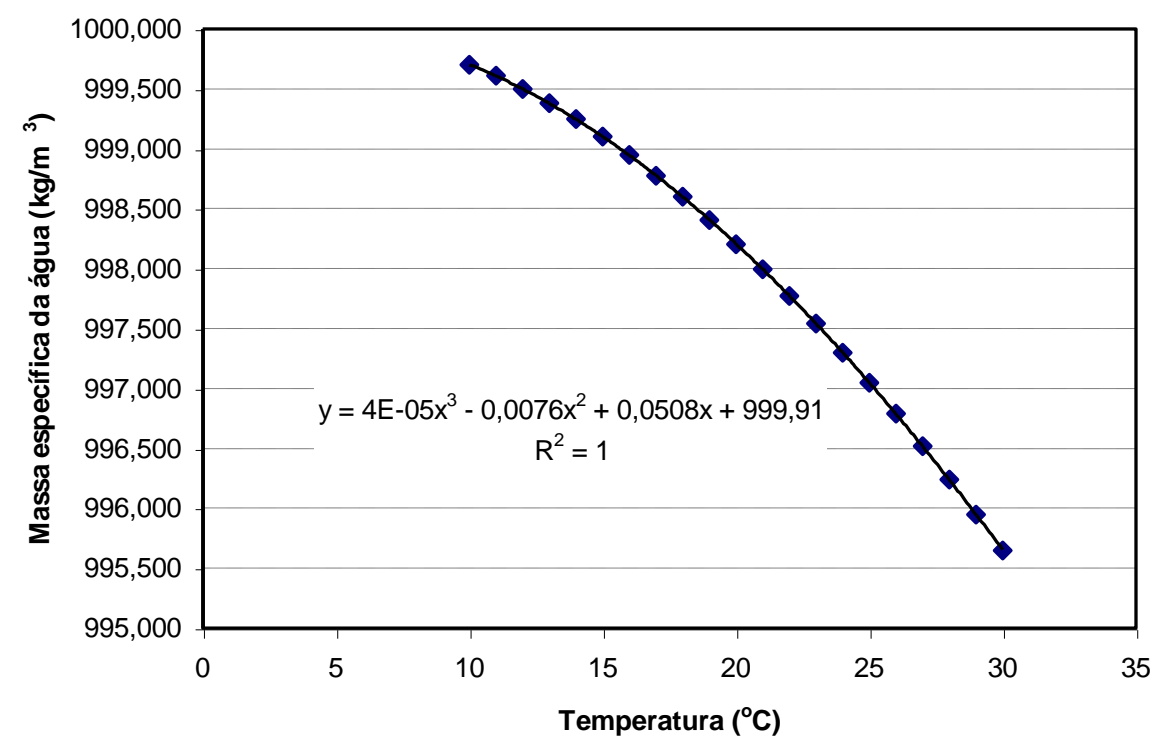

Figura 4.27 - Massa específica da água em função da temperatura.

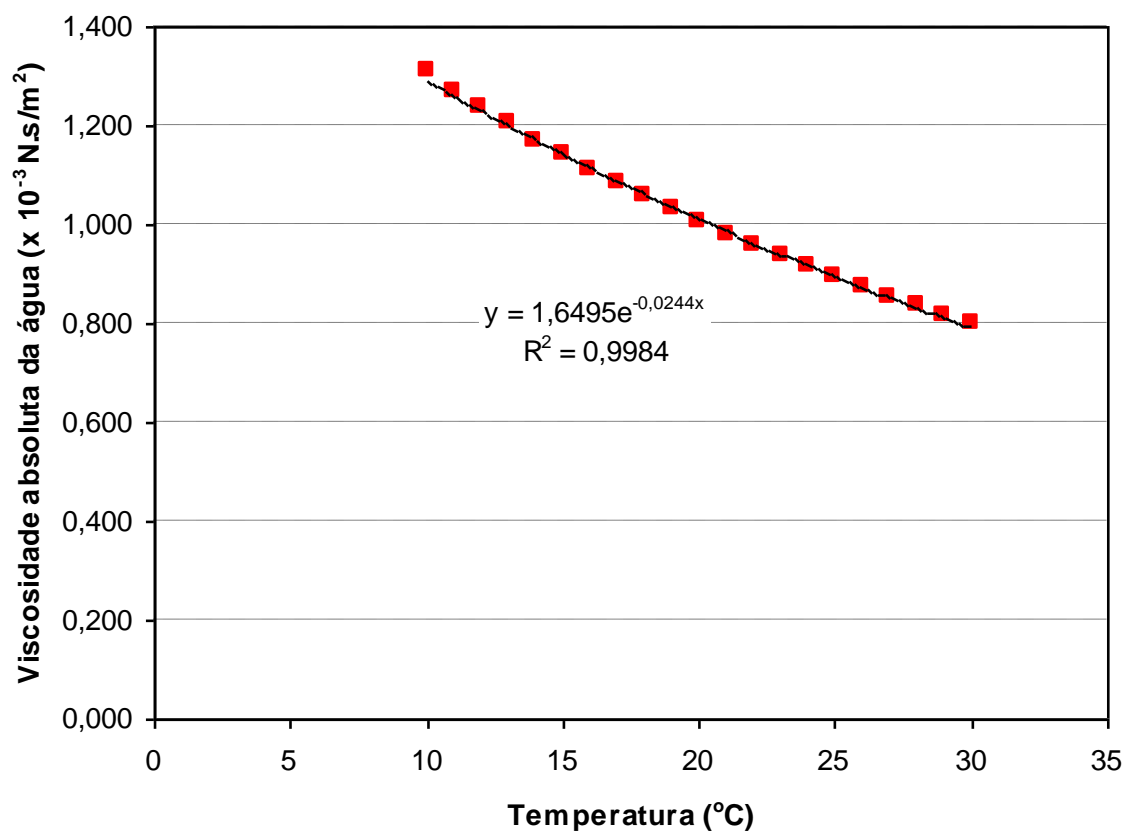

Figura 4.28 - Viscosidade absoluta da água em função da temperatura.

\subsubsection{Determinação da produção efetiva de água filtrada}

Para os ensaios da Fase 1 foi calculada a produção efetiva de água filtrada, considerando principalmente o fato de que a carreira foi, na maioria das vezes, interrompida em 72 horas de funcionamento, não chegando a atingir a perda de 
carga prevista (2,20 m no FAAG). O cálculo da produção efetiva foi feito a partir da equação (4.9), com auxílio das equações (4.10) a (4.14):

$P E=P T-V L_{F A A G}-V D F_{\text {final }}-V D F I s-V L_{F R D}$

em que:

$\mathrm{PE}=$ produção efetiva de água filtrada $\left(\mathrm{m}^{3} / \mathrm{m}^{2}\right)$;

$\mathrm{PT}=$ produção total de água filtrada $\left(\mathrm{m}^{3} / \mathrm{m}^{2}\right)$;

$\mathrm{VL}_{\mathrm{FAAG}}=$ consumo de água utilizada para as lavagens do $\mathrm{FAAG}\left(\mathrm{m}^{3} / \mathrm{m}^{2}\right)$;

$\mathrm{VDF}_{\text {final }}=$ consumo de água utilizada na interface areia-pedregulho durante a execução da descarga de fundo final $\left(\mathrm{m}^{3} / \mathrm{m}^{2}\right)$;

VDFls = consumo de água utilizada na interface areia-pedregulho durante as descargas de fundo intermediárias $\left(\mathrm{m}^{3} / \mathrm{m}^{2}\right)$;

$\mathrm{VL}_{\mathrm{FRD}}=$ consumo de água utilizada para as lavagens do $\mathrm{FRD}\left(\mathrm{m}^{3} / \mathrm{m}^{2}\right)$.

Sendo:

$\mathrm{PT}=\mathrm{TF}{ }^{*} \mathrm{DCF}$

em que:

TF = taxa de filtração $\left(\mathrm{m}^{3} / \mathrm{m}^{2} \mathrm{~d}\right)$;

DCF $=$ duração da carreira de filtração $(d)$.

$\mathrm{VL}_{\mathrm{FAAG}}=N L_{F A A G}{ }^{*} \mathrm{TL}_{\mathrm{FAAG}}{ }^{*} \mathrm{DL}_{\mathrm{FAAG}}{ }^{*}\left(\Delta \mathrm{H}_{\text {final }} \mathrm{FAAG} / \Delta \mathrm{H}_{\text {prevista }} \mathrm{FAAG}\right)$

em que:

$\mathrm{NL}_{\mathrm{FAAG}}=$ número de lavagens executadas no FAAG;

$\mathrm{TL}_{\mathrm{FAAG}}=$ taxa de aplicação de água para lavagem do FAAG $\left(\mathrm{m}^{3} / \mathrm{m}^{2} \mathrm{~d}\right)$;

$D_{\text {FAAG }}=$ duração da lavagem do FAAG (d);

$\Delta H_{\text {final }} F A A G=$ perda de carga final no FAAG $(m) ;$

$\Delta \mathrm{H}_{\text {prevista }} \mathrm{FAAG}=$ perda de carga prevista no $\mathrm{FAAG}(\mathrm{m})$.

$\mathrm{VDF}_{\text {final }}=\operatorname{TDF}^{*} \operatorname{DDF}^{*}\left(\Delta \mathrm{H}_{\text {final }} \mathrm{FAAG} / \Delta \mathrm{H}_{\text {prevista }} \mathrm{FAAG}\right)$

em que:

TDF $=$ taxa de descarga de fundo $\left(\mathrm{m}^{3} / \mathrm{m}^{2} \mathrm{~d}\right) ;$

DDF = duração da descarga de fundo (d). 
VDFIs $=\mathrm{N}^{\circ}$ DFIs $\mathrm{FAAG}^{*} \mathrm{TDF} * \mathrm{DDF}$

em que:

$\mathrm{N}^{\circ}$ DFIs $\mathrm{S}_{\mathrm{FAG}}=$ número de DFls executadas no FAAG.

$V L_{F R D}=\left(N L_{F R D}+1 *\left(\Delta H_{\text {final }} F R D / \Delta H_{\text {prevista }} F R D\right)\right) * T_{F R D}{ }^{*} D_{F R D} *\left(A_{F R D} / A_{F A A G}\right)$

em que:

$\mathrm{NL}_{\mathrm{FRD}}=$ número de lavagens executadas no FRD;

$\Delta H_{\text {final }} F R D=$ perda de carga final no FRD $(m)$;

$\Delta \mathrm{H}_{\text {prevista }} \mathrm{FRD}=$ perda de carga prevista no $\operatorname{FRD}(2,10 \mathrm{~m})$;

$\mathrm{TL}_{\mathrm{FRD}}=$ taxa de aplicação de água para lavagem do $\operatorname{FRD}\left(\mathrm{m}^{3} / \mathrm{m}^{2} \mathrm{~d}\right) ;$

$D_{F R D}=$ duração da lavagem no FRD (d);

$A_{F R D}=$ área do $F R D\left(m^{2}\right)$;

$A_{F A A G}=$ área do $F A A G\left(m^{2}\right)$.

Obs: no primeiro termo da equação 4.14 considera-se o número de lavagens executadas no FRD, em que o encerramento da carreira de filtração se deu por atingir a perda de carga prevista ou quando ocorreu o transpasse, mais a última lavagem (representada na equação pelo número 1) vezes a relação entre a perda de carga final e a perda de carga prevista, considerando o fato de que a carreira de filtração se prolongaria até que atingisse a perda de carga prevista, se não fosse encerrada pelo critério de 72 horas de funcionamento dos filtros.

\subsubsection{Remoção de substâncias húmicas e eficiência global do sistema de dupla filtração}

Técnicas analíticas indiretas como COD, absorvância 254 nm e a remoção de cor foram utilizadas para avaliar e comparar os resultados obtidos nos ensaios na instalação piloto, com relação à eficiência de remoção de substâncias húmicas.

É importante destacar que na eficiência global do sistema de dupla filtração sem e com pré-oxidação, com e sem variação de taxas de filtração, com ou sem DFIs no FAAG foram avaliados não só a remoção de substâncias húmicas, mas também as condições operacionais, a produção efetiva de água e o residual de alumínio no efluente do FRD e a formação de subprodutos. 


\section{RESULTADOS E DISCUSSÃO}

\subsection{Caracterização das Substâncias Húmicas}

\section{a) Análise Elementar}

$\mathrm{Na}$ Tabela 5.1 estão apresentados os resultados obtidos na análise elementar das substâncias húmicas e as razões atômicas.

Tabela 5.1 - Composição elementar das substâncias húmicas e as razões atômicas.

\begin{tabular}{cccc|ccc}
\hline \multicolumn{3}{c}{ Massa (\%) } & \multicolumn{3}{c}{ Razões atômicas } \\
\hline \hline $\mathbf{C}$ & $\mathbf{H}$ & $\mathbf{N}$ & $\mathbf{O}$ & $\mathbf{H} / \mathbf{C}$ & $\mathbf{O} / \mathbf{C}$ & $\mathbf{C} / \mathbf{N}$ \\
40,30 & 4,37 & 1,82 & 53,31 & 1,30 & 0,99 & 25,77 \\
\hline \hline
\end{tabular}

A composição elementar das substâncias húmicas apresentou alta porcentagem de oxigênio, indicando a presença de compostos carboxílicos e carboidratos. De acordo com ROCHA \& ROSA (2003), as razões molares H/C e $\mathrm{C} / \mathrm{N}$ geralmente têm sido utilizadas para estimar o grau de aromaticidade e de humificação das substâncias húmicas, respectivamente. A razão molar $\mathrm{H} / \mathrm{C}=1,30$ indica elevada aromaticidade e a razão molar $\mathrm{C} / \mathrm{N}$ indica alto grau de humificação.

\section{b) Análises de Infravermelho (IV)}

Na Figura 5.1 está mostrado o espectro na região do infravermelho das substâncias húmicas, o qual exibiu bandas típicas de absorção no IV. Segundo ROCHA \& ROSA (2003), os espectros na região do infravermelho das substâncias húmicas mostram bandas largas provavelmente por causa da sobreposição das bandas de absorção dos constituintes individuais da mistura heterogênea de grupos que constituem as substâncias húmicas.

Na região de $3390 \mathrm{~cm}^{-1}$ observa-se uma banda larga, que é caracterizada pela ligação de $\mathrm{H}^{+}$a grupos $\mathrm{OH}^{-}$provenientes de grupos alcoólicos e carboxílicos. 
Em $2900 \mathrm{~cm}^{-1}$ aparece uma banda característica de vibrações de grupos $\mathrm{CH}_{3} \mathrm{e}$ $\mathrm{CH}_{2}$, próxima a moléculas de oxigênio de cadeias alifáticas. Uma banda forte aparece na região próxima a $1600 \mathrm{~cm}^{-1}$, podendo ser atribuída às vibrações $\mathrm{COO}^{-} \mathrm{e}$ $\mathrm{C}=\mathrm{C}$ de aromáticos, junto com as bandas de olefinas $\mathrm{C}-\mathrm{C}$.

Próximo de $1400 \mathrm{~cm}^{-1}$ aparece uma banda característica de deformação O$\mathrm{H}$, deformação angular $\mathrm{CH}_{3}, \mathrm{C}-\mathrm{O}$ característico de estiramento de grupamentos fenólicos $\mathrm{OH}$ e estiramento anti-simétrico de COO- Ainda nessa região pode-se atribuir em $1450 \mathrm{~cm}^{-1}$ um estiramento característico de grupos $\mathrm{CH}$ de alifáticos (ROCHA \& ROSA, 2003).

$\mathrm{Na}$ região entre $500-1100 \mathrm{~cm}^{-1}$ aparecem bandas que podem ser atribuídas a estiramentos C-O de polissacarídeos e ainda a vibrações de ligações $\mathrm{C}-\mathrm{C}$ de alifáticos ou $\mathrm{CH}$ de anéis aromáticos.

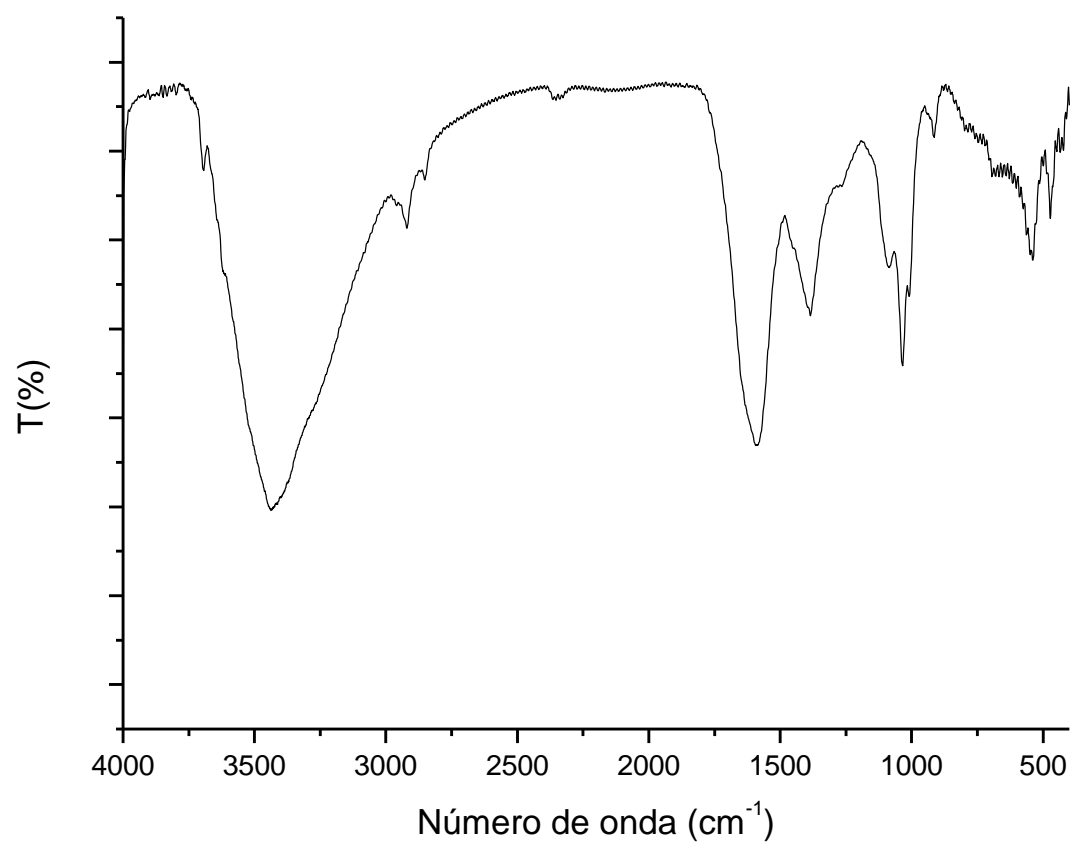

Figura 5.1 - Espectro da região do infravermelho das substâncias húmicas. Fonte: CAMPOS (2004).

\section{c) Análises de Ultravioleta Visível (UV/Vis)}

Na Figura 5.2 está apresentado o espectro de UV-Vísivel na região de 400 a $800 \mathrm{~nm}$ para a amostra de substâncias húmicas, de onde foi possível calcular a razão de absorção no comprimento de onda de $465 \mathrm{~nm}$ e 665 nm (razão $\mathrm{E}_{4} / \mathrm{E}_{6}$ ). 


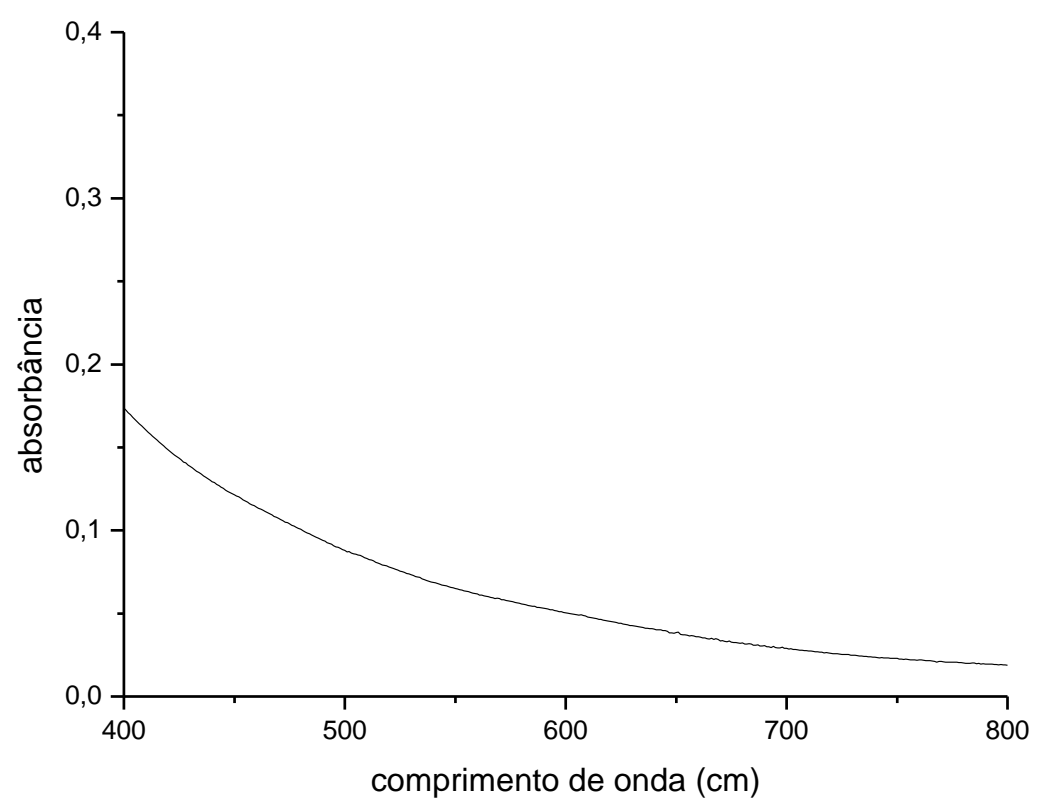

Figura 5.2 - Espectro de UV-Vísivel na região de 400 a $800 \mathrm{~nm}$ para a amostra de substâncias húmicas. Fonte: CAMPOS (2004).

O valor da razão $E_{4} / E_{6}$ encontrado foi de 3,20 , indicando que as substâncias húmicas se apresentavam em um estágio de humificação avançado. De acordo com TRAINA et al. (1990) ${ }^{10}$ apud ROCHA \& ROSA (2003) a aromaticidade das substâncias húmicas pode ser estimada quantativamente por espectroscopia na região UV/Vis. O tamanho molecular das substâncias húmicas também influi na quantidade de unidades aromáticas. Frações com maior tamanho molecular contém maior número de estruturas aromáticas, ocorrendo uma gradual diminuição das estruturas aromáticas nas frações com menor tamanho molecular.

\section{d) Análises de Metais}

Na Tabela 5.2 estão apresentados os resultados obtidos das análises de metais. Observa-se uma grande quantidade de ferro na amostra analisada.

\footnotetext{
${ }^{10}$ TRAINA, S. J.; NOVAK, J.; SMECK, N.E (1990) An Ultraviolet Absorbance Method of Estimating the Percent Aromatic Carbon Content of Humic Acids. J. Environmental Quality, v. 19, p. 151-3.
} 
Tabela 5.2 - Resultados das análises de metais no extrato de substâncias húmicas.

\begin{tabular}{l|c|c}
\hline \multicolumn{1}{c|}{ Metais } & Resultado & $\begin{array}{c}\text { Unidade de } \\
\text { medida }\end{array}$ \\
\hline Manganês & 0,113 & $\mathrm{mg} / \mathrm{L}$ \\
\hline Ferro & 18,690 & $\mathrm{mg} / \mathrm{L}$ \\
\hline Zinco & 0,405 & $\mathrm{mg} / \mathrm{L}$ \\
\hline Níquel & 0,119 & $\mathrm{mg} / \mathrm{L}$ \\
\hline Cobre & 1,542 & $\mathrm{mg} / \mathrm{L}$ \\
\hline Arsênio & 0,043 & $\mu \mathrm{g} / \mathrm{L}$ \\
\hline Cobalto & 0,061 & $\mathrm{mg} / \mathrm{L}$ \\
\hline Estanho & 2,128 & $\mathrm{mg} / \mathrm{L}$ \\
\hline Cromo & 0,612 & $\mathrm{mg} / \mathrm{L}$ \\
\hline Vanádio & $<0,05$ & $\mathrm{mg} / \mathrm{L}$ \\
\hline Prata & 0,008 & $\mathrm{mg} / \mathrm{L}$ \\
\hline \hline
\end{tabular}

A escolha do método e do procedimento analítico a ser utilizado na determinação das espécies metálicas em substâncias húmicas é de fundamental importância. O método deve ser de elevada sensibilidade, para permitir a quantificação das concentrações de metais em $\mathrm{ng} / \mathrm{mL}$, dependendo do analito de interesse e dos interferentes presentes na matriz. Os métodos baseados em espectrometria atômica utilizando-se atomizadores de chama, forno de grafite, plasma ou fluorescência total com reflectância de raio $X$ têm sido preferencialmente utilizados (ROCHA \& ROSA, 2003).

\subsection{Variação de Cor Verdadeira em relação ao pH}

Segundo DI BERNARDO et al. (2002), o tamanho molecular das substâncias húmicas varia com o pH e com o grau de polimerização (entre 3,5 e 10 $\mathrm{nm}$ ), portanto a medida de cor depende do $\mathrm{pH}$ da amostra de água, o que pode ser observado na Figura 5.3.

Com a "solução-mãe" preparada com o extrato de substâncias húmicas, obteve-se o pico de melhor absorção a $455 \mathrm{~nm}$ no espectrofotômetro UV. Com as amostras diluídas de cor verdadeira de 5, 10, 15, 20, 30, 50, 75, 100 e $120 \mathrm{uH}$, variando-se o pH de cada amostra de 4,5 a 7,0 foram obtidas as curvas de $\mathrm{pH}$ em função da cor, representadas na Figura 5.3. 


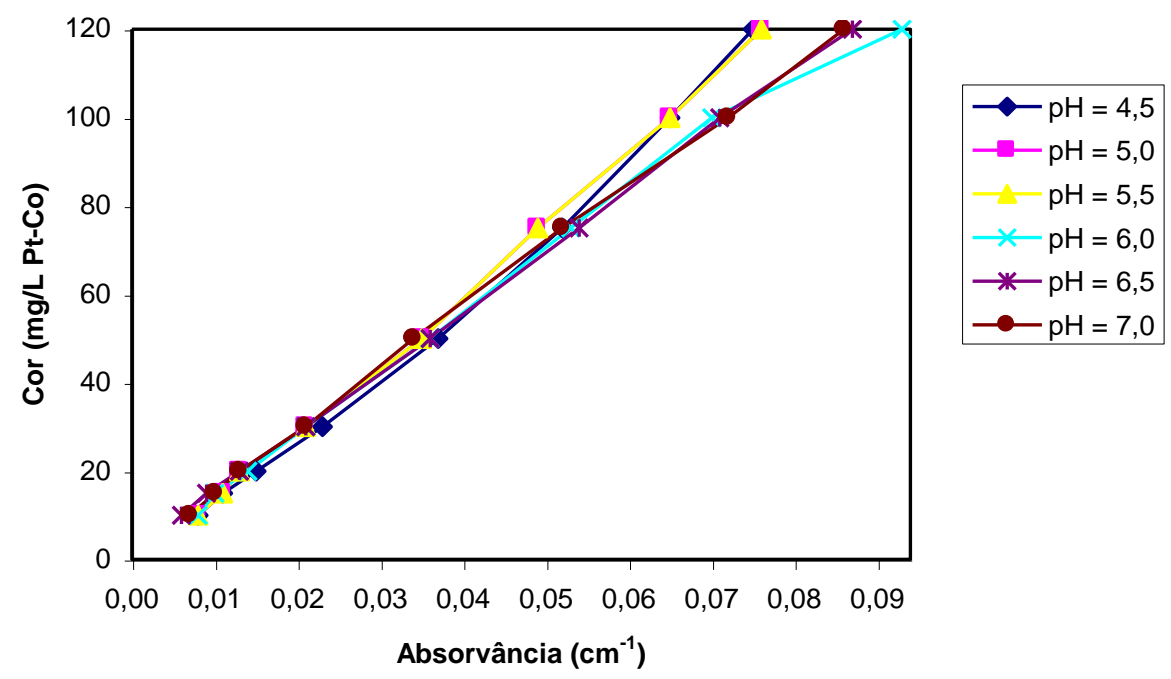

Figura 5.3 - Curvas de variação da cor verdadeira em função da absorvância ( $\lambda=455 \mathrm{~nm}$ ) em relação ao $\mathrm{pH}$.

MENDES (1985) estudou a variação de cor da água em função da absorvância $(\lambda=455 \mathrm{~nm}$ ) em relação ao $\mathrm{pH}$ e concluiu que quanto menor $\mathrm{o} \mathrm{pH}$, maior o valor da cor verdadeira, como tendência observada na Figura 5.3.

Esta verificação da variação da cor verdadeira em função do $\mathrm{pH}$ definiu a curva analítica para as medidas de cor no espectrofotômetro UV DR 4000 ( $\lambda=455$ $\mathrm{nm})$, a qual foi utilizada nos ensaios experimentais subseqüentes.

\subsection{Ensaios em Reatores Estáticos}

\subsubsection{Escolha da Granulometria da Areia Utilizada nos FLAs}

Foram estudados três tipos de areia com faixas granulométricas diferentes para os FLAs. Como mostra a Tabela 5.3, os melhores resultados de remoção de cor e turbidez nos ensaios em reatores estáticos foram para os FLAs constituídos de areia com granulometria de 0,30 a 0,59 mm (tipo 1), em que a melhor dosagem de $\mathrm{Al}_{2}\left(\mathrm{SO}_{4}\right)_{3} .14,3 \mathrm{H}_{2} \mathrm{O}$ foi de $20 \mathrm{mg} / \mathrm{L}$ e o pH de coagulação de 6,82 . 
Tabela 5.3 - Resultados dos ensaios em reatores estáticos para a escolha do tipo de areia utilizada nos filtros de laboratório de areia (FLAs).

\begin{tabular}{|c|c|c|c|c|c|c|c|c|c|c|}
\hline \multicolumn{11}{|c|}{ AREIA TIPO 1 (0,30 a 0,59 mm) } \\
\hline \multirow[t]{3}{*}{$\begin{array}{c}\text { Jarro / } \\
\text { FLA }\end{array}$} & \multirow[t]{3}{*}{$\begin{array}{c}D_{S A} \\
(m g / L)\end{array}$} & \multirow[t]{3}{*}{$\begin{array}{c}\mathrm{pH} \text { de } \\
\text { coagulação }\end{array}$} & \multirow{2}{*}{\multicolumn{4}{|c|}{$\begin{array}{c}\text { Cor aparente remanescente nos } \\
\text { FLAs (uH) } \\
\text { Tempo de Filtracão (min) }\end{array}$}} & \multirow{2}{*}{\multicolumn{4}{|c|}{$\begin{array}{c}\text { Turbidez remanescente nos } \\
\text { FLAs (uT) } \\
\text { Tempo de Filtração (min) }\end{array}$}} \\
\hline & & & & & & & & & & \\
\hline & & & 10 & 20 & 30 & 40 & 10 & 20 & 30 & 40 \\
\hline 1 & 5 & 6,87 & 130 & 130 & 135 & 133 & 7,7 & 7,9 & 7,9 & 7,7 \\
\hline 2 & 10 & 6,86 & 54 & 35 & 36 & 34 & 2,8 & 1,9 & 1,8 & 1,7 \\
\hline 3 & 15 & 6,85 & 3 & $<1$ & 6 & $<1$ & 0,5 & 0,3 & 0,3 & 0,2 \\
\hline 4 & 20 & 6,82 & $<1$ & $<1$ & $<1$ & $<1$ & 0,3 & 0,3 & 0,2 & 0,2 \\
\hline 5 & 25 & 6,63 & 19 & 4 & $<1$ & $<1$ & 1,3 & 0,4 & 0,2 & 0,2 \\
\hline 6 & 30 & 6,43 & 45 & 52 & 52 & 38 & 3,2 & 3,2 & 2,9 & 2,0 \\
\hline \multicolumn{11}{|c|}{ AREIA TIPO $2(0,42$ a $0,84 \mathrm{~mm})$} \\
\hline 1 & 5 & 6,99 & 143 & 148 & 145 & 148 & 8,7 & 8,8 & 8,3 & 8,2 \\
\hline 2 & 10 & 6,84 & 63 & 61 & 61 & 61 & 2,8 & 3,0 & 3,0 & 2,7 \\
\hline 3 & 15 & 6,85 & 6 & 6 & 9 & 10 & 0,6 & 0,3 & 0,4 & 0,3 \\
\hline 4 & 20 & 6,70 & 2 & 4 & 6 & 7 & 0,3 & 0,3 & 0,2 & 0,2 \\
\hline 5 & 25 & 6,63 & 19 & 6 & 6 & 6 & 1,1 & 0,3 & 0,2 & 0,2 \\
\hline 6 & 30 & 6,45 & 69 & 59 & 48 & 53 & 4,2 & 3,2 & 2,4 & 2,4 \\
\hline \multicolumn{11}{|c|}{ AREIA TIPO 3 (0,59 a 1,41 mm) } \\
\hline 1 & 5 & 6,87 & 153 & 142 & 141 & 143 & 9,3 & 8,5 & 8,4 & 8,5 \\
\hline 2 & 10 & 6,82 & 76 & 72 & 71 & 71 & 3,6 & 3,5 & 3,6 & 3,5 \\
\hline 3 & 15 & 6,84 & 18 & 10 & 7 & 6 & 1,0 & 0,7 & 0,5 & 0,5 \\
\hline 4 & 20 & 6,75 & 10 & 3 & 2 & $<1$ & 0,7 & 0,3 & 0,4 & 0,3 \\
\hline 5 & 25 & 6,57 & 53 & 12 & 5 & 3 & 3,0 & 0,8 & 0,5 & 0,3 \\
\hline 6 & 30 & 6,36 & 112 & 96 & 90 & 81 & 6,8 & 5,8 & 5,4 & 4,6 \\
\hline
\end{tabular}

$\mathrm{D}_{\mathrm{SA}}=$ dosagem de sulfato de alumínio; FLA = filtro de laboratório de areia

A partir deste ensaio, a areia utilizada nos FLAs quando realizavam-se ensaios em reatores estáticos, ou quando verificavam-se as condições de coagulação na instalação piloto com desvio da água coagulada para o FLA, era do Tipo 1 com faixa granulométrica de 0,30 a $0,59 \mathrm{~mm}$. Os procedimentos de operação e lavagem dos FLAs utilizados neste trabalho foram os recomendados por GUSMÃO (2001). A espessura da camada de areia e a taxa de filtração utilizada foram de $15 \mathrm{~cm}$ e $600 \mathrm{~m}^{3} / \mathrm{m}^{2} \mathrm{~d}$, respectivamente. A lavagem do FLA era feita com introdução de água no sentido ascensional durante o tempo necessário para a limpeza do meio filtrante.

\subsubsection{Determinação da Dosagem de Coagulante e pH de Coagulação e Definição das Condições de Mistura Rápida}

Fixando-se a dosagem de $\mathrm{Al}_{2}\left(\mathrm{SO}_{4}\right)_{3} \cdot 14,3 \mathrm{H}_{2} \mathrm{O}$ em $20 \mathrm{mg} / \mathrm{L}$ e variando-se 0 pH de coagulação com solução de $\mathrm{HCl}$ 0,07 M, obteve-se o pH de coagulação para a melhor remoção de cor aparente e turbidez, que foi de 5,16, conforme resultados apresentados na Tabela 5.4. 
Tabela 5.4 - Resultados dos ensaios em reatores estáticos com variação do volume de $\mathrm{HCl}$ $(0,07 \mathrm{M})$ adicionado em cada jarro para a escolha do pH de coagulação.

\begin{tabular}{|c|c|c|c|c|c|c|c|c|c|c|}
\hline \multirow[t]{3}{*}{$\begin{array}{c}\text { Jarro / } \\
\text { FLA }\end{array}$} & \multirow{3}{*}{$\begin{array}{l}\text { Volume } \\
\mathrm{HCl} \\
(\mathrm{mL})\end{array}$} & \multirow[t]{3}{*}{$\begin{array}{c}\text { pH de } \\
\text { coagulação }\end{array}$} & \multicolumn{4}{|c|}{$\begin{array}{c}\text { Cor aparente remanescente nos } \\
\text { FLAs (uH) }\end{array}$} & \multirow{2}{*}{\multicolumn{4}{|c|}{$\begin{array}{l}\text { Turbidez remanescente nos } \\
\text { FLAs (uT) } \\
\text { Tempo de filtracão (min) }\end{array}$}} \\
\hline & & & \multicolumn{4}{|c|}{ Tempo de filtração (min) } & & & & \\
\hline & & & 10 & 20 & 30 & 40 & 10 & 20 & 30 & 40 \\
\hline 1 & 7,5 & 6,48 & 23 & 2 & 21 & 15 & 1,4 & 1,2 & 1 & 0,9 \\
\hline 2 & 12,5 & 5,93 & 7 & 83 & 97 & 99 & 3,8 & 4 & 4,4 & 6 \\
\hline 3 & 17,5 & 5 & 16 & 17 & 19 & 16 & 0,6 & , & 0,7 & 0,7 \\
\hline 4 & 22,5 & 5,16 & 2 & 5 & 4 & 1 & 0,2 & 0 & 0,2 & 0,2 \\
\hline 5 & 27,5 & 4,71 & 5 & 6 & 7 & 4 & 0,2 & 0 & 0,1 & 0,2 \\
\hline 6 & 32,5 & 4,40 & 6 & 8 & 6 & 4 & 0,3 & 0,2 & 0,2 & 0,2 \\
\hline
\end{tabular}

É importante salientar que este ensaio para a determinação da dosagem de coagulante e pH de coagulação foi realizado com a água de estudo em condições controladas de temperatura. No entanto, devido ao período de execução deste ensaio, a água de estudo apresentou características diferentes das observadas durante os ensaios na instalação piloto em escoamento contínuo, havendo alterações na dosagem de $\mathrm{Al}_{2}\left(\mathrm{SO}_{4}\right)_{3} \cdot 14,3 \mathrm{H}_{2} \mathrm{O}$. Na maioria dos ensaios na instalação piloto correspondentes à Fase 1 , a dosagem de $\mathrm{Al}_{2}\left(\mathrm{SO}_{4}\right)_{3} \cdot 14,3 \mathrm{H}_{2} \mathrm{O}$ foi de aproximadamente $8 \mathrm{mg} / \mathrm{L}$, enquanto que na Fase 2 a variação da dosagem de $\mathrm{Al}_{2}\left(\mathrm{SO}_{4}\right)_{3} \cdot 14,3 \mathrm{H}_{2} \mathrm{O}$ foi de 3,5 a $7 \mathrm{mg} / \mathrm{L}$.

Para a escolha do gradiente de velocidade de mistura rápida $\left(\mathrm{G}_{\mathrm{mr}}\right)$, fixou-se a dosagem de $\mathrm{Al}_{2}\left(\mathrm{SO}_{4}\right)_{3} .14,3 \mathrm{H}_{2} \mathrm{O} \mathrm{em} 20 \mathrm{mg} / \mathrm{L}$ e manteve-se o pH de coagulação entre 5 e 5,6. Os resultados apresentados na Tabela 5.5 indicaram que o gradiente de velocidade de $750 \mathrm{~s}^{-1}$ foi o que apresentou menor variação na eficiência de remoção de cor aparente, com a variação do tempo de mistura rápida. 
Tabela 5.5 - Resultados dos ensaios em reatores estáticos para a escolha do gradiente de velocidade de mistura rápida $\left(G_{\mathrm{mr}}\right)$.

\begin{tabular}{|c|c|c|c|c|c|c|c|c|c|c|}
\hline \multicolumn{11}{|c|}{$\mathrm{G}_{\mathrm{mr}}=500 \mathrm{~s}^{-1}$} \\
\hline \multirow[t]{3}{*}{$\begin{array}{c}\text { Jarro / } \\
\text { FLA }\end{array}$} & \multirow{3}{*}{$\begin{array}{c}\text { Tempo de } \\
\text { mistura } \\
\text { (s) }\end{array}$} & \multirow[t]{3}{*}{$\begin{array}{c}\text { pH de } \\
\text { coagulação }\end{array}$} & \multicolumn{4}{|c|}{\begin{tabular}{|c|} 
Cor remanescente nos FLAs \\
$(\mathrm{uH})$
\end{tabular}} & \multicolumn{4}{|c|}{$\begin{array}{c}\text { Turbidez remanescente nos } \\
\text { FLAs (uT) }\end{array}$} \\
\hline & & & \multicolumn{4}{|c|}{ Tempo de filtração (min) } & \multicolumn{4}{|c|}{ Tempo de filtração (min) } \\
\hline & & & 10 & 20 & 30 & 40 & 10 & 20 & 30 & 40 \\
\hline 1 & 15 & 5,50 & 4 & 2 & 3 & 2 & 0,4 & 0,3 & 0,3 & 0,2 \\
\hline 2 & 20 & 5,53 & 3 & 2 & 2 & 2 & 0,3 & 0,3 & 0,2 & 0,2 \\
\hline 3 & 25 & 5,54 & 2 & 2 & 3 & 2 & 0,3 & 0,3 & 0,2 & 0,3 \\
\hline 4 & 30 & 5,57 & 3 & 2 & 3 & 2 & 0,3 & 0,3 & 0,2 & 0,3 \\
\hline 5 & 35 & 5,52 & 6 & 3 & 3 & 2 & 0,4 & 0,3 & 0,3 & 0,2 \\
\hline 6 & 40 & 5,55 & 3 & 2 & 2 & 2 & 0,3 & 0,2 & 0,3 & 0,2 \\
\hline \multicolumn{11}{|c|}{$\mathrm{G}_{\mathrm{mr}}=750 \mathrm{~s}^{-1}$} \\
\hline 1 & 15 & 5,59 & 2 & 1 & $<1$ & $<1$ & 0,3 & 0,3 & 0,3 & 0,3 \\
\hline 2 & 20 & 5,50 & 3 & 1 & $<1$ & $<1$ & 0,3 & 0,3 & 0,3 & 0,3 \\
\hline 3 & 25 & 5,47 & 3 & 2 & $<1$ & $<1$ & 0,3 & 0,3 & 0,3 & 0,3 \\
\hline 4 & 30 & 5,46 & 2 & 1 & $<1$ & $<1$ & 0,3 & 0,4 & 0,3 & 0,4 \\
\hline 5 & 35 & 5,48 & 3 & 1 & $<1$ & $<1$ & 0,3 & 0,3 & 0,3 & 0,3 \\
\hline 6 & 40 & 5,50 & 4 & 1 & $<1$ & $<1$ & 0,3 & 0,3 & 0,4 & 0,4 \\
\hline \multicolumn{11}{|c|}{$\mathrm{G}_{\mathrm{mr}}=1000 \mathrm{~s}^{-1}$} \\
\hline 1 & 15 & 5,49 & 5 & 2 & 1 & 1 & 0,4 & $\overline{0,4}$ & 0,3 & 0,4 \\
\hline 2 & 20 & 5,46 & 2 & 2 & 1 & 1 & 0,4 & 0,5 & 0,3 & 0,4 \\
\hline 3 & 25 & 5,52 & 4 & 2 & 1 & 2 & 0,4 & 0,4 & 0,3 & 0,5 \\
\hline 4 & 30 & 5,50 & 2 & 2 & 1 & 1 & 0,5 & 0,4 & 0,3 & 0,4 \\
\hline 5 & 35 & 5,47 & 2 & 2 & 1 & 1 & 0,5 & 0,4 & 0,4 & 0,3 \\
\hline 6 & 40 & 5,51 & 2 & 2 & 1 & 1 & 0,4 & 0,4 & 0,3 & 0,4 \\
\hline
\end{tabular}

\subsection{Ensaios na Instalação Piloto em Escoamento Contínuo}

Os resultados obtidos nesta etapa do trabalho experimental estão apresentados nos anexos B e C, estando no ANEXO B as tabelas com os resultados dos ensaios correspondentes à Fase 1, e no ANEXO $\mathrm{C}$, as tabelas com os resultados dos ensaios correspondentes à Fase 2.

\subsubsection{Características da Água de Estudo}

Na Tabela 5.6 estão as características da água bruta e da água de estudo durante a execução dos ensaios na instalação piloto em escoamento contínuo realizados nos períodos de julho a outubro de 2002, Fase 1, e março a outubro de 2003, Fase 2. 
Tabela 5.6 - Características da água bruta e da água de estudo durante a execução dos ensaios na instalação piloto em escoamento contínuo.

\begin{tabular}{|c|c|c|c|c|}
\hline \multirow{2}{*}{$\begin{array}{c}\text { Características } \\
\text { Ensaios }\end{array}$} & \multicolumn{2}{|c|}{ Água Bruta } & \multicolumn{2}{|c|}{ Água de Estudo } \\
\hline & Fase 1 & Fase 2 & Fase 1 & Fase 2 \\
\hline $\mathrm{pH}$ & 6,22 a 7,63 & 6,34 a 7,41 & 6,14 a 7,45 & 6,38 a 7,27 \\
\hline Temperatura $\left({ }^{\circ} \mathrm{C}\right)$ & 17 a 26 & 16 a 25,5 & 17 a 26 & 16 a 25,5 \\
\hline Alcalinidade $\left(\mathrm{mg} / \mathrm{LCaCO}_{3}\right)$ & 6,60 a 19,58 & 4,84 a $16,32^{(* *)}$ & 7,04 a 19,36 & 5,50 a $16,56^{(* *)}$ \\
\hline Cor verdadeira $(\mathrm{uH})$ & 10 a 33 & 12 a 31 & 76 a $133^{(*)}$ & 83 a 121 \\
\hline Cor aparente (uH) & 80 a $238^{(*)}$ & 73 a 184 & 168 a $366^{(*)}$ & 155 a 262 \\
\hline Turbidez (uT) & 8,8 a $48,9^{(*)}$ & 7,0 a 28,5 & 8,8 a $48,9^{(*)}$ & 7,0 a 28,5 \\
\hline Absorvância $254 \mathrm{~nm}\left(\mathrm{~cm}^{-1}\right)$ & 0,045 a 0,102 & 0,042 a 0,107 & 0,144 a 0,225 & 0,166 a 0,230 \\
\hline $\mathrm{COD}(\mathrm{mg} / \mathrm{L})$ & 2,2 a $4,0^{(*)}$ & $\begin{array}{c}1,5 \mathrm{a} \\
4,0\end{array}$ & 2,8 a $5,4^{(*)}$ & 2,2 a $6,6^{(* * *)}$ \\
\hline
\end{tabular}

"Valores observados devido a ocorrência de chuva durante o ensaio 1. ") Valores observados no ensaio com pré-oxidação com $\mathrm{NaClO}$. ${ }^{(* *)}$ Valores observados no ensaio com $\mathrm{Cl}_{2}$ (tricloro-s-triazinatriona).

Observando-se a Tabela 5.6 nota-se que praticamente não ocorreram mudanças no $\mathrm{pH}$ da água de estudo comparada à água bruta. A temperatura variou de 16 a $26^{\circ} \mathrm{C}$, esta variação foi decorrente aos diferentes períodos em que foram executados os ensaios na instalação piloto. Observam-se grandes variações na alcalinidade da água bruta e água de estudo. A água bruta apresentou cor verdadeira relativamente baixa $(10$ a $33 \mathrm{uH})$. A cor verdadeira da água de estudo apresentou-se fora da faixa proposta (90 a $110 \mathrm{uH})$, no entanto foram poucos os valores observados que se afastaram desta faixa, e isto ocorreu provavelmente devido à freqüência de amostragem para as medidas de cor ( 2 horas) e a inexperiência durante os primeiros ensaios, já que na Fase 2 a variação foi menor (83 a $121 \mathrm{uH})$.

Com relação à cor aparente e à turbidez da água bruta, foram observados valores altos (238 uH e 48, 9 uT) pela ocorrência de chuva forte durante o ensaio 1. Os valores de absorvância $254 \mathrm{~nm}$ e COD da água de estudo mostram o impacto da adição do extrato de substâncias húmicas na água bruta, caracterizado pelo aumento da concentração de matéria orgânica.

\subsubsection{Ensaios sem pré-oxidação e com variação de taxas de filtração no FAAG e FRD}

A duração da carreira de filtração na maioria dos ensaios foi de 72 horas com exceção dos ensaios 1 e 4 que tiveram duração de 50 e 70 horas, respectivamente. 
Embora a melhor dosagem de coagulante obtida nos ensaios em reatores estáticos tenha sido $20 \mathrm{mg} / \mathrm{L}$ de $\mathrm{Al}_{2}\left(\mathrm{SO}_{4}\right)_{3} .14,3 \mathrm{H}_{2} \mathrm{O}$, a dosagem de $\mathrm{Al}_{2}\left(\mathrm{SO}_{4}\right)_{3} \cdot 14,3$ $\mathrm{H}_{2} \mathrm{O}$ nos ensaios na instalação piloto em escoamento contínuo (Fase 1) foi da ordem de $8 \mathrm{mg} / \mathrm{L}$ e o pH de coagulação esteve entre 4,7 e 5,1, com exceção do ensaio 4, em que a dosagem de $\mathrm{Al}_{2}\left(\mathrm{SO}_{4}\right)_{3} .14,3 \mathrm{H}_{2} \mathrm{O}$ foi de $10 \mathrm{mg} / \mathrm{L}$ e $\circ \mathrm{pH}$ de coagulação esteve entre 4,6 e 5,5. Esta variação na dosagem de coagulante foi provavelmente devido às mudanças nas características da água bruta, principalmente turbidez, $\mathrm{pH}$ e alcalinidade, decorrentes da época do ano em que foram realizados os ensaios.

Em todas as figuras correspondentes à evolução da perda de carga e à variação de turbidez foram adotadas as seguintes abreviações: $D_{F C}=D F I$ executada quando a perda de carga atingiu o valor obtido conforme apresentado no item 4.3.1.3; $\mathrm{DFI}_{\mathrm{C} 50}=\mathrm{DFI}$ executada quando a cor aparente do efluente do FAAG apresentou valor $\geq 50 \mathrm{uH}$; Lav.FRD $D_{\mathrm{PC}}=$ lavagem do filtro rápido descendente quando atingiu a perda de carga limite; Lav.FRD transpasse = lavagem do filtro rápido descendente quando ocorreu o transpasse.

\subsubsection{Ensaio $1\left(\right.$ FAAG $=240 \mathrm{~m}^{3} / \mathrm{m}^{2} \mathrm{~d}$ e FRD $\left.=280 \mathrm{~m}^{3} / \mathrm{m}^{2} \mathrm{~d}\right)$}

Neste ensaio, as taxas de filtração médias no FAAG e no FRD foram de 243 e $289 \mathrm{~m} / \mathrm{m}^{2} \mathrm{~d}$ respectivamente, conforme Tabela B 1.4 do ANEXO B. Esta variação nas taxas de filtração ocorreu devido aos ajustes de vazões feitos durante as 50 horas de funcionamento dos filtros. $O$ resumo dos resultados obtidos no ensaio 1 estão apresentados na Tabela 5.7 e nas Tabelas B 1.1 a B 1.4 do ANEXO B estão os dados coletados durante o ensaio conforme a freqüência de coleta e análise das amostras.

Os resultados obtidos no ensaio 1 foram determinantes para limitar a taxa de filtração utilizada no FAAG. A evolução da perda de carga e a quantidade de DFIs executadas quando a cor aparente no efluente do FAAG apresentava valor $\geq$ $50 \mathrm{uH}$ durante o ensaio demonstraram que a taxa de filtração de $280 \mathrm{~m}^{3} / \mathrm{m}^{2} \mathrm{~d}$ aplicada no FAAG foi muito alta, pois a cada 2 horas o efluente do FAAG apresentava cor aparente $\geq 50 \mathrm{uH}$ (ver Figura 5.4). Nos ensaios subseqüentes foram adotadas taxas de filtração menores no FAAG (120 e $180 \mathrm{~m}^{3} / \mathrm{m}^{2} \mathrm{~d}$ ).

Nas Figuras B 1.1 e B 1.2 do ANEXO B estão apresentadas as perdas de carga na camada suporte e camada de areia grossa do FAAG e as perdas de carga 
ao longo do meio filtrante no $\mathrm{FRD}$, respectivamente. Observa-se na Figura $\mathrm{B} 1.1$ que ocorre maior retenção de partículas na camada suporte do FAAG, com recuperação da carga hidráulica disponível após a execução das DFIs. No FRD a retenção de partículas é mais intensa na subcamada superior, observando-se na Figura B 1.2 a recuperação da carga hidráulica disponível após a lavagem do filtro. As subcamadas intermediária e inferior do FRD apresentaram perda de carga praticamente constante.

Tabela 5.7 - Resumo dos resultados obtidos no ensaio 1 realizado na instalação piloto em escoamento contínuo sem pré-oxidação.

\begin{tabular}{|c|c|c|c|c|}
\hline & \multicolumn{4}{|c|}{ ENSAIO 1} \\
\hline Taxas de filtração médias & \multicolumn{4}{|c|}{ FAAG $=243 \mathrm{~m}^{3} / \mathrm{m}^{2} \mathrm{~d}$ e FRD $=289 \mathrm{~m}^{3} / \mathrm{m}^{2} \mathrm{~d}$} \\
\hline Condições de coagulação & \multicolumn{4}{|c|}{$\begin{array}{c}\mathrm{D}_{\mathrm{SA}} \cong 8 \mathrm{mg} / \mathrm{L} ; \mathrm{pH} \text { de coagulação }=4,80 \text { a } 6,03 ; \\
\text { temperatura }=18,5 \text { a } 22,0^{\circ} \mathrm{C}\end{array}$} \\
\hline Duração da carreira (h) & \multicolumn{4}{|c|}{50} \\
\hline Produção Efetiva (\%) & \multicolumn{4}{|c|}{93,4} \\
\hline Características & AB & AE & $\begin{array}{c}\text { Efluente do } \\
\text { FAAG }\end{array}$ & $\begin{array}{c}\text { Efluente do } \\
\text { FRD }\end{array}$ \\
\hline $\mathrm{pH}$ & 6,28 a 6,95 & 6,31 a 7,05 & NR & NR \\
\hline Alcalinidade $\left(\mathrm{mg} / \mathrm{L} \mathrm{CaCO}_{3}\right)$ & 6,6 a 10,6 & 8,6 a 10,6 & NR & NR \\
\hline Cor aparente $(\mathrm{uH})$ & 80 a 238 & 168 a 366 & $<1$ a 59 & $<1$ a 4 \\
\hline Cor verdadeira $(\mathrm{uH})$ & 12 a 29 & 76 a 133 & NR & NR \\
\hline Turbidez (UT) & 8,8 a $48,9^{(*)}$ & NR & 0,02 a 1,0 & $<0,01$ a 0,6 \\
\hline Absorvância 254 nm & 0,045 a 0,099 & 0,144 a 0,225 & 0,008 a 0,023 & $\begin{array}{c}0,007 \text { a } \\
0,032\end{array}$ \\
\hline $\mathrm{COD}(\mathrm{mg} / \mathrm{L})$ & 2,6 a 4,0 & 3,0 a 5,4 & 2,4 a 4,9 & 0,9 a 4,0 \\
\hline Alumínio residual (mg/L) & NR & NR & NR & NR \\
\hline
\end{tabular}

A cor aparente no efluente do FRD se manteve menor que 1,0 uH durante a maior parte do tempo de funcionamento do filtro. Na Figura 5.5 pode-se observar a variação da cor aparente do efluente do FAAG decorrente da execução consecutiva de DFls no FAAG. Da mesma forma observam-se na Figura 5.6 as variações na turbidez do efluente do FAAG, sendo que no efluente do FRD a turbidez foi $\leq 1$ uT, com exceção da ocorrência do transpasse com aproximadamente 35 horas de funcionamento, sendo necessária a lavagem do filtro.

Na Figura 5.6 observa-se o pico de turbidez no efluente do FRD próximo das 25 horas de funcionamento, decorrente do aumento da perda de carga no FRD, ocasião em que a duração da carreira de filtração no FRD encerrava por atingir a perda de carga limite $(2,10 \mathrm{~m})$, conforme apresentado na Figura 5.4. 
Nas Figuras 5.7 e 5.8 estão representadas as variações da absorvância 254 $\mathrm{nm}$ e do COD, que foram os métodos indiretos utilizados para avaliar a eficiência de remoção de substâncias húmicas da água de estudo durante os ensaios na instalação piloto em escoamento contínuo.

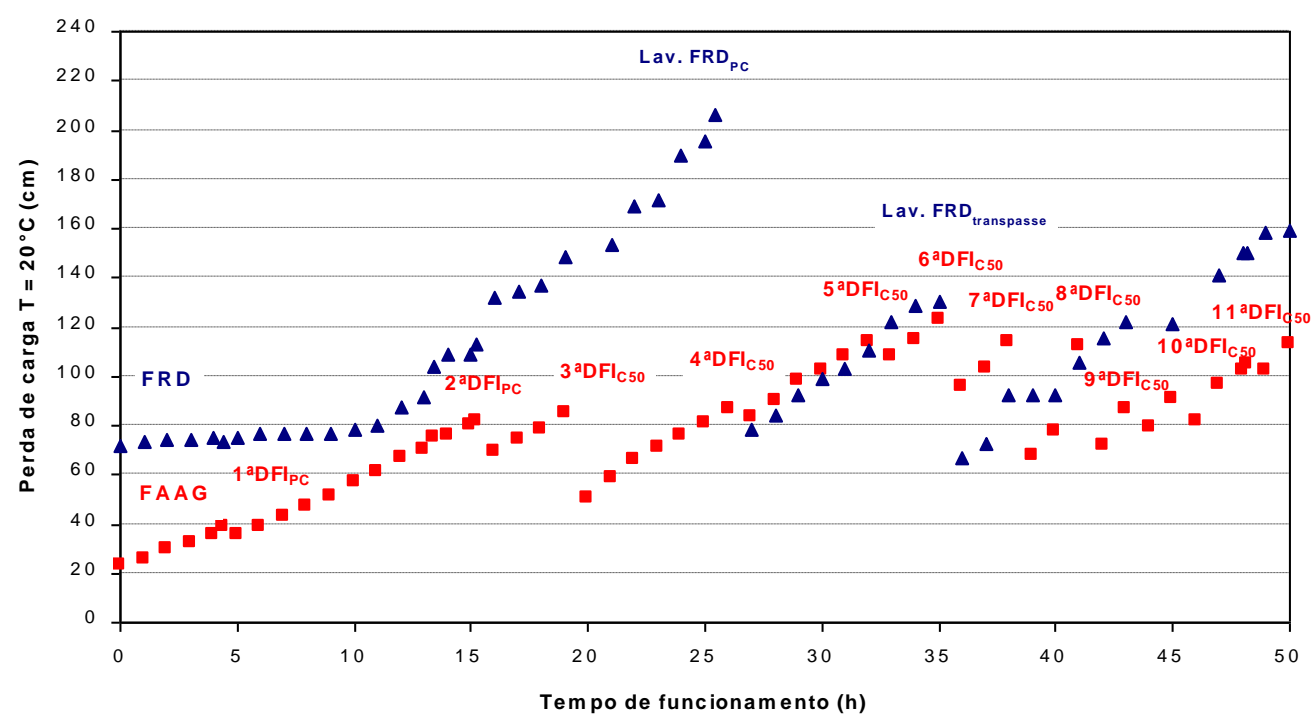

Figura 5.4 - Evolução da perda de carga no FAAG $\left(240 \mathrm{~m}^{3} / \mathrm{m}^{2} \mathrm{~d}\right)$ e FRD $\left(280 \mathrm{~m}^{3} / \mathrm{m}^{2} \mathrm{~d}\right)$ durante o ensaio 1 , para $T=20^{\circ} \mathrm{C}$, com execução de DFls no FAAG. Fonte: Tabela $B 1.3$ do ANEXO B.

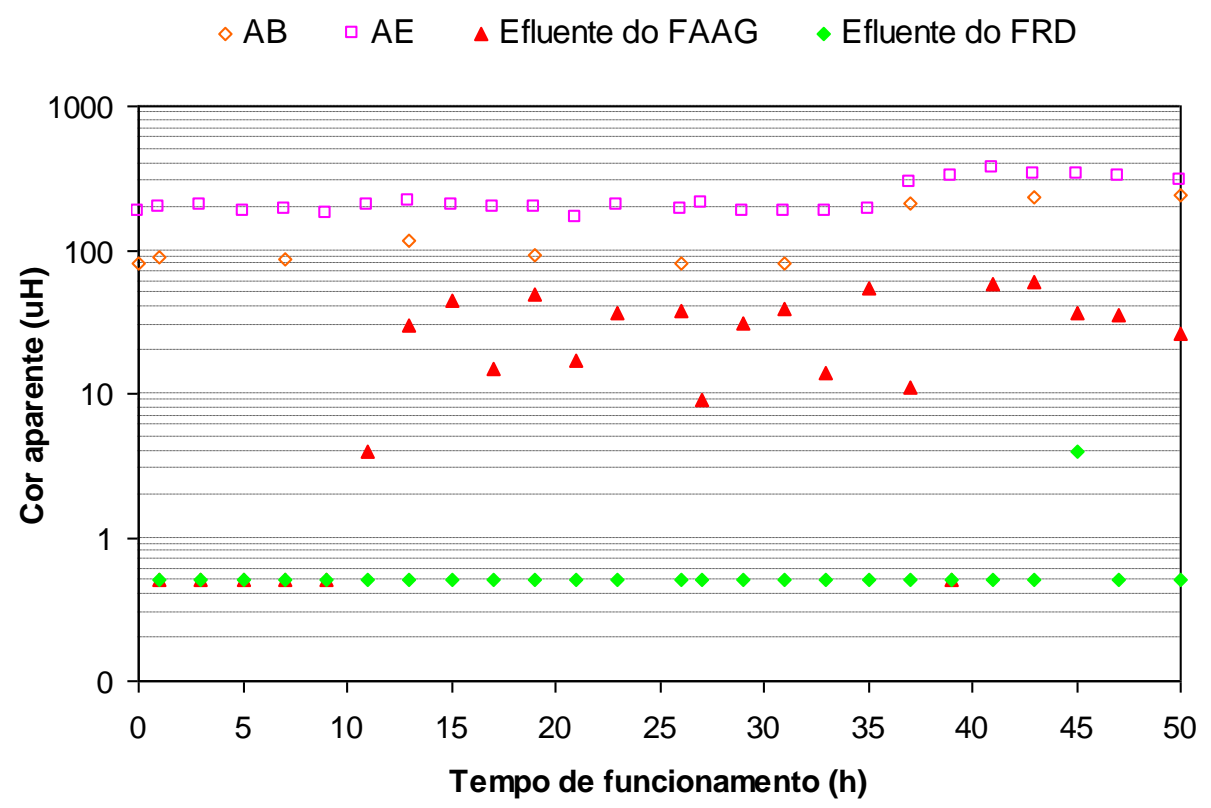

Figura 5.5 - Variação de cor aparente na $A B, A E$ e efluentes do FAAG e do FRD, e cor verdadeira na $A B$ de 12 a $29 \mathrm{uH}$ e na $A E$ de 76 a $133 \mathrm{uH}$, durante o ensaio 1 (FAAG = 240 $\mathrm{m}^{3} / \mathrm{m}^{2} \mathrm{~d}$ e FRD $=280 \mathrm{~m}^{3} / \mathrm{m}^{2} \mathrm{~d}$ ). Fonte: Tabela B 1.1 do ANEXO B. 


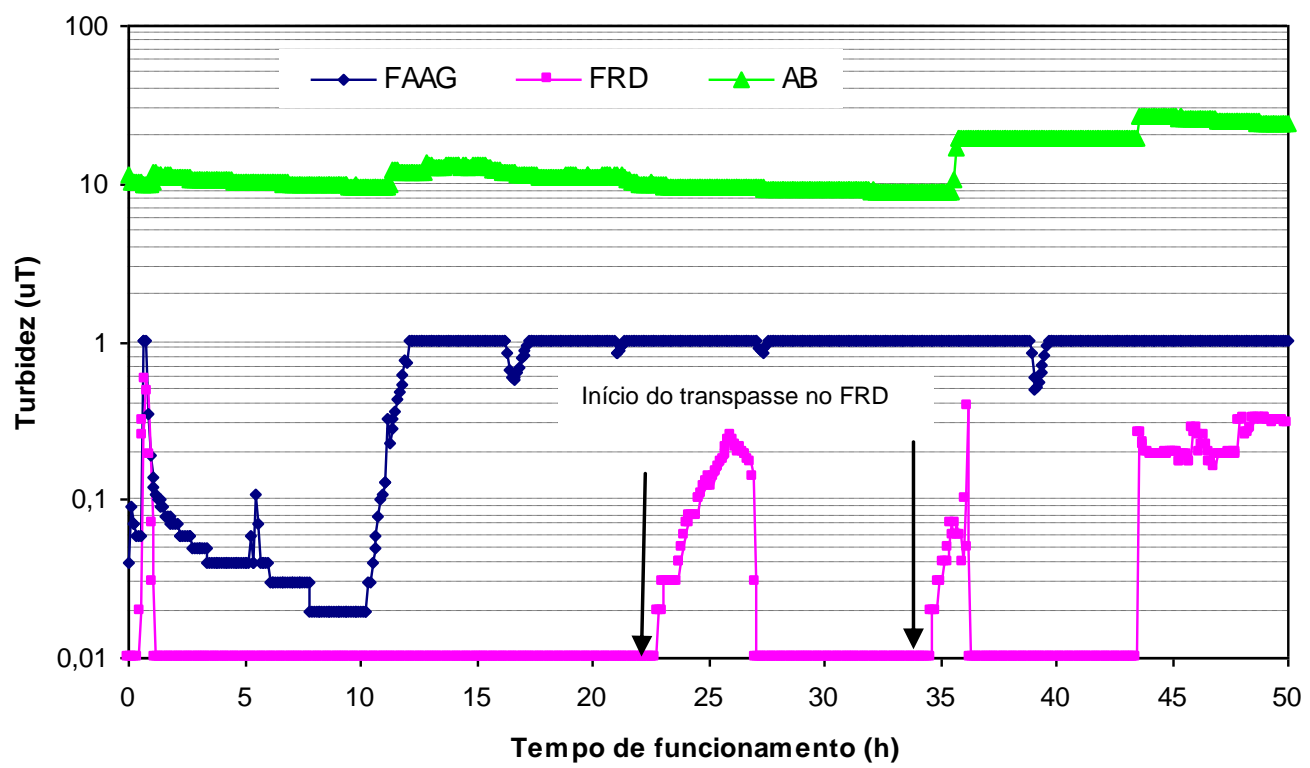

Figura 5.6 - Variação de turbidez na $A B$ e efluentes do FAAG e do FRD durante o ensaio 1 $\left(F A A G=240 \mathrm{~m}^{3} / \mathrm{m}^{2} \mathrm{~d}\right.$ e FRD $=280 \mathrm{~m}^{3} / \mathrm{m}^{2} \mathrm{~d}$ ).

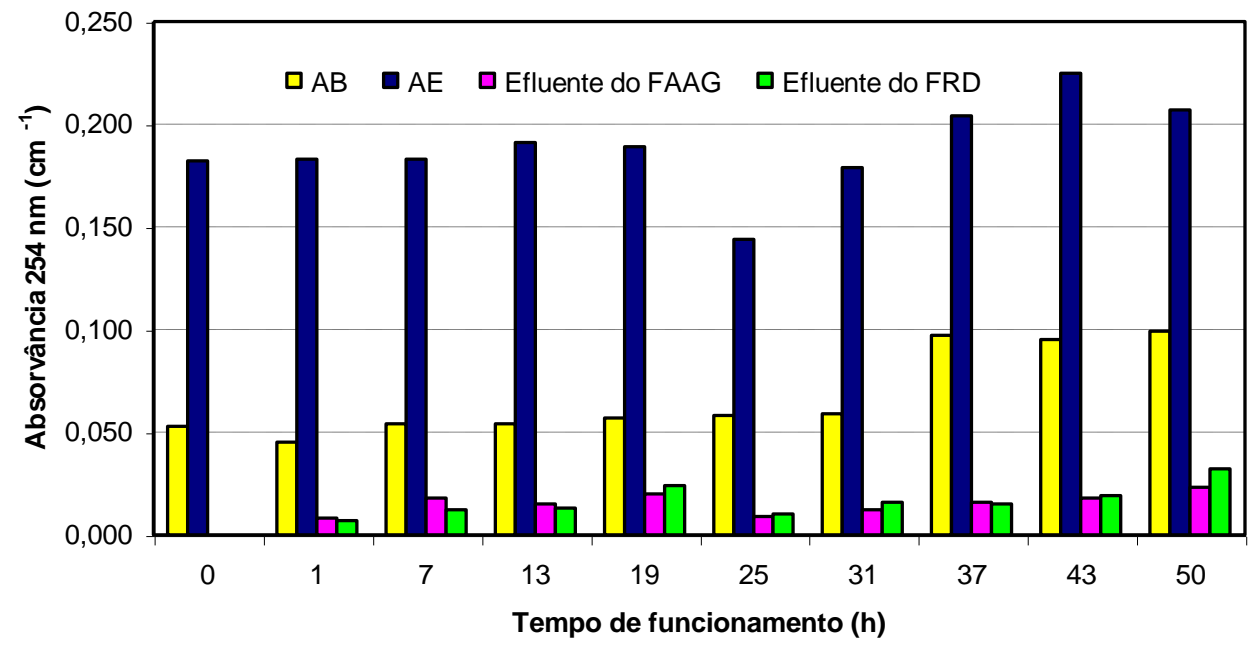

Figura 5.7 - Variação de absorvância $254 \mathrm{~nm}$ na $A B, A E$ e nos efluentes do $F A A G$ e do FRD durante o ensaio $1\left(F A A G=240 \mathrm{~m}^{3} / \mathrm{m}^{2} \mathrm{~d}\right.$ e FRD $=280 \mathrm{~m}^{3} / \mathrm{m}^{2} \mathrm{~d}$ ). Fonte: Tabela B 1.2 do ANEXO B. 


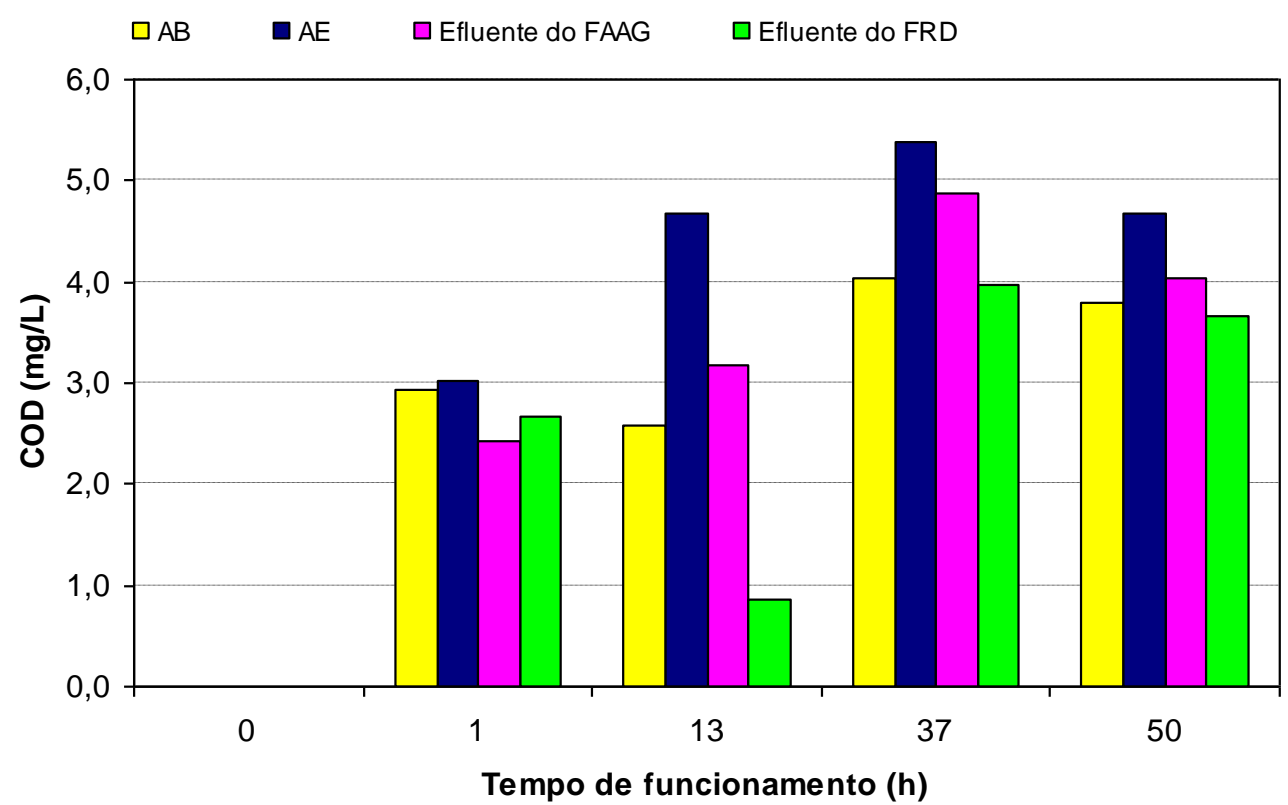

Figura 5.8 - Variação de $C O D$ na $A B, A E$ e nos efluentes do FAAG e do FRD durante o ensaio $1\left(F A A G=240 \mathrm{~m}^{3} / \mathrm{m}^{2} \mathrm{~d}\right.$ e FRD $\left.=280 \mathrm{~m}^{3} / \mathrm{m}^{2} \mathrm{~d}\right)$. Fonte: Tabela B 1.2 do ANEXO B.

A remoção de substâncias húmicas em termos de absorvância 254 nm variou de 88,9 a $95,6 \%$ no FAAG e de 84,5 a $96,2 \%$ no FRD, podendo ser observado na Figura 5.7. Com relação ao COD, observa-se na Figura 5.8 que a eficiência de remoção de COD não foi tão significativa comparada à absorvância $254 \mathrm{~nm}$. As variações de remoção foram de 9,3 a 32,2\% no FAAG e de 11,5 a $81,8 \%$ no FRD.

\subsubsection{Ensaio $2\left(\right.$ FAAG $=180 \mathrm{~m}^{3} / \mathrm{m}^{2} \mathrm{~d}$ e FRD $\left.=200 \mathrm{~m}^{3} / \mathrm{m}^{2} \mathrm{~d}\right)$}

As taxas de filtração médias neste ensaio foram de 183 e $210 \mathrm{~m}^{3} / \mathrm{m}^{2} \mathrm{~d}$ no FAAG e no FRD respectivamente, conforme apresentado na Tabela B 2.4 do ANEXO B. O resumo dos resultados obtidos neste ensaio está apresentado na Tabela 5.8 e nas Tabelas B 2.1 a B 2.4 do ANEXO B estão todos os dados coletados durante o ensaio 2 .

Na Figura 5.9 está a evolução da perda de carga no FAAG e no FRD para a temperatura de $20^{\circ} \mathrm{C}$, observam-se as DFls executadas no FAAG, sendo realizada uma lavagem no FRD por ter atingido a perda de carga limite, com aproximadamente 52 horas de funcionamento, coincidentemente a carreira de filtração do FRD foi novamente encerrada por perda de carga com 72 horas de funcionamento, com o encerramento do ensaio. Na Figura B 2.1 do ANEXO B estão 
apresentadas as perdas de carga na camada suporte e camada de areia grossa do FAAG e na Figura B 2.2 do ANEXO B estão as perdas de carga ao longo do meio filtrante do FRD. A recuperação da carga hidráulica disponível varia após a execução das DFIs no FAAG.

Tabela 5.8 - Resumo dos resultados obtidos no ensaio 2 realizado na instalação piloto em escoamento contínuo sem pré-oxidação.

\begin{tabular}{|c|c|c|c|c|}
\hline & \multicolumn{4}{|c|}{ ENSAIO 2} \\
\hline Taxas de filtração médias & \multicolumn{4}{|c|}{ FAAG $=183 \mathrm{~m}^{3} / \mathrm{m}^{2} \mathrm{~d}$ e FRD $=210 \mathrm{~m}^{3} / \mathrm{m}^{2} \mathrm{~d}$} \\
\hline Condições de coagulação & \multicolumn{4}{|c|}{$\begin{array}{c}\mathrm{D}_{\mathrm{SA}} \cong 8 \mathrm{mg} / \mathrm{L} ; \mathrm{pH} \text { de coagulação }=4,91 \text { a } 5,11 ; \\
\text { temperatura }=19,0 \text { a } 22,5^{\circ} \mathrm{C}\end{array}$} \\
\hline Duração da carreira (h) & \multicolumn{4}{|c|}{72} \\
\hline Produção Efetiva (\%) & \multicolumn{4}{|c|}{94,1} \\
\hline Características & AB & AE & $\begin{array}{c}\text { Efluente do } \\
\text { FAAG }\end{array}$ & $\begin{array}{c}\text { Efluente do } \\
\text { FRD }\end{array}$ \\
\hline $\mathrm{pH}$ & $6,23^{\left({ }^{*}\right)}$ a 6,56 & 6,28 a 7,25 & NR & NR \\
\hline Alcalinidade $\left(\mathrm{mg} / \mathrm{L} \mathrm{CaCO}_{3}\right)$ & 7,0 a 10,8 & 7,0 a 11,4 & NR & NR \\
\hline Cor aparente $(\mathrm{uH})$ & $88^{(*)}$ a 127 & 178 a 210 & $<1$ a 51 & $<1$ a 4 \\
\hline Cor verdadeira $(\mathrm{uH})$ & 10 a 26 & 78 a 121 & NR & NR \\
\hline Turbidez (uT) & 10,0 a 17,5 & NR & $<0,01$ a 20,0 & $<0,01$ a 0,7 \\
\hline Absorvância 254 nm & 0,051 a $0,077^{(*)}$ & 0,174 a 0,203 & 0,001 a $0,031^{(*)}$ & $\begin{array}{l}0,003 \underset{a}{a} \\
0,030^{(*)}\end{array}$ \\
\hline $\mathrm{COD}(\mathrm{mg} / \mathrm{L})$ & 2,3 a 3,1 & 4,1 a $4,6^{(*)}$ & 2,0 a $3,4^{(*)}$ & 2,1 a $3,1^{(*)}$ \\
\hline Alumínio residual (mg/L) & NR & NR & NR & NR \\
\hline
\end{tabular}

$\mathrm{D}_{\mathrm{SA}}=$ dosagem de $\mathrm{Al}_{2}\left(\mathrm{SO}_{4}\right)_{3} .14,3 \mathrm{H}_{2} \mathrm{O} ; \mathrm{AB}$ = água bruta; $\mathrm{AE}$ = água de estudo; $\mathrm{FAAG}$ = filtro ascendente de areia grossa; FRD = filtro rápido descendente; $\mathrm{COD}=$ carbono orgânico dissolvido; $N R=$ não realizado. ${ }^{(*)}$ Valor observado no início do ensaio.

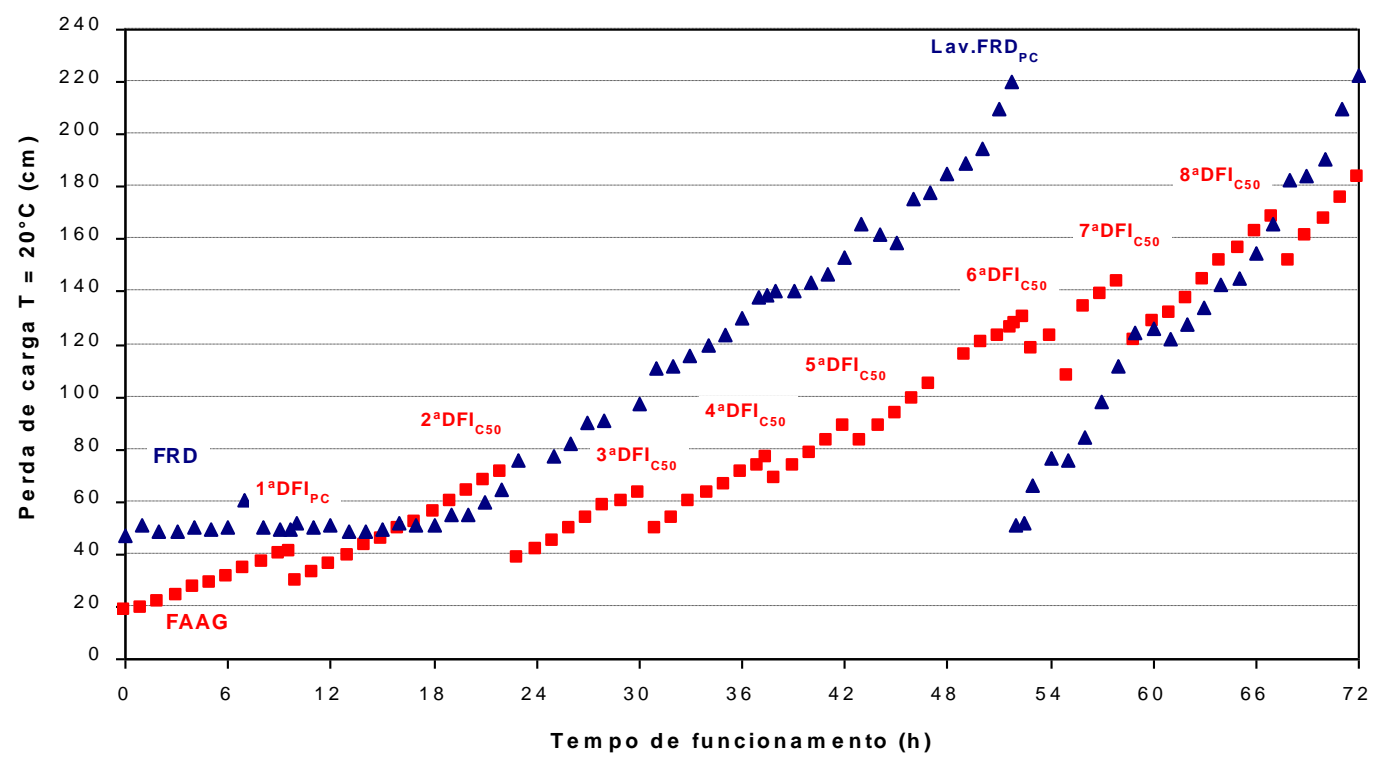

Figura 5.9 - Evolução da perda de carga no FAAG $\left(180 \mathrm{~m}^{3} / \mathrm{m}^{2} \mathrm{~d}\right)$ e FRD $\left(200 \mathrm{~m}^{3} / \mathrm{m}^{2} \mathrm{~d}\right)$ durante o ensaio 2, para $T=20^{\circ} \mathrm{C}$, com execução de DFls no FAAG. Fonte: Tabela B 2.3 no ANEXO B. 
A cor aparente no efluente do FRD foi, na maior parte do tempo, menor que 1,0 uH, com exceção dos tempos de 21 e 23 horas de funcionamento em que apresentou valores de 3,0 e 4,0 uH. Na Figura 5.10 observam-se as variações na cor aparente do efluente do FAAG, decorrentes da execução das DFIs, as quais promovem a recuperação da qualidade da água com redução da cor e da turbidez.

Na Figura 5.11 está apresentada a variação de turbidez durante o ensaio 2, notam-se os picos de turbidez no FAAG até o momento em que o efluente do FAAG atingia cor aparente $\geq 50 \mathrm{uH}$ e então executavam-se as DFls. Observa-se o pico de turbidez no FRD, decorrente do aumento da perda de carga, encerrando a carreira de filtração em aproximadamente 52 horas de funcionamento do filtro, conforme mostrado na Figura 5.9.

Nas Figuras 5.12 e 5.13 estão representadas as variações da absorvância $254 \mathrm{~nm}$ e do COD, que foram utilizados como métodos indiretos para avaliar a eficiência de remoção de substâncias húmicas da água durante os ensaios na instalação piloto em escoamento contínuo.

A remoção de substâncias húmicas em termos de absorvância $254 \mathrm{~nm}$ variou de 83,2 a $99,4 \%$ no FAAG e de 83,7 a $98,3 \%$ no FRD, podendo ser observado na Figura 5.12. Com relação ao COD, observa-se na Figura 5.13 que a eficiência na remoção de COD foi menor que a comparada com a absorvância 254 nm. As variações de remoção foram de 26,0 a $55,4 \%$ no FAAG e de 33,1 a $53,8 \%$ no FRD. 
$\diamond \mathrm{AB} \square \mathrm{AE} \triangle$ Efluente do FAAG $\diamond$ Efluente do FRD

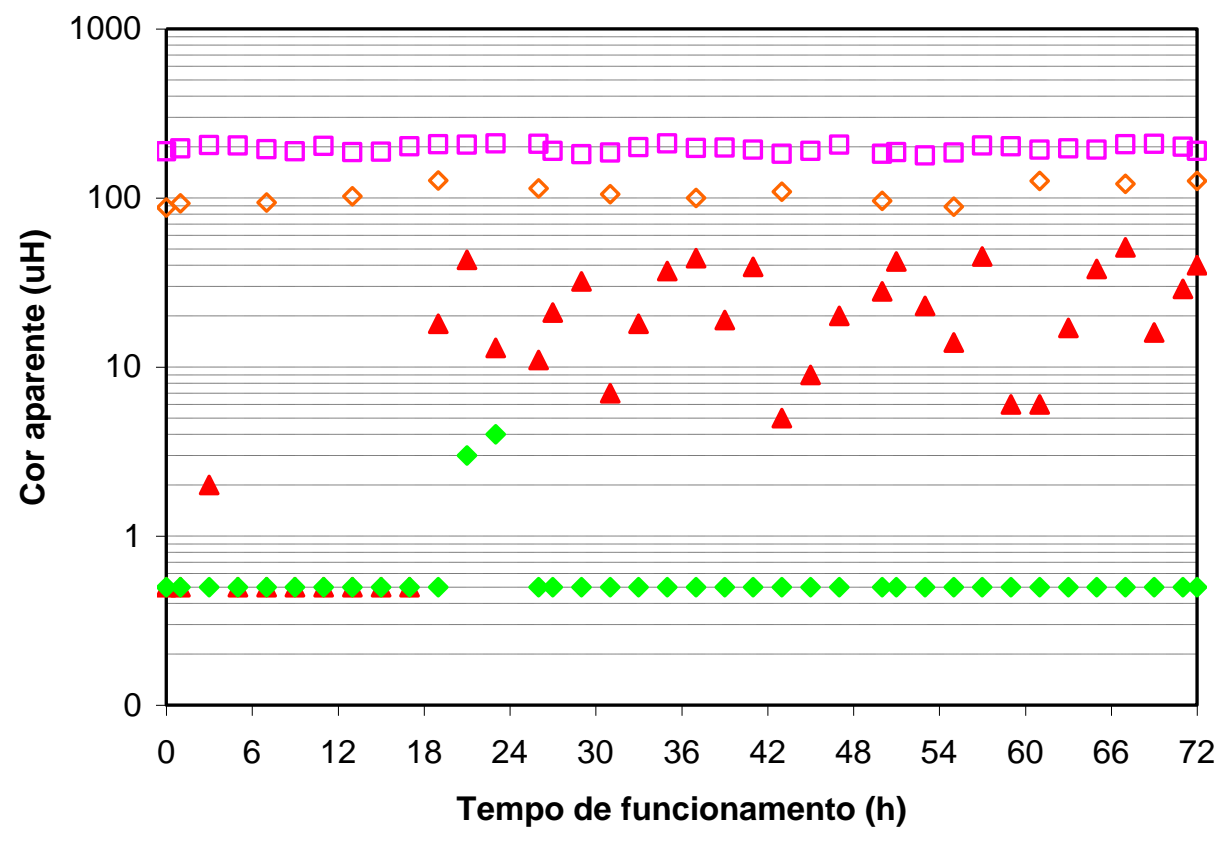

Figura 5.10 - Variação da cor aparente na $A B, A E$ e efluentes do FAAG e do FRD, e cor verdadeira na $A B$ de 10 a $26 \mathrm{uH}$ e na $A E$ de 78 a $121 \mathrm{uH}$, durante o ensaio 2 (FAAG = 180 $\mathrm{m}^{3} / \mathrm{m}^{2} \mathrm{~d}$ e FRD $=200 \mathrm{~m}^{3} / \mathrm{m}^{2} \mathrm{~d}$ ). Fonte: Tabela B 2.1 do ANEXO B.

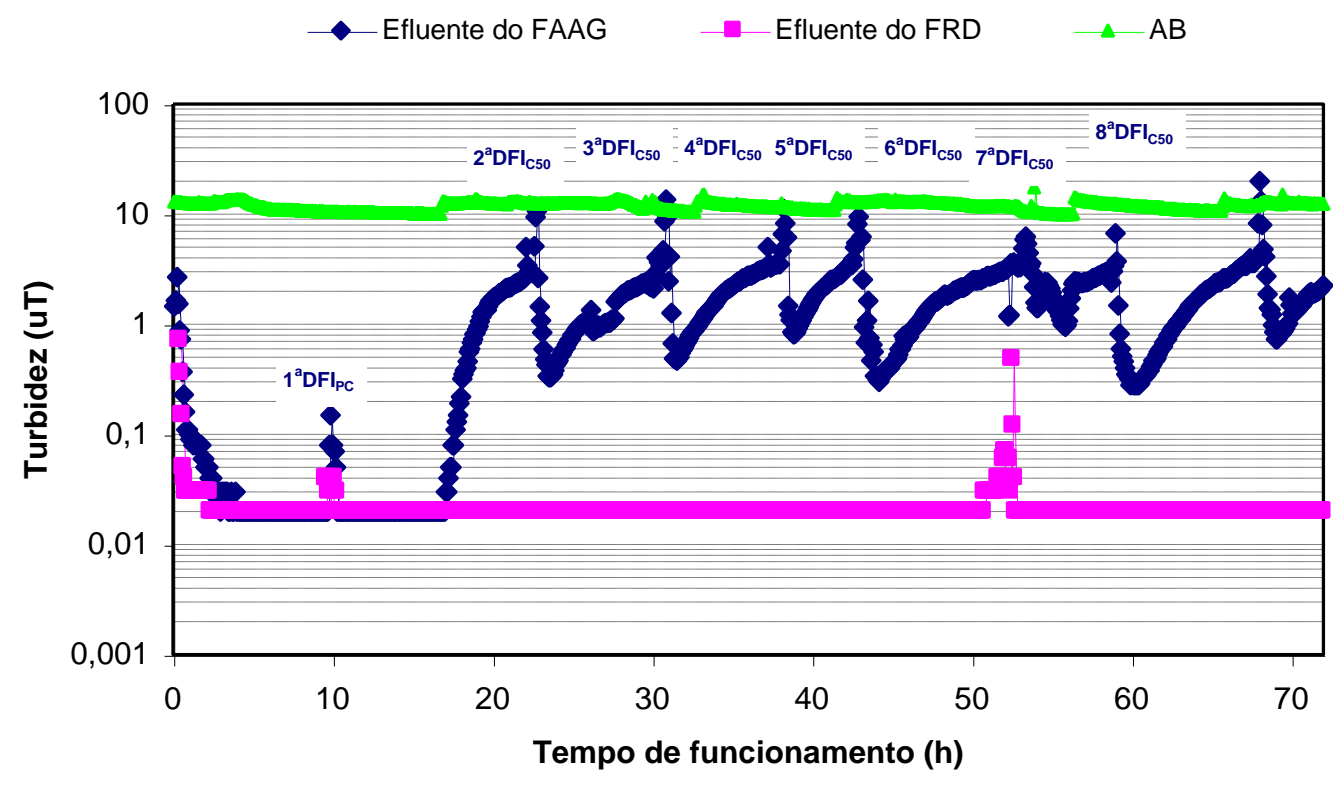

Figura 5.11 - Variação de turbidez na $A B$ e efluentes do FAAG e do FRD durante o ensaio 2 $\left(\right.$ FAAG $=180 \mathrm{~m}^{3} / \mathrm{m}^{2} \mathrm{~d}$ e FRD $\left.=200 \mathrm{~m}^{3} / \mathrm{m}^{2} \mathrm{~d}\right)$. 


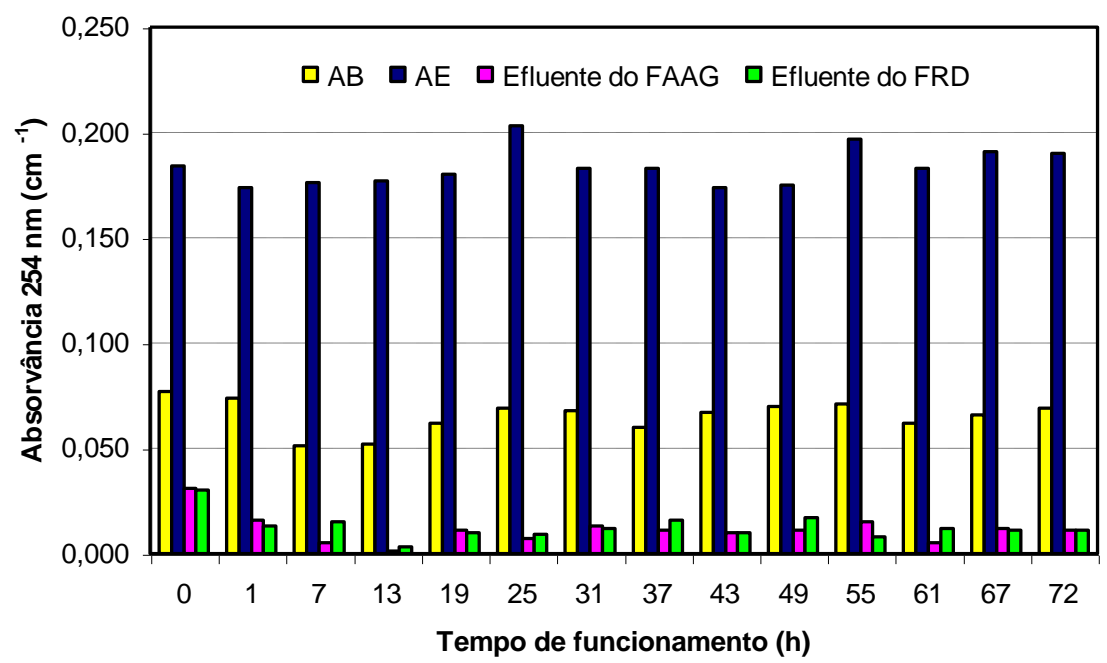

Figura 5.12 - Variação de absorvância $254 \mathrm{~nm}$ na $A B, A E$ e nos efluentes do FAAG e do FRD durante o ensaio $2\left(F A A G=180 \mathrm{~m}^{3} / \mathrm{m}^{2} \mathrm{~d}\right.$ e $\left.F R D=200 \mathrm{~m}^{3} / \mathrm{m}^{2} \mathrm{~d}\right)$. Fonte: Tabela $B 2.2$ do ANEXO B.

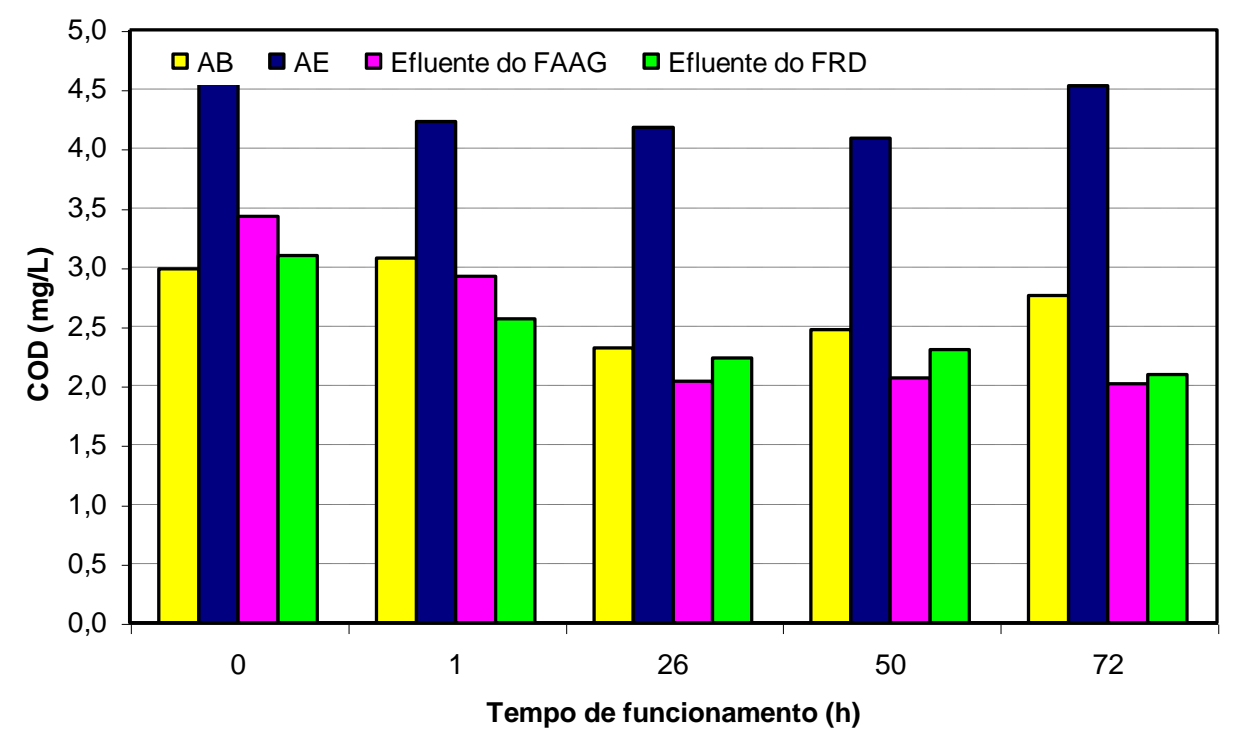

Figura 5.13 - Variação de $C O D$ na $A B, A E$ e nos efluentes do $F A A G$ e do $F R D$ durante 0 ensaio $2\left(F A A G=180 \mathrm{~m}^{3} / \mathrm{m}^{2} \mathrm{~d}\right.$ e FRD $=200 \mathrm{~m}^{3} / \mathrm{m}^{2} \mathrm{~d}$ ). Fonte: Tabela B 2.2 do ANEXO B.

\subsubsection{Ensaio $3\left(\right.$ FAAG $=180 \mathrm{~m}^{3} / \mathrm{m}^{2} \mathrm{~d}$ e FRD $=240 \mathrm{~m}^{3} / \mathrm{m}^{2} \mathrm{~d}$ )}

As taxas de filtração médias obtidas neste ensaio foram de 180 e 247 $\mathrm{m}^{3} / \mathrm{m}^{2} \mathrm{~d}$ no FAAG e no FRD, respectivamente (ver Tabela B 3.4 do ANEXO B). O resumo dos resultados obtidos neste ensaio está apresentado na Tabela 5.9 e nas 
Tabelas B 3.1 a B 3.4 do ANEXO B estão todos os dados coletados durante o ensaio 3.

Na Figura 5.14 está a evolução da perda de carga no FAAG e no FRD para a temperatura de $20^{\circ} \mathrm{C}$, observam-se as DFls executadas no FAAG, sendo realizadas três lavagens no FRD, duas por ter atingido a perda de carga limite, com aproximadamente 39 e 51 horas de funcionamento. A carreira de filtração do FRD foi encerrada por transpasse quando completava 63 horas de funcionamento, em que procedeu-se a lavagem de filtro e deu-se seqüência ao ensaio.

Nas Figuras B 3.1 e B 3.2 do ANEXO B estão as perdas de carga obtidas na camada suporte e camada de areia grossa do FAAG e ao longo do meio filtrante do FRD. Ocorreu maior retenção de impurezas na camada suporte do FAAG e na subcamada superior do FRD.

Tabela 5.9 - Resumo dos resultados obtidos no ensaio 3 realizado na instalação piloto em escoamento contínuo sem pré-oxidação.

\begin{tabular}{|c|c|c|c|c|}
\hline & \multicolumn{4}{|c|}{ ENSAIO 3} \\
\hline Taxas de filtração médias & \multicolumn{4}{|c|}{ FAAG $=180 \mathrm{~m}^{3} / \mathrm{m}^{2} \mathrm{~d}$ e FRD $=247 \mathrm{~m}^{3} / \mathrm{m}^{2} \mathrm{~d}$} \\
\hline Condições de coagulação & \multicolumn{4}{|c|}{$\begin{array}{c}\mathrm{D}_{\mathrm{SA}} \cong 8 \mathrm{mg} / \mathrm{L} ; \mathrm{pH} \text { de coagulação }=4,90 \text { a } 5,05 ; \\
\text { temperatura }=19,0 \text { a } 22,5^{\circ} \mathrm{C}\end{array}$} \\
\hline Duração da carreira (h) & \multicolumn{4}{|c|}{72} \\
\hline Produção Efetiva (\%) & \multicolumn{4}{|c|}{93,9} \\
\hline Características & $A B$ & $\mathrm{AE}$ & $\begin{array}{c}\text { Efluente do } \\
\text { FAAG }\end{array}$ & $\begin{array}{c}\text { Efluente do } \\
\text { FRD }\end{array}$ \\
\hline $\mathrm{pH}$ & 6,38 a 6,75 & 6,32 a 6,82 & NR & NR \\
\hline Alcalinidade $\left(\mathrm{mg} / \mathrm{L} \mathrm{CaCO}_{3}\right)$ & 7,70 a 11,22 & 7,46 a 11,44 & NR & NR \\
\hline Cor aparente $(\mathrm{uH})$ & 95 a 128 & 174 a 226 & $<1$ a 69 & $<1$ a $19^{(*)}$ \\
\hline Cor verdadeira $(\mathrm{uH})$ & 21 a 33 & 83 a 120 & NR & NR \\
\hline Turbidez (uT) & 9,8 a 15,5 & NR & $<0,01$ a 29,7 & $<0,01$ a 1,0 \\
\hline Absorvância 254 nm & 0,066 a 0,081 & 0,164 a 0,208 & 0,008 a 0,030 & $\begin{array}{c}0,008 \text { a } \\
0,032\end{array}$ \\
\hline $\mathrm{COD}(\mathrm{mg} / \mathrm{L})$ & 2,6 a $3,2^{(*)}$ & 4,2 a 5,0 & 2,7 a $4,3^{(*)}$ & 2,8 a $4,6^{(*)}$ \\
\hline Alumínio residual (mg/L) & NR & NR & NR & NR \\
\hline
\end{tabular}

D $\mathrm{D}_{\mathrm{SA}}=$ dosagem de $\mathrm{Al}_{2}\left(\mathrm{SO}_{4}\right)_{3} .14,3 \mathrm{H}_{2} \mathrm{O} ; \mathrm{AB}$ = água bruta; $\mathrm{AE}$ = água de estudo; $\mathrm{FAAG}$ = filtro ascendente de areia grossa; $\mathrm{FRD}=$ filtro rápido descendente; $\mathrm{COD}=$ carbono orgânico dissolvido; $\mathrm{NR}=$ não realizado. ${ }^{(*)}$ Valor observado no início do ensaio. 


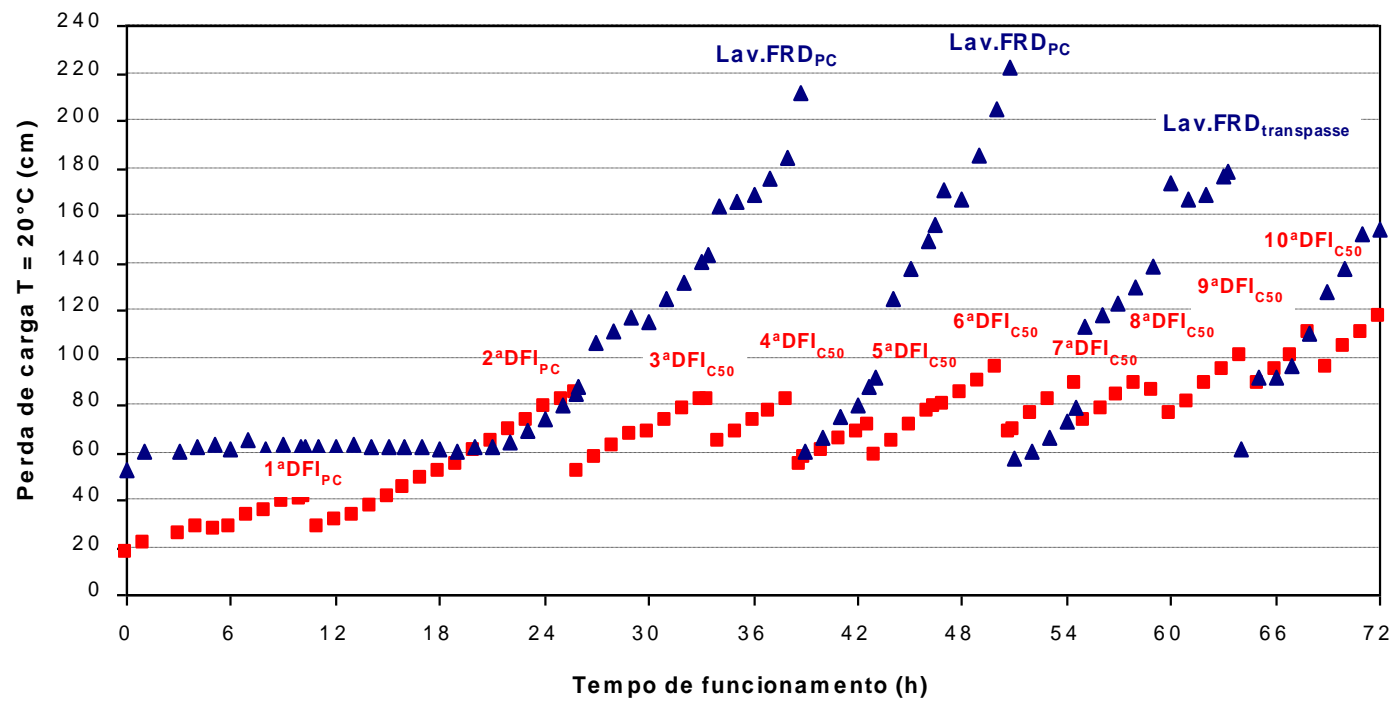

Figura 5.14 - Evolução da perda de carga no FAAG $\left(180 \mathrm{~m}^{3} / \mathrm{m}^{2} \mathrm{~d}\right)$ e FRD $\left(240 \mathrm{~m}^{3} / \mathrm{m}^{2} \mathrm{~d}\right)$ durante o ensaio 3 , para $T=20^{\circ} \mathrm{C}$, com execução de DFls no FAAG. Fonte: Tabela B 3.3 do ANEXO B.

A cor aparente no efluente do FRD foi, na maior parte do tempo, menor que $1,0 \mathrm{uH}$, conforme mostra a Figura 5.15. Observam-se as variações na cor aparente do efluente do FAAG, decorrentes da execução das DFls, as quais promoviam a recuperação da qualidade da água com redução da cor aparente e da turbidez.

Na Figura 5.16 está apresentada a variação de turbidez durante o ensaio 3, notam-se os picos de turbidez no FAAG até que fossem executadas as DFIs por atingir cor aparente $\geq 50 \mathrm{uH}$. Observam-se picos de turbidez no FRD, decorrentes do aumento da perda de carga e pela ocorrência do transpasse, encerrando a carreira de filtração para a lavagem do filtro, conforme mostrado nas Figuras $5.14 \mathrm{e}$ 5.16 .

Nas Figuras 5.17 e 5.18 estão representadas as variações da absorvância $254 \mathrm{~nm}$ e do COD durante o ensaio 3. A remoção de substâncias húmicas em termos de absorvância 254 nm variou de 85,6 a 95,8\% no FAAG e de 82,1 a 95,6\% no FRD, podendo ser observado na Figura 5.17. Com relação ao COD, observa-se na Figura 5.18 que a eficiência na remoção de COD foi menor comparada com a absorvância $254 \mathrm{~nm}$. As variações de remoção foram de 32,2 a 41,3\% no FAAG e de 20,8 a $45,0 \%$ no FRD. 
$\diamond \mathrm{AB} \quad \square \mathrm{AE} \quad \triangle$ Efluente do FAAG $\diamond$ Efluente do FRD

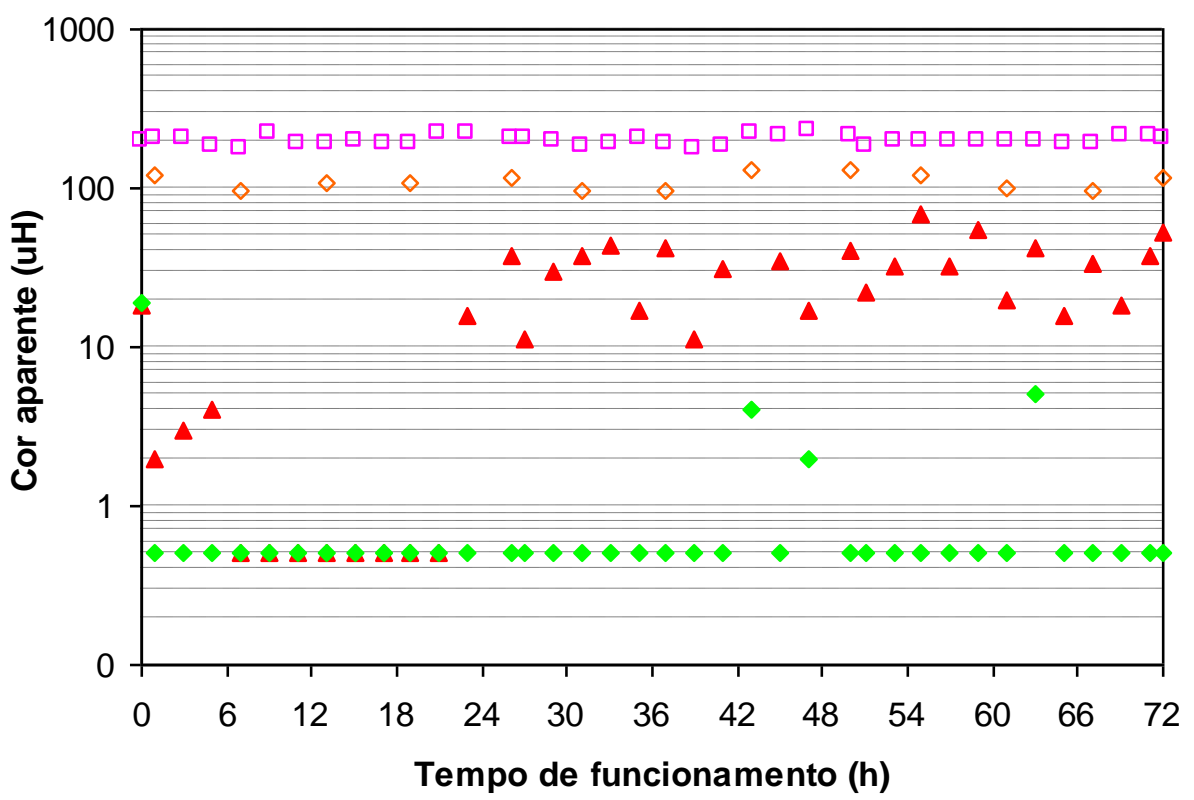

Figura 5.15 - Variação da cor aparente na $A B, A E$ e efluentes do FAAG e do FRD, e cor verdadeira na $A B$ de 21 a $33 \mathrm{uH}$ e na $A E$ de 83 a $120 \mathrm{uH}$, durante o ensaio 3 (FAAG = 180 $\mathrm{m}^{3} / \mathrm{m}^{2} \mathrm{~d}$ e FRD $=240 \mathrm{~m}^{3} / \mathrm{m}^{2} \mathrm{~d}$ ). Fonte: Tabela B 3.1 do ANEXO B.

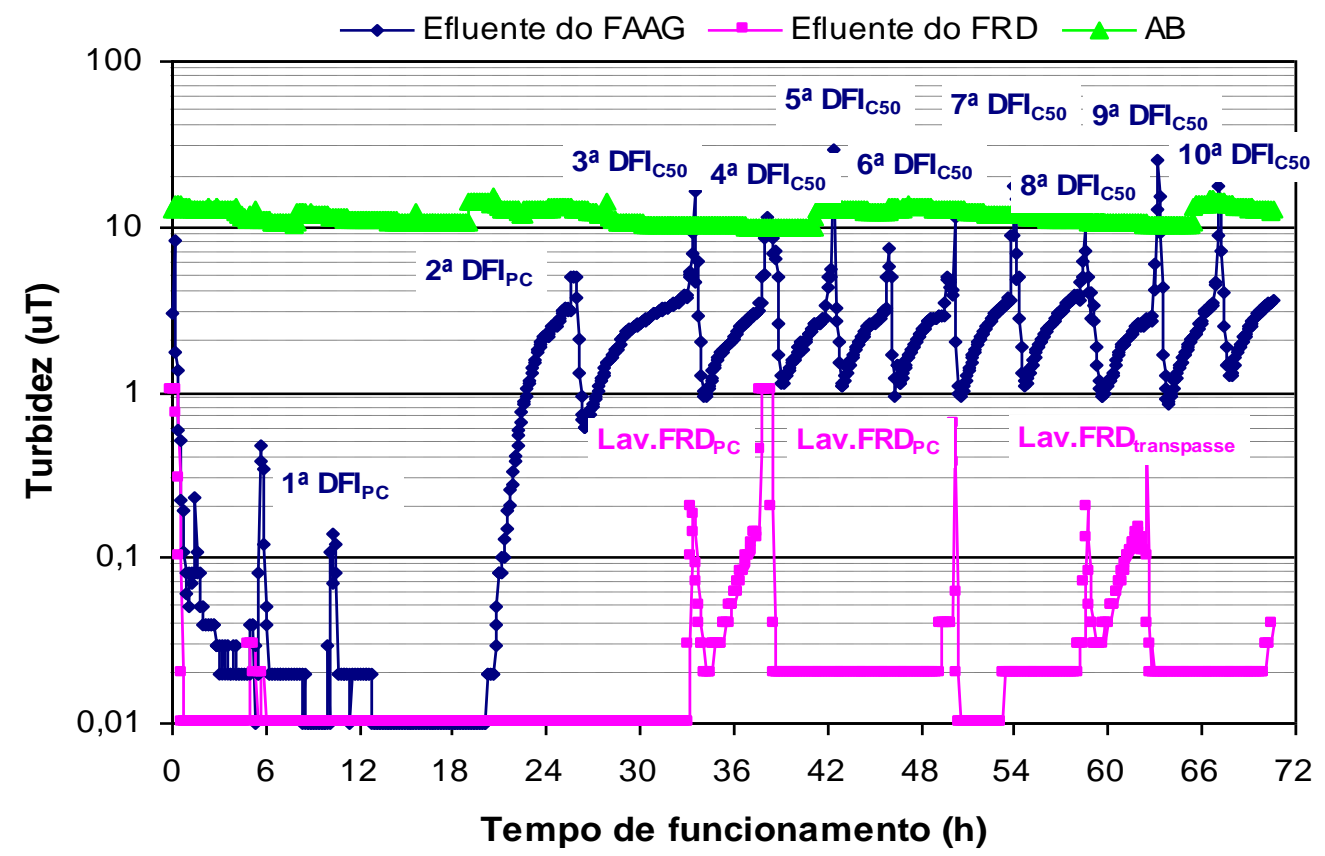

Figura 5.16 - Variação de turbidez na $A B$ e efluentes do FAAG e do FRD durante o ensaio 3 $\left(F A A G=180 \mathrm{~m}^{3} / \mathrm{m}^{2} \mathrm{~d}\right.$ e FRD $\left.=240 \mathrm{~m}^{3} / \mathrm{m}^{2} \mathrm{~d}\right)$. 


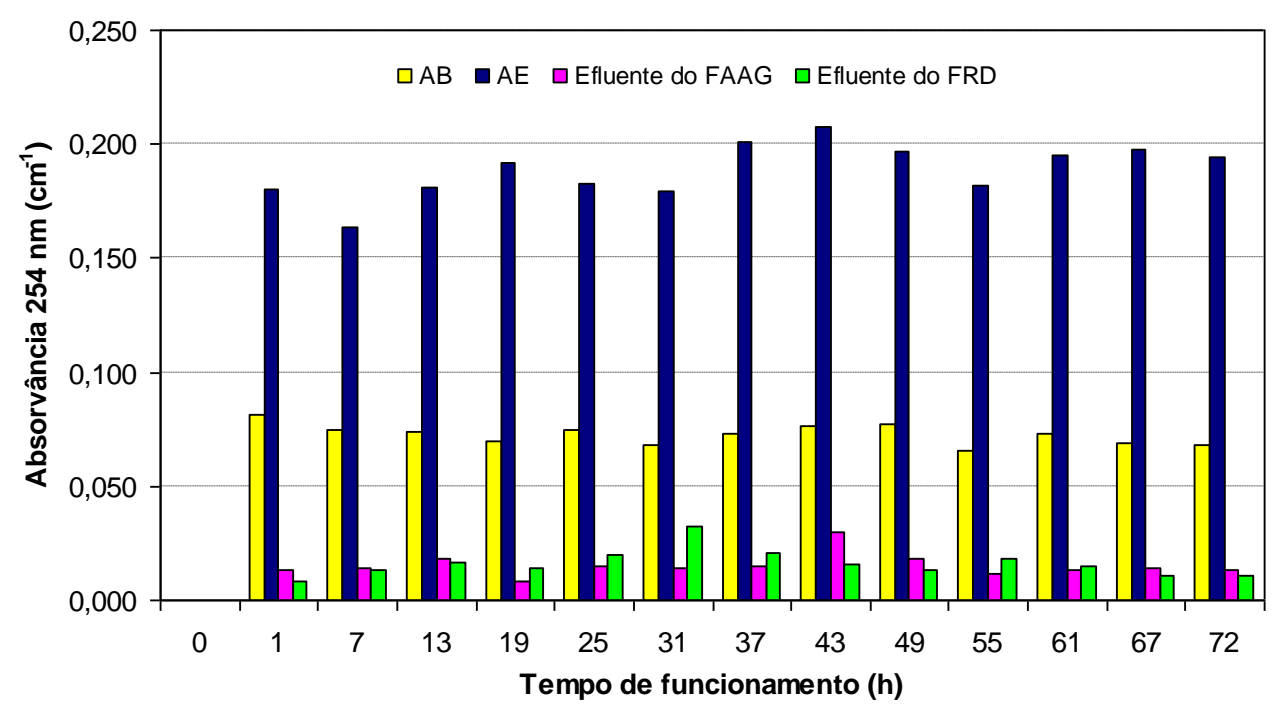

Figura 5.17 - Variação de absorvância $254 \mathrm{~nm}$ na $A B, A E$ e nos efluentes do $F A A G$ e do FRD durante o ensaio $3\left(F A A G=180 \mathrm{~m}^{3} / \mathrm{m}^{2} \mathrm{~d}\right.$ e FRD $=240 \mathrm{~m}^{3} / \mathrm{m}^{2} \mathrm{~d}$ ). Fonte: Tabela 3.2 do ANEXO B.

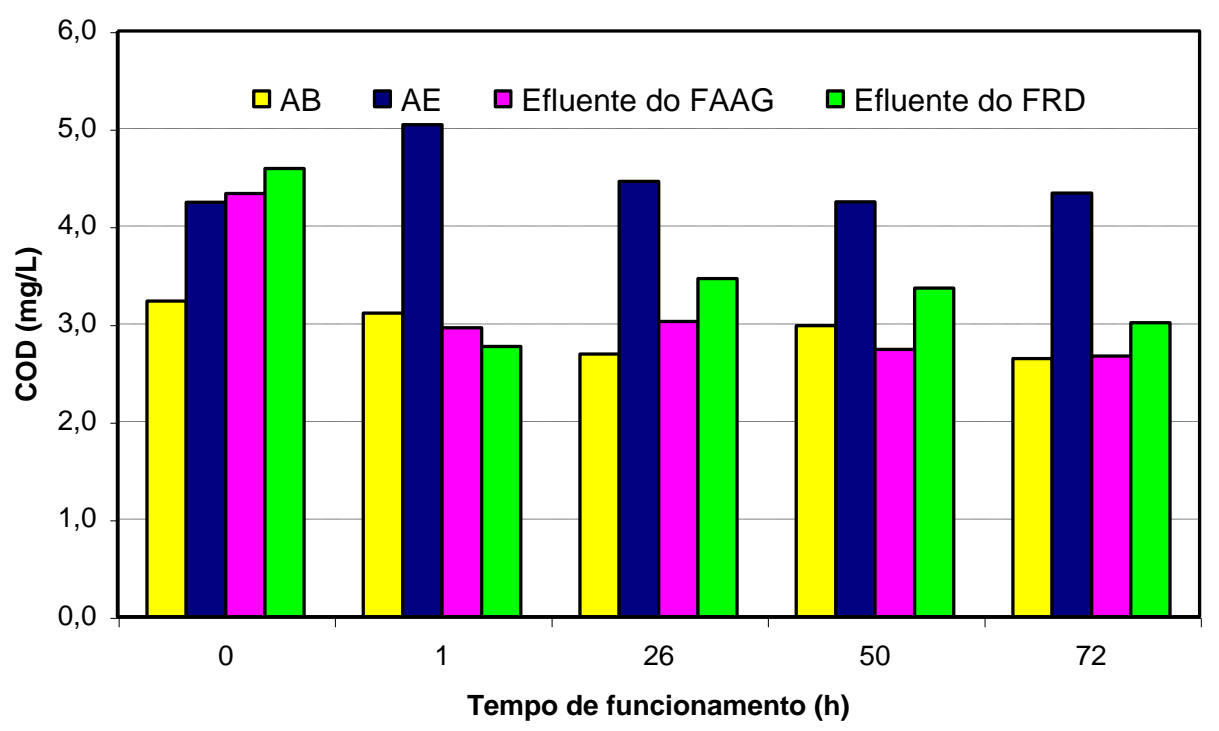

Figura 5.18 - Variação de $C O D$ na $A B, A E$ e nos efluentes do $F A A G$ e do FRD durante 0 ensaio $3\left(F A A G=180 \mathrm{~m}^{3} / \mathrm{m}^{2} \mathrm{~d}\right.$ e FRD $\left.=240 \mathrm{~m}^{3} / \mathrm{m}^{2} \mathrm{~d}\right)$. Fonte: Tabela B 3.2 do ANEXO B.

\subsubsection{Ensaio $4\left(\right.$ FAAG $=180 \mathrm{~m}^{3} / \mathrm{m}^{2} \mathrm{~d}$ e FRD $\left.=280 \mathrm{~m}^{3} / \mathrm{m}^{2} \mathrm{~d}\right)$}

Neste ensaio as condições de coagulação foram diferentes dos demais ensaios, com dosagem de coagulante de aproximadamente $10 \mathrm{mg} / \mathrm{L} \mathrm{e} \mathrm{pH}$ de coagulação entre 4,64 a 5,49, o que contribuiu para que a duração da carreira de filtração no FAAG fosse de 70 horas, com o encerramento do ensaio. 
As taxas de filtração médias no FAAG e no FRD foram de 176 e 285 $\mathrm{m}^{3} / \mathrm{m}^{2} \mathrm{~d}$, respectivamente, decorrentes das variações de vazões nos filtros (ver Tabela B 4.4 do ANEXO B). O resumo dos resultados obtidos neste ensaio está apresentado na Tabela 5.10 e nas Tabelas B 4.1 a B 4.4 do ANEXO B estão todos os dados coletados durante o ensaio 4.

Na Figura 5.19 está a evolução da perda de carga no FAAG e no FRD para a temperatura de $20^{\circ} \mathrm{C}$, observam-se as DFls executadas no FAAG, sendo realizadas três lavagens no $\mathrm{FRD}$, duas por ter atingido a perda de carga limite, com aproximadamente 57 e 69 horas de funcionamento, e uma por transpasse com o encerramento da carreira de filtração do FRD com 63 horas de funcionamento.

Nas Figuras B 4.1 e B 4.2 do ANEXO B estão apresentadas as perdas de carga na camada suporte e camada de areia grossa do FAAG e ao longo do meio filtrante do FRD. Observa-se a retenção de impurezas na camada suporte do FAAG e na subcamada superior do FRD, com destaque para a recuperação da carga hidráulica disponível após a execução das DFls no FAAG e após as lavagens do FRD.

Tabela 5.10 - Resumo dos resultados obtidos no ensaio 4 realizado na instalação piloto em escoamento contínuo sem pré-oxidação.

\begin{tabular}{|c|c|c|c|c|}
\hline & \multicolumn{4}{|c|}{ ENSAIO 4} \\
\hline Taxas de filtração médias & \multicolumn{4}{|c|}{ FAAG $=176 \mathrm{~m}^{3} / \mathrm{m}^{2} \mathrm{~d}$ e FRD $=285 \mathrm{~m}^{3} / \mathrm{m}^{2} \mathrm{~d}$} \\
\hline Condições de coagulação & \multicolumn{4}{|c|}{$\begin{array}{c}\mathrm{D}_{\mathrm{SA}} \cong 10 \mathrm{mg} / \mathrm{L} ; \mathrm{pH} \text { de coagulação }=4,64 \text { a } 5,49 ; \\
\text { temperatura }=18,0 \text { a } 22,0^{\circ} \mathrm{C}\end{array}$} \\
\hline Duração da carreira (h) & \multicolumn{4}{|c|}{70} \\
\hline Produção Efetiva (\%) & \multicolumn{4}{|c|}{93,9} \\
\hline Características & AB & AE & $\begin{array}{c}\text { Efluente do } \\
\text { FAAG }\end{array}$ & $\begin{array}{c}\text { Efluente do } \\
\text { FRD }\end{array}$ \\
\hline $\mathrm{pH}$ & 6,31 a 7,63 & 6,33 a 7,45 & NR & NR \\
\hline Alcalinidade $\left(\mathrm{mg} / \mathrm{L} \mathrm{CaCO}_{3}\right)$ & 8,1 a 19,6 & 9,2 a 19,4 & NR & NR \\
\hline Cor aparente $(\mathrm{uH})$ & 84 a 116 & 175 a 219 & $<1$ a 43 & $<1$ a 5 \\
\hline Cor verdadeira $(\mathrm{uH})$ & 14 a 25 & 82 a 112 & NR & NR \\
\hline Turbidez (uT) & 10,4 a 14,3 & NR & 0,2 a 9,0 & 0,1 a 0,5 \\
\hline Absorvância 254 nm & NR & 0,158 a 0,198 & 0,010 a 0,034 & 0,005 a 0,021 \\
\hline $\mathrm{COD}(\mathrm{mg} / \mathrm{L})$ & 2,2 a 3,1 & $3,1^{(*)}$ a 4,2 & 2,4 a 3,3 & 2,2 a 3,2 \\
\hline Alumínio residual (mg/L) & NR & NR & NR & NR \\
\hline
\end{tabular}

$\mathrm{D}_{\mathrm{SA}}=$ dosagem de $\mathrm{Al}_{2}\left(\mathrm{SO}_{4}\right)_{3} .14,3 \mathrm{H}_{2} \mathrm{O} ; \mathrm{AB}$ = água bruta; $\mathrm{AE}$ = água de estudo; $\mathrm{FAAG}$ = filtro ascendente de areia grossa; FRD = filtro rápido descendente; $\mathrm{COD}=$ carbono orgânico dissolvido; $\mathrm{NR}=$ não realizado. ${ }^{*}$ Valor observado no início do ensaio. 


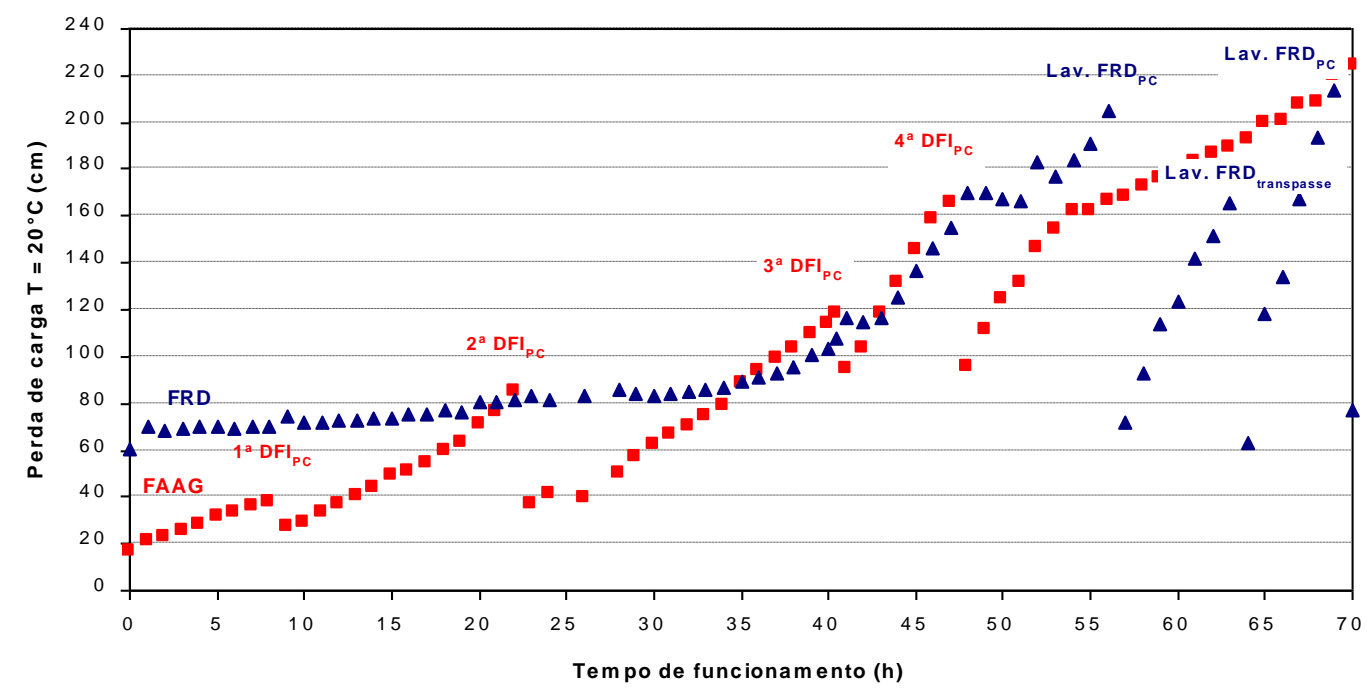

Figura 5.19 - Evolução da perda de carga no FAAG $\left(180 \mathrm{~m}^{3} / \mathrm{m}^{2} \mathrm{~d}\right)$ e FRD $\left(280 \mathrm{~m}^{3} / \mathrm{m}^{2} \mathrm{~d}\right)$ durante o ensaio 4, para $T=20^{\circ} \mathrm{C}$, com execução de DFls no FAAG. Fonte: Tabela B 4.3 do ANEXO B.

A cor aparente no efluente do FRD foi, na maior parte do tempo, menor que $1,0 \mathrm{uH}$, conforme mostra a Figura 5.20. Observa-se que a partir de 51 horas de funcionamento ocorreu o início do transpasse no FAAG, aumentando gradativamente a cor aparente no efluente do FAAG até $43 \mathrm{uH}$, não sendo necessárias a execução de DFls por atingir valores de cor aparente $\geq 50 \mathrm{uH}$ durante todo o ensaio. As DFIs no FAAG foram executadas somente com o critério da perda de carga, como mostra a Figura 5.19.

Neste ensaio ocorreram problemas na placa de aquisição de dados dos turbidímetros de escoamento contínuo, e as medidas de turbidez foram feitas em turbidímetro de bancada, da marca $\mathrm{HACH}$, modelo $2100 \mathrm{P}$, cujos resultados estão apresentados na Tabela B 4.1 do ANEXO B.

Nas Figuras 5.21 e 5.22 estão representadas as variações da absorvância $254 \mathrm{~nm}$ e do COD durante o ensaio 4. A remoção de substâncias húmicas em termos de absorvância 254 nm variou de 80,8 a 94,4\% no FAAG e de 88,5 a 97,4\% no FRD, podendo ser observado na Figura 5.21. Neste ensaio a absorvância 254 $\mathrm{nm}$ da $\mathrm{AB}$ não foi medida. Com relação ao $\mathrm{COD}$, observa-se na Figura 5.22 que a eficiência na remoção de COD foi menor comparada com a absorvância $254 \mathrm{~nm}$. As variações de remoção foram de 11,6 a $39,4 \%$ no FAAG e de 14,0 a 44,3\% no FRD. 


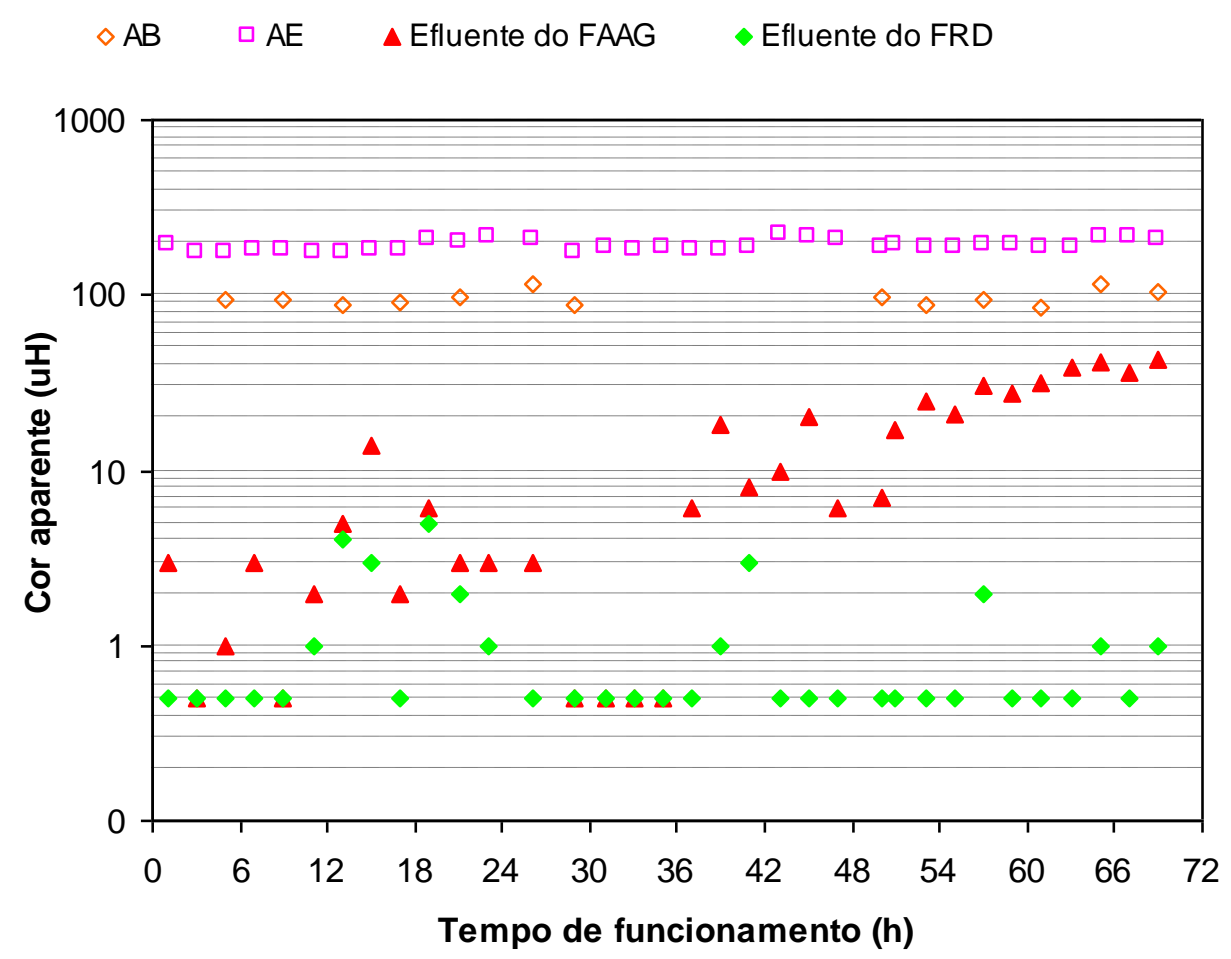

Figura 5.20 - Variação da cor aparente na $A B, A E$ e efluentes do $F A A G$ e do $F R D$, e cor verdadeira na $A B$ de 14 a 25 uH e na $A E$ de 82 a $112 \mathrm{uH}$, durante o ensaio 4 (FAAG $=180$ $\mathrm{m}^{3} / \mathrm{m}^{2} \mathrm{~d}$ e FRD $=280 \mathrm{~m}^{3} / \mathrm{m}^{2} \mathrm{~d}$ ). Fonte: Tabela B 4.1 do ANEXO B.

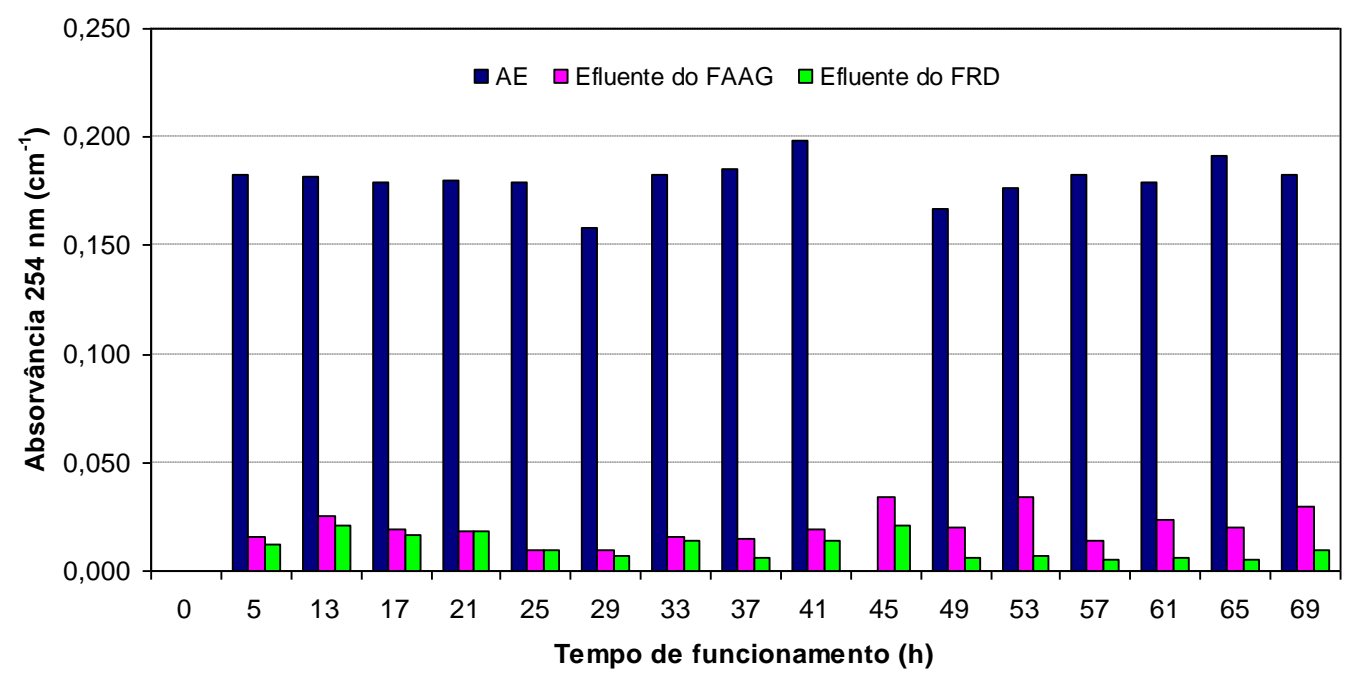

Figura 5.21 - Variação de absorvância $254 \mathrm{~nm}$ na AE e nos efluentes do FAAG e do FRD durante o ensaio $4\left(F A A G=180 \mathrm{~m}^{3} / \mathrm{m}^{2} \mathrm{~d}\right.$ e $\left.\mathrm{FRD}=280 \mathrm{~m}^{3} / \mathrm{m}^{2} \mathrm{~d}\right)$. Fonte: Tabela B 4.2 do ANEXO B. 


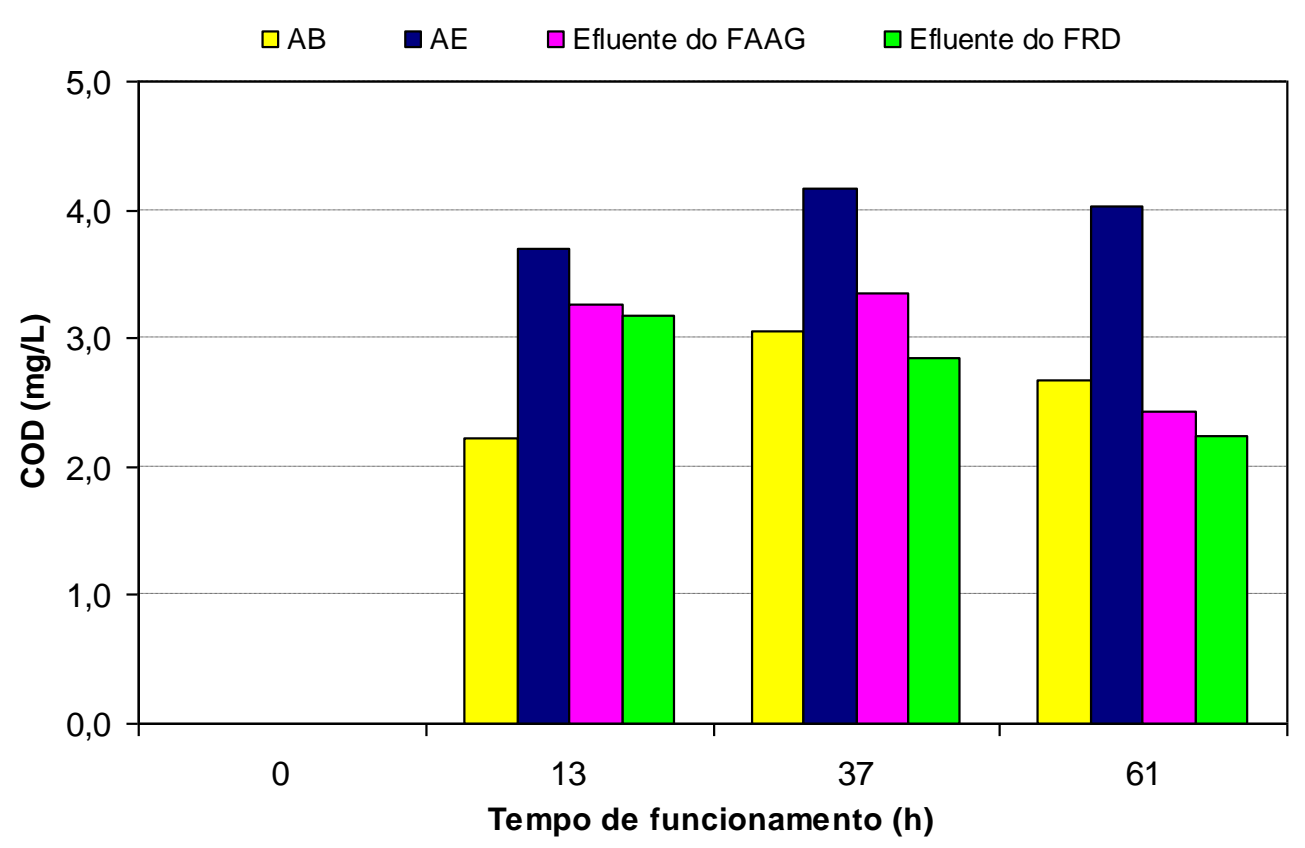

Figura 5.22 - Variação de $C O D$ da $A B, A E$ e nos efluentes do FAAG e do FRD durante o ensaio $4\left(F A A G=180 \mathrm{~m}^{3} / \mathrm{m}^{2} \mathrm{~d}\right.$ e FRD $\left.=280 \mathrm{~m}^{3} / \mathrm{m}^{2} \mathrm{~d}\right)$. Fonte: Tabela B 4.2 do ANEXO B.

\subsubsection{Ensaio $5\left(\right.$ FAAG $=120 \mathrm{~m}^{3} / \mathrm{m}^{2} \mathrm{~d}$ e FRD $\left.=160 \mathrm{~m}^{3} / \mathrm{m}^{2} \mathrm{~d}\right)$}

Neste ensaio as taxas de filtração médias foram de 124 e $165 \mathrm{~m}^{3} / \mathrm{m}^{2} \mathrm{~d}$ no FAAG e no FRD, respectivamente (ver Tabela B 5.4 do ANEXO B). O resumo dos resultados obtidos neste ensaio está apresentado na Tabela 5.11 e nas Tabelas B 5.1 a B 5.4 do ANEXO B estão todos os dados coletados durante o ensaio 5.

Na Figura 5.23 está a evolução da perda de carga no FAAG e no FRD para a temperatura de $20^{\circ} \mathrm{C}$, foram executadas quatro DFls no FAAG pelo critério de perda de carga, não sendo necessárias lavagens no FRD durante as 72 horas de funcionamento. A perda de carga no FRD permaneceu praticamente constante durante todo o ensaio.

Nas Figuras B 5.1 e B 5.2 do ANEXO B estão apresentadas as perdas de carga na camada suporte e camada de areia grossa do FAAG e ao longo do meio filtrante do FRD. 
Tabela 5.11 - Resumo dos resultados obtidos no ensaio 5 realizado na instalação piloto em escoamento contínuo sem pré-oxidação.

\begin{tabular}{|c|c|c|c|c|}
\hline & \multicolumn{4}{|c|}{ ENSAIO 5} \\
\hline Taxas de filtração médias & \multicolumn{4}{|c|}{ FAAG $=124 \mathrm{~m}^{3} / \mathrm{m}^{2} \mathrm{~d}$ e FRD $=165 \mathrm{~m}^{3} / \mathrm{m}^{2} \mathrm{~d}$} \\
\hline Condições de coagulação & \multicolumn{4}{|c|}{$\begin{array}{c}\mathrm{D}_{\mathrm{SA}} \cong 8 \mathrm{mg} / \mathrm{L} ; \mathrm{pH} \text { de coagulação }=4,67 \text { a } 5,06 ; \\
\text { temperatura }=22,5 \text { a } 26,0^{\circ} \mathrm{C}\end{array}$} \\
\hline Duração da carreira (h) & \multicolumn{4}{|c|}{72} \\
\hline Produção Efetiva (\%) & \multicolumn{4}{|c|}{93,6} \\
\hline Características & AB & AE & $\begin{array}{c}\text { Efluente do } \\
\text { FAAG }\end{array}$ & $\begin{array}{c}\text { Efluente do } \\
\text { FRD }\end{array}$ \\
\hline $\mathrm{pH}$ & 6,68 a 6,91 & 6,62 a 6,94 & NR & NR \\
\hline Alcalinidade $\left(\mathrm{mg} / \mathrm{L} \mathrm{CaCO}_{3}\right)$ & 7,0 a 12,3 & 8,4 a 12,1 & NR & NR \\
\hline Cor aparente $(\mathrm{uH})$ & 119 a 146 & 201 a 247 & $<1$ a $19^{(*)}$ & $<1$ a $3^{(*)}$ \\
\hline Cor verdadeira $(\mathrm{uH})$ & 18 a 28 & 85 a 116 & NR & NR \\
\hline Turbidez (uT) & 11,6 a 22,8 & NR & $<0,01$ a 1,1 & $<0,01$ a 0,6 \\
\hline Absorvância 254 nm & 0,063 a 0,078 & 0,177 a $0,211^{(*)}$ & 0,008 a $0,023^{(*)}$ & $\begin{array}{l}0,008 \underset{a}{a} \\
0,023^{(*)}\end{array}$ \\
\hline $\mathrm{COD}(\mathrm{mg} / \mathrm{L})$ & 2,0 a 2,4 & 2,6 a 3,9 & 1,8 a 2,5 & 1,8 a 2,4 \\
\hline Alumínio residual (mg/L) & 0,01 a 0,05 & 0,01 a 0,07 & 0,46 a 0,60 & 0,10 a 0,21 \\
\hline
\end{tabular}

O efluente do FAAG apresentou cor aparente $\leq 1 \mathrm{uH}$ na maior parte do tempo, sendo observado o valor de 19,0 uH no início do funcionamento dos filtros. No efluente do FRD a cor aparente também foi $\leq 1 \mathrm{uH}$, como mostra a Figura 5.24.

Na Figura 5.25 está mostrada a variação de turbidez na $A B, A E$ e efluentes do FAAG e do FRD. Observa-se que a turbidez no efluente do FAAG apresentou valores $\leq 1$ uT durante todo o ensaio, sem a necessidade do FRD. Com os resultados obtidos neste ensaio, as taxas de filtração no FRD foram aumentadas para 200 e $240 \mathrm{~m}^{3} / \mathrm{m}^{2} \mathrm{~d}$ nos ensaios 6 e 7 respectivamente.

Nas Figuras 5.26 e 5.27 estão representados os resultados de absorvância $254 \mathrm{~nm}$ e de COD obtidos no ensaio 5. A eficiência de remoção de substâncias húmicas em termos de absorvância 254 nm variou de 87,5 a 95,6\% no FAAG e de 89,1 a $95,6 \%$ no FRD. Com relação ao COD, a variação de remoção foi de 26,6 a $46,3 \%$ no $F A A G$ e de 16,0 a $48,3 \%$ no FRD. 


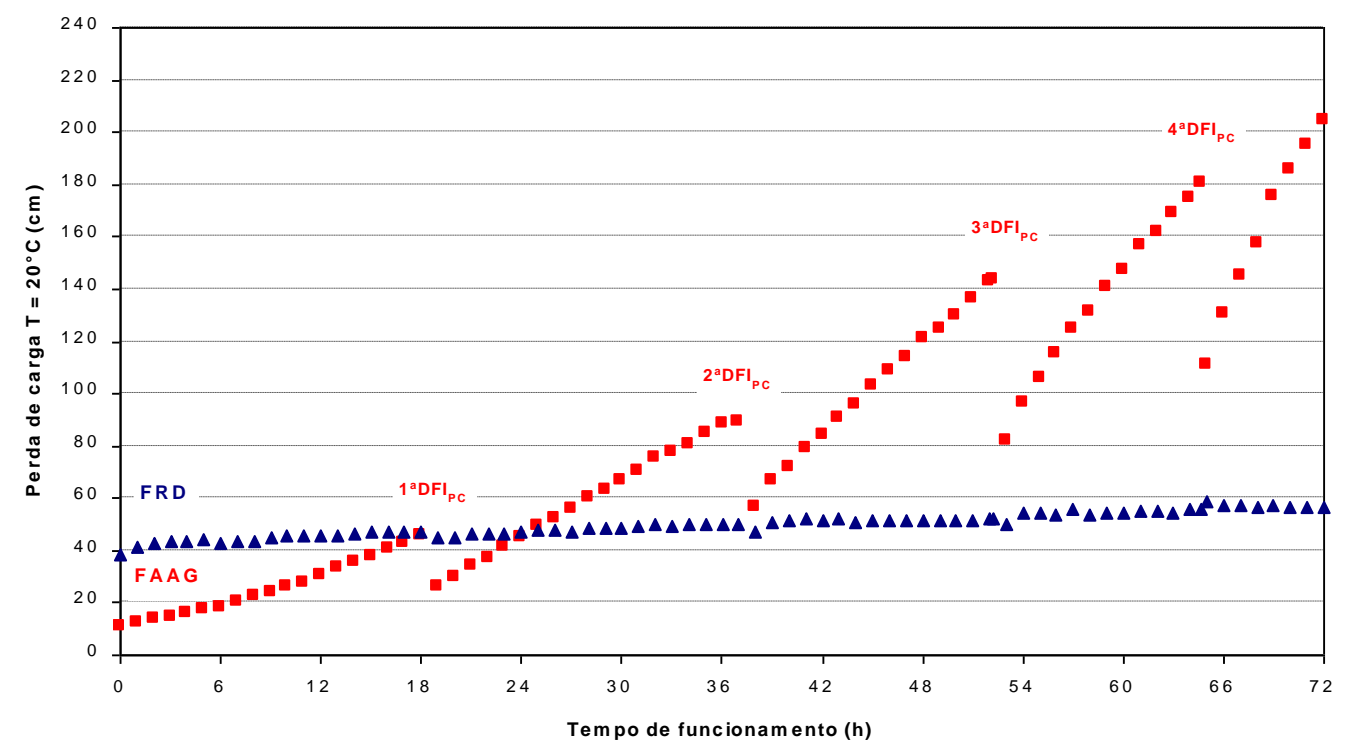

Figura 5.23 - Evolução da perda de carga no FAAG $\left(120 \mathrm{~m}^{3} / \mathrm{m}^{2} \mathrm{~d}\right)$ e FRD $\left(160 \mathrm{~m}^{3} / \mathrm{m}^{2} \mathrm{~d}\right)$ durante o ensaio 5 , para $T=20^{\circ} \mathrm{C}$, com execução de DFls no FAAG. Fonte: Tabela B 5.3 do ANEXO B.

$\diamond \mathrm{AB} \quad \square \mathrm{AE} \quad \triangle$ Efluente do FAAG $\diamond$ Efluente do FRD

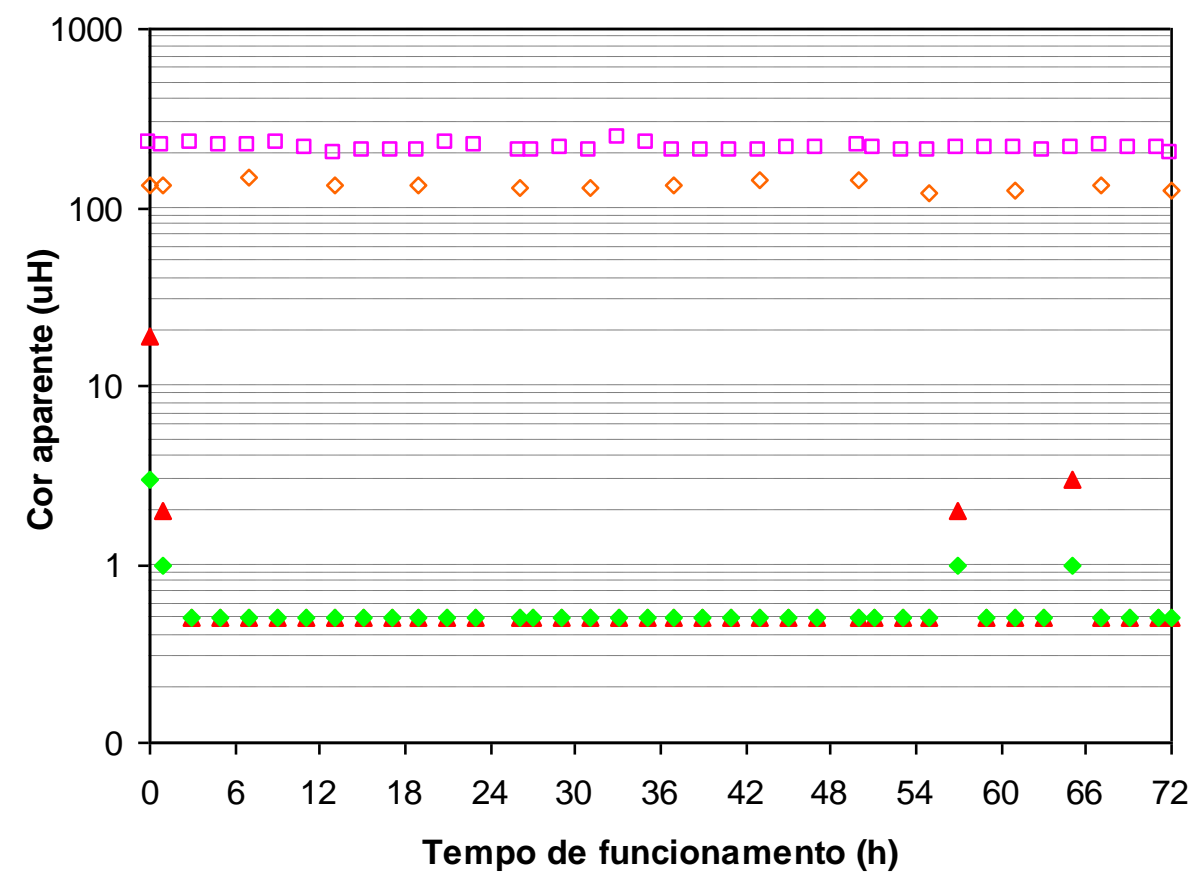

Figura 5.24 - Variação da cor aparente na $A B, A E$ e efluentes do FAAG e do FRD, e cor verdadeira na $A B$ de 18 a 28 uH e na $A E$ de 85 a $116 \mathrm{uH}$, durante o ensaio 5 (FAAG $=120$ $\mathrm{m}^{3} / \mathrm{m}^{2} \mathrm{~d}$ e FRD $=160 \mathrm{~m}^{3} / \mathrm{m}^{2} \mathrm{~d}$ ). Fonte: Tabela B 5.1 do ANEXO B. 


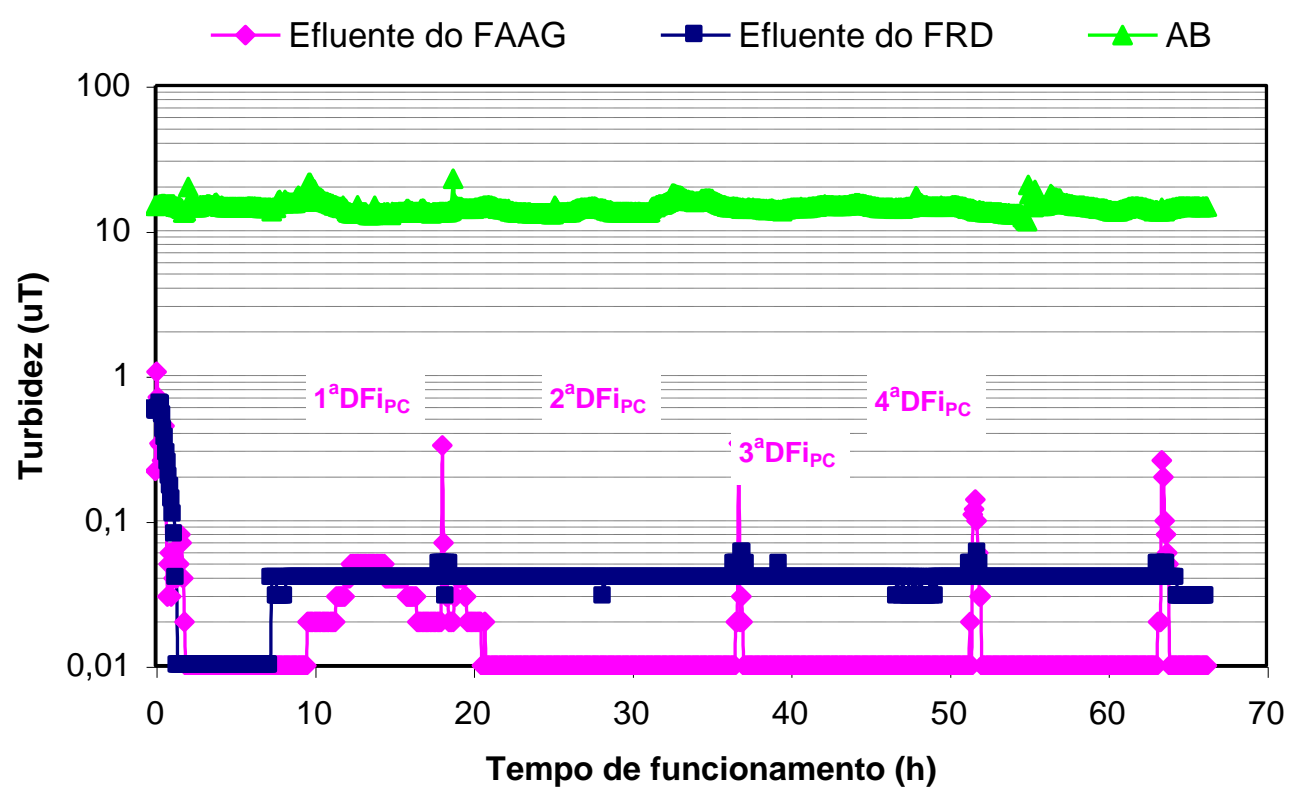

Figura 5.25 - Variação da turbidez na $A B$ e efluentes do FAAG e do FRD durante o ensaio 5 $\left(F A A G=120 \mathrm{~m}^{3} / \mathrm{m}^{2} \mathrm{~d}\right.$ e $\mathrm{FRD}=160 \mathrm{~m}^{3} / \mathrm{m}^{2} \mathrm{~d}$ ).

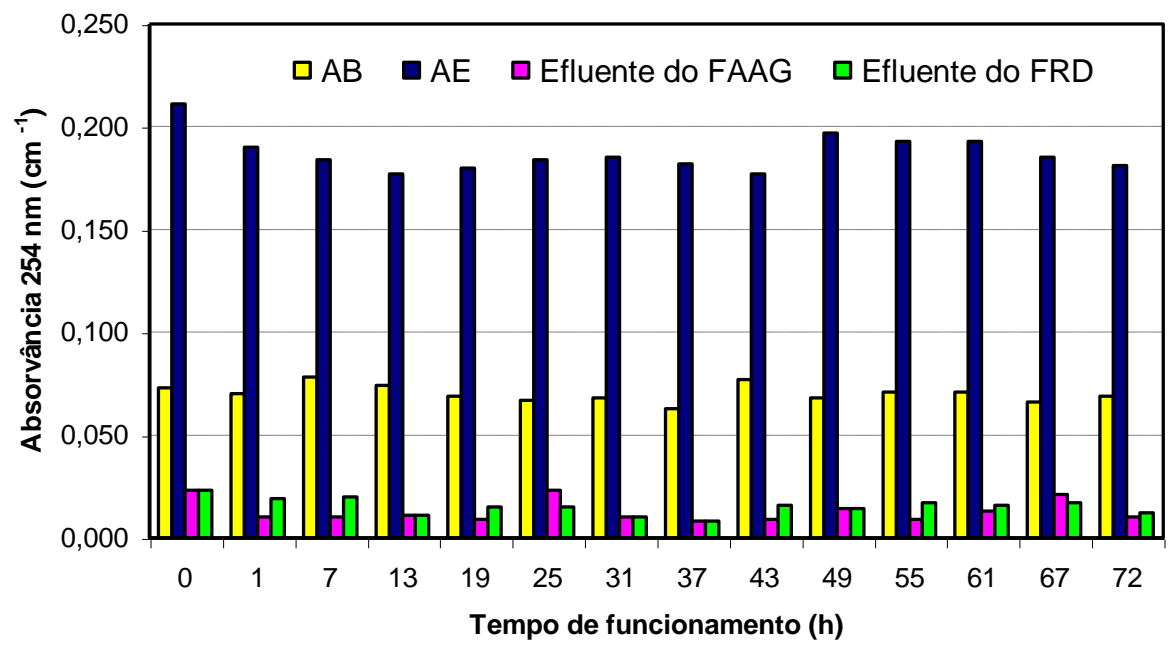

Figura 5.26 - Variação de absorvância $254 \mathrm{~nm}$ na $A B, A E$ e nos efluentes do FAAG e do FRD durante o ensaio $5\left(F A A G=120 \mathrm{~m}^{3} / \mathrm{m}^{2} \mathrm{~d}\right.$ e $\left.\mathrm{FRD}=160 \mathrm{~m}^{3} / \mathrm{m}^{2} \mathrm{~d}\right)$. Fonte: Tabela $B 5.2$ do ANEXO B. 


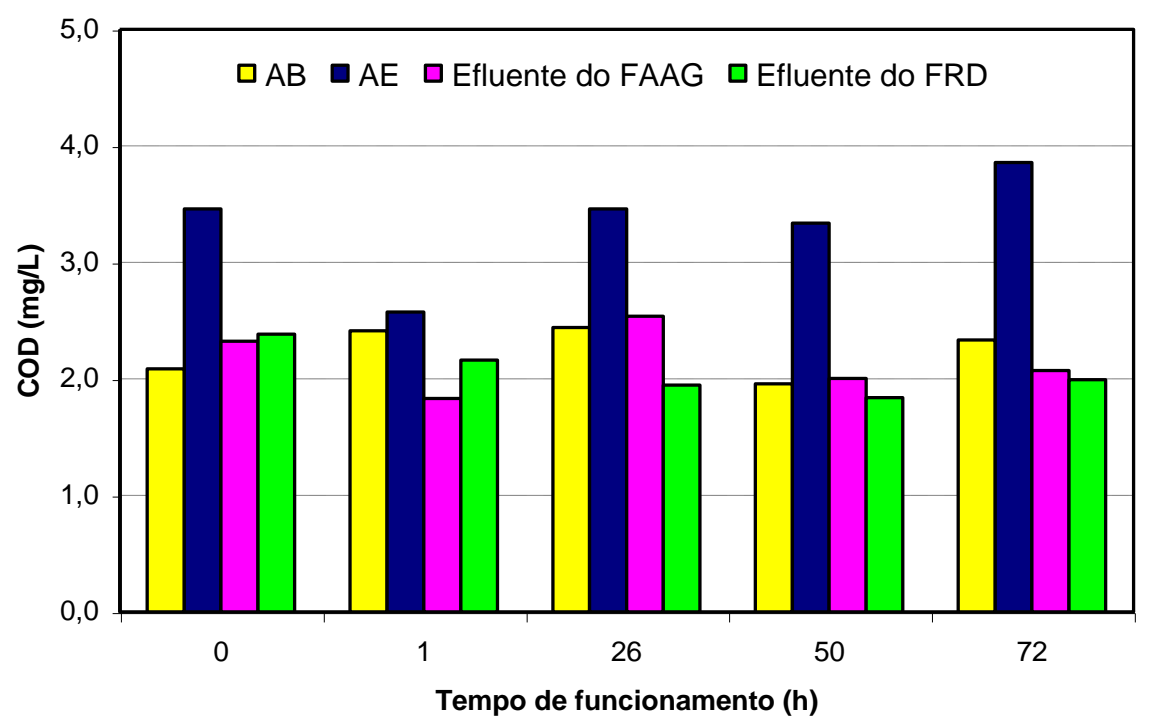

Figura 5.27 - Variação de COD na $A B, A E$ e nos efluentes do FAAG e do FRD durante o ensaio $5\left(F A A G=120 \mathrm{~m}^{3} / \mathrm{m}^{2} \mathrm{~d}\right.$ e FRD $\left.=160 \mathrm{~m}^{3} / \mathrm{m}^{2} \mathrm{~d}\right)$. Fonte: Tabela B 5.2 do ANEXO B.

\subsubsection{Ensaio $6\left(F A A G=120 \mathrm{~m}^{3} / \mathrm{m}^{2} \mathrm{~d}\right.$ e $\left.F R D=200 \mathrm{~m}^{3} / \mathrm{m}^{2} \mathrm{~d}\right)$}

As taxas de filtração médias obtidas neste ensaio foram de 124 e 205 $\mathrm{m}^{3} / \mathrm{m}^{2} \mathrm{~d}$ no FAAG e no FRD respectivamente (ver Tabela B 6.4 do ANEXO B). O resumo dos resultados obtidos neste ensaio está apresentado na Tabela 5.12 e nas Tabelas B 6.1 a B 6.4 do ANEXO B estão todos os dados coletados durante o ensaio 6.

Na Figura 5.28 está a evolução da perda de carga no FAAG e no FRD para a temperatura de $20^{\circ} \mathrm{C}$. Foram executadas seis DFIs no FAAG, a primeira DFI foi executada pelo critério de perda de carga e as demais pelo efluente do FAAG apresentar valores de cor aparente $\geq 50 \mathrm{uH}$, e uma lavagem no FRD por perda de carga após 54 horas de funcionamento.

Na Figura B 5.1 do ANEXO B estão apresentadas as perdas de carga na camada suporte e na camada de areia grossa do FAAG e na Figura B 5.2 do ANEXO B estão apresentadas as perdas de carga ao longo do meio filtrante no FRD. 
Tabela 5.12 - Resumo dos resultados obtidos no ensaio 6 realizado na instalação piloto em escoamento contínuo sem pré-oxidação.

\begin{tabular}{|c|c|c|c|c|}
\hline & \multicolumn{4}{|c|}{ ENSAIO 6} \\
\hline Taxas de filtração & \multicolumn{4}{|c|}{ FAAG $=124 \mathrm{~m}^{3} / \mathrm{m}^{2} \mathrm{~d}$ e FRD $=205 \mathrm{~m}^{3} / \mathrm{m}^{2} \mathrm{~d}$} \\
\hline Condições de coagulação & \multicolumn{4}{|c|}{$\begin{array}{c}\mathrm{D}_{\mathrm{SA}} \cong 8 \mathrm{mg} / \mathrm{L} ; \mathrm{pH} \text { de coagulação }=4,86 \text { a } 5,10 ; \\
\text { temperatura }=17,0 \text { a } 20,5^{\circ} \mathrm{C}\end{array}$} \\
\hline Duração da carreira (h) & \multicolumn{4}{|c|}{72} \\
\hline Produção Efetiva (\%) & \multicolumn{4}{|c|}{94,8} \\
\hline Características & AB & AE & $\begin{array}{c}\text { Efluente do } \\
\text { FAAG }\end{array}$ & $\begin{array}{c}\begin{array}{c}\text { Efluente do } \\
\text { FRD }\end{array} \\
\end{array}$ \\
\hline $\mathrm{pH}$ & 6,22 a 6,51 & 6,14 a 6,67 & NR & NR \\
\hline Alcalinidade $\left(\mathrm{mg} / \mathrm{L} \mathrm{CaCO}_{3}\right)$ & 6,8 a 9,2 & 7,3 a 10,8 & NR & NR \\
\hline Cor aparente $(\mathrm{uH})$ & 90 a 133 & 174 a 242 & $<1$ a 77 & $<1$ a $5^{(*)}$ \\
\hline Cor verdadeira $(\mathrm{uH})$ & 14 a 33 & 76 a 119 & NR & NR \\
\hline Turbidez (uT) & 9,8 a 22,6 & NR & $<0,01$ a 18,5 & $<0,01$ a 0,2 \\
\hline Absorvância 254 nm & 0,064 a 0,102 & 0,181 a 0,209 & 0,007 a 0,019 & $\begin{array}{l}0,011 \mathrm{a} \\
0,021^{(*)}\end{array}$ \\
\hline COD (mg/L) & 2,6 a $3,3^{(*)}$ & 4,0 a 5,0 & 2,2 a $3,0^{(*)}$ & 2,2 a $3,3^{(*)}$ \\
\hline Alumínio residual (mg/L) & 0,02 a 0,04 & 0,02 a 0,04 & NR & 0,17 a 0,25 \\
\hline
\end{tabular}

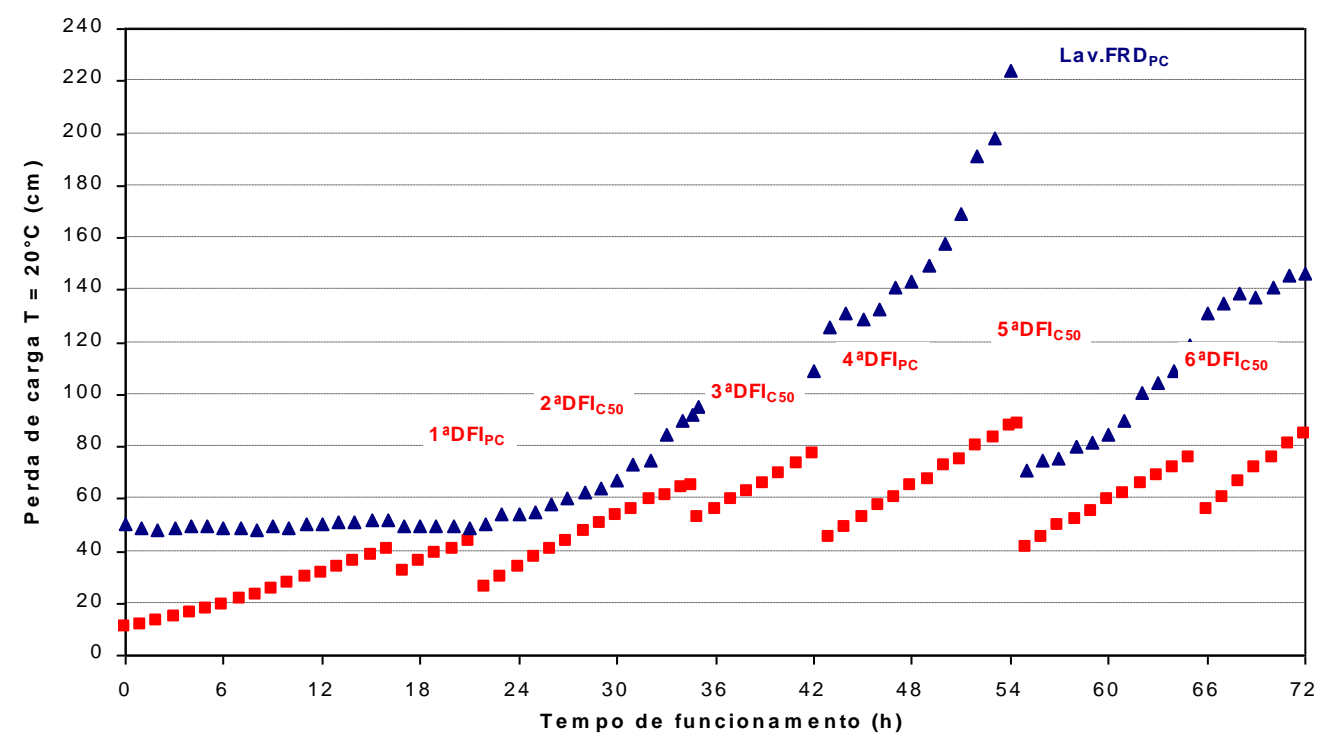

Figura 5.28 - Evolução da perda de carga no FAAG $\left(120 \mathrm{~m}^{3} / \mathrm{m}^{2} \mathrm{~d}\right)$ e FRD $\left(200 \mathrm{~m}^{3} / \mathrm{m}^{2} \mathrm{~d}\right)$ durante o ensaio 6 , para $T=20^{\circ} \mathrm{C}$, com execução de DFls no FAAG. Fonte: Tabela $B 6.3$ do ANEXO B.

Nas Figuras 5.29 e 5.30 está mostrada a variação de cor aparente e de turbidez, respectivamente, durante o ensaio 6. Na Figura 5.29 observam-se os picos de cor aparente no efluente do FAAG, até atingir valores $\geq 50 \mathrm{uH}$, quando eram executadas as DFls. A cor aparente do efluente do FRD permaneceu $\leq 1 \mathrm{uH}$, com exceção do início do ensaio em que o valor medido foi de 5,0 uH. 


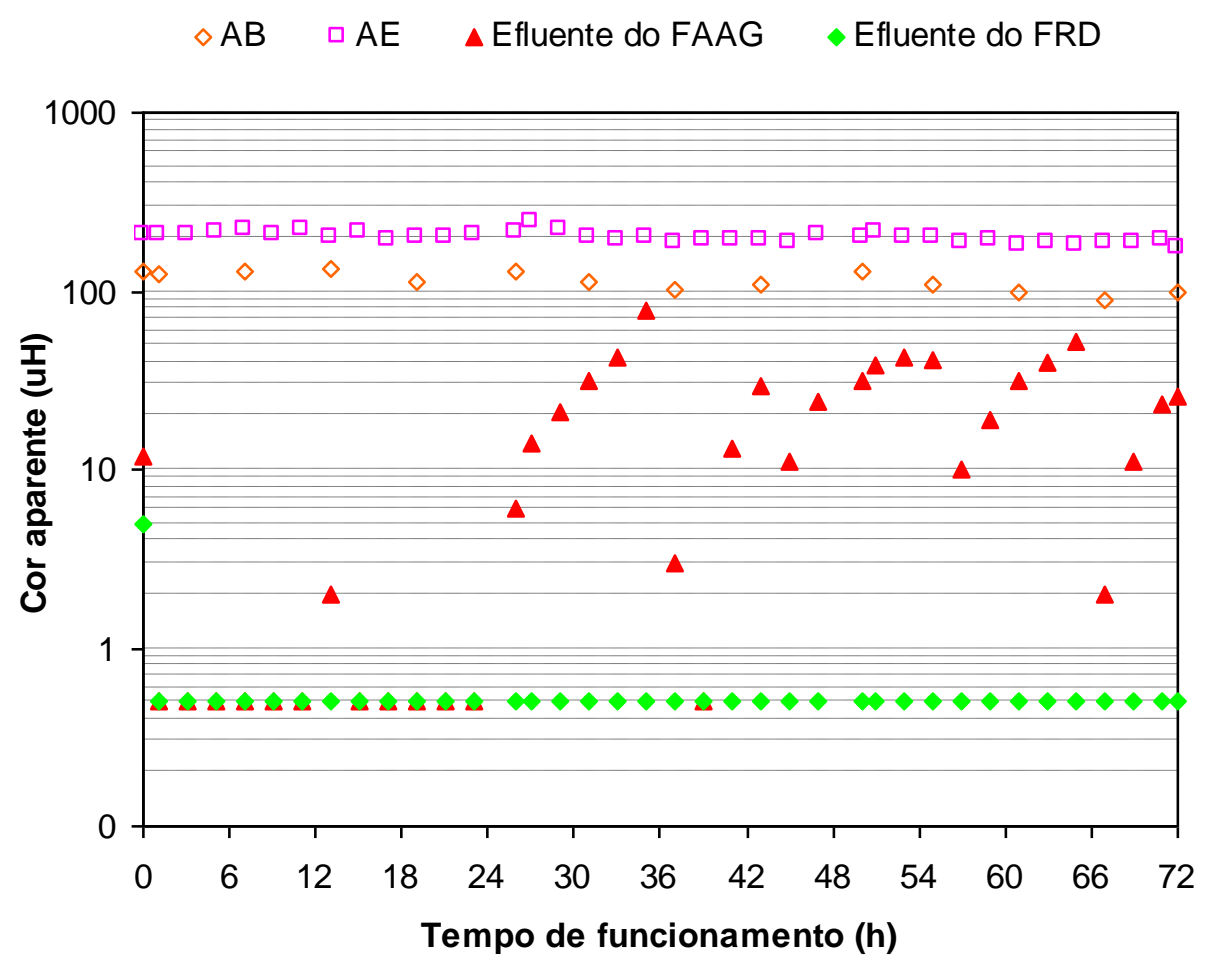

Figura 5.29 - Variação da cor aparente na $A B, A E$ e efluentes do $F A A G$ e do $F R D$, e cor verdadeira na $A B$ de 14 a $33 \mathrm{uH}$ e na $A E$ de 76 a $119 \mathrm{uH}$, durante o ensaio 6 (FAAG $=120$ $\mathrm{m}^{3} / \mathrm{m}^{2} \mathrm{~d}$ e FRD $=200 \mathrm{~m}^{3} / \mathrm{m}^{2} \mathrm{~d}$ ). Fonte: Tabela B 6.1 do ANEXO B.

Com relação à turbidez, observam-se na Figura 5.30 os picos de turbidez no efluente do FAAG, com o início do transpasse antes de cada DFI. A turbidez do efluente do FRD manteve-se abaixo de 1 uT durante todo o ensaio.

Nas Figuras 5.31 e 5.32 estão representadas as variações de absorvância 254 nm e de COD. A eficiência de remoção de substâncias húmicas em termos de absorvância 254 nm variou de 87,5 a 95,6\% no FAAG e de 89,1 a 95,6\% no FRD. Com relação ao COD, a variação foi de 35 a $51,2 \%$ no FAAG e de 28,7 a $52,4 \%$ no FRD. 


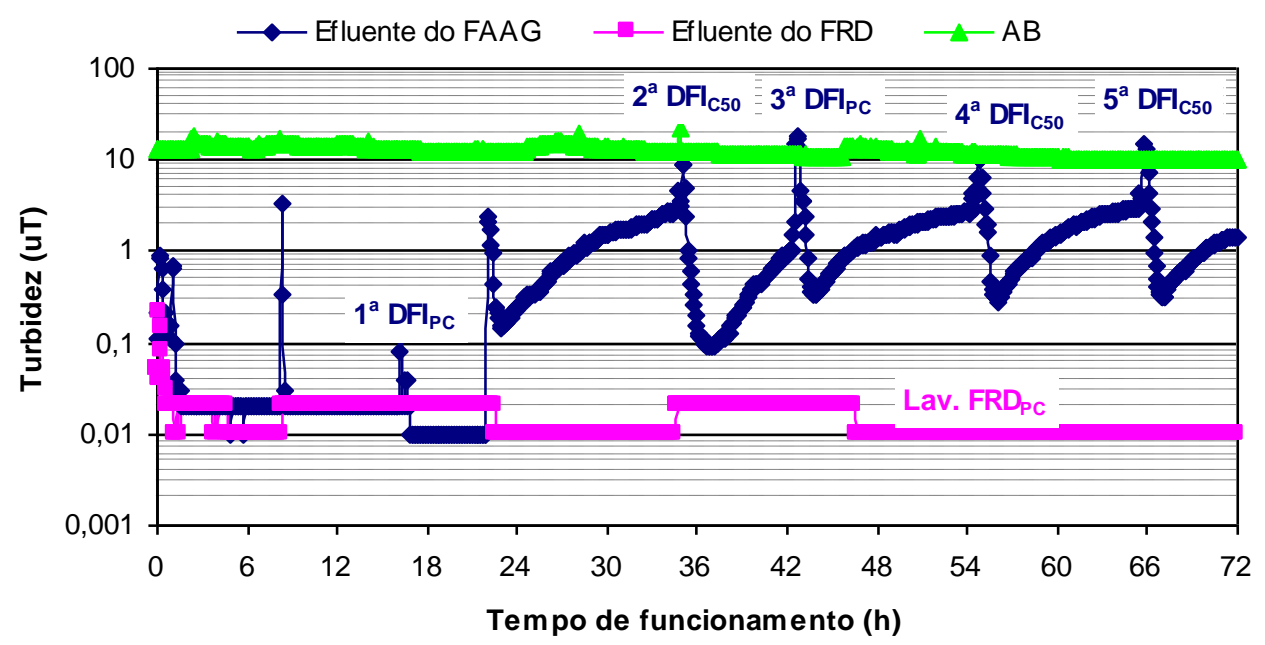

Figura 5.30 - Variação da turbidez na $A B$ e efluentes do FAAG e do FRD durante o ensaio 6 $\left(F A A G=120 \mathrm{~m}^{3} / \mathrm{m}^{2} \mathrm{~d}\right.$ e FRD $\left.=200 \mathrm{~m}^{3} / \mathrm{m}^{2} \mathrm{~d}\right)$.

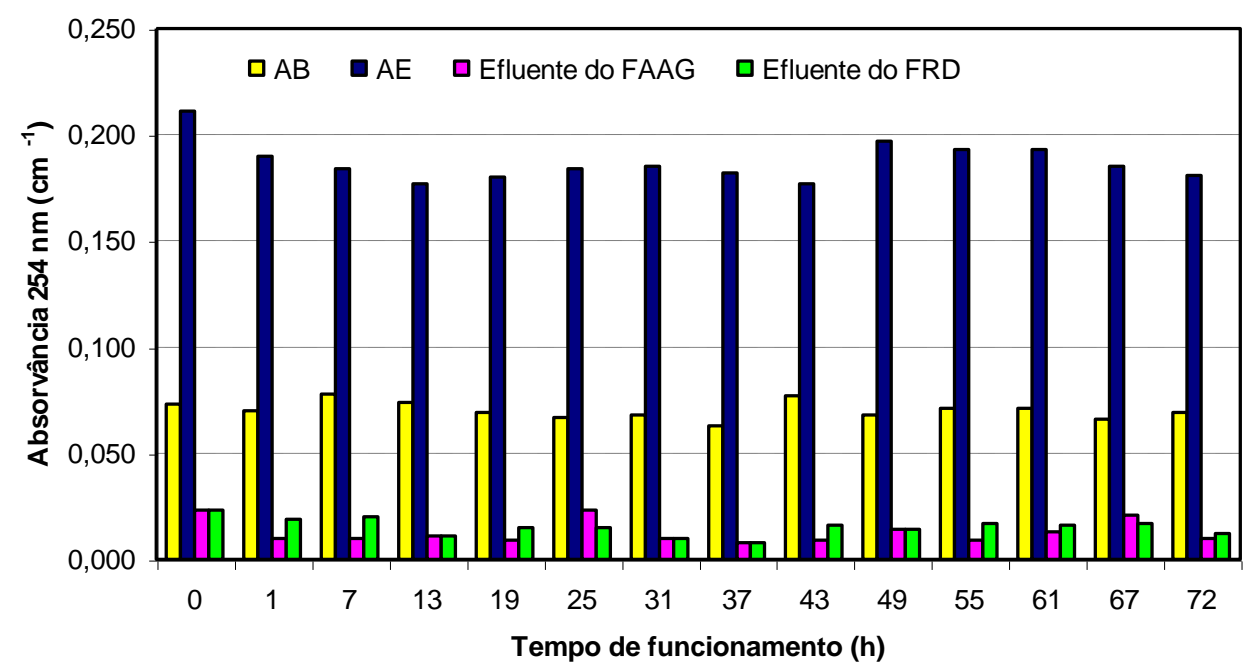

Figura 5.31 - Variação de absorvância $254 \mathrm{~nm}$ na $A B, A E$ e nos efluentes do FAAG e do FRD durante o ensaio $6\left(F A A G=120 \mathrm{~m}^{3} / \mathrm{m}^{2} \mathrm{~d}\right.$ e FRD $\left.=200 \mathrm{~m}^{3} / \mathrm{m}^{2} \mathrm{~d}\right)$. Fonte: Tabela B 6.2 do ANEXO B. 


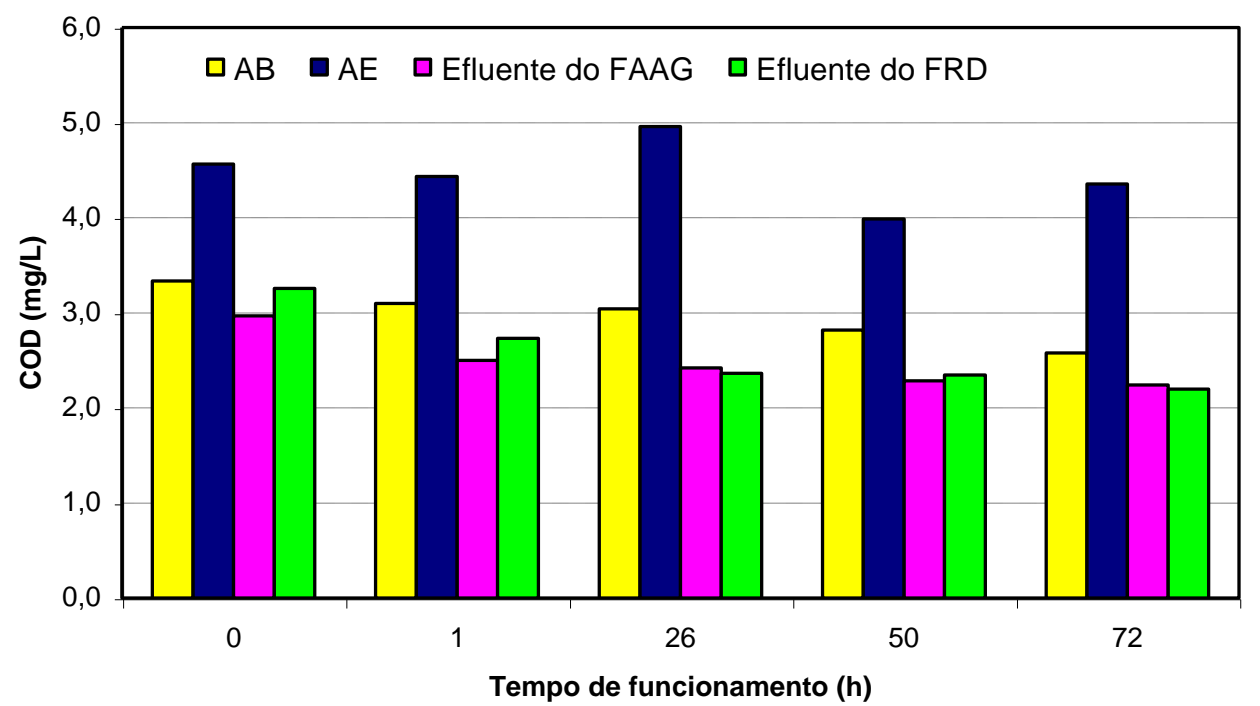

Figura 5.32 - Variação de $C O D$ na $A B, A E$ e nos efluentes do FAAG e do FRD durante o ensaio $6\left(F A A G=120 \mathrm{~m}^{3} / \mathrm{m}^{2} \mathrm{~d}\right.$ e FRD $\left.=200 \mathrm{~m}^{3} / \mathrm{m}^{2} \mathrm{~d}\right)$. Fonte: Tabela B 6.2 do ANEXO B.

\subsubsection{Ensaio $7\left(\right.$ FAAG $=120 \mathrm{~m}^{3} / \mathrm{m}^{2} \mathrm{~d}$ e $F R D=240 \mathrm{~m}^{3} / \mathrm{m}^{2} \mathrm{~d}$ )}

As taxas de filtração médias obtidas neste ensaio foram de 126 e 244 $\mathrm{m}^{3} / \mathrm{m}^{2} \mathrm{~d}$ no FAAG e no FRD respectivamente (ver Tabela B 7.4 do ANEXO B). O resumo dos resultados obtidos neste ensaio está apresentado na Tabela 5.13 e nas Tabelas B 7.1 a B 7.4 do ANEXO B estão todos os dados coletados durante o ensaio 7.

Na Figura 5.33 está a evolução da perda de carga no FAAG e no FRD para a temperatura de $20^{\circ} \mathrm{C}$, foram executadas quatro DFIs no FAAG, a primeira DFI foi executada pelo critério de perda de carga e as demais pelo efluente do FAAG ter apresentado cor aparente $\geq 50 \mathrm{uH}$, e duas lavagens no FRD, uma por perda de carga com 47 horas de funcionamento e outra por transpasse, após 62 horas de funcionamento.

Na Figura B 7.1 do ANEXO B estão apresentadas as perdas de carga na camada suporte e na camada de areia grossa do FAAG e na Figura B 7.2 do ANEXO B estão as perdas de carga ao longo do meio filtrante do FRD.

A cor aparente do efluente do FRD manteve-se menor que $1 \mathrm{uH}$ na maior parte do tempo. Na Figura 5.34 observa-se a variação da cor aparente do efluente do FAAG, decorrente da execução das DFIs, com recuperação da qualidade da água do FAAG após as DFls. 
Quanto à turbidez, observa-se na Figura 5.35 que o efluente do FRD apresentou turbidez menor que 1 uT, com exceção de picos de turbidez observados antes da lavagem do filtro. O primeiro pico de turbidez foi devido ao aumento da perda de carga pela retenção das impurezas ao longo do meio filtrante, o segundo pico de turbidez foi devido à ocorrência de transpasse no filtro, necessitando sua lavagem. No FAAG ocorreram picos de turbidez antes das DFls e após as DFls observou-se a recuperação da qualidade da água.

Tabela 5.13 - Resumo dos resultados obtidos no ensaio 7 realizado na instalação piloto em escoamento contínuo sem pré-oxidação.

\begin{tabular}{|c|c|c|c|c|}
\hline & \multicolumn{4}{|c|}{ ENSAIO 7} \\
\hline Taxas de filtração médias & \multicolumn{4}{|c|}{ FAAG $=126 \mathrm{~m}^{3} / \mathrm{m}^{2} \mathrm{~d}$ e FRD $=244 \mathrm{~m}^{3} / \mathrm{m}^{2} \mathrm{~d}$} \\
\hline Condições de coagulação & \multicolumn{4}{|c|}{$\begin{array}{c}\mathrm{D}_{\mathrm{SA}} \cong 8 \mathrm{mg} / \mathrm{L} ; \mathrm{pH} \text { de coagulação }=4,80 \text { a } 5,13 ; \\
\text { temperatura }=20,5 \text { a } 24,0^{\circ} \mathrm{C}\end{array}$} \\
\hline Duração da carreira (h) & \multicolumn{4}{|c|}{72} \\
\hline Produção Efetiva (\%) & \multicolumn{4}{|c|}{95,4} \\
\hline Características & AB & $\overline{\mathrm{AE}}$ & $\begin{array}{c}\text { Efluente do } \\
\text { FAAG }\end{array}$ & $\begin{array}{c}\text { Efluente do } \\
\text { FRD }\end{array}$ \\
\hline $\mathrm{pH}$ & 6,22 a 6,67 & $6,38^{(*)}$ a 6,84 & NR & NR \\
\hline Alcalinidade $\left(\mathrm{mg} / \mathrm{L} \mathrm{CaCO}_{3}\right)$ & 8,1 a 10,1 & 8,4 a 10,3 & NR & NR \\
\hline Cor aparente $(\mathrm{uH})$ & 114 a 153 & 196 a 231 & $<1$ a 80 & $<1$ a $7^{(*)}$ \\
\hline Cor verdadeira $(\mathrm{uH})$ & 15 a 23 & 86 a 120 & NR & NR \\
\hline Turbidez (uT) & 11,2 a 17,8 & NR & $<0,01$ a 41,8 & $<0,01$ a 1,2 \\
\hline Absorvância 254 nm & 0,059 a 0,073 & 0,172 a 0,205 & 0,008 a 0,021 & $\begin{array}{l}0,014 a \\
\left.0,040^{*}\right)\end{array}$ \\
\hline COD $(\mathrm{mg} / \mathrm{L})$ & 2,4 a 3,2 & 2,8 a $4,2^{(*)}$ & 1,9 a 2,4 & 1,8 a $2,8^{(*)}$ \\
\hline Alumínio residual (mg/L) & 0,02 a 0,07 & 0,02 a 0,06 & 0,81 a 0,84 & 0,51 \\
\hline
\end{tabular}

$\mathrm{D}_{\mathrm{SA}}=$ dosagem de $\mathrm{Al}_{2}\left(\mathrm{SO}_{4}\right)_{3} \cdot 14,3 \mathrm{H}_{2} \mathrm{O} ; \mathrm{AB}=$ água bruta; $\mathrm{AE}=$ água de estudo; $\mathrm{FAAG}$ = filtro ascendente de areia grossa; FRD = filtro rápido descendente; $\mathrm{COD}=$ carbono orgânico dissolvido; $\mathrm{NR}=$ não realizado. ${ }^{(*)}$ Valor observado no início do ensaio. 


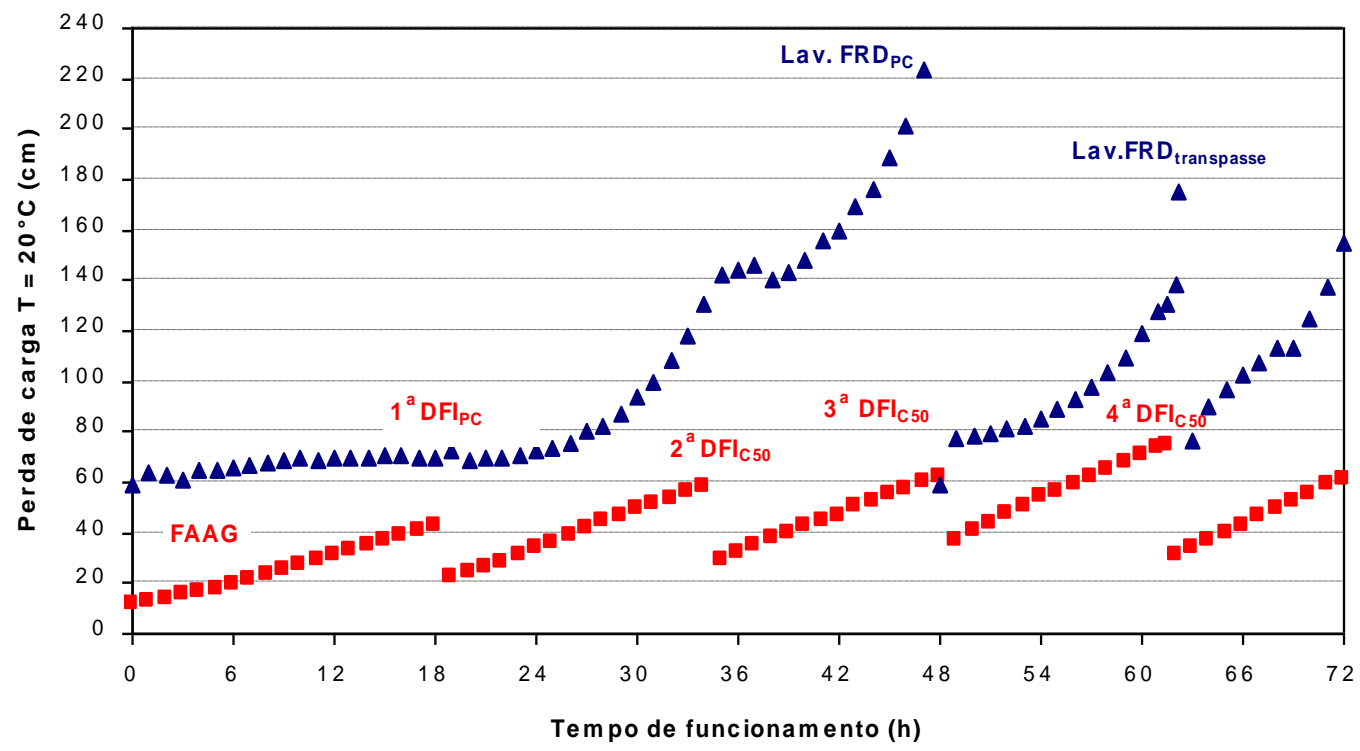

Figura 5.33 - Evolução da perda de carga no FAAG $\left(120 \mathrm{~m}^{3} / \mathrm{m}^{2} \mathrm{~d}\right)$ e FRD $\left(240 \mathrm{~m}^{3} / \mathrm{m}^{2} \mathrm{~d}\right)$ durante o ensaio 7 , para $T=20^{\circ} \mathrm{C}$, com execução de DFls no FAAG. Fonte: Tabela $B 7.3$ do ANEXO B.

$\diamond \mathrm{AB} \quad \square \mathrm{AE} \quad \triangle$ Efluente do FAAG $\diamond$ Efluente do FRD

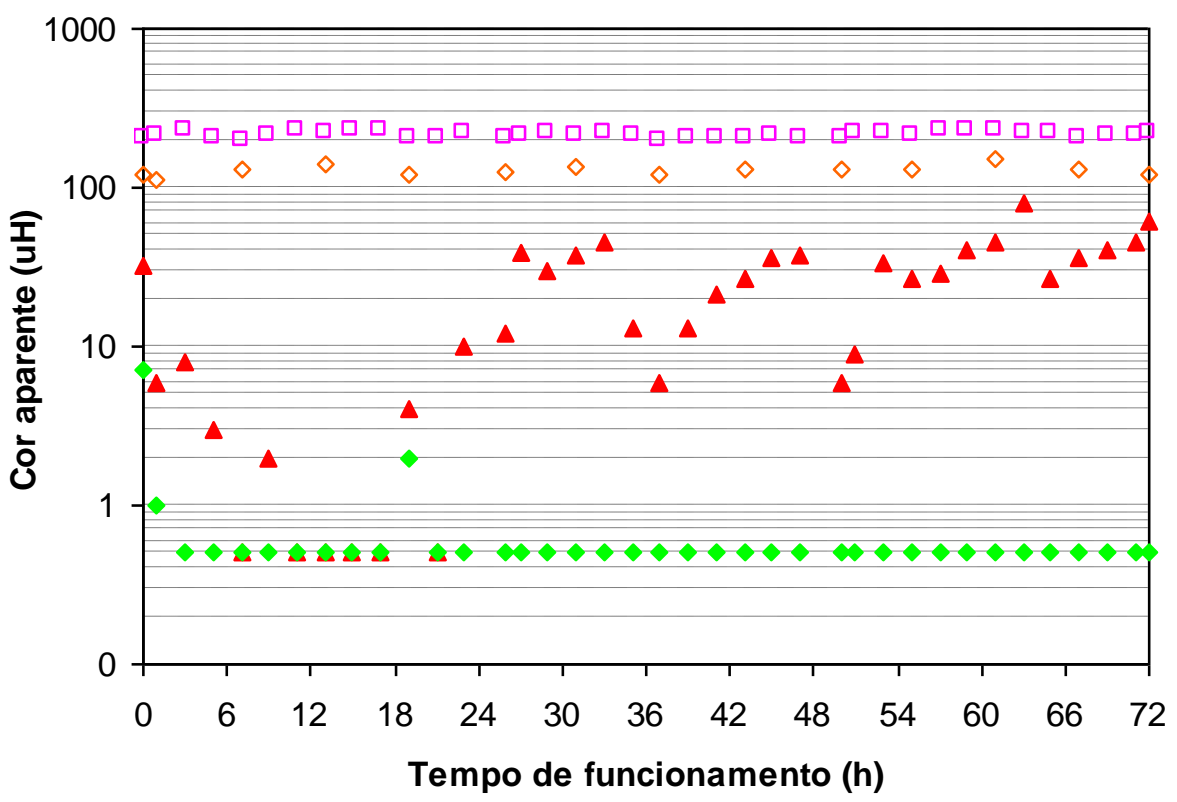

Figura 5.34 - Variação da cor aparente na $A B, A E$ e efluentes do FAAG e do FRD, e cor verdadeira na $A B$ de 15 a $23 \mathrm{uH}$ e na $A E$ de 86 a $120 \mathrm{uH}$, durante o ensaio 7 (FAAG $=120$ $\mathrm{m}^{3} / \mathrm{m}^{2} \mathrm{~d}$ e FRD $=240 \mathrm{~m}^{3} / \mathrm{m}^{2} \mathrm{~d}$ ). Fonte: Tabela 7.1 do ANEXO B. 


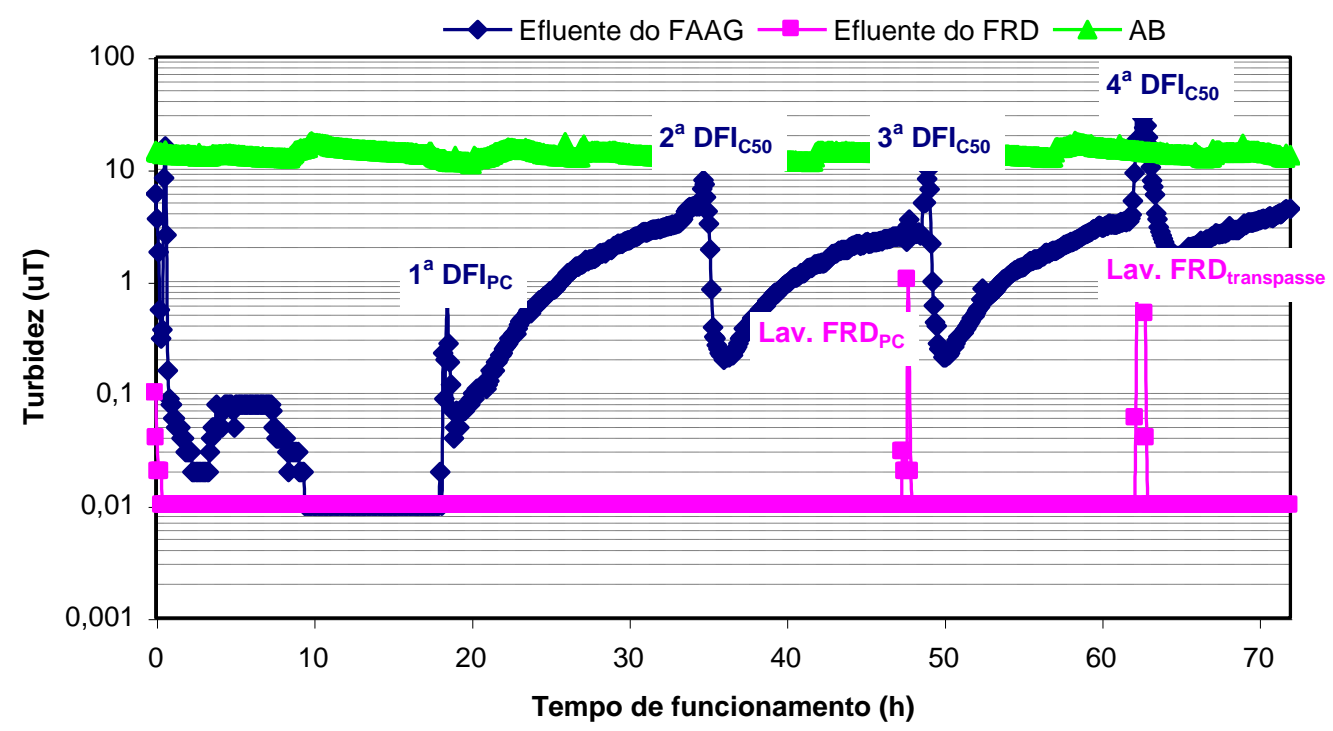

Figura 5.35 - Variação da turbidez na $A B$ e efluentes do FAAG e do FRD durante o ensaio 7 $\left(F A A G=120 \mathrm{~m}^{3} / \mathrm{m}^{2} \mathrm{~d}\right.$ e FRD $=240 \mathrm{~m}^{3} / \mathrm{m}^{2} \mathrm{~d}$ ).

Nas Figuras 5.36 e 5.37 estão os resultados de absorvância 254 nm e COD, respectivamente, obtidos durante o ensaio 7. A eficiência de remoção de substâncias húmicas em termos de absorvância 254 nm variou de 88,6 a 96,1\% no FAAG e de 79,4 a 93,1\% no FRD. Com relação ao COD, a eficiência de remoção foi de 14,2 a $53,6 \%$ no FAAG e de 11,7 a $53,7 \%$ no FRD.

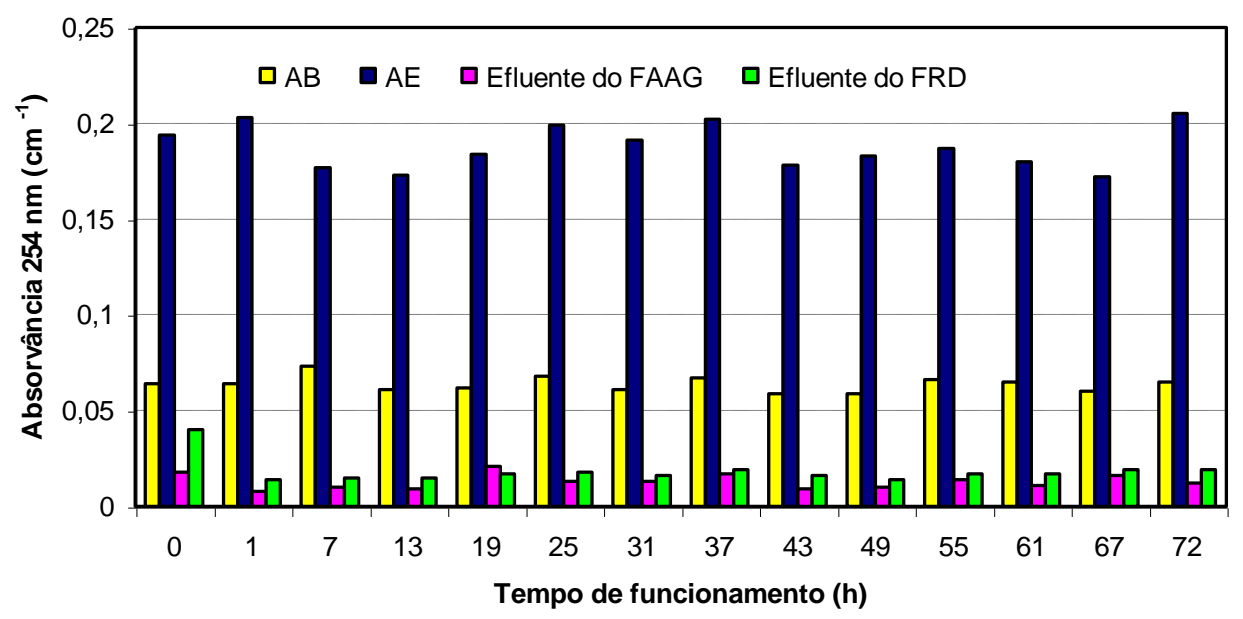

Figura 5.36 - Variação de absorvância $254 \mathrm{~nm}$ na $A B, A E$ e nos efluentes do FAAG e do FRD durante o ensaio 7 (FAAG $=120 \mathrm{~m}^{3} / \mathrm{m}^{2} \mathrm{~d}$ e FRD $=240 \mathrm{~m}^{3} / \mathrm{m}^{2} \mathrm{~d}$ ). Fonte: Tabela B 7.2 do ANEXO B. 


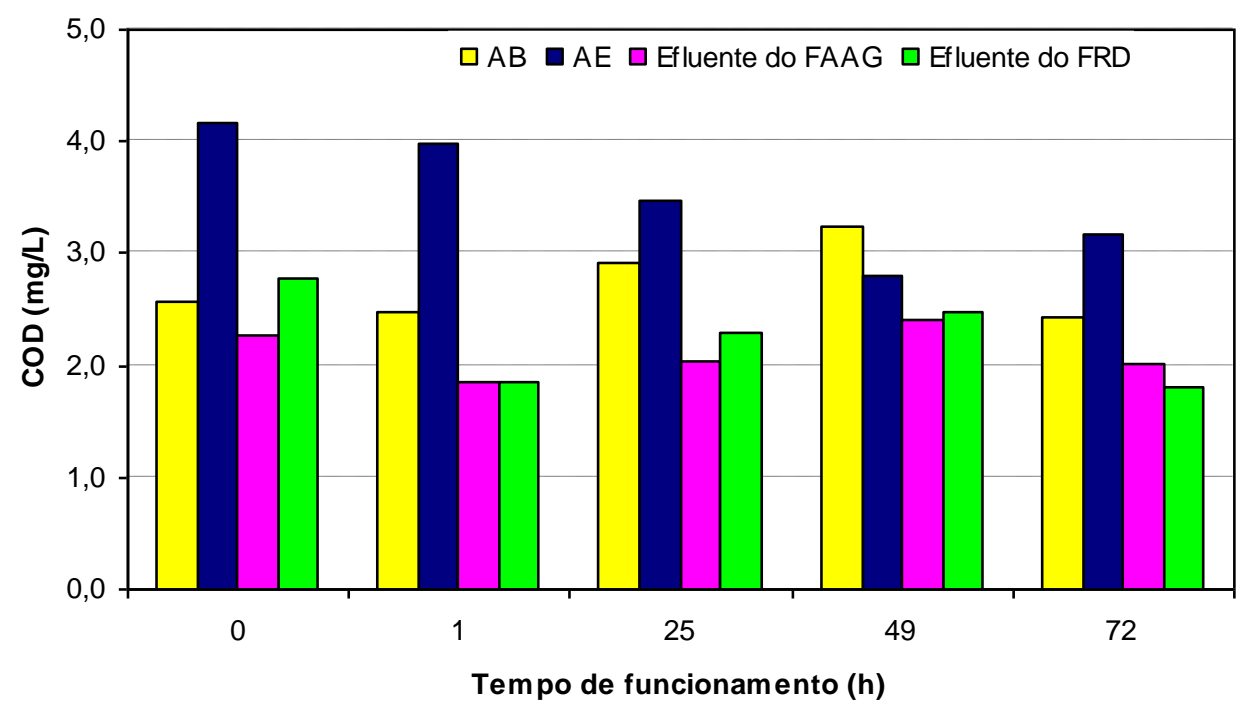

Figura 5.37 - Variação de COD na $A B, A E$ e nos efluentes do FAAG e do FRD durante o ensaio $7\left(F A A G=120 \mathrm{~m}^{3} / \mathrm{m}^{2} \mathrm{~d}\right.$ e FRD $\left.=240 \mathrm{~m}^{3} / \mathrm{m}^{2} \mathrm{~d}\right)$. Fonte: Tabela $B .2$ do ANEXO B.

Nas Tabelas 5.14 e 5.15, estão apresentados o resumo geral dos resultados obtidos em todos os ensaios na instalação piloto em escoamento contínuo, correspondentes à Fase 1 da $3^{\text {a }}$ etapa do trabalho experimental.

Nos ensaios em que foram realizadas as análises de alumínio residual, podem ser observados os elevados valores de alumínio no efluente do FRD $(>0,2$ $\mathrm{mg} / \mathrm{L}$ ), devido à coagulação ocorrer em $\mathrm{pH} \cong 5,0$ favorecendo melhor eficiência de remoção de substâncias húmicas, provavelmente com a formação de complexos solúveis de substância húmica e alumínio. GREGOR et al. (1997) estudaram a remoção de matéria orgânica natural (MON) de águas com baixa turbidez com o ajuste do $\mathrm{pH}$ de coagulação utilizando sulfato de alumínio. Os autores afirmaram que o controle do $\mathrm{pH}$ de coagulação é um dos fatores mais importantes na remoção de MON e o ajuste do pH entre 4,0 e 5,0, antes da adição do coagulante, estimula a formação de complexos solúveis de MON e alumínio. Segundo LU et al. (1999), a melhor remoção de substâncias húmicas ocorre em pH entre 5,0 e 7,0, devido à adsorção das substâncias húmicas na superfície de $\mathrm{Al}(\mathrm{OH})_{3(\mathrm{~s})}$.

O critério da execução de DFls, na maioria dos ensaios, ocorreu quando a cor aparente no FAAG atingia valores $\geq 50 \mathrm{uH}$ e se dava a partir da $2^{\mathrm{a}} \mathrm{DFI}$, geralmente executada após 20 horas de funcionamento para a taxa de $180 \mathrm{~m}^{3} / \mathrm{m}^{2} \mathrm{~d}$ e após 30 horas de funcionamento para a taxa de $120 \mathrm{~m}^{3} / \mathrm{m}^{2} \mathrm{~d}$. 
Tabela 5.14 - Resumo geral dos resultados obtidos nos ensaios 1, 2, 3 e 4 na instalação piloto em escoamento contínuo sem pré-oxidação, durante a Fase 1.

\begin{tabular}{|c|c|c|c|c|c|c|c|c|}
\hline & \multicolumn{4}{|c|}{ ENSAIO 1} & \multicolumn{4}{|c|}{ ENSAIO 2} \\
\hline $\begin{array}{l}\text { Taxas de filtração médias } \\
\end{array}$ & \multicolumn{4}{|c|}{ FAAG $=243 \mathrm{~m}^{3} / \mathrm{m}^{2} \mathrm{~d}$ e FRD $=289 \mathrm{~m}^{3} / \mathrm{m}^{2} \mathrm{~d}$} & \multicolumn{4}{|c|}{ FAAG $=183 \mathrm{~m}^{3} / \mathrm{m}^{2} \mathrm{~d}$ e FRD $=210 \mathrm{~m}^{3} / \mathrm{m}^{2} \mathrm{~d}$} \\
\hline Condições de coagulação & \multicolumn{4}{|c|}{$\begin{array}{c}\mathrm{D}_{\mathrm{SA}} \cong 8 \mathrm{mg} / \mathrm{L} ; \mathrm{pH} \text { de coagulação }=4,80 \text { a } 6,03 ; \\
\text { temperatura }=18,5 \text { a } 22,0^{\circ} \mathrm{C}\end{array}$} & \multicolumn{4}{|c|}{$\begin{array}{c}\mathrm{D}_{\mathrm{SA}} \cong 8 \mathrm{mg} / \mathrm{L} ; \mathrm{pH} \text { de coagulação }=4,91 \text { a } 5,11 ; \\
\text { temperatura }=19,0 \text { a } 22,5^{\circ} \mathrm{C}\end{array}$} \\
\hline Duração da carreira (h) & \multicolumn{4}{|c|}{50} & \multicolumn{4}{|c|}{72} \\
\hline Produção Efetiva (\%) & \multicolumn{4}{|c|}{93,4} & \multicolumn{4}{|c|}{94,1} \\
\hline Características & AB & $\overline{\mathrm{AE}}$ & FAAG & FRD & AB & $\overline{\mathrm{AE}}$ & FAAG & FRD \\
\hline $\mathrm{pH}$ & 6,28 a 6,95 & 6,31 a 7,05 & NR & NR & $6,23^{(*)}$ a 6,56 & 6,28 a 7,25 & NR & NR \\
\hline Alcalinidade $\left(\mathrm{mg} / \mathrm{L} \mathrm{CaCO}_{3}\right)$ & 6,6 a 10,6 & 8,6 a 10,6 & NR & NR & 7,0 a 10,8 & 7,0 a 11,4 & NR & NR \\
\hline Cor aparente $(\mathrm{uH})$ & 80 a 238 & 168 a 366 & $<1$ a 59 & $<1$ a 4 & $88^{(*)}$ a 127 & 178 a 210 & $<1$ a 51 & $<1$ a 4 \\
\hline Cor verdadeira $(\mathrm{uH})$ & 12 a 29 & 76 a 133 & NR & NR & 10 a 26 & 78 a 121 & NR & NR \\
\hline Turbidez (UT) & 8,8 a $48,9^{(*)}$ & NR & 0,02 a 1,0 & $<0,01$ a 0,6 & 10,0 a 17,5 & NR & $<0,01$ a 20,0 & $<0,01$ a 0,7 \\
\hline Absorvância 254 nm & 0,045 a 0,099 & 0,144 a 0,225 & 0,008 a 0,023 & 0,007 a 0,032 & 0,051 a $0,077^{(*)}$ & 0,174 a 0,203 & 0,001 a $0,031^{(*)}$ & 0,003 a $0,030^{(*)}$ \\
\hline $\mathrm{COD}(\mathrm{mg} / \mathrm{L})$ & 2,6 a 4,0 & 3,0 a 5,4 & 2,4 a 4,9 & 0,9 a 4,0 & 2,3 a 3,1 & 4,1 a $4,6^{(*)}$ & 2,0 a $3,4^{(*)}$ & 2,1 a $3,1^{(*)}$ \\
\hline \multirow[t]{2}{*}{ Alumínio residual (mg/L) } & NR & NR & NR & NR & NR & NR & NR & NR \\
\hline & \multicolumn{4}{|c|}{ ENSAIO 3} & \multicolumn{4}{|c|}{ ENSAIO 4} \\
\hline Taxas de filtração médias & \multicolumn{4}{|c|}{ FAAG $=180 \mathrm{~m}^{3} / \mathrm{m}^{2} \mathrm{~d}$ e FRD $=247 \mathrm{~m}^{3} / \mathrm{m}^{2} \mathrm{~d}$} & \multicolumn{4}{|c|}{ FAAG $=176 \mathrm{~m}^{3} / \mathrm{m}^{2} \mathrm{~d}$ e FRD $=285 \mathrm{~m}^{3} / \mathrm{m}^{2} \mathrm{~d}$} \\
\hline Condições de coagulação & \multicolumn{4}{|c|}{$\begin{array}{c}\mathrm{D}_{\mathrm{SA}} \cong 8 \mathrm{mg} / \mathrm{L} ; \mathrm{pH} \text { de coagulação }=4,90 \text { a } 5,05 ; \\
\text { temperatura }=19,0 \text { a } 22,5^{\circ} \mathrm{C}\end{array}$} & \multicolumn{4}{|c|}{$\begin{array}{c}\mathrm{D}_{\mathrm{SA}} \cong 10 \mathrm{mg} / \mathrm{L} ; \mathrm{pH} \text { de coagulação }=4,64 \text { a } 5,49 ; \\
\text { temperatura }=18,0 \text { a } 22,0^{\circ} \mathrm{C}\end{array}$} \\
\hline Duracão da carreira (h) & \multicolumn{4}{|c|}{72} & \multicolumn{4}{|c|}{70} \\
\hline Produção Efetiva (\%) & \multicolumn{4}{|c|}{93,9} & \multicolumn{4}{|c|}{93,9} \\
\hline Características & $\overline{A B}$ & $\overline{\mathrm{AE}}$ & FAAG & FRD & AB & $\overline{\mathrm{AE}}$ & FAAG & FRD \\
\hline$\overline{\mathrm{pH}}$ & 6,38 a 6,75 & 6,32 a 6,82 & NR & NR & 6,31 a 7,63 & 6,33 a 7,45 & $\overline{N R}$ & $\overline{N R}$ \\
\hline Alcalinidade $\left(\mathrm{mg} / \mathrm{L} \mathrm{CaCO}_{3}\right)$ & 7,70 a 11,22 & 7,46 a 11,44 & NR & NR & 8,1 a 19,6 & 9,2 a 19,4 & NR & NR \\
\hline Cor aparente $(\mathrm{uH})$ & 95 a 128 & 174 a 226 & $<1$ a 69 & $<1$ a $19^{(*)}$ & 84 a 116 & 175 a 219 & $<1$ a 43 & $<1$ a 5 \\
\hline Cor verdadeira $(\mathrm{uH})$ & 21 a 33 & 83 a 120 & NR & NR & 14 a 25 & 82 a 112 & NR & NR \\
\hline Turbidez (uT) & 9,8 a 15,5 & NR & $<0,01$ a 29,7 & $<0,01$ a 1,0 & 10,4 a 14,3 & NR & 0,2 a 9,0 & 0,1 a 0,5 \\
\hline Absorvância 254 nm & 0,066 a 0,081 & 0,164 a 0,208 & 0,008 a 0,030 & 0,008 a 0,032 & NR & 0,158 a 0,198 & 0,010 a 0,034 & 0,005 a 0,021 \\
\hline $\operatorname{COD}(\mathrm{mg} / \mathrm{L})$ & 2,6 a $3,2^{(*)}$ & 4,2 a 5,0 & 2,7 a $4,3^{(*)}$ & 2,8 a $4,6^{(*)}$ & 2,2 a 3,1 & $3,1^{(*)}$ a 4,2 & 2,4 a 3,3 & 2,2 a 3,2 \\
\hline Alumínio residual $(\mathrm{mg} /$ & NR & NR & NR & $\mathrm{NR}$ & NR & NR & NR & NR \\
\hline
\end{tabular}

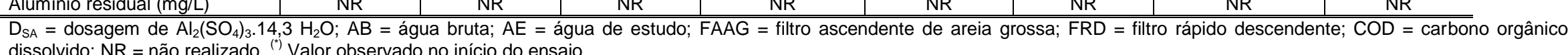


Tabela 5.15 - Resumo geral dos resultados obtidos nos ensaios 5, 6 e 7 na instalação piloto em escoamento contínuo sem pré-oxidação, durante a Fase 1.

\begin{tabular}{|c|c|c|c|c|}
\hline & \multicolumn{4}{|c|}{ ENSAIO 5} \\
\hline Taxas de filtração médias & \multicolumn{4}{|c|}{ FAAG $=124 \mathrm{~m}^{3} / \mathrm{m}^{2} \mathrm{~d}$ e FRD $=165 \mathrm{~m}^{3} / \mathrm{m}^{2} \mathrm{~d}$} \\
\hline Condições de coagulação & \multicolumn{4}{|c|}{$\begin{array}{c}\mathrm{D}_{\mathrm{SA}} \cong 8 \mathrm{mg} / \mathrm{L} ; \mathrm{pH} \text { de coagulação }=4,67 \text { a } 5,06 ; \\
\text { temperatura }=22,5 \text { a } 26,0^{\circ} \mathrm{C}\end{array}$} \\
\hline Duração da carreira $(\mathrm{h})$ & \multicolumn{4}{|c|}{72} \\
\hline Produção Efetiva (\%) & \multicolumn{4}{|c|}{93,6} \\
\hline Características & $\overline{\mathrm{AB}}$ & $\overline{\mathrm{AE}}$ & FAAG & FRD \\
\hline $\mathrm{pH}$ & 6,68 a 6,91 & 6,62 a 6,94 & NR & NR \\
\hline Alcalinidade $\left(\mathrm{mg} / \mathrm{L} \mathrm{CaCO}_{3}\right)$ & 7,0 a 12,3 & 8,4 a 12,1 & NR & NR \\
\hline Cor aparente $(\mathrm{uH})$ & 119 a 146 & 201 a 247 & $<1$ a $19^{(*)}$ & $<1 \mathrm{a} 3^{(*)}$ \\
\hline Cor verdadeira $(\mathrm{uH})$ & 18 a 28 & 85 a 116 & NR & NR \\
\hline Turbidez (uT) & 11,6 a 22,8 & NR & $<0,01$ a 1,1 & $<0,01$ a 0,6 \\
\hline Absorvância 254 nm & 0,063 a 0,078 & 0,177 a $0,211^{(*)}$ & 0,008 a $0,023^{(*)}$ & 0,008 a $0,023^{(*)}$ \\
\hline $\mathrm{COD}(\mathrm{mg} / \mathrm{L})$ & 2,0 a 2,4 & 2,6 a 3,9 & 1,8 a 2,5 & 1,8 a 2,4 \\
\hline \multirow[t]{2}{*}{ Alumínio residual $(\mathrm{mg} / \mathrm{L})$} & 0,01 a 0,05 & 0,01 a 0,07 & 0,46 a 0,60 & 0,10 a 0,21 \\
\hline & \multicolumn{4}{|c|}{ ENSAIO 7} \\
\hline Taxas de filtração médias & \multicolumn{4}{|c|}{ FAAG $=126 \mathrm{~m}^{3} / \mathrm{m}^{2} \mathrm{~d}$ e FRD $=244 \mathrm{~m}^{3} / \mathrm{m}^{2} \mathrm{~d}$} \\
\hline Condições de coagulação & \multicolumn{4}{|c|}{$\begin{array}{c}\mathrm{D}_{\mathrm{SA}} \cong 8 \mathrm{mg} / \mathrm{L} ; \mathrm{pH} \text { de coagulação }=4,80 \text { a } 5,13 ; \\
\text { temperatura }=20,5 \text { a } 24,0^{\circ} \mathrm{C}\end{array}$} \\
\hline Duração da carreira $(\mathrm{h})$ & \multicolumn{4}{|c|}{72} \\
\hline Produção Efetiva (\%) & \multicolumn{4}{|c|}{95,4} \\
\hline Características & $\overline{\mathrm{AB}}$ & $\overline{\mathrm{AE}}$ & FAAG & FRD \\
\hline $\mathrm{pH}$ & 6,22 a 6,67 & $6,38^{(*)}$ a 6,84 & NR & NR \\
\hline Alcalinidade $\left(\mathrm{mg} / \mathrm{L} \mathrm{CaCO}_{3}\right)$ & 8,1 a 10,1 & 8,4 a 10,3 & NR & $\mathrm{NR}$ \\
\hline Cor aparente (uH) & 114 a 153 & 196 a 231 & $<1$ a 80 & $<1$ a $7^{(*)}$ \\
\hline Cor verdadeira $(\mathrm{uH})$ & 15 a 23 & 86 a 120 & NR & NR \\
\hline Turbidez (uT) & 11,2 a 17,8 & NR & $<0,01$ a 41,8 & $<0,01$ a 1,2 \\
\hline Absorvância 254 nm & 0,059 a 0,073 & 0,172 a 0,205 & 0,008 a 0,021 & 0,014 a $0,040^{(*)}$ \\
\hline $\mathrm{COD}(\mathrm{mg} / \mathrm{L})$ & 2,4 a 3,2 & 2,8 a $4,2^{(*)}$ & 1,9 a 2,4 & 1,8 a $2,8^{(*)}$ \\
\hline Alumínio residual $(\mathrm{mg} / \mathrm{L})$ & 0,02 a 0,07 & 0,02 a 0,06 & 0,81 a 0,84 & 0,51 \\
\hline
\end{tabular}

D $\mathrm{D}_{\mathrm{SA}}=$ dosagem de $\mathrm{Al}_{2}\left(\mathrm{SO}_{4}\right)_{3} \cdot 14,3 \mathrm{H}_{2} \mathrm{O} ; \mathrm{AB}$ = água bruta; $\mathrm{AE}$ = água de estudo; $\mathrm{FAAG}$ = filtro ascendente de areia grossa; FRD = filtro rápido descendente; COD = carbono orgânico dissolvido; $\mathrm{NR}=$ não realizado. ${ }^{(3)}$ Valor observado no início do ensaio. 
Após as DFls ocorria o desprendimento de flocos no FAAG com picos de turbidez da ordem de 40 uT, com conseqüente prejuízo à qualidade da água no efluente do FRD, o qual, em algumas vezes, teve a carreira encerrada por transpasse.

\subsubsection{Produção Efetiva de Água Filtrada}

$\mathrm{Na}$ Tabela B 8.1 do ANEXO B estão apresentados os resultados de produção efetiva de água filtrada para as diferentes combinações de taxas de filtração, e na Tabela 5.16 está apresentado o resumo dos resultados obtidos, com destaque para o ensaio 7, com taxas de filtração de $120 \mathrm{~m}^{3} / \mathrm{m}^{2} \mathrm{~d}$ no FAAG e 240 $\mathrm{m}^{3} / \mathrm{m}^{2} \mathrm{~d}$ no $\mathrm{FRD}$, que apresentou a maior produção de água filtrada $(95,4 \%)$.

Observa-se que os melhores resultados obtidos quanto à produção efetiva ocorreram quando foram utilizadas as menores taxas de filtração no filtro ascendente e para uma taxa intermediária no filtro descendente. Deve-se considerar o fato de que para as maiores taxas de filtração no FAAG, a duração da carreira seria mais curta, comparada à de menor taxa, o que não foi observado nestes ensaios devido ao encerramento das carreiras de filtração terem resultado, na maioria dos ensaios, com o critério de 72 horas de funcionamento. Somente no Ensaio 4, com taxas de filtração de $180 \mathrm{~m}^{3} / \mathrm{m}^{2} \mathrm{~d}$ no $F A A G$ e $280 \mathrm{~m}^{3} / \mathrm{m}^{2} \mathrm{~d}$ no $F R D$, a duração do ensaio foi de 70 horas, provavelmente devido à dosagem de $10 \mathrm{mg} / \mathrm{L}$ de $\mathrm{Al}_{2}\left(\mathrm{SO}_{4}\right)_{3} \cdot 14,3 \mathrm{H}_{2} \mathrm{O}$, apresentando produção efetiva igual a do ensaio 3 quando utilizou-se a combinação de taxas de 180 e $240 \mathrm{~m}^{3} / \mathrm{m}^{2} \mathrm{~d}$ no FAAG e no FRD, respectivamente.

Tabela 5.16 - Resultados de eficiência na produção de água filtrada para as diferentes taxas de filtração utilizadas.

\begin{tabular}{c|c|c|c}
\hline \multirow{2}{*}{ Ensaio } & \multicolumn{2}{|c|}{ Taxas de filtração $\mathbf{( m}^{\mathbf{3}} \mathbf{\mathbf { m } ^ { 2 } \mathbf { d } )}$} & $\begin{array}{c}\text { Produção Efetiva } \\
\text { (\%) }\end{array}$ \\
\cline { 2 - 3 } & FAAG & FRD & 93,4 \\
\hline \hline $\mathbf{1}$ & 240 & 280 & 94,1 \\
\hline $\mathbf{2}$ & 180 & 200 & 93,9 \\
\hline $\mathbf{3}$ & 180 & 240 & 93,9 \\
\hline $\mathbf{4}$ & 180 & 280 & 93,6 \\
\hline $\mathbf{5}$ & 120 & 160 & 94,4 \\
\hline $\mathbf{6}$ & 120 & 200 & $\mathbf{9 5 , 4}$ \\
\hline $\mathbf{7}$ & $\mathbf{1 2 0}$ & $\mathbf{2 4 0}$ & \\
\hline \hline
\end{tabular}


Segundo DI BERNARDO (2003), para a adoção da melhor combinação de taxas de filtração e escolha da granulometria do filtro ascendente, é importante avaliar vários fatores além da produção efetiva, tais como, a qualidade da água bruta, a eficiência do tratamento, a operação e a manutenção do sistema, a disponibilidade de produtos químicos, entre outros.

\subsubsection{Ensaios sem e com pré-oxidação com taxas de filtração fixas no FAAG e no FRD}

Estes ensaios foram realizados sem DFls no FAAG, cujo objetivo principal foi estudar a influência da pré-oxidação com diferentes oxidantes na remoção de substâncias húmicas, e as taxas de filtração foram fixadas em $180 \mathrm{~m}^{3} / \mathrm{m}^{2} \mathrm{~d}$ no FAAG e em $280 \mathrm{~m}^{3} / \mathrm{m}^{2} \mathrm{~d}$ no $\mathrm{FRD}$. Estas taxas de filtração foram adotadas porque nesta fase do trabalho experimental, o sistema de dupla filtração com filtro ascendente de pedregulho não estava em funcionamento, sendo necessário trabalhar com taxas de filtração mais altas e duração do ensaio mais curto, pois havia somente uma pessoa para operar os filtros.

No primeiro ensaio desta fase não foi feita pré-oxidação com o intuito de comparar a influência da pré-oxidação no desempenho do sistema de dupla filtração e na remoção de substâncias húmicas. A duração de cada ensaio realizado nesta fase do trabalho experimental foi de 36 horas, com exceção do ensaio 15 que teve duração de 16 horas. Os resultados obtidos nos ensaios na instalação piloto em escoamento contínuo sem e com pré-oxidação (Fase 2) estão apresentados no ANEXO C.

Da mesma maneira como na fase 1 , nas figuras correspondentes à evolução da perda de carga foram adotadas abreviações como: Lav.FRDPC $=$ lavagem do FRD quando atingiu a perda de carga limite; Lav. $F R D_{\text {transpasse }}=$ lavagem do FRD quando ocorreu o transpasse.

\subsubsection{Determinação dos tempos de contato dos oxidantes para os ensaios com pré-oxidação}

Na Figura 5.38 está representado o tempo de detenção do traçador na coluna de ozonização sem introdução de ar, que é de aproximadamente 32 minutos, que corresponde ao tempo de detenção hidráulico teórico na coluna, 
podendo ser obtido pela equação (5.1). Este tempo de detenção corresponde ao tempo de contato dos oxidantes em solução (peróxido de hidrogênio, cloro, dióxido de cloro e permanganato de potássio) dentro da coluna de ozonização.

$\theta_{\mathrm{t}}=\frac{\mathrm{V}}{\mathrm{Q}}$

em que:

$\theta_{\mathrm{t}}=$ tempo de detenção hidráulico teórico (min);

$\mathrm{V}=$ volume de água na coluna de ozonização (L);

$\mathrm{Q}=$ vazão de água de entrada na coluna de ozonização ( $\mathrm{L} / \mathrm{min})$

Considerando que a coluna de ozonização possuía diâmetro interno de 141 $\mathrm{mm}$ e altura de água igual a 5,7 m, o volume de água na coluna era de $89 \mathrm{~L}$. A vazão de água afluente à coluna de ozonização era de $167 \mathrm{~L} / \mathrm{h}=2,78 \mathrm{~L} / \mathrm{min}$, com a equação (5.1) foi possível determinar o tempo de detenção hidráulico na coluna:

$$
\theta_{\mathrm{t}}=\frac{89}{2,78}=32 \mathrm{~min}
$$

Com o ensaio com traçador na coluna de ozonização, cujos resultados estão apresentados na Figura 5.38 foi confirmado o tempo de contato de 32 minutos para os oxidantes em solução. Na Figura 5.38 observa-se que o escoamento não é completamente do tipo pistonado.

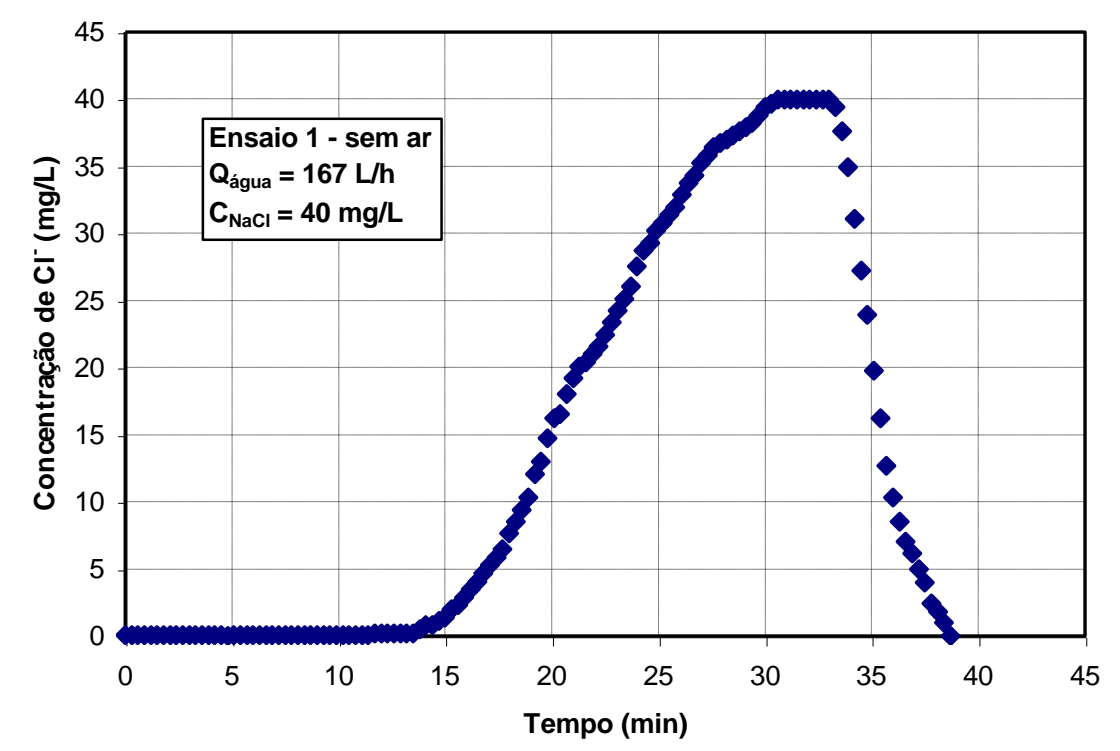

Figura 5.38 - Tempo de detenção do traçador na coluna de ozonização, sem introdução de ar. 
Para a obtenção do tempo de contato do oxidante gasoso (ozônio), o ensaio com traçador foi realizado com introdução de ar na parte inferior da coluna de ozonização, com vazão de água de $167 \mathrm{~L} / \mathrm{h}$, vazão de ar igual a $60 \mathrm{~L} / \mathrm{h}$ e concentração da solução de cloreto de sódio ( $\mathrm{NaCl}$ ) igual a 20 mg/L. Na Figura 5.39 está o gráfico que representa o tempo de detenção hidráulico teórico do traçador na coluna de ozonização com introdução de ar, que é de aproximadamente 9,6 minutos. Este tempo corresponde ao tempo de contato do ozônio na coluna de ozonização.

Observa-se nas Figuras 5.38 e 5.39 o comportamento hidráulico na coluna de ozonização diferenciado pela introdução de ar. Segundo INOUE (2001), que estudou o comportamento hidráulico de um sistema de ozonização, em um reator de contato em contra-corrente, avaliando a influência da variação da vazão de líquido e de gás, com o aumento da vazão de água, mantendo-se constante a vazão de gás, o comportamento hidráulico do reator de ozonização de contato tende a pistonado ideal. E com o aumento da vazão de gás, mantendo-se constante a vazão de água, o comportamento hidráulico do reator de ozonização de contato tende à mistura completa.

Avaliando o comportamento hidráulico da coluna de ozonização em estudo, e observando a Figura 5.39 e considerando que o escoamento foi em contracorrente e não foram variadas as vazões de água e de ar, o comportamento hidráulico da coluna de ozonização tende à mistura completa.

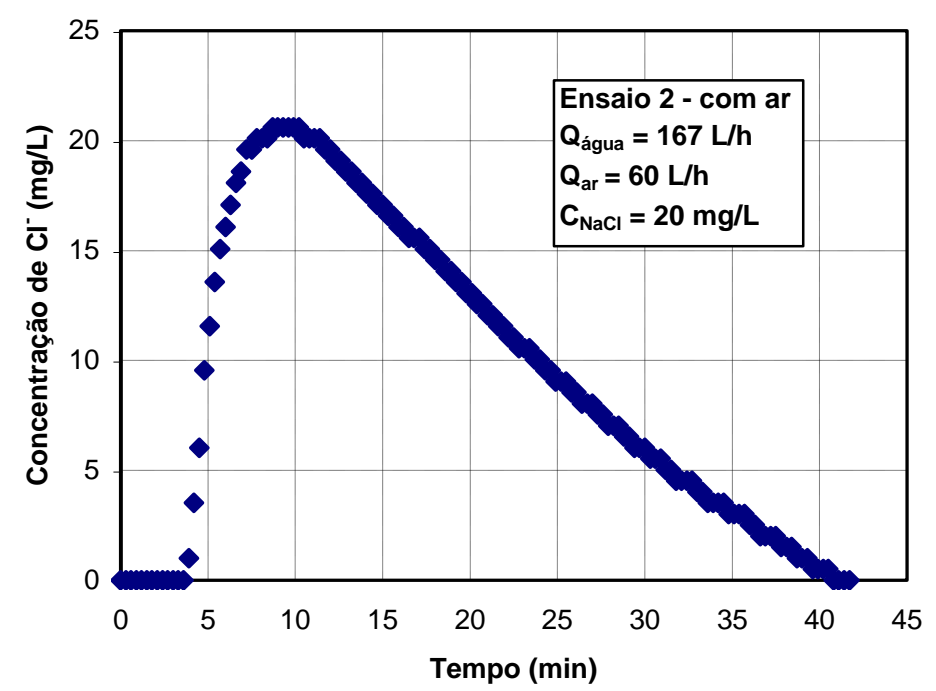

Figura 5.39 - Tempo de detenção do traçador na coluna de ozonização, com introdução de ar. 


\subsubsection{Ensaio 8 - sem pré-oxidação}

Neste ensaio a dosagem de coagulante e $\mathrm{opH}$ de coagulação foram determinados em reatores estáticos e filtros de laboratório de areia. $O$ ensaio foi iniciado com a dosagem de $\mathrm{Al}_{2}\left(\mathrm{SO}_{4}\right)_{3} .14,3 \mathrm{H}_{2} \mathrm{O}$ de $7 \mathrm{mg} / \mathrm{L}$ e pH de coagulação de 5,21 .

As taxas de filtração médias no FAAG e no FRD foram de 185 e 280 $\mathrm{m}^{3} / \mathrm{m}^{2} \mathrm{~d}$, respectivamente (ver Tabela C 1.4 do ANEXO C). Na Tabela 5.17 está apresentado o resumo dos resultados obtidos durante o ensaio 8 e nas Tabelas $C$ 1.1 a C 1.4 do ANEXO C estão os dados coletados durante o ensaio.

Na Figura 5.40 observa-se a evolução da perda de carga nos filtros, sendo necessárias duas lavagens no FRD por atingir a perda de carga limite durante as 36 horas de funcionamento. O FAAG não atingiu a perda de carga limite, mas utilizou $86,6 \%$ da perda de carga disponível, podendo ser prolongada a duração da carreira de filtração se não fosse encerrada pelo critério das 36 horas de funcionamento.

Tabela 5.17 - Resumo dos resultados obtidos no ensaio 8 realizado na instalação piloto em escoamento contínuo sem pré-oxidação.

\begin{tabular}{|c|c|c|c|c|}
\hline & \multicolumn{4}{|c|}{ ENSAIO 8 - sem pré-oxidação } \\
\hline Taxas de filtração médias & \multicolumn{4}{|c|}{ FAAG $=185$ e FRD $=280 \mathrm{~m}^{3} / \mathrm{m}^{2} \mathrm{~d}$} \\
\hline Condições de coagulação & \multicolumn{4}{|c|}{$\begin{array}{c}\mathrm{D}_{\mathrm{SA}} \cong 7 \mathrm{mg} / \mathrm{L} ; \mathrm{pH} \text { de coagulação }=5,04 \text { a } 5,32 ; \\
\text { temperatura }=20 \text { a } 23^{\circ} \mathrm{C}\end{array}$} \\
\hline Duração da carreira & \multicolumn{4}{|c|}{$36 \mathrm{~h}$} \\
\hline Características & AB & AE & $\begin{array}{c}\text { Efluente do } \\
\text { FAAG }\end{array}$ & $\begin{array}{c}\text { Efluente do } \\
\text { FRD }\end{array}$ \\
\hline $\mathrm{pH}$ & 6,52 a 6,60 & 6,44 a 6,69 & NR & NR \\
\hline Alcalinidade $\left(\mathrm{mg} / \mathrm{L} \mathrm{CaCO}_{3}\right)$ & 6,4 a 9,5 & 7,0 a 9,0 & NR & NR \\
\hline Cor aparente $(\mathrm{uH})$ & 130 a 146 & 200 a 223 & $<1$ a 93 & $<1 \mathrm{a} 10^{(*)}$ \\
\hline Cor verdadeira $(\mathrm{uH})$ & 21 a 27 & 93 a 105 & NR & NR \\
\hline Turbidez (uT) & 10,7 a 15,2 & NR & $<0,01$ a 3,13 & $<0,01$ a 1,46 \\
\hline Absorvância 254 nm & 0,069 a 0,091 & 0,183 a 0,201 & 0,005 a 0,041 & 0,007 a 0,022 \\
\hline COD (mg/L) & 1,5 a 2,0 & 2,6 a 3,6 & 1,7 a 2,0 & 1,7 a 2,0 \\
\hline Alumínio residual (mg/L) & ND & $<0,01$ a 0,02 & 0,04 a 0,15 & 0,02 a 0,16 \\
\hline
\end{tabular}

$\mathrm{D}_{\mathrm{SA}}=$ dosagem de $\mathrm{Al}_{2}\left(\mathrm{SO}_{4}\right)_{3}$.14,3 $\mathrm{H}_{2} \mathrm{O} ; \mathrm{AB}$ = água bruta; $\mathrm{AE}$ = água de estudo; $\mathrm{FAAG}=$ filtro ascendente de areia grossa; $F R D=$ filtro rápido descendente; $C O D=$ carbono orgânico dissolvido; $N D=$ não detectado; $N R=$ não realizado. ${ }^{(*)}$ Valor observado no início do ensaio.

Nas Figuras C 1.1 e C 1.2 do ANEXO C estão apresentadas as perdas de carga ao longo do meio filtrante do FAAG e do FRD respectivamente.

A cor aparente do efluente do FRD se manteve $\leq 1 \mathrm{uH}$, na maior parte do tempo, com exceção do início do ensaio em que observou-se cor aparente de 10 
uH e após 28 horas de funcionamento que apresentou cor aparente de $5 \mathrm{uH}$. Na Figura 5.41 pode-se observar o início do transpasse no efluente do FAAG a partir das 15 horas de funcionamento, resultando em $96 \mathrm{uH}$ ao término do ensaio.

A turbidez do efluente do FRD manteve-se $<1$ uT durante todo tempo de funcionamento, com exceção de 1,46 uT observado no início do ensaio. Observa-se na Figura 5.42 a ocorrência do transpasse no FRD, devido ao acúmulo de impurezas no meio filtrante, o que proporcionou aumento na perda de carga e conseqüentemente a necessidade de lavagem do FRD.

Quanto à remoção de substâncias húmicas, em termos de absorvância 254 $\mathrm{nm}$ e COD, as porcentagens de remoção foram, respectivamente, da ordem de 89 a 96\% e 12 a 59\% no FRD. Nas Figuras 5.43 e 5.44 estão apresentadas as variações de absorvância 254 nm e de COD durante o ensaio 8.

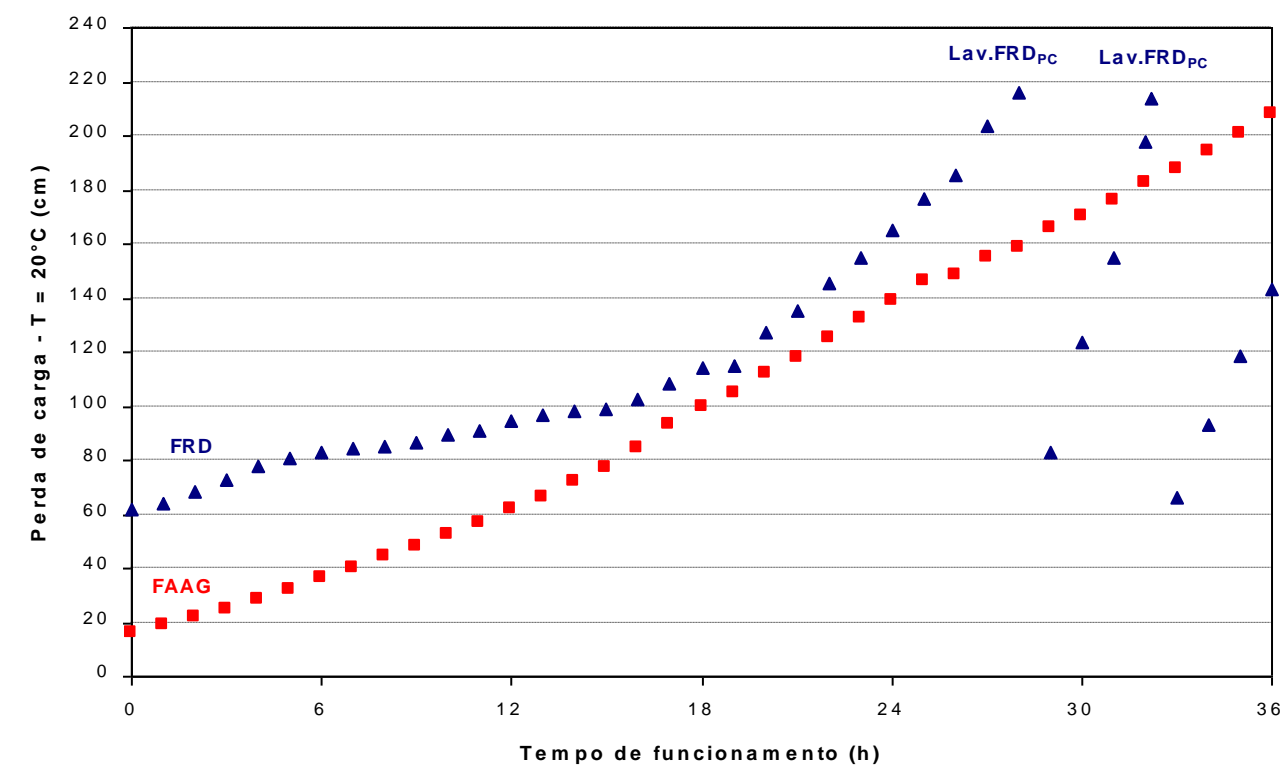

Figura 5.40 - Evolução da perda de carga no FAAG $\left(180 \mathrm{~m}^{3} / \mathrm{m}^{2} \mathrm{~d}\right)$ e no FRD $\left(280 \mathrm{~m}^{2} / \mathrm{m}^{3} \mathrm{~d}\right)$ para $\mathrm{T}=20^{\circ} \mathrm{C}$ durante 0 ensaio 8 , sem pré-oxidação e sem DFls no FAAG. Fonte: Tabela C 1.3 do ANEXO C. 


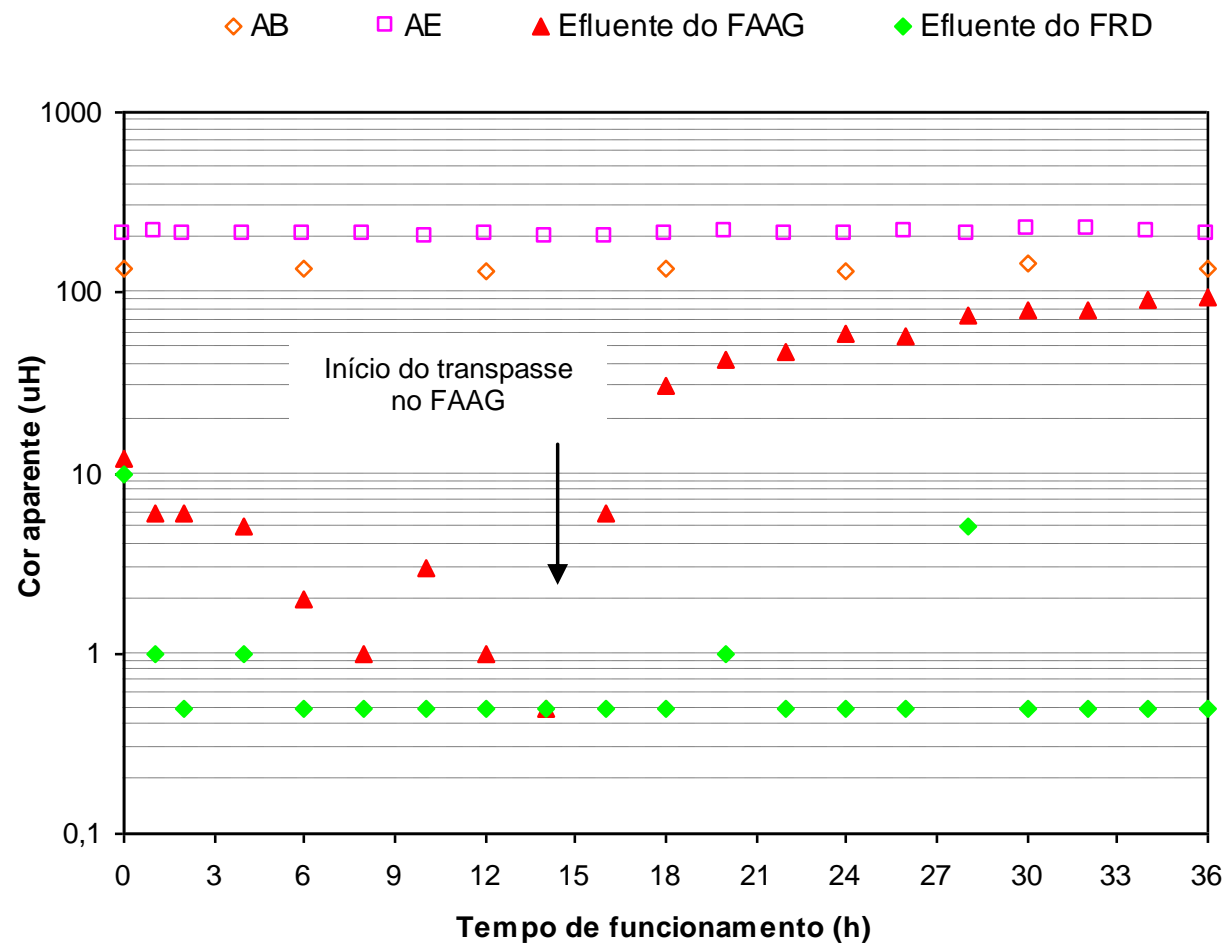

Figura 5.41 - Variação de cor aparente na $A B, A E$ e efluentes do FAAG e FRD, e cor verdadeira na $A B$ de 21 a $27 \mathrm{uH}$ e na $A E$ de 93 a $105 \mathrm{uH}$, durante o ensaio 8 - sem préoxidação $\left(F A A G=180 \mathrm{~m}^{3} / \mathrm{m}^{2} \mathrm{~d}\right.$ e FRD $\left.=280 \mathrm{~m}^{3} / \mathrm{m}^{2} \mathrm{~d}\right)$. Fonte: Tabela C 1.1 do ANEXO C.

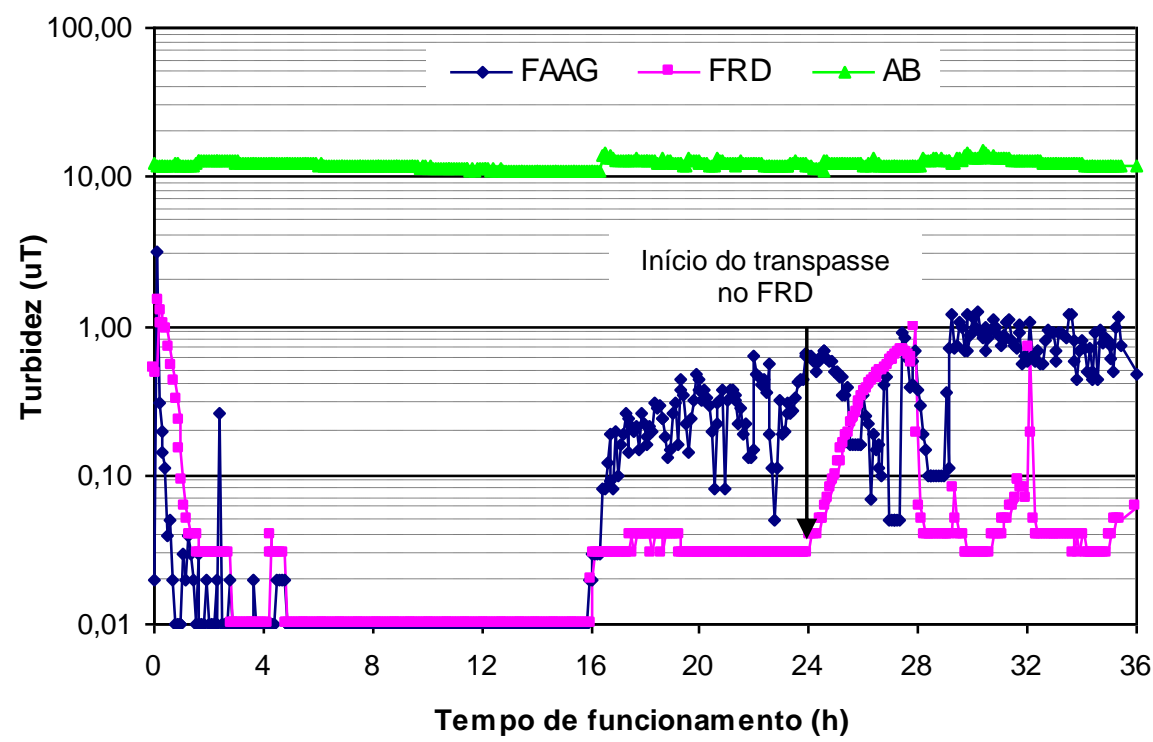

Figura 5.42 - Variação da turbidez na $A B$ e nos efluentes do FAAG $\left(180 \mathrm{~m}^{3} / \mathrm{m}^{2} \mathrm{~d}\right)$ e FRD $\left(280 \mathrm{~m}^{2} / \mathrm{m}^{3} \mathrm{~d}\right)$ durante o ensaio 8 - sem pré-oxidação e sem DFIs no FAAG. 


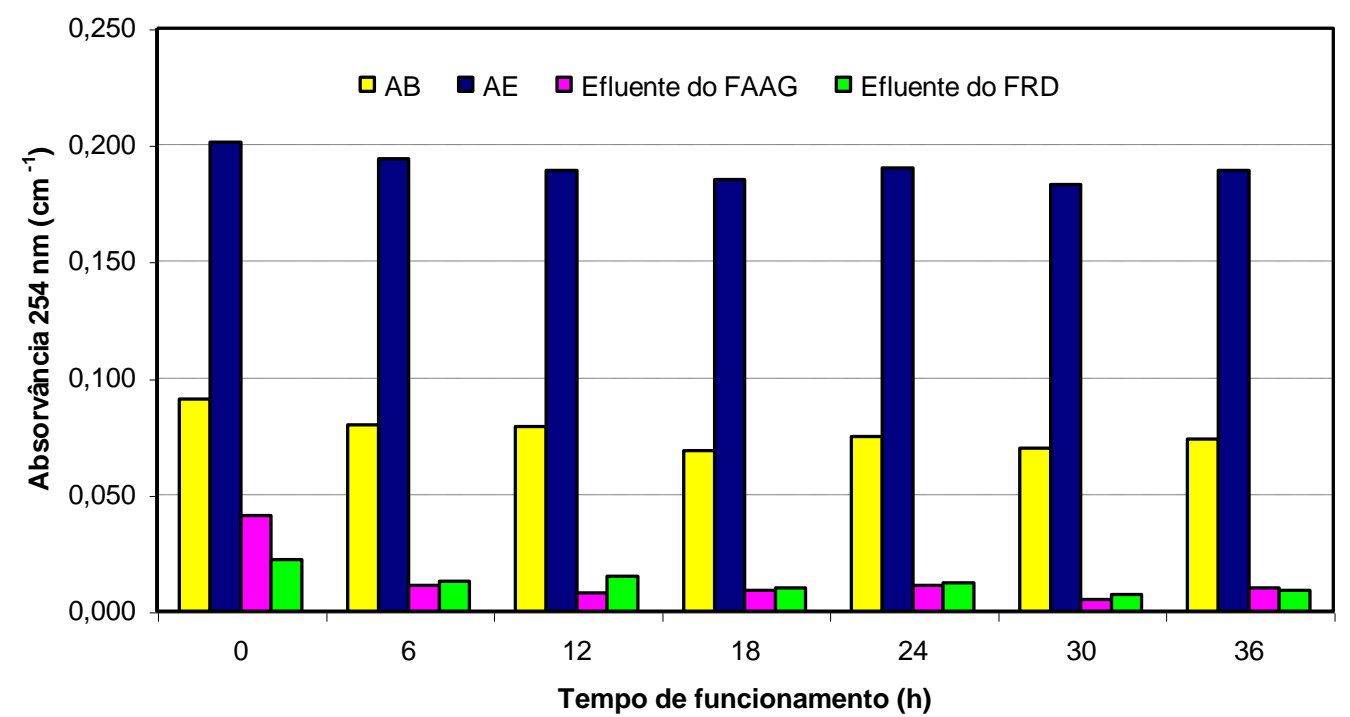

Figura 5.43 - Variação de absorvância $254 \mathrm{~nm}$ na $A B, A E$ e nos efluentes do $F A A G$ e do FRD durante o ensaio 8 , sem pré-oxidação e sem DFls no FAAG (FAAG $=180 \mathrm{~m}^{3} / \mathrm{m}^{2} \mathrm{~d}$ e $\mathrm{FRD}=280 \mathrm{~m}^{3} / \mathrm{m}^{2} \mathrm{~d}$ ). Fonte: Tabela C 1.2 do ANEXO C.

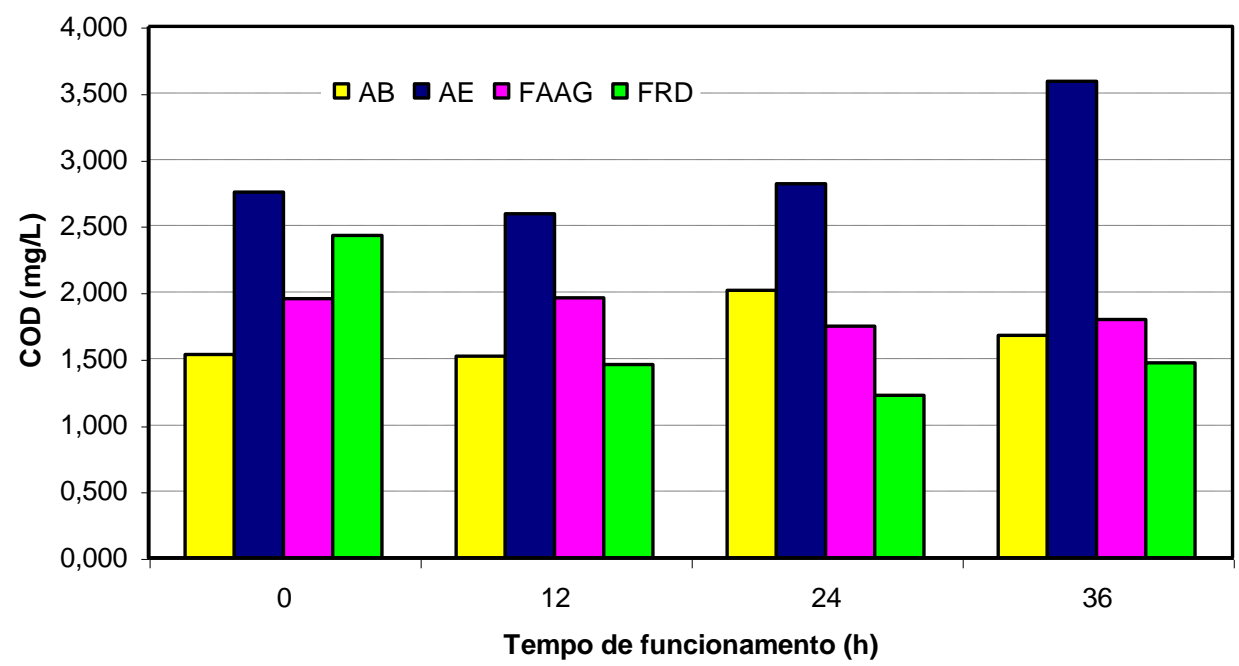

Figura 5.44 - Variação de COD na $A B, A E$ e nos efluentes do FAAG e do FRD durante o ensaio 8 , sem pré-oxidação e sem DFIs no FAAG (FAAG $=180 \mathrm{~m}^{3} / \mathrm{m}^{2} \mathrm{~d}$ e $\mathrm{FRD}=280$ $\mathrm{m}^{3} / \mathrm{m}^{2} \mathrm{~d}$ ). Fonte: Tabela C 1.2 do ANEXO C.

\subsubsection{Ensaio 9 - Pré-oxidação com Ozônio}

No ensaio 9, em que utilizou-se ozônio como pré-oxidante, a dosagem de $\mathrm{Al}_{2}\left(\mathrm{SO}_{4}\right)_{3} \cdot 14,3 \quad \mathrm{H}_{2} \mathrm{O}$ e $0 \mathrm{pH}$ de coagulação foram determinados em reatores estáticos, com água ozonizada na coluna de ozonização fixando-se a dosagem de ozônio em $5 \mathrm{mg} / \mathrm{L}$. Os ensaios em reatores estáticos (RE), utilizando equipamento 
de jarteste e FLAs foram feitos de 4 maneiras diferentes: i) ensaio RE1 - sem adição de $\mathrm{HCl}(0,07 \mathrm{M})$ e com variação das dosagens de $\mathrm{Al}_{2}\left(\mathrm{SO}_{4}\right)_{3} \cdot 14,3 \mathrm{H}_{2} \mathrm{O}$ de 4,6 , 8, 10, 12 e 14 mg/L; ii) ensaio RE2 - com adição de $\mathrm{HCl}(0,07 \mathrm{M})$ na caixa de homogeneização da instalação piloto em escoamento contínuo com variação do pH de coagulação de 5,66 a 5,00 para as dosagens de $\mathrm{Al}_{2}\left(\mathrm{SO}_{4}\right)_{3} .14,3 \mathrm{H}_{2} \mathrm{O}$ de $5,6,7,8$, 9 e 10 mg/L; iii) ensaio RE3 - com adição de $\mathrm{HCl}(0,07 \mathrm{M})$ na caixa de homogeneização da instalação piloto em escoamento contínuo com variação do $\mathrm{pH}$ de coagulação de 5,17 a 4,62 para as dosagens de $\mathrm{Al}_{2}\left(\mathrm{SO}_{4}\right)_{3} .14,3 \mathrm{H}_{2} \mathrm{O}$ de 5, 6, 7, 8, 9 e $10 \mathrm{mg} / \mathrm{L}$; iv) ensaio RE4 - com dosagem de $\mathrm{Al}_{2}\left(\mathrm{SO}_{4}\right)_{3} .14,3 \mathrm{H}_{2} \mathrm{O}$ igual a $10 \mathrm{mg} / \mathrm{L}$ e variação do $\mathrm{pH}$ de coagulação de 4,77 a 5,16 nos reatores estáticos. Na Tabela 5.18 estão as características da água de estudo e da água pré-oxidada com $\mathrm{O}_{3}$ para os ensaios em reatores estáticos.

Tabela 5.18 - Características da água de estudo e da água pré-oxidada com ozônio durante os ensaios em reatores estáticos (RE).

\begin{tabular}{c|c|c|c|c}
\hline \hline Ensaio & \multicolumn{2}{|c|}{ RE1 e RE2 } & \multicolumn{2}{c}{ RE3 e RE4 } \\
\hline Característica & AE & APO & AE & APO \\
\hline Temperatura $\left({ }^{\circ} \mathrm{C}\right)$ & 24,5 & 24,5 & 23,5 & 23,5 \\
$\mathrm{pH}$ & 6,71 & $6,65^{(1)} \mathrm{e} 6,34^{(2)}$ & 6,63 & $6,53^{(1)} \mathrm{e} 5,79^{(2)}$ \\
Alcalinidade $\left(\mathrm{mg} / \mathrm{LCaCO}{ }_{3}\right)$ & $\mathrm{NR}$ & $\mathrm{NR}$ & 8,58 & 5,28 \\
Cor aparente $(\mathrm{uH})$ & 225 & 128 & 225 & 142 \\
Cor verdadeira $(\mathrm{uH})$ & 99 & 35 & 97 & 34 \\
Turbidez $(\mathrm{uT})$ & 16,6 & 14,5 & 16,2 & 15,3 \\
Absorvância $254 \mathrm{~nm}$ & $\mathrm{NR}$ & $\mathrm{NR}$ & 0,187 & 0,101 \\
\hline \hline
\end{tabular}

$\mathrm{AE}=$ água de estudo; $\mathrm{APO}=$ água pré-oxidada. (1)Valores de $\mathrm{pH}$ sem adição de $\mathrm{HCl}(0,07 \mathrm{M})$; ${ }^{(2)}$ Valores de $\mathrm{pH}$ com adição de $\mathrm{HCl}(0,07 \mathrm{M})$; $\mathrm{NR}$ = não realizado.

As variações feitas nos ensaios em reatores estáticos foram devido aos resultados obtidos e apresentados na Tabela 5.19. Observa-se na Tabela 5.19 que no ensaio RE1 os melhores resultados obtidos foi para a dosagem de $\mathrm{Al}_{2}\left(\mathrm{SO}_{4}\right)_{3} \cdot 14,3 \quad \mathrm{H}_{2} \mathrm{O}$ de $14 \mathrm{mg} / \mathrm{L}$ e pH de coagulação de 5,05, sem a adição acidificante. Com o objetivo de reduzir a dosagem de $\mathrm{Al}_{2}\left(\mathrm{SO}_{4}\right)_{3} \cdot 14,3 \quad \mathrm{H}_{2} \mathrm{O}$ foi realizado o ensaio $\mathrm{RE2}$, utilizando-se menores dosagens de $\mathrm{Al}_{2}\left(\mathrm{SO}_{4}\right)_{3} .14,3 \mathrm{H}_{2} \mathrm{O}$ e portanto sendo necessário adicionar acidificante para baixar o pH de coagulação. Os resultados do ensaio RE2 não foram satisfatórios, sendo necessária a realização do ensaio $\mathrm{RE} 3$, utilizando-se as mesmas dosagens de $\mathrm{Al}_{2}\left(\mathrm{SO}_{4}\right)_{3} \cdot 14,3$ $\mathrm{H}_{2} \mathrm{O}$ e pH de coagulação mais baixos. O melhor resultado obtido no ensaio RE3 foi para a dosagem de $\mathrm{Al}_{2}\left(\mathrm{SO}_{4}\right)_{3} .14,3 \mathrm{H}_{2} \mathrm{O}$ de $10 \mathrm{mg} / \mathrm{L}$ e pH de coagulação de 4,62. Fixando-se a dosagem de $\mathrm{Al}_{2}\left(\mathrm{SO}_{4}\right)_{3} .14,3 \mathrm{H}_{2} \mathrm{O}$ em $10 \mathrm{mg} / \mathrm{L}$, realizou-se o ensaio 
RE4 com a variação do pH de coagulação com adição de acidificante nos reatores estáticos. No ensaio RE4 não obteve-se melhores resultados, por isso optou-se por iniciar o ensaio na instalação piloto em escoamento contínuo com a dosagem de $\mathrm{Al}_{2}\left(\mathrm{SO}_{4}\right)_{3} \cdot 14,3 \mathrm{H}_{2} \mathrm{O} \cong 9,6 \mathrm{mg} / \mathrm{L}$ e pH de coagulação da ordem de 4,6.

Tabela 5.19 - Resultados obtidos nos ensaios RE1, RE2, RE3 e RE4 em reatores estáticos.

\begin{tabular}{|c|c|c|c|c|c|c|c|c|}
\hline \multicolumn{9}{|c|}{ ENSAIO RE1 - Sem adição de $\mathrm{HCl}(0,07 \mathrm{M})$} \\
\hline \multirow{3}{*}{$\begin{array}{c}\text { Jarro / } \\
\text { FLA }\end{array}$} & \multirow{3}{*}{$\begin{array}{c}\mathrm{D}_{\mathrm{SA}} \\
(\mathrm{mg} / \mathrm{L})\end{array}$} & \multirow{3}{*}{$\begin{array}{c}\mathrm{pH} \text { de } \\
\text { coagulação }\end{array}$} & \multirow{2}{*}{\multicolumn{3}{|c|}{$\begin{array}{c}\text { Cor remanescente nos FLAs } \\
(\mathrm{uH}) \\
\text { Tempo de filtração (min) }\end{array}$}} & \multicolumn{3}{|c|}{$\begin{array}{l}\text { Turbidez remanescente nos } \\
\text { FLAs (UT) }\end{array}$} \\
\hline & & & & & & \multicolumn{3}{|c|}{ Tempo de filtração (min) } \\
\hline & & & 10 & 20 & 30 & 10 & 20 & 30 \\
\hline 1 & 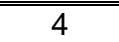 & 6,13 & 96 & 97 & 97 & 11,7 & 111,5 & 11,1 \\
\hline 2 & 6 & 5,93 & 109 & 99 & 99 & 11,3 & 11,4 & 11,5 \\
\hline 3 & 8 & 5,75 & 97 & 97 & 97 & 11,3 & 11,3 & 11,3 \\
\hline 4 & 10 & 5,54 & 53 & 50 & 45 & 6,6 & 6,1 & 5,8 \\
\hline 5 & 12 & 5,34 & 9 & 4 & $<1$ & 1,1 & 0,7 & 0,4 \\
\hline 6 & 14 & 5,05 & 3 & 1 & $<1$ & 0,5 & 0,3 & 0,1 \\
\hline \multicolumn{9}{|c|}{ ENSAIO RE2 - Com adição de $\mathrm{HCl}(0,07 \mathrm{M})$ na instalação piloto em escoamento contínuo } \\
\hline \multirow{3}{*}{$\begin{array}{l}\text { Jarro / } \\
\text { FLA }\end{array}$} & \multirow{3}{*}{$\begin{array}{c}D_{S A} \\
(m g / L)\end{array}$} & \multirow{3}{*}{$\begin{array}{c}\mathrm{pH} \text { de } \\
\text { coagulação }\end{array}$} & \multirow{2}{*}{\multicolumn{3}{|c|}{$\begin{array}{c}\text { Cor remanescente nos FLAs } \\
(\mathrm{uH}) \\
\text { Tempo de filtração (min) }\end{array}$}} & \multirow{2}{*}{\multicolumn{3}{|c|}{$\begin{array}{c}\text { Turbidez remanescente nos } \\
\text { FLAs (uT) } \\
\text { Tempo de filtração (min) }\end{array}$}} \\
\hline & & & & & & & & \\
\hline & & & 10 & 20 & 30 & 10 & 20 & 30 \\
\hline 1 & 25 & (5,66 & 92 & 89 & 87 & 111,5 & 1811,3 & 111,2 \\
\hline 2 & 6 & 5,53 & 94 & 92 & 89 & 11,5 & 11,5 & 11,3 \\
\hline 3 & 7 & 5,49 & 92 & 91 & 89 & 11,5 & 11,5 & 11,3 \\
\hline 4 & 8 & 5,29 & 87 & 85 & 81 & 10,9 & 10,8 & 10,7 \\
\hline 5 & 9 & 5,11 & 70 & 65 & 59 & 9,3 & - & 8,4 \\
\hline 6 & 10 & 5,00 & 22 & 89 & 6 & 4,2 & 3,1 & 2,5 \\
\hline \multicolumn{9}{|c|}{ ENSAIO RE3 - Com adição de $\mathrm{HCl}(0,07 \mathrm{M})$ na instalação piloto em escoamento contínuo } \\
\hline \multirow{3}{*}{$\begin{array}{l}\text { Jarro / } \\
\text { FLA }\end{array}$} & \multirow{3}{*}{$\begin{array}{c}D_{S A} \\
(m g / L)\end{array}$} & \multirow{3}{*}{$\begin{array}{c}\mathrm{pH} \text { de } \\
\text { coagulação }\end{array}$} & \multirow{2}{*}{\multicolumn{3}{|c|}{$\begin{array}{c}\text { Cor remanescente nos FLAs } \\
(\mathrm{uH}) \\
\text { Tempo de filtração (min) }\end{array}$}} & \multirow{2}{*}{\multicolumn{3}{|c|}{$\begin{array}{c}\text { Turbidez remanescente nos } \\
\text { FLAs (UT) } \\
\text { Tempo de filtração (min) }\end{array}$}} \\
\hline & & & & & & & & \\
\hline & & & 10 & 20 & 30 & 10 & 20 & 30 \\
\hline 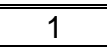 & 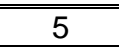 & 5,17 & 88 & 86 & 85 & 10,3 & 10,1 & 9,9 \\
\hline 2 & 6 & 5,02 & 90 & 89 & 87 & 10,3 & 10,3 & 9,7 \\
\hline 3 & 7 & 4,88 & 84 & 78 & 70 & 9,6 & 9,1 & 8,6 \\
\hline 4 & 8 & 4,81 & 35 & 30 & 24 & 5,1 & 4,5 & 3,6 \\
\hline 5 & 9 & 4,70 & 24 & 8 & 6 & 3,2 & 1,5 & 1,0 \\
\hline 6 & 10 & 4,62 & 2 & $<1$ & $<1$ & 0,5 & 0,3 & 0,2 \\
\hline \multicolumn{9}{|c|}{$\begin{array}{c}\text { ENSAIO RE4 - Com dosagem de } \mathrm{Al}_{2}\left(\mathrm{SO}_{4}\right)_{3} .14,3 \mathrm{H}_{2} \mathrm{O} \text { fixa }(=10 \mathrm{mg} / \mathrm{L}) \text { e variação do } \mathrm{pH} \text { de } \\
\text { coagulação com adição de } \mathrm{HCl}(0,07 \mathrm{M}) \text { nos jarros }\end{array}$} \\
\hline \multirow{3}{*}{$\begin{array}{l}\text { Jarro / } \\
\text { FLA }\end{array}$} & \multirow{3}{*}{$\begin{array}{c}D_{S A} \\
(m g / L)\end{array}$} & \multirow{3}{*}{$\begin{array}{c}\mathrm{pH} \text { de } \\
\text { coagulação }\end{array}$} & \multirow{2}{*}{\multicolumn{3}{|c|}{$\begin{array}{c}\text { Cor remanescente nos FLAs } \\
(\mathrm{uH}) \\
\text { Tempo de filtração (min) }\end{array}$}} & \multirow{2}{*}{\multicolumn{3}{|c|}{$\begin{array}{c}\text { Turbidez remanescente nos } \\
\text { FLAs (uT) } \\
\text { Tempo de filtração (min) }\end{array}$}} \\
\hline & & & & & & & & \\
\hline & & & 10 & 20 & 30 & 10 & 20 & 30 \\
\hline 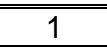 & 10 & $4,7,77$ & 38 & 9 & 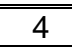 & $\begin{array}{l}4,6 \\
\end{array}$ & $1,1,2$ & 0,8 \\
\hline 2 & 10 & 4,80 & 13 & 7 & 4 & 1,9 & 0,9 & 1,0 \\
\hline 3 & 10 & 4,85 & 46 & 14 & 8 & 5,4 & 1,8 & 1,2 \\
\hline 4 & 10 & 4,91 & 23 & 14 & 9 & 2,8 & 1,7 & 1,3 \\
\hline 5 & 10 & 5,04 & 33 & 17 & 12 & 4,0 & 2,2 & - \\
\hline 6 & 10 & 5,16 & 34 & 24 & 19 & 4,1 & 3,0 & 2,6 \\
\hline
\end{tabular}

$\mathrm{D}_{\mathrm{SA}}=$ dosagem de sulfato de alumínio $\left(\mathrm{Al}_{2}\left(\mathrm{SO}_{4}\right)_{3} \cdot 14,3 \mathrm{H}_{2} \mathrm{O}\right)$. 
Durante o ensaio na instalação piloto em escoamento contínuo, a dosagem de $\mathrm{Al}_{2}\left(\mathrm{SO}_{4}\right)_{3} \cdot 14,3 \mathrm{H}_{2} \mathrm{O}$ foi reduzida lentamente até que se obteve uma dosagem de $3,3 \mathrm{mg} / \mathrm{L}$ (ver Tabela 5.20), sem que alterasse a qualidade do efluente do FRD, para a dosagem média aplicada de ozônio de aproximadamente $6 \mathrm{mg} / \mathrm{L}$. Com a redução na dosagem de $\mathrm{Al}_{2}\left(\mathrm{SO}_{4}\right)_{3} .14,3 \mathrm{H}_{2} \mathrm{O}$ e aumento do $\mathrm{pH}$ de coagulação, obtiveram-se menores residuais de alumínio no efluente dos filtros, que apresentavam concentrações maiores que $0,2 \mathrm{mg} / \mathrm{L}$, limite máximo permitido pelo Padrão de Potabilidade prescrito na Portaria 518/2004 do Ministério da Saúde.

Tabela 5.20 - Variação da dosagem de coagulante, do pH de coagulação e do alumínio residual durante o ensaio 9 - pré-oxidação com ozônio.

\begin{tabular}{|c|c|c|c|c|}
\hline \multirow{2}{*}{$\begin{array}{l}\text { Tempo de funcionamento } \\
\text { dos filtros }(\mathrm{h})\end{array}$} & \multirow{2}{*}{$\begin{array}{c}\text { Dosagem de } \\
\mathrm{Al}_{2}\left(\mathrm{SO}_{4}\right)_{3.14 .3} \mathrm{H}_{2} \mathrm{O} \\
(\mathrm{mg} / \mathrm{L})\end{array}$} & \multirow{2}{*}{$\begin{array}{c}\text { pH de } \\
\text { coagulação }\end{array}$} & \multicolumn{2}{|c|}{ Alumínio Residual (mg/L) } \\
\hline & & & $\begin{array}{l}\text { Efluente do } \\
\text { FAAG }\end{array}$ & $\begin{array}{c}\text { Efluente do } \\
\text { FRD }\end{array}$ \\
\hline $0-8$ & 9,6 & 4,57 a 4,69 & NR & NR \\
\hline $8-12$ & 8,3 & 4,66 a 4,86 & 0,90 & 0,80 \\
\hline $12-22$ & 7,5 & 4,82 a 4,96 & NR & NR \\
\hline $22-32,5$ & 5,0 & 4,82 a 4,98 & 0,34 & 0,34 \\
\hline $32,5-36$ & 3,3 & 4,95 a 5,39 & 0,10 & 0,08 \\
\hline
\end{tabular}

$\mathrm{NR}=$ não realizado.

Conforme LANGLAIS et al. (1991), ensaios em escala de laboratório demonstram que a pré-ozonização retarda a coagulação, produzindo muitas vezes, resultados que não correspondem à mesma eficiência na escala real. Um dos efeitos do ozônio na MON é o aumento dos grupos funcionais oxigenados, especialmente os ácidos carboxílicos, os quais melhoram a remoção de COD por coagulação com alumínio, devido ao: i) aumento da formação de humatos de alumínio insolúveis; ii) neutralização de cargas com a complexação com o alumínio, ou; iii) aumento da adsorção de substâncias húmicas em flocos de hidróxido de alumínio. A pré-ozonização pode aumentar o grau de adsorção da MON com alumina e hidróxido de alumínio.

A redução na dosagem de $\mathrm{Al}_{2}\left(\mathrm{SO}_{4}\right)_{3} .14,3 \quad \mathrm{H}_{2} \mathrm{O}$ durante 0 ensaio na instalação piloto em escoamento contínuo, foi devido aos resultados obtidos no ensaio com reatores estáticos que não corresponderam à mesma eficiência na instalação piloto, como observado por LANGLAIS et al. (1991). A partir deste ensaio, a determinação da dosagem de coagulante, de oxidante e $0 \mathrm{pH}$ de coagulação foi feita na instalação piloto em escoamento contínuo, não sendo mais utilizados os reatores estáticos. 
As taxas de filtração médias neste ensaio foram de 186 e $283 \mathrm{~m}^{3} / \mathrm{m}^{2} \mathrm{~d}$ no FAAG e no FRD respectivamente (ver Tabela C 2.4 do ANEXO C). Na Figura 5.45 está apresentada a evolução da perda de carga no FAAG e FRD durante o ensaio 9 para a temperatura de $20^{\circ} \mathrm{C}$. Em 33 horas de funcionamento foi necessária a lavagem do FRD por ocorrência do transpasse. A perda de carga final no FAAG foi de $70 \mathrm{~cm}$, correspondendo à aproximadamente $29 \%$ de sua perda de carga limite. Comparando com o ensaio 8 , houve redução de $66 \%$ na perda de carga final do FAAG, conseqüentemente maior duração na carreira de filtração se não fosse encerrada pelo critério de 36 horas de funcionamento.

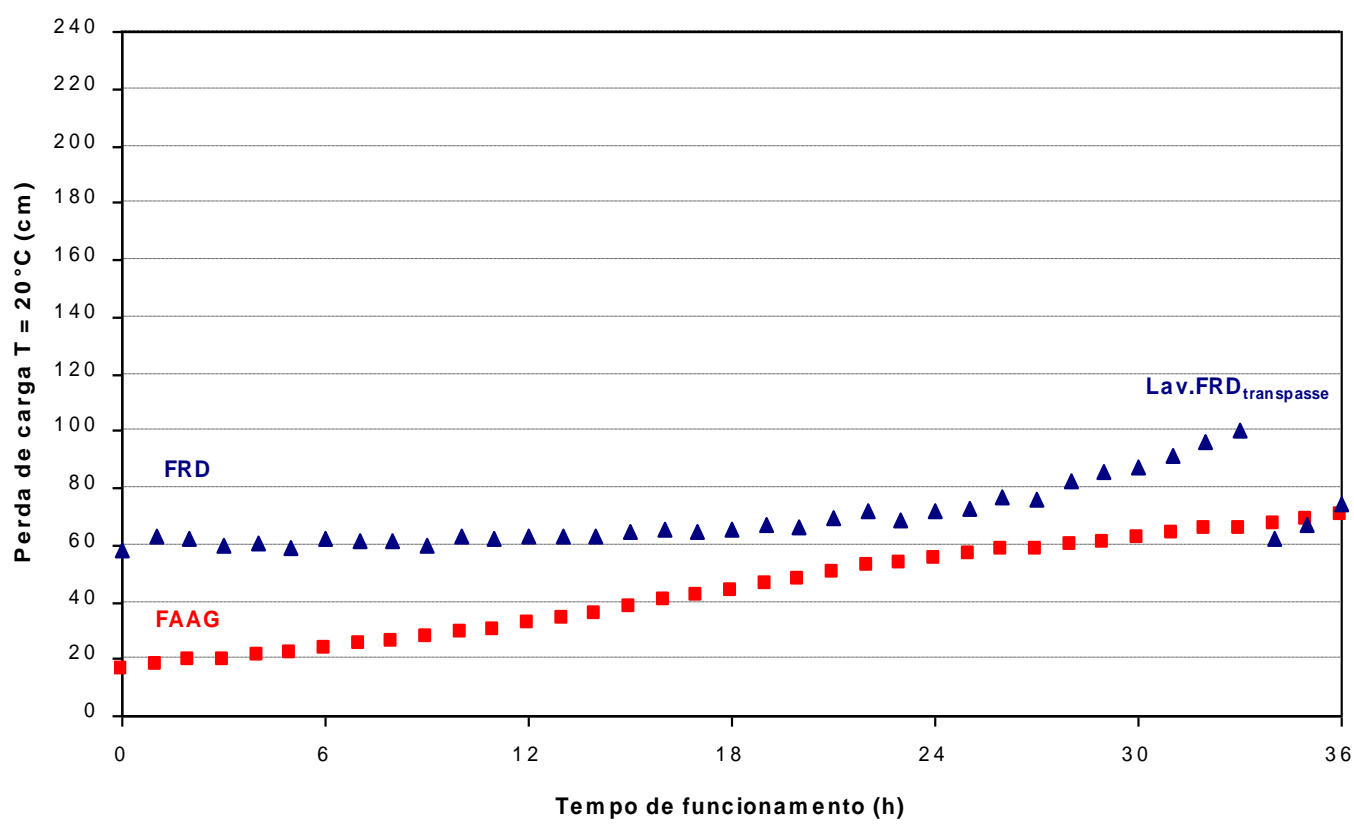

Figura 5.45 - Evolução da perda de carga no FAAG $\left(180 \mathrm{~m}^{3} / \mathrm{m}^{2} \mathrm{~d}\right)$ e no FRD $\left(280 \mathrm{~m}^{2} / \mathrm{m}^{3} \mathrm{~d}\right)$ para $T=20^{\circ} \mathrm{C}$ durante o ensaio 9, pré-oxidação com ozônio e sem DFIs no FAAG. Fonte: Tabela C 2.3 do ANEXO C.

$\mathrm{Na}$ Tabela 5.21 está apresentado o resumo dos resultados obtidos durante o ensaio 9 com pré-oxidação com ozônio. Nas Tabelas C 2.1 a C 2.4 do ANEXO C estão todos os resultados obtidos no ensaio 9. Nas Figuras C 2.1 e C 2.2 estão apresentadas as perdas de carga ao longo do meio filtrante do FAAG e do FRD respectivamente.

A cor aparente do efluente do FRD se manteve $\leq 1 \mathrm{uH}$, na maior parte do tempo, com exceção de dois valores observados de $2 \mathrm{uH}$, após 24 e 28 horas de funcionamento. Na Figura 5.46 pode-se observar o início do transpasse no efluente 
do FAAG a partir das 18 horas de funcionamento, resultando em $106 \mathrm{uH}$ ao término do ensaio.

A turbidez do efluente do FRD manteve-se $<1$ uT durante a maior parte do tempo, com exceção do transpasse que iniciou após 26 horas de funcionamento sendo necessária a lavagem do filtro. Observa-se na Figura 5.47 o início do transpasse no FAAG após 18 horas de funcionamento, em conseqüência disto, o aumento da cor observada na Figura 5.46.

Tabela 5.21 - Resumo dos resultados obtidos no ensaio 9 (pré-oxidação com ozônio).

\begin{tabular}{|c|c|c|c|c|c|}
\hline & \multicolumn{5}{|c|}{ ENSAIO 9 - pré-oxidação com ozônio } \\
\hline "Taxas de filtração médias & \multicolumn{5}{|c|}{$\mathrm{FAAG}=186$ e $\mathrm{FRD}=283 \mathrm{~m}^{3} / \mathrm{m}^{2} \mathrm{~d}$} \\
\hline Condições de coagulação & \multicolumn{5}{|c|}{$\begin{array}{c}\mathrm{D}_{\mathrm{SA}} \cong 3,3 \text { a } 9,6 \mathrm{mg} / \mathrm{L} ; \mathrm{pH} \text { de coagulação }=4,57 \text { a } 5,39 ; \\
\text { temperatura }=20 \text { a } 25,5^{\circ} \mathrm{C}\end{array}$} \\
\hline $\begin{array}{l}\text { Condições de pré- } \\
\text { oxidação }\end{array}$ & \multicolumn{5}{|c|}{ Dosagem aplicada de $\mathrm{O}_{3} \cong 6 \mathrm{mg} / \mathrm{L}$} \\
\hline Duração da carreira & \multicolumn{5}{|c|}{$36 \mathrm{~h}$} \\
\hline Características & AB & AE & APO & $\begin{array}{c}\text { Efluente do } \\
\text { FAAG }\end{array}$ & $\begin{array}{c}\text { Efluente do } \\
\text { FRD }\end{array}$ \\
\hline $\mathrm{pH}$ & 6,64 a 6,74 & 6,56 a 6,75 & $\begin{array}{c}5,91 \mathrm{a} \\
6,13\end{array}$ & NR & NR \\
\hline $\begin{array}{l}\text { Alcalinidade } \\
\left(\mathrm{mg} / \mathrm{L} \mathrm{CaCO}_{3}\right)\end{array}$ & 7,3 a 12,8 & 6,8 a 10,8 & $\begin{array}{c}4,62 \mathrm{a} \\
6,38\end{array}$ & NR & NR \\
\hline Cor aparente $(\mathrm{uH})$ & 142 a 165 & 197 a 240 & 118 a 192 & $<1$ a 106 & $<1$ a 2 \\
\hline Cor verdadeira $(\mathrm{uH})$ & 14 a 28 & 83 a 106 & 23 a 91 & NR & NR \\
\hline Turbidez (uT) & 11,6 a 28,5 & NR & NR & $<0,01$ a 12,9 & $<0,01$ a 1 \\
\hline Absorvância 254 nm & 0,072 a 0,086 & $\begin{array}{c}0,184 \mathrm{a} \\
0,201\end{array}$ & $\begin{array}{c}0,095 \mathrm{a} \\
0,105\end{array}$ & $\begin{array}{c}0,009 a \\
0,030\end{array}$ & 0,008 a 0,022 \\
\hline $\mathrm{COD}(\mathrm{mg} / \mathrm{L})$ & 1,8 a 2,3 & 2,2 a 2,7 & 2,5 a 2,8 & 2,2 a 2,3 & 2,2 \\
\hline Ferro (mg/L) & 1,716 & 1,482 & 1,696 & 0,417 & 0,399 \\
\hline Manganês (mg/L) & 0,100 & 0,078 & 0,098 & 0,044 & 0,034 \\
\hline $\begin{array}{l}\text { Residual de oxidante } \\
\text { (mg/L) }\end{array}$ & NR & NR & NR & ND & ND \\
\hline Alumínio residual (mg/L) & $<0,01$ a 0,03 & $<0,01$ a 0,05 & NR & 0,10 a 0,90 & 0,08 a 0,85 \\
\hline
\end{tabular}




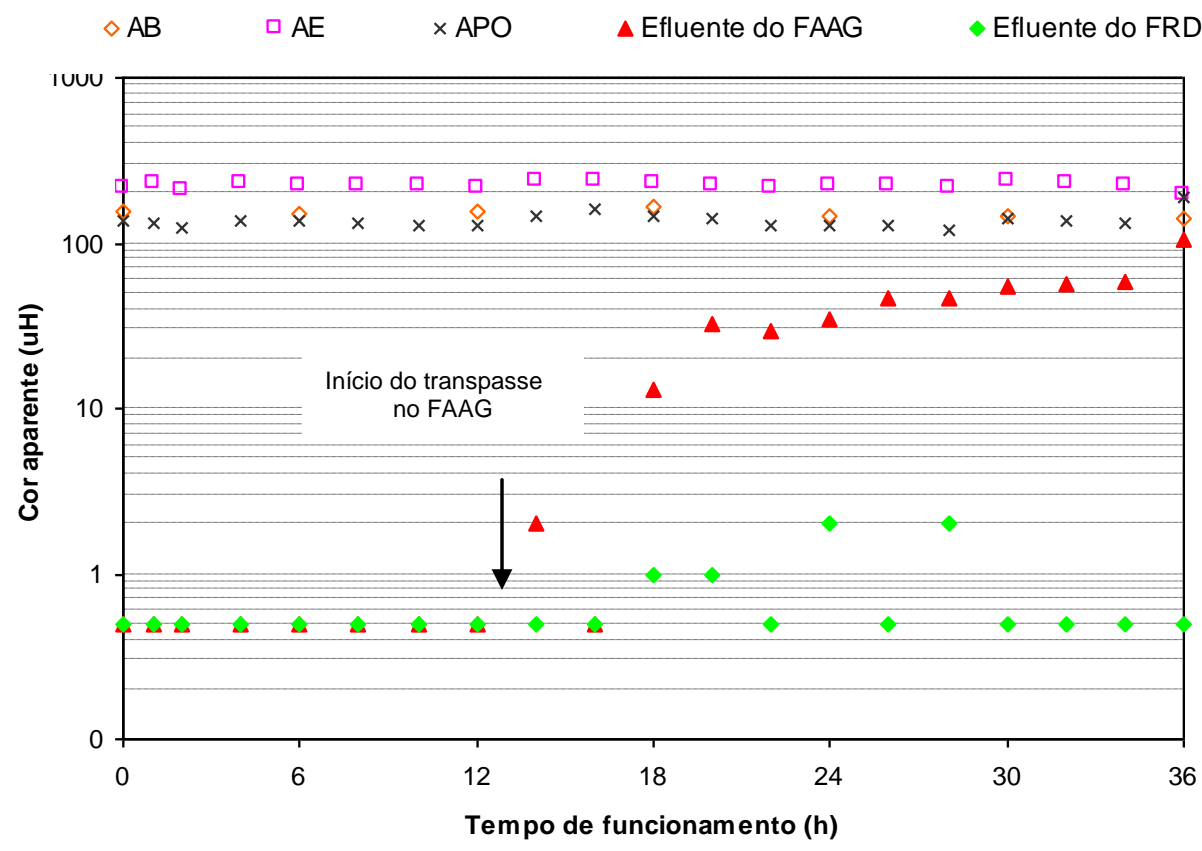

Figura 5.46 - Variação de cor aparente na $A B, A E, A P O$ e efluentes do FAAG e FRD, e cor verdadeira na $A B$ de 14 a $28 \mathrm{uH}$, na $A E$ de 83 a $106 \mathrm{uH}$ e na APO de 23 a $91 \mathrm{uH}$, durante o ensaio 9 - pré-oxidação com ozônio ( $F A A G=180 \mathrm{~m}^{3} / \mathrm{m}^{2} \mathrm{~d}$ e $\mathrm{FRD}=280 \mathrm{~m} / \mathrm{m}^{2} \mathrm{~d}$ ). Fonte: Tabela C 2.1 do ANEXO C.

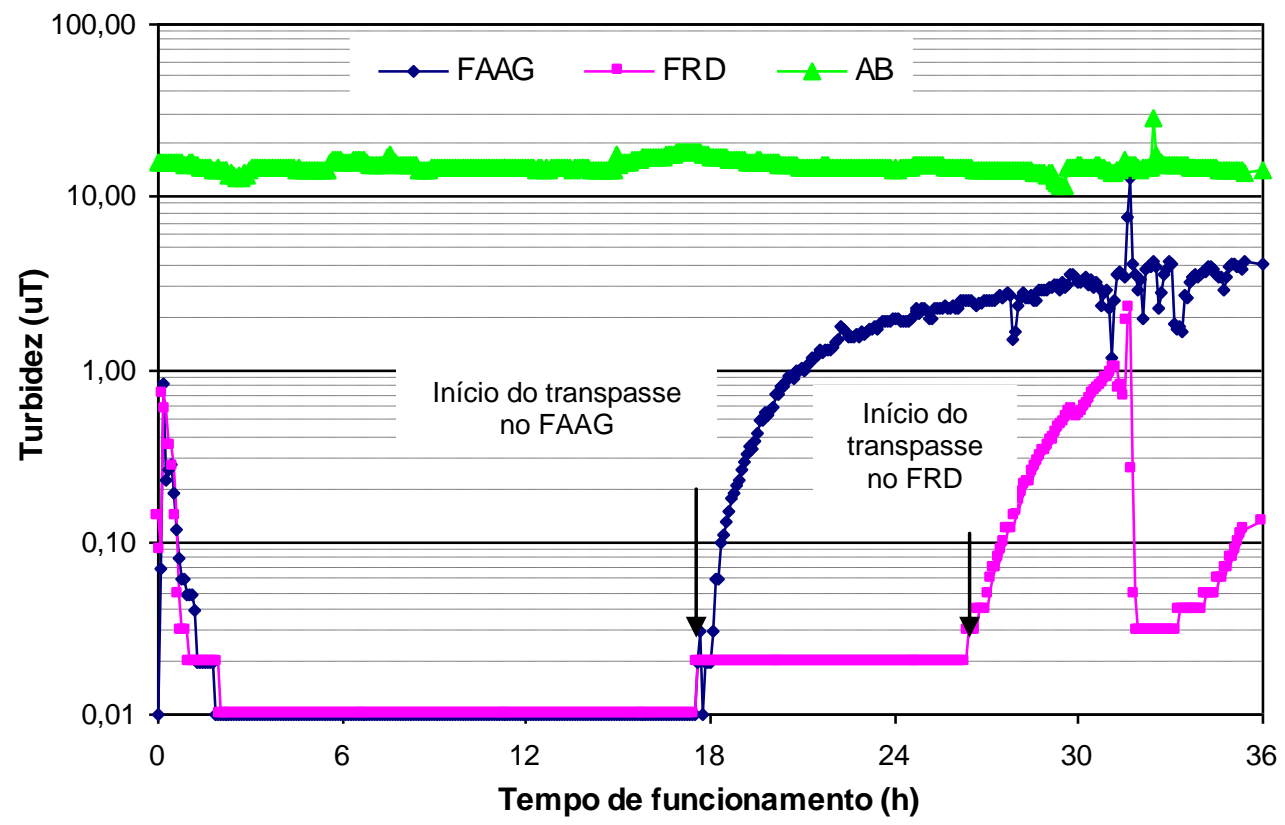

Figura 5.47 - Variação da turbidez na $A B$ e nos efluentes do FAAG $\left(180 \mathrm{~m}^{3} / \mathrm{m}^{2} \mathrm{~d}\right)$ e FRD $\left(280 \mathrm{~m}^{2} / \mathrm{m}^{3} \mathrm{~d}\right)$ durante o ensaio 9 - pré-oxidação com ozônio e sem DFIs no FAAG.

Quanto à remoção de substâncias húmicas, em termos de absorvância 254 $\mathrm{nm}$ e COD, as porcentagens de remoção foram respectivamente, da ordem de 88 a 
96\% e 12 a 16\% no FRD. Nas Figuras 5.48 e 5.49 estão apresentados os resultados de absorvância a $254 \mathrm{~nm}$ e COD durante o ensaio 9. Neste ensaio não foram coletadas amostras de água no início de funcionamento dos filtros para análises de COD.

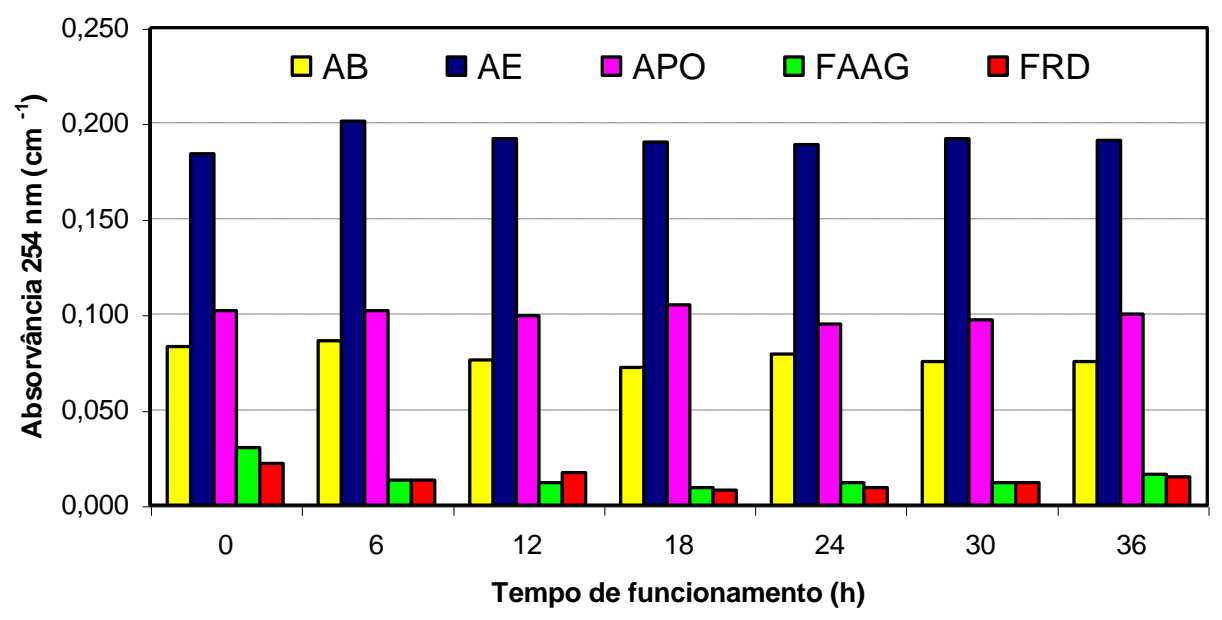

Figura 5.48 - Variação de absorvância $254 \mathrm{~nm}$ na $A B, A E, A P O$ e nos efluentes do FAAG e do FRD durante o ensaio 9, pré-oxidação com ozônio e sem DFls no FAAG (FAAG $=180$ $\mathrm{m}^{3} / \mathrm{m}^{2} \mathrm{~d}$ e FRD $=280 \mathrm{~m}^{3} / \mathrm{m}^{2} \mathrm{~d}$ ). Fonte: Tabela C 2.2 do ANEXO C.

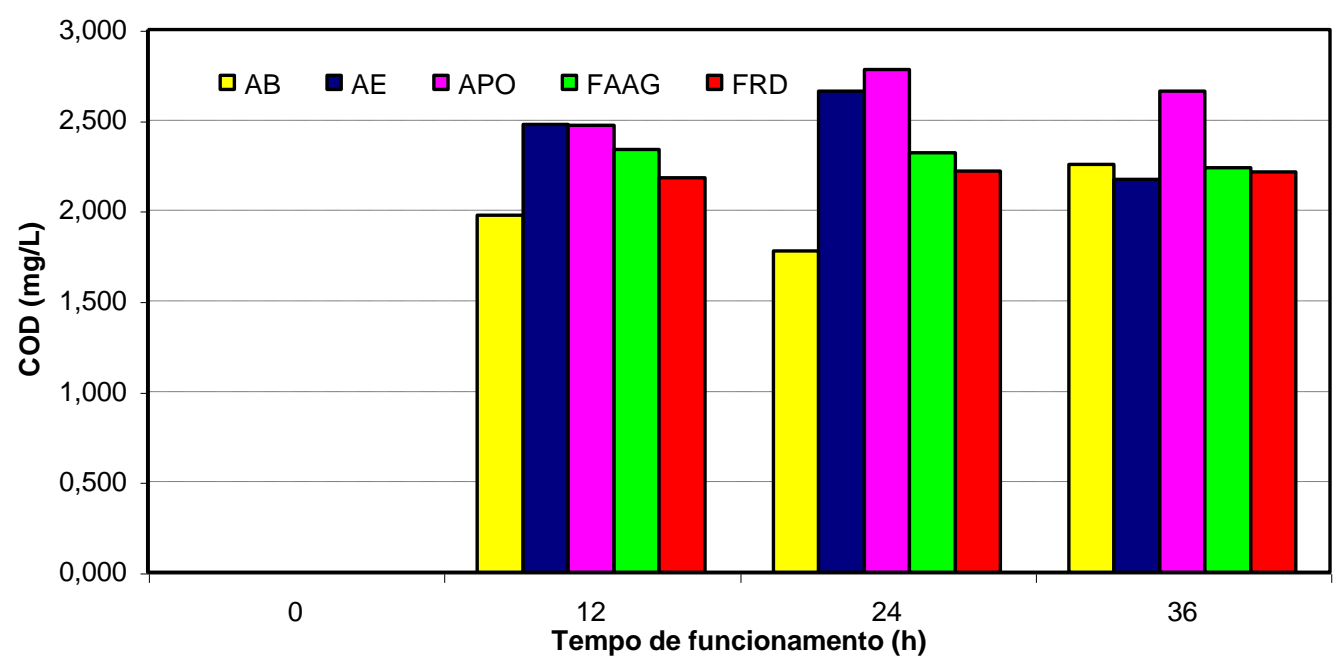

Figura 5.49 - Variação de $C O D$ na $A B, A E, A P O$ e nos efluentes do FAAG e do FRD durante o ensaio 9, pré-oxidação com ozônio e sem DFIs no FAAG (FAAG $=180 \mathrm{~m}^{3} / \mathrm{m}^{2} \mathrm{~d}$ e $\mathrm{FRD}=280 \mathrm{~m}^{3} / \mathrm{m}^{2} \mathrm{~d}$ ). Fonte: Tabela C 2.2 do ANEXO C.

\subsubsection{Ensaio 10 - Pré-oxidação com Peróxido de Hidrogênio}

Foi preparada uma solução estoque de peróxido de hidrogênio diluída com água filtrada da ETA II, com concentração de 12400 mg/L. A dosagem de peróxido 
de hidrogênio aplicada foi de $35 \mathrm{mg} / \mathrm{L}$ e a vazão na bomba dosadora foi calculada pela equação (4.5):

Para $\mathrm{C}=35 \mathrm{mg} / \mathrm{L} ; \mathrm{C}_{\mathrm{SE}}=12400 \mathrm{mg} / \mathrm{L}$ e $\mathrm{Q}_{\mathrm{ab}}=170 \mathrm{~L} / \mathrm{h}:$

$$
35=\frac{0 * 170+12400^{*} Q_{b d}}{170+Q_{b d}} \Rightarrow Q_{b d}=0,48 L / h
$$

Em ensaio preliminar na instalação piloto em escoamento contínuo obtevese dosagem de peróxido de hidrogênio de $35 \mathrm{mg} / \mathrm{L}$, dosagem de $\mathrm{Al}_{2}\left(\mathrm{SO}_{4}\right)_{3} \cdot 14,3 \mathrm{H}_{2} \mathrm{O}$ de $3,5 \mathrm{mg} / \mathrm{L}$ e pH de coagulação de 5,5 . As vazões nas bombas dosadoras foram ajustadas e o ensaio foi iniciado.

Na Figura 5.50 está apresentada a evolução da perda de carga no FAAG e FRD durante o ensaio 10 para a temperatura de $20^{\circ} \mathrm{C}$. Após 28 horas de funcionamento foi necessária a lavagem do FRD por ocorrência do transpasse e após 34 horas foi necessária outra lavagem do FRD por atingir a perda de carga limite, ocorrendo duas lavagens consecutivas no espaço de tempo de 5 horas. A perda de carga final no FAAG foi de $118,1 \mathrm{~cm}$, correspondendo aproximadamente a $49 \%$ da carga hidráulica disponível. Comparando com o ensaio 8 , houve redução de $43 \%$ na perda de carga final do FAAG, conseqüentemente maior duração na carreira de filtração se não fosse encerrada pelo critério de 36 horas de funcionamento.

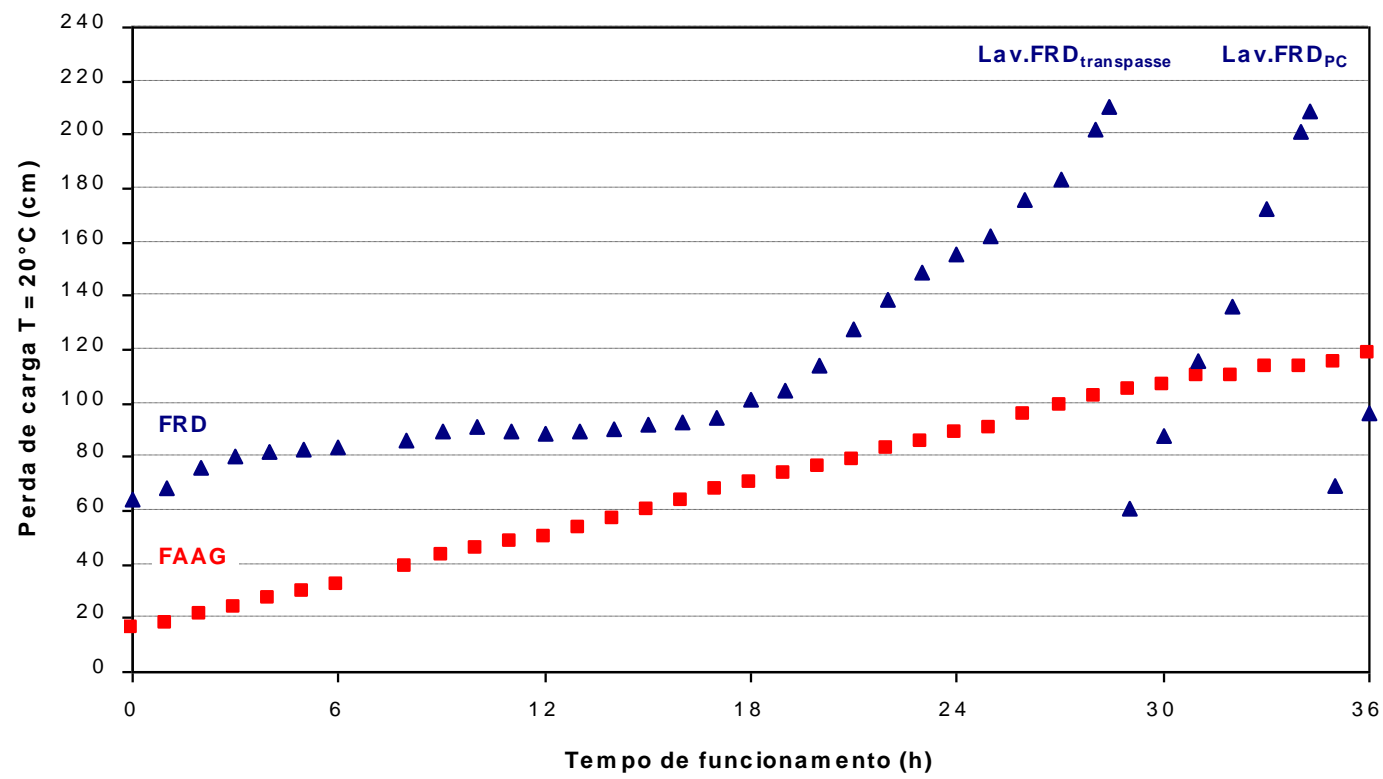

Figura 5.50 - Evolução da perda de carga no FAAG $\left(180 \mathrm{~m}^{3} / \mathrm{m}^{2} \mathrm{~d}\right)$ e no FRD $\left(280 \mathrm{~m}^{2} / \mathrm{m}^{3} \mathrm{~d}\right)$ para $\mathrm{T}=20^{\circ} \mathrm{C}$ durante o ensaio 10 - pré-oxidação com peróxido de hidrogênio e sem DFls no FAAG. Fonte: Tabela C 3.3 do ANEXO C. 
As taxas de filtração médias no FAAG e no FRD foram de 188 e $280 \mathrm{~m}^{3} / \mathrm{m}^{2} \mathrm{~d}$ respectivamente (ver Tabela C 3.4 do ANEXO C). Na Tabela 5.22 está apresentado o resumo dos resultados obtidos durante o ensaio 10, e nas Tabelas C 3.1 a C 3.4 estão todos os resultados obtidos durante o ensaio 10. Nas Figuras C 3.1 e C 3.2 do ANEXO C estão as perdas de carga ao longo do meio filtrante no FAAG e no FRD.

A cor aparente do efluente do FRD se manteve $\leq 1 \mathrm{uH}$, na maior parte do tempo, com exceção de valores observados da ordem de 21, 9 e 5 uH, após 1, 2 e 28 horas de funcionamento respectivamente. Na Figura 5.51 pode-se observar 0 início do transpasse no efluente do FAAG a partir das 15 horas de funcionamento, resultando em $106 \mathrm{uH}$ ao término do ensaio.

Tabela 5.22 - Resumo dos resultados obtidos no ensaio 10 - pré-oxidação com peróxido de hidrogênio.

\begin{tabular}{|c|c|c|c|c|c|}
\hline & \multicolumn{5}{|c|}{ ENSAIO 10 - pré-oxidação com peróxido de hidrogênio } \\
\hline Taxas de filtração médias & \multicolumn{5}{|c|}{$\mathrm{FAAG}=188$ e $\mathrm{FRD}=280 \mathrm{~m}^{3} / \mathrm{m}^{2} \mathrm{~d}$} \\
\hline Condições de coagulação & \multicolumn{5}{|c|}{$\begin{array}{c}\mathrm{D}_{\mathrm{SA}} \cong 3,5 \mathrm{mg} / \mathrm{L} ; \mathrm{pH} \text { de coagulação }=5,18 \text { a } 5,52 ; \\
\text { temperatura }=19,5 \text { a } 22^{\circ} \mathrm{C}\end{array}$} \\
\hline $\begin{array}{l}\text { Condições de pré- } \\
\text { oxidação }\end{array}$ & \multicolumn{5}{|c|}{ Dosagem aplicada de $\mathrm{H}_{2} \mathrm{O}_{2} \cong 35 \mathrm{mg} / \mathrm{L}$} \\
\hline Duração da carreira & \multicolumn{5}{|c|}{$36 \mathrm{~h}$} \\
\hline Características & AB & AE & APO & $\begin{array}{c}\text { Efluente do } \\
\text { FAAG }\end{array}$ & $\begin{array}{c}\text { Efluente do } \\
\text { FRD }\end{array}$ \\
\hline $\mathrm{pH}$ & 6,44 a 6,60 & 6,38 a 6,60 & $\begin{array}{c}5,90 \mathrm{a} \\
6,24\end{array}$ & NR & NR \\
\hline $\begin{array}{l}\text { Alcalinidade } \\
\left(\mathrm{mg} / \mathrm{L} \mathrm{CaCO}_{3}\right)\end{array}$ & 3,5 a 7,9 & 5,5 a 8,4 & 3,1 a 5,7 & NR & NR \\
\hline Cor aparente $(\mathrm{uH})$ & 130 a 184 & 197 a 262 & 192 a 259 & $<1$ a 106 & $<1 \mathrm{a} 21^{(*)}$ \\
\hline Cor verdadeira $(\mathrm{uH})$ & 18 a 31 & 90 a 121 & 91 a 117 & NR & NR \\
\hline Turbidez (uT) & 10,88 a 19,00 & NR & NR & 0,02 a 6,4 & 0,02 a 1 \\
\hline Absorvância 254 nm & 0,075 a 0,107 & $\begin{array}{c}0,176 \mathrm{a} \\
0,230\end{array}$ & $\begin{array}{c}0,186 \mathrm{a} \\
0,248\end{array}$ & $\begin{array}{c}0,018 \mathrm{a} \\
0,079\end{array}$ & 0,021 a 0,083 \\
\hline $\mathrm{COD}(\mathrm{mg} / \mathrm{L})$ & 2,4 a 3,2 & 3,0 a 4,4 & 3,6 a 5,3 & 2,1 a 2,5 & 2,1 a 2,9 \\
\hline Ferro $(\mathrm{mg} / \mathrm{L})$ & 1,211 a 1,688 & $\begin{array}{c}1,521 \mathrm{a} \\
2,408 \\
\end{array}$ & $\begin{array}{c}0,893 \mathrm{a} \\
1,537\end{array}$ & $\begin{array}{c}0,301 \mathrm{a} \\
1,059\end{array}$ & 0,012 a 0,198 \\
\hline Manganês (mg/L) & 0,041 a 0,056 & $\begin{array}{c}0,026 \mathrm{a} \\
0,043\end{array}$ & $\begin{array}{c}0,040 \mathrm{a} \\
0,053\end{array}$ & $\begin{array}{c}0,028 \mathrm{a} \\
0,044\end{array}$ & 0,011 a 0,022 \\
\hline $\begin{array}{l}\text { Residual de oxidante } \\
(\mathrm{mg} / \mathrm{L})\end{array}$ & NR & NR & NR & $\begin{array}{c}0,065 \mathrm{a} \\
0,109 \\
\end{array}$ & 0,088 a 0,095 \\
\hline Alumínio residual (mg/L) & ND & $<0,01$ a 0,01 & NR & 0,06 a 0,11 & 0,03 a 0,07 \\
\hline
\end{tabular}

A turbidez do efluente do FRD manteve-se $<1$ uT durante a maior parte do tempo, com exceção do transpasse que iniciou após 25 horas de funcionamento sendo necessária a lavagem do filtro. Observa-se na Figura 5.52 o início do 
transpasse no FAAG após 15 horas de funcionamento, da mesma forma, na Figura 5.51 é observado o aumento da cor aparente no efluente do FAAG.

Quanto à remoção de substâncias húmicas, em termos de absorvância 254 nm e COD, as porcentagens de remoção foram respectivamente, da ordem de 53 a $91 \%$ e 14 a 53\% no FRD. Nas Figuras 5.53 e 5.54 estão apresentadas as variações na absorvância 254 nm e no COD durante o ensaio 10.

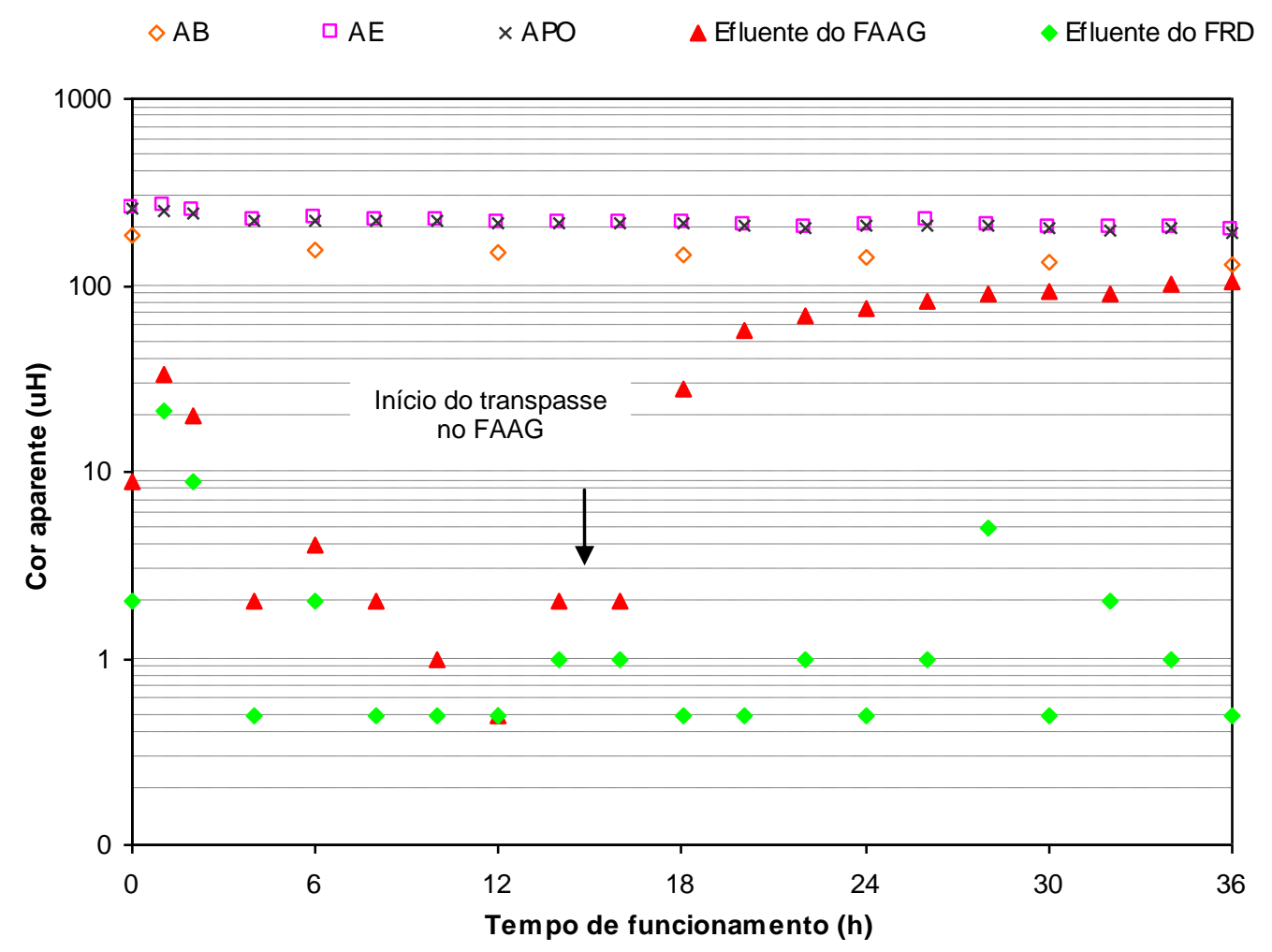

Figura 5.51 - Variação de cor aparente na $A B, A E$, APO e efluentes do FAAG e FRD, e cor verdadeira na $A B$ de 18 a $31 \mathrm{uH}$, na $A E$ de 90 a $121 \mathrm{uH}$ e na $A P O$ de 91 a $117 \mathrm{uH}$, durante o ensaio 10 - pré-oxidação com peróxido de hidrogênio (FAAG $=180 \mathrm{~m}^{3} / \mathrm{m}^{2} \mathrm{~d}$ e $\mathrm{FRD}=280$ $\mathrm{m}^{3} / \mathrm{m}^{2} \mathrm{~d}$ ). Fonte: Tabela C 3.1 do ANEXO C. 


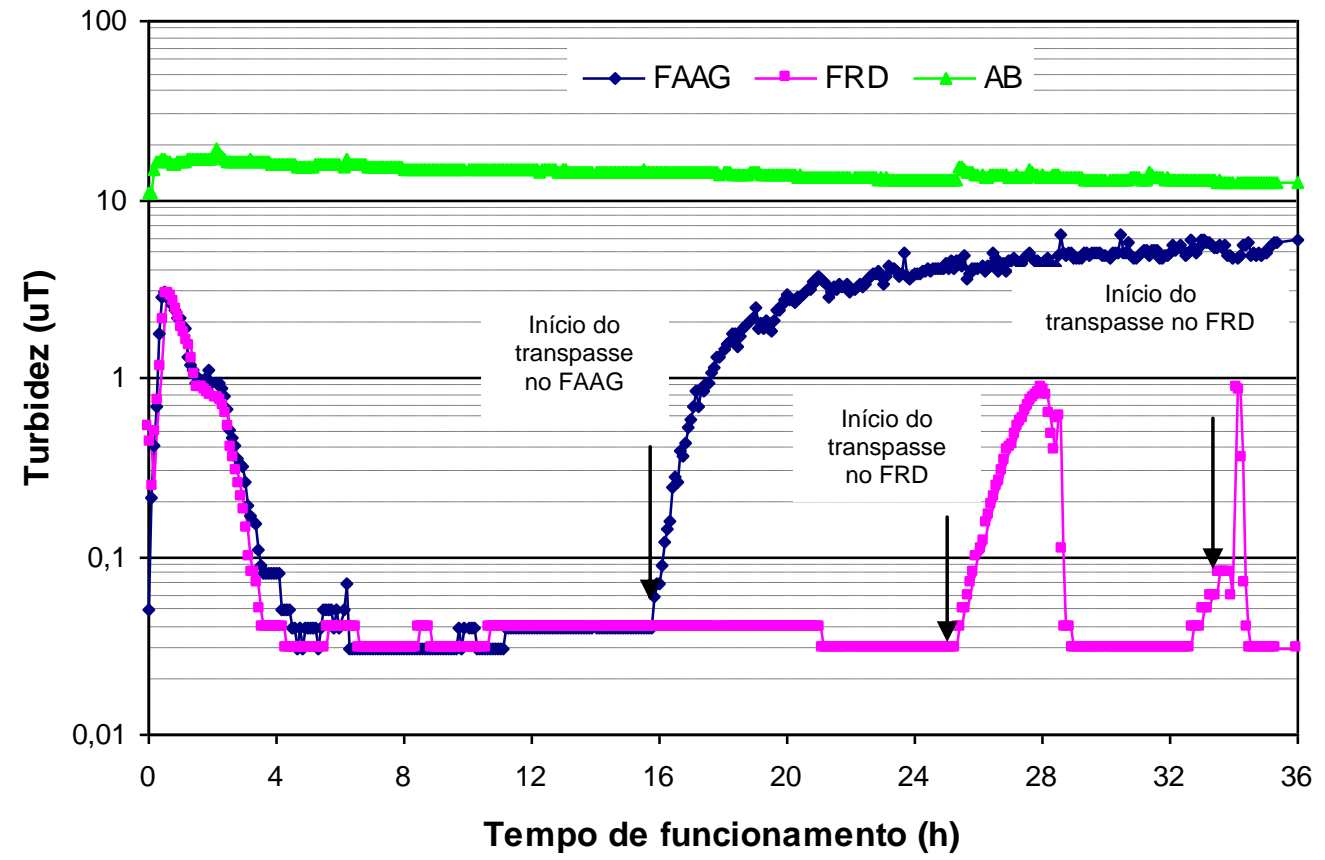

Figura 5.52 - Variação da turbidez na $A B$ e nos efluentes do FAAG $\left(180 \mathrm{~m}^{\circ} / \mathrm{m}^{<} \mathrm{d}\right)$ e $F R D$ $\left(280 \mathrm{~m}^{2} / \mathrm{m}^{3} \mathrm{~d}\right)$ durante o ensaio 10 - pré-oxidação com peróxido de hidrogênio e sem DFls no FAAG.

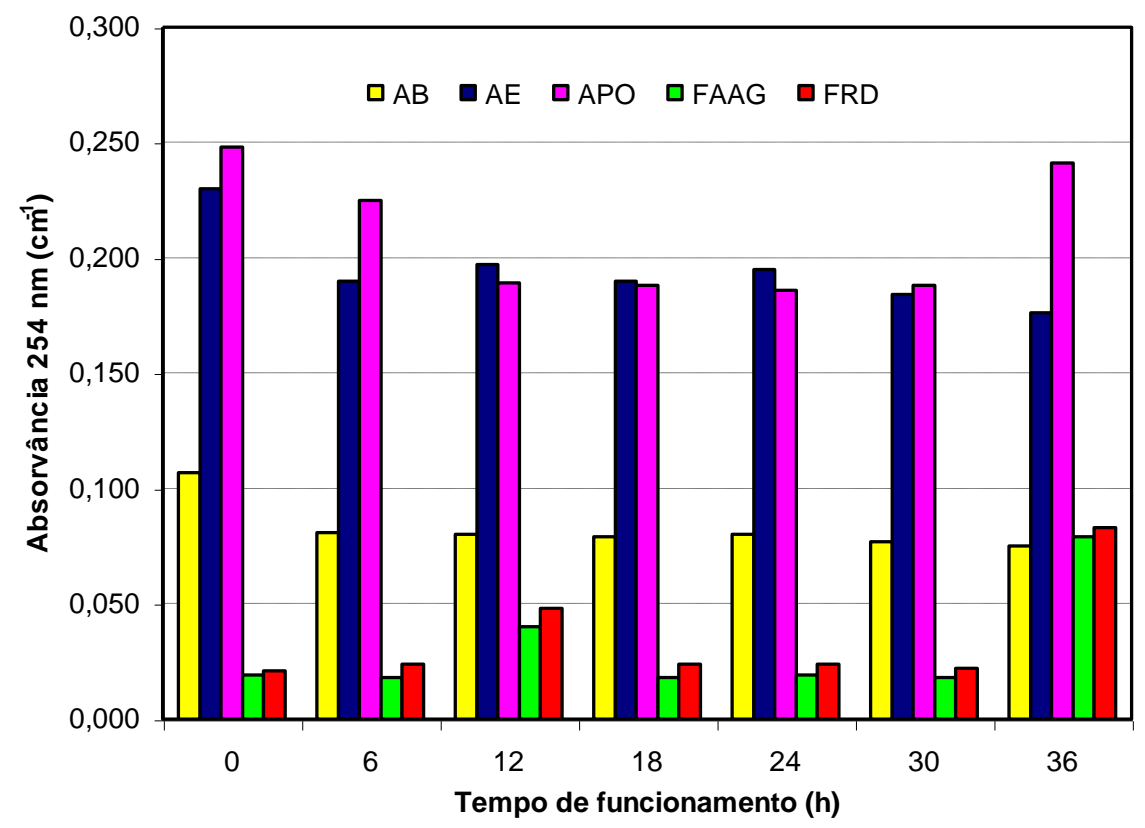

Figura 5.53 - Variação de absorvância $254 \mathrm{~nm}$ na $A B, A E, A P O$ e nos efluentes do FAAG e do FRD durante 0 ensaio 10, pré-oxidação com peróxido de hidrogênio e sem DFls no FAAG $\left(F A A G=180 \mathrm{~m}^{3} / \mathrm{m}^{2} \mathrm{~d}\right.$ e FRD $\left.=280 \mathrm{~m}^{3} / \mathrm{m}^{2} \mathrm{~d}\right)$. Fonte: Tabela C 3.2 do ANEXO C. 


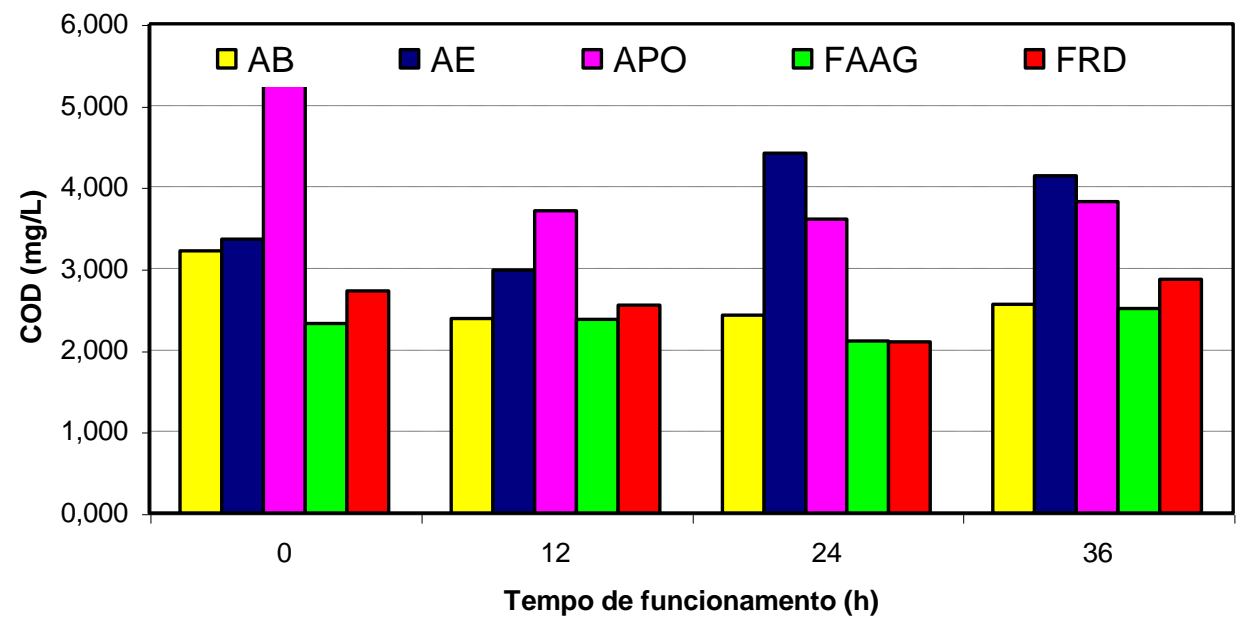

Figura 5.54 - Variação de $C O D$ na $A B, A E, A P O$ e nos efluentes do FAAG e do FRD durante o ensaio 10, pré-oxidação com peróxido de hidrogênio e sem DFls no FAAG (FAAG $=180 \mathrm{~m}^{3} / \mathrm{m}^{2} \mathrm{~d}$ e FRD $=280 \mathrm{~m}^{3} / \mathrm{m}^{2} \mathrm{~d}$ ). Fonte: Tabela C 3.2 do ANEXO C.

\subsubsection{Ensaio 11 - Pré-oxidação com Tricloro-s-triazina-triona}

Foi preparada uma solução estoque de tricloro-s-triazina-triona, no tanque de mistura, com concentração de 1000 mg/L. A dosagem de cloro aplicada durante o ensaio foi no início de $7 \mathrm{mg} / \mathrm{L}$ e de $4 \mathrm{mg} / \mathrm{L}$ após 4 horas de funcionamento. Utilizando-se a equação (4.5) foi possível determinar a vazão na bomba dosadora.

Para C = $4 \mathrm{mg} / \mathrm{L} ; \mathrm{C}_{\mathrm{SE}}=1000 \mathrm{mg} / \mathrm{L}$ e $\mathrm{Q}_{\mathrm{ab}}=170 \mathrm{~L} / \mathrm{h}$ :

$$
4=\frac{0 * 170+1000 * Q_{b d}}{170+Q_{b d}} \Rightarrow Q_{b d}=0,68 L / h
$$

As dosagens de cloro e $\mathrm{Al}_{2}\left(\mathrm{SO}_{4}\right)_{3} .14,3 \mathrm{H}_{2} \mathrm{O}$ e $\circ \mathrm{pH}$ de coagulação foram determinados em ensaio preliminar na instalação piloto em escoamento contínuo e resultaram em: dosagem de cloro $\cong 7 \mathrm{mg} / \mathrm{L}, \mathrm{D}_{\mathrm{SA}} \cong 4 \mathrm{mg} / \mathrm{L}$ e $\mathrm{pH}$ de coagulação $\cong 5,0$. Durante o ensaio 11 ocorreu redução na dosagem de cloro para $4 \mathrm{mg} / \mathrm{L}$ e de $\mathrm{Al}_{2}\left(\mathrm{SO}_{4}\right)_{3} \cdot 14,3 \mathrm{H}_{2} \mathrm{O}$ para $3,5 \mathrm{mg} / \mathrm{L}$, sem alterações na eficiência de remoção de cor no efluente do FRD.

As taxas de filtração médias no FAAG e no FRD foram de 186 e $281 \mathrm{~m}^{3} / \mathrm{m}^{2} \mathrm{~d}$ respectivamente (ver Tabela C 4.4 do ANEXO C). Na Tabela 5.23 está apresentado o resumo dos resultados obtidos durante o ensaio 11. Nas Tabelas C 4.1 a C 4.4 do ANEXO C estão apresentados todos os dados obtidos durante o ensaio 11. Nas Figuras C 4.1 e C 4.2 do ANEXO C estão apresentadas as perdas de carga ao longo do meio filtrante no FAAG e no FRD. 
Tabela 5.23 - Resumo dos resultados obtidos no ensaio 11 - pré-oxidação com tricloro-striazina-triona.

\begin{tabular}{|c|c|c|c|c|c|}
\hline & \multicolumn{5}{|c|}{ ENSAIO 11 - pré-oxidação com tricloro-s-triazina-triona } \\
\hline Taxas de filtração médias & \multicolumn{5}{|c|}{ FAAG $=186$ e $F R D=281 \mathrm{~m}^{3} / \mathrm{m}^{2} \mathrm{~d}$} \\
\hline Condições de coagulação & \multicolumn{5}{|c|}{$\begin{array}{c}\mathrm{D}_{\mathrm{SA}} \cong 3,0 \text { a } 4,0 \mathrm{mg} / \mathrm{L} ; \mathrm{pH} \text { de coagulação }=4,95 \text { a } 5,60 ; \\
\text { temperatura }=17 \text { a } 21^{\circ} \mathrm{C}\end{array}$} \\
\hline $\begin{array}{l}\text { Condições de pré- } \\
\text { oxidação }\end{array}$ & \multicolumn{5}{|c|}{ Dosagem aplicada de $\mathrm{Cl}_{2} \cong 4,0$ a $7,0 \mathrm{mg} / \mathrm{L}$} \\
\hline Duração da carreira & \multicolumn{5}{|c|}{$36 \mathrm{~h}$} \\
\hline Características & AB & AE & APO & $\begin{array}{c}\text { Efluente do } \\
\text { FAAG }\end{array}$ & $\begin{array}{c}\text { Efluente do } \\
\text { FRD }\end{array}$ \\
\hline $\mathrm{pH}$ & 6,61 a 6,76 & 6,64 a 6,87 & $\begin{array}{c}5,73 \mathrm{a} \\
6,51\end{array}$ & NR & NR \\
\hline $\begin{array}{l}\text { Alcalinidade } \\
\left(\mathrm{mg} / \mathrm{L} \mathrm{CaCO}_{3}\right)\end{array}$ & 5,1 a 8,8 & 5,5 a 7,5 & 3,5 a 7,0 & NR & NR \\
\hline Cor aparente $(\mathrm{uH})$ & 96 a 109 & 171 a 193 & 163 a 192 & $<1$ a 81 & $<1$ a 5 \\
\hline Cor verdadeira $(\mathrm{uH})$ & 12 a 16 & 92 a 102 & 83 a 96 & NR & NR \\
\hline Turbidez (uT) & 8,5 a 12,8 & NR & NR & $<0,01$ a 10,7 & $<0,01$ a 1 \\
\hline Absorvância 254 nm & 0,048 a 0,054 & $\begin{array}{c}0,170 \mathrm{a} \\
0,188 \\
\end{array}$ & $\begin{array}{c}0,161 \mathrm{a} \\
0,182 \\
\end{array}$ & $\begin{array}{c}0,014 \mathrm{a} \\
0,021\end{array}$ & 0,018 a 0,025 \\
\hline $\mathrm{COD}(\mathrm{mg} / \mathrm{L})$ & 2,7 a 4,0 & 4,6 a 6,6 & 4,7 a 5,5 & 3,3 a 4,2 & 3,1 a 6,3 \\
\hline Ferro (mg/L) & 0,752 a 1,404 & $\begin{array}{c}0,786 \mathrm{a} \\
1,166 \\
\end{array}$ & $\begin{array}{c}1,325 \mathrm{a} \\
1,362 \\
\end{array}$ & $\begin{array}{c}0,162 \mathrm{a} \\
0,854 \\
\end{array}$ & 0,205 a 0,268 \\
\hline Manganês (mg/L) & 0,008 a 0,026 & $\begin{array}{c}0,007 \mathrm{a} \\
0,018 \\
\end{array}$ & $\begin{array}{c}0,024 a \\
0,026 \\
\end{array}$ & $\begin{array}{c}0,005 a \\
0,019 \\
\end{array}$ & 0,004 a 0,007 \\
\hline $\begin{array}{l}\begin{array}{l}\text { Residual de oxidante } \\
(\mathrm{mg} / \mathrm{L})\end{array} \\
\end{array}$ & NR & NR & NR & 0,35 a 3,56 & 0,28 a 3,36 \\
\hline Alumínio residual (mg/L) & $<0,01$ a 0,04 & $<0,01$ a 0,03 & NR & 0,10 a 0,18 & 0,07 a $0,15^{(*)}$ \\
\hline
\end{tabular}

Na Figura 5.55 está apresentada a evolução da perda de carga no FAAG e FRD durante o ensaio 11. Ocorreram duas lavagens no FRD devido à ocorrência do transpasse no filtro, as lavagens foram executadas com 30 e 35 horas de funcionamento. A perda de carga final no FAAG foi de $94,1 \mathrm{~cm}$, com redução de $55 \%$ comparada ao ensaio 8 (sem pré-oxidação).

A cor aparente do efluente do FRD se manteve $\leq 1 \mathrm{uH}$, na maior parte do tempo, com exceção do valor de $5 \mathrm{uH}$ observado em 14 horas de funcionamento. $\mathrm{Na}$ Figura 5.56 pode-se observar o início do transpasse no efluente do FAAG a partir das 20 horas de funcionamento, resultando em $81 \mathrm{uH}$ ao término do ensaio.

A turbidez do efluente do FRD manteve-se $<1$ uT durante a maior parte do tempo, com exceção da ocorrência de dois transpasses no filtro que iniciaram após 27 e 32 horas de funcionamento. Ocorreu um pico de turbidez no efluente do FRD após 11 horas de funcionamento, atingindo o valor de 0,41 uT, e após este pico e com ajustes nas dosagens de oxidante, coagulante e do $\mathrm{pH}$ de coagulação a turbidez voltou a apresentar valores menores que 0,1 uT. Observa-se na Figura 
5.57 o início do transpasse no FAAG após 18 horas de funcionamento, ocorrendo também o aumento gradual na cor aparente do efluente do FAAG, mostrado na Figura 5.56.

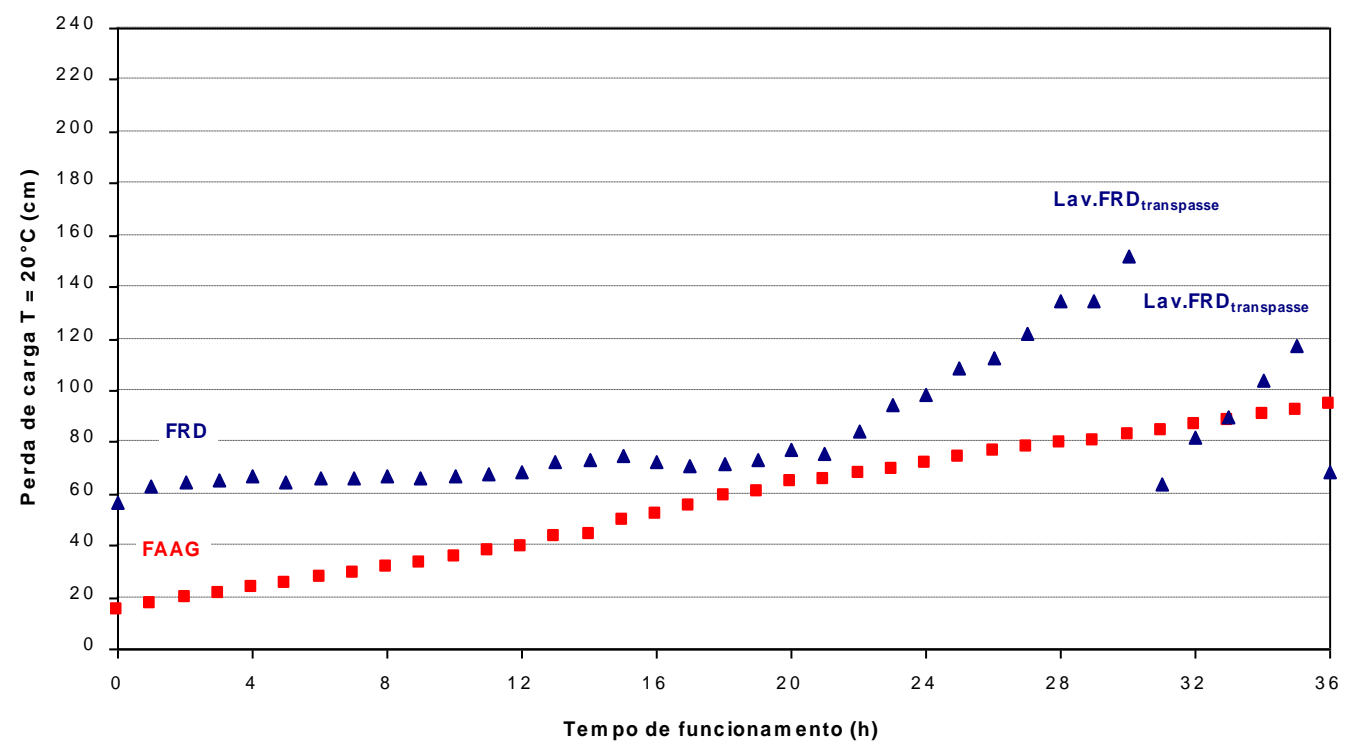

Figura 5.55 - Evolução da perda de carga no FAAG $\left(180 \mathrm{~m}^{3} / \mathrm{m}^{2} \mathrm{~d}\right)$ e no FRD $\left(280 \mathrm{~m}^{2} / \mathrm{m}^{3} \mathrm{~d}\right)$ para $T=20^{\circ} \mathrm{C}$ durante o ensaio 11 - pré-oxidação com tricloro-s-triazina-triona e sem DFIs no FAAG. Fonte: Tabela C 4.3 do ANEXO C.

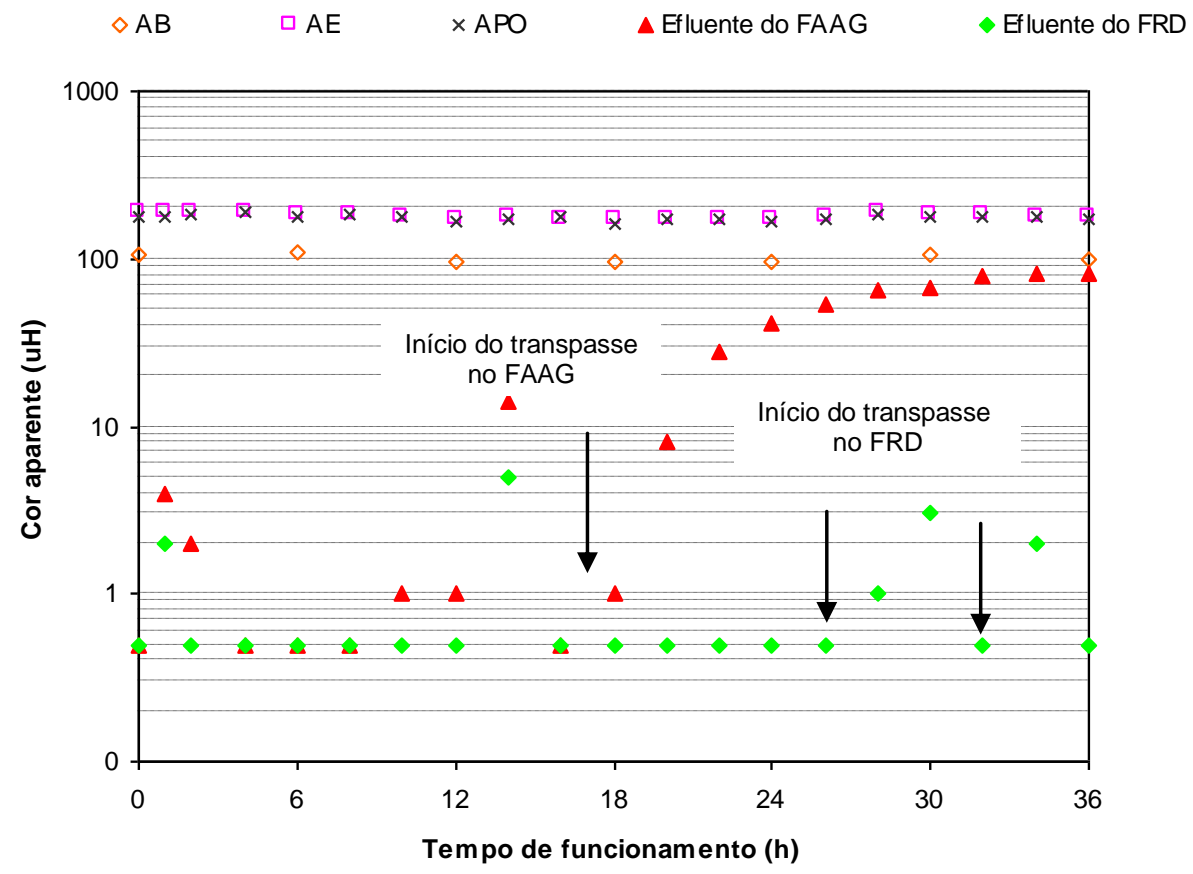

Figura 5.56 - Variação de cor aparente na $A B, A E$, APO e efluentes do FAAG e FRD, e cor verdadeira na $A B$ de 12 a $16 \mathrm{uH}$, na $A E$ de 92 a $102 \mathrm{uH}$ e na APO de 83 a $96 \mathrm{uH}$, durante o ensaio 11 - pré-oxidação com tricloro-s-triazina-triona ( $F A A G=180 \mathrm{~m}^{3} / \mathrm{m}^{2} \mathrm{~d}$ e $\mathrm{FRD}=280$ $\mathrm{m}^{2} / \mathrm{m}^{3} \mathrm{~d}$ ). Fonte: Tabela C 4.1 do ANEXO C. 


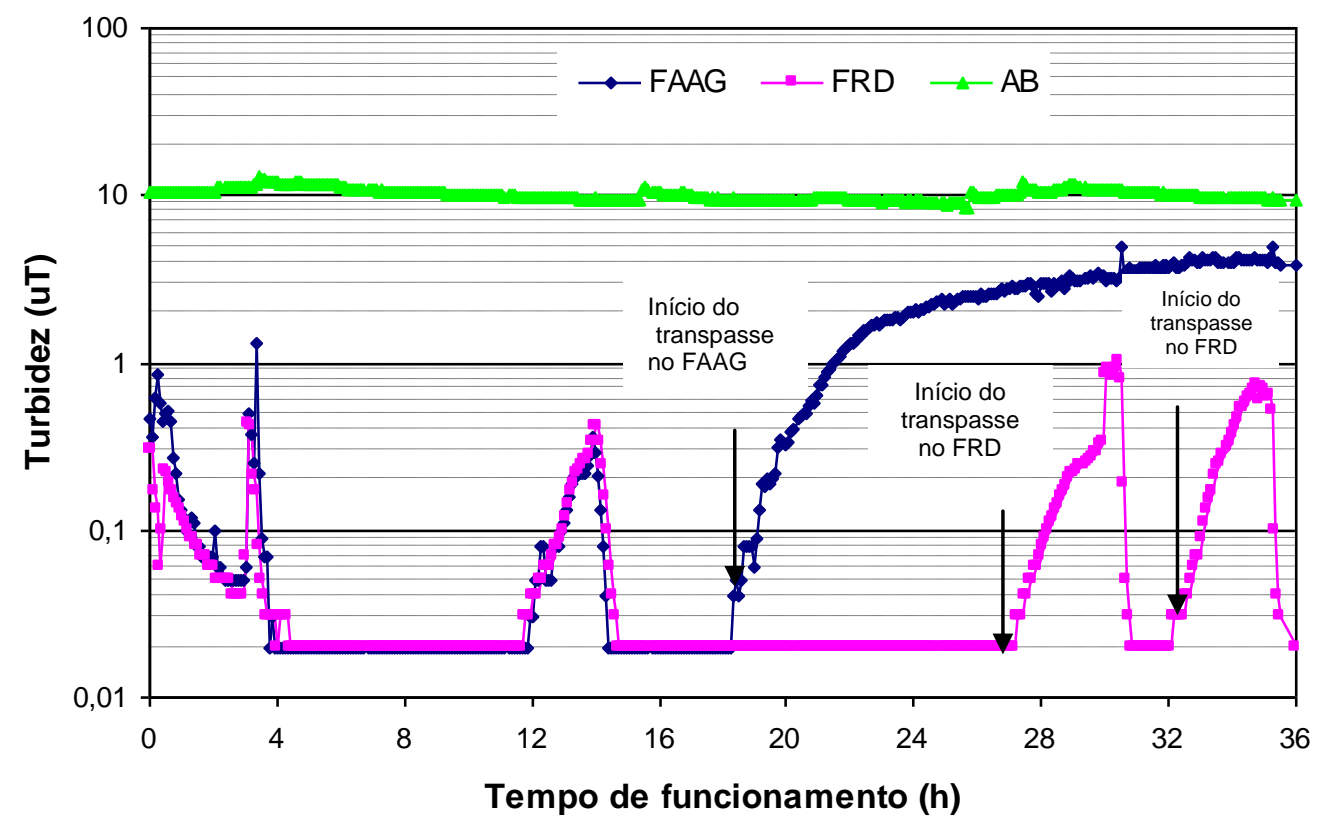

Figura 5.57 - Variação da turbidez na $A B$ e nos efluentes do FAAG $\left(180 \mathrm{~m}^{3} / \mathrm{m}^{2} \mathrm{~d}\right)$ e FRD $\left(280 \mathrm{~m}^{2} / \mathrm{m}^{3} \mathrm{~d}\right)$ durante o ensaio 11 - pré-oxidação com tricloro-s-triazina-triona e sem DFIs no FAAG.

Quanto à remoção de substâncias húmicas, em termos de absorvância 254 nm e COD, as porcentagens de remoção foram respectivamente, de 85 a 90\% e 4 a $44 \%$ no FRD. Devido a este baixo valor de remoção de COD (4\%) foram realizadas medidas de carbono orgânico total (COT), no Laboratório de Saneamento da EESC-USP, de amostras de água com extrato de substâncias húmicas até cor verdadeira de aproximadamente $100 \mathrm{uH}$ e do padrão de COT com concentração aproximada de $50 \mathrm{mg} / \mathrm{L}$, sem cloração, cloradas com hipoclorito de sódio ( $\mathrm{NaClO})$ e cloradas com tricloro-s-triazina-triona. A dosagem de cloro aplicada nas amostras foi de $10 \mathrm{mg} / \mathrm{L}$ e o tempo de contato de 30 minutos. Na Tabela 5.24 estão apresentados os resultados de COT para as diferentes amostras.

Tabela 5.24 - Valores de COT para amostras de água destilada com extrato de substâncias húmicas (ESH), não cloradas e cloradas com $\mathrm{NaClO}$ e tricloro-s-triazina-triona

\begin{tabular}{|c|c|c|}
\hline № & AMOSTRA & COT (mg/L) \\
\hline 1 & Água com ESH (cor = $107 \mathrm{uH})$ sem cloro & $2,824 \pm 0,031$ \\
\hline 2 & Água com ESH $(\mathrm{cor}=107 \mathrm{uH})$ clorada $\mathrm{c} / \mathrm{NaClO}$ & $2,771 \pm 0,070$ \\
\hline 3 & Água com ESH (cor = $107 \mathrm{uH}$ ) clorada c/ tricloro-s-triazina-triona & $4,790 \pm 0,028$ \\
\hline 4 & Padrão de COT ( $\cong 50 \mathrm{mg} / \mathrm{L}$ ) sem cloro & $48,86 \pm 0,047$ \\
\hline 5 & Padrão de COT clorado c/ NaClO & $47,30 \pm 0,221$ \\
\hline 6 & Padrão de COT clorado c/ tricloro-s-triazina-triona & $51,23 \pm 0,606$ \\
\hline
\end{tabular}


Observou-se um aumento no COT das amostras cloradas com tricloro-striazina-triona, podendo haver compostos orgânicos na composição deste produto, e nas amostras cloradas com $\mathrm{NaClO}$ os valores de COT apresentaram-se mais baixos.

Nas Figuras 5.58 e 5.59 estão apresentadas as variações de absorvância $254 \mathrm{~nm}$ e de COD obtidas durante o ensaio 11.

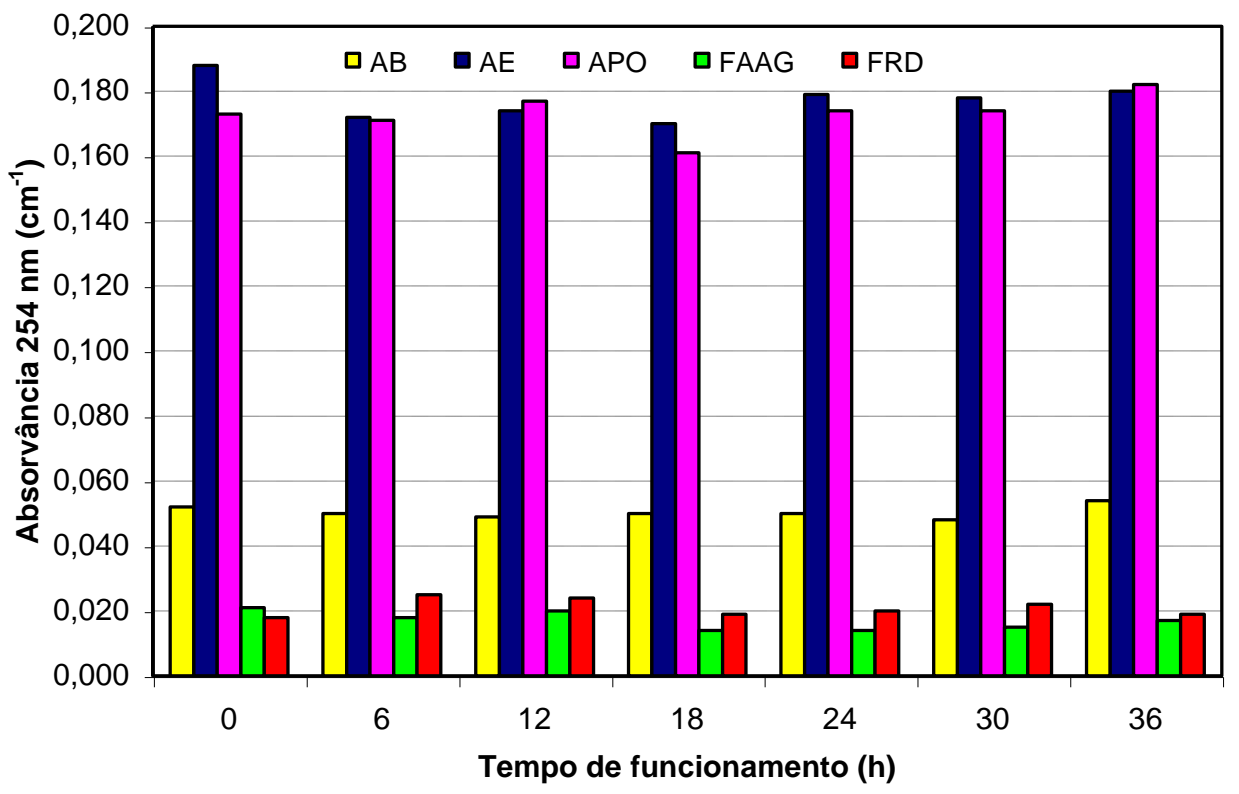

Figura 5.58 - Variação de absorvância 254 nm na AB, AE, APO e nos efluentes do FAAG e do FRD durante o ensaio 11, pré-oxidação com tricloro-s-triazina-triona e sem DFIs no FAAG $\left(F A A G=180 \mathrm{~m}^{3} / \mathrm{m}^{2} \mathrm{~d}\right.$ e FRD $=280 \mathrm{~m}^{3} / \mathrm{m}^{2} \mathrm{~d}$ ). Fonte: Tabela C 4.2 do ANEXO C.

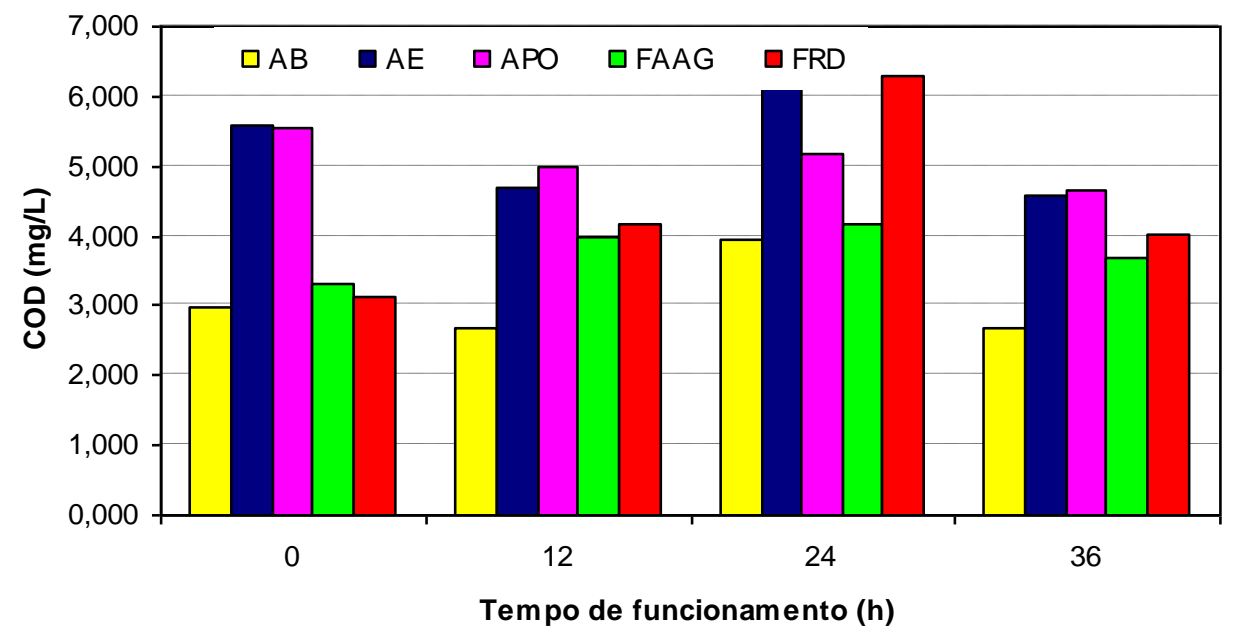

Figura 5.59 - Variação de $C O D$ na $A B, A E$, APO e nos efluentes do FAAG e do FRD durante o ensaio 11, pré-oxidação com tricloro-s-triazia-triona e sem DFIs no FAAG (FAAG $=180 \mathrm{~m}^{3} / \mathrm{m}^{2} \mathrm{~d}$ e FRD $=280 \mathrm{~m}^{3} / \mathrm{m}^{2} \mathrm{~d}$ ). Fonte: Tabela C 4.2 do ANEXO C. 


\subsubsection{Ensaio 12 - Pré-oxidação com Dióxido de Cloro}

A concentração da solução estoque de dióxido de cloro foi de $160 \mathrm{mg} / \mathrm{L}$. A dosagem de dióxido de cloro aplicada no ensaio na instalação piloto foi de 0,4 $\mathrm{mg} / \mathrm{L}$, e a dosagem da bomba dosadora foi determinada pela equação (4.5):

Para C = 0,4 mg/L; $C_{S E}=160 \mathrm{mg} / \mathrm{L}$ e $Q_{a b}=170 \mathrm{~L} / \mathrm{h}:$

$$
0,4=\frac{0 * 170+160 * Q_{b d}}{170+Q_{b d}} \Rightarrow Q_{b d}=0,43 L / h
$$

Com o ensaio preliminar na instalação piloto em escoamento contínuo foram determinadas as dosagens de dióxido de cloro e de $\mathrm{Al}_{2}\left(\mathrm{SO}_{4}\right)_{3} \cdot 14,3 \mathrm{H}_{2} \mathrm{O}$, de 0,4 e $4,0 \mathrm{mg} / \mathrm{L}$ respectivamente, para $\mathrm{pH}$ de coagulação da ordem de 5,5.

As taxas de filtração médias no FAAG e no FRD foram de 186 e $279 \mathrm{~m}^{3} / \mathrm{m}^{2} \mathrm{~d}$ respectivamente (ver Tabela C 5.4 do ANEXO C). Na Figura 5.60 está apresentada a evolução da perda de carga no FAAG e no FRD para a temperatura de $20^{\circ} \mathrm{C}$. Pode-se observar que foram executadas duas lavagens no FRD devido à ocorrência do transpasse, nos tempos de 27,5 e 34 horas de funcionamento. A perda de carga final no FAAG foi de $100,8 \mathrm{~cm}$, com redução de $51,5 \%$ comparada ao ensaio 8 (sem pré-oxidação).

Nas Figuras C 5.1 e 5.2 do ANEXO C estão as perdas de carga ao longo do meio filtrante no FAAG e no FRD.

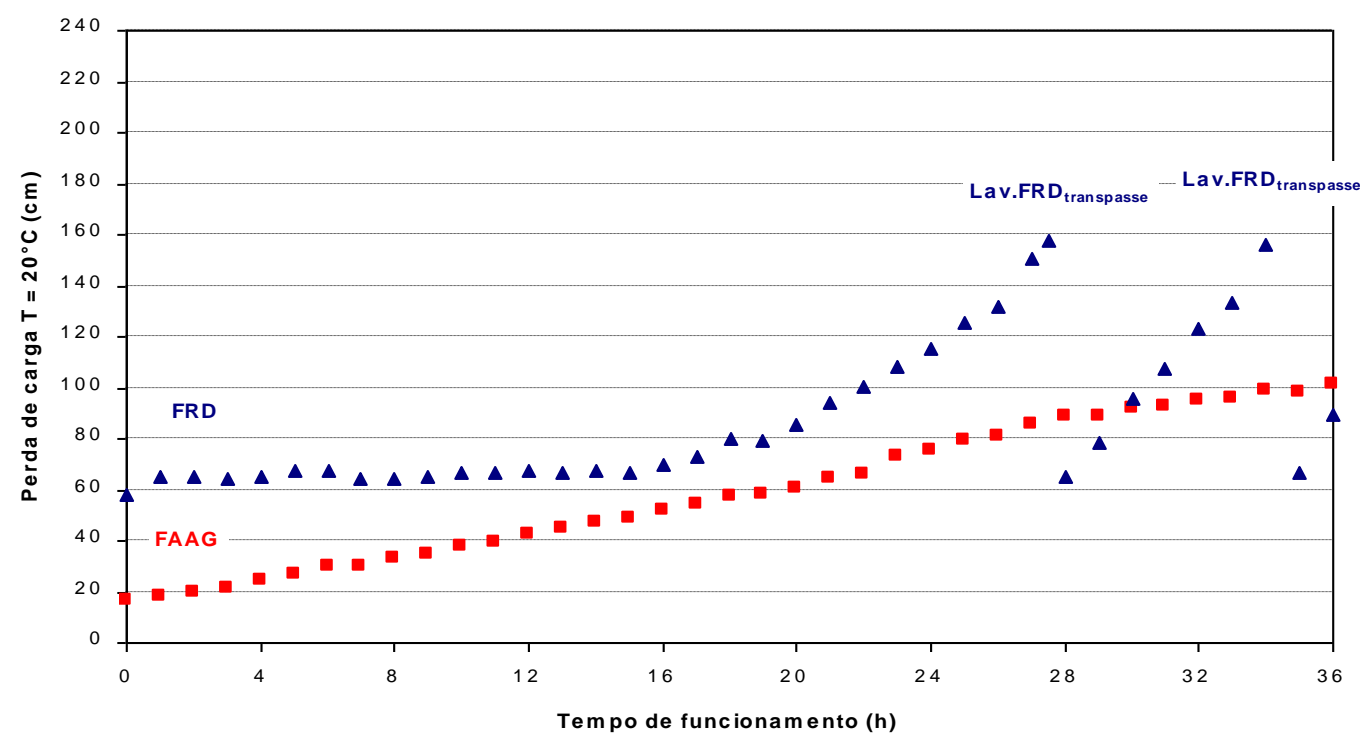

Figura 5.60 - Evolução da perda de carga no FAAG $\left(180 \mathrm{~m}^{3} / \mathrm{m}^{2} \mathrm{~d}\right)$ e no FRD $\left(280 \mathrm{~m}^{3} / \mathrm{m}^{2} \mathrm{~d}\right)$ para $T=20^{\circ} \mathrm{C}$ durante 0 ensaio 12 , pré-oxidação com dióxido de cloro e sem DFls no FAAG. Fonte: Tabela C 5.3 do ANEXO C. 
$\mathrm{Na}$ Tabela 5.25 está apresentado o resumo das condições de coagulação e oxidação, e das características da água bruta, água de estudo, água pré-oxidada e efluentes do FAAG e FRD durante o ensaio 12.

Tabela 5.25 - Resumo dos resultados obtidos no ensaio 12 - pré-oxidação com dióxido de cloro.

\begin{tabular}{|c|c|c|c|c|c|}
\hline & \multicolumn{5}{|c|}{ ENSAIO 12 - pré-oxidação com dióxido de cloro } \\
\hline Taxas de filtração médias & \multicolumn{5}{|c|}{$\mathrm{FAAG}=186$ e $\mathrm{FRD}=279 \mathrm{~m}^{3} / \mathrm{m}^{2} \mathrm{~d}$} \\
\hline Condições de coagulação & \multicolumn{5}{|c|}{$\begin{array}{c}\mathrm{D}_{\mathrm{SA}} \cong 4,0 \mathrm{mg} / \mathrm{L} ; \mathrm{pH} \text { de coagulação }=5,09 \text { a } 5,47 ; \\
\text { temperatura }=16 \text { a } 22^{\circ} \mathrm{C}\end{array}$} \\
\hline $\begin{array}{l}\text { Condições de pré- } \\
\text { oxidação }\end{array}$ & \multicolumn{5}{|c|}{ Dosagem aplicada de $\mathrm{ClO}_{2} \cong 0,4 \mathrm{mg} / \mathrm{L}$} \\
\hline Duração da carreira & \multicolumn{5}{|c|}{$36 \mathrm{~h}$} \\
\hline Características & AB & AE & APO & $\begin{array}{l}\text { Efluente do } \\
\text { FAAG }\end{array}$ & $\begin{array}{l}\text { Efluente do } \\
\text { FRD }\end{array}$ \\
\hline $\mathrm{pH}$ & 6,58 a 6,70 & 6,70 a 7,00 & $\begin{array}{c}6,25 \mathrm{a} \\
6,57 \\
\end{array}$ & NR & NR \\
\hline $\begin{array}{l}\text { Alcalinidade } \\
\left(\mathrm{mg} / \mathrm{L} \mathrm{CaCO}_{3}\right)\end{array}$ & 6,4 a 7,7 & 7,3 a 8,8 & 4,8 a 6,4 & NR & NR \\
\hline Cor aparente $(\mathrm{uH})$ & 88 a 103 & 167 a 184 & 161 a 179 & $<1$ a 88 & $<1$ a $10^{(*)}$ \\
\hline Cor verdadeira $(\mathrm{uH})$ & 12 a 16 & 94 a 107 & 88 a 102 & NR & NR \\
\hline Turbidez (uT) & 7,4 a 12,1 & NR & NR & $<0,01$ a 7,3 & $<0,01$ a 1 \\
\hline Absorvância 254 nm & 0,043 a 0,056 & $\begin{array}{c}0,174 \text { a } \\
0,189\end{array}$ & $\begin{array}{c}0,165 \text { a } \\
0,181\end{array}$ & $\begin{array}{c}0,007 \text { a } \\
0,021\end{array}$ & 0,010 a 0,023 \\
\hline $\mathrm{COD}(\mathrm{mg} / \mathrm{L})$ & 1,5 a 2,4 & 3,5 a 4,2 & 3,2 a 4,0 & 1,6 a 4,3 & 1,4 a 2,5 \\
\hline Ferro (mg/L) & 1,179 a 1,328 & $\begin{array}{l}1,164 \mathrm{a} \\
1,436\end{array}$ & $\begin{array}{c}0,958 \text { a } \\
1,063\end{array}$ & $\begin{array}{c}0,453 \mathrm{a} \\
0,517\end{array}$ & 0,126 a 0,202 \\
\hline Manganês (mg/L) & 0,046 a 0,056 & $\begin{array}{c}0,047 \text { a } \\
0,048\end{array}$ & $\begin{array}{c}0,020 \text { a } \\
0,041\end{array}$ & $\begin{array}{c}0,013 \mathrm{a} \\
0,021\end{array}$ & 0,016 a 0,019 \\
\hline $\begin{array}{l}\text { Residual de oxidante } \\
(\mathrm{mg} / \mathrm{L})\end{array}$ & NR & NR & NR & $<0,01$ & $<0,01$ \\
\hline Alumínio residual (mg/L) & $<0,01$ a 0,01 & ND & NR & 0,04 a 0,11 & 0,02 a 0,10 \\
\hline
\end{tabular}

$\mathrm{D}_{\mathrm{SA}}=$ dosagem de $\mathrm{Al}_{2}\left(\mathrm{SO}_{4}\right)_{3} .14,3 \mathrm{H}_{2} \mathrm{O} ; \mathrm{AB}$ = água bruta; $\mathrm{AE}$ = água de estudo; $\mathrm{APO}$ = água pré-oxidada; $\mathrm{FAAG}=$ filtro ascendente de areia grossa; $\mathrm{FRD}$ = filtro rápido descendente; $\mathrm{COD}=$ carbono orgânico dissolvido; $\mathrm{ND}=$ não detectado; NR = não realizado. ${ }^{(*)}$ Valor observado no início do ensaio.

Nas Tabelas C 5.1 a C 5.4 do ANEXO C estão apresentados todos os resultados obtidos durante o ensaio 12.

A cor aparente do efluente do FRD se manteve $\leq 1 \mathrm{uH}$, na maior parte do tempo, com exceção de valores de 3, 6 e 10 uH observados nos tempos de 24, 26 e 34 horas de funcionamento, caracterizados pelos inícios dos transpasses no FRD, observados na Figura 5.61. O início do transpasse no FAAG ocorreu a partir das 16 horas de funcionamento, chegando a cor aparente de $88 \mathrm{uH}$ ao término do ensaio. 


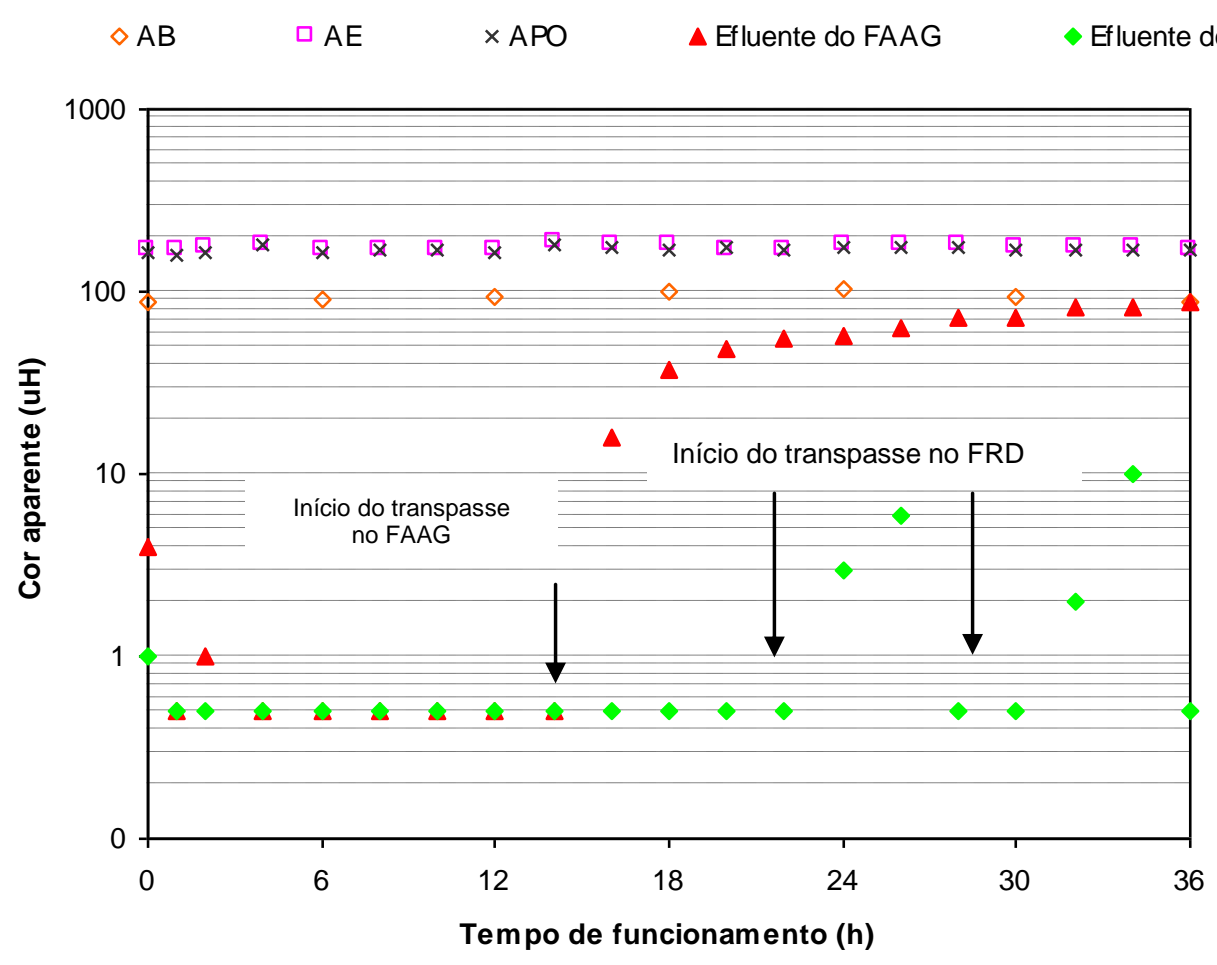

Figura 5.61 - Variação de cor aparente na AB, AE, APO e efluentes do FAAG e FRD, e cor verdadeira na $A B$ de 12 a $16 \mathrm{uH}$, na $A E$ de 94 a $107 \mathrm{uH}$ e na APO de 88 a $102 \mathrm{uH}$, durante o ensaio 12 - pré-oxidação com dióxido de cloro (FAAG $=180 \mathrm{~m}^{2} / \mathrm{m}^{3} \mathrm{~d}$ e $\mathrm{FRD}=280$ $\left.\mathrm{m}^{2} / \mathrm{m}^{3} \mathrm{~d}\right)$.

A turbidez do efluente do FRD manteve-se $<1$ uT durante a maior parte do tempo, com exceção da ocorrência de dois transpasses no filtro que iniciaram após 20 e 30 horas de funcionamento, sendo necessária a lavagem do filtro. Observa-se na Figura 5.62 o início do transpasse no FAAG após 14 horas de funcionamento, ocorrendo também o aumento gradual na cor aparente do efluente do FAAG, mostrado na Figura 5.61.

Quanto à remoção de substâncias húmicas, em termos de absorvância 254 $\mathrm{nm}$ e COD, as porcentagens de remoção foram respectivamente, da ordem de 87 a $94 \%$ e 38 a $62 \%$ no FRD. Nas Figuras 5.63 e 5.64 estão as variações da absorvância 254 nm e do COD durante o ensaio 12. 


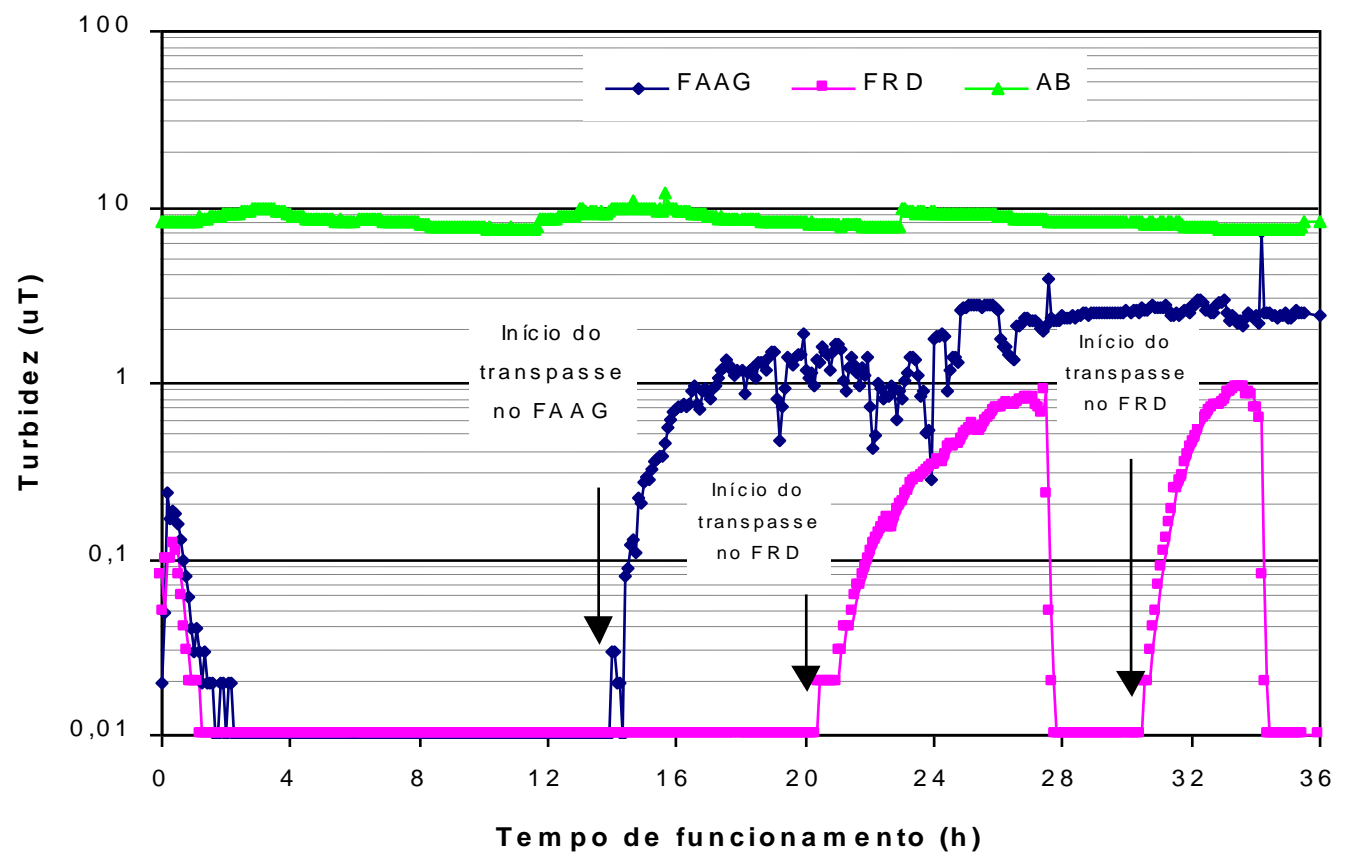

Figura 5.62 - Variação da turbidez na $A B$ e nos efluentes do FAAG $\left(180 \mathrm{~m}^{3} / \mathrm{m}^{2} \mathrm{~d}\right)$ e $F R D$ $\left(280 \mathrm{~m}^{2} / \mathrm{m}^{3} \mathrm{~d}\right)$ durante o ensaio 12 - pré-oxidação com dióxido de cloro e sem DFls no FAAG.

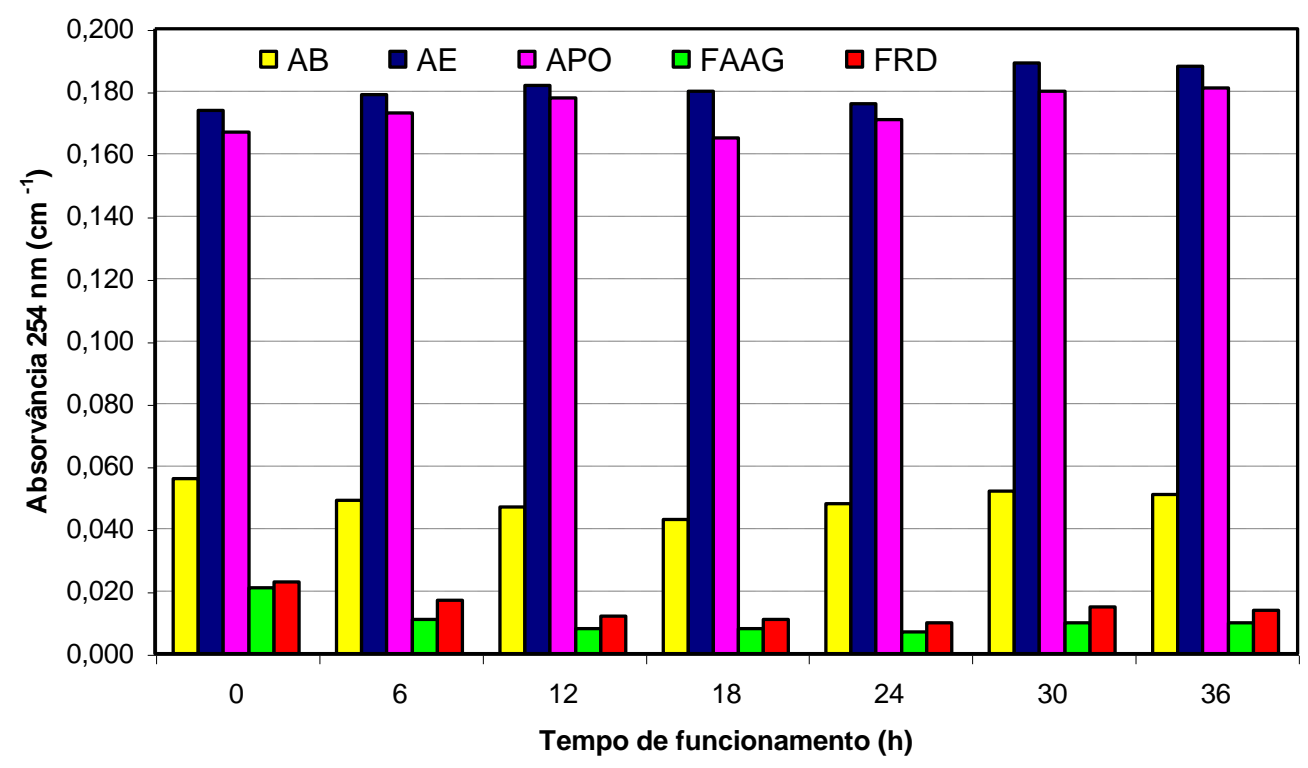

Figura 5.63 - Variação de absorvância $254 \mathrm{~nm}$ na $A B, A E, A P O$ e nos efluentes do FAAG e do FRD durante o ensaio 12, pré-oxidação com dióxido de cloro e sem DFIs no FAAG $\left(F A A G=180 \mathrm{~m}^{3} / \mathrm{m}^{2} \mathrm{~d}\right.$ e FRD $\left.=280 \mathrm{~m}^{3} / \mathrm{m}^{2} \mathrm{~d}\right)$. Fonte: Tabela C 5.2 do ANEXO C. 


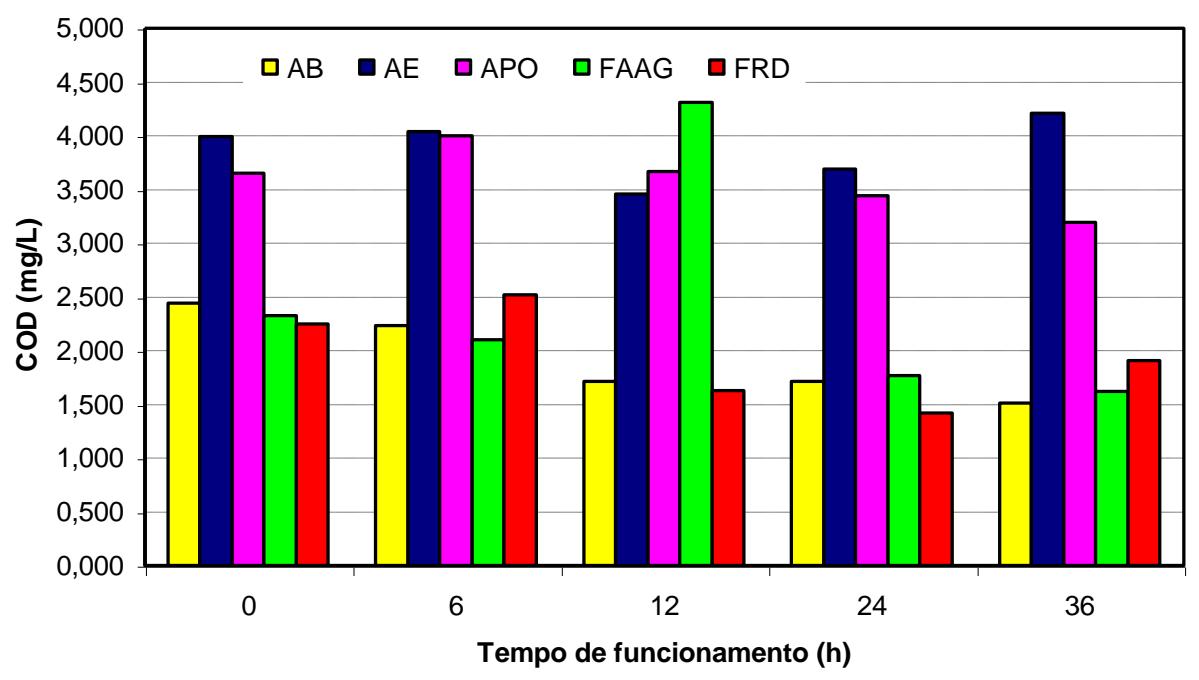

Figura 5.64 - Variação de $C O D$ na $A B, A E, A P O$ e nos efluentes do FAAG e do FRD durante o ensaio 12, pré-oxidação com dióxido de cloro e sem DFls no FAAG (FAAG $=180$ $\mathrm{m}^{3} / \mathrm{m}^{2} \mathrm{~d}$ e FRD $=280 \mathrm{~m}^{3} / \mathrm{m}^{2} \mathrm{~d}$ ). Fonte: Tabela C 5.2 do ANEXO C.

\subsubsection{Ensaio 13 - Pré-oxidação com Permanganato de Potássio}

Foi preparada uma solução estoque de permanganato de potássio com concentração de $500 \mathrm{mg} / \mathrm{L}$. Com o ensaio preliminar na instalação piloto em escoamento contínuo foram determinadas as dosagens de permanganato de potássio e de $\mathrm{Al}_{2}\left(\mathrm{SO}_{4}\right)_{3} .14,3 \mathrm{H}_{2} \mathrm{O}$, de 1,0 e $4,0 \mathrm{mg} / \mathrm{L}$ respectivamente, para $\mathrm{pH}$ de coagulação da ordem de 5,5. A vazão na bomba dosadora foi calculada pela equação (4.5):

Para $C=1 \mathrm{mg} / \mathrm{L} ; \mathrm{C}_{\mathrm{SE}}=500 \mathrm{mg} / \mathrm{L}$ e $\mathrm{Q}_{\mathrm{ab}}=170 \mathrm{~L} / \mathrm{h}:$

$$
1=\frac{0 * 170+500 * Q_{b d}}{170+Q_{b d}} \Rightarrow Q_{b d}=0,34 L / h
$$

As taxas de filtração médias no FAAG e no FRD durante este ensaio foram de 184 e $279 \mathrm{~m}^{3} / \mathrm{m}^{2} \mathrm{~d}$ respectivamente (ver Tabela C 6.4 do ANEXO C). Na Figura 5.65 está apresentada a evolução da perda de carga no FAAG e no FRD para a temperatura de $20^{\circ} \mathrm{C}$. Foram executadas duas lavagens no $\mathrm{FRD}$ devido à ocorrência do transpasse, nos tempos de 27 e 34 horas de funcionamento. A perda de carga final no FAAG foi de $107,7 \mathrm{~cm}$, com redução de $48 \%$ comparada ao ensaio 8 - sem pré-oxidação. Nas Figuras C 6.1 e C 6.2 do ANEXO C estão as perdas de carga ao longo do meio filtrante do FAAG e do FRD. 


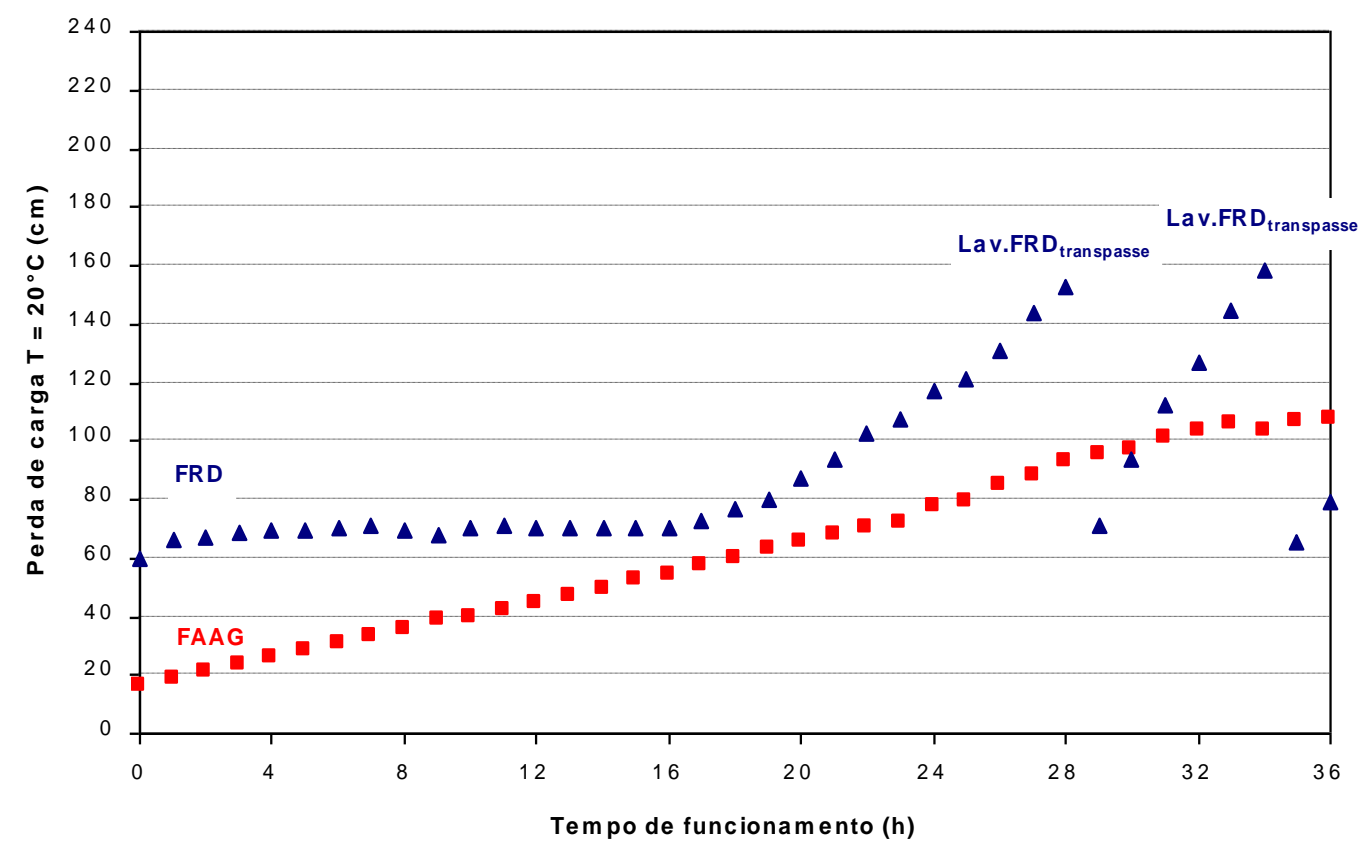

Figura 5.65 - Evolução da perda de carga no FAAG $\left(180 \mathrm{~m}^{3} / \mathrm{m}^{2} \mathrm{~d}\right)$ e no FRD $\left(280 \mathrm{~m}^{2} / \mathrm{m}^{3} \mathrm{~d}\right)$ para $T=20^{\circ} \mathrm{C}$ durante 0 ensaio 13 , pré-oxidação com permanganato de potássio e sem DFIs no FAAG. Fonte: Tabela C 6.3 do ANEXO C.

Na Tabela 5.26 está apresentado o resumo das condições de coagulação e oxidação, e das características da água bruta, água de estudo, água pré-oxidada e efluentes do FAAG e FRD durante o ensaio 13. Nas Tabelas C 6.1 a C 6.4 do ANEXO C estão todos os resultados obtidos no ensaio 13.

A cor aparente do efluente do FRD se manteve $\leq 1 \mathrm{uH}$, na maior parte do tempo, com exceção de valores de 4, 10 e 6 uH observados nos tempos de 26, 28 e 34 horas de funcionamento, caracterizados pelos inícios dos transpasses no FRD, observados na Figura 5.66. O início do transpasse no FAAG ocorreu a partir das 16 horas de funcionamento, chegando à cor aparente de $111 \mathrm{uH}$ ao término do ensaio.

A turbidez do efluente do FRD manteve-se $<1$ uT durante a maior parte do tempo, com exceção da ocorrência de dois transpasses no filtro que iniciaram após 20 e 30 horas de funcionamento, sendo necessária a lavagem do filtro. Observa-se na Figura 5.67 o início do transpasse no FAAG após 14 horas de funcionamento, ocorrendo também um aumento gradual na cor aparente do efluente do FAAG, mostrado na Figura 5.66. 
Tabela 5.26 - Resumo dos resultados obtidos no ensaio 13 - pré-oxidação com permanganato de potássio.

\begin{tabular}{|c|c|c|c|c|c|}
\hline & \multicolumn{5}{|c|}{ ENSAIO 13 - pré-oxidação com permanganato de potássio } \\
\hline "Taxas de filtração médias & \multicolumn{5}{|c|}{ FAAG $=184$ e $F R D=279 \mathrm{~m}^{3} / \mathrm{m}^{2} \mathrm{~d}$} \\
\hline Condições de coagulação & \multicolumn{5}{|c|}{$\begin{array}{c}\mathrm{D}_{\mathrm{SA}} \cong 4,0 \mathrm{mg} / \mathrm{L} ; \mathrm{pH} \text { de coagulação }=5,20 \text { a } 5,61 ; \\
\text { temperatura }=18 \text { a } 22^{\circ} \mathrm{C}\end{array}$} \\
\hline $\begin{array}{l}\text { Condições de pré- } \\
\text { oxidação }\end{array}$ & \multicolumn{5}{|c|}{ Dosagem aplicada de $\mathrm{KMnO}_{4} \cong 1,0 \mathrm{mg} / \mathrm{L}$} \\
\hline Duração da carreira & \multicolumn{5}{|c|}{$36 \mathrm{~h}$} \\
\hline Características & AB & AE & APO & $\begin{array}{c}\text { Efluente do } \\
\text { FAAG }\end{array}$ & $\begin{array}{c}\text { Efluente do } \\
\text { FRD }\end{array}$ \\
\hline $\mathrm{pH}$ & 6,34 a 6,56 & 6,52 a 6,68 & $\begin{array}{c}6,23 \mathrm{a} \\
6,50\end{array}$ & NR & NR \\
\hline $\begin{array}{l}\text { Alcalinidade } \\
\left(\mathrm{mg} / \mathrm{L} \mathrm{CaCO}_{3}\right)\end{array}$ & 4,8 a 7,3 & 6,8 a 8,8 & 5,5 a 7,5 & NR & NR \\
\hline Cor aparente $(\mathrm{uH})$ & 73 a 85 & 155 a 186 & 220 a 252 & $<1$ a 115 & $<1$ a $10^{(*)}$ \\
\hline Cor verdadeira $(\mathrm{uH})$ & 12 a 14 & 96 a 111 & 124 a 144 & NR & NR \\
\hline Turbidez (uT) & 7 a 11,2 & NR & NR & 0,03 a 14,0 & $<0,01$ a 1 \\
\hline Absorvância 254 nm & 0,042 a 0,051 & $\begin{array}{c}0,166 \mathrm{a} \\
0,183 \\
\end{array}$ & $\begin{array}{c}0,183 \mathrm{a} \\
0,198 \\
\end{array}$ & $\begin{array}{c}0,003 \mathrm{a} \\
0,013\end{array}$ & 0,007 a 0,016 \\
\hline $\mathrm{COD}(\mathrm{mg} / \mathrm{L})$ & 2,1 a 3,1 & 3,5 a 4,3 & 3,2 a 4,0 & 1,9 a 2,9 & 2,0 a 2,9 \\
\hline Ferro (mg/L) & 0,587 a 0,842 & $\begin{array}{c}0,780 \mathrm{a} \\
0,847 \\
\end{array}$ & $\begin{array}{c}0,731 \mathrm{a} \\
1,536 \\
\end{array}$ & $\begin{array}{c}0,054 \mathrm{a} \\
0,204 \\
\end{array}$ & 0,016 a 0,071 \\
\hline Manganês ( mg/L) & 0,301 a 0,408 & $\begin{array}{c}0,515 a \\
0,416 \\
\end{array}$ & $\begin{array}{c}0,401 \mathrm{a} \\
0,510 \\
\end{array}$ & $\begin{array}{c}0,157 \mathrm{a} \\
0,353 \\
\end{array}$ & 0,056 a 0,087 \\
\hline $\begin{array}{l}\text { Residual de oxidante } \\
(\mathrm{mg} / \mathrm{L})\end{array}$ & NR & NR & NR & 0,03 a 0,073 & 0,026 a 0,047 \\
\hline Alumínio residual (mg/L) & $<0,01$ a 0,01 & $<0,01$ a 0,01 & NR & 0,04 a 0,17 & 0,03 a 0,15 \\
\hline
\end{tabular}

Quanto à remoção de substâncias húmicas, em termos de absorvância 254 $\mathrm{nm}$ e COD, as porcentagens de remoção foram respectivamente, da ordem de 91 a $96 \%$ e 32 a $53 \%$ no FRD. Nas Figuras 5.68 e 5.69 estão as variações da absorvância $254 \mathrm{~nm}$ e do COD durante o ensaio 13. 


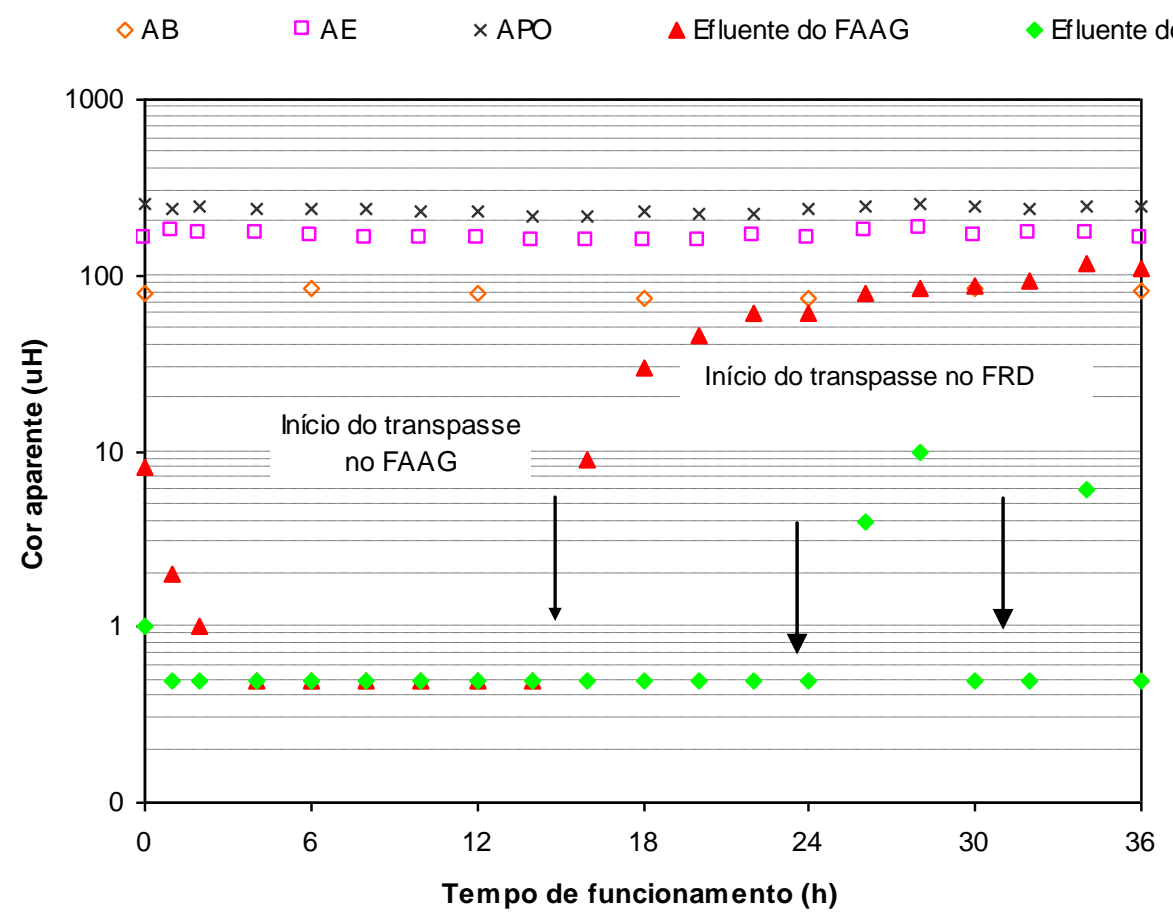

Figura 5.66 - Variação de cor aparente na $A B, A E$, APO e efluentes do FAAG e FRD, e cor verdadeira a $A B$ de 12 a $14 \mathrm{uH}$, na $A E$ de 96 a $111 \mathrm{uH}$ e na APO de 124 a $144 \mathrm{uH}$, durante o ensaio 13 - pré-oxidação com permanganato de potássio. Fonte: Tabela C 6.1 do ANEXO C.

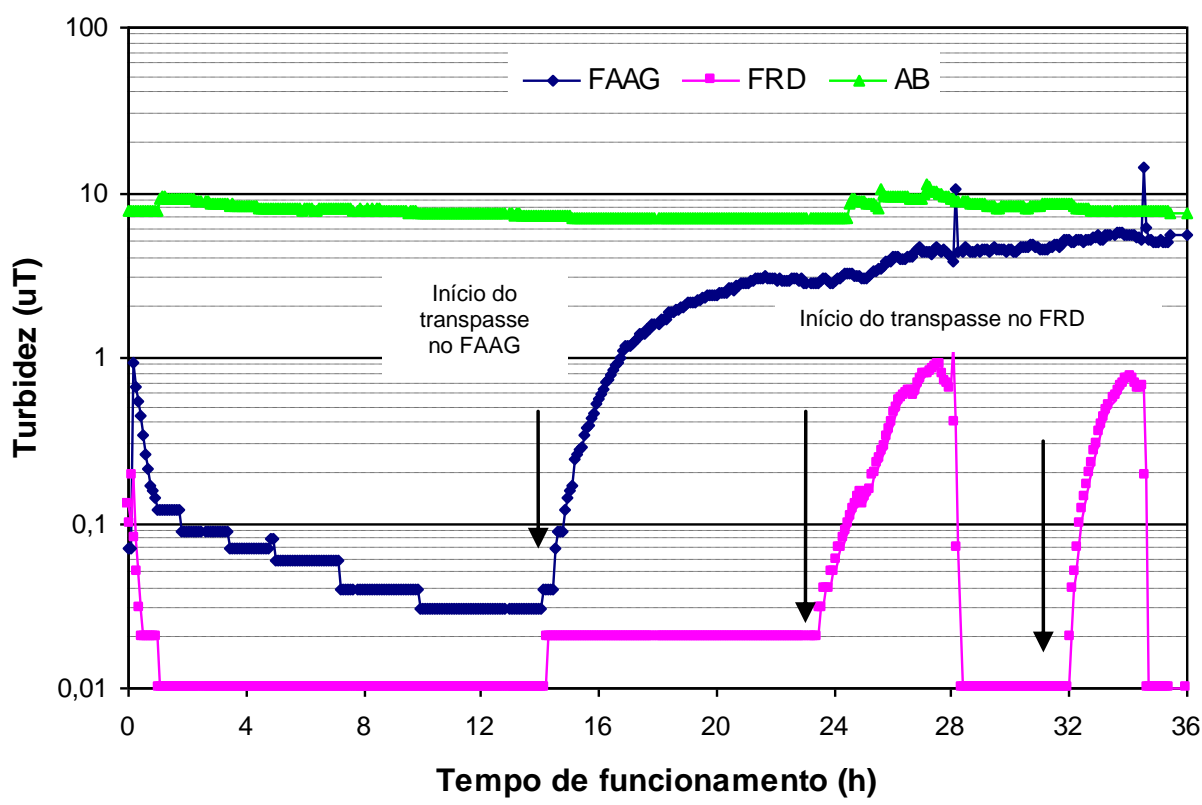

Figura 5.67 - Variação da turbidez na $A B$ e nos efluentes do FAAG $\left(180 \mathrm{~m}^{3} / \mathrm{m}^{2} \mathrm{~d}\right)$ e FRD $\left(280 \mathrm{~m}^{2} / \mathrm{m}^{3} \mathrm{~d}\right)$ durante o ensaio 13 - pré-oxidação com permanganato de potássio e sem DFIs no FAAG. 


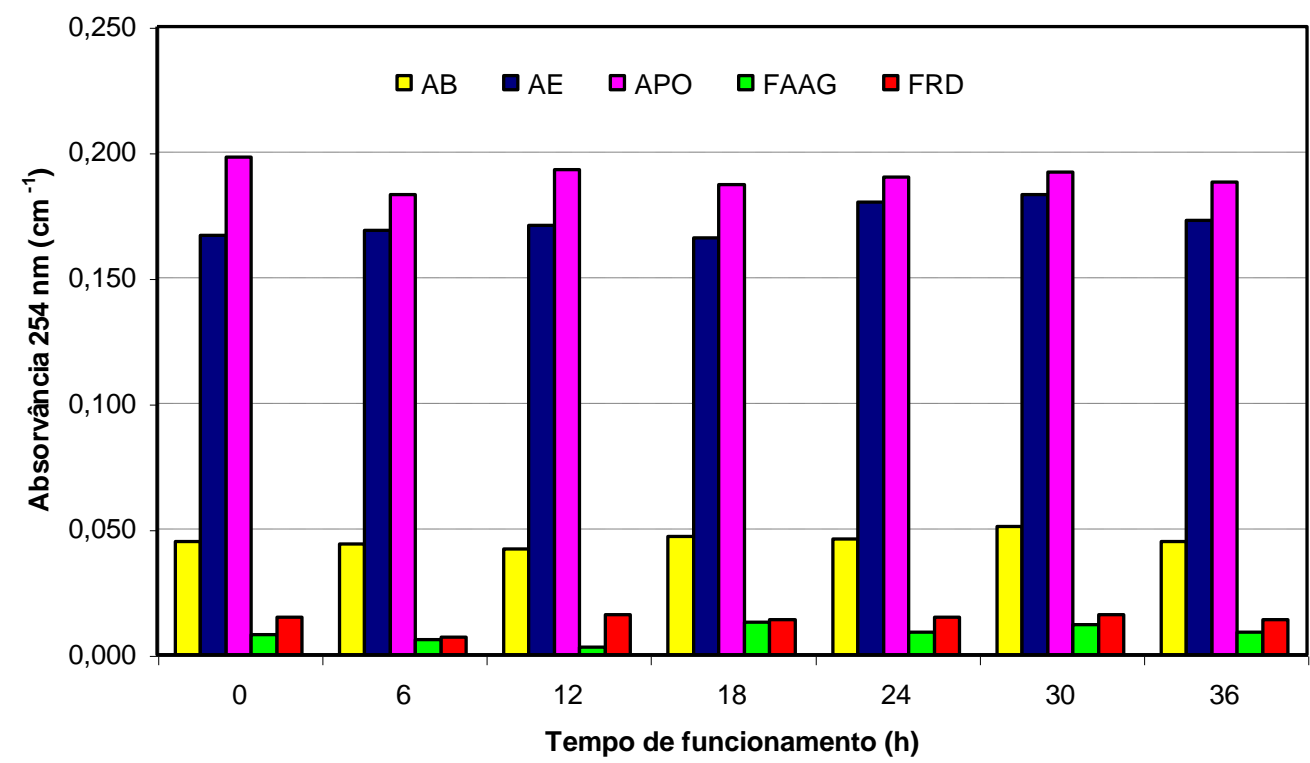

Figura 5.68 - Variação de absorvância $254 \mathrm{~nm}$ na $A B, A E, A P O$ e nos efluentes do FAAG e do FRD durante o ensaio 13, pré-oxidação com permanganato de potássio e sem DFls no FAAG $\left(F A A G=180 \mathrm{~m}^{3} / \mathrm{m}^{2} \mathrm{~d}\right.$ e FRD $=280 \mathrm{~m}^{3} / \mathrm{m}^{2} \mathrm{~d}$ ). Fonte: Tabela C 6.2 do ANEXO C.

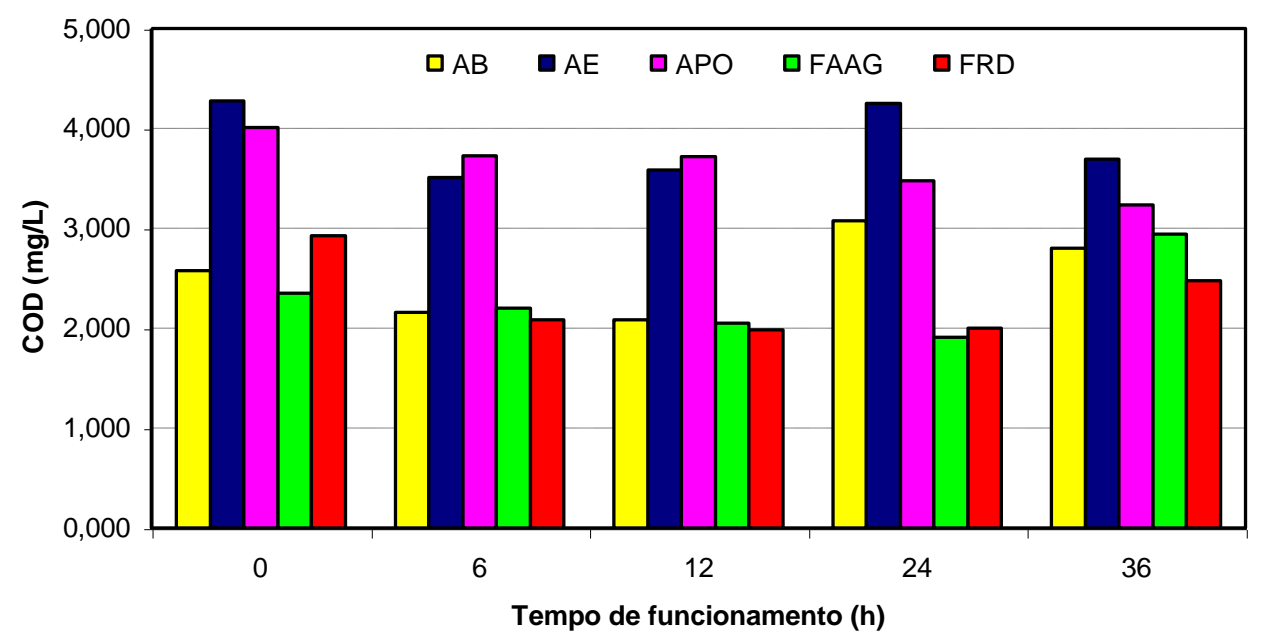

Figura 5.69 - Variação de $C O D$ na $A B, A E, A P O$ e nos efluentes do FAAG e do FRD durante 0 ensaio 13 , pré-oxidação com permanganato de potássio e sem DFls no FAAG $\left(F A A G=180 \mathrm{~m}^{3} / \mathrm{m}^{2} \mathrm{~d}\right.$ e FRD $=280 \mathrm{~m}^{3} / \mathrm{m}^{2} \mathrm{~d}$ ). Fonte: Tabela C 6.2 do ANEXO C.

\subsubsection{Ensaio 14 - Pré-oxidação com Peroxônio}

Foi preparada uma solução estoque de peróxido de hidrogênio com concentração de $250 \mathrm{mg} / \mathrm{L}$. Adicionava-se peróxido de hidrogênio na saída da caixa 
de homogeneização de substâncias húmicas e aplicava-se ozônio na coluna de ozonização.

Neste ensaio fixou-se a dosagem de ozônio e variou-se a dosagem de peróxido de hidrogênio na proporção de aproximadamente 1:2 de $\mathrm{H}_{2} \mathrm{O}_{2}: \mathrm{O}_{3}$. A dosagem de $\mathrm{Al}_{2}\left(\mathrm{SO}_{4}\right)_{3} .14,3 \mathrm{H}_{2} \mathrm{O}$ e $\circ \mathrm{pH}$ de coagulação foram variados até obter 0 par de valores que resultasse cor aparente no efluente do FRD $\leq 5 \mathrm{uH}$, no ensaio preliminar na instalação piloto em escoamento contínuo. Para esta condição, as melhores dosagens obtidas foram: $1 \mathrm{mg} / \mathrm{L}$ de $\mathrm{H}_{2} \mathrm{O}_{2}: 2 \mathrm{mg} / \mathrm{L}$ de $\mathrm{O}_{3}$, dosagem de $\mathrm{Al}_{2}\left(\mathrm{SO}_{4}\right)_{3} \cdot 14,3 \mathrm{H}_{2} \mathrm{O} \cong 4 \mathrm{mg} / \mathrm{L}$ e pH de coagulação da ordem de 5,5.

Para $C=1,0 \mathrm{mg} / \mathrm{L} ; C_{S E}=250 \mathrm{mg} / \mathrm{L}$ e $Q_{a b}=170 \mathrm{~L} / \mathrm{h}$, a vazão na bomba dosadora foi de:

$$
1=\frac{0 * 170+250 * Q_{b d}}{170+Q_{b d}} \Rightarrow Q_{b d}=0,68 L / h
$$

As taxas de filtração médias no FAAG e no FRD foram de 183 e $282 \mathrm{~m}^{3} / \mathrm{m}^{2} \mathrm{~d}$ respectivamente (ver Tabela C 7.4 do ANEXO C). Na Figura 5.70 está apresentada a evolução da perda de carga no FAAG e no FRD durante o ensaio 14, para a temperatura de $20^{\circ} \mathrm{C}$. Neste ensaio não foi necessária a lavagem do FRD e a perda de carga final no FAAG foi de $100,3 \mathrm{~cm}$, com redução de $51,7 \%$ comparada ao ensaio 8. Nas Figuras C 7.1 e C 7.2 estão as perdas de carga ao longo do meio filtrante no FAAG e no FRD.

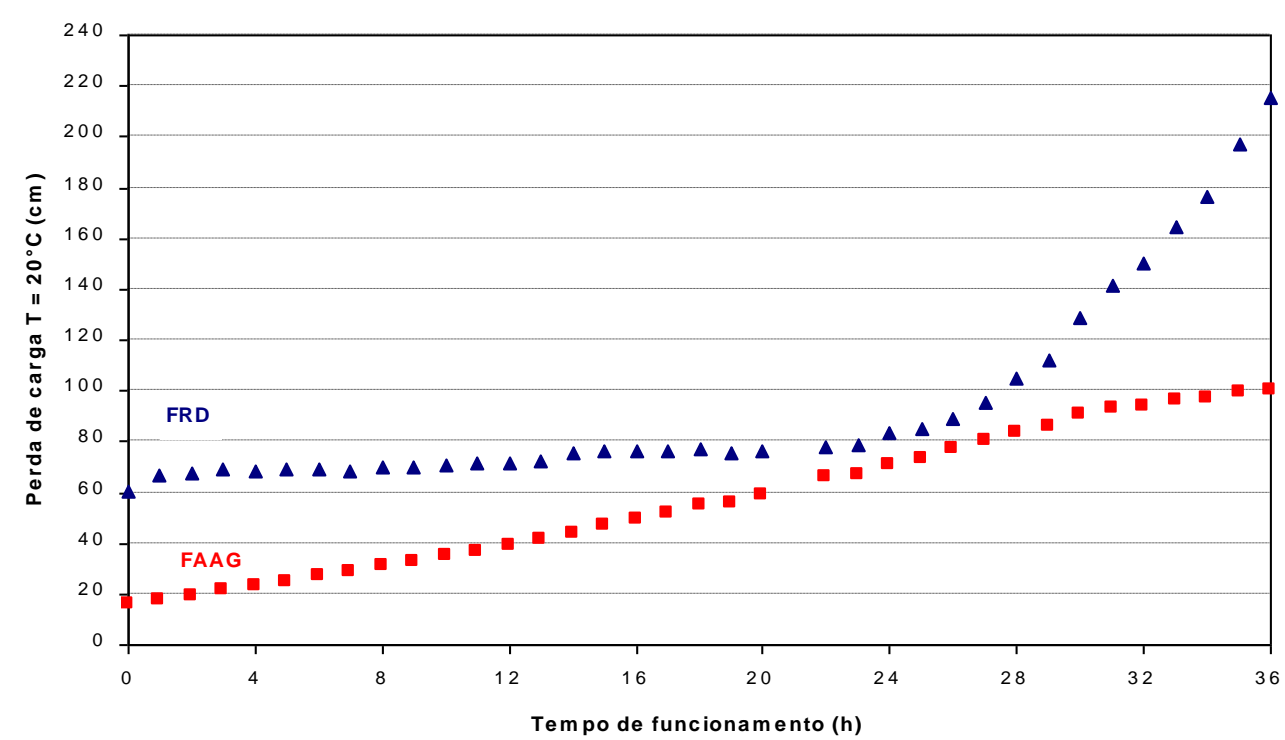

Figura 5.70 - Evolução da perda de carga no FAAG $\left(180 \mathrm{~m}^{3} / \mathrm{m}^{2} \mathrm{~d}\right)$ e no FRD $\left(280 \mathrm{~m}^{2} / \mathrm{m}^{3} \mathrm{~d}\right)$ para $\mathrm{T}=20^{\circ} \mathrm{C}$ durante o ensaio 14 , pré-oxidação com peroxônio e sem DFls no FAAG. Fonte: Tabela C 7.3 do ANEXO C. 
Na Tabela 5.27 está apresentado o resumo das condições de coagulação e oxidação, e das características da água bruta, água de estudo, água pré-oxidada e efluentes do FAAG e FRD durante o ensaio 14. Nas Tabelas C 7.1 a C 7.4 do ANEXO C estão todos os resultados obtidos durante o ensaio 14.

Na Figura 5.71 observa-se que a cor aparente do efluente do FRD se manteve $\leq 1 \mathrm{uH}$ durante todo o tempo, com exceção do valor de $6 \mathrm{uH}$ no início do ensaio. O início do transpasse no FAAG ocorreu a partir das 24 horas de funcionamento, chegando à cor aparente de $49 \mathrm{uH}$ ao término do ensaio.

A turbidez do efluente do FRD manteve-se $<1$ uT durante a maior parte do tempo. Observa-se na Figura 5.72 o início do transpasse no FAAG após 22 horas de funcionamento, ocorrendo também um aumento gradual na cor aparente do efluente do FAAG, mostrado na Figura 5.71.

Tabela 5.27 - Resumo dos resultados obtidos no ensaio 14, pré-oxidação com peroxônio.

\begin{tabular}{|c|c|c|c|c|c|}
\hline & \multicolumn{5}{|c|}{ ENSAIO 14 - pré-oxidação com peroxônio } \\
\hline "Taxas de filtração médias & \multicolumn{5}{|c|}{$\mathrm{FAAG}=183$ e $\mathrm{FRD}=282 \mathrm{~m}^{3} / \mathrm{m}^{2} \mathrm{~d}$} \\
\hline Condições de coagulação & \multicolumn{5}{|c|}{$\begin{array}{c}\mathrm{D}_{\mathrm{SA}} \cong 4,0 \mathrm{mg} / \mathrm{L} ; \mathrm{pH} \text { de coagulação }=5,12 \text { a } 5,51 ; \\
\text { temperatura }=21 \text { a } 25^{\circ} \mathrm{C}\end{array}$} \\
\hline $\begin{array}{l}\text { Condições de pré- } \\
\text { oxidação }\end{array}$ & \multicolumn{5}{|c|}{$\begin{array}{l}\text { Dosagem de } \mathrm{H}_{2} \mathrm{O}_{2} \cong 1,0 \text { a } 1,3 \mathrm{mg} / \mathrm{L} ; \text { dosagem de } \mathrm{O}_{3} \cong 2,0 \text { a } 2,6 \mathrm{mg} / \mathrm{L} \\
\qquad\left(\mathrm{H}_{2} \mathrm{O}_{2}: \mathrm{O}_{3} \cong 0,5\right)\end{array}$} \\
\hline Duração da carreira & \multicolumn{5}{|c|}{$36 \mathrm{~h}$} \\
\hline Características & AB & $\mathbf{A E}$ & APO & $\begin{array}{l}\text { Efluente do } \\
\text { FAAG }\end{array}$ & $\begin{array}{l}\text { Efluente do } \\
\text { FRD }\end{array}$ \\
\hline $\mathrm{pH}$ & 6,80 a 7,41 & 6,77 a 7,08 & $\begin{array}{c}6,15 a \\
6,61\end{array}$ & NR & NR \\
\hline $\begin{array}{l}\text { Alcalinidade } \\
\left(\mathrm{mg} / \mathrm{L} \mathrm{CaCO}_{3}\right)\end{array}$ & 8,4 a 11,5 & 9,4 a 11,3 & 6,5 a 8,4 & NR & NR \\
\hline Cor aparente $(\mathrm{uH})$ & 106 a 118 & 179 a 201 & 126 a 148 & $<1$ a 49 & $<1$ a $6^{(*)}$ \\
\hline Cor verdadeira $(\mathrm{uH})$ & 17 a 22 & 94 a 109 & 51 a 71 & NR & NR \\
\hline Turbidez (uT) & 7,7 a 12,1 & NR & NR & 0,05 a 3,7 & $<0,01$ a 1 \\
\hline Absorvância 254 nm & 0,065 a 0,073 & $\begin{array}{c}0,183 \text { a } \\
0,197\end{array}$ & $\begin{array}{c}0,113 a \\
0,137\end{array}$ & $\begin{array}{c}0,008 \mathrm{a} \\
0,026\end{array}$ & 0,011 a 0,030 \\
\hline $\mathrm{COD}(\mathrm{mg} / \mathrm{L})$ & 2,3 a 2,6 & 3,7 a 4,5 & 3,4 a 4,0 & 2,5 a 3,0 & 2,2 a 2,8 \\
\hline Ferro (mg/L) & 1,224 a 1,453 & $\begin{array}{l}1,425 a \\
1,515\end{array}$ & $\begin{array}{c}1,371 \mathrm{a} \\
1,479\end{array}$ & $\begin{array}{c}0,099 \mathrm{a} \\
0,173\end{array}$ & 0,036 a 0,098 \\
\hline Manganês (mg/L) & 0,302 a 0,515 & $\begin{array}{c}0,323 a \\
0,497\end{array}$ & $\begin{array}{c}0,328 \mathrm{a} \\
0,396\end{array}$ & $\begin{array}{c}0,104 \mathrm{a} \\
0,270\end{array}$ & 0,059 a 0,081 \\
\hline $\begin{array}{l}\text { Residual de oxidante } \\
\text { (mg/L) }\end{array}$ & NR & NR & NR & ND & ND \\
\hline Alumínio residual (mg/L) & ND & ND & NR & 0,15 a 0,23 & 0,13 a 0,20 \\
\hline
\end{tabular}

$\mathrm{D}_{\mathrm{SA}}=$ dosagem de $\mathrm{Al}_{2}\left(\mathrm{SO}_{4}\right)_{3} .14,3 \mathrm{H}_{2} \mathrm{O} ; \mathrm{AB}$ = água bruta; $\mathrm{AE}$ = água de estudo; $\mathrm{APO}$ = água pré-oxidada; $\mathrm{FAAG}=$ filtro ascendente de areia grossa; $\mathrm{FRD}$ = filtro rápido descendente; $\mathrm{COD}=$ carbono orgânico dissolvido; $\mathrm{ND}=$ não detectado; $\mathrm{NR}=$ não realizado. ${ }^{(*)}$ Valor observado no início do ensaio. 


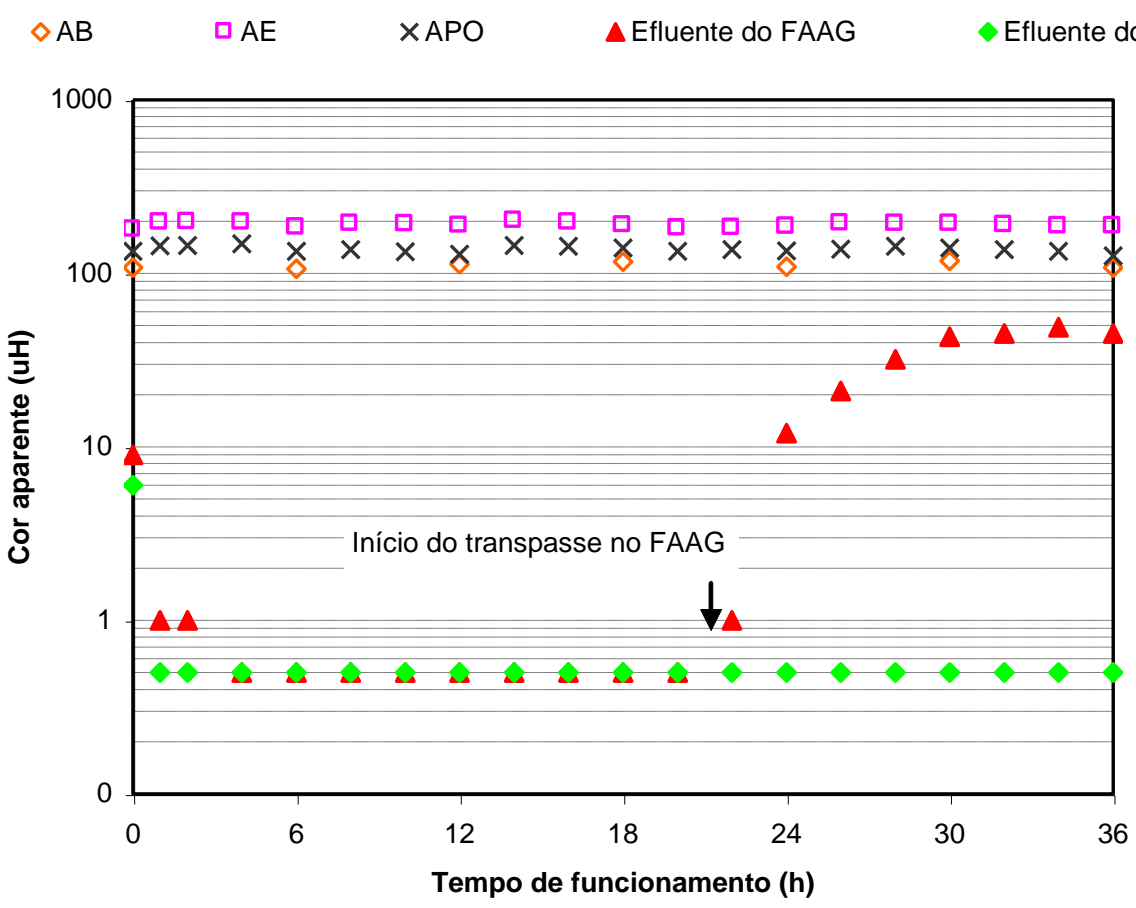

Figura 5.71 - Variação de cor aparente na $A B, A E, A P O$ e efluentes do FAAG e FRD, e cor verdadeira na $A B$ de 17 a $22 \mathrm{uH}$, na $A E$ de 94 a $109 \mathrm{uH}$ e na APO de 51 a $71 \mathrm{uH}$, durante o ensaio 14 - pré-oxidação com peroxônio. Fonte: Tabela C 7.1 do ANEXO C.

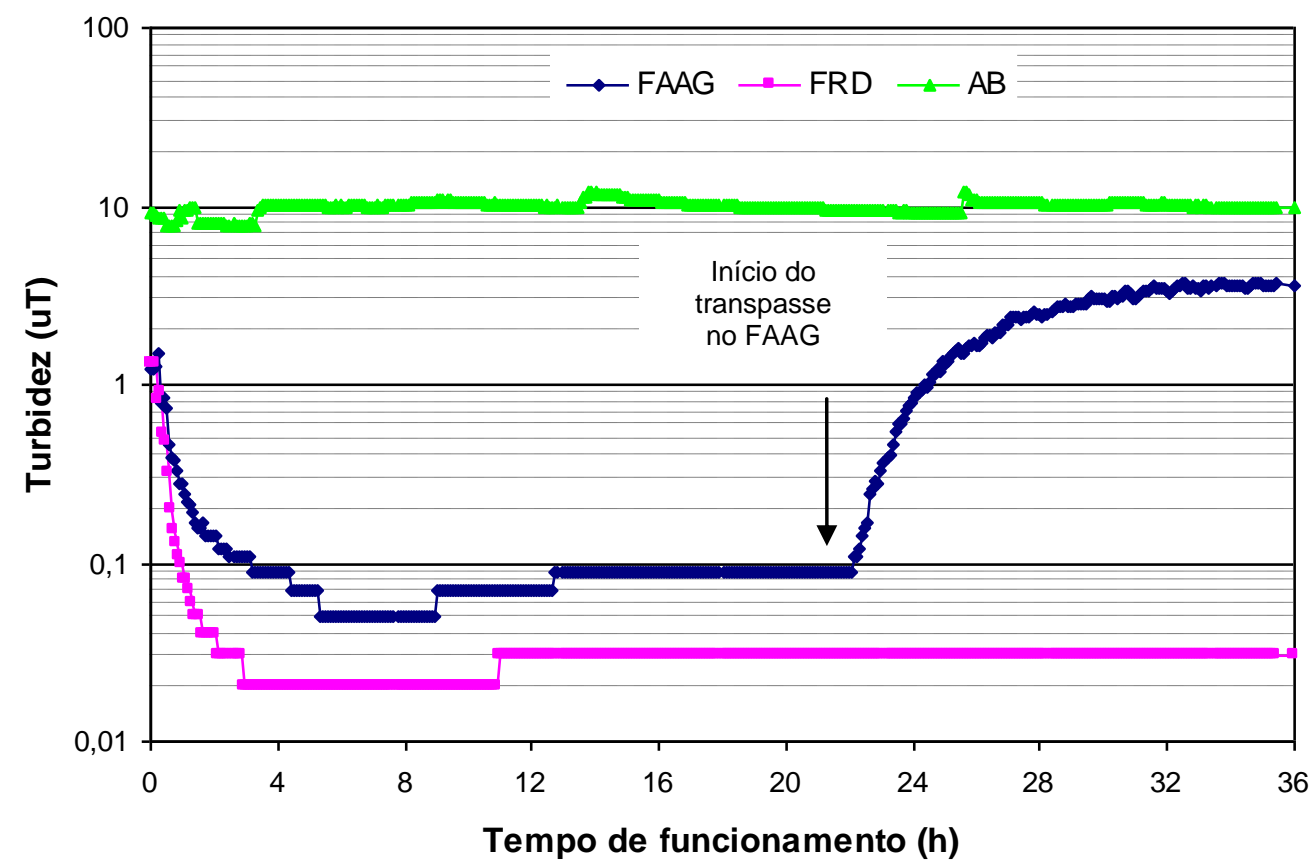

Figura 5.72 - Variação da turbidez na $A B$ e nos efluentes do FAAG $\left(180 \mathrm{~m}^{3} / \mathrm{m}^{2} \mathrm{~d}\right)$ e $F R D$ $\left(280 \mathrm{~m}^{2} / \mathrm{m}^{3} \mathrm{~d}\right)$ durante o ensaio 14 - pré-oxidação com peroxônio e sem DFIs no FAAG. 
Quanto à remoção de substâncias húmicas, em termos de absorvância 254 $\mathrm{nm}$ e COD, as porcentagens de remoção foram respectivamente, da ordem de 84 a $94 \%$ e 30 a 45\% no FRD. Nas Figuras 5.73 e 5.74 estão as variações da absorvância 254 nm e do COD durante o ensaio 14.

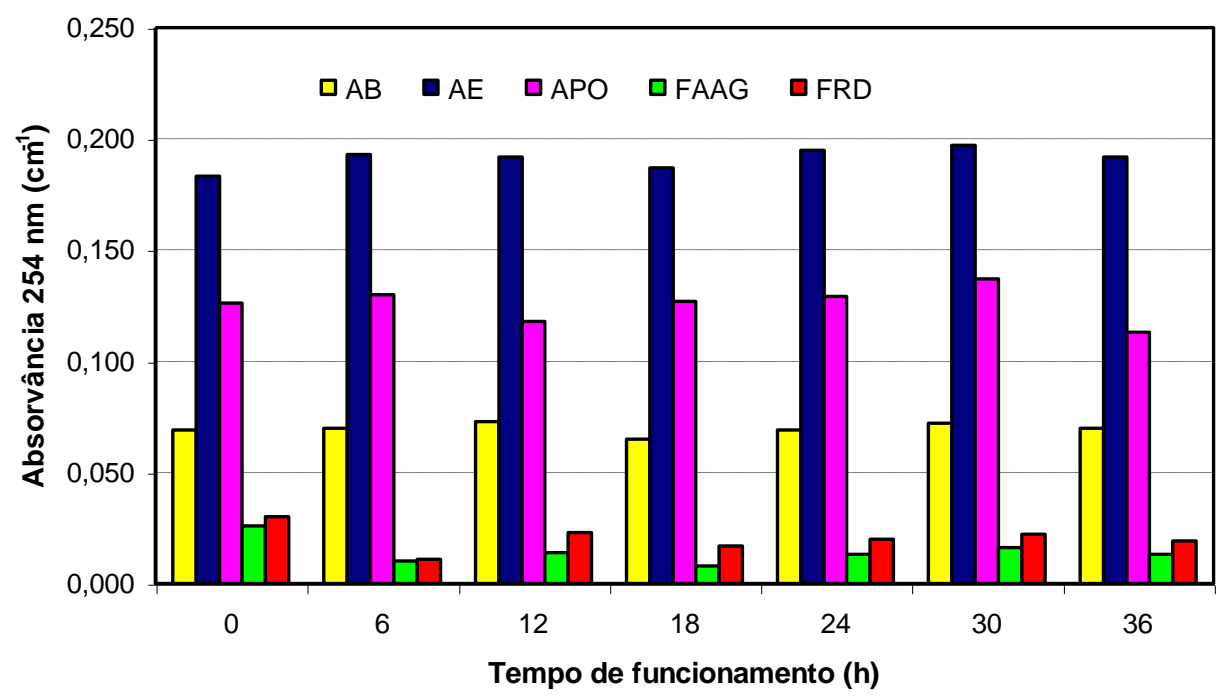

Figura 5.73 - Variação de absorvância $254 \mathrm{~nm}$ da $A B, A E, A P O$ e dos efluentes do FAAG e do FRD durante o ensaio 14, pré-oxidação com peroxônio e sem DFls no FAAG (FAAG = $180 \mathrm{~m}^{3} / \mathrm{m}^{2} \mathrm{~d}$ e FRD $=280 \mathrm{~m}^{3} / \mathrm{m}^{2} \mathrm{~d}$ ). Fonte: Tabela C 7.2 do ANEXO C.

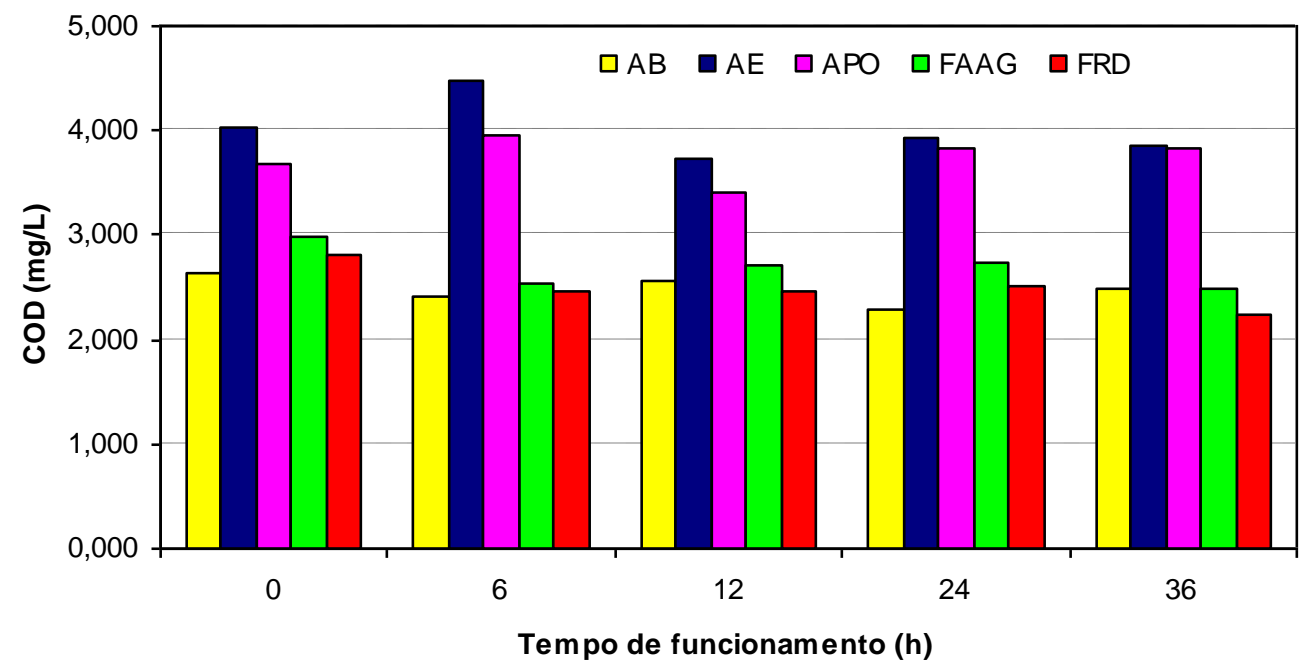

Figura 5.74 - Variação de $C O D$ na $A B, A E, A P O$ e nos efluentes do FAAG e do FRD durante o ensaio 14, pré-oxidação com peroxônio e sem DFls no FAAG (FAAG $=180$ $\mathrm{m}^{3} / \mathrm{m}^{2} \mathrm{~d}$ e FRD $=280 \mathrm{~m}^{3} / \mathrm{m}^{2} \mathrm{~d}$ ). Fonte: Tabela C 7.2 do ANEXO C. 


\subsubsection{Ensaio 15 - Pré-oxidação com Hipoclorito de Sódio}

No ensaio com cloro, utilizando hipoclorito de sódio, a solução estoque foi preparada com concentração de $500 \mathrm{mg} / \mathrm{L}$. A dosagem de cloro aplicada no ensaio na instalação piloto em escoamento contínuo foi de $1 \mathrm{mg} / \mathrm{L}$, e a vazão na bomba dosadora foi obtida pela equação (4.5):

Para $C=1 \mathrm{mg} / \mathrm{L} ; C_{S E}=500 \mathrm{mg} / \mathrm{L}$ e $Q_{a b}=170 \mathrm{~L} / \mathrm{h}:$

$$
1=\frac{0 * 170+500 * Q_{b d}}{170+Q_{b d}} \Rightarrow Q_{b d}=0,34 L / h
$$

Na Figura 5.75 está a evolução da perda de carga no FAAG e no FRD. Observa-se que os dois filtros apresentaram praticamente a mesma perda de carga final, não ocorrendo nenhuma lavagem no FRD durante as 36 horas de funcionamento.

Na Tabela 5.28 está apresentado o resumo dos resultados obtidos durante 0 ensaio 15, nas Tabelas C 8.1 a C 8.4 do ANEXO C estão todos os resultados obtidos durante o ensaio 15.

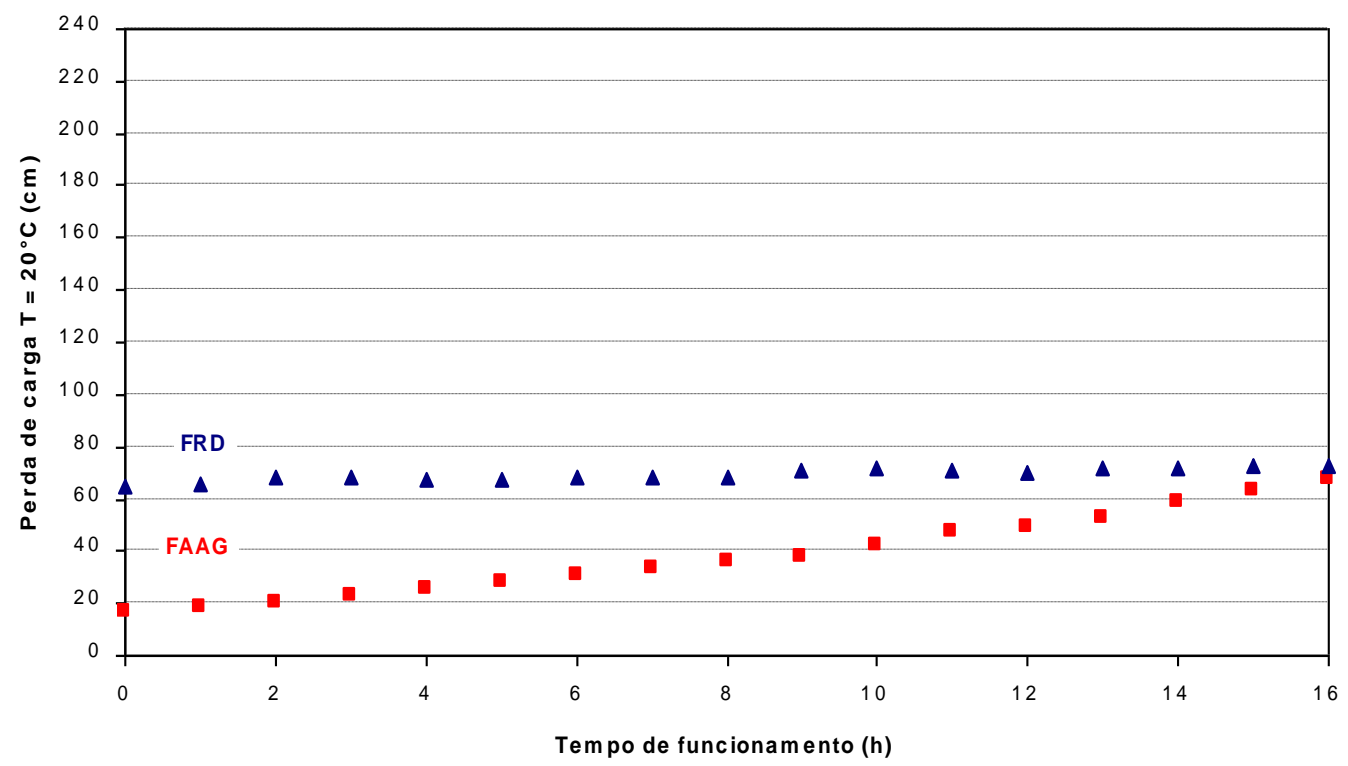

Figura 5.75 - Evolução da perda de carga no FAAG $\left(180 \mathrm{~m}^{3} / \mathrm{m}^{2} \mathrm{~d}\right)$ e no FRD $\left(280 \mathrm{~m}^{2} / \mathrm{m}^{3} \mathrm{~d}\right)$ para $T=20^{\circ} \mathrm{C}$ durante o ensaio 15 , pré-oxidação com hipoclorito de sódio e sem DFls no FAAG. Fonte: Tabela C 8.3 do ANEXO C. 
Tabela 5.28 - Resumo dos resultados obtidos no ensaio 15, pré-oxidação com hipoclorito de sódio.

\begin{tabular}{|c|c|c|c|c|c|}
\hline & \multicolumn{5}{|c|}{ ENSAIO 15 - pré-oxidação com hipoclorito de sódio } \\
\hline Taxas de filtração médias & \multicolumn{5}{|c|}{ FAAG $=183$ e FRD $=286 \mathrm{~m}^{3} / \mathrm{m}^{2} \mathrm{~d}$} \\
\hline Condições de coagulação & \multicolumn{5}{|c|}{$\begin{array}{c}\mathrm{D}_{\mathrm{SA}} \cong 4,0 \mathrm{mg} / \mathrm{L} ; \mathrm{pH} \text { de coagulação }=4,88 \text { a } 5,67 ; \\
\text { temperatura }=21 \text { a } 23^{\circ} \mathrm{C}\end{array}$} \\
\hline Condições de pré-oxidação & \multicolumn{5}{|c|}{ Dosagem aplicada de cloro $=1 \mathrm{mg} / \mathrm{L}$} \\
\hline Duração da carreira & \multicolumn{5}{|c|}{$16 \mathrm{~h}$} \\
\hline Características & AB & AE & APO & $\begin{array}{l}\text { Efluente do } \\
\text { FAAG }\end{array}$ & $\begin{array}{l}\text { Efluente do } \\
\text { FRD }\end{array}$ \\
\hline $\mathrm{pH}$ & 6,68 a 7,36 & $\begin{array}{c}6,67 \mathrm{a} \\
7,27\end{array}$ & 5,30 a 6,47 & NR & NR \\
\hline Alcalinidade $\left(\mathrm{mg} / \mathrm{L} \mathrm{CaCO}_{3}\right)$ & 9,4 a 16,3 & 9,1 a 16,6 & 5,7 a 7,7 & NR & NR \\
\hline Cor aparente $(\mathrm{uH})$ & 107 a 121 & 155 a 220 & 178 a 217 & $<1$ a 19 & $<1 \mathrm{a} 12^{(*)}$ \\
\hline Cor verdadeira $(\mathrm{uH})$ & 20 a 23 & 42 a 113 & 90 a 108 & NR & NR \\
\hline Turbidez (uT) & $\begin{array}{c}10,43 a \\
14,64\end{array}$ & NR & NR & 0,04 a 2,08 & $\begin{array}{l}<0,01 \mathrm{a} \\
1,03^{(*)}\end{array}$ \\
\hline Absorvância 254 nm & $\begin{array}{c}0,079 a \\
0,081\end{array}$ & $\begin{array}{c}0,192 \mathrm{a} \\
0,200\end{array}$ & 0,184 a 0,190 & 0,014 a 0,028 & $\begin{array}{c}0,025 a \\
0,034\end{array}$ \\
\hline $\mathrm{COD}(\mathrm{mg} / \mathrm{L})$ & 2,5 a 2,7 & 4,0 a 4,2 & 3,8 a 4,2 & 2,0 a 2,4 & 2,1 a 2,7 \\
\hline $\begin{array}{l}\text { Residual de oxidante } \\
(\mathrm{mg} / \mathrm{L})\end{array}$ & NR & NR & NR & 0,37 a 1,73 & 0,35 a 1,59 \\
\hline Alumínio residual (mg/L) & 0,01 & 0,01 & NR & 0,10 a 0,13 & 0,10 a 0,15 \\
\hline
\end{tabular}

$\mathrm{D}_{\mathrm{SA}}=$ dosagem de $\mathrm{Al}_{2}\left(\mathrm{SO}_{4}\right)_{3}$.14,3 $\mathrm{H}_{2} \mathrm{O} ; \mathrm{AB}$ = água bruta; $\mathrm{AE}$ = áqua de estudo; $\mathrm{APO}$ = água pré-oxidada; $\mathrm{FAAG}=$ filtro ascendente de areia grossa; $F R D=$ filtro rápido descendente; $C O D=$ carbono orgânico dissolvido; $N R=$ não realizado. ${ }^{(*)}$ Valor observado no início do ensaio.

A cor aparente do efluente do FRD manteve-se $\leq 1 \mathrm{uH}$ durante a maior parte do tempo, apresentando $12 \mathrm{uH}$ no início do ensaio e $5 \mathrm{uH}$ após 14 horas de funcionamento do filtro. Na Figura 5.76 está apresentada a variação da cor aparente na $A B, A E, A P O$ e efluentes do FAAG e do FRD, bem como a cor verdadeira na $A B, A E$ e $A P O$.

$\mathrm{Na}$ Figura 5.77 observa-se que os efluentes do FAAG e do FRD apresentaram turbidez < 1 uT, com pico de turbidez nos dois filtros após 8 horas de funcionamento, devido provavelmente aos problemas operacionais que ocorreram durante este ensaio, com relação às variações no pH de coagulação.

Quanto à remoção de substâncias húmicas em termos de absorvância 254 nm e COD, a eficiência de remoção no FRD variou de 83 a $87 \%$ e de 31,2 a $47,1 \%$ respectivamente. Nas Figuras 5.78 e 5.79 estão as variações da absorvância 254 nm e de COD durante o ensaio 15. 


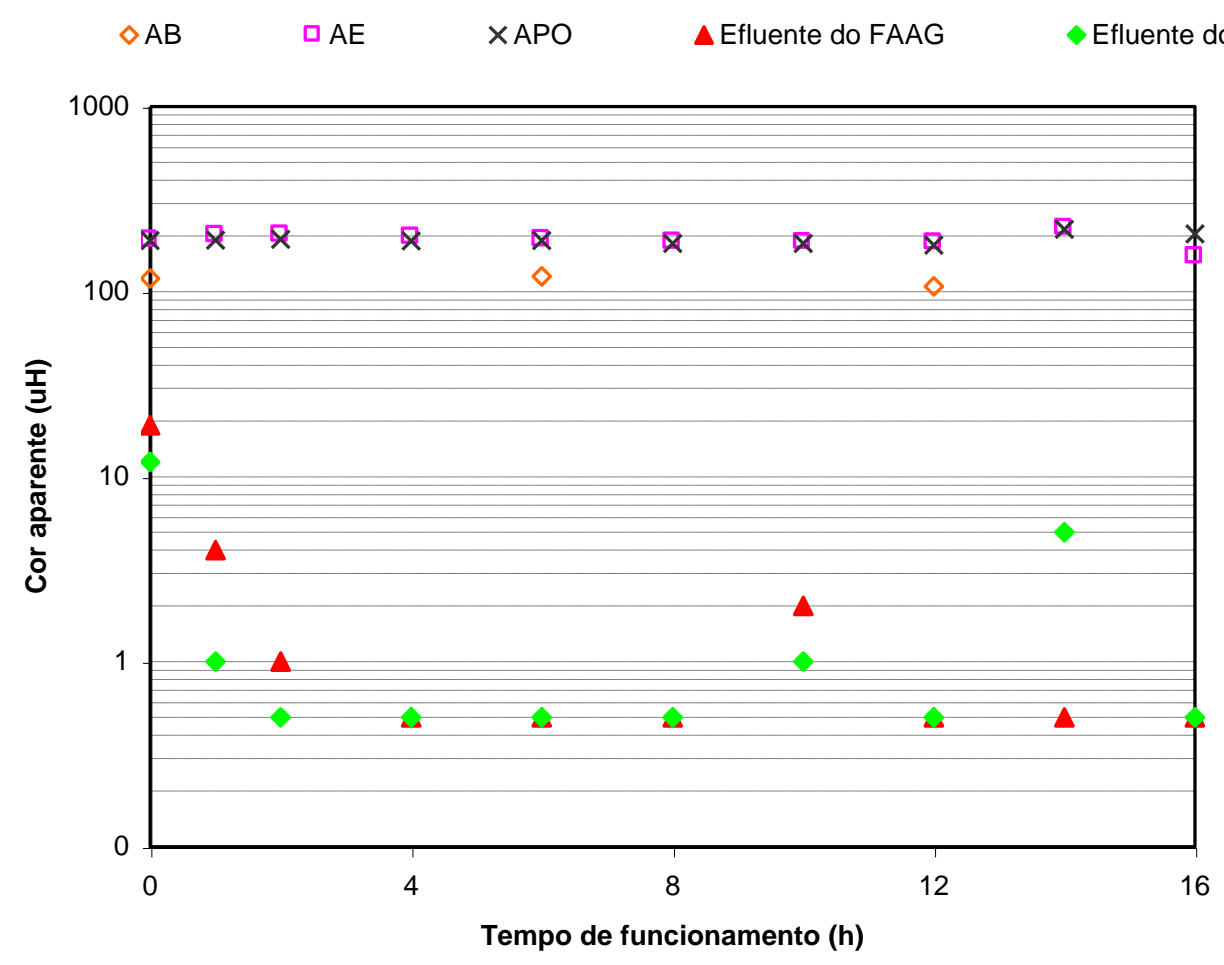

Figura 5.76 - Variação de cor aparente na $A B, A E$, APO e efluentes do FAAG e FRD, e cor verdadeira na $A B$ de 20 a $23 \mathrm{uH}$, na $A E$ de 42 a $113 \mathrm{uH}$ e na APO de 90 a $108 \mathrm{uH}$, durante o ensaio 15 - pré-oxidação com hipoclorito de sódio. Fonte: Tabela C 8.1 do ANEXO C.

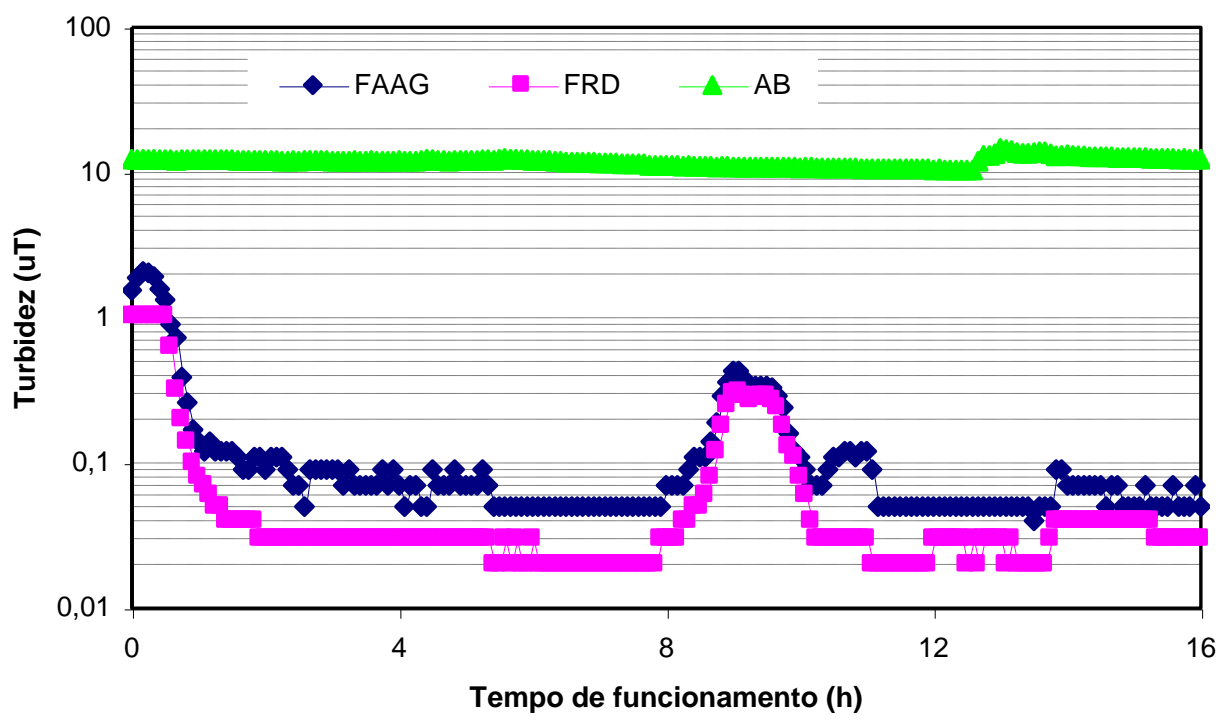

Figura 5.77 - Variação da turbidez na $A B$ e dos efluentes do FAAG $\left(180 \mathrm{~m}^{3} / \mathrm{m}^{2} \mathrm{~d}\right)$ e FRD $\left(280 \mathrm{~m}^{2} / \mathrm{m}^{3} \mathrm{~d}\right)$ durante o ensaio 15 - pré-oxidação com hipoclorito de sódio e sem DFls no FAAG. 


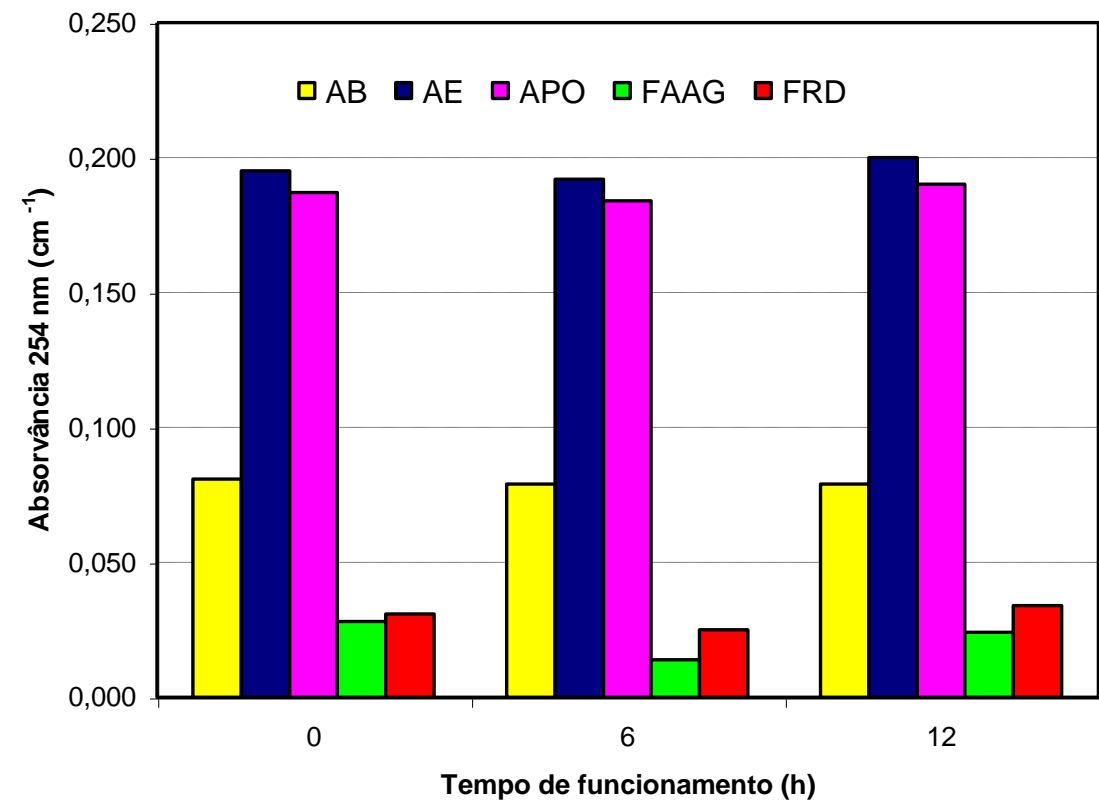

Figura 5.78 - Variação de absorvância $254 \mathrm{~nm}$ na $A B, A E$, APO e nos efluentes do FAAG e do FRD durante o ensaio 15, pré-oxidação com hipoclorito de sódio e sem DFls no FAAG $\left(F A A G=180 \mathrm{~m}^{3} / \mathrm{m}^{2} \mathrm{~d}\right.$ e FRD $\left.=280 \mathrm{~m}^{3} / \mathrm{m}^{2} \mathrm{~d}\right)$. Fonte: Tabela C 8.2 do ANEXO C.

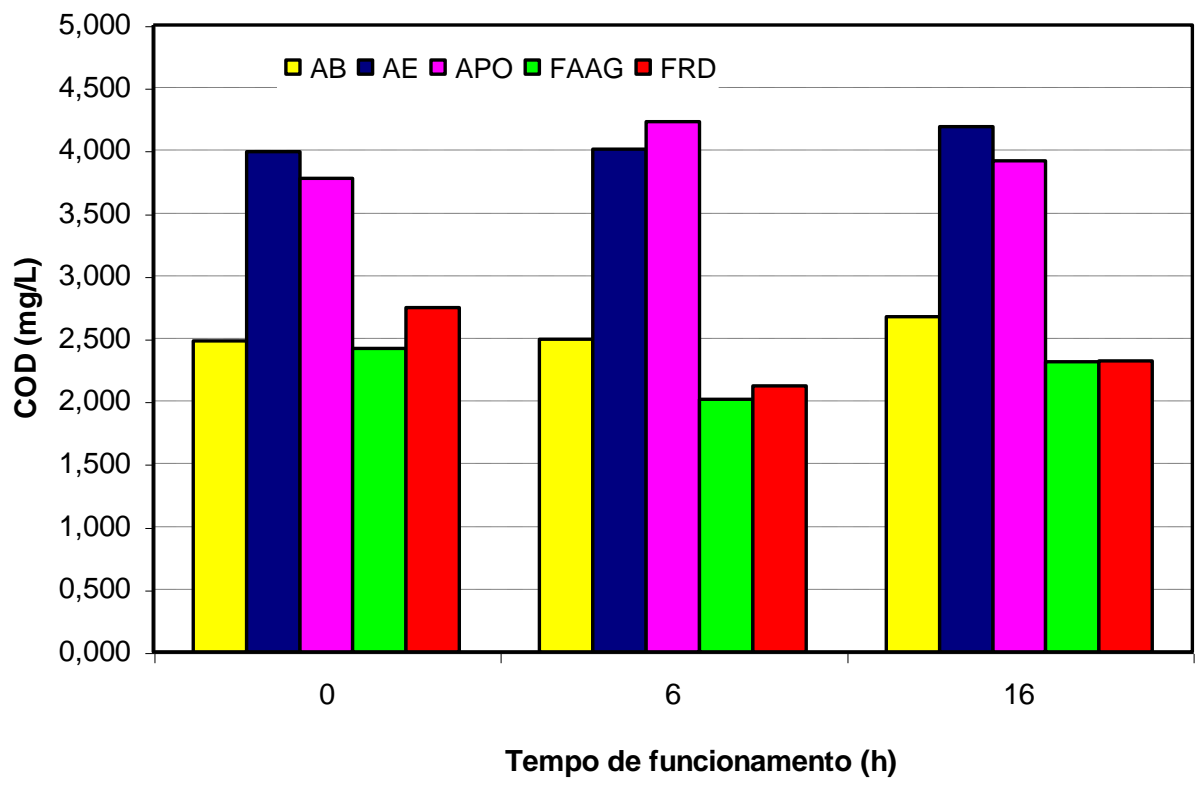

Figura 5.79 - Variação de $C O D$ da $A B, A E, A P O$ e dos efluentes do FAAG e do FRD durante o ensaio 15, pré-oxidação com hipoclorito de sódio e sem DFIs no FAAG (FAAG = $180 \mathrm{~m}^{3} / \mathrm{m}^{2} \mathrm{~d}$ e FRD $=280 \mathrm{~m}^{3} / \mathrm{m}^{2} \mathrm{~d}$ ). Fonte: Tabela C 8.2 do ANEXO C. 
Nas Tabelas 5.29, 5.30, 5.31 e 5.32, estão apresentados os resumos gerais dos resultados obtidos em todos os ensaios na instalação piloto em escoamento contínuo, correspondentes à Fase 2 da $3^{\underline{a}}$ etapa do trabalho experimental.

Com exceção do ensaio com pré-oxidação com ozônio, as determinações das dosagens de coagulante, oxidantes e $\mathrm{opH}$ de coagulação foram feitas em ensaios preliminares na instalação piloto em escoamento contínuo, obtendo-se melhores resultados comparados aos ensaios em reatores estáticos. As dosagens de oxidantes foram determinadas com base nas concentrações de residual de oxidantes obtidas nos ensaios preliminares.

Observa-se que, com a redução da dosagem de coagulante nos ensaios com pré-oxidação comparados ao ensaio sem pré-oxidação, foi possível trabalhar com pH de coagulação mais alto em que obtiveram-se menores concentrações de alumínio residual no efluente do FRD.

Com a dosagem aplicada de ozônio de aproximadamente $6 \mathrm{mg} / \mathrm{L}$, a cor verdadeira da água pré-oxidada variou de 23 a $91 \mathrm{uH}$, apresentando remoção da ordem de 62 a 76\% somente com a pré-oxidação; enquanto que, com os demais oxidantes a cor verdadeira da água pré-oxidada muitas vezes aumentou.

Em geral, a cor aparente no efluente do FRD variou de $<1$ a $10 \mathrm{uH}$ e a turbidez manteve-se menor que $1 \mathrm{uT}$, exceto nas ocasiões em que ocorreu 0 transpasse no filtro e procedia-se a lavagem do FRD. 
Tabela 5.29 - Resumo geral dos resultados obtidos nos ensaios 8 e 9 na instalação piloto em escoamento contínuo sem e com pré-oxidação, durante a Fase 2.

\begin{tabular}{|c|c|c|c|c|c|c|c|c|c|}
\hline & \multicolumn{4}{|c|}{ ENSAIO 8 - sem pré-oxidação } & \multicolumn{5}{|c|}{ ENSAIO 9 - pré-oxidação com ozônio } \\
\hline Taxas de filtração médias & \multicolumn{4}{|c|}{$\mathrm{FAAG}=185$ e $\mathrm{FRD}=280 \mathrm{~m}^{3} / \mathrm{m}^{2} \mathrm{~d}$} & \multicolumn{5}{|c|}{$\mathrm{FAAG}=186$ e $\mathrm{FRD}=283 \mathrm{~m}^{3} / \mathrm{m}^{2} \mathrm{~d}$} \\
\hline Condições de coagulação & \multicolumn{4}{|c|}{$\begin{array}{c}\mathrm{D}_{\mathrm{SA}} \cong 7 \mathrm{mg} / \mathrm{L} ; \mathrm{pH} \text { de coagulação }=5,04 \text { a } 5,32 ; \\
\text { temperatura }=20 \text { a } 23^{\circ} \mathrm{C}\end{array}$} & \multicolumn{5}{|c|}{$\begin{array}{c}\mathrm{D}_{\mathrm{SA}} \cong 3,3 \text { a } 9,6 \mathrm{mg} / \mathrm{L} ; \mathrm{pH} \text { de coagulação }=4,57 \text { a } 5,39 \\
\text { temperatura }=20 \text { a } 25,5^{\circ} \mathrm{C}\end{array}$} \\
\hline Condições de pré-oxidação & \multicolumn{4}{|c|}{-} & \multicolumn{5}{|c|}{ Dosagem aplicada de $\mathrm{O}_{3} \cong 6 \mathrm{mg} / \mathrm{L}$} \\
\hline Duração da carreira & \multicolumn{4}{|c|}{$36 \mathrm{~h}$} & \multicolumn{5}{|c|}{$36 \mathrm{~h}$} \\
\hline Características & AB & AE & FAAG & FRD & AB & AE & APO & FAAG & FRD \\
\hline $\mathrm{pH}$ & 6,52 a 6,60 & 6,44 a 6,69 & NR & NR & 6,64 a 6,74 & 6,56 a 6,75 & 5,91 a 6,13 & NR & NR \\
\hline Alcalinidade $\left(\mathrm{mg} / \mathrm{L} \mathrm{CaCO}_{3}\right)$ & 6,4 a 9,5 & 7,0 a 9,0 & NR & NR & 7,3 a 12,8 & 6,8 a 10,8 & 4,62 a 6,38 & NR & NR \\
\hline Cor aparente $(\mathrm{uH})$ & 130 a 146 & 200 a 223 & $<1$ a 93 & $<1$ a $10^{(*)}$ & 142 a 165 & 197 a 240 & 118 a 192 & $<1$ a 106 & $<1$ a 2 \\
\hline Cor verdadeira $(\mathrm{uH})$ & 21 a 27 & 93 a 105 & NR & NR & 14 a 28 & 83 a 106 & 23 a 91 & NR & NR \\
\hline Turbidez (uT) & 10,7 a 15,2 & NR & $<0,01$ a 3,13 & $<0,01$ a 1,46 & 11,6 a 28,5 & NR & NR & $<0,01$ a 12,9 & $<0,01$ a 1 \\
\hline Absorvância 254 nm & 0,069 a 0,091 & 0,183 a 0,201 & 0,005 a 0,041 & 0,007 a 0,022 & 0,072 a 0,086 & 0,184 a 0,201 & 0,095 a 0,105 & 0,009 a 0,030 & $\begin{array}{c}0,008 \text { a } \\
0,022\end{array}$ \\
\hline $\mathrm{COD}(\mathrm{mg} / \mathrm{L})$ & 1,5 a 2,0 & 2,6 a 3,6 & 1,7 a 2,0 & 1,7 a 2,0 & 1,8 a 2,3 & 2,2 a 2,7 & 2,5 a 2,8 & 2,2 a 2,3 & 2,2 \\
\hline Ferro (mg/L) & NR & NR & NR & NR & 1,716 & 1,482 & 1,696 & 0,417 & 0,399 \\
\hline Manganês (mg/L) & NR & NR & NR & NR & 0,100 & 0,078 & 0,098 & 0,044 & 0,034 \\
\hline Alumínio residual (mg/L) & ND & $<0,01$ a 0,02 & 0,04 a 0,15 & 0,02 a 0,16 & NR & NR & NR & ND & ND \\
\hline
\end{tabular}

carbono orgânico dissolvido; ND = não detectado; $N R=$ não realizado. ${ }^{(*)}$ Valor observado no início do ensaio. 
Tabela 5.30 - Resumo geral dos resultados obtidos nos ensaios 10 e 11 na instalação piloto em escoamento contínuo sem e com pré-oxidação, durante a Fase 2.

\begin{tabular}{|c|c|c|c|c|c|c|c|c|c|c|}
\hline & \multicolumn{5}{|c|}{ ENSAIO 10 - pré-oxidação com peróxido de hidrogênio } & \multicolumn{5}{|c|}{ ENSAIO 11 - pré-oxidação com tricloro-s-triazina-triona } \\
\hline "Taxas de filtração médias & \multicolumn{5}{|c|}{$\mathrm{FAAG}=188$ e $\mathrm{FRD}=280 \mathrm{~m}^{3} / \mathrm{m}^{2} \mathrm{~d}$} & \multicolumn{5}{|c|}{ FAAG $=186$ e $F R D=281 \mathrm{~m}^{3} / \mathrm{m}^{2} \mathrm{~d}$} \\
\hline Condições de coagulação & \multicolumn{5}{|c|}{$\begin{array}{c}\mathrm{D}_{\mathrm{SA}} \cong 3,5 \mathrm{mg} / \mathrm{L} ; \mathrm{pH} \text { de coagulação }=5,18 \text { a } 5,52 ; \\
\text { temperatura }=19,5 \text { a } 22^{\circ} \mathrm{C}\end{array}$} & \multicolumn{5}{|c|}{$\begin{array}{c}\mathrm{D}_{\mathrm{SA}} \cong 3,0 \text { a } 4,0 \mathrm{mg} / \mathrm{L} ; \mathrm{pH} \text { de coagulação }=4,95 \text { a } 5,60 ; \\
\text { temperatura }=17 \text { a } 21^{\circ} \mathrm{C}\end{array}$} \\
\hline $\begin{array}{l}\text { Condições de pré- } \\
\text { oxidação }\end{array}$ & \multicolumn{5}{|c|}{ Dosagem aplicada de $\mathrm{H}_{2} \mathrm{O}_{2} \cong 35 \mathrm{mg} / \mathrm{L}$} & \multicolumn{5}{|c|}{ Dosagem aplicada de $\mathrm{Cl}_{2} \cong 4,0$ a $7,0 \mathrm{mg} / \mathrm{L}$} \\
\hline Duração da carreira & \multicolumn{5}{|c|}{$36 \mathrm{~h}$} & \multicolumn{5}{|c|}{$36 \mathrm{~h}$} \\
\hline Características & AB & AE & APO & FAAG & FRD & AB & AE & APO & FAAG & FRD \\
\hline $\mathrm{pH}$ & 6,44 a 6,60 & 6,38 a 6,60 & $\begin{array}{c}5,90 \mathrm{a} \\
6,24\end{array}$ & NR & NR & 6,61 a 6,76 & 6,64 a 6,87 & $\begin{array}{c}5,73 a \\
6,51\end{array}$ & & NR \\
\hline $\begin{array}{l}\text { Alcalinidade } \quad(\mathrm{mg} / \mathrm{L} \\
\left.\mathrm{CaCO}_{3}\right)\end{array}$ & 3,5 a 7,9 & 5,5 a 8,4 & 3,1 a 5,7 & NR & NR & 5,1 a 8,8 & 5,5 a 7,5 & 3,5 a 7,0 & NR & NR \\
\hline Cor aparente $(\mathrm{uH})$ & 130 a 184 & 197 a 262 & 192 a 259 & $<1$ a 106 & $<1$ a $21^{(*)}$ & 96 a 109 & 171 a 193 & 163 a 192 & $<1$ a 81 & $<1$ a 5 \\
\hline Cor verdadeira $(\mathrm{uH})$ & 18 a 31 & 90 a 121 & 91 a 117 & NR & NR & 12 a 16 & 92 a 102 & 83 a 96 & NR & NR \\
\hline Turbidez (uT) & $\begin{array}{c}10,88 \mathrm{a} \\
19,00\end{array}$ & NR & NR & 0,02 a 6,4 & 0,02 a 1 & 8,5 a 12,8 & NR & NR & $\begin{array}{c}<0,01 \mathrm{a} \\
10,7\end{array}$ & $<0,01$ a 1 \\
\hline Absorvância 254 nm & $\begin{array}{c}0,075 \text { a } \\
0,107\end{array}$ & 0,176 a 0,230 & $\begin{array}{c}0,186 \text { a } \\
0,248\end{array}$ & 0,018 a 0,079 & $\begin{array}{c}0,021 \mathrm{a} \\
0,083\end{array}$ & 0,048 a 0,054 & 0,170 a 0,188 & $\begin{array}{c}0,161 \mathrm{a} \\
0,182 \\
\end{array}$ & $\begin{array}{c}0,014 a \\
0,021 \\
\end{array}$ & $\begin{array}{c}0,018 \mathrm{a} \\
0,025\end{array}$ \\
\hline COD (mg/L) & 2,4 a 3,2 & 3,0 a 4,4 & 3,6 a 5,3 & 2,1 a 2,5 & 2,1 a 2,9 & 2,7 a 4,0 & 4,6 a 6,6 & 4,7 a 5,5 & 3,3 a 4,2 & 3,1 a 6,3 \\
\hline Ferro $(\mathrm{mg} / \mathrm{L})$ & $\begin{array}{c}1,211 \mathrm{a} \\
1,688\end{array}$ & 1,521 a 2,408 & $\begin{array}{c}0,893 \text { a } \\
1,537\end{array}$ & 0,301 a 1,059 & $\begin{array}{c}0,012 \mathrm{a} \\
0,198\end{array}$ & 0,752 a 1,404 & 0,786 a 1,166 & $\begin{array}{c}1,325 \mathrm{a} \\
1,362\end{array}$ & $\begin{array}{c}0,162 \mathrm{a} \\
0,854\end{array}$ & $\begin{array}{c}0,205 \mathrm{a} \\
0,268\end{array}$ \\
\hline Manganês (mg/L) & $\begin{array}{c}0,041 \mathrm{a} \\
0,056\end{array}$ & 0,026 a 0,043 & $\begin{array}{c}0,040 \mathrm{a} \\
0,053\end{array}$ & 0,028 a 0,044 & $\begin{array}{c}0,011 \mathrm{a} \\
0,022 \\
\end{array}$ & 0,008 a 0,026 & 0,007 a 0,018 & $\begin{array}{c}0,024 \mathrm{a} \\
0,026 \\
\end{array}$ & $\begin{array}{c}0,005 a \\
0,019 \\
\end{array}$ & $\begin{array}{c}0,004 \mathrm{a} \\
0,007 \\
\end{array}$ \\
\hline $\begin{array}{l}\text { Residual de oxidante } \\
(\mathrm{mg} / \mathrm{L})\end{array}$ & NR & NR & NR & 0,065 a 0,109 & $\begin{array}{c}0,088 \mathrm{a} \\
0,095\end{array}$ & NR & NR & NR & $\begin{array}{c}0,35 a \\
3,56\end{array}$ & 0,28 a 3,36 \\
\hline Alumínio residual (mg/L) & ND & $<0,01$ a 0,01 & NR & 0,06 a 0,11 & 0,03 a 0,07 & $<0,01$ a 0,04 & $<0,01$ a 0,03 & NR & $\begin{array}{c}0,10 \mathrm{a} \\
0,18\end{array}$ & $\begin{array}{l}0,07 a \\
0,15^{(*)}\end{array}$ \\
\hline
\end{tabular}

$\mathrm{D}_{\mathrm{SA}}=$ dosagem de $\mathrm{Al}_{2}\left(\mathrm{SO}_{4}\right)_{3} \cdot 14,3 \mathrm{H}_{2} \mathrm{O} ; \mathrm{AB}$ = água bruta; $\mathrm{AE}$ = água de estudo; $\mathrm{APO}$ = água pré-oxidada; $\mathrm{FAAG}$ = filtro ascendente de areia grossa; $\mathrm{FRD}=$ filtro rápido descendente; $\mathrm{COD}=$ carbono orgânico dissolvido; $\mathrm{ND}=$ não detectado; $\mathrm{NR}=$ não realizado. ${ }^{(*)}$ Valor observado no iní́cio do ensaio. 
Tabela 5.31 - Resumo geral dos resultados obtidos nos ensaios 12 e 13 na instalação piloto em escoamento contínuo sem e com pré-oxidação, durante a Fase 2.

\begin{tabular}{|c|c|c|c|c|c|c|c|c|c|c|}
\hline & \multicolumn{5}{|c|}{ ENSAIO 12 - pré-oxidação com dióxido de cloro } & \multicolumn{5}{|c|}{ ENSAIO 13 - pré-oxidação com permanganato de potássio } \\
\hline Taxas de filtração médias & \multicolumn{5}{|c|}{ FAAG $=186$ e FRD $=279 \mathrm{~m}^{3} / \mathrm{m}^{2} \mathrm{~d}$} & \multicolumn{5}{|c|}{ FAAG $=184$ e $F R D=279 \mathrm{~m}^{3} / \mathrm{m}^{2} \mathrm{~d}$} \\
\hline Condições de coagulação & \multicolumn{5}{|c|}{$\begin{array}{c}\mathrm{D}_{\mathrm{SA}} \cong 4,0 \mathrm{mg} / \mathrm{L} ; \mathrm{pH} \text { de coagulação }=5,09 \text { a } 5,47 \\
\text { temperatura }=16 \text { a } 22^{\circ} \mathrm{C}\end{array}$} & \multicolumn{5}{|c|}{$\begin{array}{c}\mathrm{D}_{\mathrm{SA}} \cong 4,0 \mathrm{mg} / \mathrm{L} ; \mathrm{pH} \text { de coagulação }=5,20 \text { a } 5,61 \\
\text { temperatura }=18 \text { a } 22^{\circ} \mathrm{C}\end{array}$} \\
\hline $\begin{array}{l}\text { Condições de pré- } \\
\text { oxidação }\end{array}$ & \multicolumn{5}{|c|}{ Dosagem aplicada de $\mathrm{ClO}_{2} \cong 0,4 \mathrm{mg} / \mathrm{L}$} & \multicolumn{5}{|c|}{ Dosagem aplicada de $\mathrm{KMnO}_{4} \cong 1,0 \mathrm{mg} / \mathrm{L}$} \\
\hline Duração da carreira & \multicolumn{5}{|c|}{$36 \mathrm{~h}$} & \multicolumn{5}{|c|}{$36 \mathrm{~h}$} \\
\hline Características & $A B$ & AE & APO & FAAG & FRD & AB & AE & APO & FAAG & FRD \\
\hline $\mathrm{pH}$ & 6,58 a 6,70 & 6,70 a 7,00 & 6,25 a 6,57 & NR & NR & 6,34 a 6,56 & 6,52 a 6,68 & 6,23 a 6,50 & NR & NR \\
\hline $\begin{array}{l}\text { Alcalinidade } \\
\left(\mathrm{mg} / \mathrm{L} \mathrm{CaCO}_{3}\right)\end{array}$ & 6,4 a 7,7 & 7,3 a 8,8 & 4,8 a 6,4 & NR & NR & 4,8 a 7,3 & 6,8 a 8,8 & 5,5 a 7,5 & NR & NR \\
\hline Cor aparente (uH) & 88 a 103 & 167 a 184 & 161 a 179 & $<1$ a 88 & $<1$ a $10^{(*)}$ & 73 a 85 & 155 a 186 & 220 a 252 & $<1$ a 115 & $\begin{array}{l}<1 \mathrm{a} \\
10^{(*)}\end{array}$ \\
\hline Cor verdadeira $(\mathrm{uH})$ & 12 a 16 & 94 a 107 & 88 a 102 & NR & NR & 12 a 14 & 96 a 111 & 124 a 144 & NR & NR \\
\hline Turbidez (uT) & 7,4 a 12,1 & NR & $\mathrm{NR}$ & $\begin{array}{c}<0,01 \text { a } \\
7,3\end{array}$ & $<0,01$ a 1 & 7 a 11,2 & NR & NR & 0,03 a 14,0 & $\begin{array}{c}<0,01 \mathrm{a} \\
1\end{array}$ \\
\hline Absorvância 254 nm & $\begin{array}{l}0,043 \mathrm{a} \\
0,056\end{array}$ & $\begin{array}{c}0,174 \mathrm{a} \\
0,189\end{array}$ & $\begin{array}{c}0,165 \mathrm{a} \\
0,181\end{array}$ & $\begin{array}{c}0,007 \mathrm{a} \\
0,021\end{array}$ & 0,010 a 0,023 & $\begin{array}{c}0,042 \mathrm{a} \\
0,051\end{array}$ & 0,166 a 0,183 & $\begin{array}{c}0,183 \mathrm{a} \\
0,198\end{array}$ & 0,003 a 0,013 & $\begin{array}{c}0,007 \mathrm{a} \\
0,016\end{array}$ \\
\hline COD (mg/L) & 1,5 a 2,4 & 3,5 a 4,2 & 3,2 a 4,0 & 1,6 a 4,3 & 1,4 a 2,5 & 2,1 a 3,1 & 3,5 a 4,3 & 3,2 a 4,0 & 1,9 a 2,9 & 2,0 a 2,9 \\
\hline Ferro (mg/L) & $\begin{array}{l}1,179 \mathrm{a} \\
1,328\end{array}$ & $\begin{array}{l}1,164 \mathrm{a} \\
1,436\end{array}$ & $\begin{array}{c}0,958 \mathrm{a} \\
1,063\end{array}$ & $\begin{array}{c}0,453 \mathrm{a} \\
0,517\end{array}$ & 0,126 a 0,202 & $\begin{array}{c}0,587 \mathrm{a} \\
0,842\end{array}$ & 0,780 a 0,847 & $\begin{array}{c}0,731 \mathrm{a} \\
1,536\end{array}$ & 0,054 a 0,204 & $\begin{array}{c}0,016 \mathrm{a} \\
0,071\end{array}$ \\
\hline Manganês (mg/L) & $\begin{array}{c}0,046 \mathrm{a} \\
0,056\end{array}$ & $\begin{array}{c}0,047 \mathrm{a} \\
0,048\end{array}$ & $\begin{array}{c}0,020 \mathrm{a} \\
0,041\end{array}$ & $\begin{array}{c}0,013 \mathrm{a} \\
0,021\end{array}$ & 0,016 a 0,019 & $\begin{array}{c}0,301 \mathrm{a} \\
0,408\end{array}$ & 0,515 a 0,416 & $\begin{array}{c}0,401 \mathrm{a} \\
0,510\end{array}$ & 0,157 a 0,353 & $\begin{array}{c}0,056 \mathrm{a} \\
0,087\end{array}$ \\
\hline $\begin{array}{l}\text { Residual de oxidante } \\
\text { (mg/L) }\end{array}$ & NR & NR & NR & $<0,01$ & $<0,01$ & NR & NR & NR & 0,03 a 0,073 & $\begin{array}{c}0,026 \mathrm{a} \\
0,047\end{array}$ \\
\hline Alumínio (mg/L) & $\begin{array}{c}<0,001 \text { a } \\
0,01\end{array}$ & ND & NR & 0,04 a 0,11 & 0,02 a 0,10 & $\begin{array}{c}<0,01 \mathrm{a} \\
0,01\end{array}$ & $<0,01$ a 0,01 & NR & 0,04 a 0,17 & $\begin{array}{c}0,03 \mathrm{a} \\
0,15\end{array}$ \\
\hline
\end{tabular}

$\mathrm{D}_{\mathrm{SA}}=$ dosagem de $\mathrm{Al}_{2}\left(\mathrm{SO}_{4}\right)_{3} .14,3 \mathrm{H}_{2} \mathrm{O} ; \mathrm{AB}=$ água bruta; $\mathrm{AE}$ = água de estudo; $\mathrm{APO}$ = água pré-oxidada; $\mathrm{FAAG}$ = filtro ascendente de areia grossa; $\mathrm{FRD}=$ filtro rápido descendente; $\mathrm{COD}$ = carbono orgânico dissolvido; ND = não detectado; NR = não realizado. ${ }^{(*)}$ Valor observado no início do ensaio. 
Tabela 5.32 - Resumo geral dos resultados obtidos nos ensaios 14 e 15 na instalação piloto em escoamento contínuo sem e com pré-oxidação, durante a Fase 2.

\begin{tabular}{|c|c|c|c|c|c|c|c|c|c|c|}
\hline & \multicolumn{5}{|c|}{ ENSAIO 14 - pré-oxidação com peroxônio } & \multicolumn{5}{|c|}{ ENSAIO 15 - pré-oxidação com hipoclorito de sódio } \\
\hline "Taxas de filtração médias & \multicolumn{5}{|c|}{$\mathrm{FAAG}=183$ e $\mathrm{FRD}=282 \mathrm{~m}^{3} / \mathrm{m}^{2} \mathrm{~d}$} & \multicolumn{5}{|c|}{$\mathrm{FAAG}=183$ e $\mathrm{FRD}=286 \mathrm{~m}^{3} / \mathrm{m}^{2} \mathrm{~d}$} \\
\hline Condições de coagulação & \multicolumn{5}{|c|}{$\begin{array}{c}\mathrm{D}_{\mathrm{SA}} \cong 4,0 \mathrm{mg} / \mathrm{L} ; \mathrm{pH} \text { de coagulação }=5,12 \text { a } 5,51 ; \\
\text { temperatura }=21 \text { a } 25^{\circ} \mathrm{C}\end{array}$} & \multicolumn{5}{|c|}{$\begin{array}{c}\mathrm{D}_{\mathrm{SA}} \cong 4,0 \mathrm{mg} / \mathrm{L} ; \mathrm{pH} \text { de coagulação }=4,88 \text { a } 5,67 ; \\
\text { temperatura }=21 \text { a } 23^{\circ} \mathrm{C}\end{array}$} \\
\hline $\begin{array}{l}\text { Condições de pré- } \\
\text { oxidação }\end{array}$ & \multicolumn{5}{|c|}{$\begin{aligned} \text { Dosagem de } \mathrm{H}_{2} \mathrm{O}_{2} \cong & 1,0 \text { a } 1,3 \mathrm{mg} / \mathrm{L} ; \text { dosagem de } \mathrm{O}_{3} \cong 2,0 \text { a } 2,6 \\
& \mathrm{mg} / \mathrm{L}\left(\mathrm{H}_{2} \mathrm{O}_{2}: \mathrm{O}_{3} \cong 0,5\right)\end{aligned}$} & \multicolumn{5}{|c|}{ Dosagem aplicada de cloro $=1 \mathrm{mg} / \mathrm{L}$} \\
\hline Duração da carreira & \multicolumn{5}{|c|}{$36 \mathrm{~h}$} & \multicolumn{5}{|c|}{$16 \mathrm{~h}$} \\
\hline $\mathrm{pH}$ & 6,80 a 7,41 & 6,77 a 7,08 & $\begin{array}{c}6,15 a \\
6,61\end{array}$ & NR & NR & 6,68 a 7,36 & 6,67 a 7,27 & 5,30 a 6,47 & NR & NR \\
\hline $\begin{array}{l}\text { Alcalinidade } \\
\left(\mathrm{mg} / \mathrm{L} \mathrm{CaCO}_{3}\right)\end{array}$ & 8,4 a 11,5 & 9,4 a 11,3 & 6,5 a 8,4 & NR & NR & 9,4 a 16,3 & 9,1 a 16,6 & 5,7 a 7,7 & NR & NR \\
\hline Cor aparente $(\mathrm{uH})$ & 106 a 118 & 179 a 201 & $\begin{array}{c}126 \mathrm{a} \\
148\end{array}$ & $<1$ a 49 & $<1 \mathrm{a} 6^{(*)}$ & 107 a 121 & 155 a 220 & 178 a 217 & $<1$ a 19 & $<1$ a $12^{(*)}$ \\
\hline Cor verdadeira $(\mathrm{uH})$ & 17 a 22 & 94 a 109 & 51 a 71 & NR & $\mathrm{NR}$ & 20 a 23 & 42 a 113 & 90 a 108 & NR & NR \\
\hline Turbidez (uT) & 7,7 a 12,1 & NR & NR & 0,05 a 3,7 & $<0,01$ a 1 & $\begin{array}{c}10,43 \mathrm{a} \\
14,64\end{array}$ & NR & $\mathrm{NR}$ & 0,04 a 2,08 & $\begin{array}{l}<0,01 \mathrm{a} \\
1,03^{(*)}\end{array}$ \\
\hline Absorvância 254 nm & $\begin{array}{c}0,065 \text { a } \\
0,073\end{array}$ & $\begin{array}{c}0,183 a \\
0,197\end{array}$ & $\begin{array}{c}0,113 \mathrm{a} \\
0,137\end{array}$ & $\begin{array}{c}0,008 \text { a } \\
0,026\end{array}$ & 0,011 a 0,030 & $\begin{array}{c}0,079 \mathrm{a} \\
0,081\end{array}$ & $\begin{array}{c}0,192 \mathrm{a} \\
0,200\end{array}$ & $\begin{array}{c}0,184 a \\
0,190\end{array}$ & $\begin{array}{c}0,014 \mathrm{a} \\
0,028\end{array}$ & $\begin{array}{c}0,025 \mathrm{a} \\
0,034\end{array}$ \\
\hline COD (mg/L) & 2,3 a 2,6 & 3,7 a 4,5 & 3,4 a 4,0 & 2,5 a 3,0 & 2,2 a 2,8 & 2,5 a 2,7 & 4,0 a 4,2 & 3,8 a 4,2 & 2,0 a 2,4 & 2,1 a 2,7 \\
\hline Ferro (mg/L) & $\begin{array}{c}1,224 \mathrm{a} \\
1,453\end{array}$ & $\begin{array}{c}1,425 \mathrm{a} \\
1,515\end{array}$ & $\begin{array}{l}1,371 \mathrm{a} \\
1,479\end{array}$ & $\begin{array}{c}0,099 \mathrm{a} \\
0,173\end{array}$ & 0,036 a 0,098 & NR & NR & NR & NR & NR \\
\hline Manganês (mg/L) & $\begin{array}{c}0,302 \mathrm{a} \\
0,515\end{array}$ & $\begin{array}{c}0,323 a \\
0,497\end{array}$ & $\begin{array}{c}0,328 \mathrm{a} \\
0,396\end{array}$ & $\begin{array}{c}0,104 \mathrm{a} \\
0,270\end{array}$ & 0,059 a 0,081 & NR & NR & NR & NR & NR \\
\hline $\begin{array}{l}\text { Residual de oxidante } \\
\text { (mg/L) }\end{array}$ & NR & NR & NR & ND & ND & NR & NR & $\mathrm{NR}$ & 0,37 a 1,73 & 0,35 a 1,59 \\
\hline Alumínio residual (mg/L) & ND & ND & NR & 0,15 a 0,23 & 0,13 a 0,20 & 0,01 & 0,01 & $\mathrm{NR}$ & 0,10 a 0,13 & 0,10 a 0,15 \\
\hline
\end{tabular}

$\mathrm{D}_{\mathrm{SA}}=$ dosagem de $\mathrm{Al}_{2}\left(\mathrm{SO}_{4}\right)_{3} .14,3 \mathrm{H}_{2} \mathrm{O} ; \mathrm{AB}$ = água bruta; $\mathrm{AE}$ = água de estudo; $\mathrm{APO}$ = água pré-oxidada; $\mathrm{FAAG}$ = filtro ascendente de areia grossa; $\mathrm{FRD}=$ filtro rápido descendente; $\mathrm{CO} \mathrm{D}=$ carbono orgânico dissolvido; ND = não detectado; NR = não realizado. ${ }^{(*)}$ Valor observado no início do ensaio. 


\subsubsection{Formação de Subprodutos da Pré-Oxidação e Pós-Cloração}

Os resultados das análises de formação de subprodutos da pré-oxidação e pós-cloração estão apresentados nas Tabelas D 1.1 a D 1.4 do ANEXO D e os cromatogramas referentes a estes resultados também estão apresentados no ANEXO D. Nas Figuras 5.80 a 5.88 estão identificados e quantificados os subprodutos formados com a utilização dos diferentes oxidantes utilizados nos ensaios na instalação piloto em escoamento contínuo com pré-oxidação.

Após a coleta das amostras de água pré-oxidada e do efluente do FRD, foi feita a pós-cloração com tricloro-s-triazina-triona, com dosagem de cloro variando de 4 a $6 \mathrm{mg} / \mathrm{L}\left(\mathrm{D}_{\mathrm{Cl} 2}: \mathrm{COD}_{\text {amostra }}=2\right)$, cuja variação foi decorrente do valor do COD da amostra, e tempo de contato de 24 horas. $\mathrm{O} \mathrm{pH}$ da água pré-oxidada variou de 5,7 a 6,5 e das amostras do efluente do FRD variaram de 4,9 a 5,2 (amostra 1, $\mathrm{pH} \cong$ 5,0); 7,0 a 8,6 (amostra 2, pH 7,0); e 9,0 a 10,5 (amostra 3, $\mathrm{pH} \cong 9,0$ ).

Não foram feitas as análises de formação de subprodutos do efluente do FRD para os ensaios 8 (sem pré-oxidação), 9 (pré-oxidação com ozônio) e 10 (préoxidação com peróxido de hidrogênio), e no ensaio 11 (pré-oxidação com tricloro-striazina-triona) foram feitas somente as análises de formação de trialometanos. Os fatores que impediram a realização destas análises foram o atraso na importação dos padrões cromatográficos e conseqüentemente no desenvolvimento dos métodos para as análises dos subprodutos, e o tempo de armazenamento das amostras recomendado pelos métodos, de 7 dias da amostra sem extração e 7 dias das amostras extraídas.

No período de realização dos ensaios 11,12 , 13, 14 e 15 os métodos para a quantificação de subprodutos já haviam sido desenvolvidos e foi possível a realização das análises. Com o objetivo de verificar a formação de subprodutos utilizando-se ozônio e peróxido de hidrogênio, que corresponderiam aos ensaios 9 e 10, fez-se pré-ensaios na instalação piloto, com pré-oxidação da água de estudo, nas mesmas condições dos ensaios 9 e 10, e foram coletadas amostras de água pré-oxidada, as quais foram cloradas e após tempo de contato de 24 horas foram submetidas às análises de formação de subprodutos, cujos resultados estão apresentados nas Tabelas D 1.1 e D 1.2 do ANEXO D e nas Figuras 5.80 a 5.88.

Nas Figuras 5.80, 5.81 e 5.82 estão apresentados os trialometanos (clorofórmio, bromodiclorometano, dibromoclorometano e bromofórmio), nas Figuras 5.83, 5.84 e 5.85 estão apresentadas as haloacetonitrilas, halocetonas e 
halopicrinas (tricloroacetonitrila, dicloroacetonitrila, bromocloroacetonitrila, dibromoacetonitrila, cloropicrina, 1,1-dicloropropanona, 1,1,1-tricloropropanona) e nas Figuras 5.86, 5.87 e 5.88 estão apresentados os ácidos haloacéticos (ácido cloroacético, ácido bromoacético, ácido dicloroacético, ácido tricloroacético, ácido bromocloroacético, ácido bromodicloroacético, ácido dibromoacético, ácido clorodibromoacético e ácido tribromoacético) das amostras pré-oxidadas e do efluente do FRD, com variação do $\mathrm{pH}$, e pós-cloradas.

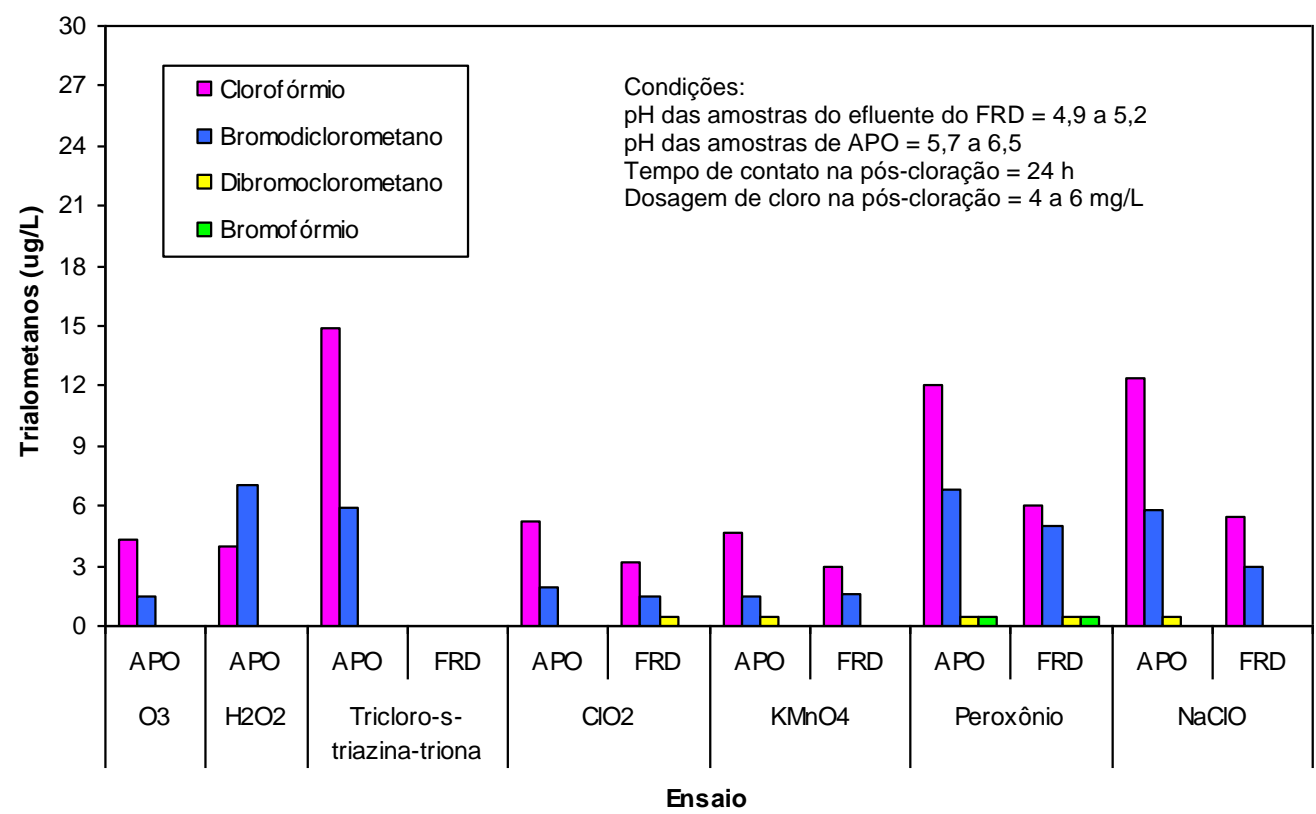

Figura 5.80 - Formação de trialometanos nas amostras de APO ( $\mathrm{pH}$ de 5,7 a 6,5) e no efluente do FRD ( $\mathrm{pH}$ de 4,9 a 5,2) pós-cloradas com dosagem de cloro de 4 a $6 \mathrm{mg} / \mathrm{L} \mathrm{e}$ tempo de contato de 24 horas, coletadas após 6 horas de funcionamento dos filtros nos ensaios na instalação piloto em escoamento contínuo com pré-oxidação e taxas de filtração de $180 \mathrm{~m}^{3} / \mathrm{m}^{2} \mathrm{~d}$ (FAAG) e $280 \mathrm{~m}^{3} / \mathrm{m}^{2} \mathrm{~d}$ (FRD). Fonte: Tabelas D 1.1 a D 1.4 e cromatogramas do ANEXO D. 


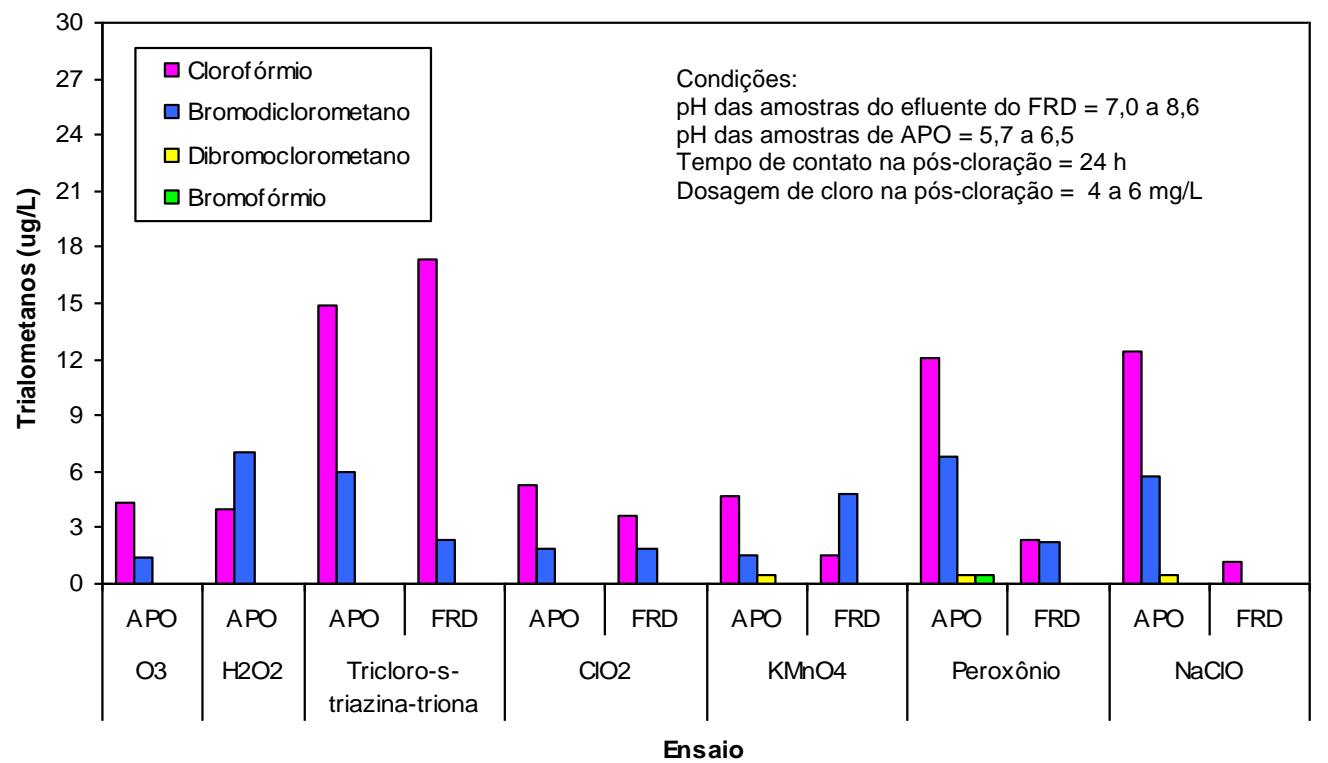

Figura 5.81 - Formação de trialometanos nas amostras de APO (pH de 5,7 a 6,5) e no efluente do FRD (pH de 7,0 a 8,6) pós-cloradas com dosagem de cloro de 4 a $6 \mathrm{mg} / \mathrm{L} \mathrm{e}$ tempo de contato de 24 horas, coletadas após 6 horas de funcionamento dos filtros nos ensaios na instalação piloto em escoamento contínuo com pré-oxidação e taxas de filtração de $180 \mathrm{~m}^{3} / \mathrm{m}^{2} \mathrm{~d}$ (FAAG) e $280 \mathrm{~m}^{3} / \mathrm{m}^{2} \mathrm{~d}$ (FRD). Fonte: Tabelas D 1.1 a D 1.4 e cromatogramas do ANEXO D.

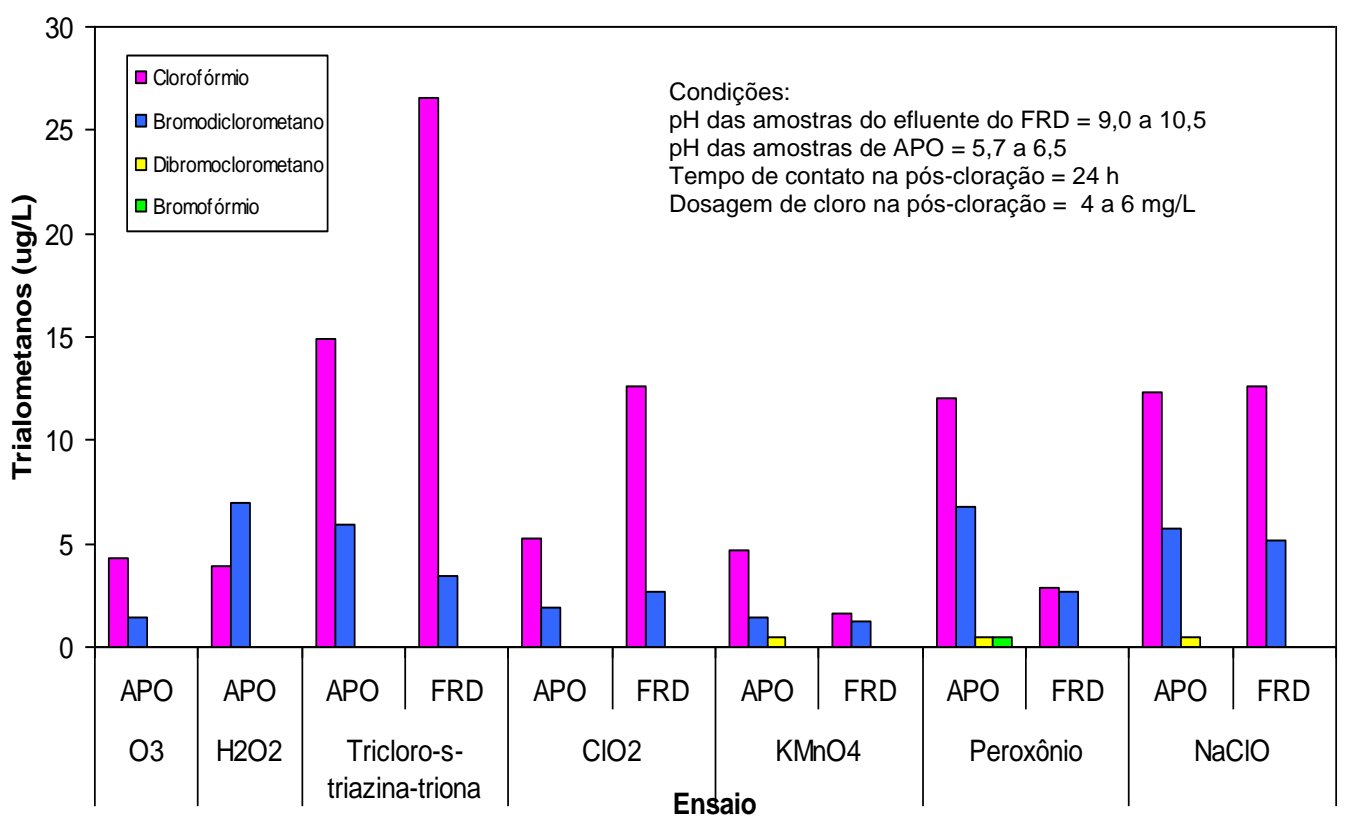

Figura 5.82 - Formação de trialometanos nas amostras de APO (pH de 5,7 a 6,5) e do efluente do FRD ( $\mathrm{pH}$ de 9,0 a 10,5) pós-cloradas com dosagem de cloro de 4 a $6 \mathrm{mg} / \mathrm{L} \mathrm{e}$ tempo de contato de 24 horas, coletadas após 6 horas de funcionamento dos filtros nos ensaios na instalação piloto em escoamento contínuo com pré-oxidação e taxas de filtração de $180 \mathrm{~m}^{3} / \mathrm{m}^{2} \mathrm{~d}$ (FAAG) e $280 \mathrm{~m}^{3} / \mathrm{m}^{2} \mathrm{~d}$ (FRD). Fonte: Tabelas D 1.1 a D 1.4 e cromatogramas do ANEXO D. 


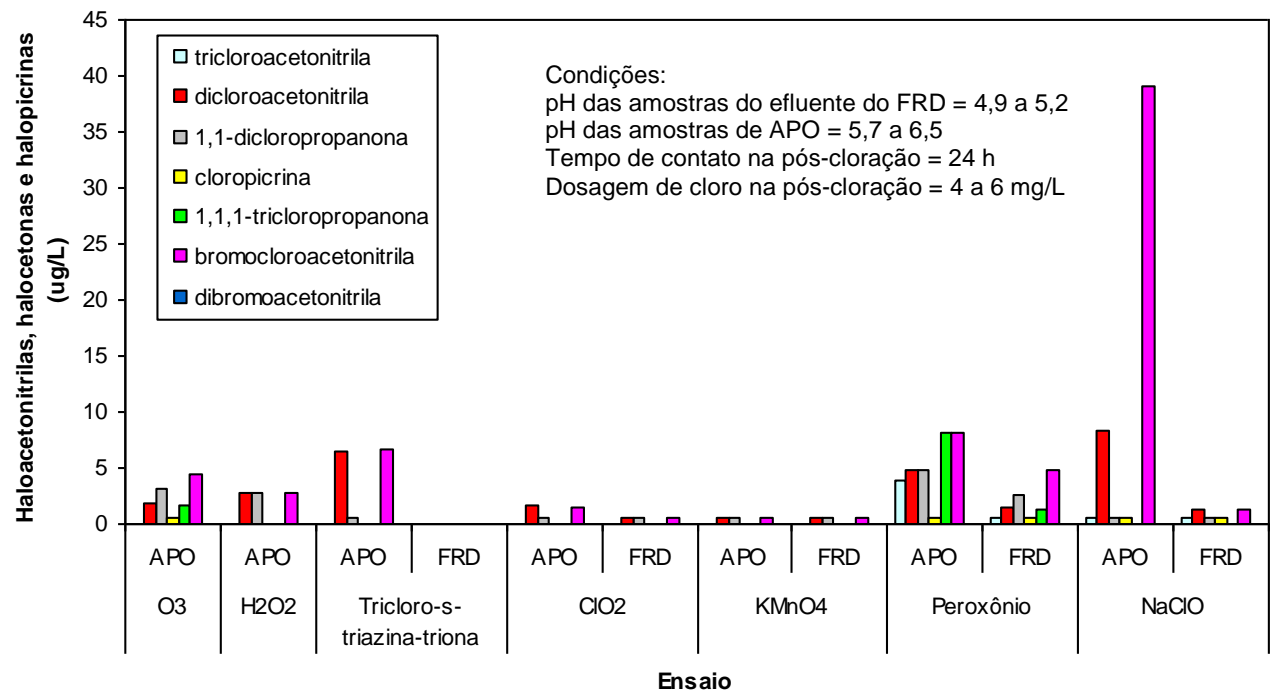

Figura 5.83 - Formação de haloacetonitrilas, halocetonas e halopicrinas nas amostras de APO ( $\mathrm{pH}$ de 5,7 a 6,5 ) e no efluente do FRD ( $\mathrm{pH}$ de 4,9 a 5,2) pós-cloradas com dosagem de cloro de 4 a $6 \mathrm{mg} / \mathrm{L}$ e tempo de contato de 24 horas, coletadas após 6 horas de funcionamento dos filtros nos ensaios na instalação piloto em escoamento contínuo com pré-oxidação e taxas de filtração de $180 \mathrm{~m}^{3} / \mathrm{m}^{2} d$ (FAAG) e $280 \mathrm{~m}^{3} / \mathrm{m}^{2} \mathrm{~d}$ (FRD). Fonte: Tabelas D 1.1 a D 1.4 e cromatogramas do ANEXO D.

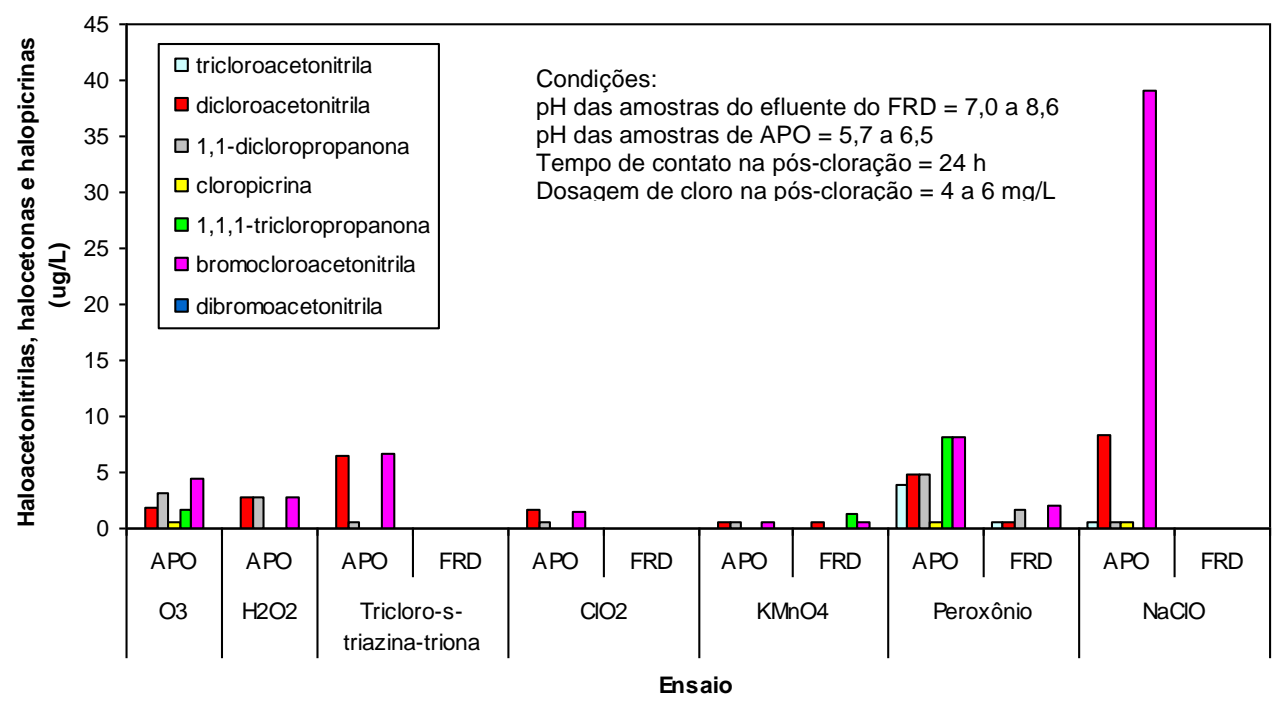

Figura 5.84 - Formação de haloacetonitrilas, halocetonas e halopicrinas nas amostras de APO ( $\mathrm{pH}$ de 5,7 a 6,5) e no efluente do FRD ( $\mathrm{pH}$ de 7,0 a 8,6) pós-cloradas com dosagem de cloro de 4 a $6 \mathrm{mg} / \mathrm{L}$ e tempo de contato de 24 horas, coletadas após 6 horas de funcionamento dos filtros nos ensaios na instalação piloto em escoamento contínuo com pré-oxidação e taxas de filtração de $180 \mathrm{~m}^{3} / \mathrm{m}^{2} d$ (FAAG) e $280 \mathrm{~m}^{3} / \mathrm{m}^{2} \mathrm{~d}$ (FRD). Fonte: Tabelas D 1.1 a D 1.4 e cromatogramas do ANEXO D. 


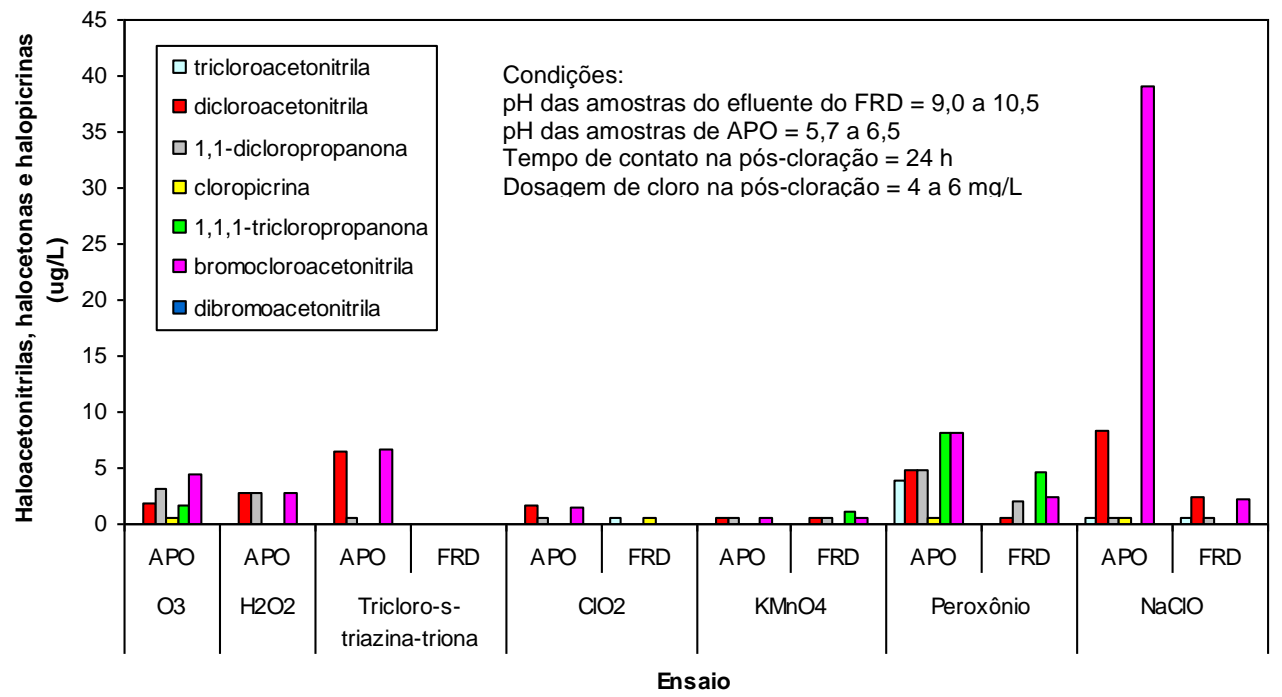

Figura 5.85 - Formação de haloacetonitrilas, halocetonas e halopicrinas nas amostras de APO (pH de 5,7 a 6,5) e no efluente do FRD ( $\mathrm{pH}$ de 9,0 a 10,5) pós-cloradas com dosagem de cloro de 4 a $6 \mathrm{mg} / \mathrm{L}$ e tempo de contato de 24 horas, coletadas após 6 horas de funcionamento dos filtros nos ensaios na instalação piloto em escoamento contínuo com pré-oxidação e taxas de filtração de $180 \mathrm{~m}^{3} / \mathrm{m}^{2} d$ (FAAG) e $280 \mathrm{~m}^{3} / \mathrm{m}^{2} \mathrm{~d}$ (FRD). Fonte: Tabelas D 1.1 a D 1.4 e cromatogramas do ANEXO D.

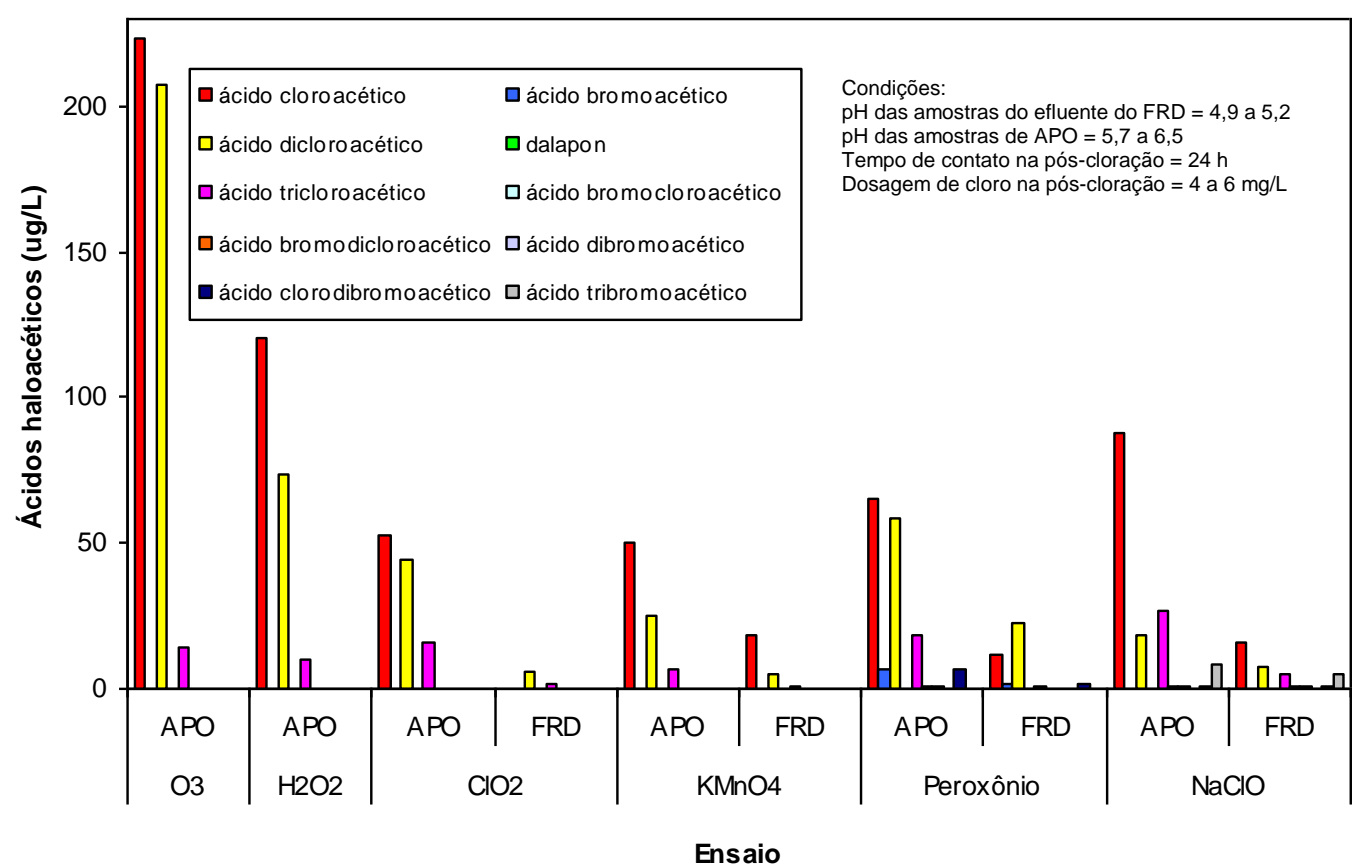

Figura 5.86 - Formação de ácidos haloacéticos nas amostras de APO (pH de 5,7 a 6,5) e no efluente do FRD ( $\mathrm{pH}$ de 4,9 a 5,2) pós-cloradas com dosagem de cloro de 4 a $6 \mathrm{mg} / \mathrm{L}$ e tempo de contato de 24 horas, coletadas após 6 horas de funcionamento dos filtros nos ensaios na instalação piloto em escoamento contínuo com pré-oxidação e taxas de filtração de $180 \mathrm{~m}^{3} / \mathrm{m}^{2} \mathrm{~d}$ (FAAG) e $280 \mathrm{~m}^{3} / \mathrm{m}^{2} \mathrm{~d}(\mathrm{FRD})$. Fonte: Tabelas $\mathrm{D} 1.1$ a D 1.4 e cromatogramas do ANEXO D. 


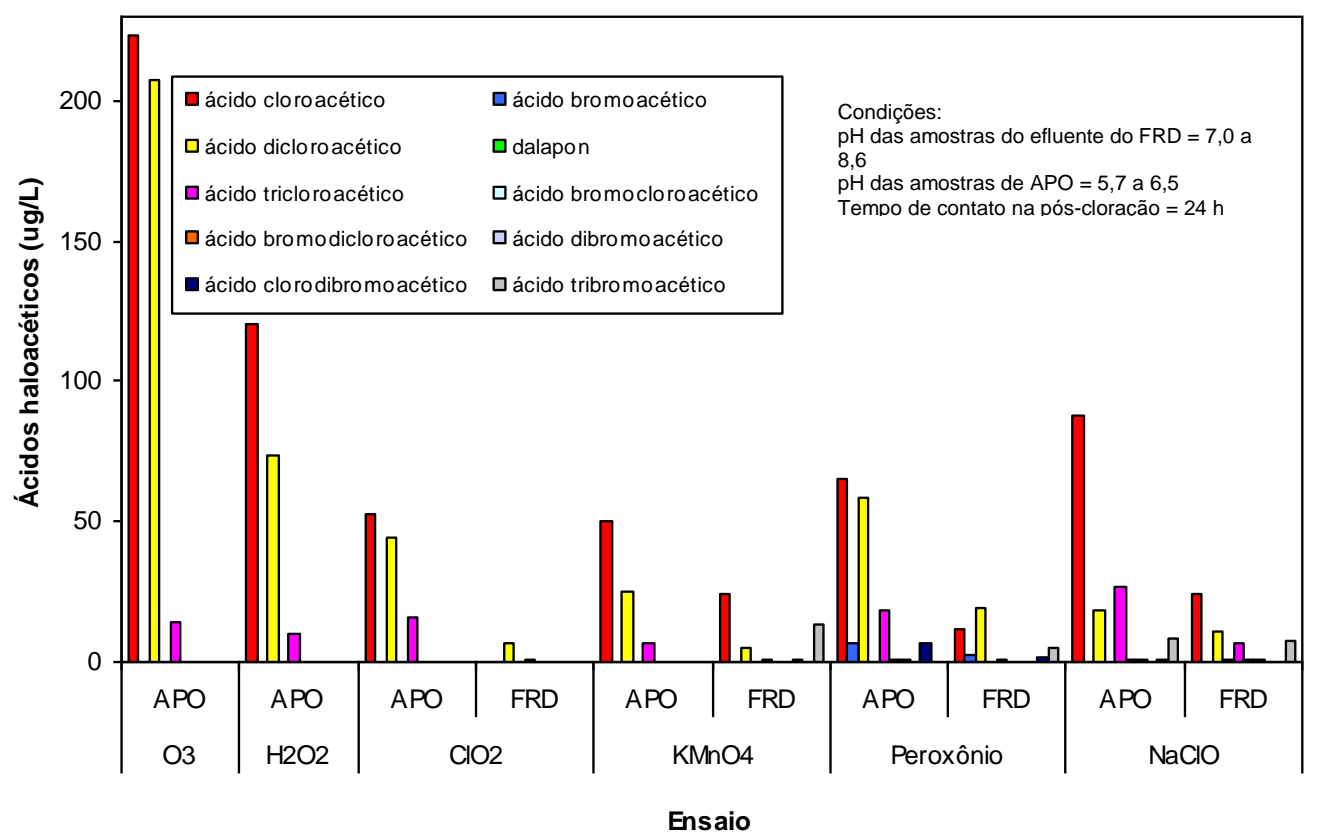

Figura 5.87 - Formação de ácidos haloacéticos nas amostras de APO (pH de 5,7 a 6,5) e no efluente do FRD (pH de 7,0 a 8,6) pós-cloradas com dosagem de cloro de 4 a $6 \mathrm{mg} / \mathrm{L}$ e tempo de contato de 24 horas, coletadas após 6 horas de funcionamento dos filtros nos ensaios na instalação piloto em escoamento contínuo com pré-oxidação e taxas de filtração de $180 \mathrm{~m}^{3} / \mathrm{m}^{2} \mathrm{~d}$ (FAAG) e $280 \mathrm{~m}^{3} / \mathrm{m}^{2} \mathrm{~d}$ (FRD). Fonte: Tabelas D 1.1 a D 1.4 e cromatogramas do ANEXO D.

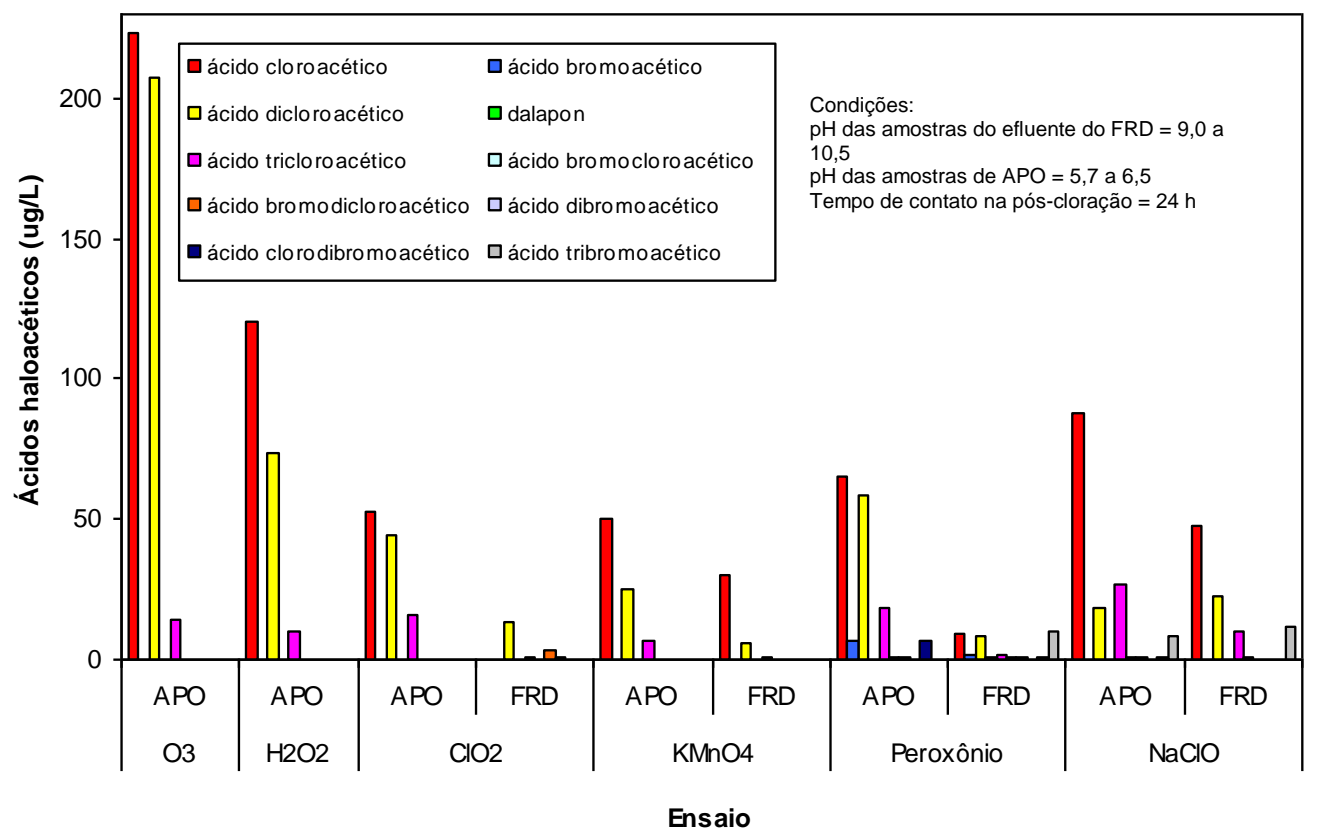

Figura 5.88 - Formação de ácidos haloacéticos nas amostras de APO (pH de 5,7 a 6,5) e no efluente do FRD (pH de 9,0 a 10,5) pós-cloradas com dosagem de cloro de 4 a 6 mg/L e tempo de contato de 24 horas, coletadas após 6 horas de funcionamento dos filtros nos 
ensaios na instalação piloto em escoamento contínuo com pré-oxidação e taxas de filtração de $180 \mathrm{~m}^{3} / \mathrm{m}^{2} \mathrm{~d}$ (FAAG) e $280 \mathrm{~m}^{3} / \mathrm{m}^{2} \mathrm{~d}$ (FRD). Fonte: Tabelas D 1.1 a D 1.4 e cromatogramas do ANEXO D.

Em todas as amostras de água pré-oxidadas e pós-cloradas foi observada a formação de subprodutos. A presença de clorofórmio e bromodiclorometano foi evidente em todos os ensaios, com valores máximos de 14,92 $\mu \mathrm{g} / \mathrm{L}$ (pré-oxidação com tricloro-s-triazina-triona) e 7,0 $\mu \mathrm{g} / \mathrm{L}$ (pré-oxidação com peróxido de hidrogênio) respectivamente, sendo encontrado em menor concentração nos ensaios 12 (préoxidação com dióxido de cloro) e 13 (pré-oxidação com permanganato de potássio). Com relação às haloacetonitrilas, halocetonas e halopicrinas, houve formação em menores concentrações em todos os ensaios $(<10 \mu \mathrm{g} / \mathrm{L})$, com exceção da formação do composto bromocloroacetonitrila, no ensaio 15 (pré-oxidação com hidróxido de sódio) que apresentou valor de 39,0 $\mu \mathrm{g} / \mathrm{L}$. Quanto aos ácidos haloacéticos, os maiores valores observados foram de 223,47 $\mu \mathrm{g} / \mathrm{L}$ de ácido cloroacético e de $177,57 \mu \mathrm{g} / \mathrm{L}$ de ácido dicloroacético na amostra de água préoxidada com ozônio e pós-clorada; e de 120,82 $\mu \mathrm{g} / \mathrm{L}$ de ácido cloroacético na amostra de água pré-oxidada com peróxido de hidrogênio e pós-clorada. Nos demais ensaios houve formação de ácidos haloacéticos em menores concentrações, com valores menores que $70 \mu \mathrm{g} / \mathrm{L}$.

Nas Figuras 5.80, 5.81 e 5.82 observa-se o aumento de clorofórmio e bromodiclorometano nas amostras do efluente do FRD com o aumento do $\mathrm{pH}$ das amostras, principalmente nas amostras do ensaio 11 (pré-oxidação com tricloro-striazina-triona). Para este ensaio, na amostra do efluente do FRD com pH =4,9 não houve formação de trialometanos, no entanto, as amostras 2 e 3 , com $\mathrm{pH}=8,4$ e $\mathrm{pH}=10,2$ respectivamente, apresentaram valores de clorofórmio e bromoclorometano maiores que os apresentados na amostra de água pré-oxidada (ver Tabela D 1.2 do ANEXO D). Em geral, nas amostras do efluente do FRD obteve-se menores concentrações de trialometanos do que nas amostras de água pré-oxidada, com exceção do ensaio 12 (pré-oxidação com dióxido de cloro) em que se obtiveram maiores concentrações de clorofórmio e bromodiclorometano na amostra do efluente do FRD com pH = 10,5. Em todos os ensaios, a concentração de clorofórmio nas amostras do efluente do FRD foi menor que $27 \mu \mathrm{g} / \mathrm{L}$ e de bromodiclorometano, menor que $6 \mu \mathrm{g} / \mathrm{L}$. 
Com relação à formação de haloacetonitrilas, halocetonas e halopicrinas, concentrações menores que $5 \mu \mathrm{g} / \mathrm{L}$ foram obtidas nas amostras do efluente do FRD, com diferentes valores de $\mathrm{pH}$.

Comparando-se as Figuras 5.86, 5.87 e 5.88 observa-se um aumento gradual na formação de ácidos haloacéticos nas amostras do efluente do FRD com o aumento do pH, com exceção do ensaio 14 (pré-oxidação com peroxônio) em que ocorreu diminuição nas concentrações de ácido dicloroacético com o aumento do pH. Em geral, as concentrações de ácidos haloacéticos obtidas para as amostras do efluente do FRD com diferentes valores de $\mathrm{pH}$, foram menores que $50 \mu \mathrm{g} / \mathrm{L}$. 


\section{CONCLUSÕES E RECOMENDAÇÕES}

Com base nos resultados obtidos nos ensaios realizados na instalação piloto em escoamento contínuo correspondentes à Fase 1, conclui-se:

a) Houve eficiência de remoção de substâncias húmicas nos ensaios sem préoxidação em termos de cor aparente, absorvância 254 nm e carbono orgânico dissolvido, no entanto, devido a coagulação ocorrer em pH próximo de 5,0, o efluente do filtro descendente apresentou, nos ensaios em que foram realizadas as análises de residual de alumínio, concentrações que ultrapassaram o limite permitido pelo Padrão de Potabilidade prescrito na Portaria 518/2004;

b) A taxa de filtração de $240 \mathrm{~m}^{3} / \mathrm{m}^{2} \mathrm{~d}$ no FAAG, utilizada no ensaio 1 , foi relativamente alta, devido à necessidade de execução de DFls quando o efluente do FAAG atingia cor aparente $\geq 50 \mathrm{uH}$, em média a cada 2 horas, inviabilizando a operação e recuperação da qualidade do efluente do FAAG;

c) Dos ensaios com duração de 72 horas, o ensaio 7, com taxas de filtração de $120 \mathrm{~m}^{3} / \mathrm{m}^{2} \mathrm{~d}$ no FAAG e $240 \mathrm{~m}^{3} / \mathrm{m}^{2} \mathrm{~d}$ no $\mathrm{FRD}$, foi o que apresentou maior produção efetiva de água filtrada, com $95,4 \%$, e o ensaio 5 , com taxas de filtração de $120 \mathrm{~m}^{3} / \mathrm{m}^{2} \mathrm{~d}$ no FAAG e $160 \mathrm{~m}^{3} / \mathrm{m}^{2} \mathrm{~d}$ no FRD, foi o ensaio em que se obteve menor produção efetiva de água filtrada, com 93,6\%;

d) No ensaio 5, com taxas de filtração de $120 \mathrm{~m}^{3} / \mathrm{m}^{2} \mathrm{~d}$ no FAAG e de 160 $\mathrm{m}^{3} / \mathrm{m}^{2} \mathrm{~d}$ no FRD, o efluente do FAAG apresentou cor aparente menor ou igual a $1 \mathrm{uH}$ e turbidez menor que $1 \mathrm{uT}$, não havendo necessidade do filtro descendente, no que se refere a estas características da água;

e) Na maioria dos ensaios na instalação piloto em escoamento contínuo sem pré-oxidação e com DFls no FAAG, o critério de execução de DFIs quando a cor aparente do FAAG atingiu valor $\geq 50 \mathrm{uH}$ foi predominante, em geral a partir da $2^{\mathrm{a}} \mathrm{DFI}$.

Com base nos resultados obtidos nos ensaios realizados na instalação piloto em escoamento contínuo correspondentes à Fase 2, conclui-se:

a) Nos ensaios com pré-oxidação a dosagem de sulfato de alumínio foi reduzida em aproximadamente $50 \%$ e o pH de coagulação variou de 5,0 a 
5,6, resultando em menores concentrações de alumínio residual no efluente do filtro descendente, com valores abaixo do limite permitido pelo Padrão de Potabilidade prescrito na Portaria 518/2004;

b) Observou-se redução de 43 a $63 \%$ na perda de carga final do filtro ascendente de areia grossa nos ensaios com pré-oxidação, comparados ao ensaio sem pré-oxidação, com taxas de filtração de $180 \mathrm{~m}^{3} / \mathrm{m}^{2} \mathrm{~d}$ no FAAG e de $280 \mathrm{~m}^{3} / \mathrm{m}^{2} \mathrm{~d}$ no FRD;

c) Com relação à formação de trialometanos e considerando o limite exigido na Portaria 518/2004, não ocorreu formação significativa destes subprodutos, apresentando valores menores que $15 \mu \mathrm{g} / \mathrm{L}$ de clorofórmio e menores que 7 $\mu \mathrm{g} / \mathrm{L}$ de bromodiclorometano nas amostras de água pré-oxidadas e póscloradas, e menores que $27 \mu \mathrm{g} / \mathrm{L}$ e $6 \mu \mathrm{g} / \mathrm{L}$ de clorofórmio e bromodiclorometano respectivamente, nas amostras do efluente do filtro descendente pós-cloradas e com variação do $\mathrm{pH}$, observando-se o aumento das concentrações destes subprodutos com 0 aumento do $\mathrm{pH}$, principalmente no ensaio 11 com pré-oxidação com tricloro-s-triazina-triona;

d) Quanto à formação de haloacetonitrilas, halocetonas e halopicrinas, as concentrações estiveram abaixo de $10 \mu \mathrm{g} / \mathrm{L}$, com exceção de $39 \mu \mathrm{g} / \mathrm{L}$ de bromocloroacetonitrila observado na amostra de água pré-oxidada e pósclorada, no ensaio 15 com pré-oxidação com hipoclorito de sódio, nas amostras do efluente do FRD com variação do $\mathrm{pH}$, as concentrações obtidas destes subprodutos foram menores que $5 \mu \mathrm{g} / \mathrm{L}$;

e) Os ácidos haloacéticos apresentaram as concentrações mais elevadas comparadas aos demais subprodutos, com concentrações de 121 e 223 $\mu \mathrm{g} / \mathrm{L}$ de ácido cloroacético e de 73 e $208 \mu \mathrm{g} / \mathrm{L}$ de ácido dicloroacético, na amostra de água pré-oxidada e pós-clorada quando utilizou-se peróxido de hidrogênio e ozônio respectivamente, com os demais pré-oxidantes houve formação de ácidos haloacéticos em concentrações de no máximo $88 \mu \mathrm{g} / \mathrm{L}$, nas amostras do efluente do FRD com diferentes valores de $\mathrm{pH}$, as concentrações obtidas foram menores que $48 \mu \mathrm{g} / \mathrm{L}$;

f) Os pré-oxidantes que apresentaram menores concentrações de subprodutos foram o dióxido de cloro e o permanganato de potássio, tanto na água pré-oxidada quanto no efluente do FRD. 
Com base no trabalho realizado, as seguintes recomendações são apresentadas:

a) Verificar a eficiência de remoção de substâncias húmicas com pré-oxidação e dupla filtração, em ensaios em instalação piloto, utilizando-se substâncias húmicas aquáticas;

b) Em ensaios em instalação piloto, quando utilizar pré-oxidação, determinar as dosagens de coagulante, oxidante e o pH de coagulação em escoamento contínuo, evitando desta maneira, erros na aplicabilidade dos resultados determinados em reatores estáticos;

c) Descartar o efluente do filtro ascendente logo após as descargas de fundo intermediárias, durante o tempo suficiente para a eliminação das partículas que se deprendem do topo do meio filtrante, evitando deste modo, lavagens do filtro descendente em períodos muito curtos;

d) Quando utilizar pré-oxidação, sempre verificar a formação de subprodutos, por representarem risco à saúde humana;

e) Não utilizar tricloro-s-triazina-triona em tratamento de água, e sim, hipoclorito de sódio, hipoclorito de cálcio ou cloro gasoso na pré-oxidação e pós-cloração;

f) Quando utilizar sulfato de alumínio como coagulante, verificar o alumínio residual na água filtrada;

g) Quando utilizar dióxido de cloro, monitorar residuais de clorito e clorato. 
ANEXOS 


\section{ANEXO A}

Características do Sulfato de Alumínio 
Tabela A.1 - Massa específica e concentração de $\mathrm{Al}_{2}\left(\mathrm{SO}_{4}\right)_{3} .14,3 \quad \mathrm{H}_{2} \mathrm{O}$ à temperatura de 20 a $24^{\circ} \mathrm{C}$.

\begin{tabular}{|c|c|c|c|}
\hline $\begin{array}{l}\text { Massa específica } \\
(\mathrm{kg} / \mathrm{L})\end{array}$ & $\begin{array}{c}\text { Concentração } \\
(\mathrm{g} / \mathrm{L})\end{array}$ & $\begin{array}{c}\text { Massa específica } \\
(\mathrm{kg} / \mathrm{L})\end{array}$ & $\begin{array}{c}\text { Concentração } \\
(\mathrm{g} / \mathrm{L})\end{array}$ \\
\hline 1,005 & 11,6 & 1,175 & 319,6 \\
\hline 1,010 & 19,7 & 1,180 & 330,4 \\
\hline 1,015 & 27,4 & 1,185 & 340,1 \\
\hline 1,020 & 35,7 & 1,190 & 349,9 \\
\hline 1,025 & 43,6 & 1,195 & 360,9 \\
\hline 1,030 & 52,0 & 1,200 & 372,0 \\
\hline 1,035 & 60,0 & 1,205 & 382,6 \\
\hline 1,040 & 68,6 & 1,210 & 393,3 \\
\hline 1,045 & 76,8 & 1,215 & 404,0 \\
\hline 1,050 & 85,6 & 1,220 & 414,8 \\
\hline 1,055 & 93,9 & 1,225 & 426,3 \\
\hline 1,060 & 102,8 & 1,230 & 437,9 \\
\hline 1,065 & 111,3 & 1,235 & 448,3 \\
\hline 1,070 & 119,8 & 1,240 & 458,8 \\
\hline 1,075 & 129,0 & 1,245 & 470,6 \\
\hline 1,080 & 138,2 & 1,250 & 482,5 \\
\hline 1,085 & 147,0 & 1,255 & 493,9 \\
\hline 1,090 & 155,9 & 1,260 & 505,3 \\
\hline 1,095 & 164,8 & 1,265 & 516,8 \\
\hline 1,100 & 173,8 & 1,270 & 528,3 \\
\hline 1,105 & 182,9 & 1,275 & 540,6 \\
\hline 1,110 & 192,0 & 1,280 & 553,0 \\
\hline 1,115 & 201,3 & 1,285 & 564,1 \\
\hline 1,120 & 210,6 & 1,290 & 575,3 \\
\hline 1,125 & 220,5 & 1,295 & 587,9 \\
\hline 1,130 & 230,5 & 1,300 & 600,6 \\
\hline 1,135 & 239,5 & 1,305 & 613,4 \\
\hline 1,140 & 240,5 & 1,310 & 626,2 \\
\hline 1,145 & 258,8 & 1,315 & 637,8 \\
\hline 1,150 & 269,1 & 1,320 & 649,4 \\
\hline 1,155 & 279,5 & 1,325 & 662,5 \\
\hline 1,160 & 290,0 & 1,330 & 675,6 \\
\hline 1,165 & 299,4 & 1,335 & 688,2 \\
\hline 1,170 & 308,9 & 1,340 & 700,8 \\
\hline
\end{tabular}

Fonte: NHEEL QUÍMICA LTDA - Rio Claro (SP) 


\section{ANEXO B}

Resultados obtidos nos Ensaios na Instalação Piloto em Escoamento Contínuo - Fase 1 
Tabela B 1.1 - Características físicas da $A B, A E$ e efluentes do FAAG e do FRD durante o ensaio 1 sem pré-oxidação e com DFIs no FAAG (FAAG $=240 \mathrm{~m}^{3} / \mathrm{m}^{2} \mathrm{~d} ; \mathrm{FRD}=280 \mathrm{~m}^{3} / \mathrm{m}^{2} \mathrm{~d}$ ).

\begin{tabular}{|c|c|c|c|c|c|c|c|}
\hline \multirow{2}{*}{$\begin{array}{l}\text { TF } \\
\text { (h) } \\
\end{array}$} & \multirow{2}{*}{\begin{tabular}{|c}
$\begin{array}{c}\text { Temperatura } \\
\left({ }^{\circ} \mathrm{C}\right)\end{array}$ \\
$\mathrm{AE}$ \\
\end{tabular}} & \multicolumn{4}{|c|}{ Cor aparente $(\mathrm{uH})$} & \multicolumn{2}{|c|}{ Cor verdadeira (uH) } \\
\hline & & AB & $\mathrm{AE}$ & FAAG & FRD & $\mathrm{AB}$ & AE \\
\hline 0 & 20,0 & 81 & 185 & & & 13 & 92 \\
\hline 1 & 19,5 & 89 & 197 & $<1,0$ & $<1,0$ & 12 & 96 \\
\hline 3 & 19,0 & & 202 & $<1,0$ & $<1,0$ & & 112 \\
\hline 5 & 19,0 & & 182 & $<1,0$ & $<1,0$ & & 93 \\
\hline 7 & 19,0 & 85 & 192 & $<1,0$ & $<1,0$ & 18 & 109 \\
\hline 9 & 18,5 & & 179 & $<1,0$ & $<1,0$ & & 95 \\
\hline 11 & 19,0 & & 201 & 4,0 & $<1,0$ & & 93 \\
\hline 13 & 20,0 & 117 & 221 & 30,0 & $<1,0$ & 17 & 114 \\
\hline 15 & 21,5 & & 205 & 44,0 & $<1,0$ & & 91 \\
\hline 17 & 22,0 & & 200 & 15,0 & $<1,0$ & & 109 \\
\hline 19 & 22,0 & 91 & 197 & 49,0 & $<1,0$ & 20 & 109 \\
\hline 21 & 21,0 & & 168 & 17,0 & $<1,0$ & & 85 \\
\hline 23 & 20,0 & & 201 & 36,0 & $<1,0$ & & 113 \\
\hline 26 & 19,5 & 80 & 190 & 38,0 & $<1,0$ & 17 & 76 \\
\hline 27 & 19,5 & & 210 & 9,0 & $<1,0$ & & 128 \\
\hline 29 & 19,5 & & 184 & 31,0 & $<1,0$ & & 104 \\
\hline 31 & 19,5 & 80 & 185 & 39,0 & $<1,0$ & 20 & 94 \\
\hline 33 & 19,5 & & 186 & 14,0 & $<1,0$ & & 122 \\
\hline 35 & 19,5 & & 192 & 55,0 & $<1,0$ & & 87 \\
\hline 37 & 19,5 & 210 & 294 & 11,0 & $<1,0$ & 26 & 97 \\
\hline 39 & 20,0 & & 329 & $<1,0$ & $<1,0$ & & 133 \\
\hline 41 & 20,0 & & 366 & 57,0 & $<1,0$ & & 112 \\
\hline 43 & 20,0 & 235 & 340 & 59,0 & $<1,0$ & 27 & 106 \\
\hline 45 & 20,0 & & 337 & 37,0 & 4,0 & & 109 \\
\hline 47 & 19,5 & & 321 & 35,0 & $<1,0$ & & 103 \\
\hline 50 & 19,0 & 238 & 308 & 26,0 & $<1,0$ & 29 & 101 \\
\hline Média & 19,8 & 131 & 230 & 24,4 & 0,6 & 20 & 103 \\
\hline Mínimo & 18,5 & 80 & 168 & $<1,0$ & $<1,0$ & 12 & 76 \\
\hline Máximo & 22,0 & 238 & 366 & 59,0 & 4,0 & 29 & 133 \\
\hline DP & 0,89 & 68,22 & 62,70 & 19,98 & 0,70 & 5,78 & 13,31 \\
\hline
\end{tabular}

$\mathrm{TF}=$ tempo de funcionamento; $\mathrm{AE}$ = água de estudo; $\mathrm{AB}$ = água bruta; $\mathrm{FAAG}$ = filtro ascendente de areia grossa; $\mathrm{FRD}=$ filtro rápido descendente; $\mathrm{DP}=$ desvio padrão . 


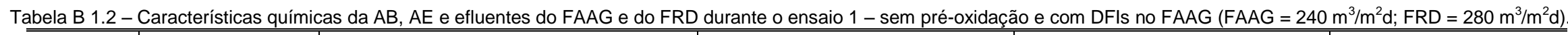

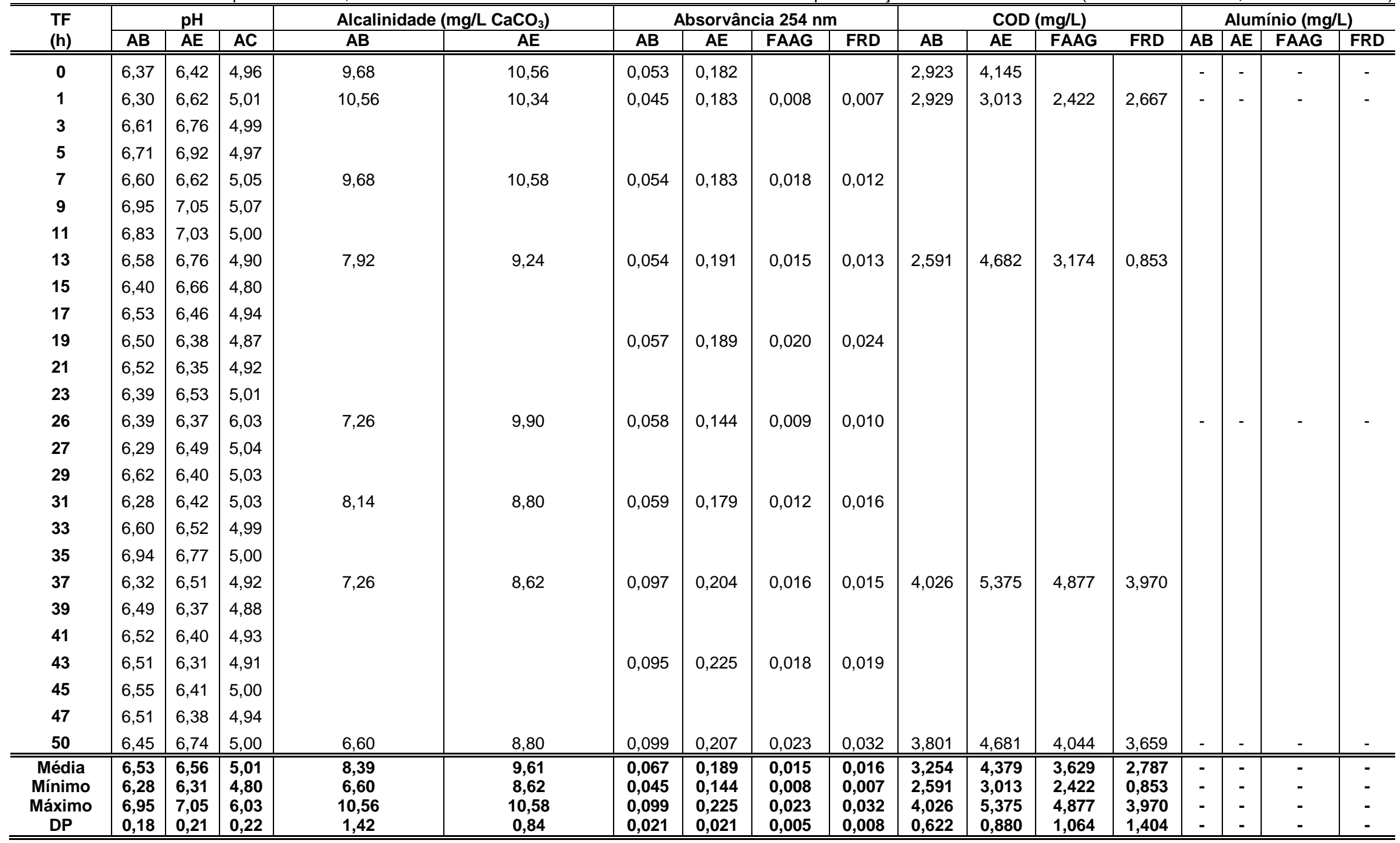


Tabela B 1.3 - Perda de carga no FAAG $\left(240 \mathrm{~m}^{3} / \mathrm{m}^{2} \mathrm{~d}\right)$ e no FRD $\left(280 \mathrm{~m}^{3} / \mathrm{m}^{2} \mathrm{~d}\right)$ durante o ensaio 1 , sem pré-oxidação e com DFIs no FAAG para a temperatura T e para T = $20^{\circ} \mathrm{C}$.

\begin{tabular}{|c|c|c|c|c|c|c|c|c|c|c|c|c|c|c|c|c|c|c|c|c|c|c|}
\hline \multirow{3}{*}{$\begin{array}{l}\text { TF } \\
(\mathrm{h})\end{array}$} & \multicolumn{10}{|c|}{ FAAG } & \multicolumn{12}{|c|}{ FRD } \\
\hline & \multicolumn{3}{|c|}{$\begin{array}{l}\text { Leitura piezométrica } \\
(\mathrm{cm})\end{array}$} & \multirow{2}{*}{$\begin{array}{c}\mathrm{T} \\
(\mathrm{cm})\end{array}$} & \multicolumn{3}{|c|}{$\begin{array}{l}\text { Perda de carga } \\
\text { (cm) }\end{array}$} & \multicolumn{3}{|c|}{$\begin{array}{c}\text { Perda de carga }(\mathrm{cm}) \\
\mathrm{T}=20^{\circ} \mathrm{C}\end{array}$} & \multicolumn{4}{|c|}{$\begin{array}{l}\text { Leitura piezométrica } \\
(\mathrm{cm})\end{array}$} & \multicolumn{4}{|c|}{$\begin{array}{l}\text { Perda de carga } \\
\text { (cm) }\end{array}$} & \multicolumn{4}{|c|}{$\begin{array}{c}\text { Perda de carga }(\mathrm{cm}) \\
\mathrm{T}=20^{\circ} \mathrm{C}\end{array}$} \\
\hline & \begin{tabular}{|l} 
P1 \\
\end{tabular} & P2 & P3 & & P2-P1 & \begin{tabular}{|l|} 
P3-P2 \\
\end{tabular} & P3-P1 & P2-P1 & P3-P2 & P3-P1 & P1 & \begin{tabular}{|l|} 
P2 \\
\end{tabular} & P3 & P4 & P2-P1 & \begin{tabular}{|l|} 
P3-P2 \\
\end{tabular} & P4-P3 & \begin{tabular}{|l|} 
P4-P1 \\
\end{tabular} & \begin{tabular}{|l|} 
P2-P1 \\
\end{tabular} & \begin{tabular}{|l|} 
P3-P2 \\
\end{tabular} & P4-P3 & \begin{tabular}{|l|} 
P4-P1 \\
\end{tabular} \\
\hline 0 & 45,0 & 66,9 & 68,5 & 20,0 & 21,9 & 1,6 & 23,5 & 21,7 & 1,6 & 23,3 & 12,1 & 39,6 & 61,0 & 84,0 & 27,5 & 21,4 & 23,0 & 71,9 & 27,3 & 21,2 & 22,8 & 71,4 \\
\hline 1 & 46,0 & 69,6 & 72,2 & 19,5 & 23,6 & 2,6 & 26,2 & 23,1 & 2,5 & 25,7 & 12,1 & 39,5 & 61,0 & 87,2 & 27,4 & 21,5 & 26,2 & 75,1 & 26,9 & 21,1 & 25,7 & 73,6 \\
\hline 2 & 46,0 & 72,3 & 76,0 & 19,5 & 26,3 & 3,7 & 30,0 & 25,8 & 3,6 & 29,4 & 12,1 & 39,2 & 60,6 & 87,4 & 27,1 & 21,4 & 26,8 & 75,3 & 26,6 & 21,0 & 26,3 & 73,8 \\
\hline 3 & 46,0 & 74,5 & 78,9 & 19,0 & 28,5 & 4,4 & 32,9 & 27,6 & 4,3 & 31,9 & 12,1 & 39,3 & 60,9 & 88,7 & 27,2 & 21,6 & 27,8 & 76,6 & 26,4 & 20,9 & 26,9 & 74,2 \\
\hline 4 & 46,0 & 77,2 & 82,4 & 19,0 & 31,2 & 5,2 & 36,4 & 30,2 & 5,0 & 35,3 & 12,1 & 39,5 & 61,2 & 89,7 & 27,4 & 21,7 & 28,5 & 77,6 & 26,5 & 21,0 & 27,6 & 75,2 \\
\hline 4,5 & 46,0 & 79,7 & 85,7 & 19,0 & 33,7 & 6,0 & 39,7 & 32,6 & 5,8 & 38,5 & 12,0 & 38,5 & 59,6 & 87,5 & 26,5 & 21,1 & 27,9 & 75,5 & 25,7 & 20,4 & 27,0 & 73,1 \\
\hline 5 & 46,0 & 79,1 & 82,2 & 19,0 & 33,1 & 3,1 & 36,2 & 32,1 & 3,0 & 35,1 & 12,0 & 39,1 & 60,6 & 89,6 & 27,1 & 21,5 & 29,0 & 77,6 & 26,3 & 20,8 & 28,1 & 75,2 \\
\hline 6 & 46,0 & 81,5 & 85,7 & 19,0 & 35,5 & 4,2 & 39,7 & 34,4 & 4,1 & 38,5 & 12,0 & 39,5 & 61,4 & 91,0 & 27,5 & 21,9 & 29,6 & 79,0 & 26,6 & 21,2 & 28,7 & 76,5 \\
\hline 7 & 46,0 & 84,5 & 90,0 & 19,0 & 38,5 & 5,5 & 44,0 & 37,3 & 5,3 & 42,6 & 12,0 & 39,4 & 61,5 & 91,4 & 27,4 & 22,1 & 29,9 & 79,4 & 26,5 & 21,4 & 29,0 & 76,9 \\
\hline 8 & 46,0 & 88,4 & 95,1 & 18,5 & 42,4 & 6,7 & 49,1 & 40,6 & 6,4 & 47,0 & 12,0 & 39,6 & 61,6 & 92,0 & 27,6 & 22,0 & 30,4 & 80,0 & 26,4 & 21,1 & 29,1 & 76,6 \\
\hline 9 & 46,0 & 90,6 & 99,3 & 18,5 & 44,6 & 8,7 & 53,3 & 42,7 & 8,3 & 51,0 & 12,0 & 39,7 & 61,9 & 92,5 & 27,7 & 22,2 & 30,6 & 80,5 & 26,5 & 21,2 & 29,3 & 77,1 \\
\hline 10 & 46,0 & 95,9 & 104,6 & 19,0 & 49,9 & 8,7 & 58,6 & 48,3 & 8,4 & 56,8 & 12,0 & 39,9 & 62,0 & 93,0 & 27,9 & 22,1 & 31,0 & 81,0 & 27,0 & 21,4 & 30,0 & 78,5 \\
\hline 11 & 46,1 & 99,9 & 109,5 & 19,0 & 53,8 & 9,6 & & & & & 12,0 & 40,0 & 62,5 & 94,3 & 28,0 & 22,5 & & & & 21,8 & & 79,7 \\
\hline 12 & 46,1 & 102,8 & 113,0 & 20,0 & 56,7 & 10,2 & 66,9 & 56,3 & 10,1 & 66,4 & 12,0 & 41,2 & 64,5 & 100,0 & 29,2 & 23,3 & 35,5 & 88,0 & 29,0 & 23,1 & 35,2 & 87,3 \\
\hline 13 & 46,2 & 106,1 & 116,9 & 20,0 & 59,9 & 10,8 & 70,7 & 59,5 & 10,7 & 70,2 & 12,1 & 40,3 & 63,0 & 104,6 & 28,2 & 22,7 & 41,6 & 92,5 & 28,0 & 22,5 & 41,3 & 91,8 \\
\hline 13,4 & 46,1 & 107,8 & 119,0 & 21,5 & 61,7 & 11,2 & 72,9 & 63,5 & 11,5 & 75,0 & 12,1 & 41,4 & 65,0 & 113,3 & 29,3 & 23,6 & 48,3 & 101,2 & 30,2 & 24,3 & 49,7 & \begin{tabular}{|r}
104,2 \\
\end{tabular} \\
\hline 14 & 46,1 & 108,7 & 120,0 & 21,5 & 62,6 & 11,3 & 73,9 & 64,4 & 11,6 & 76,1 & 12,2 & 42,0 & 66,2 & 118,0 & 29,8 & 24,2 & 51,8 & 105,8 & 30,7 & 24,9 & 53,3 & 108,9 \\
\hline 15 & 46,1 & 111,5 & 123,2 & 22,0 & 65,4 & 11,7 & 77,1 & 68,1 & 12,2 & 80,3 & 12,1 & 37,7 & 59,5 & 116,5 & 25,6 & 21,8 & 57,0 & 104,4 & 26,7 & 22,7 & 59,4 & \begin{tabular}{|l}
108,8 \\
\end{tabular} \\
\hline 15,2 & 46,1 & 112,5 & 124,7 & 22,0 & 66,4 & 12,2 & 78,6 & 69,2 & 12,7 & 81,9 & 12,0 & 37,9 & 60,2 & 120,7 & 25,9 & 22,3 & 60,5 & 108,7 & 27,0 & 23,2 & 63,0 & \begin{tabular}{|l}
113,2 \\
\end{tabular} \\
\hline 16 & 46,1 & 107,5 & 112,4 & 22,0 & 61,4 & 4,9 & 66,3 & 64,0 & 5,1 & 69,1 & 12,2 & 39,6 & 65,3 & 138,5 & 27,4 & 25,7 & 73,2 & 126,3 & 28,5 & 26,8 & 76,3 & 131,6 \\
\hline 17 & 46,1 & 111,5 & 117,6 & 22,0 & 65,4 & 6,1 & 71,5 & 68,1 & 6,4 & 74,5 & 12,2 & 39,8 & 66,0 & 141,2 & 27,6 & 26,2 & 75,2 & 129,0 & 28,8 & 27,3 & 78,3 & \begin{tabular}{|r}
134,4 \\
\end{tabular} \\
\hline 18 & 46,1 & 116,0 & 123,5 & 21,0 & 69,9 & 7,5 & 77,4 & 71,1 & 7,6 & 78,7 & 12,2 & 40,2 & 67,2 & 147,2 & 28,0 & 27,0 & 80,0 & 135,0 & 28,5 & 27,5 & 81,3 & \begin{tabular}{|l}
137,3 \\
\end{tabular} \\
\hline 19 & 46,1 & 121,0 & 129,5 & 21,0 & 74,9 & 8,5 & 83,4 & 76,2 & 8,6 & 84,8 & 12,2 & 41,0 & 69,5 & 158,5 & 28,8 & 28,5 & 89,0 & 146,3 & 29,3 & 29,0 & 90,5 & 148,8 \\
\hline 20 & 46,1 & 94,0 & 97,2 & 20,0 & 47,9 & 3,2 & 51,1 & 47,5 & 3,2 & 50,7 & & & & & & & & & & & & \\
\hline 21 & 46,1 & 99,8 & 105,0 & 20,0 & 53,7 & 5,2 & 58,9 & 53,3 & 5,2 & 58,5 & 12,0 & 39,3 & 66,5 & 166,4 & 27,3 & 27,2 & 99,9 & 154,4 & 27,1 & 27,0 & 99,2 & \begin{tabular}{|l}
153,2 \\
\end{tabular} \\
\hline
\end{tabular}


(continuação)

\begin{tabular}{|c|c|c|c|c|c|c|c|c|c|c|c|c|c|c|c|c|c|c|c|c|c|c|}
\hline 22 & 46,0 & 106,2 & 113,0 & 19,5 & 60,2 & 6,8 & 67,0 & 59,0 & 6,7 & 65,7 & 11,9 & 41,9 & 71,9 & 184,0 & 30,0 & 30,0 & 112,1 & 172,1 & 29,4 & 29,4 & 109,9 & 168,8 \\
\hline 22 & 46,0 & 106,2 & 113,0 & 19,5 & 60,2 & 6,8 & 67,0 & 59,0 & 6,7 & 65,7 & 11,9 & 41,9 & 71,9 & 184,0 & 30,0 & 30,0 & 112,1 & 172,1 & 29,4 & 29,4 & 109,9 & 168,8 \\
\hline 23 & 46,0 & 110,3 & 118,3 & 19,5 & 64,3 & 8,0 & 72,3 & 63,1 & 7,8 & 70,9 & 11,8 & 41,0 & 68,9 & 186,9 & 29,2 & 27,9 & 118,0 & 175,1 & 28,6 & 27,4 & 115,7 & 171,7 \\
\hline 24 & 46,0 & 113,9 & 123,0 & 19,5 & 67,9 & 9,1 & 77,0 & 66,6 & 8,9 & 75,5 & 11,9 & 43,8 & 73,8 & 205,7 & 31,9 & 30,0 & 131,9 & 193,8 & 31,3 & 29,4 & 129,3 & 190,0 \\
\hline 25 & 46,0 & 118,3 & 128,3 & 19,5 & 72,3 & 10,0 & 82,3 & 70,9 & 9,8 & 80,7 & 11,8 & 42,5 & 72,1 & 211,4 & 30,7 & 29,6 & 139,3 & 199,6 & 30,1 & 29,0 & 136,6 & 195,7 \\
\hline 25,4 & & & & 19,5 & & & & & & & 11,8 & 43,3 & 73,6 & 221,8 & 31,5 & 30,3 & 148,2 & 210,0 & 30,9 & 29,7 & 145,3 & 205,9 \\
\hline 26 & 45,9 & 123,0 & 134,5 & 19,5 & 77,1 & 11,5 & 88,6 & 75,6 & 11,3 & 86,9 & & & & & & & & & & & & \\
\hline 27 & 46,0 & 125,0 & 131,0 & 19,5 & 79,0 & 6,0 & 85,0 & 77,5 & 5,9 & 83,4 & 11,8 & 40,1 & 61,9 & 91,8 & 28,3 & 21,8 & 29,9 & 80,0 & 27,8 & 21,4 & 29,3 & 78,4 \\
\hline 28 & 46,0 & 130,1 & 137,8 & 19,5 & 84,1 & 7,7 & 91,8 & 82,5 & 7,6 & 90,0 & 11,9 & 40,4 & 62,5 & 97,6 & 28,5 & 22,1 & 35,1 & 85,7 & 27,9 & 21,7 & 34,4 & 84,0 \\
\hline 29 & 46,0 & 136,5 & 146,0 & 19,5 & 90,5 & 9,5 & 100,0 & 88,7 & 9,3 & 98,1 & 11,8 & 40,5 & 63,2 & 105,7 & 28,7 & 22,7 & 42,5 & 93,9 & 28,1 & 22,3 & 41,7 & 92,1 \\
\hline 30 & 46,0 & 140,3 & 150,6 & 19,5 & 94,3 & 10,3 & 104,6 & 92,5 & 10,1 & 102,6 & 11,8 & 40,8 & 65,0 & 113,1 & 29,0 & 24,2 & 48,1 & 101,3 & 28,4 & 23,7 & 47,2 & 99,3 \\
\hline 31 & 46,0 & 144,5 & 155,8 & 19,5 & 98,5 & 11,3 & 109,8 & 96,6 & 11,1 & 107,7 & 11,8 & 39,7 & 65,0 & 117,0 & 27,9 & 25,3 & 52,0 & 105,2 & 27,4 & 24,8 & 51,0 & 103,2 \\
\hline 32 & 46,0 & 149,5 & 162,1 & 19,5 & 103,5 & 12,6 & 116,1 & 101,5 & 12,4 & 113,8 & 11,8 & 39,5 & 66,6 & 124,9 & 27,7 & 27,1 & 58,3 & 113,1 & 27,2 & 26,6 & 57,2 & 110,9 \\
\hline 33 & 46,0 & 149,6 & 156,0 & 19,5 & 103,6 & 6,4 & 110,0 & 101,6 & 6,3 & 107,9 & 11,8 & 40,2 & 69,9 & 136,1 & 28,4 & 29,7 & 66,2 & 124,3 & 27,8 & 29,1 & 64,9 & 121,9 \\
\hline 34 & 46,0 & 155,3 & 163,3 & 19,5 & 109,3 & 8,0 & 117,3 & 107,2 & 7,8 & 115,0 & 11,8 & 41,4 & 72,8 & 142,7 & 29,6 & 31,4 & 69,9 & 130,9 & 29,0 & 30,8 & 68,5 & 128,4 \\
\hline 35 & 46,0 & 161,7 & 171,5 & 19,5 & 115,7 & 9,8 & 125,5 & 113,5 & 9,6 & 123,1 & 11,8 & 40,5 & 72,4 & 144,3 & 28,7 & 31,9 & 71,9 & 132,5 & 28,1 & 31,3 & 70,5 & 129,9 \\
\hline 36 & 46,0 & 136,4 & 142,7 & 20,0 & 90,4 & 6,3 & 96,7 & 89,7 & 6,3 & 96,0 & 12,1 & 38,1 & 57,0 & 79,4 & 26,0 & 18,9 & 22,4 & 67,3 & 25,8 & 18,8 & 22,2 & 66,8 \\
\hline 37 & 46,0 & 141,3 & 149,5 & 20,0 & 95,3 & 8,2 & 103,5 & 94,6 & 8,1 & 102,7 & 12,1 & 39,2 & 58,9 & 85,2 & 27,1 & 19,7 & 26,3 & 73,1 & 26,9 & 19,6 & 26,1 & 72,6 \\
\hline 38 & 46,0 & 149,8 & 160,4 & 20,0 & 103,8 & 10,6 & 114,4 & 103,0 & 10,5 & 113,5 & 12,2 & 40,1 & 63,8 & 105,0 & 27,9 & 23,7 & 41,2 & 92,8 & 27,7 & 23,5 & 40,9 & 92,1 \\
\hline 39 & 46,1 & 109,5 & 113,9 & 20,0 & 63,4 & 4,4 & 67,8 & 62,9 & 4,4 & 67,3 & 12,3 & 40,2 & 60,4 & 105,5 & 27,9 & 20,2 & 45,1 & 93,2 & 27,7 & 20,0 & 44,8 & 92,5 \\
\hline 40 & 46,1 & 118,1 & 124,2 & 20,0 & 72,0 & 6,1 & 78,1 & 71,5 & 6,1 & 77,5 & 12,1 & 39,0 & 58,7 & 105,5 & 26,9 & 19,7 & 46,8 & 93,4 & 26,7 & 19,6 & 46,5 & 92,7 \\
\hline 41 & 46,1 & 126,8 & 158,8 & 20,0 & 80,7 & 32,0 & 112,7 & 80,1 & 31,8 & 111,9 & 12,2 & 39,6 & 59,9 & 118,8 & 27,4 & 20,3 & 58,9 & 106,6 & 27,2 & 20,1 & 58,5 & 105,8 \\
\hline 42 & 46,1 & 112,3 & 118,4 & 20,0 & 66,2 & 6,1 & 72,3 & 65,7 & 6,1 & 71,8 & 12,2 & 40,0 & 61,2 & 128,3 & 27,8 & 21,2 & 67,1 & 116,1 & 27,6 & 21,0 & 66,6 & 115,2 \\
\hline 43 & 46,1 & 126,1 & 133,7 & 20,0 & 80,0 & 7,6 & 87,6 & 79,4 & 7,5 & 86,9 & 12,2 & 40,6 & 62,7 & 135,4 & 28,4 & 22,1 & 72,7 & 123,2 & 28,2 & 21,9 & 72,2 & 122,3 \\
\hline 44 & 46,0 & 120,3 & 125,6 & 20,0 & 74,3 & 5,3 & 79,6 & 73,7 & 5,3 & 79,0 & & & & & & & & & & & & \\
\hline 45 & 46,0 & 131,2 & 138,8 & 19,5 & 85,2 & 7,6 & 92,8 & 83,5 & 7,5 & 91,0 & 12,2 & 42,5 & 67,3 & 136,0 & 30,3 & 24,8 & 68,7 & 123,8 & 29,7 & 24,3 & 67,4 & 121,4 \\
\hline 46 & 46,0 & 124,7 & 129,1 & 19,5 & 78,7 & 4,4 & 83,1 & 77,2 & 4,3 & 81,5 & & & & & & & & & & & & \\
\hline 47 & 46,0 & 137,1 & 144,7 & 19,5 & 91,1 & 7,6 & 98,7 & 89,3 & 7,5 & 96,8 & 12,0 & 40,1 & 64,8 & 156,2 & 28,1 & 24,7 & 91,4 & 144,2 & 27,6 & 24,2 & 89,6 & 141,4 \\
\hline 48 & 46,0 & 142,7 & 151,6 & 19,0 & 96,7 & 8,9 & 105,6 & 93,7 & 8,6 & 102,3 & 12,2 & 42,2 & 68,8 & 167,0 & 30,0 & 26,6 & 98,2 & 154,8 & 29,1 & 25,8 & 95,1 & 150,0 \\
\hline
\end{tabular}




\begin{tabular}{|c|c|c|c|c|c|c|c|c|c|c|c|c|c|c|c|c|c|c|c|c|c|c|}
\hline 48,2 & 46,0 & 145,0 & 154,5 & 19,0 & 99,0 & 9,5 & 108,5 & 95,9 & 9,2 & 105,1 & 12,1 & 41,1 & 67,1 & 167,2 & 29,0 & 26,0 & 100,1 & 155,1 & 28,1 & 25,2 & 97,0 & 150,3 \\
\hline 49 & 46,0 & 145,3 & 151,7 & 19,0 & 99,3 & 6,4 & 105,7 & 96,2 & 6,2 & 102,4 & 12,1 & 42,0 & 69,3 & 175,4 & 29,9 & 27,3 & 106,1 & 163,3 & 29,0 & 26,4 & 102,8 & 158,2 \\
\hline 50 & 46,0 & 154,0 & 162,6 & 19,0 & 108,0 & 8,6 & 116,6 & 104,6 & 8,3 & 113,0 & 12,0 & 40,7 & 67,4 & 176,5 & 28,7 & 26,7 & 109,1 & 164,5 & 27,8 & 25,9 & 105,7 & 159,4 \\
\hline
\end{tabular}

TF = tempo de funcionamento; $\mathrm{T}$ = temperatura; DFIs = descargas de fundo intermediárias por perda de carga; DFls = descargas de fundo intermediárias quando a cor aparente do FAAG atingiu valor $\geq 50 \mathrm{uH}$; Lavagem do FRD por perda de carga; Lavagem do FRD por transpasse. 


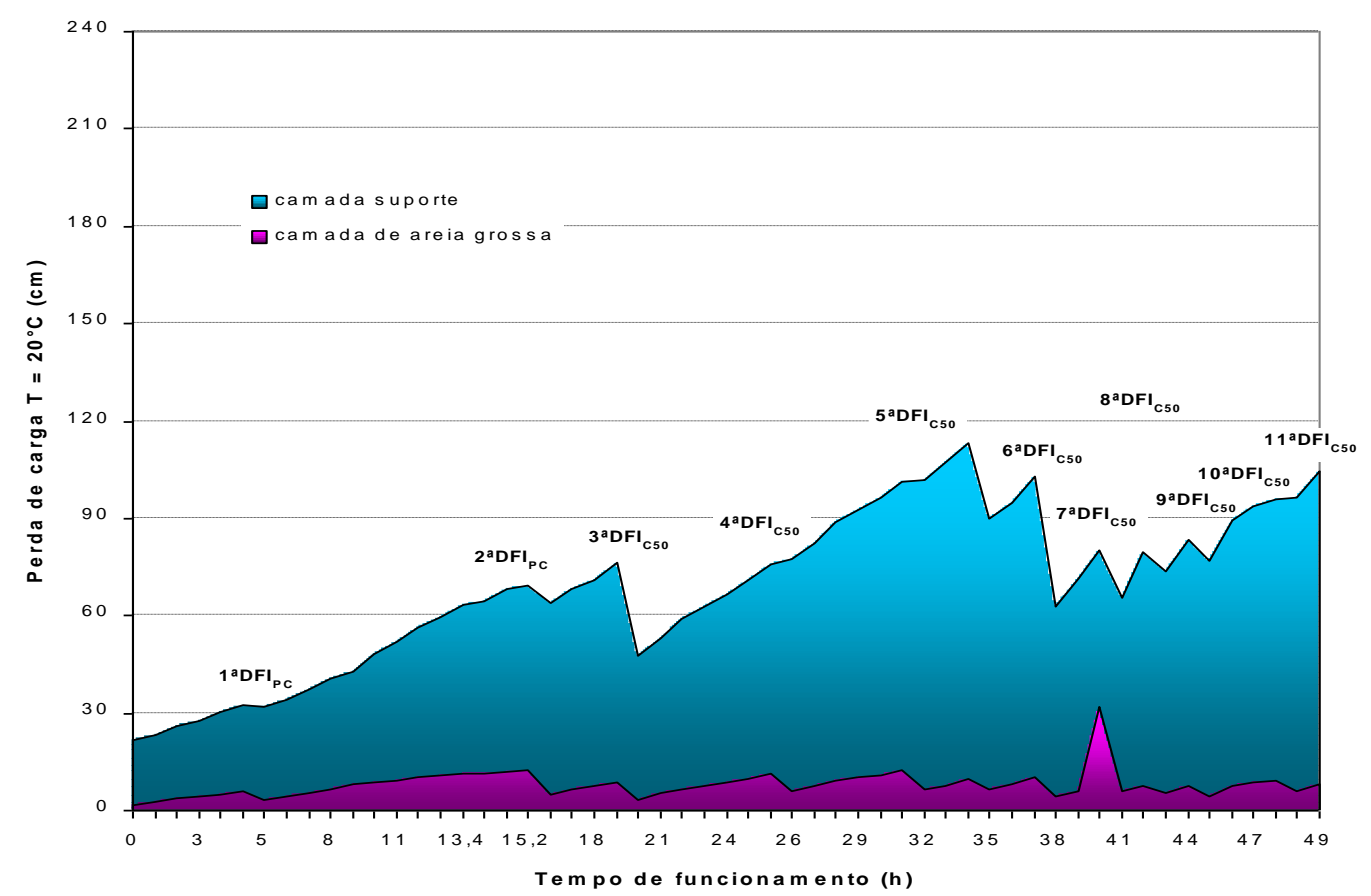

Figura B 1.1 - Perda de carga na camada suporte e camada de areia grossa no FAAG durante o ensaio $1\left(F A A G=240 \mathrm{~m}^{3} / \mathrm{m}^{2} \mathrm{~d}\right.$ e $\left.\mathrm{FRD}=280 \mathrm{~m}^{3} / \mathrm{m}^{2} \mathrm{~d}\right)$. Fonte: Tabela B $1.3-$ ANEXO B.

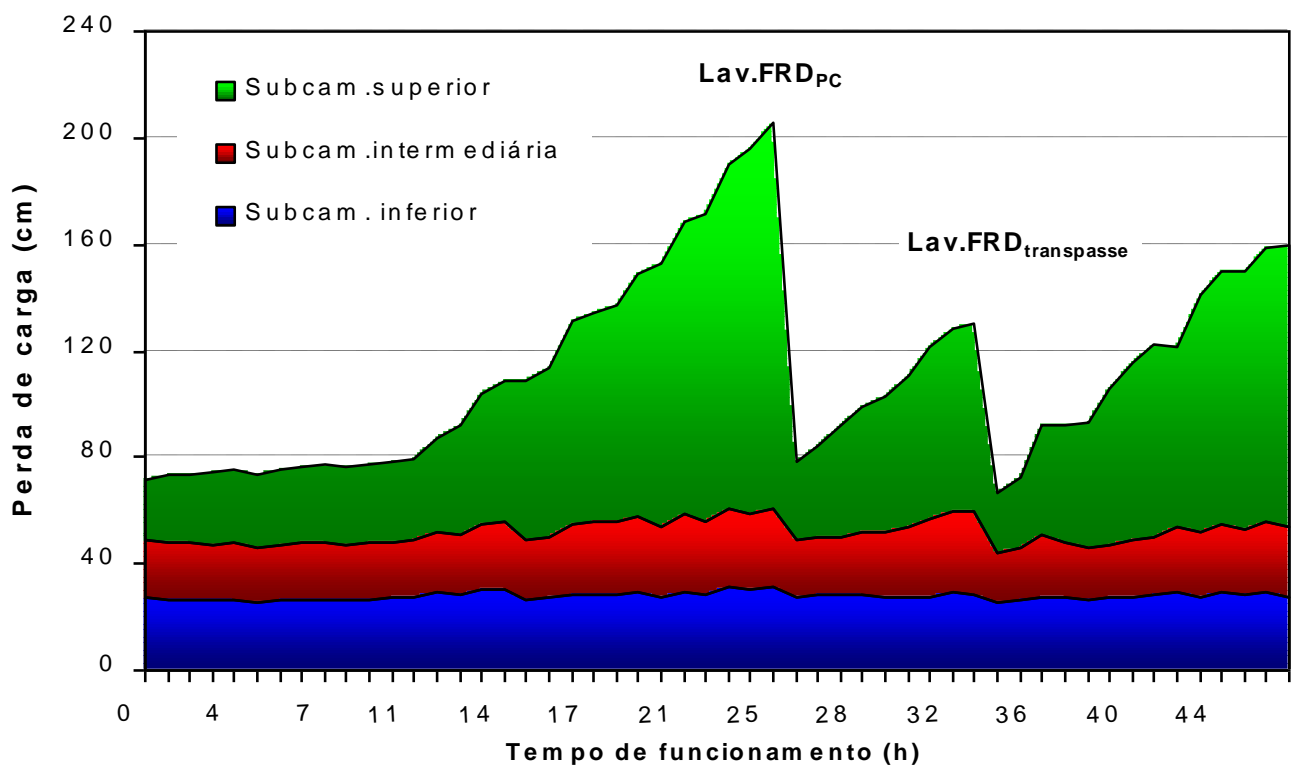

Figura B 1.2 - Perda de carga ao longo do meio filtrante do FRD durante o ensaio 1 (FAAG $=240$ $\mathrm{m}^{3} / \mathrm{m}^{2} \mathrm{~d}$ e FRD $=280 \mathrm{~m}^{3} / \mathrm{m}^{2} \mathrm{~d}$ ). Fonte: Tabela B $1.3-$ ANEXO B. 
Tabela B 1.4 - Variação de vazões e taxas de filtração do FAAG e do FRD durante o ensaio 1 - sem pré-oxidação e com DFIs (FAAG $=240 \mathrm{~m}^{3} / \mathrm{m}^{2} \mathrm{~d} ; \mathrm{FRD}=280 \mathrm{~m}^{3} / \mathrm{m}^{2} \mathrm{~d}$ ).

\begin{tabular}{|c|c|c|c|c|c|c|c|c|}
\hline \multirow[b]{2}{*}{ TF (h) } & \multicolumn{2}{|c|}{ descartes (L/h) } & \multicolumn{2}{|c|}{ turbidímetros $(\mathrm{L} / \mathrm{h})$} & \multicolumn{2}{|c|}{ vazão total (L/h) } & \multicolumn{2}{|c|}{ taxas de filtração $\left(\mathrm{m}^{3} / \mathrm{m}^{2} \mathrm{~d}\right)$} \\
\hline & FAAG & FRD & FAAG & FRD & FAAG & FRD & FAAG & FRD \\
\hline 0 & 54,07 & 55,26 & 30,90 & 22,60 & 162,83 & 77,86 & 250 & 285 \\
\hline 1 & 51,94 & 56,42 & 28,35 & 22,26 & 158,97 & 78,68 & 244 & 288 \\
\hline 2 & 53,59 & 56,03 & 28,27 & 22,07 & 159,96 & 78,10 & 246 & 286 \\
\hline 3 & 54,74 & 54,82 & 27,95 & 21,99 & 159,50 & 76,81 & 245 & 281 \\
\hline 4 & 53,26 & 57,67 & 29,40 & 22,56 & 162,89 & 80,23 & 250 & 293 \\
\hline 5 & 53,98 & 54,65 & 29,39 & 23,28 & 161,30 & 77,93 & 248 & 285 \\
\hline 6 & 52,67 & 55,86 & 28,24 & 22,76 & 160,05 & 79,14 & 246 & 289 \\
\hline 7 & 53,27 & 53,96 & 28,01 & 23,12 & 158,00 & 76,72 & 243 & 281 \\
\hline 8 & 52,41 & 53,95 & 28,49 & 22,22 & 157,97 & 77,07 & 243 & 282 \\
\hline 9 & 53,23 & 56,19 & 28,36 & 22,46 & 160,00 & 78,41 & 246 & 287 \\
\hline 10 & 53,52 & 55,54 & 28,14 & 23,55 & 159,66 & 78,00 & 245 & 285 \\
\hline 11 & 53,91 & 53,79 & 28,42 & 22,61 & 159,67 & 77,34 & 245 & 283 \\
\hline 12 & 48,66 & 57,71 & 26,32 & 23,38 & 155,30 & 80,32 & 239 & 294 \\
\hline 13 & 54,01 & 56,95 & 23,36 & 22,57 & 157,70 & 80,33 & 242 & 294 \\
\hline 14 & 53,33 & 53,46 & 21,87 & 22,92 & 151,23 & 76,03 & 232 & 278 \\
\hline 15 & 63,09 & 52,20 & 21,25 & 23,23 & 159,46 & 75,12 & 245 & 275 \\
\hline 16 & 58,91 & 57,54 & 17,07 & 22,90 & 156,75 & 80,77 & 241 & 295 \\
\hline 17 & 59,04 & 58,07 & 17,14 & 23,50 & 157,15 & 80,97 & 242 & 296 \\
\hline 18 & 60,90 & 57,49 & 16,35 & 21,99 & 158,24 & 80,99 & 243 & 296 \\
\hline 19 & 57,30 & 58,09 & 16,15 & 22,77 & 153,53 & 80,08 & 236 & 293 \\
\hline 20 & 53,65 & 54,05 & 30,49 & 23,23 & 160,96 & 76,82 & 247 & 281 \\
\hline 21 & 49,93 & 54,42 & 35,89 & 23,00 & 163,47 & 77,65 & 251 & 284 \\
\hline 22 & 48,95 & 51,86 & 39,15 & 22,89 & 162,96 & 74,86 & 250 & 274 \\
\hline 23 & 38,10 & 57,22 & 38,54 & 22,97 & 156,75 & 80,11 & 241 & 293 \\
\hline 24 & 53,43 & 56,76 & 22,80 & 23,83 & 155,96 & 79,73 & 240 & 292 \\
\hline 25 & 57,96 & 56,49 & 18,92 & 23,01 & 157,20 & 80,32 & 242 & 294 \\
\hline 26 & 56,55 & 57,12 & 16,62 & 22,94 & 153,30 & 80,13 & 236 & 293 \\
\hline 28 & 65,52 & 56,42 & 13,76 & 24,06 & 159,76 & 80,48 & 246 & 294 \\
\hline 29 & 62,90 & 54,00 & 13,77 & 22,24 & 152,91 & 76,24 & 235 & 279 \\
\hline 30 & 63,17 & 55,82 & 12,45 & 22,74 & 154,18 & 78,56 & 237 & 287 \\
\hline 31 & 62,33 & 58,08 & 12,48 & 22,47 & 155,36 & 80,55 & 239 & 295 \\
\hline 32 & 68,69 & 53,72 & 12,29 & 23,88 & 158,58 & 77,60 & 244 & 284 \\
\hline 33 & 66,48 & 55,45 & 12,89 & 23,34 & 158,16 & 78,79 & 243 & 288 \\
\hline 34 & 69,41 & 56,69 & 11,56 & 23,97 & 161,63 & 80,66 & 248 & 295 \\
\hline 35 & 65,19 & 56,97 & 11,78 & 23,31 & 157,25 & 80,28 & 242 & 294 \\
\hline 36 & 62,38 & 49,05 & 19,89 & 23,12 & 154,44 & 72,17 & 237 & 264 \\
\hline 37 & 60,38 & 57,06 & 17,68 & 23,23 & 158,35 & 80,29 & 243 & 294 \\
\hline 38 & 59,39 & 57,09 & 14,40 & 23,24 & 154,12 & 80,33 & 237 & 294 \\
\hline 39 & 63,12 & 58,05 & 14,52 & 22,81 & 158,50 & 80,86 & 244 & 296 \\
\hline 40 & 66,58 & 57,02 & 13,92 & 23,72 & 161,24 & 80,74 & 248 & 295 \\
\hline 41 & 65,93 & 55,57 & 12,64 & 22,71 & 156,85 & 78,28 & 241 & 286 \\
\hline 42 & 68,21 & 57,60 & 11,36 & 22,90 & 160,07 & 80,50 & 246 & 294 \\
\hline 43 & 64,19 & 57,60 & 11,70 & 22,97 & 156,46 & 80,57 & 240 & 295 \\
\hline 44 & 66,11 & 57,86 & 9,63 & 22,70 & 156,30 & 80,56 & 240 & 295 \\
\hline
\end{tabular}


(continuação)

\begin{tabular}{|c|c|c|c|c|c|c|c|c|}
\hline 45 & 63,52 & 58,04 & 9,41 & 22,86 & 153,83 & 80,90 & 236 & 296 \\
\hline 46 & 69,61 & 56,76 & 8,15 & 22,77 & 157,29 & 79,53 & 242 & 291 \\
\hline 47 & 52,05 & 52,81 & 23,29 & 23,39 & 151,54 & 76,20 & 233 & 279 \\
\hline 48 & 61,24 & 57,06 & 18,87 & 23,16 & 160,33 & 80,22 & 246 & 293 \\
\hline 49 & 59,26 & 56,74 & 17,98 & 23,44 & 157,42 & 80,18 & 242 & 293 \\
\hline \multirow[t]{5}{*}{50} & 63,24 & 56,69 & 17,90 & 23,51 & 161,34 & 80,20 & 248 & 293 \\
\hline & & & & Mínima & 151,23 & 72,17 & 232 & 264 \\
\hline & & & & Média & 157,93 & 78,90 & 243 & 289 \\
\hline & & & & Máxima & 163,47 & 80,99 & 251 & 296 \\
\hline & & & & DP & 2,99 & 1,97 & 4,60 & 7,19 \\
\hline
\end{tabular}

$\mathrm{TF}=$ tempo de funcionamento; FAAG $=$ filtro ascendente de areia grossa; FRD = filtro rápido descendente; $\mathrm{DP}=$ desvio padrão. 
Tabela B 2.1 - Características físicas da AB, AE e efluentes do FAAG e do FRD durante o ensaio 2 sem pré-oxidação e com DFIs no FAAG (FAAG $=180 \mathrm{~m}^{3} / \mathrm{m}^{2} \mathrm{~d} ; \mathrm{FRD}=200 \mathrm{~m}^{3} / \mathrm{m}^{2} \mathrm{~d}$ ).

\begin{tabular}{|c|c|c|c|c|c|c|c|}
\hline \multirow{2}{*}{$\begin{array}{l}\text { TF } \\
\text { (h) }\end{array}$} & \multirow{2}{*}{\begin{tabular}{|c|}
$\begin{array}{c}\text { Temperatura } \\
\left({ }^{\circ} \mathrm{C}\right)\end{array}$ \\
$\mathrm{AE}$ \\
\end{tabular}} & \multicolumn{4}{|c|}{ Cor aparente (uH) } & \multicolumn{2}{|c|}{ Cor verdadeira (uH) } \\
\hline & & $A B$ & $\mathrm{AE}$ & FAAG & FRD & $A B$ & AE \\
\hline 0 & 21,5 & 88 & 188 & $<1,0$ & $<1,0$ & 12 & 82 \\
\hline 1 & 22,0 & 93 & 196 & $<1,0$ & $<1,0$ & 10 & 78 \\
\hline 3 & 22,0 & & 205 & 2,0 & $<1,0$ & & 92 \\
\hline 5 & 21,0 & & 204 & $<1,0$ & $<1,0$ & & 107 \\
\hline 7 & 20,5 & 94 & 194 & $<1,0$ & $<1,0$ & 18 & 96 \\
\hline 9 & 20,5 & & 188 & $<1,0$ & $<1,0$ & & 102 \\
\hline 11 & 20,5 & & 203 & $<1,0$ & $<1,0$ & & 115 \\
\hline 13 & 20,0 & 102 & 186 & $<1,0$ & $<1,0$ & 23 & 105 \\
\hline 15 & 20,0 & & 187 & $<1,0$ & $<1,0$ & & 92 \\
\hline 17 & 19,0 & & 202 & $<1,0$ & $<1,0$ & & 104 \\
\hline 19 & 19,5 & 127 & 208 & 18,0 & $<1,0$ & 25 & 98 \\
\hline 21 & 20,5 & & 206 & 43,0 & 3,0 & & 96 \\
\hline 23 & 21,5 & & 210 & 13,0 & 4,0 & & 106 \\
\hline 26 & 22,0 & 114 & 209 & 11,0 & $<1,0$ & 25 & 120 \\
\hline 27 & 22,0 & & 190 & 21,0 & $<1,0$ & & 87 \\
\hline 29 & 21,0 & & 181 & 32,0 & $<1,0$ & & 90 \\
\hline 31 & 21,0 & 105 & 185 & 7,0 & $<1,0$ & 24 & 103 \\
\hline 33 & 21,0 & & 199 & 18,0 & $<1,0$ & & 86 \\
\hline 35 & 20,5 & & 210 & 37,0 & $<1,0$ & & 121 \\
\hline 37 & 20,5 & 100 & 197 & 44,0 & $<1,0$ & 20 & 102 \\
\hline 39 & 20,0 & & 198 & 19,0 & $<1,0$ & & 101 \\
\hline 41 & 20,0 & & 193 & 39,0 & $<1,0$ & & 106 \\
\hline 43 & 20,5 & 109 & 182 & 5,0 & $<1,0$ & 22 & 92 \\
\hline 45 & 21,0 & & 189 & 9,0 & $<1,0$ & & 85 \\
\hline 47 & 22,0 & & 206 & 20,0 & $<1,0$ & & 116 \\
\hline 50 & 22,5 & 96 & 182 & 28,0 & $<1,0$ & 26 & 90 \\
\hline 51 & 22,0 & & 186 & 42,0 & $<1,0$ & & 92 \\
\hline 53 & 21,5 & & 178 & 23,0 & $<1,0$ & & 89 \\
\hline 55 & 21,0 & 89 & 185 & 14,0 & $<1,0$ & 21 & 99 \\
\hline 57 & 21,0 & & 204 & 45,0 & $<1,0$ & & 102 \\
\hline 59 & 21,0 & & 202 & 6,0 & $<1,0$ & & 106 \\
\hline 61 & 20,0 & 126 & 193 & 6,0 & $<1,0$ & 21 & 105 \\
\hline 63 & 20,0 & & 196 & 17,0 & $<1,0$ & & 103 \\
\hline 65 & 20,0 & & 193 & 38,0 & $<1,0$ & & 105 \\
\hline 67 & 20,5 & 121 & 207 & 51,0 & $<1,0$ & 21 & 98 \\
\hline 69 & 21,5 & & 209 & 16,0 & $<1,0$ & & 109 \\
\hline 71 & 22,0 & & 201 & 29,0 & $<1,0$ & & 108 \\
\hline 72 & 22,5 & 126 & 190 & 40,0 & $<1,0$ & 22 & 103 \\
\hline Média & 20,9 & 106 & 196 & 18,4 & 0,7 & 21 & 100 \\
\hline Mínimo & 19,0 & 88 & 178 & $<1,0$ & $<1,0$ & 10 & 78 \\
\hline Máximo & 22,5 & 127 & 210 & 51,0 & 4,0 & 26 & 121 \\
\hline DP & 0,86 & 14,18 & 9,45 & 16,11 & 0,69 & 4,66 & 10,09 \\
\hline
\end{tabular}

$\mathrm{TF}=$ tempo de funcionamento; $\mathrm{AE}=$ água de estudo; $\mathrm{AB}=$ água bruta; $\mathrm{FAAG}=$ filtro ascendente de areia grossa; $\mathrm{FRD}=$ filtro rápido descendente; $\mathrm{DP}=$ desvio padrão. 
Tabela B 2.2 - Características químicas da $A B, A E$ e efluentes do FAAG e do FRD durante o ensaio 2 - sem pré-oxidação e com DFls no FAAG (FAAG = 180 m ${ }^{3} / \mathrm{m}^{2} \mathrm{~d}$; $\mathrm{FRD}=200 \mathrm{~m}^{3} / \mathrm{m}^{2} \mathrm{~d}$ )

\begin{tabular}{|c|c|c|c|c|c|c|c|c|c|c|c|c|c|c|c|c|c|}
\hline \multirow{2}{*}{$\begin{array}{l}\text { TF } \\
\text { (h) }\end{array}$} & \multicolumn{3}{|c|}{$\mathrm{pH}$} & \multicolumn{2}{|c|}{ Alcalinidade $\left(\mathrm{mg} / \mathrm{L} \mathrm{CaCO}_{3}\right)$} & \multicolumn{4}{|c|}{ Absorvância 254 nm } & \multicolumn{4}{|c|}{ COD (mg/L) } & \multicolumn{4}{|c|}{ Alumínio (mg/L) } \\
\hline & $\mathrm{AB}$ & $\mathrm{AE}$ & AC & $\mathrm{AB}$ & $\mathrm{AE}$ & $\mathrm{AB}$ & $\mathrm{AE}$ & FAAG & FRD & $\mathrm{AB}$ & $\mathrm{AE}$ & FAAG & FRD & $\mathrm{AB}$ & $\mathrm{AE}$ & FAAG & FRD \\
\hline 0 & 6,23 & 6,37 & 4,96 & 8,58 & 11,44 & 0,077 & 0,184 & 0,031 & 0,030 & 2,983 & 4,628 & 3,425 & 3,095 & - & - & - & - \\
\hline 1 & 6,56 & 6,45 & 4,94 & 9,02 & 8,80 & 0,074 & 0,174 & 0,016 & 0,013 & 3,077 & 4,229 & 2,921 & 2,566 & - & - & - & - \\
\hline 3 & & 6,33 & 5,02 & & & & & & & & & & & & & & \\
\hline 5 & & 6,54 & 4,91 & & & & & & & & & & & & & & \\
\hline 7 & 6,32 & 6,67 & 4,96 & 10,12 & 11,22 & 0,051 & 0,176 & 0,005 & 0,015 & & & & & & & & \\
\hline 9 & & 6,28 & 4,94 & & & & & & & & & & & & & & \\
\hline 11 & & 6,53 & 4,94 & & & & & & & & & & & & & & \\
\hline 13 & 6,32 & 6,33 & 5,02 & 7,04 & 9,90 & 0,052 & 0,177 & 0,001 & 0,003 & & & & & & & & \\
\hline 15 & & 6,43 & 5,02 & & & & & & & & & & & & & & \\
\hline 17 & & 6,42 & 5,04 & & & & & & & & & & & & & & \\
\hline 19 & 6,31 & 6,38 & 5,03 & 7,92 & 10,12 & 0,062 & 0,180 & 0,011 & 0,010 & & & & & & & & \\
\hline 21 & & 6,49 & 4,95 & & & & & & & & & & & & & & \\
\hline 23 & & 6,66 & 4,99 & & & & & & & & & & & & & & \\
\hline 26 & 6,41 & 6,45 & 5,00 & 9,68 & 7,92 & 0,069 & 0,203 & 0,007 & 0,009 & 2,316 & 4,176 & 2,034 & 2,233 & - & - & - & - \\
\hline 27 & & 6,43 & 4,92 & & & & & & & & & & & & & & \\
\hline 29 & & 6,41 & 5,02 & & & & & & & & & & & & & & \\
\hline 31 & 6,43 & 6,52 & 5,01 & 10,78 & 10,78 & 0,068 & 0,183 & 0,013 & 0,012 & & & & & & & & \\
\hline 33 & & 6,52 & 5,09 & & & & & & & & & & & & & & \\
\hline 35 & & 6,53 & 5,07 & & & & & & & & & & & & & & \\
\hline 37 & 6,35 & 6,43 & 4,99 & 9,24 & 7,04 & 0,060 & 0,183 & 0,011 & 0,016 & & & & & & & & \\
\hline 39 & & 6,50 & 5,05 & & & & & & & & & & & & & & \\
\hline 41 & & 6,48 & 5,07 & & & & & & & & & & & & & & \\
\hline 43 & 6,47 & 6,47 & 5,11 & 8,36 & 9,90 & 0,067 & 0,174 & 0,010 & 0,010 & & & & & & & & \\
\hline 45 & & 6,53 & 4,99 & & & & & & & & & & & & & & \\
\hline 47 & & 6,43 & 4,92 & & & & & & & & & & & & & & \\
\hline 50 & 6,52 & 6,43 & 5,03 & 7,70 & 7,92 & 0,070 & 0,175 & 0,011 & 0,017 & 2,471 & 4,088 & 2,063 & 2,301 & - & - & - & - \\
\hline 51 & & 7,25 & 5,01 & & & & & & & & & & & & & & \\
\hline
\end{tabular}


(continuação)

\begin{tabular}{|c|c|c|c|c|c|c|c|c|c|c|c|c|c|c|c|c|c|}
\hline 53 & & 6,40 & 5,03 & & & & & & & & & & & & & & \\
\hline 55 & 6,33 & 6,46 & 5,05 & 9,02 & 10,72 & 0,071 & 0,197 & 0,015 & 0,008 & & & & & & & & \\
\hline 57 & & 6,45 & 5,04 & & & & & & & & & & & & & & \\
\hline 59 & & 6,67 & 5,07 & & & & & & & & & & & & & & \\
\hline 61 & 6,40 & 6,49 & 5,03 & 7,70 & 10,78 & 0,062 & 0,183 & 0,005 & 0,012 & & & & & & & & \\
\hline 63 & & 6,43 & 5,04 & & & & & & & & & & & & & & \\
\hline 65 & & 6,44 & 5,08 & & & & & & & & & & & & & & \\
\hline 67 & 6,37 & 6,47 & 5,04 & 10,78 & 9,46 & 0,066 & 0,191 & 0,012 & 0,011 & & & & & & & & \\
\hline 71 & & 6,41 & 4,97 & & & & & & & & & & & & & & \\
\hline 72 & 6,50 & 6,56 & 5,00 & 9,24 & 10,12 & 0,069 & 0,190 & 0,011 & 0,011 & 2,761 & 4,526 & 2,018 & 2,093 & - & - & - & - \\
\hline Média & 6,39 & 6,49 & 5,01 & 8,94 & 9,72 & 0,066 & 0,184 & 0,011 & 0,013 & 2,722 & 4,329 & 2,492 & 2,458 & - & - & - & - \\
\hline Mínimo & 6,23 & 6,28 & 4,91 & 7,04 & 7,04 & 0,051 & 0,174 & 0,001 & 0,003 & 2,316 & 4,088 & 2,018 & 2,093 & - & - & - & - \\
\hline Máximo & 6,56 & 7,25 & 5,11 & 10,78 & 11,44 & 0,077 & 0,203 & 0,031 & 0,030 & 3,077 & 4,628 & 3,425 & 3,095 & - & - & - & - \\
\hline DP & 0,09 & 0,15 & 0,05 & 1,15 & 1,34 & 0,008 & 0,009 & 0,007 & 0,006 & 0,325 & 0,234 & 0,647 & 0,396 & - & - & - & - \\
\hline
\end{tabular}

$\mathrm{TF}$ = tempo de funcionamento; $\mathrm{AE}$ = água de estudo; $\mathrm{AB}$ = água bruta; $\mathrm{AC}$ = água coagulada; $\mathrm{FAAG}$ = filtro ascendente de areia grossa; $\mathrm{FRD}=$ filtro rápido descendente; $\mathrm{DP}=$ desvio padrão. 
Tabela B 2.3 - Perda de carga no FAAG $\left(180 \mathrm{~m}^{3} / \mathrm{m}^{2} \mathrm{~d}\right)$ e no FRD $\left(200 \mathrm{~m}^{3} / \mathrm{m}^{2} \mathrm{~d}\right)$ durante o ensaio 2 , sem pré-oxidação e com DFls no FAAG para a temperatura T e para T = $20^{\circ} \mathrm{C}$.

\begin{tabular}{|c|c|c|c|c|c|c|c|c|c|c|c|c|c|c|c|c|c|c|c|c|c|c|}
\hline \multirow{3}{*}{$\begin{array}{l}\text { TF } \\
\text { (h) }\end{array}$} & \multicolumn{10}{|c|}{ FAAG } & \multicolumn{12}{|c|}{ FRD } \\
\hline & \multicolumn{3}{|c|}{\begin{tabular}{|c|} 
Leitura piezométrica \\
$(\mathbf{c m})$
\end{tabular}} & \multirow{2}{*}{$\begin{array}{c}\mathbf{T} \\
\left({ }^{\circ} \mathbf{C}\right)\end{array}$} & \multicolumn{3}{|c|}{$\begin{array}{l}\text { Perda de carga } \\
\text { (cm) }\end{array}$} & \multicolumn{3}{|c|}{$\begin{array}{c}\text { Perda de carga }(\mathrm{cm}) \\
T=20^{\circ} \mathrm{C}\end{array}$} & \multicolumn{4}{|c|}{$\begin{array}{c}\text { Leitura piezométrica } \\
\text { (cm) }\end{array}$} & \multicolumn{4}{|c|}{$\begin{array}{l}\text { Perda de carga } \\
\text { (cm) }\end{array}$} & \multicolumn{4}{|c|}{$\begin{array}{c}\text { Perda de carga }(\mathrm{cm}) \\
T=20^{\circ} \mathrm{C}\end{array}$} \\
\hline & $\mathrm{P} 1$ & $\mathrm{P} 2$ & P3 & & P2-P1 & P3-P2 & P3-P1 & P2-P1 & P3-P2 & P3-P1 & $\mathrm{P} 1$ & $\mathrm{P} 2$ & P3 & $\mathrm{P} 4$ & P2-P1 & P3-P2 & P4-P3 & P4-P1 & P2-P1 & P3-P2 & P4-P3 & P4-P1 \\
\hline 0 & 44,9 & 61,3 & 62,8 & 21,5 & 16,4 & 1,5 & 17,9 & 16,9 & 1,5 & 18,4 & 11,7 & 30,5 & 45,9 & 57,2 & 18,8 & 15,4 & 11,3 & 45,5 & 19,3 & 15,8 & 11,6 & 46,8 \\
\hline 1 & 46,0 & 62,2 & 64,4 & 22,0 & 16,2 & 2,2 & 18,4 & 6,9 & 2,3 & 19,2 & 11,8 & 30,6 & 47,9 & 60,7 & 18,8 & 17,3 & 12,8 & 48,9 & 19,6 & 18,0 & 13,3 & 50,9 \\
\hline 2 & 46,0 & 63,6 & 66,7 & 22,0 & 17,6 & 3,1 & 20,7 & 18,3 & 3,2 & 21,6 & 11,7 & 30,4 & 45,9 & 58,6 & 18,7 & 15,5 & 12,7 & 46,9 & 19,5 & 6,1 & 13,2 & 48,9 \\
\hline 3 & 46,0 & 65,3 & 69,0 & 22,0 & 19,3 & 3,7 & 23,0 & 20,1 & 3,9 & 24,0 & 11,7 & 30,4 & 46,0 & 58,7 & 18,7 & 15,6 & 12,7 & 47,0 & 19,5 & 16,3 & 13,2 & 49,0 \\
\hline 4 & 46,0 & 67,1 & 71,7 & 22,0 & 21,1 & 4,6 & 25,7 & 22,0 & 4,8 & 26,8 & 11,7 & 30,6 & 46,4 & 59,6 & 18,9 & 15,8 & 13,2 & 47,9 & 19,7 & 16,5 & 13,8 & 49,9 \\
\hline 5 & 46,0 & 69,0 & 74,2 & 21,0 & 23,0 & 5,2 & 28,2 & 23,4 & 5,3 & 28,7 & 11,7 & 30,9 & 47,0 & 60,5 & 19,2 & 16,1 & 13,5 & 48,8 & 19,5 & & 7 & 49,6 \\
\hline 6 & 46,0 & 70,7 & 76,5 & 21,0 & 24,7 & 5,8 & 30,5 & 251 & & & & & & & & & 13,7 & & 8 & & 9 & 0,4 \\
\hline 7 & 46,0 & 73,4 & 80,2 & 20,5 & 27,4 & 6,8 & 34,2 & 27,5 & 6,8 & 34,4 & 11,8 & 35,5 & 55,4 & 72,4 & 23,7 & 19,9 & 17,0 & 60,6 & 23,8 & 20,0 & 17,1 & 60,9 \\
\hline 8 & 45,9 & 74,9 & 82,1 & 20,5 & 29,0 & 7,2 & 36,2 & 29,1 & 7,2 & 36,4 & 11,6 & 31,3 & 47,7 & 61,6 & 19,7 & 16,4 & 13,9 & 50,0 & 9,8 & 16,5 & 14,0 & 50,2 \\
\hline 9 & 45,9 & 77,2 & & 20,5 & & & & & & & & & & & & & & & & & & \\
\hline 9,6 & 45,9 & 78,2 & 86,5 & 20,5 & 32,3 & 8,3 & 40,6 & 32,4 & 8,3 & 40,8 & 11,6 & 30,8 & 46,9 & 60,8 & 19,2 & 16,1 & 13,9 & 49,2 & 19,3 & 16,2 & 14,0 & 49,4 \\
\hline 10 & 45,9 & 73,2 & 75,4 & 20,5 & 27,3 & 2,2 & 29,5 & 27,4 & 2,2 & 29,6 & 11,6 & 31,7 & 48,4 & 62,9 & 20,1 & 16,7 & 14,5 & 51,3 & 20,2 & 16,8 & 14,6 & 51,5 \\
\hline 11 & 45,9 & 75,5 & 78,7 & 20,5 & 29,6 & 3,2 & 32,8 & 29,7 & 3,2 & 33,0 & 11,6 & 31,1 & 47,5 & 61,8 & 19,5 & 16,4 & 14,3 & 50,2 & 19,6 & 16,5 & 14,4 & 50,4 \\
\hline 12 & 45,9 & 77,8 & 82,0 & 20,5 & 31,9 & 4,2 & 36,1 & 32,0 & 4,2 & 36,3 & 11,6 & 31,2 & 47,7 & 62,2 & 19,6 & 16,5 & 14,5 & 50,6 & 19,7 & 16,6 & 14,6 & 50,8 \\
\hline 13 & 45,9 & 80,3 & 85,4 & 20,0 & 34,4 & 5,1 & 39,5 & 34,1 & 5,1 & 39,2 & 11,5 & 30,5 & 46,4 & 60,3 & 19,0 & 15,9 & 13,9 & 48,8 & 18,9 & 15,8 & 13,8 & 48,4 \\
\hline 14 & 45,9 & 83,0 & 88,9 & 20,0 & 37,1 & 5,9 & 43,0 & 36,8 & 5,9 & 42,7 & 11,5 & 30,5 & 46,4 & 60,5 & 19,0 & 15,9 & 14,1 & 49,0 & 18,9 & 15,8 & 14,0 & 48,6 \\
\hline 15 & 45,9 & 85,3 & 91,8 & 20,0 & 39,4 & 6,5 & 45,9 & 39,1 & 6,5 & & 11,5 & 30,7 & 46,9 & 61,3 & 19,2 & 2 & 4,4 & 49,8 & 19,1 & 1 & 4,3 & 49,4 \\
\hline 16 & 45,9 & 87,4 & 96,1 & 20,0 & 41,5 & 8,7 & 50,2 & 41,2 & 8,6 & 49,8 & 11,5 & 31,6 & 48,5 & 63,4 & 20,1 & 16,9 & 14,9 & 51,9 & 20,0 & 16,8 & 14,8 & 51,5 \\
\hline 17 & 45,9 & 91,0 & 99,3 & 19,0 & 45,1 & 8,3 & 53,4 & 43,7 & 8,0 & 51,7 & 11,6 & 31,8 & 48,8 & 64,0 & 20,2 & 17,0 & 15,2 & 52,4 & 19,6 & 16,5 & 14,7 & 50,8 \\
\hline 18 & 45,9 & 94,8 & 103,8 & 19,0 & 48,9 & 9,0 & 57,9 & 47,4 & 8,7 & 56,1 & 11,6 & 31,9 & 49,0 & 64,5 & 20,3 & 17,1 & 15,5 & 52,9 & 19,7 & 16,6 & 15,0 & 51,3 \\
\hline 19 & 46,0 & 97,4 & 107,2 & 19,5 & 51,4 & 9,8 & 61,2 & 50,4 & 9,6 & 60,0 & 11,6 & 32,6 & 50,2 & 67,3 & 21,0 & 17,6 & 17,1 & 55,7 & 20,6 & 17,3 & 16,8 & 54,6 \\
\hline 20 & 45,9 & 100,3 & 110,7 & 19,5 & 54,4 & 10,4 & 64,8 & 53,3 & 10,2 & 63,5 & 11,6 & 31,1 & 47,6 & 67,5 & 19,5 & 16,5 & 19,9 & 55,9 & 19,1 & 16,2 & 19,5 & 54,8 \\
\hline 21 & 45,9 & 102,3 & 113,1 & 20,5 & 56,4 & 10,8 & 67,2 & 56,7 & 10,8 & 67,5 & 11,6 & 30,7 & 46,7 & 71,4 & 19,1 & 16,0 & 24,7 & 59,8 & 19,2 & 16,1 & 24,8 & 60,1 \\
\hline 22 & 46,0 & 104,9 & 116,5 & 20,5 & 58,9 & 11,6 & 70,5 & 59,2 & 11,7 & 70,8 & 11,6 & 30,7 & 46,8 & 75,5 & 19,1 & 16,1 & 28,7 & 63,9 & 19,2 & 16,2 & 28,8 & 64,2 \\
\hline
\end{tabular}


(continuação)

\begin{tabular}{|c|c|c|c|c|c|c|c|c|c|c|c|c|c|c|c|c|c|c|c|c|c|c|}
\hline 23 & 45,9 & 80,0 & 83,0 & 21,5 & 34,1 & 3,0 & 37,1 & 35,1 & 3,1 & 38,2 & 11,8 & 31,1 & 47,4 & 85,5 & 19,3 & 16,3 & 38,1 & 73,7 & 19,9 & 16,8 & 39,2 & 75,9 \\
\hline 24 & 46,0 & 82,5 & 86,3 & 21,5 & 36,5 & 3,8 & 40,3 & 37,6 & 3,9 & 41,5 & & & & & & & & & & & & \\
\hline 26 & 46,0 & 87,5 & 93,4 & 22,0 & 41,5 & 5,9 & 47,4 & 43,2 & 6,1 & 49,4 & 11,7 & 30,9 & 47,3 & 90,5 & 19,2 & 16,4 & 43,2 & 78,8 & 20,0 & 17,1 & 45,0 & 82,1 \\
\hline 28 & 46,0 & 93,6 & 101,6 & 22,0 & 47,6 & 8,0 & 55,6 & 49,6 & 8,3 & 57,9 & 11,7 & 31,0 & 47,0 & 99,0 & 19,3 & 16,0 & 52,0 & 87,3 & 20,1 & 16,7 & 54,2 & 90,9 \\
\hline 29 & 46,0 & 96,1 & 104,8 & 21,0 & 50,1 & 8,7 & 58,8 & 50,9 & 8,8 & 59,8 & & & & & & & & & & & & \\
\hline 30 & 45,7 & 98,4 & 107,8 & 21,0 & 52,7 & 9,4 & 62,1 & 53,6 & 9,6 & 63,1 & 11,7 & 30,3 & 48,2 & 107,0 & 18,6 & 17,9 & 58,8 & 95,3 & 18,9 & 18,2 & 59,8 & 96,9 \\
\hline 31 & 45,8 & 90,5 & 94,1 & 21,0 & 44,7 & 3,6 & 48,3 & 45,5 & 3,7 & 49,1 & 11,6 & 30,6 & 51,4 & 120,7 & 19,0 & 20,8 & 69,3 & 109,1 & 19,3 & 21,2 & 70,5 & 110,9 \\
\hline 34 & 45,8 & 100,7 & 108,0 & 21,0 & 54,9 & 7,3 & 62,2 & 55,8 & 7,4 & 63,2 & 11,6 & 31,3 & 54,4 & 129,0 & 19,7 & 23,1 & 74,6 & 117,4 & 20,0 & 23,5 & 75,9 & 119,4 \\
\hline 35 & 45,8 & 103,7 & 111,7 & 20,5 & 57,9 & 8,0 & 65,9 & 58,2 & 8,0 & 66,2 & 11,6 & 31,4 & 56,0 & 135,0 & 19,8 & 24,6 & 79,0 & 123,4 & 19,9 & 24,7 & 79,4 & 124,0 \\
\hline 36 & 45,8 & 107,3 & 116,5 & 20,5 & 61,5 & 9,2 & 70,7 & 61,8 & 9,2 & 71,0 & 11,7 & 31,9 & 58,2 & 141,0 & 20,2 & 26,3 & 82,8 & 129,3 & 20,3 & 26,4 & 83,2 & 129,9 \\
\hline 37 & 45,8 & 109,3 & 119,0 & 20,5 & 63,5 & 9,7 & 73,2 & 63,8 & 9,7 & 73,5 & 11,6 & 32,4 & 60,9 & 148,7 & 20,8 & 28,5 & 87,8 & 137,1 & 20,9 & 28,6 & 88,2 & 137,7 \\
\hline 37,5 & 45,9 & 111,7 & 121,9 & 20,5 & 65,8 & 10,2 & 76,0 & 66,1 & 10,2 & 76,4 & 11,6 & 32,0 & 60,9 & 150,0 & 20,4 & 28,9 & 89,1 & 138,4 & 20,5 & 29,0 & 89,5 & 139,0 \\
\hline 38 & 45,9 & 109,6 & 114,4 & 20,5 & 63,7 & 4,8 & 68,5 & 64,0 & 4,8 & 68,8 & 11,5 & 31,3 & 60,4 & 151,4 & 19,8 & 29,1 & 91,0 & 139,9 & 19,9 & 29,2 & 91,4 & 140,5 \\
\hline 43 & 45,9 & 122,3 & 128,2 & 20,5 & 76,4 & 5,9 & 82,3 & 76,8 & 5,9 & 82,7 & 11,5 & 33,5 & 68,2 & 176,3 & 22,0 & 34,7 & 108,1 & 164,8 & 22,1 & 34,9 & 108,6 & 165,6 \\
\hline 44 & 45,9 & 126,2 & 133,7 & 20,5 & 80,3 & 7,5 & 87,8 & 80,7 & 7,5 & 88,2 & 11,5 & 33,3 & 67,1 & 172,8 & 21,8 & 33,8 & 105,7 & 161,3 & 21,9 & 34,0 & 106,2 & 162,0 \\
\hline 45 & 45,9 & 129,4 & 137,8 & 21,0 & 83,5 & 8,4 & 91,9 & 84,9 & 8,5 & 93,4 & 11,5 & 32,3 & 64,8 & 167,5 & 20,8 & 32,5 & 102,7 & 156,0 & 21,2 & 33,0 & 104,4 & 158,6 \\
\hline 46 & 45,9 & 133,2 & 143,0 & 21,0 & 87,3 & 9,8 & 97,1 & 88,8 & 10,0 & 98,7 & 11,6 & 34,2 & 69,8 & 183,8 & 22,6 & 35,6 & 114,0 & 172,2 & 23,0 & 36,2 & 115,9 & 175,1 \\
\hline 47 & 46,0 & 136,1 & 146,6 & 22,0 & 90,1 & 10,5 & 100,6 & 93,9 & 10,9 & 104,8 & 11,6 & 33,4 & 68,0 & 182,0 & 21,8 & 34,6 & 114,0 & 170,4 & 22,7 & 36,0 & 118,8 & 177,5 \\
\hline 48 & & & & 22,0 & & & & & & & 11,6 & 33,5 & 68,5 & 189,3 & 21,9 & 35,0 & 120,8 & 177,7 & 22,8 & 36,5 & 125,8 & 185,1 \\
\hline 49 & 46,0 & 142,8 & 155,7 & 22,5 & 96,8 & 12,9 & 109,7 & 102,1 & 13,6 & 115,7 & 11,5 & 32,7 & 64,9 & 190,4 & 21,2 & 32,2 & 125,5 & 178,9 & 22,4 & 34,0 & 132,3 & 188,6 \\
\hline 50 & 46,0 & 146,4 & 160,1 & 22,5 & 100,4 & 13,7 & 114,1 & 105,9 & 14,4 & 120,3 & 11,5 & 32,3 & 66,2 & 195,7 & 20,8 & 33,9 & 129,5 & 184,2 & 21,9 & 35,7 & 136,5 & 194,2 \\
\hline
\end{tabular}


(continuação)

\begin{tabular}{|c|c|c|c|c|c|c|c|c|c|c|c|c|c|c|c|c|c|c|c|c|c|c|}
\hline 51 & 46,0 & 149,5 & 164,2 & 22,0 & 103,5 & 14,7 & 118,2 & 107,8 & 15,3 & 123,1 & 11,5 & 33,0 & 68,5 & 212,5 & 21,5 & 35,5 & 144,0 & 201,0 & 22,4 & 37,0 & 150,0 & 209,4 \\
\hline 51,7 & 46,0 & 151,8 & 167,0 & 22,0 & 105,8 & 5,2 & 121,0 & 110,2 & 15,8 & 126,0 & 11,5 & 33,6 & 70,4 & 223,0 & 22,1 & 6,8 &, 6 & 5 & 3,0 & 8,3 & 0 & 3 \\
\hline 52 & 46,0 & 153,0 & 168,7 & 22,0 & 07,0 & 5,7 & 122,7 & 111,5 & 16,4 & 127,8 & 1,9 & 30,4 & 45,0 & 1 & 18,5 & 14,6 & 6,1 & ge & 9,3 & 5,2 & 8 & 1,3 \\
\hline 52,5 & 46,0 & 154,8 & 170,6 & 22,0 & 108,8 & 5,8 & 124,6 & 113,3 & 16,5 & 129,8 & 11,5 & 29,3 & 43,3 & 1,4 & 17,8 & 14,0 & , & 9,9 & 8,5 & 4,6 & 8,9 & 2,0 \\
\hline 53 & 45,9 & 154,4 & 160,7 & 21,5 & 108,5 & 6,3 & 114,8 & 11,7 & 6,5 & 18,2 & 11,5 & 29,6 & 43,9 & 76,0 & 18,1 & 14,3 & 32,1 & 4,5 & 18,6 & 14,7 & 33,0 & 6,4 \\
\hline 54 & 46,0 & 157,8 & 165,5 & 21,5 & 111,8 & 7,7 & 119,5 & 115,1 & 7,9 & 123,0 & 11,5 & 30,5 & 45,5 & 85,5 & 19,0 & 15,0 & 40,0 & 74,0 & 9,6 & 15,4 & 1,2 & 76,2 \\
\hline 55 & 45,9 & 143,6 & 151,5 & 21,0 & 97,7 & 7,9 & 105,6 & 9,3 & 8,0 & 07,4 & 11,5 & 29,4 & 43,5 & 86,0 & 7,9 & 14,1 & 42 & 5 & 8,2 & 4,3 & $\leq$ & 8 \\
\hline 56 & 45,9 & 166,7 & 177,5 & 21,0 & 120,8 & 10,8 & 131,6 & 22,8 & 11,0 & 133,8 & 11,5 & 29,5 & 43,7 & 95,0 & 18,0 & 14,2 & & 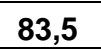 & 18,3 & 4,4 & & \\
\hline 57 & 45,9 & 170,3 & 182,4 & 21,0 & 124,4 & 12,1 & 136,5 & 126,5 & 12,3 & 138,8 & 11,5 & 30,3 & 45,3 & 108,2 & 18,8 & 5,0 & 62,9 & 7 & 9,1 & 5,3 & 0 & 3 \\
\hline 58 & 45,9 & 173,7 & 187,0 & 21,0 & 127,8 & 13,3 & 141,1 & 130,0 & 13,5 & 143,5 & 11,5 & 30,9 & 46,2 & 121,6 & 19,4 & 15,3 & 75,4 & 110,1 & 19,7 & 15,6 & 76,7 & 112,0 \\
\hline 59 & 45,9 & 159,2 & 164,9 & 21,0 & 113,3 & 5, & 119,0 & 115,2 & 5,8 & 1,0 & 11,4 & 29,6 & 46,5 & 133,8 & 18,2 & 16,9 & 87,3 & 2,4 & 8,5 & 17,2 & 8 & 1,5 \\
\hline 60 & & & & & & & & & & & & & & & & & & & 3,9 & & & \\
\hline 61 & 45,9 & 169,5 & 178,3 & 20,0 & 123,6 & 8,8 & 132,4 & 122,7 & 8,7 & 131,4 & 11,4 & 29,7 & 46,9 & 134,7 & 18,3 & 17,2 & 87,8 & 123,3 & 18,2 & 17,1 & 87,1 & 122,4 \\
\hline 62 & 45,9 & 174,4 & 184,4 & 20,0 & 128,5 & 10,0 & 138,5 & 127,5 & 9,9 & 137,5 & 11,4 & 30,2 & 48,0 & 140,1 & 18,8 & 17,8 & 92,1 & 128,7 & 18,7 & 17,7 & 91,4 & 127,7 \\
\hline 63 & 45,9 & 179,5 & 191,0 & 20,0 & 133,6 & 11,5 & 145,1 & 132,6 & 11,4 & 4,0 & 11,4 & 30,6 & 49,1 & 146,1 & 19,2 & 18,5 & 97,0 & 134,7 & 9,1 & 8,4 & 6,3 & 133,7 \\
\hline 64 & 45,8 & 185,7 & 198,3 & 20 & 139,9 & 12 & 152,5 & 138,9 & 12,5 & 151,4 & 11,4 & 3 & 51,0 & 155,3 & 19,9 & 19,7 & 104,0 & 43,9 & 19,8 & 19,6 &, 5 & 2,8 \\
\hline 65 & 45,9 & 189,5 & 203,2 & 20,0 & 143,6 & 13,7 & 157,3 & 142,5 & 13,6 & 156,1 & 11,4 & 30,9 & 50,5 & 157,3 & 19,5 & 19,6 & 106,8 & 45,9 & 19,4 & 19,5 & 106,0 & 144,8 \\
\hline 66 & 45,8 & 195,1 & 210,0 & 20,0 & 149,3 & 14,9 & 164,2 & 148,2 & 14,8 & 163,0 & 11,4 & 31,1 & 51,7 & 167,5 & 19,7 & 20,6 & 115,8 & 156,1 & 19,6 & 20,4 & 114,9 & 154,9 \\
\hline 67 & 45,9 & 197,4 & 213,0 & 20,5 & 151,5 & 15,6 & & 152,2 & 15,7 & 167,9 & 11,4 & 31,0 & 52,0 & 176,7 & 19,6 & 21,0 & 124,7 & 165,3 & 19,7 & 21,1 & 25,3 & 166,1 \\
\hline 68 & 45,9 & 186,1 & 196,4 & 20,5 & 140,2 & 10,3 & 150,5 & 140,8 & 10,3 & 151,2 & 11,5 & 31,1 & 52,8 & 193,0 & 19,6 & 21,7 & 140,2 & 181,5 & 19,7 & 21,8 & 140,8 & 182,3 \\
\hline 69 & 46,0 & 190,5 & 202,4 & 21,5 & 144,5 & 11,9 & 156,4 & 148,7 & 12,2 & 161,0 & 11,4 & 29,8 & 50,0 & 190,2 & 18,4 & 20,2 & 140,2 & 178,8 & 18,9 & 20,8 & 144,3 & 184,0 \\
\hline 70 & 46,0 & 195,0 & 208,4 & 21,5 & 149,0 & 13,4 & 162,4 & 153,4 & 13,8 & 167,1 & 11,5 & 29,8 & 50,1 & 197,0 & 18,3 & 20,3 & 146,9 & 185,5 & 18,8 & 20,9 & 151,2 & 190,9 \\
\hline 71 & 46,0 & 199,7 & 214,7 & 22,0 & 153,7 & 15,0 & 168,7 & 160,1 & 15,6 & 175,7 & 11,5 & 30,1 & 51,1 & 213,1 & 18,6 & 21,0 & 162,0 & 201,6 & 19,4 & 21,9 & 168,8 & 210,0 \\
\hline 72 & 46,0 & 204,3 & 220,3 & 22,5 & 158,3 & 16,0 & 174,3 & 166,9 & 16,9 & 183,8 & 11,5 & 29,3 & 49,7 & 222,5 & 17,8 & 20,4 & 172,8 & 211,0 & 18,8 & 21,5 & 182,2 & 222,5 \\
\hline
\end{tabular}

Média $\left({ }^{\circ} \mathrm{C}\right)=20,9$

FAAG = filtro ascendente de areia grossa; FRD = filtro rápido descendente; $T F$ = tempo de funcionamento; $T$ = temperatura; Lavagem do FRD por perda de carga . 


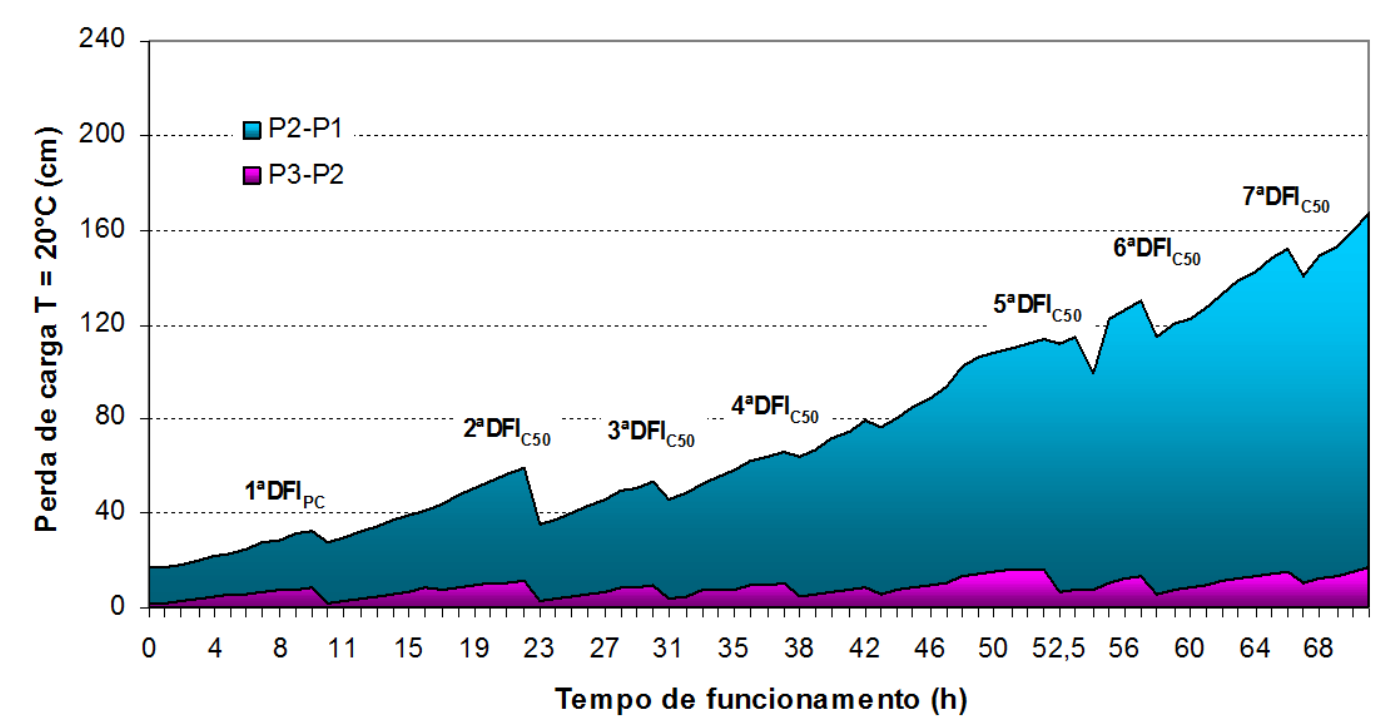

Figura B 2.1 - Perda de carga na camada suporte e camada de areia grossa no FAAG durante o ensaio 2 - sem pré-oxidação e com DFIs no FAAG (FAAG $=180 \mathrm{~m}^{3} / \mathrm{m}^{2} \mathrm{~d}$ e FRD $=200 \mathrm{~m} / \mathrm{m}^{2} \mathrm{~d}$ ). Fonte: Tabela B 2.3 - ANEXO B.

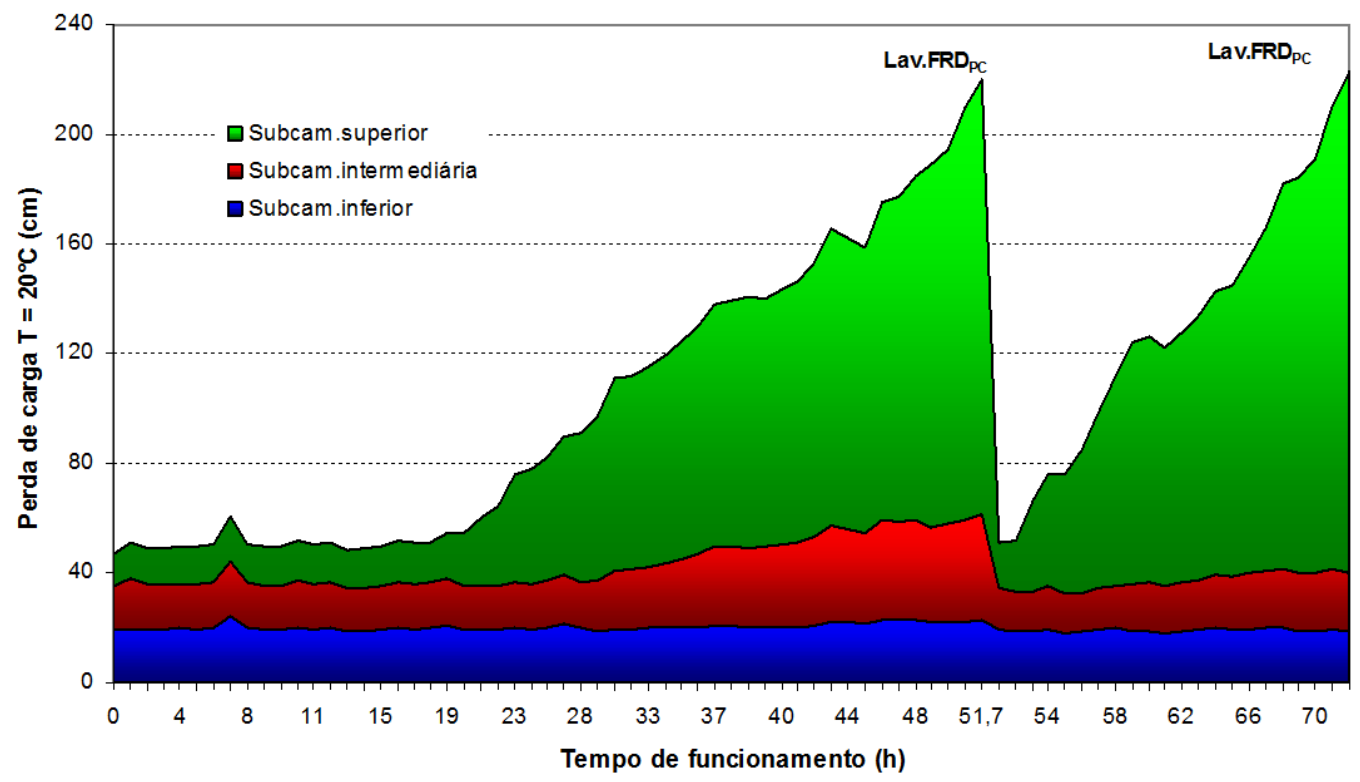

Figura B 2.2 - Perda de carga ao longo do meio filtrante do FRD durante o ensaio 2 - sem préoxidação e com DFls no FAAG (FAAG $=180 \mathrm{~m}^{3} / \mathrm{m}^{2} \mathrm{~d}$ e FRD $=200 \mathrm{~m}^{3} / \mathrm{m}^{2} \mathrm{~d}$ ). Fonte: Tabela B $2.3-$ ANEXO B. 
Tabela B 2.4 - Variação de vazões e taxas de filtração do FAAG e do FRD durante o ensaio 2 - sem pré-oxidação e com DFls no FAAG (FAAG $=180 \mathrm{~m}^{3} / \mathrm{m}^{2} \mathrm{~d} ; \mathrm{FRD}=200 \mathrm{~m}^{3} / \mathrm{m}^{2} \mathrm{~d}$ ).

\begin{tabular}{|c|c|c|c|c|c|c|c|c|}
\hline \multirow{2}{*}{$\begin{array}{l}\text { TF } \\
\text { (h) }\end{array}$} & \multicolumn{2}{|c|}{ descartes (L/h) } & \multicolumn{2}{|c|}{ turbidímetros (L/h) } & \multicolumn{2}{|c|}{ vazão total (L/h) } & \multicolumn{2}{|c|}{ taxas de filtração $\left(\mathrm{m}^{3} / \mathrm{m}^{2} \mathrm{~d}\right)$} \\
\hline & FAAG & FRD & FAAG & FRD & FAAG & FRD & FAAG & FRD \\
\hline 0 & 53,00 & 34,48 & 11,97 & 23,85 & 123,30 & 58,33 & 190 & 213 \\
\hline 1 & 51,21 & 35,17 & 11,82 & 23,68 & 121,88 & 58,85 & 187 & 215 \\
\hline 2 & 54,99 & 32,80 & 10,54 & 24,28 & 122,61 & 57,08 & 188 & 209 \\
\hline 3 & 53,65 & 33,16 & 10,71 & 23,67 & 121,19 & 56,83 & 186 & 208 \\
\hline 4 & 52,83 & 32,55 & 10,68 & 23,38 & 119,44 & 55,93 & 184 & 205 \\
\hline 5 & 53,25 & 34,38 & 11,28 & 23,05 & 121,96 & 57,43 & 187 & 210 \\
\hline 6 & 53,47 & 33,70 & 11,00 & 22,76 & 121,22 & 56,75 & 186 & 208 \\
\hline 7 & 53,60 & 34,97 & 10,87 & 23,04 & 122,20 & 57,73 & 188 & 211 \\
\hline 8 & 51,78 & 33,99 & 11,16 & 23,46 & 119,97 & 57,03 & 184 & 209 \\
\hline 9 & 51,61 & 33,64 & 11,45 & 23,26 & 120,16 & 57,10 & 185 & 209 \\
\hline 10 & 49,16 & 34,77 & 11,30 & 23,03 & 118,49 & 58,03 & 182 & 212 \\
\hline 11 & 51,70 & 34,36 & 11,19 & 23,60 & 120,28 & 57,39 & 185 & 210 \\
\hline 12 & 51,34 & 33,64 & 10,76 & 23,30 & 119,34 & 57,24 & 183 & 209 \\
\hline 13 & 54,32 & 31,02 & 11,11 & 24,00 & 119,75 & 54,32 & 184 & 199 \\
\hline 14 & 53,83 & 30,68 & 10,89 & 23,38 & 119,40 & 54,68 & 184 & 200 \\
\hline 15 & 52,68 & 30,95 & 10,72 & 22,96 & 117,73 & 54,33 & 181 & 199 \\
\hline 16 & 50,27 & 33,10 & 9,76 & 24,10 & 116,09 & 56,06 & 178 & 205 \\
\hline 17 & 51,61 & 34,00 & 10,80 & 23,09 & 120,51 & 58,10 & 185 & 213 \\
\hline 18 & 51,40 & 31,94 & 10,47 & 22,24 & 116,90 & 55,03 & 180 & 201 \\
\hline 19 & 49,71 & 36,00 & 9,73 & 23,04 & 117,68 & 58,24 & 181 & 213 \\
\hline 20 & 54,92 & 32,78 & 8,15 & 23,56 & 118,89 & 55,82 & 183 & 204 \\
\hline 21 & 55,46 & 35,17 & 7,32 & 23,15 & 121,51 & 58,73 & 187 & 215 \\
\hline 22 & 32,36 & 30,76 & 30,38 & 24,18 & 116,65 & 53,91 & 179 & 197 \\
\hline 23 & 36,70 & 34,43 & 22,59 & 24,24 & 117,90 & 58,61 & 181 & 214 \\
\hline 24 & 39,63 & 34,49 & 21,18 & 23,17 & 119,54 & 58,73 & 184 & 215 \\
\hline 25 & 41,84 & 32,73 & 20,63 & 23,06 & 118,37 & 55,90 & 182 & 204 \\
\hline 26 & 39,81 & 35,18 & 19,48 & 22,42 & 117,53 & 58,24 & 181 & 213 \\
\hline 28 & 36,57 & 38,85 & 30,05 & 23,87 & 129,34 & 62,72 & 199 & 229 \\
\hline 29 & 43,09 & 35,20 & 16,69 & 25,13 & 120,11 & 60,33 & 185 & 221 \\
\hline 30 & 44,09 & 37,21 & 13,87 & 22,02 & 117,19 & 59,23 & 180 & 217 \\
\hline 31 & 48,23 & 30,41 & 15,07 & 24,32 & 118,03 & 54,73 & 181 & 200 \\
\hline 32 & 51,03 & 32,73 & 10,28 & 23,66 & 117,70 & 56,39 & 181 & 206 \\
\hline 33 & 51,57 & 32,38 & 9,99 & 23,42 & 117,36 & 55,80 & 180 & 204 \\
\hline 34 & 51,48 & 32,21 & 9,96 & 22,82 & 116,47 & 55,03 & 179 & 201 \\
\hline 35 & 50,19 & 34,32 & 10,57 & 23,34 & 118,42 & 57,66 & 182 & 211 \\
\hline 36 & 49,94 & 34,42 & 9,74 & 22,79 & 116,89 & 57,21 & 180 & 209 \\
\hline 37 & 51,14 & 34,98 & 9,50 & 24,08 & 119,70 & 59,06 & 184 & 216 \\
\hline 38 & 47,40 & 35,50 & 9,75 & 22,92 & 115,57 & 58,42 & 178 & 214 \\
\hline 39 & 53,01 & 33,95 & 9,10 & 23,79 & 119,85 & 57,74 & 184 & 211 \\
\hline 40 & 53,62 & 32,52 & 8,67 & 23,12 & 117,93 & 55,64 & 181 & 204 \\
\hline 41 & 52,19 & 32,87 & 8,89 & 23,96 & 117,91 & 56,83 & 181 & 208 \\
\hline 42 & 53,29 & 32,80 & 8,86 & 24,34 & 119,29 & 57,14 & 183 & 209 \\
\hline 43 & 54,40 & 32,73 & 8,84 & 23,93 & 119,90 & 56,66 & 184 & 207 \\
\hline 44 & 56,95 & 33,50 & 7,18 & 24,00 & 121,63 & 57,50 & 187 & 210 \\
\hline
\end{tabular}


(continuação)

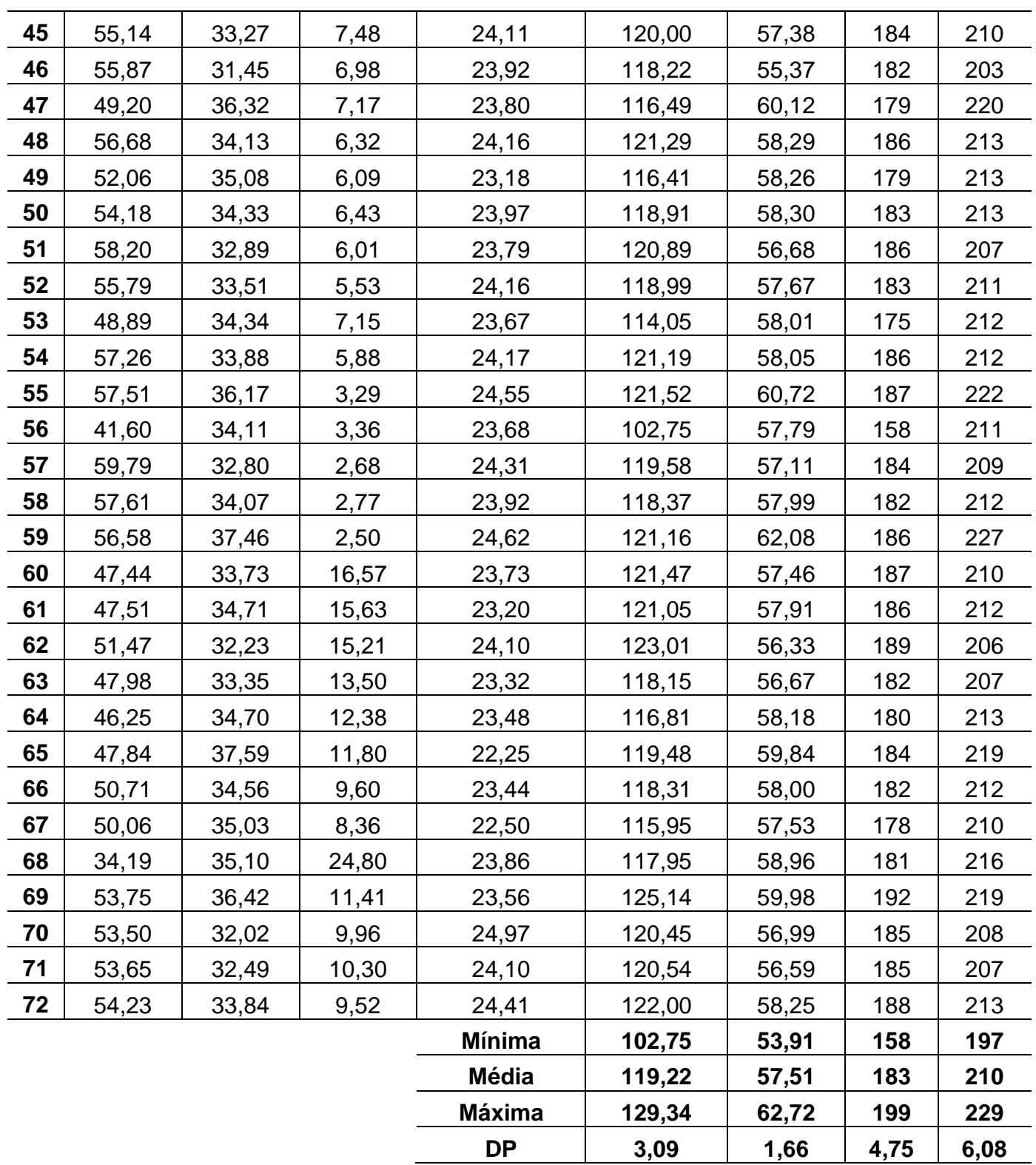

$\mathrm{TF}=$ tempo de funcionamento; FAAG = filtro ascendente de areia grossa; FRD = filtro rápido descendente; $A C=$ água coagulada; DP = desvio padrão. 
Tabela B 3.1 - Características físicas da AB, AE e efluentes do FAAG e do FRD durante o ensaio 3 sem pré-oxidação e com DFls no FAAG (FAAG $=180 \mathrm{~m}^{3} / \mathrm{m}^{2} \mathrm{~d} ; \mathrm{FRD}=240 \mathrm{~m}^{3} / \mathrm{m}^{2} \mathrm{~d}$ ).

\begin{tabular}{|c|c|c|c|c|c|c|c|}
\hline \multirow{2}{*}{$\begin{array}{l}\text { TF } \\
\text { (h) } \\
\end{array}$} & \multirow{2}{*}{\begin{tabular}{|c|}
$\begin{array}{c}\text { Temperatura } \\
\left({ }^{\circ} \mathrm{C}\right)\end{array}$ \\
$\mathrm{AE}$ \\
\end{tabular}} & \multicolumn{4}{|c|}{ Cor aparente (uH) } & \multicolumn{2}{|c|}{ Cor verdadeira (uH) } \\
\hline & & $\mathrm{AB}$ & $\mathrm{AE}$ & FAAG & FRD & $\mathrm{AB}$ & $\mathbf{A E}$ \\
\hline 0 & 22,0 & & 194 & 18,0 & 19,0 & & 95 \\
\hline 1 & 22,5 & 120 & 202 & 2,0 & $<1,0$ & 27 & 102 \\
\hline 3 & 22,0 & & 206 & 3,0 & $<1,0$ & & 95 \\
\hline 5 & 21,5 & & 185 & 4,0 & $<1,0$ & & 98 \\
\hline 7 & 21,0 & 95 & 174 & $<1,0$ & $<1,0$ & 33 & 83 \\
\hline 9 & 20,0 & & 221 & $<1,0$ & $<1,0$ & & 119 \\
\hline 11 & 19,5 & & 191 & $<1,0$ & $<1,0$ & & 86 \\
\hline 13 & 19,5 & 107 & 189 & $<1,0$ & $<1,0$ & 24 & 91 \\
\hline 15 & 19,5 & & 194 & $<1,0$ & $<1,0$ & & 105 \\
\hline 17 & 19,0 & & 187 & $<1,0$ & $<1,0$ & & 91 \\
\hline 19 & 20,0 & 106 & 190 & $<1,0$ & $<1,0$ & 23 & 107 \\
\hline 21 & 21,0 & & 218 & $<1,0$ & $<1,0$ & & 98 \\
\hline 23 & 22,0 & & 218 & 16,0 & $<1,0$ & & 111 \\
\hline 26 & 22,0 & 118 & 203 & 38,0 & $<1,0$ & 25 & 92 \\
\hline 27 & 22,0 & & 202 & 11,0 & $<1,0$ & & 91 \\
\hline 29 & 21,0 & & 199 & 30,0 & $<1,0$ & & 110 \\
\hline 31 & 21,0 & 95 & 186 & 38,0 & $<1,0$ & 22 & 91 \\
\hline 33 & 20,5 & & 187 & 44,0 & $<1,0$ & & 87 \\
\hline 35 & 20,0 & & 207 & 17,0 & $<1,0$ & & 120 \\
\hline 37 & 20,0 & 96 & 187 & 42,0 & $<1,0$ & 23 & 106 \\
\hline 39 & 20,0 & & 178 & 11,0 & $<1,0$ & & 85 \\
\hline 41 & 19,5 & & 180 & 31,0 & $<1,0$ & & 90 \\
\hline 43 & 20,0 & 128 & 222 & & 4,0 & 27 & 112 \\
\hline 45 & 21,5 & & 216 & 35,0 & $<1,0$ & & 110 \\
\hline 47 & 22,0 & & 226 & 17,0 & 2,0 & & 117 \\
\hline 50 & 22,5 & 128 & 216 & 40,0 & $<1,0$ & 27 & 110 \\
\hline 51 & 22,5 & & 185 & 22,0 & $<1,0$ & & 85 \\
\hline 53 & 21,5 & & 197 & 32,0 & $<1,0$ & & 93 \\
\hline 55 & 21,0 & 122 & 198 & 69,0 & $<1,0$ & 22 & 97 \\
\hline 57 & 21,0 & & 196 & 32,0 & $<1,0$ & & 93 \\
\hline 59 & 20,5 & & 201 & 55,0 & $<1,0$ & & 95 \\
\hline 61 & 20,0 & 100 & 195 & 20,0 & $<1,0$ & 27 & 100 \\
\hline 63 & 20,0 & & 195 & 42,0 & 5,0 & & 96 \\
\hline 65 & 20,0 & & 193 & 16,0 & $<1,0$ & & 106 \\
\hline 67 & 21,0 & 96 & 193 & 34,0 & $<1,0$ & 25 & 111 \\
\hline 69 & 21,0 & & 212 & 18,0 & $<1,0$ & & 101 \\
\hline 71 & 21,0 & & 209 & 37,0 & $<1,0$ & & 96 \\
\hline 72 & 21,5 & 115 & 202 & 52,0 & $<1,0$ & 21 & 107 \\
\hline Média & 20,9 & 110 & 199 & 22,4 & 1,2 & 25 & 100 \\
\hline Mínimo & 19,0 & 95 & 174 & $<1,0$ & $<1,0$ & 21 & 83 \\
\hline Máximo & 22,5 & 128 & 226 & 69,0 & 19,0 & 33 & 120 \\
\hline DP & 0,98 & 12,74 & 13,05 & 18,54 & 3,10 & 3,20 & 10,06 \\
\hline
\end{tabular}

$\mathrm{TF}=$ tempo de funcionamento; $\mathrm{AE}=$ água de estudo; $\mathrm{AB}$ = água bruta; $\mathrm{FAAG}=$ filtro ascendente de areia grossa; $\mathrm{FRD}=$ filtro rápido descendente; $\mathrm{DP}=$ desvio padrão. 
Tabela B 3.2 - Características químicas da $A B, A E$ e efluentes do $F A A G$ e do $F R D$ durante o ensaio 3 - sem pré-oxidação e com DFls no $F A A G\left(F A A G=180\right.$ m ${ }^{3} / m^{2}$ d; $\mathrm{FRD}=240 \mathrm{~m}^{3} / \mathrm{m}^{2} \mathrm{~d}$ )

\begin{tabular}{|c|c|c|c|c|c|c|c|c|c|c|c|c|c|c|c|c|c|}
\hline \multirow{2}{*}{$\begin{array}{l}\text { TF } \\
\text { (h) }\end{array}$} & \multicolumn{3}{|c|}{$\mathrm{pH}$} & \multicolumn{2}{|c|}{ Alcalinidade $\left(\mathrm{mg} / \mathrm{L} \mathrm{CaCO}_{3}\right)$} & \multicolumn{4}{|c|}{ Absorvância 254 nm } & \multicolumn{4}{|c|}{ COD (mg/L) } & \multicolumn{4}{|c|}{ Alumínio (mg/L) } \\
\hline & $A B$ & $\mathrm{AE}$ & AC & $\mathrm{AB}$ & $\mathrm{AE}$ & $\mathrm{AB}$ & $\mathrm{AE}$ & FAAG & FRD & $\mathrm{AB}$ & $\mathrm{AE}$ & FAAG & FRD & $\mathrm{AB}$ & $\mathrm{AE}$ & FAAG & FRD \\
\hline 0 & & 6,65 & 5,01 & & & & & & & 3,234 & 4,246 & 4,333 & 4,591 & - & - & - & - \\
\hline 1 & 6,56 & 6,50 & 4,98 & 7,70 & 7,46 & 0,081 & 0,180 & 0,013 & 0,008 & 3,110 & 5,039 & 2,959 & 2,769 & - & - & - & - \\
\hline 3 & & 6,72 & 4,98 & & & & & & & & & & & & & & \\
\hline 5 & & 6,50 & 5,02 & & & & & & & & & & & & & & \\
\hline 7 & 6,50 & 6,54 & 5,00 & 11,00 & 9,02 & 0,075 & 0,164 & 0,014 & 0,013 & & & & & & & & \\
\hline 9 & & 6,80 & 4,97 & & & & & & & & & & & & & & \\
\hline 11 & & 6,42 & 5,03 & & & & & & & & & & & & & & \\
\hline 13 & 6,51 & 6,32 & 4,93 & 10,34 & 9,24 & 0,074 & 0,181 & 0,018 & 0,017 & & & & & & & & \\
\hline 15 & & 6,65 & 4,97 & & & & & & & & & & & & & & \\
\hline 17 & & 6,73 & 4,96 & & & & & & & & & & & & & & \\
\hline 19 & 6,57 & 6,42 & 4,92 & 9,90 & 10,56 & 0,070 & 0,192 & 0,008 & 0,014 & & & & & & & & \\
\hline 21 & & 6,52 & 4,90 & & & & & & & & & & & & & & \\
\hline 23 & & 6,57 & 5,03 & & & & & & & & & & & & & & \\
\hline 26 & 6,38 & 6,63 & 4,98 & 9,90 & 9,24 & 0,075 & 0,183 & 0,015 & 0,020 & 2,689 & 4,457 & 3,022 & 3,463 & - & - & - & - \\
\hline 27 & & 6,75 & 4,93 & & & & & & & & & & & & & & \\
\hline 29 & & 6,59 & 4,99 & & & & & & & & & & & & & & \\
\hline 31 & 6,55 & 6,50 & 5,01 & 9,02 & 11,44 & 0,068 & 0,179 & 0,014 & 0,032 & & & & & & & & \\
\hline 33 & & 6,81 & 5,00 & & & & & & & & & & & & & & \\
\hline 35 & & 6,78 & 5,00 & & & & & & & & & & & & & & \\
\hline 37 & 6,55 & 6,56 & 5,02 & 8,58 & 9,02 & 0,073 & 0,201 & 0,015 & 0,021 & & & & & & & & \\
\hline 39 & & 6,52 & 5,04 & & & & & & & & & & & & & & \\
\hline 41 & & 6,52 & 5,05 & & & & & & & & & & & & & & \\
\hline 43 & 6,60 & 6,57 & 5,01 & 8,14 & 9,90 & 0,076 & 0,208 & 0,030 & 0,016 & & & & & & & & \\
\hline 45 & & 6,57 & 4,92 & & & & & & & & & & & & & & \\
\hline 47 & & 6,53 & 4,99 & & & & & & & & & & & & & & \\
\hline 50 & 6,64 & 6,58 & 4,95 & 7,70 & 9,46 & 0,077 & 0,197 & 0,018 & 0,013 & 2,980 & 4,247 & 2,738 & 3,363 & - & - & - & - \\
\hline 51 & & 6,51 & 4,96 & & & & & & & & & & & & & & \\
\hline
\end{tabular}




\begin{tabular}{|c|c|c|c|c|c|c|c|c|c|c|c|c|c|c|c|c|c|}
\hline 53 & & 6,82 & 5,02 & & & & & & & & & & & & & & \\
\hline 55 & 6,60 & 6,49 & 5,02 & 10,34 & 9,90 & 0,066 & 0,182 & 0,012 & 0,018 & & & & & & & & \\
\hline 57 & & 6,55 & 5,01 & & & & & & & & & & & & & & \\
\hline 59 & & 6,65 & 5,02 & & & & & & & & & & & & & & \\
\hline 61 & 6,51 & 6,54 & 5,04 & 9,90 & 9,68 & 0,073 & 0,195 & 0,013 & 0,015 & & & & & & & & \\
\hline 63 & & 6,58 & 5,02 & & & & & & & & & & & & & & \\
\hline 65 & & 6,59 & 5,01 & & & & & & & & & & & & & & \\
\hline 67 & 6,54 & 6,62 & 5,02 & 11,22 & 9,68 & 0,069 & 0,198 & 0,014 & 0,011 & & & & & & & & \\
\hline 69 & & 6,76 & 5,03 & & & & & & & & & & & & & & \\
\hline 71 & & 6,55 & 4,99 & & & & & & & & & & & & & & \\
\hline 72 & 6,75 & 6,46 & 5,02 & 9,46 & 9,68 & 0,068 & 0,194 & 0,013 & 0,011 & 2,642 & 4,337 & 2,669 & 3,009 & - & - & - & - \\
\hline Média & 6,56 & 6,59 & 4,99 & 9,48 & 9,56 & 0,073 & 0,189 & 0,015 & 0,016 & 2,931 & 4,465 & 3,144 & 3,439 & - & - & - & - \\
\hline Mínimo & 6,38 & 6,32 & 4,90 & 7,70 & 7,46 & 0,066 & 0,164 & 0,008 & 0,008 & 2,642 & 4,246 & 2,669 & 2,769 & - & - & - & - \\
\hline Máximo & 6,75 & 6,82 & 5,05 & 11,22 & 11,44 & 0,081 & 0,208 & 0,030 & 0,032 & 3,234 & 5,039 & 4,333 & 4,591 & - & - & - & - \\
\hline DP & 0,09 & 0,12 & 0,04 & 1,17 & 0,91 & 0,004 & 0,012 & 0,005 & 0,006 & 0,259 & 0,332 & 0,681 & 0,701 & - & - & - & - \\
\hline
\end{tabular}

$\mathrm{TF}=$ tempo de funcionamento; $\mathrm{AE}$ = água de estudo; $\mathrm{AB}$ = água bruta; $\mathrm{AC}$ = água coagulada; $\mathrm{FAAG}$ = filtro ascendente de areia grossa; $\mathrm{FRD}=$ filtro rápido descendente; $\mathrm{DP}=$ desvio padrão. 
Tabela B 3.3 - Perda de carga no FAAG $\left(180 \mathrm{~m}^{3} / \mathrm{m}^{2} \mathrm{~d}\right)$ e no FRD $\left(240 \mathrm{~m}^{3} / \mathrm{m}^{2} \mathrm{~d}\right)$ durante o ensaio 3 , sem pré-oxidação e com DFls no FAAG para a temperatura T e para T = $20^{\circ} \mathrm{C}$.

\begin{tabular}{|c|c|c|c|c|c|c|c|c|c|c|c|c|c|c|c|c|c|c|c|c|c|c|}
\hline \multirow{3}{*}{$\begin{array}{l}\text { TF } \\
\text { (h) }\end{array}$} & \multicolumn{10}{|c|}{ FAAG } & \multicolumn{12}{|c|}{ FRD } \\
\hline & \multicolumn{3}{|c|}{$\begin{array}{c}\begin{array}{c}\text { Leitura piezométrica } \\
(\mathrm{cm})\end{array} \\
\end{array}$} & \multirow{2}{*}{$\begin{array}{c}\mathbf{T} \\
\left({ }^{\circ} \mathbf{C}\right)\end{array}$} & \multicolumn{3}{|c|}{$\begin{array}{r}\text { Perda de carga } \\
(\mathrm{cm})\end{array}$} & \multicolumn{3}{|c|}{$\begin{array}{c}\text { Perda de carga }(\mathrm{cm}) \\
T=20^{\circ} \mathrm{C}\end{array}$} & \multicolumn{4}{|c|}{$\begin{array}{c}\text { Leitura piezométrica } \\
(\mathrm{cm})\end{array}$} & \multicolumn{4}{|c|}{$\begin{array}{l}\text { Perda de carga } \\
(\mathrm{cm})\end{array}$} & \multicolumn{4}{|c|}{$\begin{array}{c}\text { Perda de carga }(\mathrm{cm}) \\
\mathrm{T}=20^{\circ} \mathrm{C}\end{array}$} \\
\hline & $\mathrm{P} 1$ & $\mathrm{P} 2$ & P3 & & P2-P1 & P3-P2 & P3-P1 & P2-P1 & P3-P2 & P3-P1 & $\mathrm{P} 1$ & P2 & P3 & $\mathrm{P} 4$ & P2-P1 & \begin{tabular}{|l|} 
P3-P2 \\
\end{tabular} & P4-P3 & P4-P1 & P2-P1 & P3-P2 & P4-P3 & P4-P1 \\
\hline 0 & 44,9 & 60,0 & 61,4 & 22,0 & 15,1 & 1,4 & 16,5 & 15,7 & 1,5 & 17,2 & 11,9 & 31,0 & 46,8 & 62,1 & 19,1 & 15,8 & 15,3 & 50,2 & 19,9 & 16,5 & 15,9 & 52,3 \\
\hline 1 & 45,8 & 64,1 & 66,4 & 22,5 & 18,3 & 2,3 & 20,6 & 19,3 & 2,4 & 21,7 & 12,0 & 33,3 & 51,0 & 69,0 & 21,3 & 17,7 & 18,0 & 57,0 & 22,5 & 18,7 & 19,0 & 60,1 \\
\hline 3 & 46,0 & 66,7 & 70,3 & 22,5 & 20,7 & 3,6 & 24,3 & 21,8 & 3,8 & 25,6 & 12,0 & 33,0 & 50,5 & 69,1 & 21,0 & 17,5 & 18,6 & 57,1 & 22,1 & 18,5 & 19,6 & 60,2 \\
\hline 4 & 46,0 & 68,1 & 72,7 & 22,0 & 22,1 & 4,6 & 26,7 & 23,0 & 4,8 & 27,8 & 12,0 & 33,9 & 52,3 & 72,3 & 21,9 & 18,4 & 20,0 & 60,3 & 22,8 & 19,2 & 20,8 & 62,8 \\
\hline 5 & 46,0 & 68,4 & 72,0 & 22,0 & 22,4 & 3,6 & 26,0 & 23,3 & 3,8 & 27,1 & 12,0 & 34,1 & 52,8 & 73,0 & 22,1 & 18,7 & 20,2 & 61,0 & 23,0 & 19,5 & 21,0 & 63,5 \\
\hline 6 & 45,9 & 69,5 & 73,8 & 21,5 & 23,6 & 4,3 & 27,9 & 24,3 & 4,4 & 28,7 & 11,9 & 33,4 & 51,4 & 71,7 & 21,5 & 18,0 & 20,3 & 59,8 & 22,1 & 18,5 & 20,9 & 61,5 \\
\hline 7 & 45,9 & 72,4 & 78,3 & 21,5 & 26,5 & 5,9 & 32,4 & 27,3 & 6,1 & 33,3 & 12,0 & 34,8 & 53,9 & 75,6 & 22,8 & 19,1 & 21,7 & 63,6 & 23,5 & 7 & 3 & 5 \\
\hline 8 & 45,9 & 73,7 & 80,2 & 21,0 & 27,8 & 6,5 & 34,3 & 28,3 & 6,6 & 34,9 & 11,9 & 33,4 & 51,6 & 72,2 & 21,5 & 18,2 & 20,6 & 60,3 & 21,9 & 18,5 & 20,9 & 61,3 \\
\hline 9 & 45,9 & 76,7 & 84,1 & 21,0 & 30,8 & 7,4 & 38,2 & 31,3 & 7,5 & 38,8 & 11,9 & 34,1 & 53,0 & 74,0 & 22,2 & 18,9 & 21,0 & 62,1 & 22,6 & 19,2 & 21,4 & 63,1 \\
\hline 10 & 45,9 & 78,7 & 86,0 & 20,0 & 32,8 & 7,3 & 40,1 & 32,6 & 7,2 & 39,8 & 11,9 & 34,3 & 53,3 & 74,9 & 22,4 & 19,0 & 21,6 & 63,0 & 22,2 & 18,9 & 21,4 & 62,5 \\
\hline 10,2 & 45,9 & 79,3 & 86,7 & 20,0 & 33,4 & 7,4 & 40,8 & 33,2 & 7,3 & 40,5 & 11,9 & 34,4 & 53,4 & 75,0 & 22,5 & 19,0 & 21,6 & 63,1 & 22,3 & 18,9 & 21,4 & 62,6 \\
\hline 11 & 45,9 & 71,6 & 74,5 & 20,0 & 25,7 & 2,9 & 28,6 & 25,5 & 2,9 & 28,4 & 12,0 & 34,1 & 53,0 & 74,8 & 22,1 & 18,9 & 21,8 & 62,8 & 21,9 & 18,8 & 21,6 & 62,3 \\
\hline 12 & 45,8 & 73,2 & 77,5 & 19,5 & 27,4 & 4,3 & 31,7 & 26,9 & 4,2 & 31,1 & 11,8 & 34,5 & 53,6 & 75,5 & 22,7 & 19,1 & 21,9 & 63,7 & 22,3 & 18,7 & 21,5 & 62,5 \\
\hline 13 & 45,8 & 75,3 & 80,0 & 19,5 & 29,5 & 4,7 & 34,2 & 28,9 & 4,6 & 33,5 & 11,8 & 34,5 & 53,8 & 76,0 & 22,7 & 19,3 & 22,2 & 64,2 & 22,3 & 18,9 & 21,8 & 63,0 \\
\hline 14 & 45,8 & 78,0 & 84,1 & 19,5 & 32,2 & 6,1 & 38,3 & 31,6 & 6,0 & 37,6 & 11,8 & 34,2 & 53,1 & 75,2 & 22,4 & 18,9 & 22,1 & 63,4 & 22,0 & 18,5 & 21,7 & 62,2 \\
\hline 15 & 45,8 & 80,7 & 87,8 & 19,5 & 34,9 & 7,1 & 42,0 & 34,2 & 7,0 & 41,2 & 11,8 & 34,2 & 53,2 & 75,2 & 22,4 & 19,0 & 22,0 & 63,4 & 22,0 & 18,6 & 21,6 & 62,2 \\
\hline 16 & 45,8 & 83,0 & 91,1 & 19,5 & 37,2 & 8,1 & 45,3 & 36,5 & 7,9 & 44,4 & 11,7 & 34,1 & 52,9 & 74,9 & 22,4 & 18,8 & 22,0 & 63,2 & 22,0 & 18,4 & 21,6 & 62,0 \\
\hline 17 & 45,8 & 86,0 & 95,7 & 19,5 & 40,2 & 9,7 & 49,9 & 39,4 & 9,5 & 48,9 & 11,7 & 34,2 & 53,0 & 75,2 & 22,5 & 18,8 & 22,2 & 63,5 & 22,1 & 18,4 & 21,8 & 62,3 \\
\hline 18 & 45,8 & 88,6 & 98,7 & 19,0 & 42,8 & 10,1 & 52,9 & 41,5 & 9,8 & 51,3 & 11,7 & 34,1 & 53,0 & 75,2 & 22,4 & 18,9 & 22,2 & 63,5 & 21,7 & 18,3 & 21,5 & 61,5 \\
\hline 19 & 45,8 & 91,5 & 102,2 & 19,0 & 45,7 & 10,7 & 56,4 & 44,3 & 10,4 & 54,6 & 11,7 & 33,8 & 52,5 & 74,5 & 22,1 & 18,7 & 22,0 & 62,8 & 21,4 & 18,1 & 21,3 & 60,8 \\
\hline 20 & 45,8 & 95,3 & 107,1 & 20,0 & 49,5 & 11,8 & 61,3 & 49,1 & 11,7 & 60,8 & 11,7 & 33,8 & 52,5 & 74,7 & 22,1 & 18,7 & 22,2 & 63,0 & 21,9 & 18,6 & 22,0 & 62,5 \\
\hline 21 & 45,8 & 98,0 & 110,3 & 20,0 & 52,2 & 12,3 & 64,5 & 51,8 & 12,2 & 64,0 & 11,7 & 34,1 & 53,0 & 75,0 & 22,4 & 18,9 & 22,0 & 63,3 & 22,2 & 18,8 & 21,8 & 62,8 \\
\hline 22 & 45,9 & 101,0 & 114,0 & 21,0 & 55,1 & 13,0 & 68,1 & 56,0 & 13,2 & 69,2 & 11,8 & 34,0 & 52,7 & 75,1 & 22,2 & 18,7 & 22,4 & 63,3 & 22,6 & 19,0 & 22,8 & 64,4 \\
\hline 23 & 46,0 & 104.3 & 118,3 & 21,0 & 58,3 & 14,0 & 72,3 & 59,3 & 14,2 & 73,5 & 11,9 & 35.0 & 54,5 & 80,0 & 23,1 & 19,5 & 25,5 & 68,1 & 23,5 & 19,8 & 25,9 & 69,2 \\
\hline
\end{tabular}


(continuação)

\begin{tabular}{|c|c|c|c|c|c|c|c|c|c|c|c|c|c|c|c|c|c|c|c|c|c|c|}
\hline 24 & 46,0 & 107,2 & 121,8 & 22,0 & 61,2 & 14,6 & 75,8 & 63,8 & 15,2 & 79,0 & 11,9 & 34,5 & 58,7 & 83,3 & 22,6 & 24,2 & 24,6 & 71,4 & 23,5 & 25,2 & 25,6 & 74,4 \\
\hline 25 & 46,0 & 109,8 & 125,1 & 22,0 & 63,8 & 15,3 & 79,1 & 66,5 & 15,9 & 82,4 & 11,9 & 33,9 & 52,5 & 88,7 & 22,0 & 18,6 & 36,2 & 76,8 & 22,9 & 19,4 & 37,7 & 80,0 \\
\hline 25,8 & 45,9 & 111,5 & 127,3 & 22,0 & 65,6 & 15,8 & 81,4 & 68,3 & 16,5 & 84,8 & 11,9 & 33,6 & 52,2 & 93,7 & 21,7 & 18,6 & 41,5 & 81,8 & 22,6 & 19,4 & 43,2 & 85,2 \\
\hline 26 & 45,9 & 91,8 & 95,7 & 22,0 & 45,9 & 3,9 & 49,8 & 47,8 & 4,1 & 51,9 & 11,9 & 33,1 & 51,2 & 96,6 & 21,2 & 18,1 & 45,4 & 84,7 & 22,1 & 18,9 & 47,3 & 88,2 \\
\hline 27 & 45,9 & 95,2 & 100,8 & 22,0 & 49,3 & 5,6 & 54,9 & 51,4 & 5,8 & 57,2 & 11,9 & 33,9 & 54,1 & 114,0 & 22,0 & 20,2 & 59,9 & 102,1 & 22,9 & 21,0 & 62,4 & 106,4 \\
\hline 28 & 45,9 & 98,6 & 105,6 & 22,0 & 52,7 & 7,0 & 59,7 & 54,9 & 7,3 & 62,2 & 11,9 & 34,4 & 55,3 & 119,0 & 22,5 & 20,9 & 63,7 & 107,1 & 23,4 & 21,8 & 66,4 & 111,6 \\
\hline 29 & 45,9 & 102,2 & 110,3 & 22,0 & 56,3 & 8,1 & 64,4 & 58,6 & 8,4 & 67,1 & 11,9 & 34,4 & 56,1 & 124,7 & 22,5 & 21,7 & 68,6 & 112,8 & 23,4 & 22,6 & 71,5 & 117,5 \\
\hline 30 & 45,9 & 104,7 & 113,5 & 21,0 & 58,8 & 8,8 & 67,6 & 59,8 & 8,9 & 68,7 & 11,8 & 33,4 & 55,0 & 125,4 & 21,6 & 21,6 & 70,4 & 113,6 & 22,0 & 22,0 & 71,6 & 115,5 \\
\hline 31 & 45,9 & 107,6 & 117,5 & 21,0 & 61,7 & 9,9 & 71,6 & 62,7 & 10,1 & 72,8 & 11,8 & 33,8 & 57,1 & 134,2 & 22,0 & 23,3 & 77,1 & 122,4 & 22,4 & 23,7 & 78,4 & 124,5 \\
\hline 32 & 45,9 & 111,2 & 122,2 & 21,0 & 65,3 & 11,0 & 76,3 & 66,4 & 11,2 & 77,6 & 11,7 & 33,8 & 58,5 & 141,0 & 22,1 & 24,7 & 82,5 & 129,3 & 22,5 & 25,1 & 83,9 & 131,5 \\
\hline 33 & 45,9 & 114,0 & 126,2 & 21,0 & 68,1 & 12,2 & 80,3 & 69,2 & 12,4 & 81,7 & 11,7 & 34,5 & 60,8 & 150,3 & 22,8 & 26,3 & 89,5 & 138,6 & 23,2 & 26,7 & 91,0 & 140,9 \\
\hline 33,4 & 45,9 & 115,3 & 127,7 & 20,5 & 69,4 & 12,4 & 81,8 & 69,7 & 12,5 & 82,2 & 11,7 & 34,9 & 61,9 & 154,7 & 23,2 & 27,0 & 92,8 & 3,0 & 3,3 & 7,1 & 3,2 & 3,7 \\
\hline 34 & 45,8 & 104,2 & 110,1 & 20,5 & 58,4 & 5,9 & 64,3 & 58,7 & 5,9 & 64,6 & 11,6 & 35,8 & 65,1 & 175,2 & 24,2 & 29,3 & 110,1 & 163,6 & 24,3 & 29,4 & 110,6 & 164,4 \\
\hline 35 & 45,8 & 107,1 & 114,1 & 20,5 & 61,3 & 7,0 & 68,3 & 61,6 & 7,0 & 68,6 & 11,7 & 36,4 & 66,2 & 176,8 & 24,7 & 29,8 & 110,6 & 165,1 & 24,8 & 29,9 & 111,1 & 165,9 \\
\hline 36 & 45,8 & 110,8 & 119,2 & 20,0 & 65,0 & 8,4 & 73,4 & 64,5 & 8,3 & 72,9 & 11,6 & 36,5 & 66,7 & 181,6 & 24,9 & 30,2 & 114,9 & 170,0 & 4,7 & 30,0 & 114,0 & 168,7 \\
\hline 37 & 45,8 & 113,7 & 123,0 & 20,0 & 67,9 & 9,3 & 77,2 & 67,4 & 9,2 & 76,6 & 11,6 & 36,8 & 67,9 & 189,0 & 25,2 & 31,1 & 121,1 & 177,4 & 25,0 & 30,9 & 120,2 & 176,1 \\
\hline 38 & 45,8 & 117,3 & 128,1 & 20,0 & 71,5 & 10,8 & 82,3 & 71,0 & 10,7 & 81,7 & 11,6 & 37,3 & 69,4 & 197,7 & 25,7 & 32,1 & 128,3 & 186,1 & 25,5 & 31,9 & 127,3 & 184,7 \\
\hline 38,7 & 45,8 & 96,0 & 100,9 & 20,0 & 50,2 & 4,9 & 55,1 & 49,8 & 4,9 & 54,7 & 11,6 & 64,0 & & 225,0 & 52,4 & & & 213,4 & 52,0 & & & 211,8 \\
\hline 39 & 45,8 & 97,9 & 103,7 & 20,0 & 52,1 & 5,8 & 57,9 & 51,7 & 5,8 & 57,5 & 11,7 & 30,8 & $4+, 1$ & 73,0 & 19,1 & 18,9 & 20,0 & 61,3 & 19,0 & 18,8 & 3,1 & 60,8 \\
\hline 40 & 45,8 & 100,2 & 107,0 & 20,0 & 54,4 & 6,8 & 61,2 & 54,0 & 6,7 & 60,7 & 11,8 & 31,8 & 52,1 & 78,8 & 20,0 & 20,3 & 26,7 & 67,0 & 19,9 & 20,1 & 26,5 & 66,5 \\
\hline 41 & 45,8 & 103,4 & 111,3 & 20,0 & 57,6 & 7,9 & 65,5 & 57,2 & 7,8 & 65,0 & 11,8 & 32,3 & 53,5 & 87,8 & 20,5 & 21,2 & 34,3 & 76,0 & 20,3 & 21,0 & 34,0 & 75,4 \\
\hline 42 & 45,8 & 106,2 & 115,4 & 19,5 & 60,4 & 9,2 & 69,6 & 59,2 & 9,0 & 68,3 & 11,8 & 31,9 & 52,6 & 93,2 & 20,1 & 20,7 & 40,6 & 81,4 & 19,7 & 20,3 & 39,8 & 79,8 \\
\hline 42,6 & 45,8 & 108,7 & 118,8 & 19,5 & 62,9 & 10,1 & 73,0 & 61,7 & 9,9 & 71,6 & 11,8 & 31,9 & 53,6 & 101,1 & 20,1 & 21,7 & 47,5 & 89,3 & 19,7 & 21,3 & 46,6 & 87,6 \\
\hline 43 & 45,8 & 99,8 & 104,8 & 20,0 & 54,0 & 5,0 & 59,0 & 53,6 & 5,0 & 58,6 & 11,8 & 31,6 & 53,2 & 104,6 & 19,8 & 21,6 & 51,4 & 92,8 & 19,7 & 21,4 & 51,0 & 92,1 \\
\hline 44 & 45,9 & 103,6 & 110,6 & 20,0 & 57,7 & 7,0 & 64,7 & 57,3 & 6,9 & 64,2 & 11,8 & 31,2 & 56,5 & 137,5 & 19,4 & 25,3 & 81,0 & 125,7 & 19,3 & 25,1 & 80,4 & 124,8 \\
\hline 45 & 45,9 & 106,8 & 115,2 & 21,5 & 60,9 & 8,4 & 69,3 & 62,7 & 8,6 & 71,3 & 11,8 & 31,5 & 57,4 & 145,0 & 19,7 & 25,9 & 87,6 & 133,2 & 20,3 & 26,7 & 90,2 & 137,1 \\
\hline 46 & 46,0 & 110,5 & 120,5 & 21,5 & 64,5 & 10,0 & 74,5 & 66,4 & 10,3 & 76,7 & 11,9 & 32,0 & 59,3 & 156,6 & 20,1 & 27,3 & 97,3 & 144,7 & 20,7 & 28,1 & 100,1 & 148,9 \\
\hline 46,5 & 46,0 & 112,0 & 122,3 & 22,0 & 66,0 & 10,3 & 76,3 & 68,8 & 10,7 & 79,5 & 11,9 & 32,1 & 59,7 & 161,3 & 20,2 & 27,6 & 101,6 & 149,4 & 21,0 & 28,8 & 105,8 & 155,6 \\
\hline
\end{tabular}


(continuação)

\begin{tabular}{|c|c|c|c|c|c|c|c|c|c|c|c|c|c|c|c|c|c|c|c|c|c|c|}
\hline 47 & 46,0 & 113,7 & 122,4 & 22,0 & 67,7 & 8,7 & 76,4 & 70,5 & 9,1 & 79,6 & 12,0 & 32,8 & 61,6 & 175,6 & 20,8 & 28,8 & 114,0 & 163,6 & 21,7 & 30,0 & 118,8 & 170,4 \\
\hline 48 & 46,0 & 116,8 & 126,6 & 22,5 & 70,8 & 9,8 & 80,6 & 74,7 & 10,3 & 85,0 & 11,9 & 31,1 & 58,0 & 170,1 & 19,2 & 26,9 & 112,1 & 158,2 & 20,2 & 28,4 & 118,2 & 166,8 \\
\hline 49 & 46,0 & 120,0 & 131,5 & 22,5 & 74,0 & 11,5 & 85,5 & 78,0 & 12,1 & 90,2 & 11,9 & 31,6 & 59,8 & 187,4 & 19,7 & 28,2 & 127,6 & 175,5 & 0,8 & 29,7 & 134,5 & 185,0 \\
\hline 50 & 45,9 & 123,6 & 136,4 & 22,5 & 77,7 & 12,8 & 90,5 & 81,9 & 13,5 & 95,4 & 11,9 & 31,3 & 59,5 & 206,0 & 19,4 & 28,2 & 146,5 & 194,1 & 20,5 & 29,7 & 154,5 & 204,7 \\
\hline 50,8 & 45,9 & 104,6 & 110,5 & 22,5 & 58,7 & 5,9 & 64,6 & 61,9 & 6,2 & 68,1 & 11,9 & 32,1 & 61,0 & 223,0 & 20,2 & 28,9 & 162,0 & 211,1 & 21,3 & 30,5 & 170,8 & 222,6 \\
\hline 51 & 45,9 & 106,7 & 113,3 & 21,5 & 60,8 & 6,6 & 67,4 & 62,6 & 6,8 & 69,4 & 11,8 & 31,7 & 49,2 & 68,0 & 19,9 & 17,5 & 18,8 & 56,2 & 20,5 & 18,0 & 19,3 & 57,8 \\
\hline 52 & 45,9 & 111,6 & 120,2 & 21,5 & 65,7 & 8,6 & 74,3 & 67,6 & 8,9 & 76,5 & 11,8 & 31,6 & 49,2 & 70,2 & 19,8 & 17,6 & 21,0 & 58,4 & 20,4 & 18,1 & 21,6 & 60,1 \\
\hline 53 & 45,9 & 116,3 & 126,5 & 21,0 & 70,4 & 10,2 & 80,6 & 71,6 & 10,4 & 82,0 & 11,8 & 32,0 & 50,0 & 77,3 & 20,2 & 18,0 & 27,3 & 5,5 & 20,5 & 18,3 & 8 & 66,6 \\
\hline 54 & & & & 21,0 & & & & & & & 11,8 & 31,8 & 49,8 & 84,2 & 20,0 & 18,0 & 34,4 & 72,4 & 20,3 & 18,3 & 35,0 & 73,6 \\
\hline 54,5 & 45,9 & 121,0 & 133,6 & 21,0 & 75,1 & 12,6 & 87,7 & 76,4 & 12,8 & 89,2 & 11,8 & 31,8 & 49,9 & 89,2 & 20,0 & 18,1 & 39,3 & 77,4 & 20,3 & 18,4 & 40,0 & 78,7 \\
\hline 55 & 45,9 & 110,7 & 117,6 & 21,0 & 64,8 & 6,9 & 71,7 & 65,9 & 7,0 & 72,9 & 11,7 & 31,5 & 52,0 & 123,0 & 19,8 & 20,5 & 71,0 & 111,3 & 20,1 & 20,8 & 72,2 & 113,2 \\
\hline 56 & 45,9 & 115,1 & 123,6 & 20,5 & 69,2 & 8,5 & 77,7 & 69,5 & 8,5 & 78,1 & 11,7 & 32,7 & 54,5 & 129,2 & 21,0 & 21,8 & 74,7 & 117,5 & 21,1 & 21,9 & 75,0 & 18,0 \\
\hline 57 & 45,9 & 119,1 & 129,0 & 20,5 & 73,2 & 9,9 & 83,1 &, 5 & 9 & 83,5 & 11,7 & 32,4 &, 5 & 6 & 20,7 & 22,1 & 79,1 & & 20,8 & 22,2 & & 2,5 \\
\hline 58 & 45,9 & 124,1 & 135,8 & 20,0 & 78,2 & 11,7 & 89,9 & 77,6 & 11,6 & 89,2 & 11,7 & 32,9 & 55,1 & 142,0 & 21,2 & 22,2 & 86,9 & 130,3 & 21,0 & 22,0 & 86,3 & 129,3 \\
\hline 59 & 45,9 & 127,2 & 132,5 & 20,0 & 81,3 & 5,3 & 86,6 & 80,7 & 5,3 & 86,0 & 11,7 & 33,2 & 57,9 & 151,1 & 21,5 & 24,7 & 93,2 & 139,4 & 21,3 & 24,5 & 92,5 & 138,4 \\
\hline 60 & 45,9 & 114,9 & 123,0 & 20,0 & 69,0 & 8,1 & 77,1 & 68,5 & 8,0 & 76,5 & 11,7 & 36,3 & 65,5 & 186,7 & 24,6 & 29,2 & 121,2 & 175,0 & 24,4 & 29,0 & 120,3 & 173,7 \\
\hline 61 & 45,8 & 118,6 & 127,8 & 20,0 & 72,8 & 9,2 & 82,0 & 72,3 & 9,1 & 81,4 & 11,6 & 34,7 & 62,3 & 180,0 & 23,1 & 27,6 & 117,7 & 168,4 & 22,9 & 27,4 & 116,8 & 167,1 \\
\hline 62 & 45,9 & 123,8 & 135,2 & 20,0 & 77,9 & 11,4 & 89,3 & 77,3 & 11,3 & 88,6 & 11,5 & 34,0 & 60,9 & 181,5 & 22,5 & 26,9 & 120,6 & 170,0 & 22,3 & 26,7 & 119,7 & 168,7 \\
\hline 63 & 45,9 & 128,3 & 141,2 & 20,0 & 82,4 & 12,9 & 95,3 & 81,8 & 12,8 & 94,6 & 11,5 & 34,1 & 61,6 & 189,0 & 22,6 & 27,5 & 127,4 & 177,5 & 22,4 & 27,3 & 126,5 & 176,2 \\
\hline 63,3 & & & & 20,0 & & & & & & & 11,5 & 34,2 & 62,0 & 191,8 & 22,7 & 27,8 & 129,8 & 180,3 & 22,5 & 27,6 & 128,8 & 179,0 \\
\hline 64 & 45,9 & 133,0 & 147,5 & 20,0 & 87,1 & 14,5 & 101,6 & 86,5 & 14,4 & 100,8 & 11,8 & 33,6 & 51,8 & 73,9 & 21,8 & 18,2 & 22,1 & 62,1 & 21,6 & 18,1 & 21,9 & 61,6 \\
\hline 65 & 45,9 & 124,2 & 133,0 & 21,0 & 78,3 & 8,8 & 87,1 & 79,6 & 8,9 & 88,6 & 11,8 & 33,8 & 62,7 & 102,2 & 22,0 & 28,9 & 39,5 & 90,4 & 22,4 & 29,4 & 40,2 & 91,9 \\
\hline 66 & 46,0 & 128,8 & 139,2 & 21,0 & 82,8 & 10,4 & 93,2 & 84,2 & 10,6 & 94,8 & 11,7 & 33,1 & 61,5 & 102,0 & 21,4 & 28,4 & 40,5 & 90,3 & 21,8 & 28,9 & 41,2 & 91,8 \\
\hline 67 & 46,0 & 133,0 & 144,9 & 21,0 & 87,0 & 11,9 & 98,9 & 88,5 & 12,1 & 100,6 & 11,7 & 33,9 & 51,7 & 106,4 & 22,2 & 17,8 & 54,7 & 94,7 & 22,6 & 18,1 & 55,6 & 96,3 \\
\hline 68 & 46,1 & 140,3 & 154,5 & 21,0 & 94,2 & 14,2 & 108,4 & 95,8 & 14,4 & 110,2 & 11,8 & 34,0 & 55,0 & 120,0 & 22,2 & 21,0 & 65,0 & 108,2 & 22,6 & 21,4 & 66,1 & 110,0 \\
\hline 69 & 46,1 & 130,5 & 140,4 & 21,0 & 84,4 & 9,9 & 94,3 & 85,8 & 10,1 & 95,9 & 11,8 & 33,7 & 56,6 & 137,4 & 21,9 & 22,9 & 80,8 & 125,6 & 22,3 & 23,3 & 82,2 & 127,7 \\
\hline 70 & 46,0 & 136,4 & 148,5 & 21,0 & 90,4 & 12,1 & 102,5 & 91,9 & 12,3 & 104,2 & 11,8 & 34,9 & 59,1 & 147,4 & 23,1 & 24,2 & 88,3 & 135,6 & 23,5 & 24,6 & 89,8 & 137,9 \\
\hline
\end{tabular}


(continuação)

\begin{tabular}{c|c|c|c|c|c|c|c|c|c|c|c|c|c|c|c|c|c|c|c|c|c|c|}
\hline $\mathbf{7 1}$ & 46,0 & 140,0 & 153,5 & 21,5 & $\mathbf{9 4 , 0}$ & $\mathbf{1 3 , 5}$ & $\mathbf{1 0 7 , 5}$ & $\mathbf{9 6 , 7}$ & $\mathbf{1 3 , 9}$ & $\mathbf{1 1 0 , 6}$ & 11,9 & 36,2 & 61,9 & 160,0 & $\mathbf{2 4 , 3}$ & $\mathbf{2 5 , 7}$ & $\mathbf{9 8 , 1}$ & $\mathbf{1 4 8 , 1}$ & $\mathbf{2 5 , 0}$ & $\mathbf{2 6 , 5}$ & $\mathbf{1 0 1 , 0}$ & $\mathbf{1 5 2 , 4}$ \\
\hline $\mathbf{7 2}$ & 46,0 & 144,7 & 160,0 & 21,5 & $\mathbf{9 8 , 7}$ & $\mathbf{1 5 , 3}$ & $\mathbf{1 1 4 , 0}$ & $\mathbf{1 0 1 , 6}$ & $\mathbf{1 5 , 7}$ & $\mathbf{1 1 7 , 3}$ & 11,8 & 34,0 & 58,2 & 162,0 & $\mathbf{2 2 , 2}$ & $\mathbf{2 4 , 2}$ & $\mathbf{1 0 3 , 8}$ & $\mathbf{1 5 0 , 2}$ & $\mathbf{2 2 , 8}$ & $\mathbf{2 4 , 9}$ & $\mathbf{1 0 6 , 8}$ & $\mathbf{1 5 4 , 6}$ \\
\hline
\end{tabular}

FAAG = filtro ascendente de areia grossa; FRD = filtro rápido descendente; TF = tempo de funcionamento; $T$ = temperatura; Descargas de fundo intermediárias por perda de carga; Lavagem do FRD por perda de carga; Lavagem do FRD por transpasse 


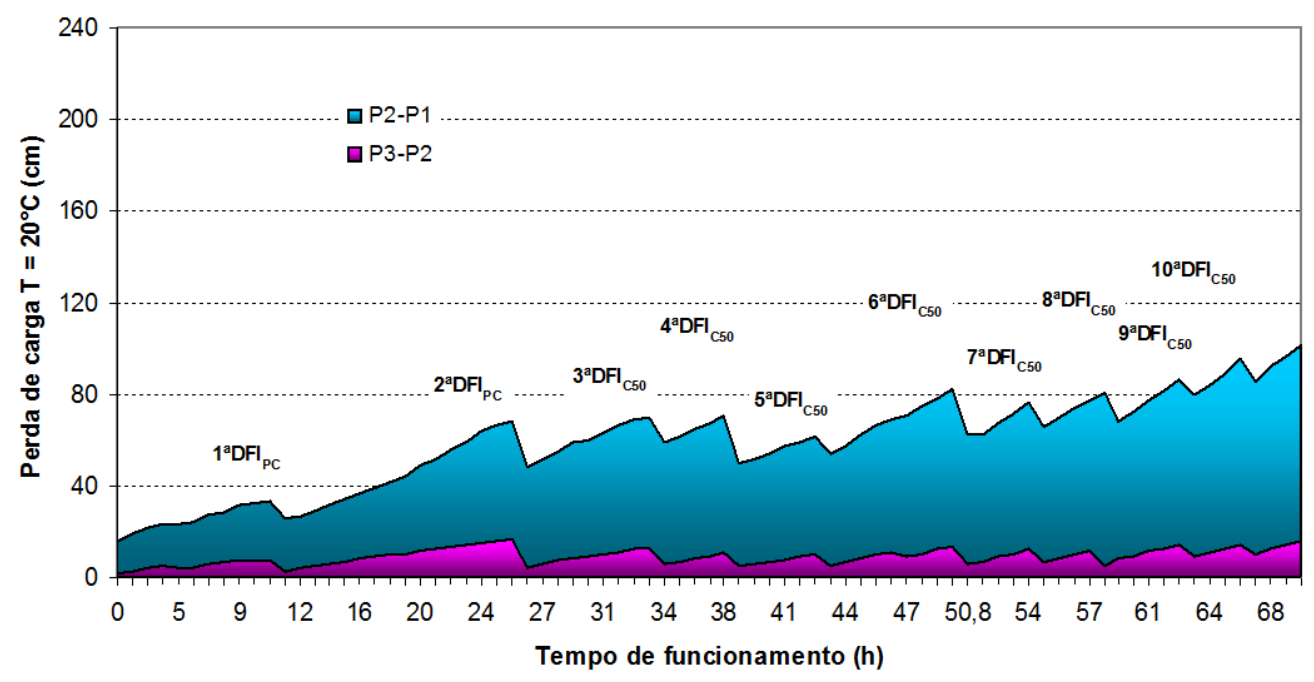

Figura B 3.1 - Perda de carga na camada suporte e camada de areia grossa no FAAG durante o ensaio 3 - sem pré-oxidação e com DFIs no FAAG (FAAG $=180 \mathrm{~m}^{3} / \mathrm{m}^{2} \mathrm{~d}$ e $\mathrm{FRD}=240 \mathrm{~m}^{3} / \mathrm{m}^{2} \mathrm{~d}$ ). Fonte: Tabela B 3.3 - ANEXO B.

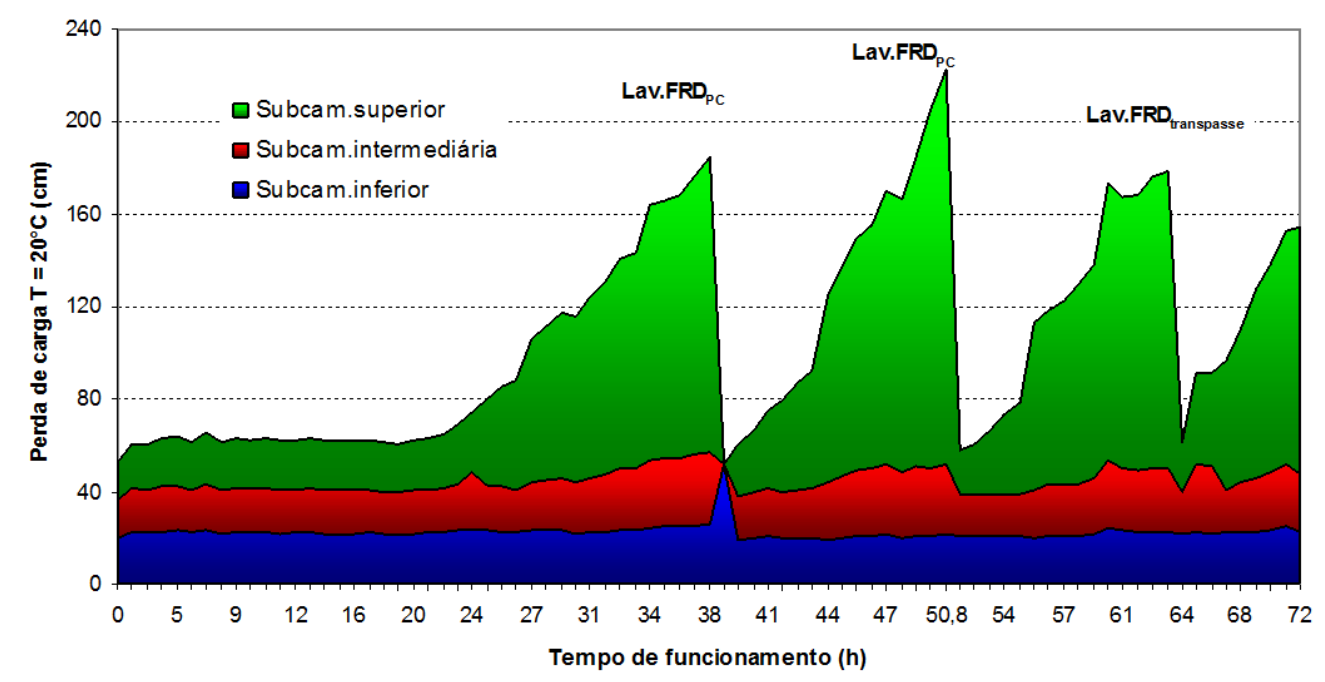

Figura B 3.2 - Perda de carga ao longo do meio filtrante do FRD durante o ensaio 3 - sem préoxidação e com DFls no FAAG (FAAG $=180 \mathrm{~m}^{3} / \mathrm{m}^{2} \mathrm{~d}$ e FRD $=240 \mathrm{~m}^{3} / \mathrm{m}^{2} \mathrm{~d}$ ). Fonte: Tabela B $3.3-$ ANEXO B. 
Tabela B 3.4 - Variação de vazões e taxas de filtração do FAAG e do FRD durante o ensaio 3 - sem pré-oxidação e com DFIs no FAAG (FAAG $=180 \mathrm{~m}^{3} / \mathrm{m}^{2} \mathrm{~d} ; \mathrm{FRD}=240 \mathrm{~m}^{3} / \mathrm{m}^{2} \mathrm{~d}$ ).

\begin{tabular}{|c|c|c|c|c|c|c|c|c|}
\hline \multirow{2}{*}{$\begin{array}{l}\text { TF } \\
\text { (h) }\end{array}$} & \multicolumn{2}{|c|}{ descartes (L/h) } & \multicolumn{2}{|c|}{ turbidímetros (L/h) } & \multicolumn{2}{|c|}{ vazão total (L/h) } & \multicolumn{2}{|c|}{ taxas de filtração $\left(\mathrm{m}^{3} / \mathrm{m}^{2} \mathrm{~d}\right)$} \\
\hline & FAAG & FRD & FAAG & FRD & FAAG & FRD & FAAG & FRD \\
\hline 0 & 25,67 & 43,20 & 23,51 & 24,47 & 116,85 & 67,67 & 180 & 248 \\
\hline 1 & 25,20 & 43,92 & 23,03 & 23,95 & 116,10 & 67,87 & 178 & 248 \\
\hline 2 & 22,73 & 40,93 & 27,17 & 23,51 & 114,34 & 64,44 & 176 & 236 \\
\hline 3 & 23,16 & 43,05 & 27,35 & 23,30 & 116,86 & 66,35 & 180 & 243 \\
\hline 4 & 23,20 & 45,62 & 27,46 & 23,96 & 120,24 & 69,58 & 185 & 255 \\
\hline 5 & 25,16 & 47,80 & 25,22 & 24,27 & 122,45 & 72,07 & 188 & 264 \\
\hline 6 & 24,52 & 42,17 & 24,42 & 23,81 & 115,38 & 66,44 & 177 & 243 \\
\hline 7 & 24,53 & 46,75 & 24,57 & 23,90 & 119,66 & 70,56 & 184 & 258 \\
\hline 8 & 26,76 & 40,24 & 24,22 & 23,33 & 115,12 & 64,14 & 177 & 235 \\
\hline 9 & 27,27 & 42,76 & 24,19 & 23,48 & 117,55 & 66,09 & 181 & 242 \\
\hline 10 & 26,67 & 43,34 & 23,63 & 23,57 & 117,12 & 66,82 & 180 & 244 \\
\hline 11 & 26,20 & 43,90 & 25,83 & 22,80 & 119,50 & 67,47 & 184 & 247 \\
\hline 12 & 25,60 & 43,68 & 25,55 & 23,34 & 117,63 & 66,48 & 181 & 243 \\
\hline 13 & 26,18 & 44,54 & 25,49 & 22,88 & 119,55 & 67,88 & 184 & 248 \\
\hline 14 & 27,88 & 43,79 & 25,24 & 23,34 & 119,79 & 66,67 & 184 & 244 \\
\hline 15 & 27,49 & 43,20 & 25,82 & 23,76 & 119,85 & 66,54 & 184 & 243 \\
\hline 16 & 27,10 & 42,49 & 25,60 & 23,28 & 118,95 & 66,25 & 183 & 242 \\
\hline 17 & 27,54 & 42,96 & 25,04 & 23,26 & 118,82 & 66,24 & 183 & 242 \\
\hline 18 & 28,02 & 42,26 & 25,25 & 22,84 & 118,79 & 65,52 & 183 & 240 \\
\hline 19 & 27,69 & 42,09 & 24,85 & 23,63 & 117,47 & 64,93 & 181 & 238 \\
\hline 20 & 27,28 & 41,92 & 24,97 & 22,96 & 117,80 & 65,55 & 181 & 240 \\
\hline 21 & 26,86 & 44,17 & 23,71 & 23,14 & 117,70 & 67,13 & 181 & 246 \\
\hline 22 & 26,07 & 43,56 & 23,41 & 23,45 & 116,18 & 66,70 & 179 & 244 \\
\hline 23 & 26,46 & 48,19 & 19,57 & 23,48 & 117,67 & 71,64 & 181 & 262 \\
\hline 24 & 30,26 & 48,06 & 15,93 & 23,23 & 117,73 & 71,54 & 181 & 262 \\
\hline 25 & 33,87 & 44,24 & 12,99 & 23,03 & 114,33 & 67,47 & 176 & 247 \\
\hline 26 & 35,44 & 43,66 & 13,25 & 24,22 & 115,38 & 66,69 & 177 & 244 \\
\hline 28 & 35,79 & 45,09 & 11,52 & 24,30 & 116,70 & 69,39 & 179 & 254 \\
\hline 29 & 36,64 & 45,87 & 11,00 & 23,78 & 117,29 & 69,65 & 180 & 255 \\
\hline 30 & 39,64 & 45,79 & 9,80 & 23,93 & 119,16 & 69,72 & 183 & 255 \\
\hline 31 & 39,89 & 43,20 & 9,87 & 23,38 & 116,34 & 66,58 & 179 & 244 \\
\hline 32 & 39,74 & 44,72 & 9,31 & 23,17 & 116,94 & 67,89 & 180 & 248 \\
\hline 33 & 40,74 & 44,00 & 3,17 & 22,78 & 110,69 & 66,78 & 170 & 244 \\
\hline 34 & 40,48 & 44,24 & 8,84 & 23,02 & 116,58 & 67,26 & 179 & 246 \\
\hline 35 & 43,89 & 43,52 & 6,31 & 23,83 & 117,55 & 67,35 & 181 & 246 \\
\hline 36 & 43,31 & 45,74 & 6,78 & 23,05 & 118,88 & 68,79 & 183 & 252 \\
\hline 37 & 42,96 & 46,40 & 6,43 & 23,14 & 118,93 & 69,54 & 183 & 254 \\
\hline 38 & 42,89 & 44,08 & 6,48 & 22,83 & 116,28 & 66,91 & 179 & 245 \\
\hline 39 & 43,10 & 44,13 & 6,33 & 22,47 & 116,03 & 66,60 & 178 & 244 \\
\hline 40 & 44,75 & 42,72 & 4,68 & 23,20 & 115,35 & 65,92 & 177 & 241 \\
\hline 41 & 43,05 & 44,35 & 5,59 & 23,20 & 116,19 & 67,55 & 179 & 247 \\
\hline 42 & 42,90 & 45,40 & 5,76 & 23,45 & 117,51 & 68,85 & 181 & 252 \\
\hline 43 & 45,47 & 44,10 & 5,71 & 23,86 & 119,14 & 67,96 & 183 & 249 \\
\hline 44 & 34,77 & 38,68 & 14,00 & 22,90 & 110,35 & 61,58 & 170 & 225 \\
\hline
\end{tabular}


(continuação)

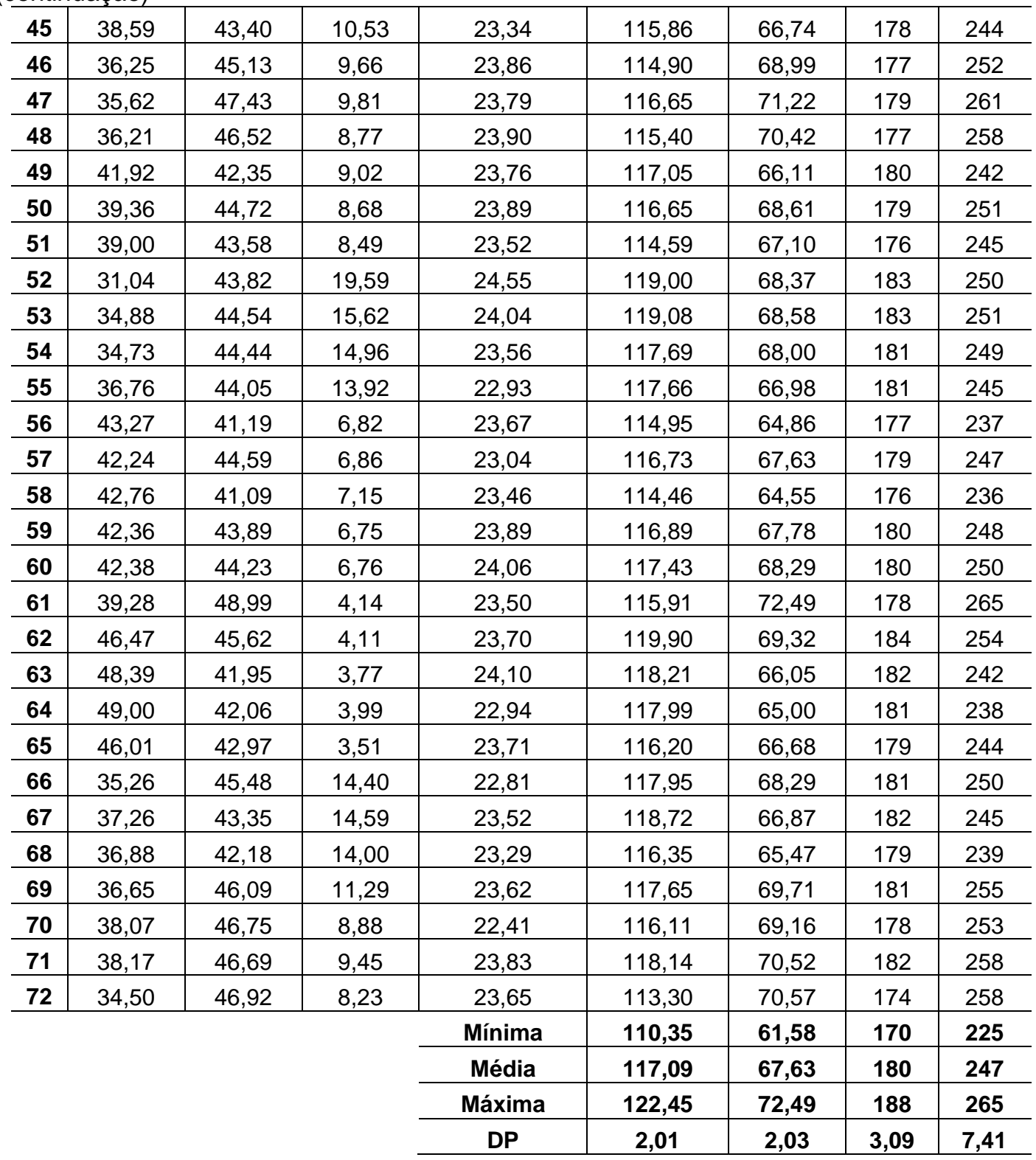

$\mathrm{TF}=$ tempo de funcionamento; FAAG = filtro ascendente de areia grossa; $F R D=$ filtro rápido descendente; $A C=$ água coagulada; $\mathrm{DP}=$ desvio padrão. 
Tabela B 4.1 - Características físicas da AB, AE e efluentes do FAAG e do FRD durante o ensaio 4 sem pré-oxidação e com DFIs no FAAG (FAAG $=180 \mathrm{~m}^{3} / \mathrm{m}^{2} \mathrm{~d} ; \mathrm{FRD}=240 \mathrm{~m}^{3} / \mathrm{m}^{2} \mathrm{~d}$ ).

\begin{tabular}{|c|c|c|c|c|c|c|c|}
\hline \multirow{2}{*}{$\begin{array}{l}\text { TF } \\
\text { (h) }\end{array}$} & \multirow{2}{*}{$\begin{array}{c}\begin{array}{c}\text { Temperatura } \\
\left({ }^{\circ} \mathrm{C}\right)\end{array} \\
\mathrm{AE} \\
\end{array}$} & \multicolumn{4}{|c|}{ Cor aparente (uH) } & \multicolumn{2}{|c|}{ Cor verdadeira (uH) } \\
\hline & & $\mathrm{AB}$ & $\mathrm{AE}$ & FAAG & FRD & $\mathrm{AB}$ & $\mathrm{AE}$ \\
\hline 0 & & & & & & & \\
\hline 1 & 21,5 & & 193 & 3,0 & $<1,0$ & & 102 \\
\hline 3 & 21,0 & & 177 & $<1,0$ & $<1,0$ & & 97 \\
\hline 5 & 20,0 & 94 & 176 & 1,0 & $<1,0$ & 20 & 85 \\
\hline 7 & 19,0 & & 181 & 3,0 & $<1,0$ & & 104 \\
\hline 9 & 19,0 & 93 & 182 & $<1,0$ & $<1,0$ & 25 & 99 \\
\hline 11 & 18,2 & & 175 & 2,0 & 1,0 & & 101 \\
\hline 13 & 18,2 & 87 & 177 & 5,0 & 4,0 & 23 & 104 \\
\hline 15 & 18,0 & & 182 & 14,0 & 3,0 & & 100 \\
\hline 17 & 18,5 & 90 & 180 & 2,0 & $<1,0$ & 20 & 101 \\
\hline 19 & 20,0 & & 204 & 6,0 & 5,0 & & 99 \\
\hline 21 & 21,0 & 98 & 199 & 3,0 & 2,0 & 16 & 105 \\
\hline 23 & 21,5 & & 212 & 3,0 & 1,0 & & 98 \\
\hline 26 & 22,0 & 116 & 207 & 3,0 & $<1,0$ & 19 & 109 \\
\hline 27 & & & & & & & \\
\hline 29 & 20,0 & 89 & 176 & $<1,0$ & $<1,0$ & 14 & 82 \\
\hline 31 & 19,0 & & 187 & $<1,0$ & $<1,0$ & & 99 \\
\hline 33 & 19,0 & & 183 & $<1,0$ & $<1,0$ & & 103 \\
\hline 35 & 19,0 & & 185 & $<1,0$ & $<1,0$ & & 106 \\
\hline 37 & 18,5 & & 183 & 6,0 & $<1,0$ & & 104 \\
\hline 39 & 18,5 & & 180 & 18,0 & 1,0 & & 104 \\
\hline 41 & 19,0 & & 184 & 8,0 & 3,0 & & 98 \\
\hline 43 & 19,5 & & 219 & 10,0 & $<1,0$ & & 112 \\
\hline 45 & 20,5 & & 212 & 20,0 & $<1,0$ & & 110 \\
\hline 47 & 21,0 & & 204 & 6,0 & $<1,0$ & & 112 \\
\hline 50 & 21,5 & 96 & 189 & 7,0 & $<1,0$ & 17 & 91 \\
\hline 51 & 20,0 & & 192 & 17,0 & $<1,0$ & & 95 \\
\hline 53 & 19,5 & 87 & 184 & 25,0 & $<1,0$ & 22 & 101 \\
\hline 55 & 19,0 & & 184 & 21,0 & $<1,0$ & & 89 \\
\hline 57 & 18,5 & 93 & 193 & 30,0 & 2,0 & 22 & 97 \\
\hline 59 & 18,0 & & 191 & 27,0 & $<1,0$ & & 93 \\
\hline 61 & 18,0 & 84 & 189 & 32,0 & $<1,0$ & 16 & 95 \\
\hline 63 & 18,0 & & 190 & 39,0 & $<1,0$ & & 93 \\
\hline 65 & 18,5 & 116 & 217 & 42,0 & 1,0 & 19 & 111 \\
\hline 67 & 19,5 & & 211 & 36,0 & $<1,0$ & & 98 \\
\hline 69 & 21,0 & 105 & 206 & 43,0 & 1,0 & 19 & 101 \\
\hline Média & 19,5 & 96 & 191 & 12,8 & 1,0 & 19 & 100 \\
\hline Mínimo & 18,0 & 84 & 175 & $<1,0$ & $<1,0$ & 14 & 82 \\
\hline Máximo & 22,0 & 116 & 219 & 43,0 & 5,0 & 25 & 112 \\
\hline DP & 1,21 & 10,40 & 12,99 & 13,70 & 1,11 & 3,12 & 7,10 \\
\hline
\end{tabular}

$\mathrm{T} \overline{\mathrm{F} \text { = tempo de funcionamento; } \overline{\mathrm{AE}} \text { = água de estudo; } \mathrm{AB} \text { = água bruta; } \mathrm{FAAG} \text { = filtro ascendente de areia grossa; }}$ $\mathrm{FRD}=$ filtro rápido descendente; $\mathrm{DP}=$ desvio padrão 
Tabela B 4.2 - Características químicas da AB, AE e efluentes do FAAG e do FRD durante o ensaio 4 - sem pré-oxidação e com DFls no $F A A G$ (FAAG = 180 m ${ }^{3} / m^{2} d$; $\mathrm{FRD}=280 \mathrm{~m}^{3} / \mathrm{m}^{2} \mathrm{~d}$ ).

\begin{tabular}{|c|c|c|c|c|c|c|c|c|c|c|c|c|c|c|c|c|c|}
\hline \multirow{2}{*}{$\begin{array}{l}\text { TF } \\
\text { (h) }\end{array}$} & \multicolumn{3}{|c|}{$\mathrm{pH}$} & \multicolumn{2}{|c|}{ Alcalinidade $\left(\mathrm{mg} / \mathrm{L} \mathrm{CaCO}_{3}\right)$} & \multicolumn{4}{|c|}{ Absorvância 254 nm } & \multicolumn{4}{|c|}{ COD (mg/L) } & \multicolumn{4}{|c|}{ Alumínio (mg/L) } \\
\hline & $A B$ & AE & AC & $A B$ & $\mathrm{AE}$ & AB & $\mathrm{AE}$ & FAAG & FRD & $A B$ & $\mathrm{AE}$ & FAAG & FRD & $A B$ & $\mathrm{AE}$ & FAAG & FRD \\
\hline 0 & & & 4,64 & & & & & & & 2,816 & 3,050 & & & - & - & - & - \\
\hline 1 & 6,95 & 6,44 & 5,00 & 19,58 & 18,26 & & & & & & & & & - & - & - & - \\
\hline 3 & & 6,90 & 5,49 & & & & & & & & & & & & & & \\
\hline 5 & 6,93 & 7,45 & 5,38 & 18,48 & 19,36 & & 0,183 & 0,016 & 0,012 & & & & & & & & \\
\hline 7 & & 6,88 & 5,07 & & & & & & & & & & & & & & \\
\hline 9 & 7,63 & 6,96 & 5,08 & 14,96 & 17,60 & & & & & & & & & & & & \\
\hline 11 & & 6,80 & 5,00 & & & & & & & & & & & & & & \\
\hline 13 & 7,07 & 6,76 & 5,08 & 17,60 & 17,38 & & 0,182 & 0,025 & 0,021 & 2,222 & 3,699 & 3,269 & 3,180 & & & & \\
\hline 15 & & 7,10 & 4,98 & & & & & & & & & & & & & & \\
\hline 17 & 6,57 & 6,97 & 5,01 & 8,80 & 10,34 & & 0,179 & 0,019 & 0,017 & & & & & & & & \\
\hline 19 & & 6,53 & 4,94 & & & & & & & & & & & & & & \\
\hline 21 & 6,63 & 6,68 & 5,03 & 8,80 & 9,46 & & 0,180 & 0,018 & 0,018 & & & & & & & & \\
\hline 23 & & 6,50 & 5,05 & & & & & & & & & & & & & & \\
\hline 26 & 6,41 & & & & & & 0,179 & 0,010 & 0,010 & & & & & - & - & - & - \\
\hline 27 & & & & & & & & & & & & & & & & & \\
\hline 29 & 6,60 & 6,50 & 5,12 & 8,58 & 9,46 & & 0,158 & 0,010 & 0,007 & & & & & & & & \\
\hline 31 & & 6,70 & 5,16 & & & & & & & & & & & & & & \\
\hline 33 & 6,83 & 6,40 & 5,17 & & & & 0,183 & 0,016 & 0,014 & & & & & & & & \\
\hline 35 & & 6,40 & 5,14 & & & & & & & & & & & & & & \\
\hline 37 & 6,56 & 6,33 & 5,15 & & & & 0,185 & 0,015 & 0,006 & 3,061 & 4,174 & 3,345 & 2,844 & & & & \\
\hline 39 & & 6,51 & 5,19 & & & & & & & & & & & & & & \\
\hline 41 & 6,36 & 6,50 & 5,16 & & & & 0,198 & 0,019 & 0,014 & & & & & & & & \\
\hline 43 & & 6,41 & 5,04 & & & & & & & & & & & & & & \\
\hline 45 & 6,62 & 6,49 & 5,14 & & & & & 0,034 & 0,021 & & & & & & & & \\
\hline 47 & & 6,40 & 5,03 & & & & & & & & & & & & & & \\
\hline 50 & 6,51 & 6,66 & 5,02 & 8,14 & 9,46 & & 0,167 & 0,020 & 0,006 & & & & & - & - & - & - \\
\hline 51 & & 6,68 & 5,03 & & & & & & & & & & & & & & \\
\hline
\end{tabular}


(continuação)

\begin{tabular}{|c|c|c|c|c|c|c|c|c|c|c|c|c|c|c|c|c|}
\hline 53 & 6,69 & 6,57 & 5,13 & & & 0,177 & 0,034 & 0,007 & & & & & & & & \\
\hline 55 & & 6,54 & 4,99 & 8,80 & 9,24 & & & & & & & & & & & \\
\hline 57 & 6,51 & 6,52 & 5,01 & 10,12 & 11,66 & 0,183 & 0,014 & 0,005 & & & & & & & & \\
\hline 59 & & 6,45 & 5,02 & & & & & & & & & & & & & \\
\hline 63 & & 6,49 & 5,01 & & & & & & & & & & & & & \\
\hline 65 & 6,35 & 6,44 & 5,02 & 8,80 & 9,68 & 0,191 & 0,020 & 0,005 & & & & & & & & \\
\hline 67 & & 6,60 & 4,97 & & & & & & & & & & & & & \\
\hline Média & 6,66 & 6,62 & 5,07 & 11,85 & 12,69 & 0,180 & 0,020 & 0,011 & 2,695 & 3,736 & 3,016 & 2,755 & - & - & - & - \\
\hline Mínimo & 6,31 & 6,33 & 4,64 & 8,14 & 9,24 & 0,158 & 0,010 & 0,005 & 2,222 & 3,050 & 2,435 & 2,241 & - & - & - & - \\
\hline Máximo & 7,63 & 7,45 & 5,49 & 19,58 & 19,36 & 0,198 & 0,034 & 0,021 & 3,061 & 4,174 & 3,345 & 3,180 & - & - & - & - \\
\hline DP & 0,33 & 0,24 & 0,13 & 4,43 & 4,11 & 0,009 & 0,007 & 0,006 & 0,352 & 0,498 & 0,505 & 0,476 & - & - & - & - \\
\hline
\end{tabular}

$\mathrm{TF}=$ tempo de funcionamento; $\mathrm{AE}$ = água de estudo; $\mathrm{AB}$ = água bruta; $\mathrm{AC}$ = água coagulada; FAAG = filtro ascendente de areia grossa; FRD = filtro rápido descendente; $\mathrm{DP}=$ desvio padrão. 
Tabela B 4.3 - Perda de carga no FAAG $\left(180 \mathrm{~m}^{3} / \mathrm{m}^{2} \mathrm{~d}\right)$ e no FRD $\left(280 \mathrm{~m}^{3} / \mathrm{m}^{2} \mathrm{~d}\right)$ durante o ensaio 4 , sem pré-oxidação e com DFls no FAAG para a temperatura T e para T = $20^{\circ} \mathrm{C}$.

\begin{tabular}{|c|c|c|c|c|c|c|c|c|c|c|c|c|c|c|c|c|c|c|c|c|c|c|}
\hline \multirow{3}{*}{$\begin{array}{l}\text { TF } \\
\text { (h) }\end{array}$} & \multicolumn{10}{|c|}{ FAAG } & \multicolumn{12}{|c|}{ FRD } \\
\hline & \multicolumn{3}{|c|}{$\begin{array}{c}\text { Leitura piezométrica } \\
(\mathrm{cm})\end{array}$} & \multirow{2}{*}{$\begin{array}{c}\mathrm{T} \\
\left({ }^{\circ} \mathrm{C}\right)\end{array}$} & \multicolumn{3}{|c|}{$\begin{array}{l}\text { Perda de carga } \\
\text { (cm) }\end{array}$} & \multicolumn{3}{|c|}{$\begin{array}{c}\text { Perda de carga }(\mathrm{cm}) \\
\mathrm{T}=20^{\circ} \mathrm{C}\end{array}$} & \multicolumn{4}{|c|}{$\begin{array}{c}\text { Leitura piezométrica } \\
(\mathrm{cm})\end{array}$} & \multicolumn{4}{|c|}{$\begin{array}{l}\text { Perda de carga } \\
\text { (cm) }\end{array}$} & \multicolumn{4}{|c|}{$\begin{array}{c}\text { Perda de carga }(\mathrm{cm}) \\
\qquad \mathrm{T}=20^{\circ} \mathrm{C}\end{array}$} \\
\hline & $\mathrm{P} 1$ & $\mathrm{P} 2$ & P3 & & P2-P1 & P3-P2 & P3-P1 & P2-P1 & \begin{tabular}{|l|} 
P3-P2 \\
\end{tabular} & P3-P1 & $\mathrm{P} 1$ & P2 & P3 & P4 & P2-P1 & \begin{tabular}{|l|} 
P3-P2 \\
\end{tabular} & P4-P3 & P4-P1 & P2-P1 & P3-P2 & P4-P3 & P4-P1 \\
\hline 0 & 45,7 & 60,3 & 61,7 & 21,5 & 14,6 & 1,4 & 16,0 & 15,0 & 1,4 & 16,5 & 12,3 & 35,3 & 53,8 & 71,0 & 23,0 & 18,5 & 17,2 & 58,7 & 23,7 & 19,0 & 17,7 & 60,4 \\
\hline 1 & 45,9 & 63,6 & 66,0 & 21,5 & 17,7 & 2,4 & 20,1 & 18,2 & 2,5 & 20,7 & 12,4 & 38,6 & 59,7 & 80,9 & 26,2 & 21,1 & 21,2 & 68,5 & 27,0 & 21,7 & 21,8 & 70,5 \\
\hline 2 & 45,9 & 64,9 & 68,0 & 21,0 & 19,0 & 3,1 & 22,1 & 19,3 & 3,2 & 22,5 & 12,4 & 37,8 & 58,2 & 79,8 & 25,4 & 20,4 & 21,6 & 67,4 & 25,8 & 20,7 & 22,0 & 68,5 \\
\hline 3 & 45,9 & 66,5 & 71,0 & 21,0 & 20,6 & 4,5 & 25,1 & 20,9 & 4,6 & 25,5 & 12,4 & 38,3 & 58,7 & 80,7 & 25,9 & 20,4 & 22,0 & 68,3 & 26,3 & 20,7 & 22,4 & 69,5 \\
\hline 4 & 45,9 & 68,8 & 74,5 & 20,0 & 22,9 & 5,7 & 28,6 & 22,7 & 5,7 & 28,4 & 12,4 & 28,6 & 59,6 & 82,7 & 16,2 & 31,0 & 23,1 & 70,3 & 16,1 & 30,8 & 22,9 & 69,8 \\
\hline 5 & 45,9 & 70,1 & 77,7 & 20,0 & 24,2 & 7,6 & 31,8 & 24,0 & & 31,6 & 12,4 & 38,3 & 59,3 & 83,0 & 25,9 & 21,0 & 23,7 & 70,6 & 25,7 & 0,8 & 3,5 & 70,1 \\
\hline 6 & 45,9 & 73,2 & 80,5 & 19,0 & 27,3 & 7,3 & 34,6 & 26,4 & 7,1 & 33,5 & 12,4 & 38,6 & 59,6 & 83,6 & 26,2 & 21,0 & 24,0 & 71,2 & 25,4 & 20,3 & 23,3 & 69,0 \\
\hline 7 & 45,9 & 75,4 & 83,0 & 19,0 & 29,5 & 7,6 & 37,1 & 28,6 & 7,4 & 35,9 & 12,4 & 38,8 & 60,0 & 84,3 & 26,4 & 21,2 & 24,3 & 71,9 & 25,6 & 20,5 & 23,5 & 69,7 \\
\hline 8 & 45,9 & 77,3 & 85,2 & 19,0 & 31,4 & 7,9 & 39,3 & 30,4 & 7,7 & 38,1 & 12,4 & 38,9 & 60,4 & 85,1 & 26,5 & 21,5 & 24,7 & 72,7 & 25,7 & 20,8 & 23,9 & 70,4 \\
\hline 9 & 45,9 & 70,0 & 73,6 & 19,0 & 24,1 & 3,6 & 27,7 & 23,3 & 3,5 & 26,8 & 12,4 & 40,0 & 62,4 & 89,0 & 27,6 & 22,4 & 26,6 & 76,6 & 26,7 & 21,7 & 25,8 & 74,2 \\
\hline 10 & 45,8 & 72,7 & 76,2 & 18,2 & 26,9 & 3,5 & 30,4 & 25,6 & 3,3 & 28,9 & 12,2 & 39,1 & 60,8 & 87,4 & 26,9 & 21,7 & 26,6 & 75,2 & 25,6 & 20,6 & 25,3 & 71,5 \\
\hline 11 & 45,8 & 76,0 & 80,8 & 18,2 & 30,2 & 4,8 & 35,0 & 28,7 & 4,6 & 33,3 & 12,2 & 39,0 & 60,8 & 88,0 & 26,8 & 21,8 & 27,2 & 75,8 & 25,5 & 20,7 & 25,8 & 72,0 \\
\hline 12 & 45,8 & 78,8 & 84,2 & 18,2 & & 5,4 & & & & & 12,2 & 39,0 & 60,9 & 88,5 & 26,8 & 21,9 & 27,6 & 76,3 & 25,5 & 20,8 & 26,2 & 72,5 \\
\hline 13 & 45,8 & 81,8 & 88,3 & 18,2 & 36,0 & 6,5 & 42,5 & 34,2 & 6,2 & 40,4 & 12,2 & 39,0 & 61,0 & 89,0 & 26,8 & 22,0 & 28,0 & 76,8 & 25,5 & 20,9 & 26,6 & 73,0 \\
\hline 14 & 45,8 & 84,7 & 92,0 & 18,0 & 38,9 & 7,3 & 46,2 & 36,8 & 6,9 & 43,7 & 12,2 & 39,0 & 61,1 & 89,6 & 26,8 & 22,1 & 28,5 & 77,4 & 25,3 & 20,9 & 27,0 & 73,2 \\
\hline 15 & 45,8 & 88,0 & 98,0 & 18,0 & 42,2 & 10,0 & 52,2 & 39,9 & 9,5 & 49,4 & 12,2 & 39,2 & 61,3 & 90,3 & 27,0 & 22,1 & 29,0 & 78,1 & 25,5 & 20,9 & 27,4 & 73,9 \\
\hline 16 & 45,8 & 89,9 & 98,8 & 18,5 & 44,1 & 8,9 & 53,0 & 42,2 & 8,5 & 50,7 & 12,2 & 39,3 & 61,5 & 90,6 & 27,1 & 22,2 & 29,1 & 78,4 & 25,9 & 21,2 & 27,9 & 75,0 \\
\hline 17 & 45,8 & 93,3 & 102,9 & 18,5 & 47,5 & 9,6 & 57,1 & 45,5 & 9,2 & 54,7 & 12,2 & 38,8 & 61,3 & 91,1 & 26,6 & 22,5 & 29,8 & 78,9 & 25,5 & 21,5 & 28,5 & 75,5 \\
\hline 18 & 45,8 & 95,8 & 106,1 & 20,0 & 50,0 & 10,3 & 60,3 & 49,6 & 10,2 & 59,9 & 12,2 & 38,3 & 60,7 & 90,2 & 26,1 & 22,4 & 29,5 & 78,0 & 25,9 & 22,2 & 29,3 & 77,4 \\
\hline 19 & 45,8 & 98,3 & 109,5 & 20,0 & 52,5 & 11,2 & 63,7 & 52,1 & 11,1 & 63,2 & 12,2 & 39,2 & 59,8 & 89,4 & 27,0 & 20,6 & 29,6 & 77,2 & 26,8 & 20,4 & 29,4 & 76,6 \\
\hline 20 & 45,9 & 103,6 & 115,7 & 21,0 & 57,7 & 12,1 & 69,8 & 58,7 & 12,3 & 71,0 & 12,3 & 39,2 & 61,5 & 91,9 & 26,9 & 22,3 & 30,4 & 79,6 & 27,4 & 22,7 & 30,9 & 80,9 \\
\hline 21 & 45,9 & 107,3 & 120,9 & 21,0 & 61,4 & 13,6 & 75,0 & 62,4 & 13,8 & 76,3 & 12,3 & 39,2 & 61,2 & 91,7 & 26,9 & 22,0 & 30,5 & 79,4 & 27,4 & 22,4 & 31,0 & 80,7 \\
\hline 22 & 45,9 & 114,7 & 128,2 & 21,5 & 68,8 & 13,5 & 82,3 & 70,8 & 13,9 & 84,7 & 12,3 & 39,0 & 60,9 & 91,3 & 26,7 & 21,9 & 30,4 & 79,0 & 27,5 & 22,5 & 31,3 & 81,3 \\
\hline 23 & 45,9 & 79,1 & 81,8 & 21,5 & 33,2 & 2,7 & 35,9 & 34,2 & 2,8 & 36,9 & 12,3 & \begin{tabular}{|l|}
39,5 \\
\end{tabular} & 61,9 & 93,4 & 27,2 & 22,4 & 31,5 & 81,1 & 28,0 & 23,1 & 32,4 & 83,5 \\
\hline
\end{tabular}


(continuação)

\begin{tabular}{|c|c|c|c|c|c|c|c|c|c|c|c|c|c|c|c|c|c|c|c|c|c|c|}
\hline 24 & \begin{tabular}{|l|}
45,9 \\
\end{tabular} & 82,6 & 85,6 & 22,0 & 36,7 & 3,0 & 39,7 & 38,2 & 3,1 & 41,4 & 12,3 & 38,1 & 59,6 & 90,4 & 25,8 & 21,5 & 30,8 & 78,1 & 26,9 & 22,4 & 32,1 & 81,4 \\
\hline 26 & 45,9 & 81,8 & 83,9 & 22,0 & 35,9 & 2,1 & 38,0 & 37,4 & 2,2 & 39,6 & 12,3 & 38,3 & 59,9 & 92,5 & 26,0 & 21,6 & 32,6 & 80,2 & 27,1 & 22,5 & 34,0 & 83,5 \\
\hline 28 & 45,8 & 91,2 & 95,3 & 21,0 & 45,4 & 4,1 & 49,5 & 46,2 & 4,2 & 50,3 & 12,2 & 38,9 & 61,2 & 96,2 & 26,7 & 22,3 & 35,0 & 84,0 & 27,1 & 22,7 & 35,6 & 85,4 \\
\hline 29 & 45,8 & 96,4 & 101,5 & 21,0 & 50,6 & 5,1 & 55,7 & 51,5 & 5,2 & 56,6 & 12,1 & 38,1 & 59,8 & 94,9 & 26,0 & 21,7 & 35,1 & 82,8 & 26,4 & 22,1 & 35,7 & 84,2 \\
\hline 30 & 45,8 & 102,3 & 108,5 & 20,0 & 56,5 & 6,2 & 62,7 & 56,1 & 6,2 & 62,2 & 12,1 & 38,3 & 60,1 & 96,3 & 26,2 & 21,8 & 36,2 & 84,2 & 26,0 & 21,6 & 35,9 & 83,6 \\
\hline 31 & 45,8 & 105,9 & 112,7 & 20,0 & 60,1 & 6,8 & 66,9 & 59,7 & 6,7 & 66,4 & 12,1 & 38,3 & 60,2 & 97,1 & 26,2 & 21,9 & 36,9 & 85,0 & 26,0 & 21,7 & 36,6 & 84,4 \\
\hline 32 & 45,8 & 111,0 & 118,5 & 19,0 & 65,2 & 7,5 & 72,7 & 63,2 & 7,3 & 70,4 & 12,1 & 38,9 & 61,4 & 100,0 & 26,8 & 22,5 & 38,6 & 87,9 & 26,0 & 21,8 & 37,4 & 85,2 \\
\hline 33 & 45,8 & 114,8 & 122,5 & 19,0 & 69,0 & 7,7 & 76,7 & 66,8 & 7,5 & 74,3 & 12,1 & 39,0 & 61,6 & 101,0 & 26,9 & 22,6 & 39,4 & 88,9 & 26,1 & 21,9 & 38,2 & 86,1 \\
\hline 34 & 45,8 & 118,5 & 127,0 & 19,0 & 72,7 & 8,5 & 81,2 & 70,4 & 8,2 & 78,7 & 12,1 & 39,1 & 61,8 & 101,6 & 27,0 & 22,7 & 39,8 & 89,5 & 26,2 & 22,0 & 38,6 & 86,7 \\
\hline 35 & 45,8 & 127,2 & 137,2 & 19,0 & 81,4 & 10,0 & 91,4 & 78,9 & 9,7 & 88,5 & 12,1 & 39,6 & 62,7 & 104,2 & 27,5 & 23,1 & 41,5 & 92,1 & 26,6 & 22,4 & 40,2 & 89,2 \\
\hline 36 & 45,8 & 132,2 & 142,3 & 19,0 & 86,4 & 10,1 & 96,5 & 83,7 & 9,8 & 93,5 & 12,1 & 39,9 & 63,3 & 106,1 & 27,8 & 23,4 & 42,8 & 94,0 & 26,9 & 2,7 & 41,5 & 1,1 \\
\hline 37 & 45,8 & 137,2 & 147,9 & 19,0 & 91,4 & 10,7 & 102,1 & 88,5 & 10,4 & 98,9 & 12,1 & 40,0 & 63,4 & 108,3 & 27,9 & 23,4 & 44,9 & 96,2 & 27,0 & 2,7 & 3,5 & 3,2 \\
\hline 38 & 45,8 & 142,4 & 153,5 & 18,5 & 96,6 & 11,1 & 107,7 & 92,5 & 10,6 & 103,1 & 12,1 & 40,1 & 63,5 & 112,0 & 28,0 & 23,4 & 48,5 & 99,9 & 6,8 & 2,4 & 6,4 & 5,6 \\
\hline 39 & 45,8 & 148,8 & 160,6 & 18,5 & 103,0 & 11,8 & 114,8 & 98,6 & 11,3 & 09,9 & 12,1 & 40,3 & 63,9 & 117,2 & 28,2 & 23,6 & 53,3 & 105,1 & 27,0 & 22,6 & 1,0 & 00,6 \\
\hline 40 & 45,8 & 153,7 & 164,8 & 18,5 & 107,9 & 11,1 & 119,0 & 103,3 & 10,6 & 113,9 & 12,1 & 39,2 & 61,9 & 120,1 & 27,1 & 22,7 & 58,2 & 108,0 & 25,9 & 21,7 & 5,7 & 103,4 \\
\hline 40,5 & 5,8 & 156,8 & 169,3 & 18,5 & 111,0 & 12,5 & 123,5 & 106,2 & 12,0 & 18,2 & 12,0 & 39,3 & 62,0 & 124,7 & 27,3 & 22,7 & 62,7 & 112,7 & 26,1 & 21,7 & 0,0 & 107,9 \\
\hline 41 & 45,8 & 140,0 & 143,3 & 19,0 & 4,2 & 3,3 & 97,5 & 91,3 & 3,2 & 94,5 & 12,0 & 39,0 & 61,8 & 132,3 & 27,0 & 22,8 & 70,5 & 120,3 & 26,2 & 22,1 & 68,3 & 116,5 \\
\hline 42 & 45,8 & 147,6 & 152,2 & 19,0 & 101,8 & 4,6 & 106,4 & 98,6 & 4,5 & 103,1 & 12,0 & 38,4 & 60,6 & 130,4 & 26,4 & 22,2 & 69,8 & 118,4 & 25,6 & 21,5 & 67,6 & 114,7 \\
\hline 43 & 45,8 & 160,4 & 166,3 & 19,5 & 114,6 & 5,9 & 120,5 & 112,4 & 5,8 & 118,2 & 12,0 & 37,9 & 60,0 & 130,4 & 25,9 & 22,1 & 70,4 & 118,4 & 25,4 & 21,7 & 69,0 & 116,1 \\
\hline 44 & 45,9 & 172,9 & 180,1 & 19,5 & 127,0 & 7,2 & 134,2 & 124,5 & 7,1 & 131,6 & 12,0 & 39,2 & 62,2 & 140,0 & 27,2 & 23,0 & 77,8 & 128,0 & 26,7 & 22,6 & 76,3 & 125,5 \\
\hline 45 & 46,0 & 183,0 & 191,1 & 20,5 & 137,0 & 8,1 & 145,1 & 137,6 & 8,1 & 145,8 & 12,1 & 40,0 & 63,9 & 148,0 & 27,9 & 23,9 & 84,1 & 135,9 & 28,0 & 24,0 & 84,5 & 136,5 \\
\hline 46 & 45,9 & 193,9 & 203,5 & 20,5 & 148,0 & 9,6 & 157,6 & 148,7 & 9,6 & 158,3 & 12,1 & 40,4 & 65,4 & 158,0 & 28,3 & 25,0 & 92,6 & 145,9 & 28,4 & 25,1 & 93,0 & 146,6 \\
\hline 47 & 45,9 & 198,6 & 209,1 & 21,0 & 152,7 & 10,5 & 163,2 & 155,3 & 10,7 & 165,9 & 12,1 & 40,4 & 66,2 & 164,3 & 28,3 & 25,8 & 98,1 & 152,2 & 28,8 & 26,2 & 99,8 & 154,8 \\
\hline 48 & 46,0 & 135,7 & 139,8 & 21,0 & 89,7 & 4,1 & 93,8 & 91,2 & 4,2 & 95,4 & 12,1 & 40,2 & 68,0 & 178,8 & 28,1 & \begin{tabular}{|l|}
27,8 \\
\end{tabular} & 110,8 & 166,7 & 28,6 & 28,3 & 12,7 & 169,5 \\
\hline 49 & 46,0 & 147,8 & 154,4 & 1,5 & 101,8 & 6,6 & 108,4 & 104,8 & 6,8 & 111,6 & 12,1 & 40,0 & 67,5 & 177,0 & 27,9 & 27,5 & 109,5 & 164,9 & 28,7 & 28,3 & 12,7 & 169,7 \\
\hline 50 & 46,0 & 159,2 & 167,1 & 1,5 & 3,2 & 7,9 & 121,1 & 116,5 & 8,1 & 124,6 & 12,1 & 38,7 & 65,2 & 174,5 & 26,6 & 26,5 & 109,3 & 162,4 & 27,4 & 27,3 & 12,5 & 67,1 \\
\hline 51 & 46,0 & 69,1 & 178,7 & 20,0 & 123,1 & 9,6 & 132,7 & 122,2 & 9,5 & 131,7 & 12,0 & 39,2 & 65,4 & 180,0 & 27,2 & 26,2 & 114,6 & 168,0 & 27,0 & 6,0 & 13,7 & 166,7 \\
\hline 52 & 46,0 & 81,8 & 193,2 & 20,0 & 35,8 & 1,4 & 47,2 & 134,8 & 11, & 146,1 & 12,0 & 40,2 & 69,9 & 196,0 & 28,2 & 29,7 & 126,1 & 184,0 & 28,0 & 9,5 & 25,2 & 182,6 \\
\hline 53 & 46,0 & 90,6 & 203,5 & $\begin{array}{r}19,5 \\
\end{array}$ & 144,6 & 12,9 & 157,5 & 141,8 & 12,6 & 154,4 & 12,0 & 39,2 & 68,8 & 192,4 & 27,2 & 29,6 & 123,6 & 180,4 & 26,7 & 29,0 & 121,2 & 176,9 \\
\hline
\end{tabular}


(continuação)

\begin{tabular}{|c|c|c|c|c|c|c|c|c|c|c|c|c|c|c|c|c|c|c|c|c|c|c|}
\hline 54 & 45,9 & 197,0 & 210,8 & 19,5 & 151,1 & 13,8 & 164,9 & 148,2 & 13,5 & 161,7 & 12,0 & 39,4 & 70,8 & 200,0 & 27,4 & 31,4 & 129,2 & 188,0 & 26,9 & 30,8 & 126,7 & 184,4 \\
\hline 55 & 45,9 & 199,5 & 213,6 & 19,0 & 153,6 & 14,1 & 167,7 & 148,8 & 13,7 & 162,5 & 12,0 & 40,3 & 73,7 & 209,5 & 28,3 & 33,4 & 135,8 & 197,5 & 7,4 & 32,4 & 131,6 & 191,3 \\
\hline 56 & 45,9 & 203,4 & 217,7 & 19,0 & 157,5 & 14,3 & 171,8 & 152,6 & 3,9 & 166,4 & 12,0 & 40,9 & 78,1 & 224,0 & 28,9 & 7,2 & 45,9 & 212,0 & 8,0 & 36,0 & 41,3 & 05,4 \\
\hline 57 & 45,8 & 206,0 & 221,1 & 18,5 & 160,2 & 15,1 & 175,3 & 153,3 & 4,5 & 167,8 & 12,2 & 38,5 & 59,1 & 87,0 & 26,3 & 0,6 & 27,9 & 4,8 & 25,2 & 19,7 & 6,7 & 71,6 \\
\hline 58 & 45,8 & 210,5 & 226,3 & 18,5 & 164,7 & 15,8 & 180,5 & 157,6 & 15,1 & 172,8 & 12,2 & 37,7 & 60,5 & 109,3 & 25,5 & 22,8 & 48,8 & 97,1 & 24,4 & 8 & 6,7 & 92,9 \\
\hline 59 & 45,8 & 215,7 & 232,0 & 18,0 & 169,9 & 16,3 & 2 & 160,7 & 5,4 & 176,1 & 12,2 & 38,7 & 65,7 & 133,0 & 26,5 & 7,0 & 67,3 & 120,8 & 5,1 & 25,5 & 3,6 & 14,2 \\
\hline 60 & 45,8 & 229,0 & 234,2 & 18,0 & 183,2 & 5,2 & 188,4 & 173,2 & 4,9 & 178,2 & 12,2 & 38,7 & 67,2 & 143,0 & 26,5 & 28,5 & 75,8 & 130,8 & 25,1 & 27,0 & 71,7 & 123,7 \\
\hline 61 & 45,8 & 222,4 & 239,5 & 18,0 & 176,6 & 17,1 & 193,7 & 167,0 & 16,2 & 183,2 & 12,2 & 40,2 & 72,0 & 161,8 & 28,0 & 31,8 & 89,8 & 149,6 & 26,5 & 30,1 & 84,9 & 141,5 \\
\hline 62 & 45,7 & 225,3 & 243,0 & 18,0 & 179,6 & 17,7 & 197,3 & 169,8 & 7 & 186,6 & 12,2 & 41,4 & 75,0 & 172,3 & 9,2 & 3,6 & 7,3 & 0,1 & 7,6 & 1,8 & 2,0 & 1,4 \\
\hline 63 & 45,7 & 227,6 & 245,7 & 18,0 & 181,9 & 18,1 & 200,0 & 172,0 & 17,1 & 189,1 & 12,2 & 42,4 & 78,1 & 187,0 & 30,2 & 35,7 & 108,9 & 174,8 & 28,6 & 33,8 & 103,0 & 165,3 \\
\hline 64 & 45,8 & 231,3 & 249,5 & 18,0 & 185,5 & 18,2 & 203,7 & 175,4 & 17,2 & 192,6 & 11,9 & 31,5 & 52,1 & 78,5 & 19,6 & 20,6 & 26,4 & 66,6 & 18,5 & 19,5 & 25,0 & 63,0 \\
\hline 65 & 45,8 & 235,6 & 254,2 & 18,5 & 189,8 & 18,6 & 208,4 & 181,7 & 17,8 & 199,5 & 12,1 & 36,2 & 63,8 & 135,2 & 24,1 & 27,6 & 71,4 & 123,1 & 23,1 & 26,4 & 68,3 & 117,8 \\
\hline 66 & 45,9 & 236,6 & 255,6 & 18,5 & 190,7 & 19,0 & 209,7 & 182,5 & 18,2 & 200,7 & 12,1 & 37,0 & 67,2 & 152,2 & 24,9 & 30,2 & 85,0 & 140,1 & 23,8 & 28,9 & 81,4 & 34,1 \\
\hline 67 & 45,8 & 238,0 & 257,2 & 19,5 & 192,2 & 19,2 & 211,4 & 188,5 & 18,8 & 207,3 & 12,0 & 35,8 & 66,5 & 183,0 & 23,8 & 30,7 & 116,5 & 171,0 & 23,3 & 30,1 & 14,2 & 167,7 \\
\hline 68 & 45,9 & 239,3 & 258,7 & 19,5 & 193,4 & 19,4 & 212,8 & 189,6 & 19,0 & 208,7 & 12,0 & 36,7 & 66,5 & 209,8 & 24,7 & 29,8 & 143,3 & 197,8 & 24,2 & 29,2 & 140,5 & 194,0 \\
\hline 69 & 45,9 & 242,0 & 262,1 & 21,0 & 196,1 & 20,1 & 216,2 & 199,4 & 20,4 & 219,8 & 12,0 & 37,0 & 67,2 & 222,0 & 25,0 & 30,2 & 154,8 & 210,0 & 25,4 & 30,7 & 157,4 & 213,5 \\
\hline 70 & 45,9 & 245,1 & 266,0 & 21,0 & 199,2 & 20,9 & 220,1 & 202,6 & 21,3 & 223,8 & 12,0 & 37,8 & 59,4 & 88,1 & 25,8 & 21,6 & 28,7 & 76,1 & 26,2 & 22,0 & 29,2 & 77,4 \\
\hline
\end{tabular}

Média $\left({ }^{\circ} \mathrm{C}\right)=19,6$

FAAG = filtro ascendente de areia grossa; $F R D$ = filtro rápido descendente; TF = tempo de funcionamento; $T$ = temperatura; Descargas de fundo intermediárias por perda de carga;

Lavagem do FRD por perda de carga; Lavagem do FRD por transpasse 


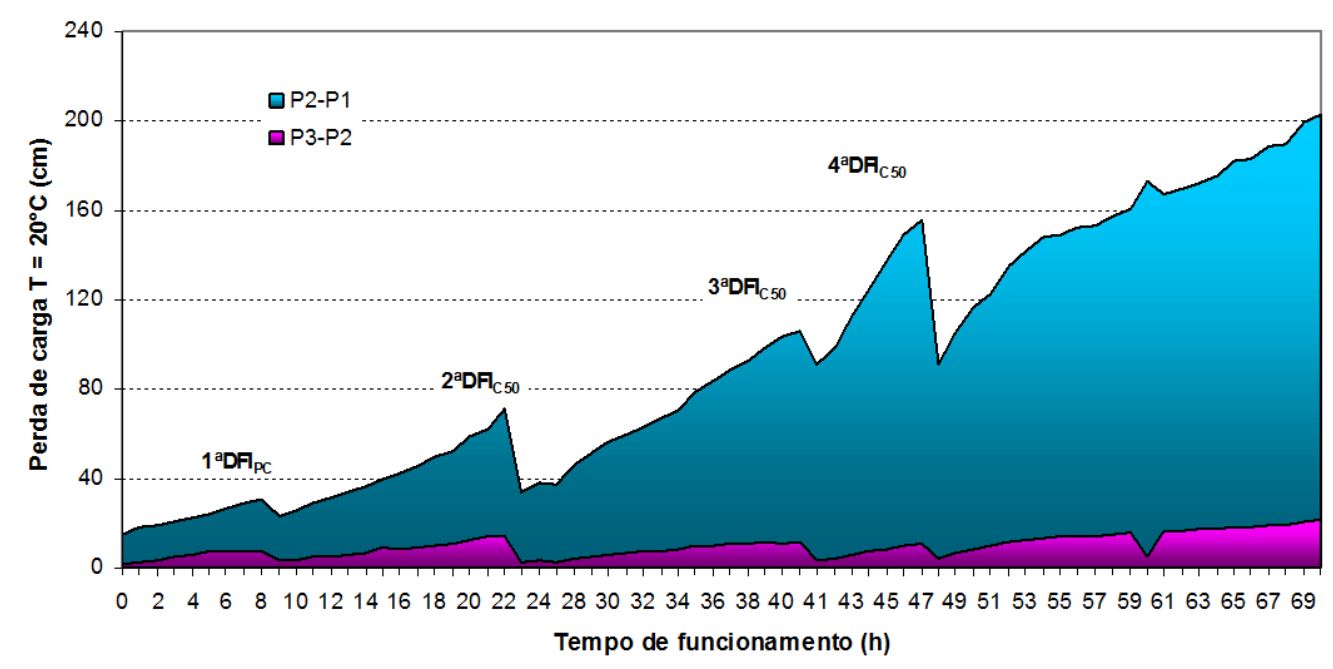

Figura B 4.1 - Perda de carga na camada suporte e camada de areia grossa no FAAG durante o ensaio 4 - sem pré-oxidação e com DFIs no FAAG (FAAG $=180 \mathrm{~m}^{3} / \mathrm{m}^{2} \mathrm{~d}$ e $\mathrm{FRD}=280 \mathrm{~m} / \mathrm{m}^{2} \mathrm{~d}$ ). Fonte: Tabela B 4.3 - ANEXO B.

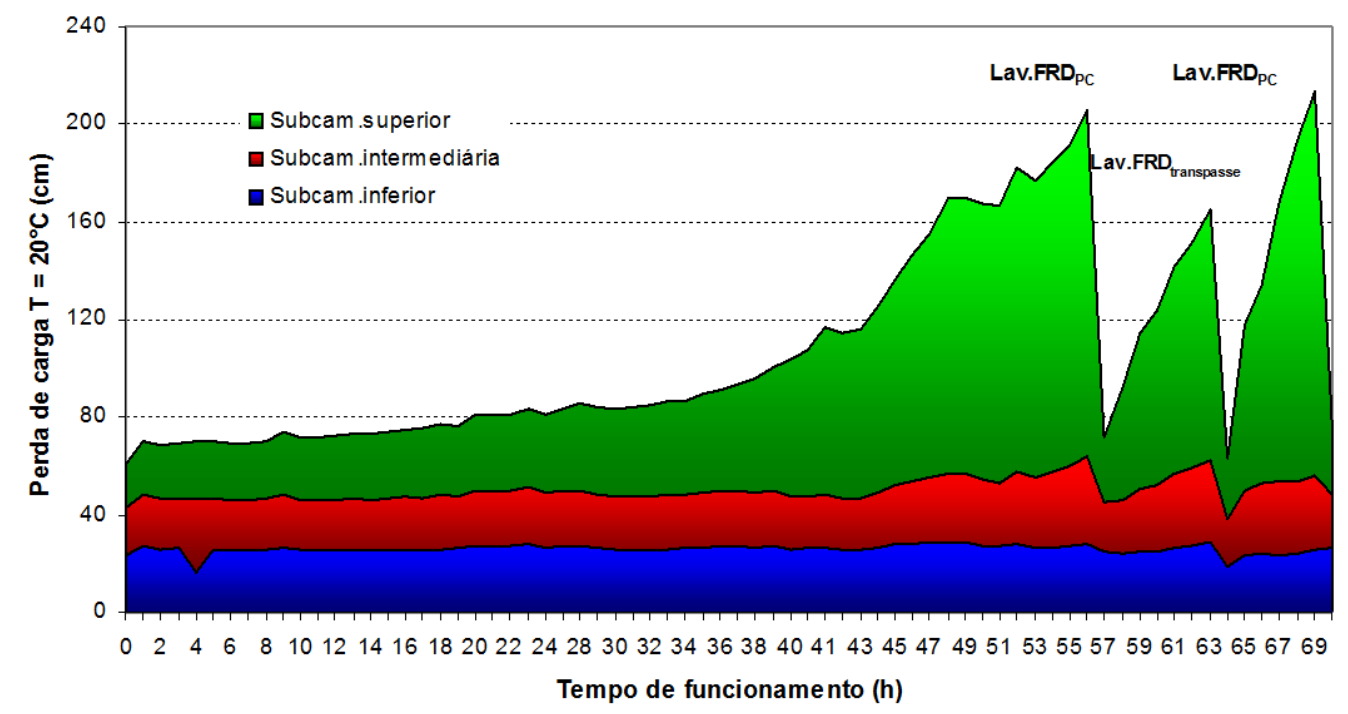

Figura B 4.2 - Perda de carga ao longo do meio filtrante do FRD durante o ensaio 4 - sem préoxidação e com DFls no FAAG (FAAG $=180 \mathrm{~m}^{3} / \mathrm{m}^{2} \mathrm{~d}$ e FRD $\left.=280 \mathrm{~m}^{3} / \mathrm{m}^{2} \mathrm{~d}\right)$. Fonte: Tabela B $4.3-$ ANEXO B. 
Tabela B 4.4 - Variação de vazões e taxas de filtração do FAAG e do FRD durante o ensaio 4 - sem pré-oxidação e com DFIs no FAAG (FAAG $=180 \mathrm{~m}^{3} / \mathrm{m}^{2} \mathrm{~d} ; \mathrm{FRD}=280 \mathrm{~m}^{3} / \mathrm{m}^{2} \mathrm{~d}$ ).

\begin{tabular}{|c|c|c|c|c|c|c|c|c|}
\hline \multirow{2}{*}{$\begin{array}{l}\text { TF } \\
\text { (h) }\end{array}$} & \multicolumn{2}{|c|}{ descartes (L/h) } & \multicolumn{2}{|c|}{ turbidímetros (L/h) } & \multicolumn{2}{|c|}{ vazão total (L/h) } & \multicolumn{2}{|c|}{ taxas de filtração $\left(\mathrm{m}^{3} / \mathrm{m}^{2} \mathrm{~d}\right)$} \\
\hline & FAAG & FRD & FAAG & FRD & FAAG & FRD & FAAG & FRD \\
\hline 0 & 14,29 & 53,40 & 23,51 & 24,47 & 115,67 & 77,87 & 178 & 285 \\
\hline 1 & 13,96 & 54,88 & 23,03 & 23,95 & 115,82 & 78,83 & 178 & 288 \\
\hline 2 & 14,40 & 54,98 & 27,17 & 23,51 & 120,06 & 78,49 & 185 & 287 \\
\hline 3 & 13,33 & 54,00 & 27,35 & 23,30 & 117,98 & 77,30 & 181 & 283 \\
\hline 4 & 13,40 & 54,94 & 27,46 & 23,96 & 119,76 & 78,90 & 184 & 289 \\
\hline 5 & 13,37 & 54,68 & 25,22 & 24,27 & 117,54 & 78,95 & 181 & 289 \\
\hline 6 & 13,76 & 53,33 & 24,42 & 23,81 & 115,78 & 77,60 & 178 & 284 \\
\hline 7 & 13,67 & 53,47 & 24,57 & 23,90 & 115,52 & 77,28 & 178 & 283 \\
\hline 8 & 13,68 & 53,14 & 24,22 & 23,33 & 114,94 & 77,04 & 177 & 282 \\
\hline 9 & 13,37 & 55,80 & 24,19 & 23,48 & 116,69 & 79,13 & 179 & 289 \\
\hline 10 & 13,96 & 53,13 & 23,63 & 23,57 & 114,20 & 76,61 & 176 & 280 \\
\hline 11 & 13,01 & 52,73 & 25,83 & 22,80 & 115,14 & 76,30 & 177 & 279 \\
\hline 12 & 13,97 & 52,31 & 25,55 & 23,34 & 114,63 & 75,11 & 176 & 275 \\
\hline 13 & 13,89 & 52,96 & 25,49 & 22,88 & 115,68 & 76,30 & 178 & 279 \\
\hline 14 & 14,00 & 52,30 & 25,24 & 23,34 & 114,42 & 75,18 & 176 & 275 \\
\hline 15 & 14,01 & 51,96 & 25,82 & 23,76 & 115,13 & 75,30 & 177 & 275 \\
\hline 16 & 14,12 & 53,60 & 25,60 & 23,28 & 117,08 & 77,36 & 180 & 283 \\
\hline 17 & 14,02 & 52,39 & 25,04 & 23,26 & 114,73 & 75,67 & 176 & 277 \\
\hline 18 & 13,85 & 53,73 & 25,25 & 22,84 & 116,09 & 76,99 & 178 & 282 \\
\hline 19 & 14,68 & 52,03 & 24,85 & 23,63 & 114,40 & 74,87 & 176 & 274 \\
\hline 20 & 14,03 & 54,17 & 24,97 & 22,96 & 116,80 & 77,80 & 180 & 285 \\
\hline 21 & 13,78 & 54,92 & 23,71 & 23,14 & 115,37 & 77,88 & 177 & 285 \\
\hline 22 & 14,00 & 53,44 & 23,41 & 23,45 & 113,99 & 76,58 & 175 & 280 \\
\hline 23 & 14,19 & 55,07 & 19,57 & 23,48 & 112,28 & 78,52 & 173 & 287 \\
\hline 24 & 16,34 & 54,75 & 17,93 & 23,23 & 112,50 & 78,23 & 173 & 286 \\
\hline 25 & 16,38 & 54,00 & 17,99 & 23,03 & 111,60 & 77,23 & 172 & 282 \\
\hline 26 & 16,20 & 54,98 & 18,25 & 24,22 & 112,46 & 78,01 & 173 & 285 \\
\hline 28 & 16,16 & 55,33 & 18,52 & 24,30 & 114,31 & 79,63 & 176 & 291 \\
\hline 29 & 16,53 & 54,28 & 18,00 & 23,78 & 112,59 & 78,06 & 173 & 286 \\
\hline 30 & 16,26 & 53,30 & 19,80 & 23,93 & 113,29 & 77,23 & 174 & 282 \\
\hline 31 & 16,35 & 52,73 & 19,87 & 23,38 & 112,33 & 76,11 & 173 & 278 \\
\hline 32 & 16,51 & 53,88 & 19,31 & 23,17 & 112,87 & 77,05 & 173 & 282 \\
\hline 33 & 16,96 & 52,86 & 19,17 & 22,78 & 111,77 & 75,64 & 172 & 277 \\
\hline 34 & 17,13 & 53,23 & 18,84 & 23,02 & 112,22 & 76,25 & 172 & 279 \\
\hline 35 & 16,57 & 53,44 & 18,31 & 23,83 & 112,15 & 77,27 & 172 & 283 \\
\hline 36 & 16,23 & 54,39 & 18,78 & 23,05 & 112,45 & 77,44 & 173 & 283 \\
\hline 37 & 16,91 & 54,43 & 18,43 & 23,14 & 112,91 & 77,57 & 174 & 284 \\
\hline 38 & 16,35 & 54,75 & 18,48 & 22,83 & 112,41 & 77,58 & 173 & 284 \\
\hline 39 & 16,20 & 55,33 & 18,33 & 22,47 & 112,33 & 77,80 & 173 & 285 \\
\hline 40 & 17,13 & 53,25 & 19,68 & 23,20 & 113,26 & 76,45 & 174 & 280 \\
\hline 41 & 16,91 & 52,67 & 19,59 & 23,20 & 112,37 & 75,87 & 173 & 278 \\
\hline 42 & 16,66 & 52,11 & 19,76 & 23,45 & 111,98 & 75,56 & 172 & 276 \\
\hline 43 & 16,27 & 52,27 & 19,71 & 23,86 & 112,11 & 76,13 & 172 & 278 \\
\hline 44 & 16,15 & 54,08 & 19,00 & 22,90 & 112,13 & 76,98 & 172 & 282 \\
\hline
\end{tabular}


(continuação)

\begin{tabular}{|c|c|c|c|c|c|c|c|c|}
\hline 45 & 16,16 & 55,17 & 19,53 & 23,34 & 114,20 & 78,51 & 176 & 287 \\
\hline 46 & 16,68 & 56,47 & 19,66 & 23,86 & 116,67 & 80,33 & 179 & 294 \\
\hline 47 & 16,89 & 56,50 & 19,81 & 23,79 & 116,99 & 80,29 & 180 & 294 \\
\hline 48 & 16,15 & 56,01 & 18,77 & 23,90 & 114,83 & 79,91 & 176 & 292 \\
\hline 49 & 16,06 & 56,22 & 18,02 & 23,76 & 114,06 & 79,98 & 175 & 293 \\
\hline 50 & 16,08 & 54,26 & 18,68 & 23,89 & 112,91 & 78,15 & 174 & 286 \\
\hline 51 & 16,69 & 54,62 & 18,49 & 23,52 & 113,32 & 78,14 & 174 & 286 \\
\hline 52 & 16,53 & 53,13 & 19,59 & 24,55 & 113,80 & 77,68 & 175 & 284 \\
\hline 53 & 16,21 & 53,25 & 18,62 & 24,04 & 112,12 & 77,29 & 172 & 283 \\
\hline 54 & 16,64 & 53,19 & 19,96 & 23,56 & 113,35 & 76,75 & 174 & 281 \\
\hline 55 & 16,49 & 53,20 & 19,92 & 22,93 & 112,54 & 76,13 & 173 & 278 \\
\hline 56 & 15,25 & 55,74 & 19,82 & 23,67 & 114,48 & 79,41 & 176 & 290 \\
\hline 57 & 15,44 & 56,95 & 19,86 & 23,04 & 115,29 & 79,99 & 177 & 293 \\
\hline 58 & 16,96 & 55,81 & 19,15 & 23,46 & 115,38 & 79,27 & 177 & 290 \\
\hline 59 & 17,26 & 56,07 & 19,75 & 23,89 & 116,97 & 79,96 & 180 & 292 \\
\hline 60 & 16,59 & 56,66 & 19,76 & 24,06 & 117,07 & 80,72 & 180 & 295 \\
\hline 61 & 16,90 & 56,45 & 19,14 & 23,50 & 115,99 & 79,95 & 178 & 292 \\
\hline 62 & 16,47 & 56,77 & 19,11 & 23,70 & 116,05 & 80,47 & 178 & 294 \\
\hline 64 & 16,70 & 56,68 & 19,99 & 22,94 & 116,31 & 79,62 & 179 & 291 \\
\hline 65 & 16,30 & 56,35 & 19,51 & 23,71 & 115,87 & 80,06 & 178 & 293 \\
\hline 66 & 16,38 & 56,86 & 18,40 & 22,81 & 114,45 & 79,67 & 176 & 291 \\
\hline & & & & Mínima & 111,60 & 74,87 & 172 & 274 \\
\hline & & & & Média & 114,50 & 77,79 & 176 & 285 \\
\hline & & & & Máxima & 120,06 & 80,72 & 185 & 295 \\
\hline & & & & DP & 1,98 & 1,54 & 3,04 & 5,63 \\
\hline
\end{tabular}

$\mathrm{TF}=$ tempo de funcionamento; FAAG = filtro ascendente de areia grossa; FRD = filtro rápido descendente; $\mathrm{DP}=$ desvio padrão. 
Tabela B 5.1 - Características físicas da AB, AE e efluentes do FAAG e do FRD durante o ensaio 5 sem pré-oxidação e com DFIs no FAAG ( $F A A G=120 \mathrm{~m}^{3} / \mathrm{m}^{2} \mathrm{~d} ; \mathrm{FRD}=160 \mathrm{~m}^{3} / \mathrm{m}^{2} \mathrm{~d}$ ).

\begin{tabular}{|c|c|c|c|c|c|c|c|}
\hline \multirow[b]{2}{*}{ TF (h) } & \multirow{2}{*}{\begin{tabular}{|c|}
$\begin{array}{c}\text { Temperatura } \\
\left({ }^{\circ} \mathrm{C}\right)\end{array}$ \\
$\mathrm{AE}$ \\
\end{tabular}} & \multicolumn{4}{|c|}{ Cor aparente (uH) } & \multicolumn{2}{|c|}{ Cor verdadeira (uH) } \\
\hline & & $\mathrm{AB}$ & $\mathrm{AE}$ & FAAG & FRD & $\mathrm{AB}$ & $\mathrm{AE}$ \\
\hline 0 & 25,5 & 131 & 225 & 19,0 & 3,0 & 24 & 114 \\
\hline 1 & 25,5 & 133 & 220 & 2,0 & 1,0 & 18 & 92 \\
\hline 3 & 25,0 & & 231 & 0,5 & 0,5 & & 101 \\
\hline 5 & 24,5 & & 224 & 0,5 & 0,5 & & 96 \\
\hline 7 & 24,5 & 146 & 224 & 0,5 & 0,5 & 26 & 102 \\
\hline 9 & 24,0 & & 229 & 0,5 & 0,5 & & 98 \\
\hline 11 & 24,0 & & 214 & 0,5 & 0,5 & & 92 \\
\hline 13 & 23,5 & 131 & 201 & 0,5 & 0,5 & 23 & 94 \\
\hline 15 & 23,0 & & 205 & 0,5 & 0,5 & & 85 \\
\hline 17 & 23,0 & & 207 & 0,5 & 0,5 & & 95 \\
\hline 19 & 24,0 & 134 & 205 & 0,5 & 0,5 & 21 & 90 \\
\hline 21 & 25,0 & & 225 & 0,5 & 0,5 & & 99 \\
\hline 23 & 25,0 & & 221 & 0,5 & 0,5 & & 115 \\
\hline 26 & 26,0 & 127 & 205 & 0,5 & 0,5 & 28 & 103 \\
\hline 27 & 26,0 & & 209 & 0,5 & 0,5 & & 91 \\
\hline 29 & 25,0 & & 211 & 0,5 & 0,5 & & 96 \\
\hline 31 & 25,0 & 128 & 209 & 0,5 & 0,5 & 18 & 89 \\
\hline 33 & 24,5 & & 247 & 0,5 & 0,5 & & 113 \\
\hline 35 & 24,0 & & 227 & 0,5 & 0,5 & & 116 \\
\hline 37 & 22,5 & 131 & 205 & 0,5 & 0,5 & 20 & 98 \\
\hline 39 & 23,0 & & 208 & 0,5 & 0,5 & & 103 \\
\hline 41 & 23,0 & & 204 & 0,5 & 0,5 & & 94 \\
\hline 43 & 24,0 & 141 & 209 & 0,5 & 0,5 & 26 & 98 \\
\hline 45 & 25,0 & & 212 & 0,5 & 0,5 & & 88 \\
\hline 47 & 25,5 & & 210 & 0,5 & 0,5 & & 111 \\
\hline 50 & 25,5 & 144 & 217 & 0,5 & 0,5 & 19 & 95 \\
\hline 51 & 26,0 & & 214 & 0,5 & 0,5 & & 103 \\
\hline 53 & 25,0 & & 209 & 0,5 & 0,5 & & 104 \\
\hline 55 & 25,0 & 119 & 208 & 0,5 & 0,5 & 23 & 95 \\
\hline 57 & 24,5 & & 211 & 2,0 & 1,0 & & 95 \\
\hline 59 & 24,0 & & 210 & 0,5 & 0,5 & & 97 \\
\hline 61 & 23,5 & 126 & 211 & 0,5 & 0,5 & 22 & 96 \\
\hline 63 & 23,0 & & 209 & 0,5 & 0,5 & & 97 \\
\hline 65 & 23,0 & & 211 & 3,0 & 1,0 & & 98 \\
\hline 67 & 24 & 135 & 218 & 0,5 & 0,5 & 23 & 97 \\
\hline 69 & 24,5 & & 216 & 0,5 & 0,5 & & 92 \\
\hline 71 & 25,5 & & 216 & 0,5 & 0,5 & & 114 \\
\hline 72 & 25,5 & 125 & 202 & 0,5 & 0,5 & 20 & 89 \\
\hline Média & 24,4 & 132 & 214 & 1,1 & 0,6 & 22 & 99 \\
\hline Mínimo & 22,5 & 119 & 201 & 0,5 & 0,5 & 18 & 85 \\
\hline Máximo & 26,0 & 146 & 247 & 19,0 & 3,0 & 28 & 116 \\
\hline DP & 0,98 & 7,51 & 9,57 & 3,02 & 0,42 & 3,09 & 8,02 \\
\hline
\end{tabular}

TF = tempo de funcionamento; $\mathrm{AE}$ = água de estudo; $\mathrm{AB}$ = água bruta; FAAG = filtro ascendente de areia grossa; $\mathrm{FRD}=$ filtro rápido descendente; $\mathrm{DP}=$ desvio padrão . 
Tabela B 5.2 - Características químicas da AB, AE e efluentes do FAAG e do FRD durante o ensaio 5 - sem pré-oxidação e com DFls no FAAG (FAAG = 120 m ${ }^{3} / \mathrm{m}^{2} \mathrm{~d}$; $\mathrm{FRD}=160 \mathrm{~m}^{3} / \mathrm{m}^{2} \mathrm{~d}$ ).

\begin{tabular}{|c|c|c|c|c|c|c|c|c|c|c|c|c|c|c|c|c|c|}
\hline \multirow{2}{*}{$\begin{array}{c}\text { TF } \\
\text { (h) } \\
\end{array}$} & \multicolumn{3}{|c|}{$\mathrm{pH}$} & \multicolumn{2}{|c|}{ Alcalinidade $\left(\mathrm{mg} / \mathrm{L} \mathrm{CaCO}_{3}\right)$} & \multicolumn{4}{|c|}{ Absorvância 254 nm } & \multicolumn{4}{|c|}{ COD (mg/L) } & \multicolumn{4}{|c|}{ Alumínio (mg/L) } \\
\hline & $A B$ & $\mathrm{AE}$ & $\mathrm{AC}$ & $\mathrm{AB}$ & $\mathrm{AE}$ & $\mathrm{AB}$ & $\mathrm{AE}$ & FAAG & FRD & $\mathrm{AB}$ & $\mathrm{AE}$ & FAAG & FRD & $\mathrm{AB}$ & $\mathbf{A E}$ & FAAG & FRD \\
\hline 0 & 6,88 & 6,86 & 4,86 & 9,46 & 10,78 & 0,073 & 0,211 & 0,023 & 0,023 & 2,086 & 3,460 & 2,321 & 2,384 & 0,01 & 0,01 & 0,46 & 0,10 \\
\hline 1 & 6,90 & 6,86 & 4,84 & 9,02 & 9,02 & 0,070 & 0,190 & 0,010 & 0,019 & 2,411 & 2,572 & 1,830 & 2,160 & 0,01 & 0,01 & 0,44 & 0,12 \\
\hline 3 & & 6,74 & 4,67 & & & & & & & & & & & & & & \\
\hline 5 & & 6,75 & 4,74 & & & & & & & & & & & & & & \\
\hline 7 & 6,78 & 6,77 & 4,80 & 7,04 & 9,24 & 0,078 & 0,184 & 0,010 & 0,020 & & & & & & & & \\
\hline 9 & & 6,82 & 4,87 & & & & & & & & & & & & & & \\
\hline 11 & & 6,76 & 4,89 & & & & & & & & & & & & & & \\
\hline 13 & 6,80 & 6,85 & 4,93 & 8,14 & 8,36 & 0,074 & 0,177 & 0,011 & 0,011 & & & & & & & & \\
\hline 15 & & 6,62 & 4,93 & & & & & & & & & & & & & & \\
\hline 17 & & 6,71 & 4,92 & & & & & & & & & & & & & & \\
\hline 19 & 6,80 & 6,92 & 4,96 & 9,90 & 9,68 & 0,069 & 0,180 & 0,009 & 0,015 & & & & & & & & \\
\hline 21 & & 6,84 & 4,97 & & & & & & & & & & & & & & \\
\hline 23 & & 6,84 & 4,91 & & & & & & & & & & & & & & \\
\hline 26 & 6,90 & 6,88 & 4,88 & 10,12 & 8,58 & 0,067 & 0,184 & 0,023 & 0,015 & 2,442 & 3,458 & 2,537 & 1,947 & 0,02 & 0,02 & 0,40 & 0,15 \\
\hline 27 & & 6,82 & 4,90 & & & & & & & & & & & & & & \\
\hline 29 & & 6,82 & 4,98 & & & & & & & & & & & & & & \\
\hline 31 & 6,88 & 6,83 & 4,96 & 7,70 & 8,80 & 0,068 & 0,185 & 0,010 & 0,010 & & & & & & & & \\
\hline 33 & & 6,75 & 5,01 & & & & & & & & & & & & & & \\
\hline 35 & & 6,86 & 4,99 & & & & & & & & & & & & & & \\
\hline 37 & 6,86 & 6,90 & 5,05 & 9,02 & 8,80 & 0,063 & 0,182 & 0,008 & 0,008 & & & & & & & & \\
\hline 39 & & 6,94 & 5,05 & & & & & & & & & & & & & & \\
\hline 41 & & 6,89 & 5,06 & & & & & & & & & & & & & & \\
\hline 43 & 6,88 & 6,90 & 4,99 & 12,32 & 11,22 & 0,077 & 0,177 & 0,009 & 0,016 & & & & & & & & \\
\hline 45 & & 6,87 & 4,97 & & & & & & & & & & & & & & \\
\hline 47 & & 6,86 & 4,93 & & & & & & & & & & & & & & \\
\hline 50 & 6,91 & 6,83 & 4,95 & 12,32 & 9,46 & 0,068 & 0,197 & 0,014 & 0,014 & 1,957 & 3,338 & 2,002 & 1,838 & 0,05 & 0,07 & 0,50 & 0,21 \\
\hline 51 & & 6,84 & 4,95 & & & & & & & & & & & & & & \\
\hline
\end{tabular}




\begin{tabular}{|c|c|c|c|c|c|c|c|c|c|c|c|c|c|c|c|c|c|}
\hline 53 & & 6,86 & 4,99 & & & & & & & & & & & & & & \\
\hline 55 & 6,85 & 6,86 & 5,00 & 9,46 & 12,10 & 0,071 & 0,193 & 0,009 & 0,017 & & & & & & & & \\
\hline 57 & & 6,80 & 4,92 & & & & & & & & & & & & & & \\
\hline 59 & & 6,87 & 4,98 & & & & & & & & & & & & & & \\
\hline 61 & 6,83 & 6,80 & 4,99 & 10,12 & 11,00 & 0,071 & 0,193 & 0,013 & 0,016 & & & & & & & & \\
\hline 63 & & 6,83 & 5,01 & & & & & & & & & & & & & & \\
\hline 65 & & 6,83 & 5,02 & & & & & & & & & & & & & & \\
\hline 67 & 6,77 & 6,82 & 4,99 & 8,36 & 9,24 & 0,066 & 0,185 & 0,021 & 0,017 & & & & & & & & \\
\hline 69 & & 6,86 & 4,97 & & & & & & & & & & & & & & \\
\hline 71 & & 6,80 & 4,91 & & & & & & & & & & & & & & \\
\hline 72 & 6,68 & 6,83 & 4,91 & 8,80 & 9,90 & 0,069 & 0,181 & 0,010 & 0,012 & 2,332 & 3,855 & 2,070 & 1,994 & 0,01 & 0,03 & 0,60 & 0,15 \\
\hline Média & 6,84 & 6,83 & 4,94 & 9,41 & 9,73 & 0,070 & $\mid 0,187$ & 0,013 & 0,015 & 2,246 & 3,337 & 2,152 & 2,065 & 0,020 & 0,028 & 0,480 & 0,146 \\
\hline Mínimo & 6,68 & 6,62 & 4,67 & 7,04 & 8,36 & 0,063 & 0,177 & 0,008 & 0,008 & 1,957 & 2,572 & 1,830 & 1,838 & 0,010 & 0,010 & 0,400 & 0,100 \\
\hline Máximo & 6,91 & 6,94 & 5,06 & 12,32 & 12,10 & 0,078 & 0,211 & 0,023 & 0,023 & 2,442 & 3,855 & 2,537 & 2,384 & 0,050 & 0,070 & 0,600 & 0,210 \\
\hline DP & 0,06 & 0,06 & 0,08 & 1,52 & 1,13 & 0,004 & 0,009 & 0,005 & 0,004 & 0,213 & 0,470 & 0,278 & 0,213 & 0,017 & 0,025 & 0,076 & 0,042 \\
\hline
\end{tabular}

$T F=$ tempo de funcionamento; $A E$ = água de estudo; $A B=$ água bruta; $A C$ = água coagulada; $F A A G=$ filtro ascendente de areia grossa; FRD = filtro rápido descendente; $D P=$ desvio padrão. 


$$
\text { FAAG }
$$

$$
\text { FRD }
$$

\begin{tabular}{|c|c|c|c|c|c|c|c|c|c|c|c|c|c|c|c|c|c|c|c|c|c|c|}
\hline \multirow{2}{*}{$\begin{array}{l}\text { TF } \\
\text { (h) }\end{array}$} & \multicolumn{3}{|c|}{$\begin{array}{c}\text { Leitura piezométrica } \\
(\mathbf{c m})\end{array}$} & \multirow{2}{*}{$\begin{array}{c}\mathrm{T} \\
\left({ }^{\circ} \mathrm{C}\right)\end{array}$} & \multicolumn{3}{|c|}{$\begin{array}{l}\text { Perda de carga } \\
(\mathbf{c m})\end{array}$} & \multicolumn{3}{|c|}{$\begin{array}{c}\text { Perda de carga }(\mathrm{cm}) \\
\mathrm{T}=20^{\circ} \mathrm{C}\end{array}$} & \multicolumn{4}{|c|}{$\begin{array}{c}\text { Leitura piezométrica } \\
(\mathbf{c m})\end{array}$} & \multicolumn{4}{|c|}{$\begin{array}{l}\text { Perda de carga } \\
(\mathbf{c m})\end{array}$} & \multicolumn{4}{|c|}{$\begin{array}{c}\text { Perda de carga }(\mathrm{cm}) \\
\mathrm{T}=20^{\circ} \mathrm{C}\end{array}$} \\
\hline & $\mathrm{P} 1$ & $\mathrm{P} 2$ & P3 & & P2-P1 & P3-P2 & P3-P1 & P2-P1 & P3-P2 & P3-P1 & $\mathrm{P} 1$ & $\mathrm{P} 2$ & P3 & $\mathrm{P} 4$ & P2-P1 & P3-P2 & P4-P3 & P4-P1 & P2-P1 & P3-P2 & P4-P3 & P4-P1 \\
\hline 0 & 45,7 & 54,7 & 5,4 & 25,5 & 9,0 & & & & & & 11,7 & 22,7 & 33,3 & 45,3 & 11,0 & & & 326 & 12,5 & 12,0 & & 38,1 \\
\hline 1 & 45,8 & 55,8 & 56,8 & 25,5 & 10,0 & 0 & 11,0 & 11,3 & 10 & 12,5 & 11,7 & 23,5 & 34,9 & 48,2 & 11,8 & 11,4 & 3,3 & 6,5 & 3,4 & 12,9 & 5,1 & 1,4 \\
\hline 2 & 45,9 & 56,5 & 58,1 & 25,0 & 10,6 & 6 & 12,2 & 11,9 & 10 & 13,7 & 11,7 & 23,5 & 35,1 & 50,0 & 11,8 & 11,6 & 14,9 & 38,3 & 13,2 & 13,0 & 16,7 & 42,9 \\
\hline 3 & 45,9 & 56,8 & 58,9 & 25,0 & 10,9 & & 13,0 & 2,2 & 2,4 & 14,6 & 11,7 & 23,6 & 35,3 & 50,5 & 11,9 & 11,7 & 15,2 & 38,8 & , & 13,1 & 17,0 &, 5 \\
\hline 4 & 5,9 & 57,5 & 0,0 & 25,0 & & & & & & & 11,7 & 23,6 & 35,3 & 50,7 & 11,9 & & & & & & & \\
\hline 5 & 5,9 & 58,2 & 1,3 & 24,5 & 1 & 3,1 & 5,4 & 13,6 & ,4 & 17,0 & 11,7 & 23,7 & 35,6 & 51,4 & 12,0 & 1,9 & 5,8 & 7 & 3,3 & 3,2 & 17,5 & 9 \\
\hline 6 & 45,8 & 59,0 & 62,5 & 24,5 & 13,2 & 3,5 & 16,7 & 14,6 & 3,9 & 18,5 & 11,7 & 23,4 & 35,0 & 50,6 & 11,7 & 11,6 & 15,6 & 38,9 & 12,9 & 12,8 & 17,3 & 43,0 \\
\hline 7 & 4 & 60 , & 64,0 & 24,5 & 14,2 & 4 & 18 & 1 & 4 & 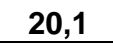 & 11,6 & 23,4 & 35,1 & 51,0 & 11,8 & ,7 & 9 & 39,4 & 1 & 9 & 6 & 6 \\
\hline 8 & 8 & 61,2 & 65,8 & 24,5 & & & & & & & 11,6 & 23,4 & 35,1 & 51,1 & 11,8 & & & & & & & \\
\hline 9 & 45,8 & 62,3 & 67,4 & 24,0 & 16,5 & 5 & 21,6 & 18,0 & 5, & 23,6 & 11,6 & 23,9 & 36,0 & 52,8 & 12,3 & 12,1 & 16,8 & 2 & 13,4 & 13,2 & 18,4 & 45,0 \\
\hline 10 & 45,8 & 64,2 & 70,0 & 24,0 & 18,4 & 5,8 & 24,2 & 20,1 & 6,3 & 26,5 & 11,6 & 24,0 & 36,3 & 53,5 & 12,4 & 12,3 & 17,2 & 41,9 & 13,6 & 13,4 & 18,8 & 45,8 \\
\hline 11 & 45,8 & 65,0 & 71,3 & 24,0 & 19,2 & 6,3 & 2 & 21,0 & 6,9 & 2 & 11,6 & 23,8 & 35,9 & 53,1 & 12,2 & 12,1 & 17,2 & 5 & 13,3 & 13,2 & 18,8 & 45,4 \\
\hline 12 & 45,8 & 66,7 & 73,5 & 24,0 & 20,9 & & & 西 & & & 11,6 & 23,8 & 35,9 & 53,5 & 12,2 & 12,1 & 17,6 & 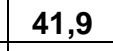 & & 13,2 & 19,2 & 45,8 \\
\hline 13 & 45,8 & 68,8 & 76,4 & 23,5 & 23,0 & 7,6 & 30,6 & 24,8 & 8,2 & 33,1 & 11,6 & 23,8 & 36,0 & 54,0 & 12,2 & 12,2 & 18,0 & 42,4 & 13,2 & 13,2 & 19,4 & 45,8 \\
\hline 14 & 45,8 & 70,5 & 78,7 & 23,5 & 24,7 & 8,2 & 32,9 & 26,7 & 8,9 & 35,5 & 11,6 & 23,9 & 36,2 & 54,8 & 12,3 & 12,3 & 18,6 & 43,2 & 13,3 & 13,3 & 20,1 & 46,7 \\
\hline 15 & 45,8 & 72,7 & 81,2 & 23,0 & 26,9 & 8,5 & 35,4 & 28,7 & 9,1 & 37,8 & 11,6 & 24,0 & 36,5 & 55,8 & 12,4 & 12,5 & 19,3 & 44,2 & 13,2 & 13,3 & 20,6 & 47,2 \\
\hline 16 & 45,8 & 74,2 & 83,7 & 23,0 & 28,4 & & 37,9 & 30,3 & 10,1 & 40,4 & 11,6 & 23,9 & 36,3 & 55,8 & 12,3 & 12,4 & 19,5 & 44,2 & 13,1 & 13,2 & 20,8 & 47,2 \\
\hline 17 & 45,8 & 76,3 & 86,2 & 23,0 & 30,5 & 9,9 & 40,4 & 32,6 & 10,6 & 43,1 & 11,6 & 23,9 & 36,4 & 56,0 & 12,3 & 12,5 & 19,6 & 44,4 & 13,1 & 13,3 & 20,9 & 47,4 \\
\hline 18 & 45,9 & 78,0 & 88,6 & 23,0 & 32,1 & 10,6 & 42,7 & 34,3 & 11,3 & 45,6 & 11,6 & 23,9 & 35,3 & 55,8 & 12,3 & 11,4 & 20,5 & 44,2 & 13,1 & 12,2 & 21,9 & 47,2 \\
\hline 19 & 45,9 & 67,6 & 69,8 & 24,0 & 21,7 & 2,2 & 23,9 & 23,7 & 2,4 & 26,1 & 11,5 & 23,6 & 35,6 & 52,5 & 12,1 & 12,0 & 16,9 & 41,0 & 13,2 & 13,1 & 18,5 & 44,8 \\
\hline 20 & 46,0 & 70,0 & 73,4 & 24,0 & 24,0 & 3,4 & 27,4 & 26,2 & 3,7 & 30,0 & 11,5 & 23,4 & 35,3 & 52,4 & 11,9 & 11,9 & 17,1 & 40,9 & 13,0 & 13,0 & 18,7 & 44,7 \\
\hline 21 & 45,9 & 72,0 & 76,3 & 25,0 & 26,1 & 4,3 & 30,4 & 29,2 & 4,8 & 34,0 & 11,5 & 23,4 & 35,3 & 53,0 & 11,9 & 11,9 & 17,7 & 41,5 & 13,3 & 13,3 & 19,8 & 46,5 \\
\hline 22 & 45,9 & 74,0 & 79,2 & 25,0 & 28,1 & 5,2 & 33,3 & & 5,8 & 37,3 & 11,6 & 23,3 & 35,1 & \begin{tabular}{|l|}
52,9 \\
\end{tabular} & 11,7 & 11,8 & 17,8 & 41,3 & 13,1 & 13,2 & 19,9 & 46,3 \\
\hline 23 & 45,9 & 76,6 & 83,0 & 25,0 & 30,7 & 6,4 & 37,1 & 34,4 & 7,2 & 41,6 & 11,6 & 23,3 & 35,0 & 53,1 & 11,7 & 11,7 & 18,1 & 41,5 & 13,1 & 13,1 & 20,3 & 46,5 \\
\hline
\end{tabular}


(continuação)

\begin{tabular}{|c|c|c|c|c|c|c|c|c|c|c|c|c|c|c|c|c|c|c|c|c|c|c|}
\hline 24 & 45,9 & 78,7 & 86,0 & 25,0 & 32,8 & 7,3 & 40,1 & 36,7 & 8,2 & 44,9 & 11,6 & 23,3 & 35,1 & 53,5 & 11,7 & 11,8 & 18,4 & 41,9 & 13,1 & 13,2 & 20,6 & 46,9 \\
\hline 25 & 45,9 & 80,7 & 88,7 & 26,0 & 34,8 & 8,0 & 42,8 & 39,9 & 9,2 & 49,1 & 11,6 & 23,1 & 34,7 & 53,0 & 11,5 & 11,6 & 18,3 & 41,4 & 13,2 & 13,3 & 21,0 & 47,5 \\
\hline 26 & 5,9 & 82,7 & 91,5 & 26,0 & 36,8 & 8,8 & 45,6 & 42,2 & 10,1 & 52,3 & 11,6 & 23,0 & 34,6 & 53,1 & 11,4 & 11,6 & 18,5 & 41,5 & 13,1 & 13,3 & 21,2 & 47,6 \\
\hline 27 & 5,9 & 84,9 & 94,7 & 26,0 & 39,0 & 9,8 & 48,8 & 44,7 & 11,2 & 56,0 & 11,6 & 22,9 & 34,4 & 52,8 & 11,3 & 11,5 & 18,4 & 41,2 & 13,0 & 13,2 & 21,1 & 47,3 \\
\hline 28 & 45,8 & 87,7 & 98,3 & 26,0 & 41,9 & 10,6 & 52,5 & 48,1 & 12,2 & 60,2 & 11,6 & 23,1 & 34,8 & 54,0 & 11,5 & 11,7 & 19,2 & 42,4 & 13,2 & 3,4 & 22,0 & 8,6 \\
\hline 29 & 45,8 & 90,8 & 102,3 & 25,0 & 45,0 & 11,5 & 56,5 & 50,4 & 12,9 & 63,3 & 11,5 & 23,3 & 35,1 & 54,7 & 11,8 & 11,8 & 19,6 & 43,2 & 13,2 & 3,2 & 22,0 & 8,4 \\
\hline 30 & 45,8 & 92,8 & 105,1 & 25,0 & 47,0 & 12,3 & 59,3 & 52,6 & 13,8 & 66,4 & 11,5 & 23,3 & 35,3 & 55,0 & 11,8 & 12,0 & 19,7 & 43,5 & 13,2 & 13,4 & 22,1 & 48,7 \\
\hline 31 & 45,8 & 95,7 & 108,8 & 25,0 & 49,9 & 13,1 & 63,0 & 55,9 & 14,7 & 70,6 & 11,5 & 23,3 & 35,3 & 55,5 & 11,8 & 12,0 & 20,2 & 44,0 & 13,2 & 13,4 & 22,6 & 49,3 \\
\hline 32 & 45,8 & 99,0 & 113,0 & 25,0 & 53,2 & 14,0 & 67,2 & 59,6 & 15,7 & 75,3 & 11,5 & 23,4 & 35,6 & 56,1 & 11,9 & 12,2 & 20,5 & 44,6 & 13,3 & 13,7 & 23,0 & 50,0 \\
\hline 33 & 45,8 & 101,0 & 115,6 & 24,5 & 55,2 & 14,6 & 69,8 & 61,1 & 16,2 & 77,2 & 11,5 & 23,5 & 35,7 & 56,3 & 12,0 & 12,2 & 20,6 & 44,8 & 13,3 & 13,5 & 22,8 & 49,6 \\
\hline 34 & 45,8 & 103,5 & 118,5 & 24,5 & 57,7 & 15,0 & 72,7 & 63,9 & 16,6 & 80,4 & 11,5 & 23,6 & 36,0 & 57,0 & 12,1 & 12,4 & 21,0 & 45,5 & 13,4 & 13,7 & 23,2 & 50,4 \\
\hline 35 & 45,8 & 107,2 & 123,2 & 24,0 & 61,4 & 16,0 & 77,4 & 67,1 & 17,5 & 84,6 & 11,5 & 23,8 & 36,2 & 57,5 & 12,3 & 12,4 & 21,3 & 46,0 & 13,4 & 13,6 & 23,3 & 0,3 \\
\hline 36 & 45,8 & 110,1 & 126,9 & 24,0 & 64,3 & 16,8 & 81,1 & 70,3 & 18,4 & 88,7 & 11,5 & 24,0 & 36,6 & 57,5 & 12,5 & 12,6 & 20,9 & 46,0 & 13,7 & 13,8 & 22,9 & 0,3 \\
\hline 37 & 45,8 & 112,9 & 130,6 & 22,5 & 67,1 & 17,7 & 84,8 & 70,8 & 18,7 & 89,4 & 11,4 & 24,0 & 36,7 & 58,6 & 12,6 & 12,7 & 21,9 & 47,2 & 13,3 & 13,4 & 23,1 & 9,8 \\
\hline 38 & 45,6 & 94,8 & 99,0 & 22,5 & 49,2 & 4,2 & 53,4 & 51,9 & 4,4 & 56,3 & 11,5 & 23,3 & 35,4 & 56,5 & 11,8 & 12,1 & 21,1 & 45,0 & 12,4 & 12,8 & 22,2 & ,4 \\
\hline 39 & 45,7 & 101,0 & 107,9 & 23,0 & 55,3 & 6,9 & 62,2 & 59,0 & 7,4 & 66,4 & 11,5 & 24,1 & 36,9 & 59,2 & 12,6 & 12,8 & 22,3 & 47,7 & 13,4 & 13,7 & 23,8 & 50,9 \\
\hline 40 & 45,7 & 105,3 & 113,3 & 23,0 & 59,6 & 8,0 & 67,6 & 63,6 & 8,5 & 72,1 & 11,5 & 24,2 & 37,1 & 59,9 & 12,7 & 12,9 & 22,8 & 48,4 & 13,6 & 13,8 & 24,3 & 1,7 \\
\hline 41 & 5,7 & 110,0 & 119,8 & 23,0 & 64,3 & 9,8 & 74,1 & 68,6 & 10,5 & 79,1 & 11,6 & 24,4 & 37,4 & 60,6 & 12,8 & 13,0 & 23,2 & 49,0 & 13,7 & 13,9 & 24,8 & 2,3 \\
\hline 42 & 45,8 & 113,6 & 124,8 & 23,0 & 67,8 & 11,2 & 79,0 & 72,4 & 12,0 & 84,3 & 11,6 & 24,1 & 36,9 & 59,8 & 12,5 & 12,8 & 22,9 & 48,2 & 13,3 & 13,7 & 24,4 & 51,4 \\
\hline 43 & 45,9 & 116,5 & 128,7 & 24,0 & 70,6 & 12,2 & 82,8 & 77,2 & 13,3 & 90,5 & 11,6 & 23,9 & 36,4 & 59,2 & 12,3 & 12,5 & 22,8 & 47,6 & 13,4 & 13,7 & 24,9 & 2,0 \\
\hline 44 & 46,0 & 120,1 & 133,5 & 24,0 & 74,1 & 13,4 & 87,5 & 81,0 & 14,7 & 95,7 & 11,6 & 23,5 & 35,7 & 58,0 & 11,9 & 12,2 & 22,3 & 46,4 & 13,0 & 13,3 & 24,4 & 50,7 \\
\hline 45 & 46,0 & 124,0 & 138,0 & 25,0 & 78,0 & 14,0 & 92,0 & 87,4 & 15,7 & 103,0 & 11,6 & 23,4 & 35,5 & 57,6 & 11,8 & 12,1 & 22,1 & 46,0 & 13,2 & 13,6 & 24,8 & 51,5 \\
\hline 46 & 46,0 & 128,1 & 143,4 & 25,0 & 82,1 & 15,3 & 97,4 & 92,0 & 17,1 & 109,1 & 11,6 & 23,3 & 35,3 & 57,6 & 11,7 & 12,0 & 22,3 & 46,0 & 13,1 & 13,4 & 25,0 & 51,5 \\
\hline 47 & 46,0 & 130,5 & 146,7 & 25,5 & 84,5 & 16,2 & 100,7 & 95,8 & 18,4 & 114,2 & 11,6 & 23,2 & 35,0 & 57,1 & 11,6 & 11,8 & 22,1 & 45,5 & 13,2 & 13,4 & 25,1 & 51,6 \\
\hline 48 & 46,0 & 135,5 & 152,8 & 25,5 & 89,5 & 17,3 & 106,8 & 101,5 & 19,6 & 121,1 & 11,6 & 23,1 & 34,9 & 56,8 & 11,5 & 11,8 & 21,9 & 45,2 & 13,0 & 13,4 & 24,8 & 51,2 \\
\hline 49 & 46,0 & 138,2 & 156,3 & 25,5 & 92,2 & 18,1 & 110,3 & 104,5 & 20,5 & 125,0 & 11,6 & 23,1 & 34,9 & 56,9 & 11,5 & 1,8 & 22,0 & 45,3 & 13,0 & 13,4 & 24,9 & 51,4 \\
\hline 50 & 45,9 & 141,6 & 160,1 & 25,5 & 95,7 & 18,5 & 114,2 & 108,5 & 21,0 & 129,5 & 11,6 & 23,1 & 34,8 & 56,9 & 11,5 & 11,7 & 22,1 & 45,3 & 13,0 & 13,3 & 25,1 & 51,4 \\
\hline 51 & 45,9 & 145,2 & 164,8 & 26,0 & 99,3 & 19,6 & 118,9 & 113,9 & 22,5 & 136,4 & 11,6 & 22,9 & 34,5 & 56,3 & 11,3 & 11,6 & 21,8 & 44,7 & 13,0 & 13,3 & 25,0 & 51,3 \\
\hline
\end{tabular}


(continuação)

\begin{tabular}{|c|c|c|c|c|c|c|c|c|c|c|c|c|c|c|c|c|c|c|c|c|c|c|}
\hline 52 & 45,9 & 150,0 & 170,1 & 26,0 & 104,1 & 20,1 & 124,2 & 119,4 & 23,1 & 142,5 & 11,5 & 23,0 & 34,8 & 57,1 & 11,5 & 11,8 & 22,3 & \begin{tabular}{|l|}
45,6 \\
\end{tabular} & 13,2 & 13,5 & 25,6 & 52,3 \\
\hline 52,2 & 45,9 & 151,0 & 171,3 & 26,0 & 105,1 & 20,3 & 125,4 & 120,6 & 23,3 & 143,9 & 11,5 & 23,0 & 34,8 & 57,1 & 11,5 & 11,8 & 22,3 & 45,6 & 13,2 & 13,5 & 25,6 & 52,3 \\
\hline 53 & 45,8 & 114,0 & 118,7 & 25,0 & 68,2 & 4,7 & 72,9 & 76,4 & 5,3 & 81,7 & 11,5 & 22,6 & 34,0 & 56,2 & 11,1 & 11,4 & 22,2 & 44,7 & 12,4 & 12,8 & 24,9 & 50,1 \\
\hline 54 & 45,8 & 126,2 & 131,9 & 25,0 & 80,4 & 5,7 & 86,1 & 90,1 & 6,4 & 96,4 & 11,6 & 23,8 & 36,2 & 60,4 & 12,2 & 12,4 & 24,2 & 48,8 & 13,7 & 13,9 & 27,1 & 54,7 \\
\hline 55 & 45,8 & 132,0 & 140,0 & 25,0 & 86,2 & 8,0 & 94,2 & 96,5 & 9,0 & 105,5 & 11,5 & 23,5 & 35,8 & 59,8 & 12,0 & 12,3 & 24,0 & 48,3 & 13,4 & 13,8 & 26,9 & 54,1 \\
\hline 56 & 45,8 & 139,3 & 149,7 & 24,5 & 93,5 & 10,4 & 103,9 & 103,5 & 11,5 & 115,0 & 11,5 & 23,5 & 35,7 & 59,7 & 12,0 & 12,2 & 24,0 & 48,2 & 13,3 & 13,5 & 26,6 & 53,3 \\
\hline 57 & 45,8 & 145,9 & 158,5 & 24,5 & 100,1 & 12,6 & 112,7 & 110,8 & 13,9 & 124,7 & 11,5 & 23,9 & 36,7 & 61,8 & 12,4 & 12,8 & 25,1 & 50,3 & 13,7 & 14,2 & 27,8 & 55,7 \\
\hline 58 & 45,8 & 151,4 & 166,0 & 24,0 & 105,6 & 14,6 & 120,2 & 115,5 & 16,0 & 131,4 & 11,5 & 23,6 & 36,0 & 60,6 & \begin{tabular}{|l|}
12,1 \\
\end{tabular} & 12,4 & 24,6 & \begin{tabular}{|c|}
49,1 \\
\end{tabular} & 13,2 & 13,6 & 26,9 & 53,7 \\
\hline 59 & 45,8 & 158,3 & 174,3 & 24,0 & 112,5 & 16,0 & 128,5 & 123,0 & 17,5 & 140,5 & 11,5 & 23,8 & 36,4 & 61,3 & 12,3 & 12,6 & 24,9 & 49,8 & 13,4 & 13,8 & 27,2 & 54,4 \\
\hline 60 & 45,7 & 164,1 & 182,0 & 23,5 & 118,4 & 17,9 & 136,3 & 127,9 & 19,3 & 147,2 & 11,5 & 23,9 & 36,6 & 61,9 & 12,4 & 12,7 & 25,3 & 50,4 & 13,4 & 13,7 & 27,3 & 54,4 \\
\hline 61 & 45,9 & 171,6 & 191,2 & 23,5 & 125,7 & 19,6 & 145,3 & 135,8 & 21,2 & 157,0 & 11,5 & 23,9 & 36,7 & 62,5 & 12,4 & 12,8 & 25,8 & 51,0 & 13,4 & 13,8 & 27,9 & 55,1 \\
\hline 62 & 45,8 & 176,8 & 197,2 & 23,0 & 131,0 & 20,4 & 151,4 & 139,8 & 21,8 & 161,6 & 11,5 & 24,0 & 36,9 & 63,0 & 12,5 & 12,9 & 26,1 & 51,5 & 13,3 & 13,8 & 27,9 & 55,0 \\
\hline 63 & 45,8 & 182,4 & 204,1 & 23,0 & 136,6 & 21,7 & 158,3 & 145,8 & 23,2 & 168,9 & 11,5 & 23,9 & 36,7 & 62,7 & 12,4 & 12,8 & 26,0 & \begin{tabular}{|l}
51,2 \\
\end{tabular} & 13,2 & 13,7 & 27,7 & 54,6 \\
\hline 64 & 45,7 & 186,9 & 209,5 & 23,0 & 141,2 & 22,6 & 163,8 & 150,7 & 24,1 & 174,8 & 11,5 & 24,1 & 37,1 & 63,6 & 12,6 & 13,0 & 26,5 & 52,1 & 13,4 & 13,9 & 28,3 & 55,6 \\
\hline 64,7 & 45,7 & 191,8 & 214,8 & 23,0 & 146,1 & 23,0 & 169,1 & 155,9 & 24,5 & 180,5 & 11,5 & 24,1 & 37,1 & 63,9 & 12,6 & 13,0 & 26,8 & 52,4 & 13,4 & 13,9 & 28,6 & 55,9 \\
\hline 65 & 45,8 & 137,1 & 147,0 & 24,0 & 91,3 & 9,9 & 101,2 & 99,8 & 10,8 & 110,6 & 11,5 & 24,3 & 37,5 & 65,0 & 12,8 & 13,2 & 27,5 & 53,5 & 14,0 & 14,4 & 30,1 & 58,5 \\
\hline 66 & 45,8 & 152,1 & 165,5 & 24,0 & 106,3 & 13,4 & 119,7 & 116,2 & 14,7 & 130,9 & 11,5 & 24,0 & 36,8 & 63,7 & 12,5 & 12,8 & 26,9 & 52,2 & 13,7 & 14,0 & 29,4 & 57,1 \\
\hline 67 & 45,8 & 161,5 & 177,1 & 24,5 & 115,7 & 15,6 & 131,3 & 128,0 & 17,3 & 145,3 & 11,5 & 23,8 & 36,4 & 63,0 & 12,3 & 12,6 & 26,6 & 51,5 & 13,6 & 13,9 & 29,4 & 57,0 \\
\hline 68 & 45,9 & 170,5 & 188,0 & 24,5 & 124,6 & 17,5 & 142,1 & 137,9 & 19,4 & 157,2 & 11,5 & 23,7 & 36,2 & 62,6 & 12,2 & 12,5 & 26,4 & 51,1 & 13,5 & 13,8 & 29,2 & 56,5 \\
\hline 69 & 45,9 & 181,2 & 200,6 & 25,5 & 135,3 & 19,4 & 154,7 & 153,4 & 22,0 & 175,4 & 11,5 & 23,5 & 35,9 & 62,1 & 12,0 & 12,4 & 26,2 & 50,6 & 13,6 & 14,1 & 29,7 & 57,4 \\
\hline 70 & 45,9 & 187,8 & 209,4 & 25,5 & 141,9 & 21,6 & 163,5 & 160,9 & 24,5 & 185,4 & 11,6 & 23,5 & 35,7 & 61,7 & 11,9 & 12,2 & 26,0 & 50,1 & 13,5 & 13,8 & 29,5 & 56,8 \\
\hline 71 & 45,9 & 195,1 & 218,0 & 25,5 & 149,2 & 22,9 & 172,1 & 169,1 & 26,0 & 195,1 & 11,6 & 23,5 & 35,7 & 61,7 & 11,9 & 12,2 & 26,0 & 50,1 & 13,5 & 13,8 & 29,5 & 56,8 \\
\hline 72 & 45,9 & 202,2 & 226,3 & 25,5 & 156,3 & 24,1 & 180,4 & 177,2 & 27,3 & 204,5 & 11,6 & 23,3 & 35,4 & 61,2 & 11,7 & 12,1 & 25,8 & 49,6 & 13,3 & 13,7 & 29,2 & 56,2 \\
\hline
\end{tabular}

FAAG = filtro ascendente de areia grossa; FRD = filtro rápido descendente; TF = tempo de funcionamento; $T$ = temperatura; Descargas de fundo intermediárias por perda de carga. 


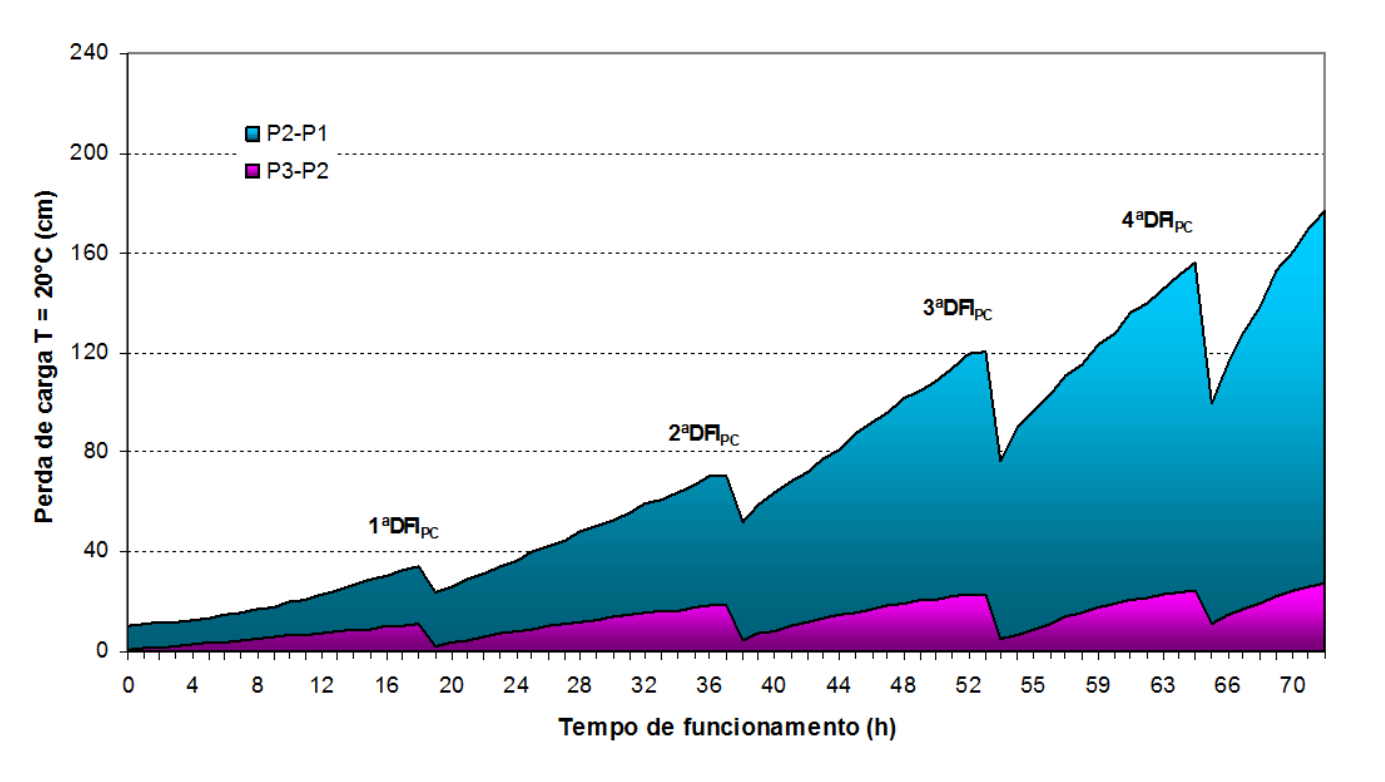

Figura B 5.1 - Perda de carga na camada suporte e camada de areia grossa no FAAG durante o ensaio 5 - sem pré-oxidação e com DFIs no FAAG (FAAG $=120 \mathrm{~m}^{3} / \mathrm{m}^{2} \mathrm{~d}$ e FRD $=160 \mathrm{~m}^{3} / \mathrm{m}^{2} \mathrm{~d}$ ). Fonte: Tabela B 5.3 - ANEXO B.

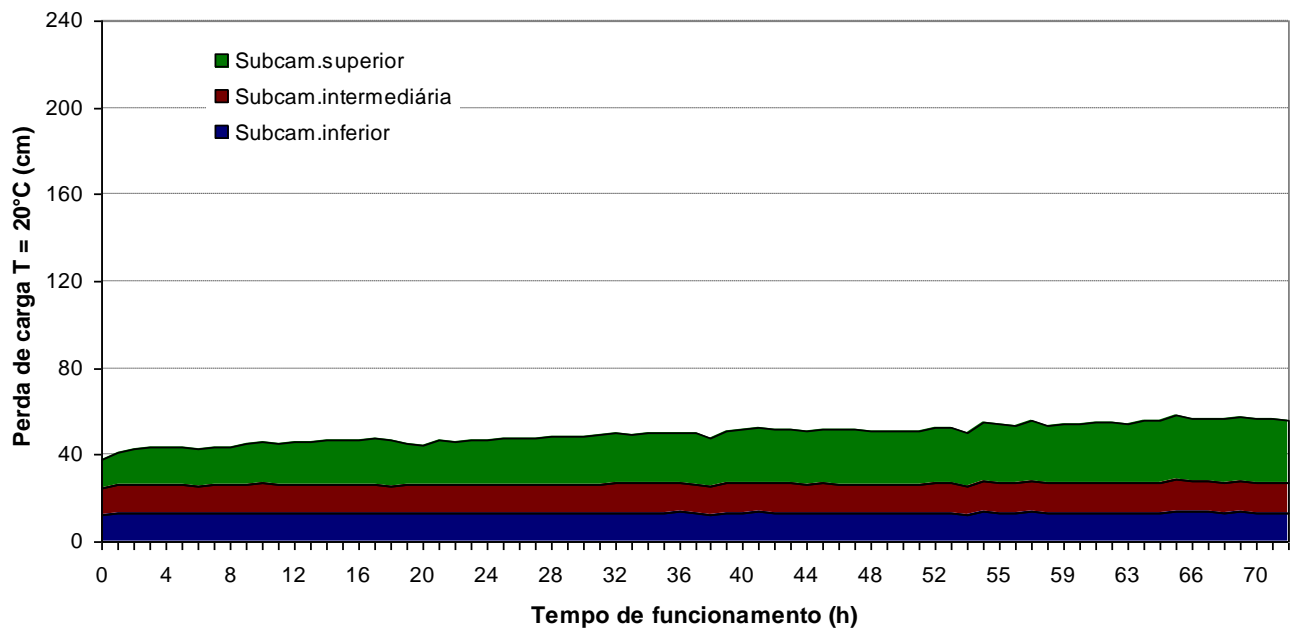

Figura B 5.2 - Perda de carga ao longo do meio filtrante do FRD durante o ensaio 5 - sem préoxidação e com DFIs no FAAG (FAAG $=120 \mathrm{~m}^{3} / \mathrm{m}^{2} \mathrm{~d}$ e FRD $=160 \mathrm{~m}^{3} / \mathrm{m}^{2} \mathrm{~d}$ ). Fonte: Tabela B $5.3-$ ANEXO B. 
Tabela B 5.4 - Variação de vazões e taxas de filtração do FAAG e do FRD durante o ensaio 5 - sem pré-oxidação e com DFIs no FAAG (FAAG $=120 \mathrm{~m}^{3} / \mathrm{m}^{2} \mathrm{~d} ; \mathrm{FRD}=160 \mathrm{~m}^{3} / \mathrm{m}^{2} \mathrm{~d}$ ).

\begin{tabular}{|c|c|c|c|c|c|c|c|c|}
\hline \multirow{2}{*}{$\begin{array}{l}\text { TF } \\
\text { (h) }\end{array}$} & \multicolumn{2}{|c|}{ descartes (L/h) } & \multicolumn{2}{|c|}{ turbidímetros (L/h) } & \multicolumn{2}{|c|}{ vazão total (L/h) } & \multicolumn{2}{|c|}{ taxas de filtração $\left(\mathrm{m}^{3} / \mathrm{m}^{2} \mathrm{~d}\right)$} \\
\hline & FAAG & FRD & FAAG & FRD & FAAG & FRD & FAAG & FRD \\
\hline 0 & 19,78 & 19,62 & 16,03 & 25,15 & 80,58 & 44,77 & 124 & 164 \\
\hline 1 & 20,52 & 20,66 & 15,30 & 25,16 & 81,64 & 45,82 & 125 & 168 \\
\hline 2 & 19,75 & 20,06 & 15,23 & 24,48 & 79,52 & 44,54 & 122 & 163 \\
\hline 3 & 19,57 & 21,00 & 15,24 & 24,71 & 80,52 & 45,71 & 124 & 167 \\
\hline 4 & 20,03 & 20,72 & 15,58 & 24,90 & 81,23 & 45,62 & 125 & 167 \\
\hline 5 & 19,28 & 21,55 & 16,53 & 24,79 & 82,15 & 46,34 & 126 & 170 \\
\hline 6 & 21,34 & 20,62 & 15,53 & 25,29 & 82,28 & 45,41 & 126 & 166 \\
\hline 7 & 20,89 & 19,50 & 15,97 & 25,12 & 81,65 & 44,79 & 125 & 164 \\
\hline 8 & 20,69 & 20,09 & 16,09 & 25,17 & 81,99 & 45,21 & 126 & 165 \\
\hline 9 & 19,90 & 22,06 & 15,86 & 24,24 & 82,99 & 47,23 & 128 & 173 \\
\hline 10 & 19,80 & 21,80 & 16,39 & 24,42 & 82,23 & 46,04 & 126 & 168 \\
\hline 11 & 20,03 & 20,85 & 16,32 & 24,59 & 81,62 & 45,27 & 125 & 166 \\
\hline 12 & 20,98 & 20,71 & 15,74 & 24,18 & 82,02 & 45,30 & 126 & 166 \\
\hline 13 & 20,93 & 20,41 & 15,93 & 24,85 & 81,45 & 44,59 & 125 & 163 \\
\hline 14 & 20,24 & 20,14 & 15,97 & 23,79 & 81,20 & 44,99 & 125 & 165 \\
\hline 15 & 20,66 & 20,61 & 16,19 & 24,16 & 81,25 & 44,40 & 125 & 162 \\
\hline 16 & 20,06 & 20,45 & 15,81 & 23,66 & 80,48 & 44,61 & 124 & 163 \\
\hline 17 & 19,90 & 20,36 & 15,76 & 24,54 & 79,68 & 44,02 & 122 & 161 \\
\hline 18 & 20,49 & 20,88 & 15,68 & 23,73 & 81,59 & 45,42 & 125 & 166 \\
\hline 19 & 20,34 & 20,51 & 15,45 & 24,35 & 80,03 & 44,24 & 123 & 162 \\
\hline 20 & 20,83 & 20,57 & 15,90 & 24,40 & 81,65 & 44,92 & 125 & 164 \\
\hline 21 & 20,55 & 19,94 & 15,84 & 24,65 & 80,73 & 44,34 & 124 & 162 \\
\hline 22 & 19,91 & 19,59 & 14,64 & 24,33 & 78,79 & 44,24 & 121 & 162 \\
\hline 23 & 19,79 & 19,85 & 14,55 & 25,20 & 78,52 & 44,18 & 121 & 162 \\
\hline 24 & 20,27 & 21,24 & 14,59 & 25,35 & 81,30 & 46,44 & 125 & 170 \\
\hline 25 & 20,36 & 20,25 & 15,47 & 24,89 & 81,43 & 45,60 & 125 & 167 \\
\hline 26 & 19,61 & 20,88 & 14,76 & 25,01 & 80,14 & 45,77 & 123 & 167 \\
\hline 27 & 19,98 & 20,11 & 15,33 & 25,20 & & & & \\
\hline 28 & 20,66 & 20,91 & 15,50 & 25,07 & 82,14 & 45,98 & 126 & 168 \\
\hline 29 & 20,10 & 21,04 & 15,65 & 24,30 & 81,09 & 45,34 & 125 & 166 \\
\hline 30 & 20,35 & 20,37 & 15,12 & 25,02 & 80,86 & 45,39 & 124 & 166 \\
\hline 31 & 20,40 & 19,88 & 15,48 & 24,00 & 79,76 & 43,88 & 123 & 161 \\
\hline 32 & 20,00 & 19,80 & 14,82 & 24,30 & 78,92 & 44,10 & 121 & 161 \\
\hline 33 & 20,45 & 19,48 & 15,00 & 24,17 & 79,10 & 43,65 & 122 & 160 \\
\hline 34 & 19,97 & 19,92 & 14,77 & 24,29 & 78,95 & 44,21 & 121 & 162 \\
\hline 35 & 19,95 & 19,95 & 15,28 & 24,29 & 79,47 & 44,24 & 122 & 162 \\
\hline 36 & 19,29 & 20,80 & 15,05 & 23,87 & 79,01 & 44,67 & 121 & 163 \\
\hline 37 & 20,99 & 20,69 & 15,27 & 24,20 & 81,15 & 44,89 & 125 & 164 \\
\hline 38 & 20,86 & 20,55 & 15,63 & 24,35 & 81,39 & 44,90 & 125 & 164 \\
\hline 39 & 20,28 & 20,40 & 15,63 & 24,16 & 80,47 & 44,56 & 124 & 163 \\
\hline 40 & 21,26 & 20,58 & 15,79 & 24,71 & 82,34 & 45,29 & 127 & 166 \\
\hline 41 & 19,96 & 21,98 & 15,99 & 23,76 & 81,69 & 45,74 & 126 & 167 \\
\hline 42 & 19,90 & 20,77 & 15,56 & 23,86 & 80,09 & 44,63 & 123 & 163 \\
\hline 43 & 20,22 & 20,50 & 15,00 & 25,08 & 80,80 & 45,58 & 124 & 167 \\
\hline
\end{tabular}


(continuação)

\begin{tabular}{|c|c|c|c|c|c|c|c|c|}
\hline 44 & 21,21 & 20,40 & 15,21 & 24,83 & 81,65 & 45,23 & 125 & 165 \\
\hline 45 & 21,29 & 20,00 & 15,20 & 24,56 & 81,05 & 44,56 & 125 & 163 \\
\hline 46 & 19,92 & 19,61 & 14,20 & 24,56 & 78,29 & 44,17 & 120 & 162 \\
\hline 47 & 20,20 & 19,90 & 14,25 & 24,49 & 78,84 & 44,39 & 121 & 162 \\
\hline 48 & 20,66 & 19,45 & 14,18 & 24,32 & 78,61 & 43,77 & 121 & 160 \\
\hline 49 & 20,93 & 20,51 & 14,57 & 24,70 & 80,71 & 45,21 & 124 & 165 \\
\hline 50 & 20,97 & 20,09 & 14,55 & 24,55 & 80,16 & 44,64 & 123 & 163 \\
\hline 51 & 20,40 & 20,00 & 14,56 & 24,69 & 79,65 & 44,69 & 122 & 163 \\
\hline 52 & 20,92 & 20,92 & 15,00 & 24,88 & 81,72 & 45,80 & 126 & 168 \\
\hline 53 & 21,08 & 16,45 & 16,17 & 25,58 & 79,28 & 42,03 & 122 & 154 \\
\hline 54 & 18,33 & 21,48 & 15,26 & 25,61 & 80,68 & 47,09 & 124 & 172 \\
\hline 55 & 18,47 & 19,09 & 15,44 & 26,60 & 79,60 & 45,69 & 122 & 167 \\
\hline 56 & 18,87 & 18,75 & 14,75 & 23,97 & 76,34 & 42,72 & 117 & 156 \\
\hline 57 & 19,00 & 22,45 & 15,40 & 25,01 & 81,86 & 47,46 & 126 & 174 \\
\hline 58 & 20,07 & 20,68 & 16,00 & 24,41 & 81,16 & 45,09 & 125 & 165 \\
\hline 59 & 20,16 & 20,88 & 14,89 & 24,85 & 80,78 & 45,73 & 124 & 167 \\
\hline 60 & 20,02 & 20,91 & 15,15 & 24,22 & 80,30 & 45,13 & 123 & 165 \\
\hline 61 & 20,22 & 21,00 & 15,27 & 24,64 & 81,13 & 45,64 & 125 & 167 \\
\hline 62 & 19,97 & 20,91 & 15,41 & 24,14 & 80,43 & 45,05 & 124 & 165 \\
\hline 63 & 19,96 & 20,66 & 15,10 & 23,62 & 79,34 & 44,28 & 122 & 162 \\
\hline 64 & 20,06 & 20,71 & 15,67 & 24,00 & 80,44 & 44,71 & 124 & 164 \\
\hline 65 & 19,93 & 22,36 & 15,94 & 24,38 & 82,61 & 46,74 & 127 & 171 \\
\hline 66 & 20,16 & 20,62 & 15,61 & 24,80 & 81,19 & 45,42 & 125 & 166 \\
\hline 67 & 20,19 & 20,80 & 15,35 & 25,07 & 81,41 & 45,87 & 125 & 168 \\
\hline 68 & 20,39 & 20,07 & 15,97 & 25,77 & 82,20 & 45,84 & 126 & 168 \\
\hline 69 & 20,06 & 20,45 & 14,75 & 24,93 & 80,19 & 45,38 & 123 & 166 \\
\hline 70 & 19,92 & 21,22 & 14,40 & 24,64 & 80,18 & 45,86 & 123 & 168 \\
\hline 71 & 20,27 & 21,21 & 15,13 & 25,43 & 82,04 & 46,64 & 126 & 171 \\
\hline \multirow[t]{5}{*}{72} & 20,41 & 20,39 & 15,26 & 25,84 & 81,90 & 46,23 & 126 & 169 \\
\hline & & & & Mínima & 76,34 & 42,03 & 117 & 154 \\
\hline & & & & Média & 80,69 & 45,11 & 124 & 165 \\
\hline & & & & Máxima & 82,99 & 47,46 & 128 & 174 \\
\hline & & & & DP & 1,24 & 0,95 & 1,90 & 3,47 \\
\hline
\end{tabular}

$\mathrm{TF}=$ tempo de funcionamento; $\mathrm{FAAG}=$ filtro ascendente de areia grossa; $\mathrm{FRD}=$ filtro rápido descendente; $\mathrm{AC}=$ água coagulada; DP = desvio padrão. 
Tabela B 6.1 - Características físicas da AB, AE e efluentes do FAAG e do FRD durante o ensaio 6 sem pré-oxidação e com DFIs no FAAG (FAAG $=120 \mathrm{~m}^{3} / \mathrm{m}^{2} \mathrm{~d} ; \mathrm{FRD}=200 \mathrm{~m}^{3} / \mathrm{m}^{2} \mathrm{~d}$ ).

\begin{tabular}{|c|c|c|c|c|c|c|c|}
\hline \multirow{2}{*}{$\begin{array}{l}\text { TF } \\
\text { (h) }\end{array}$} & \multirow{2}{*}{\begin{tabular}{|c|}
$\begin{array}{c}\text { Temperatura } \\
\left({ }^{\circ} \mathrm{C}\right)\end{array}$ \\
$\mathrm{AE}$ \\
\end{tabular}} & \multicolumn{4}{|c|}{ Cor aparente (uH) } & \multicolumn{2}{|c|}{ Cor verdadeira (uH) } \\
\hline & & $\mathrm{AB}$ & $\mathrm{AE}$ & FAAG & FRD & $\mathrm{AB}$ & $\mathrm{AE}$ \\
\hline 0 & 19,5 & 127 & 203 & 12,0 & 5,0 & 33 & 97 \\
\hline 1 & 19,0 & 123 & 204 & $<1,0$ & $<1,0$ & 14 & 76 \\
\hline 3 & 19,0 & & 204 & $<1,0$ & $<1,0$ & & 88 \\
\hline 5 & 19,0 & & 216 & $<1,0$ & $<1,0$ & & 96 \\
\hline 7 & 19,0 & 128 & 218 & $<1,0$ & $<1,0$ & 28 & 110 \\
\hline 9 & 19,0 & & 209 & $<1,0$ & $<1,0$ & & 87 \\
\hline 11 & 19,0 & & 224 & $<1,0$ & $<1,0$ & & 119 \\
\hline 13 & 18,5 & 133 & 199 & 2,0 & $<1,0$ & 18 & 87 \\
\hline 15 & 18,5 & & 212 & $<1,0$ & $<1,0$ & & 107 \\
\hline 17 & 18,0 & & 193 & $<1,0$ & $<1,0$ & & 100 \\
\hline 19 & 18,0 & 111 & 202 & $<1,0$ & $<1,0$ & 29 & 109 \\
\hline 21 & 18,0 & & 199 & $<1,0$ & $<1,0$ & & 92 \\
\hline 23 & 18,0 & & 204 & $<1,0$ & $<1,0$ & & 99 \\
\hline 26 & 18,5 & 130 & 212 & 6,0 & $<1,0$ & 25 & 109 \\
\hline 27 & 19,0 & & 242 & 14,0 & $<1,0$ & & 97 \\
\hline 29 & 19,0 & & 220 & 21,0 & $<1,0$ & & 115 \\
\hline 31 & 19,0 & 113 & 198 & 31,0 & $<1,0$ & 20 & 88 \\
\hline 33 & 18,5 & & 190 & 42,0 & $<1,0$ & & 88 \\
\hline 35 & 18,0 & & 200 & 77,0 & $<1,0$ & & 95 \\
\hline 37 & 17,5 & 103 & 189 & 3,0 & $<1,0$ & 23 & 99 \\
\hline 39 & 17,0 & & 194 & $<1,0$ & $<1,0$ & & 90 \\
\hline 41 & 17,0 & & 190 & 13,0 & $<1,0$ & & 96 \\
\hline 43 & 17,0 & 107 & 193 & 29,0 & $<1,0$ & 16 & 90 \\
\hline 45 & 17,0 & & 186 & 11,0 & $<1,0$ & & 91 \\
\hline 47 & 18,0 & & 203 & 24,0 & $<1,0$ & & 105 \\
\hline 50 & 18,5 & 128 & 201 & 31,0 & $<1,0$ & 21 & 95 \\
\hline 51 & 19,0 & & 210 & 39,0 & $<1,0$ & & 106 \\
\hline 53 & 20,0 & & 201 & 43,0 & $<1,0$ & & 95 \\
\hline 55 & 20,5 & 110 & 201 & 41,0 & $<1,0$ & 20 & 96 \\
\hline 57 & 20,0 & & 189 & 10,0 & $<1,0$ & & 106 \\
\hline 59 & 19,5 & & 191 & 19,0 & $<1,0$ & & 106 \\
\hline 61 & 19,0 & 98 & 183 & 31,0 & $<1,0$ & 19 & 98 \\
\hline 63 & 18,0 & & 189 & 40,0 & $<1,0$ & & 94 \\
\hline 65 & 18,0 & & 183 & 52,0 & $<1,0$ & & 104 \\
\hline 67 & 18,0 & 90 & 185 & 2,0 & $<1,0$ & 16 & 93 \\
\hline 69 & 18,5 & & 187 & 11,0 & $<1,0$ & & 94 \\
\hline 71 & 19,0 & & 193 & 23,0 & $<1,0$ & & 118 \\
\hline 72 & 20,0 & 97 & 174 & 26,0 & $<1,0$ & 25 & 88 \\
\hline Média & 18,6 & 114 & 200 & 17,3 & 0,6 & 22 & 98 \\
\hline Mínimo & 17,0 & 90 & 174 & $<1,0$ & $<1,0$ & 14 & 76 \\
\hline Máximo & 20,5 & 133 & 242 & 77,0 & 5,0 & 33 & 119 \\
\hline DP & 0,87 & 14,08 & 13,29 & 18,62 & 0,73 & 5,51 & 9,47 \\
\hline
\end{tabular}

$\mathrm{TF}=$ tempo de funcionamento; $\mathrm{AE}$ = água de estudo; $\mathrm{AB}$ = água bruta; FAAG = filtro ascendente de areia grossa; $F R D=$ filtro rápido descendente; $\mathrm{DP}=$ desvio padrão . 
Tabela B 6.2 - Características químicas da $A B, A E$ e efluentes do $F A A G$ e do FRD durante o ensaio 6 - sem pré-oxidação e com DFls no $F A A G\left(F A A G=120\right.$ m ${ }^{3} / m^{2}$ d; $\mathrm{FRD}=200 \mathrm{~m}^{3} / \mathrm{m}^{2} \mathrm{~d}$ )

\begin{tabular}{|c|c|c|c|c|c|c|c|c|c|c|c|c|c|c|c|c|c|}
\hline \multirow{2}{*}{$\begin{array}{l}\text { TF } \\
\text { (h) }\end{array}$} & \multicolumn{3}{|c|}{$\mathrm{pH}$} & \multicolumn{2}{|c|}{ Alcalinidade $\left(\mathrm{mg} / \mathrm{L} \mathrm{CaCO}_{3}\right)$} & \multicolumn{4}{|c|}{ Absorvância 254 nm } & \multicolumn{4}{|c|}{ COD (mg/L) } & \multicolumn{4}{|c|}{ Alumínio (mg/L) } \\
\hline & $\mathrm{AB}$ & $\mathrm{AE}$ & AC & $\mathrm{AB}$ & $\mathrm{AE}$ & $\mathrm{AB}$ & $\mathrm{AE}$ & FAAG & FRD & AB & $\mathrm{AE}$ & FAAG & FRD & $\mathrm{AB}$ & $\mathrm{AE}$ & FAAG & FRD \\
\hline 0 & 6,28 & 6,25 & 4,96 & 8,80 & 8,14 & 0,093 & 0,202 & 0,017 & 0,021 & 3,335 & 4,566 & 2,968 & 3,254 & 0,02 & 0,02 & - & 0,17 \\
\hline 1 & 6,22 & 6,19 & 4,86 & 6,82 & 7,26 & 0,102 & 0,197 & 0,016 & 0,011 & 3,097 & 4,432 & 2,500 & 2,732 & 0,02 & 0,02 & - & 0,18 \\
\hline 3 & & 6,14 & 5,00 & & & & & & & & & & & & & & \\
\hline 5 & & 6,42 & 5,02 & & & & & & & & & & & & & & \\
\hline 7 & 6,36 & 6,30 & 5,04 & 9,24 & 10,78 & 0,088 & 0,209 & 0,017 & 0,014 & & & & & & & & \\
\hline 9 & & 6,32 & 4,99 & & & & & & & & & & & & & & \\
\hline 11 & & 6,43 & 4,88 & & & & & & & & & & & & & & \\
\hline 13 & 6,48 & 6,40 & 4,99 & 8,58 & 8,58 & 0,073 & 0,188 & 0,013 & 0,020 & & & & & & & & \\
\hline 15 & & 6,24 & 4,97 & & & & & & & & & & & & & & \\
\hline 17 & & 6,46 & 5,05 & & & & & & & & & & & & & & \\
\hline 19 & 6,49 & 6,41 & 5,04 & 7,26 & 9,02 & 0,086 & 0,200 & 0,014 & 0,014 & & & & & & & & \\
\hline 21 & & 6,35 & 5,02 & & & & & & & & & & & & & & \\
\hline 23 & & 6,47 & 5,04 & & & & & & & & & & & & & & \\
\hline 26 & 6,41 & 6,46 & 5,03 & 7,26 & 7,92 & 0,087 & 0,203 & 0,016 & 0,016 & 3,040 & 4,957 & 2,421 & 2,362 & 0,02 & 0,02 & - & 0,19 \\
\hline 27 & & 6,57 & 5,06 & & & & & & & & & & & & & & \\
\hline 29 & & 6,49 & 5,05 & & & & & & & & & & & & & & \\
\hline 31 & 6,37 & 6,48 & 5,01 & 9,24 & 10,34 & 0,076 & 0,182 & 0,014 & 0,021 & & & & & & & & \\
\hline 33 & & 6,25 & 4,90 & & & & & & & & & & & & & & \\
\hline 35 & & 6,46 & 5,05 & & & & & & & & & & & & & & \\
\hline 37 & 6,34 & 6,28 & 5,04 & 7,70 & 10,78 & 0,075 & 0,196 & 0,015 & 0,021 & & & & & & & & \\
\hline 39 & & 6,33 & 5,01 & & & & & & & & & & & & & & \\
\hline 41 & & 6,33 & 5,02 & & & & & & & & & & & & & & \\
\hline 43 & 6,36 & 6,41 & 4,88 & 8,80 & 9,02 & 0,064 & 0,185 & 0,007 & 0,014 & & & & & & & & \\
\hline 45 & & 6,14 & 4,89 & & & & & & & & & & & & & & \\
\hline 47 & & 6,47 & 5,01 & & & & & & & & & & & & & & \\
\hline 50 & 6,40 & 6,55 & 5,03 & 8,80 & 9,02 & 0,073 & 0,198 & 0,017 & 0,020 & 2,819 & 3,989 & 2,284 & 2,344 & 0,04 & 0,04 & - & 0,25 \\
\hline 51 & & 6,50 & 4,97 & & & & & & & & & & & & & & \\
\hline
\end{tabular}




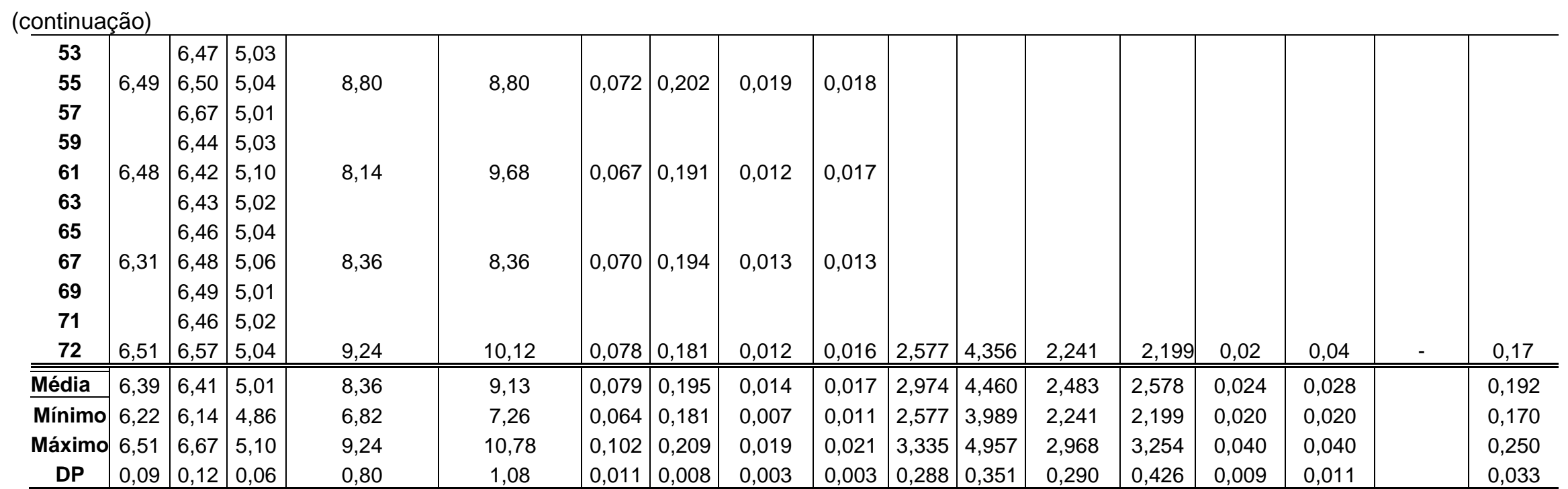

$\mathrm{TF}=$ tempo de funcionamento; $\mathrm{AE}$ = água de estudo; $\mathrm{AB}=$ água bruta; $\mathrm{AC}$ = água coagulada; $\mathrm{FAAG}$ = filtro ascendente de areia grossa; $\mathrm{FRD}=$ filtro rápido descendente; $\mathrm{DP}=$ desvio padrão. 
Tabela B 6.3 - Perda de carga no FAAG $\left(120 \mathrm{~m}^{3} / \mathrm{m}^{2} \mathrm{~d}\right)$ e no FRD $\left(200 \mathrm{~m}^{3} / \mathrm{m}^{2} \mathrm{~d}\right)$ durante o ensaio 6 , sem pré-oxidação e com DFls no FAAG para a temperatura T e para T = $20^{\circ} \mathrm{C}$.

\begin{tabular}{|c|c|c|c|c|c|c|c|c|c|c|c|c|c|c|c|c|c|c|c|c|c|c|}
\hline \multirow{3}{*}{$\begin{array}{l}\text { TF } \\
\text { (h) }\end{array}$} & \multicolumn{10}{|c|}{ FAAG } & \multicolumn{12}{|c|}{ FRD } \\
\hline & \multicolumn{3}{|c|}{$\begin{array}{c}\text { Leitura piezométrica } \\
(\mathrm{cm})\end{array}$} & \multirow{2}{*}{$\begin{array}{c}\mathrm{T} \\
\left({ }^{\circ} \mathrm{C}\right)\end{array}$} & \multicolumn{3}{|c|}{$\begin{array}{l}\text { Perda de carga } \\
\text { (cm) }\end{array}$} & \multicolumn{3}{|c|}{$\begin{array}{c}\text { Perda de carga }(\mathrm{cm}) \\
T=20^{\circ} \mathrm{C}\end{array}$} & \multicolumn{4}{|c|}{$\begin{array}{c}\text { Leitura piezométrica } \\
(\mathbf{c m})\end{array}$} & \multicolumn{4}{|c|}{$\begin{array}{l}\text { Perda de carga } \\
\text { (cm) }\end{array}$} & \multicolumn{4}{|c|}{$\begin{array}{l}\text { Perda de carga } \\
\text { (cm) }\end{array}$} \\
\hline & $\mathrm{P} 1$ & $\mathrm{P} 2$ & P3 & & P2-P1 & P3-P2 & P3-P1 & P2-P1 & P3-P2 & P3-P1 & $\mathrm{P} 1$ & P2 & P3 & $\mathrm{P} 4$ & P2-P1 & P3-P2 & P4-P3 & P4-P1 & P2-P1 & P3-P2 & P4-P3 & P4-P1 \\
\hline 0 & 45,4 & 55,9 & 56,6 & 19,5 & 10,5 & 0,7 & 11,2 & 10,3 & 0,7 & 11,0 & 12,0 & 35,5 & 49,5 & 63,6 & 23,5 & 14,0 & 14,1 & 51,6 & 23,0 & 13,7 & 13,8 & 50,6 \\
\hline 1 & 45,4 & 56,1 & 57,3 & 19,0 & 10,7 & 1,2 & 11,9 & 10,4 & 1,2 & 11,5 & 11,9 & 34,5 & 48,1 & 62,5 & 22,6 & 13,6 & 14,4 & 50,6 & 21,9 & 13,2 & 14,0 & 49,0 \\
\hline 2 & 45,4 & 57,0 & 59,0 & 19,0 & 11,6 & 2,0 & 13,6 & 11,2 & 1,9 & 13,2 & 11,9 & 33,9 & 47,0 & 61,4 & 22,0 & 13,1 & 14,4 & 49,5 & 21,3 & 12,7 & 14,0 & 48,0 \\
\hline 3 & 45,4 & 57,9 & 60,5 & 19,0 & 12,5 & 2,6 & 15,1 & 12,1 & 2,5 & 14,6 & 11,9 & 34,0 & 47,2 & 62,0 & 22,1 & 13,2 & 14,8 & 50,1 & 21,4 & 12,8 & 14,3 & 48,5 \\
\hline 4 & 45,4 & 58,7 & 61,7 & 19,0 & 13,3 & 3,0 & 16,3 & 12,9 & 2,9 & 15,8 & 11,9 & 34,3 & 47,6 & 62,7 & 22,4 & 13,3 & 15,1 & 50,8 & 21,7 & 12,9 & 14,6 & 49,2 \\
\hline 5 & 45,4 & 59,9 & 63,4 & 19,0 & 14,5 & 3,5 & 18,0 & 14,0 & 3,4 & 17,4 & 11,9 & 34,4 & 47,7 & 62,8 & 22,5 & 13,3 & 15,1 & 50,9 & 21,8 & 12,9 & 14,6 & 49,3 \\
\hline 6 & 45,4 & 61,2 & 65,2 & 19,0 & 15,8 & 4,0 & 19,8 & 15,3 & 3,9 & 19,2 & 11,9 & 33,9 & 47,1 & 62,1 & 22,0 & 13,2 & 15,0 & 50,2 & 21,3 & 12,8 & 14,5 & 48,6 \\
\hline 7 & 45,5 & 62,6 & 67,3 & 19,0 & 17,1 & 4,7 & 21,8 & 16,6 & 4,6 & 21,1 & 11,9 & 33,9 & 47,1 & 62,2 & 22,0 & 13,2 & 15,1 & 50,3 & 21,3 & 12,8 & 14,6 & 48,7 \\
\hline 8 & 45,5 & 64,3 & 69,4 & 19,0 & 18,8 & 5,1 & 23,9 & 18,2 & 4,9 & 23,2 & 11,9 & 33,5 & 46,5 & 61,5 & 21,6 & 13,0 & 15,0 & 49,6 & 20,9 & 12,6 & 14,5 & 48,1 \\
\hline 9 & 45,5 & 65,7 & 71,3 & 19,0 & 20,2 & 5,6 & 25,8 & 19,6 & 5,4 & 25,0 & 11,9 & 34,2 & 47,5 & 63,1 & 22,3 & 13,3 & 15,6 & 51,2 & 21,6 & 12,9 & 15,1 & 49,6 \\
\hline 10 & 45,5 & 67,5 & 73,5 & 19,0 & 22,0 & 6,0 & 28,0 & 21,3 & 5,8 & 27,1 & 11,9 & 34,9 & 47,2 & 62,3 & 23,0 & 12,3 & 15,1 & 50,4 & 22,3 & 11,9 & 14,6 & 48,8 \\
\hline 11 & 45,5 & 69,3 & 75,9 & 19,0 & 23,8 & 6,6 & 30,4 & 23,1 & 6,4 & 29,5 & 11,9 & 34,4 & 47,8 & 63,5 & 22,5 & 13,4 & 15,7 & 51,6 & 21,8 & 13,0 & 15,2 & 50,0 \\
\hline 12 & 45,5 & 71,2 & 78,1 & 19,0 & 25,7 & 6,9 & 32,6 & 24,9 & 6,7 & 31,6 & 11,9 & 34,5 & 48,0 & 64,0 & 22,6 & 13,5 & 16,0 & 52,1 & 21,9 & 13,1 & 15,5 & 50,5 \\
\hline 13 & 45,5 & 73,2 & 80,7 & 18,5 & 27,7 & 7,5 & 35,2 & 26,5 & 7,2 & 33,7 & 11,9 & 35,1 & 49,0 & 65,1 & 23,2 & 13,9 & 16,1 & 53,2 & 22,2 & 13,3 & 15,4 & 50,9 \\
\hline 14 & 45,5 & 75,0 & 83,0 & 18,5 & 29,5 & 8,0 & 37,5 & 28,2 & 7,7 & 35,9 & 11,9 & 34,9 & 48,8 & 65,0 & 23,0 & 13,9 & 16,2 & 53,1 & 22,0 & 13,3 & 15,5 & 50,8 \\
\hline 15 & 45,5 & 77,1 & 85,5 & 18,5 & 31,6 & 8,4 & 40,0 & 30,2 & 8,0 & 38,3 & 11,9 & 35,3 & 49,3 & 66,0 & 23,4 & 14,0 & 16,7 & 54,1 & 22,4 & 13,4 & 16,0 & 51,8 \\
\hline 16 & 45,5 & 78,7 & 87,5 & 18,5 & 33,2 & 8,8 & 42,0 & 31,8 & 8,4 & 40,2 & 11,9 & 35,4 & 49,4 & 65,8 & 23,5 & 14,0 & 16,4 & 53,9 & 22,5 & 13,4 & 15,7 & 51,6 \\
\hline 17 & 45,4 & 76,0 & 79,3 & 18,0 & 30,6 & 3,3 & 33,9 & 28,9 & 3,1 & 32,1 & 12,0 & 34,8 & 48,5 & 64,6 & 22,8 & 13,7 & 16,1 & 52,6 & 21,6 & 13,0 & 15,2 & 49,7 \\
\hline 18 & 45,4 & 78,7 & 83,2 & 18,0 & 33,3 & 4,5 & 37,8 & 31,5 & 4,3 & 35,7 & 11,8 & 34,7 & 48,4 & 64,5 & 22,9 & 13,7 & 16,1 & 52,7 & 21,7 & 13,0 & 15,2 & 49,8 \\
\hline 19 & 45,4 & 81,1 & 86,3 & 18,0 & 35,7 & 5,2 & 40,9 & 33,8 & 4,9 & 38,7 & 11,8 & 34,6 & 48,3 & 64,4 & 22,8 & 13,7 & 16,1 & 52,6 & 21,6 & 13,0 & 15,2 & 49,7 \\
\hline 20 & 45,4 & 82,8 & 88,5 & 18,0 & 37,4 & 5,7 & 43,1 & 35,4 & 5,4 & 40,8 & 11,8 & 34,5 & 48,0 & 64,0 & 22,7 & 13,5 & 16,0 & 52,2 & 21,5 & 12,8 & 15,1 & 49,4 \\
\hline 21 & 45,4 & 84,9 & 91,1 & 18,0 & 39,5 & 6,2 & 45,7 & 37,4 & 5,9 & 43,2 & 11,8 & 34,3 & 47,6 & 63,6 & 22,5 & 13,3 & 16,0 & 51,8 & 21,3 & 12,6 & 15,1 & 49,0 \\
\hline 22 & 45,5 & 71,1 & 73,1 & 18,0 & 25,6 & 2,0 & 27,6 & 24,2 & 1,9 & 26,1 & 11,8 & 34,8 & 48,6 & 65,0 & 23,0 & 13,8 & 16,4 & 53,2 & 21,7 & 13,0 & 15,5 & 50,3 \\
\hline 23 & 45,5 & 73,8 & 77,3 & 18,0 & 28,3 & 3,5 & 31,8 & 26,8 & 3,3 & 30,1 & 11,8 & 35,6 & 49,9 & 68,8 & 23,8 & 14,3 & 18,9 & 57,0 & 22,5 & 13,5 & 17,9 & 53,9 \\
\hline
\end{tabular}


(continuação)

\begin{tabular}{|c|c|c|c|c|c|c|c|c|c|c|c|c|c|c|c|c|c|c|c|c|c|c|}
\hline 24 & 45,5 & 76,4 & 80,6 & 18,0 & 30,9 & 4,2 & 35,1 & 29,2 & 4,0 & 33,2 & 11,8 & 35,5 & 49,8 & 69,1 & 23,7 & 14,3 & 19,3 & 57,3 & 22,4 & 13,5 & 18,3 & 54,2 \\
\hline 25 & 45,5 & 79,3 & 84,4 & 18,5 & 33,8 & 5,1 & 38,9 & 32,4 & 4,9 & 37,2 & 11,8 & 35,2 & 49,2 & 69,4 & 23,4 & 14,0 & 20,2 & 57,6 & 22,4 & 13,4 & 19,3 & 55,1 \\
\hline 26 & 45,5 & 82,2 & 87,8 & 18,5 & 36,7 & 5,6 & 42,3 & 35,1 & 5,4 & 40,5 & 11,8 & 35,7 & 50,1 & 72,2 & 23,9 & 14,4 & 22,1 & 60,4 & 22,9 & 13,8 & 21,2 & 57,8 \\
\hline 27 & 45,5 & 84,2 & 90,5 & 19,0 & 38,7 & 6,3 & 45,0 & 37,5 & 6,1 & 43,6 & 11,8 & 36,0 & 50,4 & 74,1 & 24,2 & 14,4 & 23,7 & 62,3 & 23,4 & 14,0 & 23,0 & 60,4 \\
\hline 28 & 45,5 & 86,9 & 93,9 & 19,0 & 41,4 & 7,0 & 48,4 & 40,1 & 6,8 & 46,9 & 11,8 & 35,7 & 50,1 & 76,3 & 23,9 & 14,4 & 26,2 & 64,5 & 23,2 & 14,0 & 25,4 & 62,5 \\
\hline 29 & 45,5 & 89,7 & 97,4 & 19,0 & 44,2 & 7,7 & 51,9 & 42,8 & 7,5 & 50,3 & 11,8 & 34,9 & 48,8 & 77,7 & 23,1 & 13,9 & 28,9 & 65,9 & 22,4 & 13,5 & 28,0 & 63,8 \\
\hline 30 & 45,5 & 92,6 & 100,9 & 19,0 & 47,1 & 8,3 & 55,4 & 45,6 & 8,0 & 53,7 & 11,8 & 34,2 & 47,9 & 81,0 & 22,4 & 13,7 & 33,1 & 69,2 & 21,7 & 13,3 & 32,1 & 67,0 \\
\hline 31 & 45,5 & 94,5 & 103,3 & 19,0 & 49,0 & 8,8 & 57,8 & 47,5 & 8,5 & 56,0 & 11,8 & 35,2 & 49,5 & 87,2 & 23,4 & 14,3 & 37,7 & 75,4 & 22,7 & 13,9 & 36,5 & 73,0 \\
\hline 32 & 45,5 & 97,2 & 106,5 & 19,0 & 51,7 & 9,3 & 61,0 & 50,1 & 9,0 & 59,1 & 11,8 & 35,2 & 50,1 & 88,5 & 23,4 & 14,9 & 38,4 & 76,7 & 22,7 & 14,4 & 37,2 & 74,3 \\
\hline 33 & 45,5 & 99,7 & 109,5 & 18,5 & 54,2 & 9,8 & 64,0 & 51,9 & 9,4 & 61,3 & 11,8 & 35,6 & 51,4 & 100,2 & 23,8 & 15,8 & 48,8 & 88,4 & 22,8 & 15,1 & 46,7 & 84,6 \\
\hline 34 & 45,5 & 101,8 & 112,4 & 18,5 & 56,3 & 10,6 & 66,9 & 53,9 & 10,1 & 64,0 & 11,8 & 35,5 & 51,9 & 106,0 & 23,7 & 16,4 & 54,1 & 94,2 & 22,7 & 15,7 & 51,8 & 90,2 \\
\hline 34,6 & 45,5 & 103,5 & 114,3 & 18,0 & 58,0 & 10,8 & 68,8 & 54,8 & 10,2 & 65,1 & 11,8 & 35,2 & 51,9 & 109,4 & 23,4 & 16,7 & 57,5 & 97,6 & 22,1 & 15,8 & 54,4 & 92,3 \\
\hline 35 & 45,5 & 97,8 & 101,0 & 18,0 & 52,3 & 3,2 & 55,5 & 49,5 & 3,0 & 52,5 & 11,7 & 35,0 & 51,9 & 112,1 & 23,3 & 16,9 & 60,2 & 100,4 & 22,0 & 16,0 & 56,9 & 94,9 \\
\hline 36 & 45,5 & 99,9 & 105,0 & 17,5 & 54,4 & 5,1 & 59,5 & 50,8 & 4,8 & 55,6 & 11,7 & 35,7 & 53,7 & 117,7 & 24,0 & 18,0 & 64,0 & 106,0 & 22,4 & 16,8 & 59,8 & 99,0 \\
\hline 37 & 45,5 & 102,8 & 108,8 & 17,5 & 57,3 & 6,0 & 63,3 & 53,5 & 5,6 & 59,1 & 11,7 & 35,4 & 53,3 & 116,4 & 23,7 & 17,9 & 63,1 & 104,7 & 22,1 & 16,7 & 59,0 & 97,8 \\
\hline 38 & 45,5 & 106,5 & 113,6 & 17,0 & & 7,1 & & 56,3 & & & 11,7 & 35,7 & 53,7 & 117,7 & 24,0 & 18,0 & & & 22,2 & 16,6 & 99,1 & 97,8 \\
\hline 39 & 45,5 & 109,2 & 116,9 & 17,0 & 63,7 & 7,7 & 71,4 & 58,8 & 7,1 & 65,9 & 11,7 & 35,6 & 53,6 & 118,3 & 23,9 & 18,0 & 64,7 & 106,6 & 22,1 & 16,6 & 59,7 & 98,4 \\
\hline 40 & 45,5 & 112,3 & 120,8 & 17,0 & 66,8 & 8,5 & 75,3 & 61,7 & 7,8 & 69,5 & 11,7 & 35,2 & 53,0 & 118,4 & 23,5 & 17,8 & 65,4 & 106,7 & 21,7 & 16,4 & 60,4 & 98,5 \\
\hline 41 & 45,5 & 115,5 & 124,6 & 17,0 & 70,0 & 9,1 & 79,1 & 64,6 & 8,4 & 73,0 & 11,7 & 36,5 & 55,4 & 125,2 & 24,8 & 18,9 & 69,8 & 113,5 & 22,9 & 17,4 & 64,4 & 104,8 \\
\hline 42 & 45,5 & 118,8 & 129,2 & 17,0 & 73,3 & 10,4 & 83,7 & 67,7 & 9,6 & 77,3 & 11,7 & 36,8 & 56,2 & 129,5 & 25,1 & 19,4 & 73,3 & 117,8 & 23,2 & 17,9 & 67,7 & 108,7 \\
\hline 43 & 45,4 & 91,0 & 94,4 & 17,0 & 45,6 & 3,4 & 49,0 & 42,1 & 3,1 & 45,2 & 11,7 & 37,1 & 57,3 & 147,6 & 25,4 & 20,2 & 90,3 & 135,9 & 23,4 & 18,6 & 83,3 & 125,4 \\
\hline 44 & 45,4 & 94,8 & 98,0 & 17,0 & 49,4 & 3,2 & 52,6 & 45,6 & 3,0 & 48,6 & 11,8 & 39,3 & 60,8 & 154,0 & 27,5 & 21,5 & 93,2 & 142,2 & 25,4 & 19,8 & 86,0 & 131,3 \\
\hline 45 & 45,4 & 97,1 & 102,2 & 17,0 & 51,7 & 5,1 & 56,8 & 47,7 & 4,7 & 52,4 & 11,7 & 38,3 & 59,1 & 151,5 & 26,6 & 20,8 & 92,4 & 139,8 & 24,6 & 19,2 & 85,3 & 129,0 \\
\hline 46 & 45,5 & 100,1 & 106,2 & 18,0 & 54,6 & 6,1 & 60,7 & 51,6 & 5,8 & 57,4 & 11,7 & 37,6 & 62,9 & 151,5 & 25,9 & 25,3 & 88,6 & 139,8 & 24,5 & 23,9 & 83,8 & 132,2 \\
\hline 47 & 45,5 & 102,7 & 109,5 & 18,0 & 57,2 & 6,8 & 64,0 & 54,1 & 6,4 & 60,5 & 11,7 & 38,7 & 60,0 & 161,0 & 27,0 & 21,3 & 101,0 & 149,3 & 25,5 & 20,1 & 95,5 & 141,2 \\
\hline 48 & 45,6 & 105,2 & 113,0 & 18,5 & 59,6 & 7,8 & 67,4 & 57,0 & 7,5 & 64,5 & 11,8 & 37,8 & 58,5 & 161,8 & 26,0 & 20,7 & 103,3 & 150,0 & 24,9 & 19,8 & 98,9 & 143,6 \\
\hline 49 & 45,6 & 107,7 & 115,9 & 18,5 & 62,1 & 8,2 & 70,3 & 59,4 & 7,8 & 67,3 & 11,8 & 37,7 & 58,4 & 168,0 & 25,9 & 20,7 & 109,6 & 156,2 & 24,8 & 19,8 & 104,9 & 149,5 \\
\hline 50 & 45,6 & 111,0 & 120,0 & 19,0 & 65,4 & 9,0 & 74,4 & 63,4 & 8,7 & 72,1 & 11,8 & 36,9 & 57,3 & 174,5 & 25,1 & 20,4 & 117,2 & 162,7 & 24,3 & 19,8 & 113,5 & 157,6 \\
\hline
\end{tabular}


(continuação)

\begin{tabular}{|c|c|c|c|c|c|c|c|c|c|c|c|c|c|c|c|c|c|c|c|c|c|c|}
\hline 51 & 45,6 & 113,2 & 123,0 & 19,0 & 67,6 & 9,8 & 77,4 & 65,5 & 9,5 & 75,0 & 11,8 & 37,3 & 58,2 & 186,3 & 25,5 & 20,9 & 128,1 & 174,5 & 24,7 & 20,2 & 124,1 & 169,1 \\
\hline 52 & 45,6 & 115,6 & 126,0 & 20,0 & 70,0 & 10,4 & 80,4 & 69,5 & 10,3 & 79,8 & 11,9 & 38,0 & 59,8 & 204,7 & 26,1 & 21,8 & 144,9 & 192,8 & 25,9 & 21,6 & 143,8 & 191,4 \\
\hline 53 & 45,6 & 118,0 & 128,9 & 20,0 & 72,4 & 10,9 & 83,3 & 71,9 & 10,8 & 82,7 & 11,9 & 36,1 & 56,7 & 211,5 & 24,2 & 20,6 & 154,8 & 199,6 & 24,0 & 20,4 & 153,6 & 198,1 \\
\hline 54 & 45,6 & 120,9 & 132,7 & 20,5 & 75,3 & 11,8 & 87,1 & 75,6 & 11,9 & 87,5 & 11,9 & 37,4 & 59,4 & 235,0 & 25,5 & 22,0 & 175,6 & 223,1 & 25,6 & 22,1 & 176,4 & 224,1 \\
\hline 54,5 & 45,6 & 121,0 & 133,7 & 20,5 & 75,4 & 12,7 & 88,1 & 75,7 & 12,8 & 88,5 & & & & & \multicolumn{8}{|c|}{ Lavagem do FRD por perda de carga } \\
\hline 55 & 45,6 & 84,2 & 87,1 & 20,0 & 38,6 & 2,9 & 41,5 & 38,3 & 2,9 & 41,2 & 11,8 & 32,5 & 45,1 & 83,3 & 20,7 & 12,6 & 38,2 & 71,5 & 20,5 & 12,5 & 37,9 & 71,0 \\
\hline 56 & 45,6 & 86,9 & 90,7 & 20,0 & 41,3 & 3,8 & 45,1 & 41,0 & 3,8 & 44,8 & 11,8 & 32,5 & 44,9 & 87,0 & 20,7 & 12,4 & 42,1 & 75,2 & 20,5 & 12,3 & 41,8 & 74,6 \\
\hline 57 & 45,6 & 91,0 & 96,1 & 19,5 & 45,4 & 5,1 & 50,5 & 44,5 & 5,0 & 49,5 & 11,8 & 31,8 & 44,0 & 88,7 & 20,0 & 12,2 & 44,7 & 76,9 & 19,6 & 12,0 & 43,8 & 75,4 \\
\hline 58 & 45,6 & 93,1 & 98,6 & 19,5 & 47,5 & 5,5 & 53,0 & 46,6 & 5,4 & 52,0 & 11,8 & 32,5 & 45,1 & 93,1 & 20,7 & 12,6 & 48,0 & 81,3 & 20,3 & 12,4 & 47,1 & 79,7 \\
\hline 59 & 45,6 & 96,5 & 102,6 & 19,0 & 50,9 & 6,1 & 57,0 & 49,3 & 5,9 & 55,2 & 11,8 & 32,1 & 44,5 & 96,1 & 20,3 & 12,4 & 51,6 & 84,3 & 19,7 & 12,0 & 50,0 & 81,7 \\
\hline 60 & 45,5 & 99,7 & 106,5 & 19,0 & 54,2 & 6,8 & 61,0 & 52,5 & 6,6 & 59,1 & 11,8 & 31,7 & 43,9 & 99,2 & 19,9 & 12,2 & 55,3 & 87,4 & 19,3 & 11,8 & 53,6 & 84,7 \\
\hline 61 & 45,5 & 103,0 & 110,4 & 18,0 & 57,5 & 7,4 & 64,9 & 54,4 & 7,0 & 61,4 & 11,8 & 32,2 & 44,9 & 106,5 & 20,4 & 12,7 & 61,6 & 94,7 & 19,3 & 12,0 & 58,3 & 89,6 \\
\hline 62 & 45,5 & 106,3 & 114,7 & 18,0 & 60,8 & 8,4 & 69,2 & 57,5 & 7,9 & 65,4 & 11,8 & 33,5 & $\begin{array}{l}47,7 \\
\end{array}$ & 118,1 & 21,7 & 14,2 & 70,4 & 106,3 & 20,5 & 13,4 & 66,6 & 100,5 \\
\hline 63 & 45,5 & 109,2 & 118,4 & 18,0 & 63,7 & 9,2 & 72,9 & 60,2 & 8,7 & 68,9 & 11,8 & 33,1 & 47,6 & 122,4 & 21,3 & 14,5 & 74,8 & 110,6 & 20,1 & 13,7 & 70,7 & 104,6 \\
\hline 64 & 45,5 & 111,6 & 121,2 & 18,0 & 66,1 & 9,6 & 75,7 & 62,5 & 9,1 & 71,6 & 11,8 & 33,1 & 48,1 & 127,3 & 21,3 & 15,0 & 79,2 & 115,5 & 20,1 & 14,2 & 74,9 & 109,2 \\
\hline 65 & 45,5 & 115,0 & 125,4 & 18,0 & 69,5 & 10,4 & 79,9 & 65,7 & 9,8 & 75,6 & 11,8 & 34,1 & 50,3 & 137,6 & 22,3 & 16,2 & 87,3 & 125,8 & 21,1 & 15,3 & 82,6 & 119,0 \\
\hline 66 & 45,5 & 100,6 & 104,3 & 18,0 & 55,1 & 3,7 & 58,8 & 52,1 & 3,5 & 55,6 & 11,7 & 33,2 & 49,8 & 150,1 & 21,5 & 16,6 & 100,3 & 138,4 & 20,3 & 15,7 & 94,8 & 130,9 \\
\hline 67 & 45,5 & 104,0 & 108,7 & 18,5 & 58,5 & 4,7 & 63,2 & 56,0 & 4,5 & 60,5 & 11,7 & 33,8 & 50,8 & 152,2 & 22,1 & 17,0 & 101,4 & 140,5 & 21,2 & 16,3 & 97,1 & 134,5 \\
\hline 68 & 45,4 & 109,4 & 114,9 & 18,5 & 64,0 & 5,5 & 69,5 & 61,3 & 5,3 & 66,5 & 11,7 & 34,5 & 52,0 & 156,3 & 22,8 & 17,5 & 104,3 & 144,6 & 21,8 & 16,8 & 99,8 & 138,4 \\
\hline 69 & 45,4 & 112,8 & 119,2 & 19,0 & 67,4 & 6,4 & 73,8 & 65,3 & 6,2 & 71,5 & 11,7 & 33,7 & 50,7 & 153,6 & 22,0 & 17,0 & 102,9 & 141,9 & 21,3 & 16,5 & 99,7 & 137,5 \\
\hline 70 & 45,6 & 116,1 & 123,2 & 19,0 & 70,5 & 7,1 & 77,6 & 68,3 & 6,9 & 75,2 & 11,7 & 33,8 & 50,9 & 156,8 & 22,1 & 17,1 & 105,9 & 145,1 & 21,4 & 16,6 & 102,6 & 140,6 \\
\hline 71 & 45,7 & 119,1 & 127,1 & 20,0 & 73,4 & 8,0 & 81,4 & 72,9 & 7,9 & 80,8 & 11,7 & 33,4 & 50,3 & 158,2 & 21,7 & 16,9 & 107,9 & 146,5 & 21,5 & 16,8 & 107,1 & 145,4 \\
\hline 72 & 45,7 & 120,1 & 130,8 & 20,0 & 74,4 & 10,7 & 85,1 & 73,8 & 10,6 & 84,5 & 11,7 & 32,8 & 49,5 & 159,1 & 21,1 & 16,7 & 109,6 & 147,4 & 20,9 & 16,6 & 108,8 & 146,3 \\
\hline
\end{tabular}

FAAG = filtro ascendente de areia grossa; FRD = filtro rápido descendente; $T F=$ tempo de funcionamento; $T$ = temperatura; Descargas de fundo intermediárias por perda de carga;

Descargas de fundo intermediárias quando a cor aparente do efluente do FAAG atingiu valor $\geq 50 \mathrm{uH}$; Lavagem do FRD por perda de carga; Lavagem do FRD por transpasse 


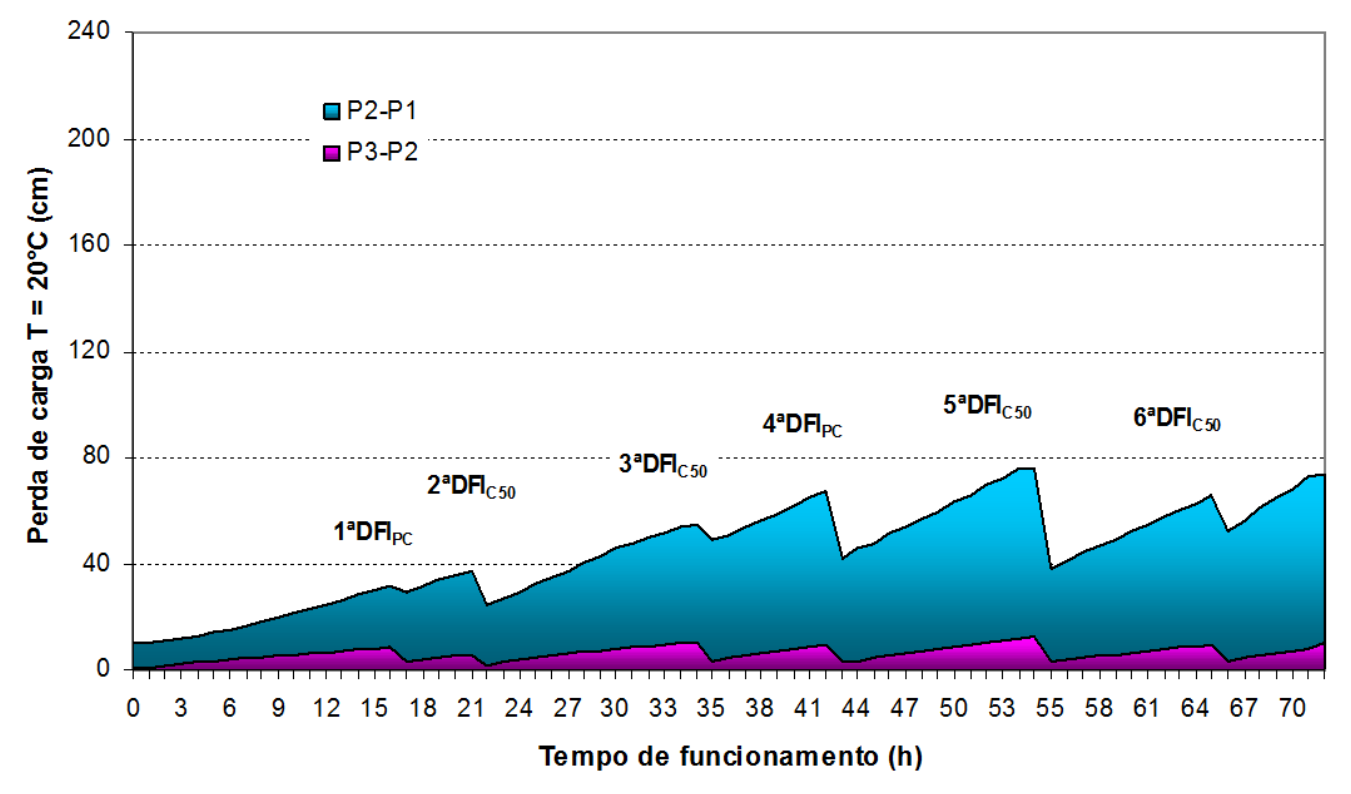

Figura B 6.1 - Perda de carga na camada suporte e camada de areia grossa no FAAG durante o ensaio 6 - sem pré-oxidação e com DFIs no FAAG (FAAG $=120 \mathrm{~m}^{3} / \mathrm{m}^{2} \mathrm{~d}$ e FRD $=200 \mathrm{~m}^{3} / \mathrm{m}^{2} \mathrm{~d}$ ). Fonte: Tabela B 6.3 - ANEXO B.

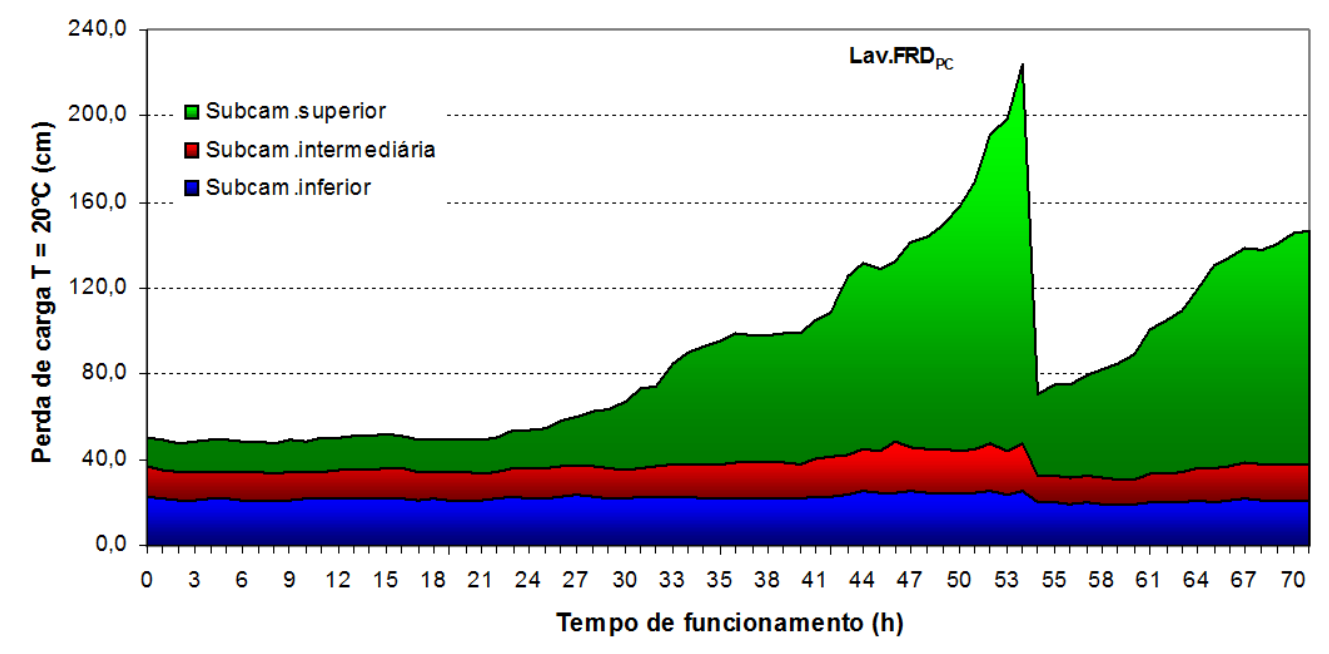

Figura B 6.2 - Perda de carga ao longo do meio filtrante do FRD durante o ensaio 6 - sem préoxidação e com DFIs no FAAG (FAAG $=120 \mathrm{~m}^{3} / \mathrm{m}^{2} \mathrm{~d}$ e FRD $=200 \mathrm{~m}^{3} / \mathrm{m}^{2} \mathrm{~d}$ ). Fonte: Tabela B $6.3-$ ANEXO B. 
Tabela B 6.4 - Variação de vazões e taxas de filtração do FAAG e do FRD durante o ensaio 6 - sem pré-oxidação e com DFIs no FAAG (FAAG $=120 \mathrm{~m}^{3} / \mathrm{m}^{2} \mathrm{~d} ; \mathrm{FRD}=200 \mathrm{~m}^{3} / \mathrm{m}^{2} \mathrm{~d}$ ).

\begin{tabular}{|c|c|c|c|c|c|c|c|c|}
\hline \multirow{2}{*}{$\begin{array}{l}\text { TF } \\
\text { (h) }\end{array}$} & \multicolumn{2}{|c|}{ descartes (L/h) } & \multicolumn{2}{|c|}{ turbidímetros (L/h) } & \multicolumn{2}{|c|}{ vazão total (L/h) } & \multicolumn{2}{|c|}{ taxas de filtração $\left(\mathrm{m}^{3} / \mathrm{m}^{2} \mathrm{~d}\right)$} \\
\hline & FAAG & FRD & FAAG & FRD & FAAG & FRD & FAAG & FRD \\
\hline 0 & 6,35 & 32,00 & 18,79 & 22,35 & 79,49 & 54,35 & 122 & 199 \\
\hline 1 & 6,95 & 32,24 & 18,02 & 23,50 & 80,71 & 55,74 & 124 & 204 \\
\hline 2 & 8,07 & 31,90 & 17,36 & 23,89 & 81,22 & 55,79 & 125 & 204 \\
\hline 3 & 8,67 & 30,71 & 17,68 & 23,53 & 80,59 & 54,24 & 124 & 198 \\
\hline 4 & 8,02 & 31,40 & 17,51 & 23,50 & 80,43 & 54,90 & 124 & 201 \\
\hline 5 & 7,84 & 32,09 & 17,71 & 23,65 & 81,29 & 55,74 & 125 & 204 \\
\hline 6 & 8,12 & 32,16 & 17,48 & 23,06 & 80,82 & 55,22 & 124 & 202 \\
\hline 7 & 8,20 & 31,76 & 17,60 & 23,70 & 81,26 & 55,46 & 125 & 203 \\
\hline 8 & 9,06 & 30,21 & 17,48 & 23,03 & 79,78 & 53,24 & 123 & 195 \\
\hline 9 & 8,60 & 32,73 & 17,21 & 23,82 & 82,36 & 56,55 & 127 & 207 \\
\hline 10 & 9,47 & 32,08 & 16,38 & 23,46 & 81,39 & 55,54 & 125 & 203 \\
\hline 11 & 8,46 & 32,73 & 17,65 & 23,39 & 82,23 & 56,12 & 126 & 205 \\
\hline 12 & 7,91 & 32,25 & 17,60 & 24,22 & 81,98 & 56,47 & 126 & 207 \\
\hline 13 & 8,25 & 32,69 & 16,73 & 23,29 & 80,96 & 55,98 & 124 & 205 \\
\hline 14 & 8,00 & 31,55 & 16,54 & 22,97 & 79,06 & 54,52 & 122 & 199 \\
\hline 15 & 7,56 & 31,00 & 16,46 & 22,68 & 77,70 & 53,68 & 119 & 196 \\
\hline 16 & 7,52 & 33,60 & 17,07 & 23,86 & 82,05 & 57,46 & 126 & 210 \\
\hline 17 & 10,14 & 30,98 & 16,14 & 23,67 & 80,93 & 54,65 & 124 & 200 \\
\hline 18 & 10,00 & 32,41 & 16,09 & 23,38 & 81,88 & 55,79 & 126 & 204 \\
\hline 19 & 9,74 & 31,60 & 16,00 & 23,13 & 80,47 & 54,73 & 124 & 200 \\
\hline 20 & 10,14 & 30,87 & 16,46 & 23,28 & 80,75 & 54,15 & 124 & 198 \\
\hline 21 & 9,46 & 30,28 & 16,41 & 23,23 & 79,38 & 53,51 & 122 & 196 \\
\hline 22 & 8,77 & 32,73 & 15,70 & 23,58 & 80,78 & 56,31 & 124 & 206 \\
\hline 23 & 8,49 & 35,08 & 14,06 & 23,60 & 81,23 & 58,68 & 125 & 215 \\
\hline 24 & 9,35 & 33,79 & 13,80 & 23,68 & 80,62 & 57,47 & 124 & 210 \\
\hline 25 & 10,03 & 34,12 & 13,65 & 23,40 & 81,20 & 57,52 & 125 & 210 \\
\hline 26 & 9,14 & 34,29 & 13,01 & 24,00 & 80,44 & 58,29 & 124 & 213 \\
\hline 27 & 8,36 & 35,58 & 13,05 & 23,17 & 80,16 & 58,75 & 123 & 215 \\
\hline 28 & 8,58 & 35,68 & 13,17 & 23,28 & 80,71 & 58,96 & 124 & 216 \\
\hline 29 & 10,63 & 33,93 & 12,39 & 23,15 & 80,10 & 57,08 & 123 & 209 \\
\hline 30 & 13,60 & 31,94 & 12,17 & 23,26 & 80,97 & 55,20 & 124 & 202 \\
\hline 31 & 11,32 & 34,45 & 11,25 & 23,69 & 80,71 & 58,14 & 124 & 213 \\
\hline 32 & 10,87 & 35,64 & 11,22 & 23,26 & 80,99 & 58,90 & 124 & 215 \\
\hline 33 & 12,90 & 32,07 & 11,68 & 23,13 & 79,78 & 55,20 & 123 & 202 \\
\hline 34 & 11,55 & 33,36 & 11,15 & 23,15 & 79,21 & 56,51 & 122 & 207 \\
\hline 35 & 10,26 & 31,23 & 13,26 & 22,83 & 77,58 & 54,06 & 119 & 198 \\
\hline 36 & 10,94 & 33,41 & 13,17 & 23,38 & 80,90 & 56,79 & 124 & 208 \\
\hline 37 & 10,75 & 32,81 & 13,85 & 23,17 & 80,58 & 55,98 & 124 & 205 \\
\hline 38 & 10,76 & 32,43 & 13,92 & 23,42 & 80,53 & 55,85 & 124 & 204 \\
\hline 39 & 10,50 & 32,16 & 14,03 & 22,59 & 79,28 & 54,75 & 122 & 200 \\
\hline 40 & 12,12 & 30,51 & 14,68 & 23,53 & 80,84 & 54,04 & 124 & 198 \\
\hline 41 & 9,60 & 32,34 & 14,05 & 19,09 & 75,08 & 51,43 & 115 & 188 \\
\hline 42 & 9,45 & 34,56 & 13,37 & 19,59 & 76,97 & 54,15 & 118 & 198 \\
\hline 43 & 9,14 & 30,07 & 14,02 & 23,52 & 76,75 & 53,59 & 118 & 196 \\
\hline
\end{tabular}


(continuação)

\begin{tabular}{|c|c|c|c|c|c|c|c|c|}
\hline 44 & 8,79 & 35,00 & 13,82 & 22,93 & 80,54 & 57,93 & 124 & 212 \\
\hline 45 & 10,88 & 32,91 & 13,95 & 23,15 & 80,89 & 56,06 & 124 & 205 \\
\hline 46 & 11,92 & 32,18 & 13,39 & 22,31 & 79,80 & 54,49 & 123 & 199 \\
\hline 47 & 9,75 & 34,51 & 14,32 & 23,04 & 81,62 & 57,55 & 125 & 211 \\
\hline 48 & 11,28 & 33,47 & 13,51 & 23,31 & 81,57 & 56,78 & 125 & 208 \\
\hline 49 & 11,89 & 33,60 & 12,69 & 23,96 & 82,14 & 57,56 & 126 & 211 \\
\hline 50 & 12,93 & 30,99 & 12,02 & 24,57 & 80,51 & 55,56 & 124 & 203 \\
\hline 51 & 12,17 & 32,12 & 11,83 & 23,85 & 79,97 & 55,97 & 123 & 205 \\
\hline 52 & 10,59 & 34,29 & 12,03 & 23,69 & 80,60 & 57,98 & 124 & 212 \\
\hline 53 & 13,95 & 31,68 & 11,42 & 23,72 & 80,77 & 55,40 & 124 & 203 \\
\hline 54 & 11,80 & 32,42 & 11,52 & 23,08 & 78,82 & 55,50 & 121 & 203 \\
\hline 55 & 12,15 & 34,56 & 11,83 & 23,46 & 82,00 & 58,02 & 126 & 212 \\
\hline 56 & 11,07 & 34,00 & 11,09 & 24,28 & 80,44 & 58,28 & 124 & 213 \\
\hline 57 & 13,55 & 32,80 & 11,31 & 24,22 & 81,88 & 57,02 & 126 & 209 \\
\hline 58 & 12,55 & 35,33 & 11,47 & 23,46 & 82,81 & 58,79 & 127 & 215 \\
\hline 59 & 13,93 & 33,55 & 11,08 & 23,18 & 81,74 & 56,73 & 126 & 208 \\
\hline 60 & 14,90 & 30,41 & 10,85 & 24,06 & 80,22 & 54,47 & 123 & 199 \\
\hline 61 & 14,27 & 30,87 & 10,97 & 23,09 & 79,20 & 53,96 & 122 & 197 \\
\hline 62 & 11,04 & 34,56 & 10,47 & 23,44 & 79,51 & 58,00 & 122 & 212 \\
\hline 63 & 12,46 & 33,52 & 10,47 & 23,55 & 80,00 & 57,07 & 123 & 209 \\
\hline 64 & 12,36 & 33,57 & 10,32 & 23,49 & 79,74 & 57,06 & 123 & 209 \\
\hline 65 & 11,40 & 34,98 & 10,27 & 23,40 & 80,05 & 58,38 & 123 & 214 \\
\hline 66 & 12,03 & 30,71 & 11,25 & 22,50 & 76,49 & 53,21 & 118 & 195 \\
\hline 67 & 13,62 & 31,98 & 11,22 & 23,90 & 80,72 & 55,88 & 124 & 204 \\
\hline 68 & 14,09 & 33,27 & 11,10 & 23,62 & 82,08 & 56,89 & 126 & 208 \\
\hline 69 & 14,94 & 32,00 & 11,34 & 23,45 & 81,73 & 55,45 & 126 & 203 \\
\hline 70 & 14,61 & 32,09 & 10,99 & 23,62 & 81,31 & 55,71 & 125 & 204 \\
\hline 71 & 14,79 & 32,02 & 11,52 & 23,34 & 81,67 & 55,36 & 126 & 203 \\
\hline \multirow[t]{5}{*}{72} & 14,36 & 30,52 & 10,94 & 23,69 & 79,51 & 54,21 & 122 & 198 \\
\hline & & & & Mínima & 75,08 & 51,43 & 115 & 188 \\
\hline & & & & Média & 80,42 & 55,98 & 124 & 205 \\
\hline & & & & Máxima & 82,81 & 58,96 & 127 & 216 \\
\hline & & & & $\overline{\mathrm{DP}}$ & 1,42 & 1,64 & 2,18 & 6,01 \\
\hline
\end{tabular}

$\mathrm{TF}=$ tempo de funcionamento; FAAG = filtro ascendente de areia grossa; FRD = filtro rápido descendente; DP = desvio padrão. 
Tabela B 7.1 - Características físicas da AB, AE e efluentes do FAAG e do FRD durante o ensaio 7 sem pré-oxidação e com DFIs no FAAG (FAAG $=120 \mathrm{~m}^{3} / \mathrm{m}^{2} \mathrm{~d} ; \mathrm{FRD}=240 \mathrm{~m}^{3} / \mathrm{m}^{2} \mathrm{~d}$ ).

\begin{tabular}{|c|c|c|c|c|c|c|c|}
\hline \multirow{2}{*}{$\frac{\overline{T F}}{\text { (h) }}$} & \multirow{2}{*}{\begin{tabular}{|c|}
$\begin{array}{c}\text { Temperatura } \\
\left({ }^{\circ} \mathrm{C}\right)\end{array}$ \\
$\mathrm{AE}$ \\
\end{tabular}} & \multicolumn{4}{|c|}{ Cor aparente (uH) } & \multicolumn{2}{|c|}{ Cor verdadeira (uH) } \\
\hline & & $\mathrm{AB}$ & $\mathrm{AE}$ & FAAG & FRD & $\mathrm{AB}$ & $\mathrm{AE}$ \\
\hline 0 & 22,0 & 123 & 206 & 32,0 & 7,0 & 20 & 106 \\
\hline 1 & 22,0 & 114 & 212 & 6,0 & 1,0 & 18 & 105 \\
\hline 3 & 22,5 & & 228 & 8,0 & $<1,0$ & & 118 \\
\hline 5 & 22,0 & & 205 & 3,0 & $<1,0$ & & 97 \\
\hline 7 & 21,5 & 130 & 196 & $<1,0$ & $<1,0$ & 22 & 88 \\
\hline 9 & 21,0 & & 214 & 2,0 & $<1,0$ & & 101 \\
\hline 11 & 21,0 & & 231 & $<1,0$ & $<1,0$ & & 115 \\
\hline 13 & 21,0 & 140 & 218 & $<1,0$ & $<1,0$ & 16 & 86 \\
\hline 15 & 21,0 & & 226 & $<1,0$ & $<1,0$ & & 86 \\
\hline 17 & 20,5 & & 229 & $<1,0$ & $<1,0$ & & 120 \\
\hline 19 & 21,0 & 123 & 205 & 4,0 & 2,0 & 20 & 95 \\
\hline 21 & 22,0 & & 207 & $<1,0$ & $<1,0$ & & 105 \\
\hline 23 & 22,5 & & 219 & 10,0 & $<1,0$ & & 99 \\
\hline 26 & 22,5 & 127 & 202 & 12,0 & $<1,0$ & 18 & 99 \\
\hline 27 & 23,0 & & 211 & 39,0 & $<1,0$ & & 99 \\
\hline 29 & 22,5 & & 221 & 30,0 & $<1,0$ & & 97 \\
\hline 31 & 22,0 & 133 & 214 & 38,0 & $<1,0$ & 19 & 103 \\
\hline 33 & 22,0 & & 217 & 45,0 & $<1,0$ & & 88 \\
\hline 35 & 21,5 & & 213 & 13,0 & $<1,0$ & & 90 \\
\hline 37 & 21,5 & 122 & 200 & 6,0 & $<1,0$ & 19 & 108 \\
\hline 39 & 21,0 & & 208 & 13,0 & $<1,0$ & & 103 \\
\hline 41 & 21,0 & & 207 & 21,0 & $<1,0$ & & 110 \\
\hline 43 & 21,5 & 132 & 207 & 27,0 & $<1,0$ & 19 & 95 \\
\hline 45 & 22,0 & & 209 & 36,0 & $<1,0$ & & 92 \\
\hline 47 & 22,5 & & 202 & 38,0 & $<1,0$ & & 94 \\
\hline 50 & 23,5 & 131 & 205 & 6,0 & $<1,0$ & 21 & 100 \\
\hline 51 & 24,0 & & 221 & 9,0 & $<1,0$ & & 96 \\
\hline 53 & 23,0 & & 218 & 34,0 & $<1,0$ & & 108 \\
\hline 55 & 22,5 & 131 & 209 & 27,0 & $<1,0$ & 19 & 105 \\
\hline 57 & 22,0 & & 231 & 29,0 & $<1,0$ & & 101 \\
\hline 59 & 22,0 & & 230 & 40,0 & $<1,0$ & & 95 \\
\hline 61 & 22,0 & 153 & 230 & 46,0 & $<1,0$ & 19 & 99 \\
\hline 63 & 22,0 & & 221 & 80,0 & $<1,0$ & & 94 \\
\hline 65 & 22,0 & & 221 & 27,0 & $<1,0$ & & 110 \\
\hline 67 & 22,0 & 130 & 205 & 36,0 & $<1,0$ & 15 & 90 \\
\hline 69 & 22,0 & & 211 & 41,0 & $<1,0$ & & 91 \\
\hline 71 & 21,0 & & 214 & 46,0 & $<1,0$ & & 87 \\
\hline 72 & 21,0 & 123 & 222 & 62,0 & $<1,0$ & 23 & 113 \\
\hline Média & 21,9 & 129 & 214 & 22,9 & 0,7 & 19 & 100 \\
\hline Mínimo & 20,5 & 114 & 196 & $<1,0$ & $<1,0$ & 15 & 86 \\
\hline Máximo & 24,0 & 153 & 231 & 80,0 & 7,0 & 23 & 120 \\
\hline DP & 0,76 & 9,26 & 9,63 & 19,68 & 1,08 & 2,11 & 8,93 \\
\hline
\end{tabular}

$\mathrm{T} \overline{\bar{F} \text { = tempo de funcionamento; } \mathrm{AE} \text { = água de estudo; } \mathrm{AB} \text { = água bruta; FAAG = filtro ascendente de areia grossa; }}$ $\mathrm{FRD}=$ filtro rápido descendente; $\mathrm{DP}=$ desvio padrão . 
Tabela B 7.2 - Características químicas da $A B, A E$ e efluentes do FAAG e do FRD durante o ensaio 7 - sem pré-oxidação e com DFls no FAAG $\left(F A A G=120\right.$ m ${ }^{3} / m^{2}$ d; $\left.\mathrm{FRD}=240 \mathrm{~m}^{3} / \mathrm{m}^{2} \mathrm{~d}\right)$.

\begin{tabular}{|c|c|c|c|c|c|c|c|c|c|c|c|c|c|c|c|c|c|}
\hline \multirow{2}{*}{$\begin{array}{l}\text { TF } \\
\text { (h) }\end{array}$} & \multicolumn{3}{|c|}{$\mathrm{pH}$} & \multicolumn{2}{|c|}{ Alcalinidade $\left(\mathrm{mg} / \mathrm{L} \mathrm{CaCO}_{3}\right)$} & \multicolumn{4}{|c|}{ Absorvância 254 nm } & \multicolumn{4}{|c|}{ COD (mg/L) } & \multicolumn{4}{|c|}{ Alumínio (mg/L) } \\
\hline & $\mathrm{AB}$ & $\mathrm{AE}$ & $\mathrm{AC}$ & AB & $\mathbf{A E}$ & AB & $\mathrm{AE}$ & FAAG & FRD & AB & $\mathbf{A E}$ & FAAG & FRD & AB & $\mathrm{AE}$ & FAAG & FRD \\
\hline 0 & 6,40 & 6,38 & 4,97 & 8,36 & 9,24 & 0,064 & 0,194 & 0,018 & 0,040 & 2,571 & 4,160 & 2,279 & 2,779 & 0,02 & 0,02 & 0,81 & - \\
\hline 1 & 6,22 & 6,40 & 4,96 & 8,58 & 8,36 & 0,064 & 0,203 & 0,008 & 0,014 & 2,483 & 3,979 & 1,852 & 1,842 & 0,05 & 0,06 & - & - \\
\hline 3 & & 6,62 & 4,95 & & & & & & & & & & & & & & \\
\hline 5 & & 6,76 & 5,04 & & & & & & & & & & & & & & \\
\hline 7 & 6,44 & 6,60 & 5,09 & 10,12 & 9,68 & 0,073 & 0,177 & 0,010 & 0,015 & & & & & & & & \\
\hline 9 & & 6,70 & 5,13 & & & & & & & & & & & & & & \\
\hline 11 & & 6,45 & 5,10 & & & & & & & & & & & & & & \\
\hline 13 & 6,62 & 6,44 & 5,11 & 9,90 & 9,90 & 0,061 & 0,173 & 0,009 & 0,015 & & & & & & & & \\
\hline 15 & & 6,47 & 5,10 & & & & & & & & & & & & & & \\
\hline 17 & & 6,38 & 4,97 & & & & & & & & & & & & & & \\
\hline 19 & 6,67 & 6,41 & 5,05 & 9,24 & 9,24 & 0,062 & 0,184 & 0,021 & 0,017 & & & & & & & & \\
\hline 21 & & 6,49 & 4,99 & & & & & & & & & & & & & & \\
\hline 23 & & 6,58 & 5,01 & & & & & & & & & & & & & & \\
\hline 25 & 6,63 & 6,48 & 4,97 & 8,58 & 10,34 & 0,068 & 0,199 & 0,013 & 0,018 & 2,914 & 3,464 & 2,037 & 2,295 & 0,07 & 0,06 & 0,83 & - \\
\hline 27 & & 6,49 & 4,94 & & & & & & & & & & & & & & \\
\hline 29 & & 6,52 & 5,00 & & & & & & & & & & & & & & \\
\hline 31 & 6,46 & 6,42 & 5,06 & 8,58 & 8,80 & 0,061 & 0,191 & 0,013 & 0,016 & & & & & & & & \\
\hline 33 & & 6,72 & 4,92 & & & & & & & & & & & & & & \\
\hline 35 & & 6,44 & 4,99 & & & & & & & & & & & & & & \\
\hline 37 & 6,53 & 6,44 & 5,01 & 8,36 & 8,58 & 0,067 & 0,202 & 0,017 & 0,019 & & & & & & & & \\
\hline 39 & & 6,65 & 5,01 & & & & & & & & & & & & & & \\
\hline 41 & & 6,58 & 4,99 & & & & & & & & & & & & & & \\
\hline 43 & 6,56 & 6,53 & 5,00 & 8,36 & 10,12 & 0,059 & 0,178 & 0,009 & 0,016 & & & & & & & & \\
\hline 45 & & 6,56 & 4,99 & & & & & & & & & & & & & & \\
\hline 47 & & 6,62 & 4,99 & & & & & & & & & & & & & & \\
\hline 49 & 6,59 & 6,48 & 4,99 & 8,14 & 8,80 & 0,059 & 0,183 & 0,010 & 0,014 & 3,239 & 2,808 & 2,409 & 2,480 & - & - & - & - \\
\hline 51 & & 6,56 & 4,99 & & & & & & & & & & & & & & \\
\hline
\end{tabular}




\begin{tabular}{|c|c|c|c|c|c|c|c|c|c|c|c|c|c|c|c|c|c|}
\hline 53 & & 659 & 499 & & & & & & & & & & & & & & \\
\hline 55 & 6,63 & 6,61 & 5,02 & 8,14 & 9,90 & 0,066 & 0,187 & 0,014 & 0,017 & & & & & & & & \\
\hline 57 & & 6,71 & 4,91 & & & & & & & & & & & & & & \\
\hline 59 & & 6,84 & 4,96 & & & & & & & & & & & & & & \\
\hline 61 & 6,58 & 6,55 & 5,07 & 8,36 & 9,90 & 0,065 & 0,180 & 0,011 & 0,017 & & & & & & & & \\
\hline 63 & & 6,50 & 5,08 & & & & & & & & & & & & & & \\
\hline 65 & & 6,60 & 4,97 & & & & & & & & & & & & & & \\
\hline 67 & 6,61 & 6,53 & 4,97 & 9,02 & 10,12 & 0,060 & 0,172 & 0,016 & 0,019 & & & & & & & & \\
\hline 69 & & 6,43 & 4,80 & & & & & & & & & & & & & & \\
\hline 71 & & 6,53 & 4,92 & & & & & & & & & & & & & & \\
\hline 72 & 6,46 & 6,53 & 4,82 & 9,20 & 9,20 & 0,065 & 0,205 & 0,012 & 0,019 & 2,422 & 3,161 & 2,022 & 1,815 & 0,02 & 0,02 & 0,82 & 0,51 \\
\hline Média & 6,53 & 6,54 & 5,00 & 8,78 & 9,44 & 0,064 & 0,188 & 0,013 & 0,018 & 2,726 & 3,514 & 2,120 & 2,242 & 0,040 & 0,040 & 0,820 & \\
\hline Mínimo & 6,22 & 6,38 & 4,80 & 8,14 & 8,36 & 0,059 & 0,172 & 0,008 & 0,014 & 2,422 & 2,808 & 1,852 & 1,815 & 0,020 & 0,020 & 0,810 & \\
\hline Máximo & 6,67 & 6,84 & 5,13 & 10,12 & 10,34 & 0,073 & 0,205 & 0,021 & 0,040 & 3,239 & 4,160 & 2,409 & 2,779 & 0,070 & 0,060 & 0,830 & \\
\hline DP & 0,12 & 0,11 & 0,07 & 0,63 & 0,64 & 0,004 & 0,011 & 0,004 & 0,006 & 0,344 & 0,561 & 0,222 & 0,415 & 0,024 & 0,023 & 0,010 & \\
\hline
\end{tabular}

$\mathrm{TF}$ = tempo de funcionamento; $\mathrm{AE}$ = água de estudo; $\mathrm{AB}=$ água bruta; $\mathrm{AC}=$ água coagulada; $\mathrm{FAAG}=$ filtro ascendente de areia grossa; $\mathrm{FRD}=$ filtro rápido descendente; $\mathrm{DP}=$ desvio padrão. 
Tabela B 7.3 - Perda de carga no FAAG $\left(120 \mathrm{~m}^{3} / \mathrm{m}^{2} \mathrm{~d}\right)$ e no FRD $\left(240 \mathrm{~m}^{3} / \mathrm{m}^{2} \mathrm{~d}\right)$ durante o ensaio 7 , sem pré-oxidação e com DFls no FAAG para a temperatura $\mathrm{T}$ e para $\mathrm{T}=20^{\circ} \mathrm{C}$.

\begin{tabular}{|c|c|c|c|c|c|c|c|c|c|c|c|c|c|c|c|c|c|c|c|c|c|c|}
\hline \multirow{3}{*}{$\begin{array}{l}\text { TF } \\
\text { (h) }\end{array}$} & \multicolumn{10}{|c|}{ FAAG } & \multicolumn{12}{|c|}{ FRD } \\
\hline & \multicolumn{3}{|c|}{$\begin{array}{c}\text { Leitura piezométrica } \\
(\mathbf{c m})\end{array}$} & \multirow{2}{*}{$\begin{array}{c}\mathrm{T} \\
\left({ }^{\circ} \mathrm{C}\right)\end{array}$} & \multicolumn{3}{|c|}{$\begin{array}{c}\text { Perda de carga } \\
\text { (cm) }\end{array}$} & \multicolumn{3}{|c|}{$\begin{array}{c}\text { Perda de carga }(\mathrm{cm}) \\
\mathrm{T}=20^{\circ} \mathrm{C}\end{array}$} & \multicolumn{4}{|c|}{\begin{tabular}{|c|} 
Leitura piezométrica \\
$(\mathrm{cm})$
\end{tabular}} & \multicolumn{4}{|c|}{$\begin{array}{l}\text { Perda de carga } \\
\text { (cm) }\end{array}$} & \multicolumn{4}{|c|}{$\begin{array}{c}\text { Perda de carga }(\mathrm{cm}) \\
\mathrm{T}=20^{\circ} \mathrm{C}\end{array}$} \\
\hline & $\mathrm{P} 1$ & $\mathrm{P} 2$ & P3 & & P2-P1 & P3-P2 & P3-P1 & P2-P1 & P3-P2 & P3-P1 & P1 & P2 & P3 & $\mathrm{P} 4$ & P2-P1 & P3-P2 & P4-P3 & P4-P1 & P2-P1 & P3-P2 & P4-P3 & P4-P1 \\
\hline 0 & 45,6 & 55,6 & 56,6 & 22,0 & 10,0 & 1,0 & 11,0 & 10,4 & 1,0 & 11,5 & 12,0 & 32,0 & 48,4 & 68,3 & 20,0 & 16,4 & 19,9 & 56,3 & 20,8 & 17,1 & 20,7 & 58,6 \\
\hline 1 & 45,7 & 56,4 & 57,5 & 22,0 & 10,7 & 1,1 & 11,8 & 11,1 & 1,1 & 12,3 & 12,1 & 33,3 & 50,8 & 73,8 & 21,2 & 17,5 & 23,0 & 61,7 & 22,1 & 18,2 & 24,0 & 64,3 \\
\hline 2 & 45,7 & 57,0 & 58,6 & 22,0 & 11,3 & 1,6 & 12,9 & 11,8 & 1,7 & 13,4 & 12,1 & 32,3 & 49,1 & 72,3 & 20,2 & 16,8 & 23,2 & 60,2 & 21,0 & 17,5 & 24,2 & 62,7 \\
\hline 3 & 45,8 & 58,0 & 60,2 & 22,5 & 12,2 & 2,2 & 14,4 & 12,9 & 2,3 & 15,2 & 12,1 & 31,0 & 46,9 & 70,0 & 18,9 & 15,9 & 23,1 & 57,9 & 19,9 & 16,8 & 24,4 & 61,0 \\
\hline 4 & 45,8 & 58,9 & 61,6 & 22,5 & 13,1 & 2,7 & 15,8 & 13,8 & 2,8 & 16,7 & 12,1 & 32,1 & 48,7 & 73,6 & 20,0 & 16,6 & 24,9 & 61,5 & 21,1 & 17,5 & 26,3 & 64,8 \\
\hline 5 & 45,8 & 59,8 & 62,8 & 22,0 & 14,0 & 3,0 & 17,0 & 14,6 & 3,1 & 17,7 & 12,1 & 32,1 & 48,9 & 74,8 & 20,0 & 16,8 & 25,9 & 62,7 & 20,8 & 17,5 & 27,0 & 65,3 \\
\hline 6 & 45,7 & 61,0 & 64,6 & 22,0 & 15,3 & 3,6 & 18,9 & 15,9 & 3,8 & 19,7 & 12,0 & 32,0 & 48,8 & 75,4 & 20,0 & 16,8 & 26,6 & 63,4 & 20,8 & 17,5 & 27,7 & 66,0 \\
\hline 7 & 45,7 & 62,4 & 66,5 & 21,5 & 16,7 & 4,1 & 20,8 & 17,2 & 4,2 & 21,4 & 12,0 & 32,3 & 49,4 & 77,2 & 20,3 & 17,1 & 27,8 & 65,2 & 20,9 & 17,6 & 28,6 & 67,1 \\
\hline 8 & 45,7 & 63,9 & 68,5 & 21,5 & 18,2 & 4,6 & 22,8 & 18,7 & 4,7 & 23,5 & 12,0 & 32,3 & 49,4 & 78,0 & 20,3 & 17,1 & 28,6 & 66,0 & 20,9 & 17,6 & 29,4 & 67,9 \\
\hline 9 & 45,7 & 65,4 & 70,5 & 21,0 & 19,7 & 5,1 & 24,8 & 20,0 & 5,2 & 25,2 & 12,0 & 32,6 & 49,9 & 79,3 & 20,6 & 17,3 & 29,4 & 67,3 & 20,9 & 17,6 & 29,9 & 68,4 \\
\hline 10 & 45,7 & 66,9 & 72,4 & 21,0 & 21,2 & 5,5 & 26,7 & 21,6 & 5,6 & 27,1 & 12,0 & 32,8 & 50,3 & 80,1 & 20,8 & 17,5 & 29,8 & 68,1 & 21,2 & 17,8 & 30,3 & 69,2 \\
\hline 11 & 45,7 & 68,1 & 73,9 & 21,0 & 22,4 & 5,8 & 28,2 & 22,8 & 5,9 & 28,7 & 12,0 & 32,8 & 50,3 & 80,0 & 20,8 & 17,5 & 29,7 & 68,0 & 21,2 & 17,8 & 30,2 & 69,1 \\
\hline 12 & 45,7 & 69,8 & 76,0 & 21,0 & 24,1 & 6,2 & 30,3 & 24,5 & 6,3 & 30,8 & 12,0 & 32,9 & 50,6 & 80,6 & 20,9 & 17,7 & 30,0 & 68,6 & 21,3 & 18,0 & 30,5 & 69,8 \\
\hline 13 & 45,6 & 71,2 & 77,7 & 21,0 & 25,6 & 6,5 & 32,1 & 26,0 & 6,6 & 32,6 & 12,0 & 33,0 & 50,6 & 80,6 & 21,0 & 17,6 & 30,0 & 68,6 & 21,4 & 17,9 & 30,5 & 69,8 \\
\hline 14 & 45,7 & 72,7 & 79,5 & 21,0 & 27,0 & 6,8 & 33,8 & 27,5 & 6,9 & 34,4 & 12,0 & 33,0 & 50,6 & 80,6 & 21,0 & 17,6 & 30,0 & 68,6 & 21,4 & 17,9 & 30,5 & 69,8 \\
\hline 15 & 45,6 & 74,6 & 81,8 & 21,0 & 29,0 & 7,2 & 36,2 & 29,5 & 7,3 & 36,8 & 12,0 & 33,3 & 51,4 & 81,8 & 21,3 & 18,1 & 30,4 & 69,8 & 21,7 & 18,4 & 30,9 & 71,0 \\
\hline 16 & 45,6 & 76,0 & 83,7 & 21,0 & 30,4 & 7,7 & 38,1 & 30,9 & 7,8 & 38,7 & 12,0 & 33,3 & 51,4 & 81,8 & 21,3 & 18,1 & 30,4 & 69,8 & 21,7 & 18,4 & 30,9 & 71,0 \\
\hline 17 & 45,7 & 78,7 & 85,7 & 20,5 & 33,0 & 7,0 & 40,0 & 33,2 & 7,0 & 40,2 & 11,9 & 33,3 & 51,3 & 81,7 & 21,4 & 18,0 & 30,4 & 69,8 & 21,5 & 18,1 & 30,5 & 70,1 \\
\hline 18 & 45,7 & 79,3 & 87,7 & 20,5 & 33,6 & 8,4 & 42,0 & 33,8 & 8,4 & 42,2 & 11,9 & 33,3 & 51,3 & 81,7 & 21,4 & 18,0 & 30,4 & 69,8 & 21,5 & 18,1 & 30,5 & 70,1 \\
\hline 19 & 45,8 & 65,8 & 67,6 & 21,0 & 20,0 & 1,8 & 21,8 & 20,3 & 1,8 & 22,2 & 11,9 & 33,7 & 51,9 & 83,1 & 21,8 & 18,2 & 31,2 & 71,2 & 22,2 & 18,5 & 31,7 & 72,4 \\
\hline 20 & 45,8 & 67,0 & 69,4 & 21,0 & 21,2 & 2,4 & 23,6 & 21,6 & 2,4 & 24,0 & 11,9 & 32,5 & 49,9 & 79,6 & 20,6 & 17,4 & 29,7 & 67,7 & 20,9 & 17,7 & 30,2 & 68,8 \\
\hline 21 & 45,8 & 68,4 & 71,2 & 22,0 & 22,6 & 2,8 & 25,4 & 23,5 & 2,9 & 26,5 & 11,9 & 32,3 & 49,4 & 79,1 & 20,4 & 17,1 & 29,7 & 67,2 & 21,3 & 17,8 & 30,9 & 70,0 \\
\hline 22 & 45,8 & 69,8 & 73,2 & 22,0 & 24,0 & 3,4 & 27,4 & 25,0 & 3,5 & 28,5 & 11,9 & 32,0 & 48,9 & 78,8 & 20,1 & 16,9 & 29,9 & 66,9 & 20,9 & 17,6 & 31,1 & 69,7 \\
\hline 23 & 45,8 & 71,6 & 75,6 & 22,5 & 25,8 & 4,0 & 29,8 & 27,2 & 4,2 & 31,4 & 11,9 & 31,9 & 48,7 & 79,2 & 20,0 & 16,8 & 30,5 & 67,3 & 21,1 & 17,7 & 32,2 & 71,0 \\
\hline
\end{tabular}


(continuação)

\begin{tabular}{|c|c|c|c|c|c|c|c|c|c|c|c|c|c|c|c|c|c|c|c|c|c|c|}
\hline 24 & 45,7 & 73,2 & 77,7 & 22,5 & 27,5 & 4,5 & 32,0 & 29,0 & 4,7 & 33,7 & 11,9 & 32,0 & 48,8 & 80,3 & 20,1 & 16,8 & 31,5 & 68,4 & 21,2 & 17,7 & 33,2 & 72,1 \\
\hline 25 & 45,7 & 74,8 & 80,0 & 22,5 & 29,1 & 5,2 & 34,3 & 30,7 & 5,5 & 36,2 & 11,9 & 31,9 & 48,5 & 81,5 & 20,0 & 16,6 & 33,0 & 69,6 & 1,1 & 17,5 & 34,8 & 73,4 \\
\hline 26 & 45,7 & 76,7 & 82,5 & 22,5 & 31,0 & 5,8 & 36,8 & 32,7 & 6,1 & 38,8 & 11,9 & 31,9 & 48,6 & 83,6 & 20,0 & 16,7 & 35,0 & 71,7 & 1,1 & 17,6 & 6,9 & 75,6 \\
\hline 27 & 45,7 & 78,2 & 84,4 & 23,0 & 32,5 & 6,2 & 38,7 & 34,7 & 6,6 & 41,3 & 11,9 & 32,0 & 49,0 & 87,5 & 20,1 & 17,0 & 38,5 & 75,6 & 21,5 & 18,1 & 41,1 & 80,7 \\
\hline 28 & 45,7 & 80,0 & 87,0 & 23,0 & 34,3 & 7,0 & 41,3 & 36,6 & 7,5 & 44,1 & 11,9 & 31,5 & 48,7 & 89,0 & 19,6 & 17,2 & 40,3 & 77,1 & 20,9 & 18,4 & 43,0 & 82,3 \\
\hline 29 & 45,7 & 82,2 & 89,6 & 22,5 & 36,5 & 7,4 & 43,9 & 38,5 & 7,8 & 46,3 & 11,9 & 31,7 & 48,9 & 94,2 & 19,8 & 17,2 & 45,3 & 82,3 & 20,9 & 18,1 & 47,8 & 86,8 \\
\hline 30 & 45,7 & 84,2 & 92,3 & 22,5 & 38,5 & 8,1 & 46,6 & 40,6 & 8,5 & 49,1 & 11,9 & 32,2 & 50,4 & 100,6 & 20,3 & 18,2 & 50,2 & 88,7 & 21,4 & 19,2 & 52,9 & 93,5 \\
\hline 31 & 45,7 & 86,0 & 94,6 & 22,0 & 40,3 & 8,6 & 48,9 & 42,0 & 9,0 & 50,9 & 11,9 & 32,4 & 51,5 & 108,0 & 20,5 & 19,1 & 56,5 & 96,1 & 21,4 & 19,9 & 58,9 & 100,1 \\
\hline 32 & 45,7 & 88,0 & 96,9 & 22,0 & 42,3 & 8,9 & 51,2 & 44,1 & 9,3 & 53,3 & 11,9 & 32,8 & 53,0 & 116,1 & 20,9 & 20,2 & 63,1 & 104,2 & 21,8 & 21,0 & 65,7 & 08,5 \\
\hline 33 & 45,7 & 89,9 & 99,4 & 22,0 & 44,2 & 9,5 & 53,7 & 46,0 & 9,9 & 55,9 & 11,9 & 33,3 & 54,7 & 125,3 & 21,4 & 21,4 & 70,6 & 113,4 & 22,3 & 22,3 & 73,5 & 118,1 \\
\hline 34 & 45,7 & 91,8 & 101,7 & 22,0 & 46,1 & 9,9 & 56,0 & 48,0 & 10,3 & 58,3 & 11,9 & 34,7 & 56,2 & 137,0 & 22,8 & 21,5 & 80,8 & 125,1 & 3,8 & 22,4 & 84,2 & 130,3 \\
\hline 35 & 45,6 & 71,5 & & 21,5 & 25,9 & 2,6 & 28,5 & & 2,7 & & & 33,9 &, 7 & & 2,0 & 2,8 & & & 2,6 & 3,5 & & \\
\hline 36 & 45,6 & 73,3 & 76,7 & 21,5 & 27,7 & 3,4 & 31,1 & 28,5 & 3,5 & 32,0 & 11,9 & 34,6 & 58,0 & 152,1 & 22,7 & 23,4 & 94,1 & 140,2 & 23,4 & 24,1 & 96,8 & 144,3 \\
\hline 37 & 45,6 & 76,3 & 79,2 & 21,5 & 30,7 & 2,9 & 33,6 & 31,6 & 3,0 & 34,6 & 11,9 & 34,6 & 58,0 & 154,0 & 22,7 & 23,4 & 96,0 & 142,1 & 23,4 & 24,1 & 98,8 & 146,3 \\
\hline 38 & 45,6 & 77,3 & 82,0 & 21,5 & 31,7 & 4,7 & 36,4 & 32,6 & 4,8 & 37,5 & 11,8 & 33,0 & 54,9 & 148,5 & 21,2 & 21,9 & 93,6 & 136,7 & 1,8 & 22,5 & 6,3 & 40,7 \\
\hline 39 & 45,7 & 79,4 & 84,7 & 21,0 & 33,7 & 5,3 & 39,0 & 34,3 & 5,4 & 39,7 & 11,8 & 33,2 & 55,3 & 152,4 & 21,4 & 22,1 & 97,1 & 140,6 & 21,8 & 22,5 & 98,7 & 143,0 \\
\hline 40 & 45,6 & 81,2 & 87,1 & 21,0 & 35,6 & 5,9 & 41,5 & 36,2 & 6,0 & 42,2 & 11,8 & 33,4 & 55,9 & 157,8 & 21,6 & 22,5 & 101,9 & 146,0 & 22,0 & 22,9 & 103,6 & 148,5 \\
\hline 41 & 45,6 & 83,1 & 89,4 & 21,0 & 37,5 & 6,3 & 43,8 & 38,1 & 6,4 & 44,5 & 11,8 & 33,8 & 56,8 & 164,6 & 22,0 & 23,0 & 107,8 & 152,8 & 22,4 & 23,4 & 109,6 & 155,4 \\
\hline 42 & 45,7 & 84,8 & 91,8 & 21,0 & 39,1 & 7,0 & 46,1 & & & 46,9 & 11,8 & 33,7 & 56,9 & 168,8 & 21,9 & 23,2 & 111,9 & & 2,3 & 23,6 & & 159,6 \\
\hline 43 & 45,7 & 87,1 & 94,8 & 21,5 & 41,4 & 7,7 & 49,1 & 42,6 & 7,9 & 50,5 & 11,8 & 33,6 & 56,7 & 176,5 & 21,8 & 23,1 & 119,8 & 164,7 & 22,4 & 23,8 & 123,3 & 169,5 \\
\hline 44 & 45,8 & 88,7 & 96,8 & 21,5 & 42,9 & 8,1 & 51,0 & 44,2 & 8,3 & 52,5 & 11,9 & 33,6 & 56,9 & 183,2 & 21,7 & 23,3 & 126,3 & 171,3 & 22,3 & 24,0 & 130,0 & 176,3 \\
\hline 45 & 45,8 & 89,8 & 98,4 & 22,0 & 44,0 & 8,6 & 52,6 & 45,8 & 9,0 & 54,8 & 11,9 & 33,5 & 57,0 & 193,4 & 21,6 & 23,5 & 136,4 & 181,5 & 22,5 & 24,5 & 142,1 & 189,1 \\
\hline 46 & 45,8 & 91,5 & 100,6 & 22,0 & 45,7 & 9,1 & 54,8 & 47,6 & 9,5 & 57,1 & 11,9 & 33,2 & 56,8 & 205,5 & 21,3 & 23,6 & 148,7 & 193,6 & 22,2 & 24,6 & 154,9 & 201,7 \\
\hline 47 & 45,8 & 93,2 & 102,8 & 22,5 & 47,4 & 9,6 & 57,0 & 50,0 & 10,1 & 60,1 & 11,9 & 33,1 & 56,9 & 223,6 & 21,2 & 23,8 & 166,7 & 211,7 & 22,4 & 25,1 & 175,8 & 223,2 \\
\hline 48 & 45,8 & 94,8 & 104,9 & 22,5 & 49,0 & 10,1 & 59,1 & 51,7 & 10,6 & 62,3 & 12,0 & 31,9 & 48,5 & 67,9 & 19,9 & 16,6 & 19,4 & 55,9 & 21,0 & 17,5 & 20,5 & 58,9 \\
\hline 49 & 45,7 & 76,3 & 79,6 & 23,5 & 30,6 & 3,3 & 33,9 & 33,1 & 3,6 & 36,6 & 12,0 & 32,3 & 49,5 & 83,3 & 20,3 & 17,2 & 33,8 & 71,3 & 21,9 & 18,6 & 36,5 & 77,0 \\
\hline 50 & 45,8 & 78,8 & 83,0 & 23,5 & 33,0 & 4,2 & 37,2 & 35,6 & 4,5 & 40,2 & 12,0 & 32,4 & 49,6 & 84,5 & 20,4 & 17,2 & 34,9 & 72,5 & 22,0 & 18,6 & 37,7 & 78,3 \\
\hline 51 & 45,7 & 80,8 & 85,7 & 24,0 & 35,1 & 4,9 & 40,0 & 38,4 & 5,4 & 43,7 & 12,0 & 32,2 & 49,3 & 85,0 & 20,2 & 17,1 & 35,7 & 73,0 & 22,1 & 18,7 & 39,0 & 79,8 \\
\hline
\end{tabular}


(continuação)

\begin{tabular}{|c|c|c|c|c|c|c|c|c|c|c|c|c|c|c|c|c|c|c|c|c|c|c|}
\hline 52 & 45,7 & 83,4 & 89,1 & 24,0 & 37,7 & 5,7 & 43,4 & 41,2 & 6,2 & 47,4 & 12,0 & 32,2 & 49,4 & 86,6 & 20,2 & 17,2 & 37,2 & 74,6 & 22,1 & 18,8 & 40,7 & 81,6 \\
\hline 55 & 45,7 & 91,0 & 98,9 & 22,5 & 45,3 & 7,9 & 53,2 & 47,8 & 8,3 & 56,1 & 11,9 & 32,2 & 50,0 & 96,2 & 20,3 & 17,8 & 46,2 & 84,3 & 21,4 & 18,8 & 48,7 & 88,9 \\
\hline 56 & 45,7 & 93,1 & 101,6 & 22,5 & 47,4 & 8,5 & 55,9 & 50,0 & 9,0 & 58,9 & 11,9 & 32,2 & 50,3 & 99,6 & 20,3 & 18,1 & 49,3 & 87,7 & 21,4 & 19,1 & 52,0 & 92,5 \\
\hline 58 & 45,7 & 98,3 & 108,3 & 22,0 & 52,6 & 10,0 & 62,6 & 54,8 & 10,4 & 65,2 & 11,9 & 31,9 & 51,1 & 111,6 & 20,0 & 19,2 & 60,5 & 99,7 & 20,8 & 20,0 & 63,0 & 103,9 \\
\hline 59 & 45,7 & 100,3 & 110,7 & 22,0 & 54,6 & 10,4 & 65,0 & 56,9 & 10,8 & 67,7 & 11,9 & 31,7 & 51,5 & 117,1 & 19,8 & 19,8 & 65,6 & 105,2 & 20,6 & 20,6 & 68,3 & 109,6 \\
\hline 60 & 45,7 & 102,9 & 113,8 & 22,0 & 57,2 & 10,9 & 68,1 & 59,6 & 11,4 & 70,9 & 11,8 & 32,0 & 53,2 & 125,8 & 20,2 & 21,2 & 72,6 & 114,0 & 21,0 & 22,1 & 75,6 & 118,8 \\
\hline 62 & 45,7 & 73,0 & 75,3 & 22,0 & 27,3 & 2,3 & 29,6 & 28,4 & 2,4 & 30,8 & 11,8 & 31,0 & 53,7 & 145,0 & 19,2 & 22,7 & 91,3 & 133,2 & 20,0 & 23,6 & 95,1 & 138,8 \\
\hline 62,2 & & & & 22,0 & & & & & & & 11,8 & 33,0 & 54,0 & 180,0 & 21,2 & 21,0 & 126,0 & 168,2 & 22,1 & 21,9 & 131,3 & 175,2 \\
\hline 63 & 45,7 & 75,0 & 77,8 & 22,0 & 29,3 & 2,8 & 32,1 & 30,5 & 2,9 & 33,4 & 12,0 & 33,7 & 50,0 & 85,3 & 21,7 & 16,3 & 35,3 & 73,3 & 22,6 & 17,0 & 36,8 & 76,4 \\
\hline 64 & 45,7 & 77,3 & 80,6 & 22,0 & 31,6 & 3,3 & 34,9 & 32,9 & 3,4 & 36,4 & 12,0 & 33,4 & 49,8 & 98,8 & 21,4 & 16,4 & 49,0 & 86,8 & 22,3 & 17,1 & 51,0 & 90,4 \\
\hline 65 & 45,7 & 79,6 & 83,7 & 22,0 & 33,9 & 4,1 & 38,0 & 35,3 & 4,3 & 39,6 & 12,0 & 33,8 & 50,5 & 105,2 & 21,8 & 16,7 & 54,7 & 93,2 & 22,7 & 17,4 & 57,0 & 97,1 \\
\hline 66 & 45,7 & 82,2 & 86,9 & 22,0 & 36,5 & 4,7 & 41,2 & 38,0 & 4,9 & 42,9 & 12,0 & 33,9 & 51,0 & 110,1 & 21,9 & 17,1 & 59,1 & 98,1 & 22,8 & 17,8 & 61,6 & 102,2 \\
\hline 71 & 45,7 & 95,2 & 103,3 & 21,0 & 49,5 & 8,1 & 57,6 & 50,3 & 8,2 & 58,6 & 11,8 & 32,6 & 52,1 & 147,2 & 20,8 & 19,5 & 95,1 & 135,4 & 21,2 & 19,8 & 96,7 & 137,7 \\
\hline 72 & 45,7 & 97,4 & 106,1 & 21,0 & 51,7 & 8,7 & 60,4 & 52,6 & 8,8 & 61,4 & 11,8 & 32,8 & 52,7 & 164,4 & 21,0 & 19,9 & 111,7 & 152,6 & 21,4 & 20,2 & 113,6 & 155,2 \\
\hline
\end{tabular}

FAAG = filtro ascendente de areia grossa; $F R D$ = filtro rápido descendente; $T F$ = tempo de funcionamento; $T$ = temperatura; Descargas de fundo intermediárias por perda de carga; Descargas de fundo intermediárias quando a cor aparente do efluente do FAAG atingiu valor $\geq 50 \mathrm{uH}$; Lavagem do FRD por perda de carga; Lavagem do FRD por transpasse 


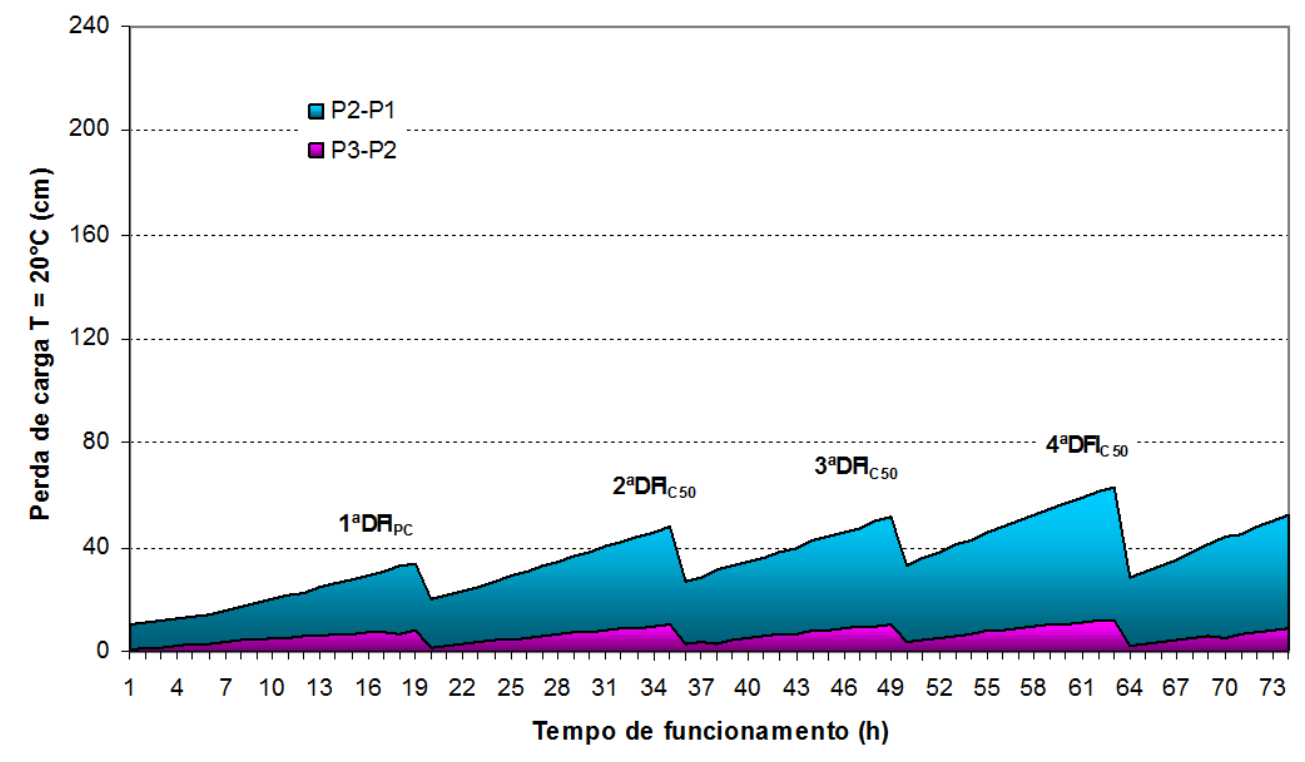

Figura B 7.1 - Perda de carga na camada suporte e camada de areia grossa no FAAG durante o ensaio 7 sem pré-oxidação e com DFls no FAAG (FAAG $=120 \mathrm{~m}^{3} / \mathrm{m}^{2} \mathrm{~d}$ e FRD $=240 \mathrm{~m}^{3} / \mathrm{m}^{2} \mathrm{~d}$ ). Fonte: Tabela B 7.3 - ANEXO B.

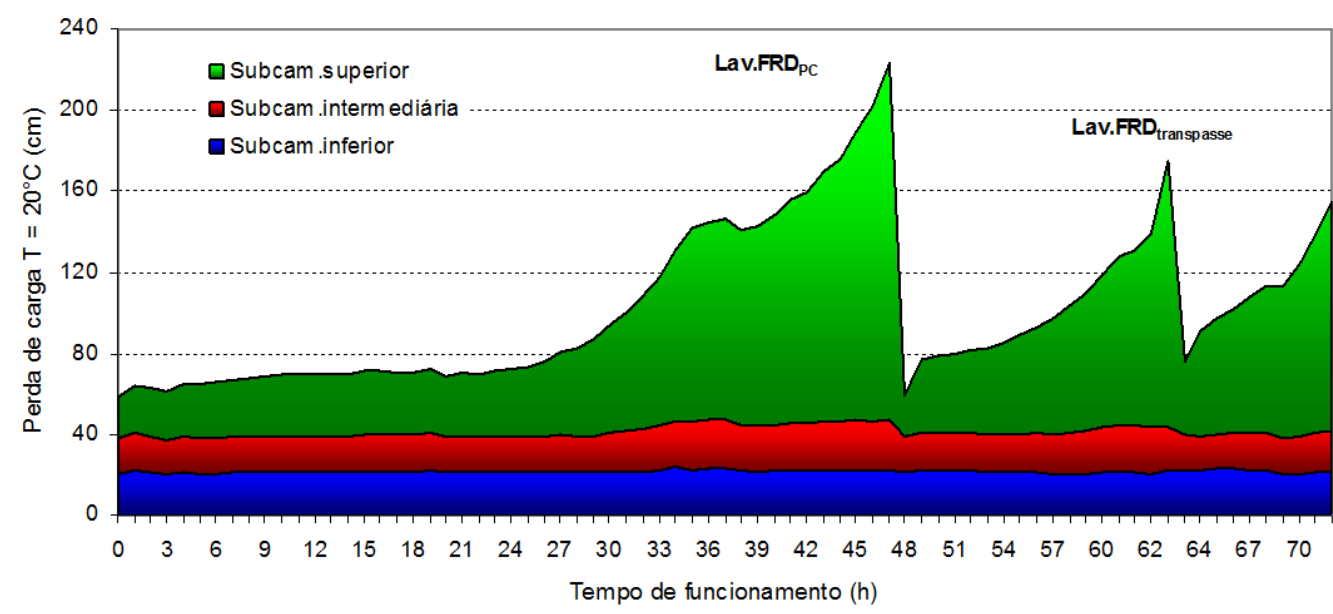

Figura B 7.2 - Perda de carga ao longo do meio filtrante do FRD durante o ensaio 7 sem pré-oxidação e com DFIs no FAAG (FAAG $=120 \mathrm{~m}^{3} / \mathrm{m}^{2} \mathrm{~d}$ e FRD $=240 \mathrm{~m}^{3} / \mathrm{m}^{2} \mathrm{~d}$ ). Fonte: Tabela B $7.3-$ ANEXO B. 
Tabela B 7.4 - Variação de vazões e taxas de filtração do FAAG e do FRD durante o ensaio 7 - sem pré-oxidação e com DFls no FAAG (FAAG $=120 \mathrm{~m}^{3} / \mathrm{m}^{2} \mathrm{~d} ; \mathrm{FRD}=240 \mathrm{~m}^{3} / \mathrm{m}^{2} \mathrm{~d}$ ).

\begin{tabular}{|c|c|c|c|c|c|c|c|c|}
\hline \multirow{2}{*}{$\begin{array}{l}\text { TF } \\
\text { (h) }\end{array}$} & \multicolumn{2}{|c|}{ descartes (L/h) } & \multicolumn{2}{|c|}{ turbidímetros $(\mathrm{L} / \mathrm{h})$} & \multicolumn{2}{|c|}{ vazão total (L/h) } & \multicolumn{2}{|c|}{ taxas de filtração $\left(\mathrm{m}^{3} / \mathrm{m}^{2} \mathrm{~d}\right)$} \\
\hline & FAAG & FRD & FAAG & FRD & FAAG & FRD & FAAG & FRD \\
\hline 0 & 0,00 & 42,88 & 14,80 & 24,00 & 81,68 & 66,88 & 126 & 245 \\
\hline 1 & 0,00 & 46,61 & 11,48 & 24,88 & 82,97 & 71,49 & 128 & 262 \\
\hline 2 & 0,00 & 44,05 & 14,22 & 24,77 & 83,04 & 68,82 & 128 & 252 \\
\hline 3 & 0,00 & 40,32 & 18,00 & 22,90 & 81,22 & 63,22 & 125 & 231 \\
\hline 4 & 0,00 & 42,82 & 14,55 & 24,62 & 81,99 & 67,44 & 126 & 247 \\
\hline 5 & 0,00 & 43,20 & 15,39 & 24,83 & 83,42 & 68,03 & 128 & 249 \\
\hline 6 & 0,00 & 41,24 & 16,60 & 24,23 & 82,07 & 65,47 & 126 & 239 \\
\hline 7 & 0,00 & 41,75 & 16,04 & 24,07 & 81,86 & 65,82 & 126 & 241 \\
\hline 8 & 0,00 & 40,80 & 15,98 & 24,25 & 81,03 & 65,05 & 125 & 238 \\
\hline 9 & 0,00 & 42,93 & 16,93 & 23,60 & 83,46 & 66,53 & 128 & 243 \\
\hline 10 & 0,00 & 41,21 & 17,10 & 23,58 & 81,89 & 64,79 & 126 & 237 \\
\hline 11 & 0,00 & 42,47 & 16,08 & 24,34 & 82,89 & 66,81 & 127 & 244 \\
\hline 12 & 0,00 & 42,35 & 16,01 & 23,46 & 81,82 & 65,81 & 126 & 241 \\
\hline 13 & 0,00 & 42,55 & 16,44 & 24,17 & 83,16 & 66,72 & 128 & 244 \\
\hline 14 & 0,00 & 41,89 & 16,36 & 24,49 & 82,74 & 66,38 & 127 & 243 \\
\hline 15 & 0,00 & 43,20 & 16,06 & 23,42 & 82,68 & 66,62 & 127 & 244 \\
\hline 16 & 0,00 & 42,76 & 16,22 & 23,89 & 82,87 & 66,65 & 127 & 244 \\
\hline 17 & 0,00 & 41,87 & 16,06 & 23,31 & 81,24 & 65,18 & 125 & 238 \\
\hline 18 & 0,00 & 41,07 & 16,03 & 24,04 & 81,14 & 65,11 & 125 & 238 \\
\hline 19 & 0,00 & 43,03 & 15,07 & 24,49 & 82,59 & 67,52 & 127 & 247 \\
\hline 20 & 0,00 & 42,22 & 16,60 & 24,56 & 83,38 & 66,78 & 128 & 244 \\
\hline 21 & 0,00 & 41,43 & 16,99 & 24,41 & 82,83 & 65,84 & 127 & 241 \\
\hline 22 & 0,00 & 41,99 & 16,04 & 24,81 & 82,84 & 66,80 & 127 & 244 \\
\hline 23 & 0,00 & 39,87 & 16,43 & 23,40 & 79,70 & 63,27 & 123 & 231 \\
\hline 24 & 0,00 & 42,00 & 15,88 & 24,32 & 82,20 & 66,32 & 126 & 243 \\
\hline 25 & 0,00 & 42,76 & 15,89 & 24,09 & 82,74 & 66,85 & 127 & 245 \\
\hline 26 & 0,00 & 42,82 & 15,11 & 24,59 & 82,52 & 67,41 & 127 & 247 \\
\hline 27 & 0,00 & 42,99 & 15,13 & 24,51 & 82,63 & 67,50 & 127 & 247 \\
\hline 28 & 0,00 & 41,16 & 16,24 & 24,83 & 82,23 & 65,99 & 126 & 241 \\
\hline 29 & 0,00 & 41,73 & 16,53 & 24,58 & 82,84 & 66,31 & 127 & 243 \\
\hline 30 & 0,00 & 44,23 & 15,23 & 23,86 & 83,32 & 68,09 & 128 & 249 \\
\hline 31 & 0,00 & 45,00 & 14,82 & 23,41 & 83,23 & 68,41 & 128 & 250 \\
\hline 32 & 0,00 & 42,47 & 14,22 & 23,26 & 79,95 & 65,73 & 123 & 240 \\
\hline 33 & 0,00 & 42,88 & 13,54 & 24,23 & 80,65 & 67,11 & 124 & 245 \\
\hline 34 & 0,00 & 43,29 & 12,82 & 24,07 & 80,18 & 67,36 & 123 & 246 \\
\hline 35 & 0,00 & 43,53 & 12,74 & 23,84 & 80,11 & 67,37 & 123 & 246 \\
\hline 36 & 0,00 & 44,13 & 13,14 & 23,48 & 80,75 & 67,61 & 124 & 247 \\
\hline 37 & 0,00 & 44,10 & 12,62 & 23,83 & 80,55 & 67,93 & 124 & 248 \\
\hline 38 & 0,00 & 40,17 & 17,76 & 23,70 & 81,63 & 63,87 & 125 & 234 \\
\hline 39 & 0,00 & 40,95 & 17,38 & 23,95 & 82,28 & 64,90 & 126 & 237 \\
\hline 40 & 0,00 & 39,90 & 18,06 & 23,61 & 81,57 & 63,51 & 125 & 232 \\
\hline 41 & 0,00 & 42,35 & 16,20 & 24,48 & 83,03 & 66,83 & 128 & 244 \\
\hline 42 & 0,00 & 42,30 & 15,84 & 24,00 & 82,14 & 66,30 & 126 & 243 \\
\hline 43 & 0,00 & 41,14 & 16,39 & 24,65 & 82,18 & 65,79 & 126 & 241 \\
\hline
\end{tabular}


(continuação)

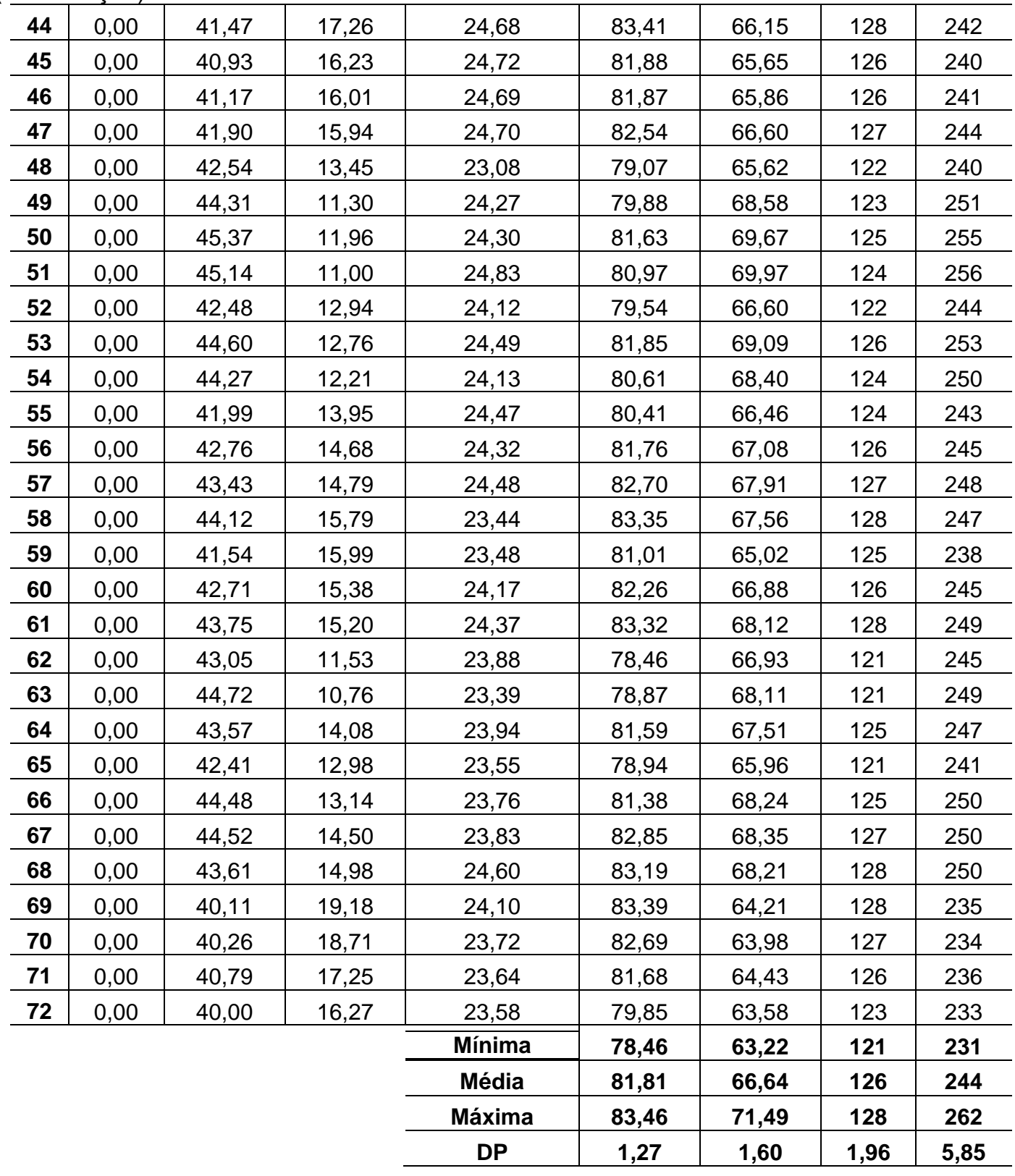

$\mathrm{TF}=$ tempo de funcionamento; $\mathrm{FAAG}=$ filtro ascendente de areia grossa; $\mathrm{FRD}=$ filtro rápido descendente; $\mathrm{AC}=$ água coagulada; DP = desvio padrão. 


\section{Produção Efetiva de Água Filtrada}

Considerando os seguintes dados:

- Número de lavagens do FAAG $\left(\mathrm{NL}_{\mathrm{FAAG}}\right)=1$

- Taxa de aplicação de água para lavagem do FAAG $\left(\mathrm{TL}_{\mathrm{FAAG}}\right)=2592 \mathrm{~m}^{3} / \mathrm{m}^{2} \mathrm{~d}$

- Duração da lavagem do FAAG $\left(D_{\text {FAAG }}\right)=10 \mathrm{~min}=0,007$ dia

- Perda de carga prevista no FAAG $\left(\Delta \mathrm{H}_{\text {prevista }} F A A G\right)=2,20 \mathrm{~m}$

- Perda de carga prevista no FRD $\left(\Delta \mathrm{H}_{\text {prevista }} F R D\right)=2,10 \mathrm{~m}$

- Taxa de descarga de fundo no FAAG (TDF) $=1152 \mathrm{~m}^{3} / \mathrm{m}^{2} \mathrm{~d}$

- Duração da descarga de fundo (DDF) $=2 \mathrm{~min}=0,0014 \mathrm{dia}$

- Taxa de aplicação de água para a lavagem do $\operatorname{FRD}\left(\mathrm{TL}_{\mathrm{FRD}}\right)=864 \mathrm{~m}^{3} / \mathrm{m}^{2} \mathrm{~d}$

- Duração da lavagem do FRD (DLFRD) $=7 \mathrm{~min}=0,0049$ dia

- Área do FRD $\left(\mathrm{A}_{\mathrm{FRD}}\right)=0,00656 \mathrm{~m}^{2}$

- Área do $F A A G\left(A_{F A A G}\right)=0,0156 \mathrm{~m}^{2}$

Tabela B 8.1 - Resultados de produção efetiva de água filtrada para os ensaios na instalação piloto em escoamento contínuo - Fase 1.

\begin{tabular}{|c|c|c|c|c|c|c|c|}
\hline Ensaio & 1 & 2 & 3 & 4 & 5 & 6 & 7 \\
\hline$\overline{T_{F}} F_{\text {FAG }}\left(m^{3} / m^{2} d\right)$ & 240 & 180 & 180 & 180 & 120 & 120 & 120 \\
\hline $\operatorname{TF}_{\mathrm{FRD}}\left(\mathrm{m}^{3} / \mathrm{m}^{2} \mathrm{~d}\right)$ & 280 & 200 & 240 & 280 & 160 & 200 & 240 \\
\hline DF (dia) & 2,08 & 3 & 3 & 2,92 & 3 & 3 & 3 \\
\hline PT $\left(\mathrm{m}^{3} / \mathrm{m}^{2}\right)$ & 500 & 540 & 540 & 525 & 360 & 360 & 360 \\
\hline$\Delta \mathrm{H}_{\text {final }} \mathrm{FAAG}(\mathrm{m})$ & 1,17 & 1,74 & 1,14 & 2,20 & 1,80 & 0,85 & 0,60 \\
\hline $\operatorname{VL}_{F A A G}\left(m^{3}\right)$ & 9,65 & 14,35 & 9,40 & 18,14 & 14,85 & 7,01 & 4,95 \\
\hline $\operatorname{VDF}_{\text {final }}\left(\mathrm{m}^{3}\right)$ & 0,86 & 1,28 & 0,84 & 1,61 & 1,32 & 0,62 & 0,44 \\
\hline $\mathrm{N}^{\circ} \mathrm{DF}$ Is & 11 & 8 & 10 & 4 & 4 & 6 & 4 \\
\hline VDFIs $\left(\mathrm{m}^{3}\right)$ & 17,74 & 12,90 & 16,13 & 6,45 & 6,45 & 9,68 & 6,45 \\
\hline$\Delta \mathrm{H}_{\text {final }} \mathrm{FRD}(\mathrm{m})$ & 1,65 & 2,10 & 1,50 & 0,76 & 0,50 & 1,47 & 1,53 \\
\hline$N L_{F R D}$ & 2 & 1 & 3 & 3 & 0 & 1 & 2 \\
\hline $\operatorname{VL}_{F R D}\left(m^{3}\right)$ & 4,96 & 3,56 & 6,61 & 5,99 & 0,42 & 3,03 & 4,86 \\
\hline $\mathrm{PE}\left(\mathrm{m}^{3} / \mathrm{m}^{2}\right)$ & 467 & 508 & 507 & 493 & 337 & 340 & 343 \\
\hline PE (\%) & 93,4 & 94,1 & 93,9 & 93,9 & 93,6 & 94,4 & 95,4 \\
\hline
\end{tabular}

Em que: $\mathrm{TF}_{\mathrm{FAAG}}=$ taxa de filtração no $\mathrm{FAAG} ; \mathrm{TF}_{\mathrm{FRD}}=$ taxa de filtração no $\mathrm{FRD}$; $\mathrm{DCF}=$ duração da carreira de filtração; $\mathrm{PT}=$ produção total de água; $\Delta \mathrm{H}_{\text {final }} \mathrm{FAAG}=$ perda de carga final no FAAG; $\mathrm{VL}_{\mathrm{FAAG}}=$ consumo de água utilizada para a lavagem do $\mathrm{FAAG}$; $\mathrm{VDF}_{\text {final }}=$ consumo de água utilizada para a descarga de fundo final; $\mathrm{N}^{\circ} \mathrm{DFls}$ = número de descargas de fundo intermediárias; VDFIs = consumo de água utilizada para as descargas de fundo intermediárias; $\Delta \mathrm{H}_{\text {final }} F R D=$ perda de carga final no FRD; $\mathrm{NL}_{F R D}=$ número de lavagens executadas no $\mathrm{FRD}$; $V L_{F R D}=$ cosumo de água utilizada para as lavagens do FRD; $P E$ = produção efetiva de água. 


\section{ANEXO C}

Resultados obtidos nos Ensaios na Instalação Piloto em Escoamento Contínuo - Fase 2 
Tabela $C 1.1$ - Características físicas da $A B, A E$ e efluentes do FAAG e do FRD durante o ensaio 8 sem pré-oxidação (FAAG $=180 \mathrm{~m}^{3} / \mathrm{m}^{2} \mathrm{~d} ; \mathrm{FRD}=280 \mathrm{~m}^{3} / \mathrm{m}^{2} \mathrm{~d}$ ).

\begin{tabular}{|c|c|c|c|c|c|c|c|}
\hline \multirow[b]{2}{*}{ TF (h) } & \multirow{2}{*}{$\begin{array}{c}\begin{array}{c}\text { Temperatura } \\
\left({ }^{\circ} \mathrm{C}\right)\end{array} \\
\mathrm{AE} \\
\end{array}$} & \multicolumn{4}{|c|}{ Cor aparente (uH) } & \multicolumn{2}{|c|}{ Cor verdadeira (uH } \\
\hline & & $A B$ & $\mathrm{AE}$ & FAAG & FRD & AB & $\mathrm{AE}$ \\
\hline 0 & 22,5 & 138 & 210 & 12,0 & 10,0 & 27 & 103 \\
\hline 1 & 22,0 & & 214 & 6,0 & 1,0 & & 96 \\
\hline 2 & 22,0 & & 208 & 6,0 & $<1,0$ & & 93 \\
\hline 4 & 21,5 & & 213 & 5,0 & 1,0 & & 102 \\
\hline 6 & 21,0 & 134 & 211 & 2,0 & $<1,0$ & 23 & 100 \\
\hline 8 & 20,5 & & 208 & 1,0 & $<1,0$ & & 100 \\
\hline 10 & 20,0 & & 205 & 3,0 & $<1,0$ & & 102 \\
\hline 12 & 20,0 & 130 & 210 & 1,0 & $<1,0$ & 22 & 98 \\
\hline 14 & 20,0 & & 200 & 0,5 & $<1,0$ & & 103 \\
\hline 16 & 21,5 & & 204 & 6,0 & $<1,0$ & & 103 \\
\hline 18 & 22,0 & 138 & 213 & 30,0 & $<1,0$ & 22 & 96 \\
\hline 20 & 22,5 & & 215 & 42,0 & 1,0 & & 101 \\
\hline 22 & 23,0 & & 213 & 47,0 & $<1,0$ & & 102 \\
\hline 24 & 23,0 & 130 & 212 & 60,0 & $<1,0$ & 23 & 102 \\
\hline 26 & 22,0 & & 214 & 57,0 & $<1,0$ & & 105 \\
\hline 28 & 21,5 & & 208 & 75,0 & 5,0 & & 102 \\
\hline 30 & 21,0 & 146 & 223 & 81,0 & $<1,0$ & 24 & 99 \\
\hline 32 & 21,0 & & 222 & 80,0 & $<1,0$ & & 101 \\
\hline 34 & 21,0 & & 220 & 90,0 & $<1,0$ & & 103 \\
\hline 36 & 21,0 & 136 & 211 & 93,0 & $<1,0$ & 21 & 101 \\
\hline Média & 21,45 & 136,00 & 211,70 & 34,88 & 1,28 & 23 & 100,60 \\
\hline Mínimo & 20,00 & 130,00 & 200,00 & $<1,0$ & $<1,0$ & 21 & 93,00 \\
\hline Máximo & 23,00 & 146,00 & 223,00 & 93,00 & 10,00 & 27 & 105,00 \\
\hline DP & 0,93 & 5,54 & 5,70 & 34,81 & 2,29 & 2 & 2,93 \\
\hline
\end{tabular}

$\overline{\mathrm{TF}}=$ tempo de funcionamento; $\mathrm{AE}$ = água de estudo; $\mathrm{AB}$ = água bruta; FAAG = filtro ascendente de areia grossa; $\mathrm{FRD}$ = filtro rápido descendente; $\mathrm{DP}=$ desvio padrão. 
Tabela C 1.2 - Características químicas da AB, AE e efluentes do FAAG e do FRD durante o ensaio 8 - sem pré-oxidação ( $F A A G=180 \mathrm{~m} / \mathrm{m}^{2} \mathrm{~d} ; \mathrm{FRD}=280 \mathrm{~m}^{3} / \mathrm{m}^{2} \mathrm{~d}$ ).

\begin{tabular}{|c|c|c|c|c|c|c|c|c|c|c|c|c|c|c|c|c|c|}
\hline \multirow[b]{2}{*}{ TF (h) } & \multicolumn{3}{|c|}{ pH } & \multicolumn{2}{|c|}{ Alcalinidade $\left(\mathrm{mg} / \mathrm{L} \mathrm{CaCO}_{3}\right)$} & \multicolumn{4}{|c|}{ Absorvância 254 nm } & \multicolumn{4}{|c|}{ COD (mg/L) } & \multicolumn{4}{|c|}{ Alumínio (mg/L) } \\
\hline & $A B$ & $\mathrm{AE}$ & AC & $A B$ & $\mathrm{AE}$ & $A B$ & $\mathrm{AE}$ & FAAG & FRD & $A B$ & $\mathrm{AE}$ & FAAG & FRD & $A B$ & $\mathrm{AE}$ & FAAG & FRD \\
\hline 0 & 6,54 & 6,59 & 5,21 & 6,38 & 7,70 & 0,091 & 0,201 & 0,041 & 0,022 & 1,530 & 2,754 & 1,948 & 2,424 & ND & ND & 0,04 & 0,02 \\
\hline 1 & & 6,65 & 5,15 & & & & & & & & & & & & & & \\
\hline 2 & & 6,66 & 5,16 & & & & & & & & & & & & & & \\
\hline 4 & & 6,65 & 5,21 & & & & & & & & & & & & & & \\
\hline 6 & 6,55 & 6,62 & 5,28 & 8,14 & 7,26 & 0,080 & 0,194 & 0,011 & 0,013 & & & & & & & & \\
\hline 8 & & 6,58 & 5,25 & & & & & & & & & & & & & & \\
\hline 10 & & 6,57 & 5,29 & & & & & & & & & & & & & & \\
\hline 12 & 6,59 & 6,63 & 5,26 & 8,58 & 7,48 & 0,079 & 0,189 & 0,008 & 0,015 & 1,515 & 2,590 & 1,953 & 1,454 & ND & 0,02 & 0,09 & 0,10 \\
\hline 14 & & 6,63 & 5,28 & & & & & & & & & & & & & & \\
\hline 16 & & 6,60 & 5,22 & & & & & & & & & & & & & & \\
\hline 18 & 6,52 & 6,62 & 5,08 & 9,46 & 8,14 & 0,069 & 0,185 & 0,009 & 0,010 & & & & & & & & \\
\hline 20 & & 6,44 & 5,16 & & & & & & & & & & & & & & \\
\hline 22 & & 6,54 & 5,04 & & & & & & & & & & & & & & \\
\hline 24 & 6,54 & 6,62 & 5,07 & 8,36 & 9,02 & 0,075 & 0,190 & 0,011 & 0,012 & 2,010 & 2,812 & 1,745 & 1,221 & ND & ND & 0,15 & 0,16 \\
\hline 26 & & 6,58 & 5,09 & & & & & & & & & & & & & & \\
\hline 28 & & 6,69 & 5,19 & & & & & & & & & & & & & & \\
\hline 30 & 6,60 & 6,57 & 5,20 & 6,82 & 8,36 & 0,070 & 0,183 & 0,005 & 0,007 & & & & & & & & \\
\hline 32 & & 6,66 & 5,20 & & & & & & & & & & & & & & \\
\hline 34 & & 6,52 & 5,26 & & & & & & & & & & & & & & \\
\hline 36 & 6,58 & 6,57 & 5,32 & 7,70 & 7,04 & 0,074 & 0,189 & 0,010 & 0,009 & 1,673 & 3,586 & 1,794 & 1,469 & ND & ND & 0,09 & 0,10 \\
\hline Média & 6,56 & 6,60 & 5,20 & 7,92 & 7,86 & 0,077 & 0,190 & 0,014 & 0,013 & 1,682 & 2,936 & 1,860 & 1,642 & - & - & 0,09 & 0,10 \\
\hline Mínimo & 6,52 & 6,44 & 5,04 & 6,38 & 7,04 & 0,069 & 0,183 & 0,005 & 0,007 & 1,515 & 2,590 & 1,745 & 1,221 & - & - & 0,04 & 0,02 \\
\hline Máximo & 6,60 & 6,69 & 5,32 & 9,46 & 9,02 & 0,091 & 0,201 & 0,041 & 0,022 & 2,010 & 3,586 & 1,953 & 2,424 & - & - & 0,15 & 0,16 \\
\hline DP & 0,03 & 0,06 & 0,08 & 1,06 & 0,69 & 0,007 & 0,006 & 0,012 & 0,005 & 0,230 & 0,444 & 0,106 & 0,534 & - & - & 0,05 & 0,06 \\
\hline
\end{tabular}

$\mathrm{TF}=$ tempo de funcionamento; $\mathrm{AE}$ = água de estudo; $\mathrm{AB}$ = água bruta; $\mathrm{AC}$ = água coagulada; FAAG = filtro ascendente de areia grossa; FRD = filtro rápido descendente; $\mathrm{DP}=$ desvio padrão. 
Tabela C 1.3 - Perda de carga no FAAG $\left(180 \mathrm{~m}^{3} / \mathrm{m}^{2} \mathrm{~d}\right)$ e no FRD $\left(280 \mathrm{~m}^{3} / \mathrm{m}^{2} \mathrm{~d}\right)$ durante o ensaio 8 , sem pré-oxidação e sem DFIs no FAAG para a temperatura T e para

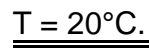

\begin{tabular}{|c|c|c|c|c|c|c|c|c|c|c|c|c|c|c|c|c|c|c|c|c|c|c|}
\hline \multirow{3}{*}{$\begin{array}{l}\text { TF } \\
\text { (h) }\end{array}$} & \multicolumn{10}{|c|}{ FAAG } & \multicolumn{12}{|c|}{ FRD } \\
\hline & \multicolumn{3}{|c|}{$\begin{array}{l}\text { Leitura piezométrica } \\
(\mathrm{cm})\end{array}$} & \multirow{2}{*}{$\begin{array}{c}\mathrm{T} \\
\left({ }^{\circ} \mathrm{C}\right)\end{array}$} & \multicolumn{3}{|c|}{$\begin{array}{l}\text { Perda de carga } \\
\quad(\mathrm{cm})\end{array}$} & \multicolumn{3}{|c|}{$\begin{array}{l}\text { Perda de carga }(\mathrm{cm}) \\
\mathrm{T}=20^{\circ} \mathrm{C}\end{array}$} & \multicolumn{4}{|c|}{$\begin{array}{l}\text { Leitura piezométrica } \\
\qquad(\mathrm{cm})\end{array}$} & \multicolumn{4}{|c|}{$\begin{array}{l}\text { Perda de carga } \\
\quad(\mathbf{c m})\end{array}$} & \multicolumn{4}{|c|}{$\begin{array}{l}\text { Perda de carga }(\mathrm{cm}) \\
\mathrm{T}=20^{\circ} \mathrm{C}\end{array}$} \\
\hline & $\mathrm{P} 1$ & P2 & P3 & & P2-P1 & P3-P2 & P3 - P1 & P2-P1 & P3-P2 & P3 - P1 & $\mathrm{P} 1$ & $\mathrm{P} 2$ & P3 & P4 & P2-P1 & P3-P2 & \begin{tabular}{|l|} 
P4-P3 \\
\end{tabular} & P4 - P1 & P2-P1 & P3-P2 & P4-P3 & P4 - P1 \\
\hline 0 & 45,9 & 60,1 & 61,1 & 22,5 & 14,2 & 1,0 & 15,2 & 15,0 & 1,1 & 16,0 & 12,0 & 34,9 & 53,6 & 70,6 & 22,9 & 18,7 & 17,0 & 58,6 & 24,1 & 19,7 & 17,9 & 61,8 \\
\hline 1 & 45,9 & 62,5 & 64,1 & 22,0 & 16,6 & 1,6 & 18,2 & 17,3 & 1,7 & 19,0 & 12,0 & 35,3 & 54,9 & 73,7 & 23,3 & 19,6 & 18,8 & 61,7 & 24,3 & 20,4 & 19,6 & 64,3 \\
\hline 2 & 45,9 & 64,4 & 66,7 & 22,0 & 18,5 & 2,3 & 20,8 & 19,3 & 2,4 & 21,7 & 12,0 & 35,3 & 54,8 & 77,7 & 23,3 & 19,5 & 22,9 & 65,7 & 24,3 & 20,3 & 23,9 & 68,4 \\
\hline 3 & 45,9 & 66,9 & 69,9 & 22,0 & 21,0 & 3,0 & 24,0 & 21,9 & 3,1 & 25,0 & 12,0 & 35,3 & 55,2 & 82,1 & 23,3 & 19,9 & 26,9 & 70,1 & 24,3 & 20,7 & 28,0 & 73,0 \\
\hline 4 & 45,9 & 69,4 & 73,3 & 21,5 & 23,5 & 3,9 & 27,4 & 24,2 & 4,0 & 28,2 & 11,9 & 36,2 & 57,0 & 87,6 & 24,3 & 20,8 & 30,6 & 75,7 & 25,0 & 21,4 & 31,5 & 77,9 \\
\hline 5 & 45,9 & 72,4 & 77,0 & 21,5 & 26,5 & 4,6 & 31,1 & 27,3 & 4,7 & 32,0 & 12,0 & 36,5 & 57,7 & 90,5 & 24,5 & 21,2 & 32,8 & 78,5 & 25,2 & 21,8 & 33,8 & 80,8 \\
\hline 6 & 45,9 & 75,8 & 81,4 & 21,0 & 29,9 & 5,6 & 35,5 & 30,4 & 5,7 & 36,1 & 12,0 & 36,7 & 58,3 & 93,6 & 24,7 & 21,6 & 35,3 & 81,6 & 25,1 & 22,0 & 35,9 & 83,0 \\
\hline 7 & 45,9 & 78,8 & 85,2 & 21,0 & 32,9 & 6,4 & 39,3 & 33,5 & 6,5 & 40,0 & 11,9 & 36,2 & 57,5 & 94,8 & 24,3 & 21,3 & 37,3 & 82,9 & 24,7 & 21,7 & 37,9 & 84,3 \\
\hline 8 & 45,9 & 82,8 & 90,0 & 20,5 & 36,9 & 7,2 & 44,1 & 37,1 & 7,2 & 44,3 & 11,9 & 36,2 & 57,7 & 96,6 & 24,3 & 21,5 & 38,9 & 84,7 & 24,4 & 21,6 & 39,1 & 85,1 \\
\hline 9 & 45,9 & 85,8 & 93,9 & 20,5 & 39,9 & 8,1 & 48,0 & 40,1 & 8,1 & 48,2 & 11,9 & 36,1 & 57,7 & 98,4 & 24,2 & 21,6 & 40,7 & 86,5 & 24,3 & 1,7 & 40,9 & 86,9 \\
\hline 10 & 45,9 & 89,8 & 98,9 & 20,0 & 43,9 & 9,1 & 53,0 & 43,6 & 9,0 & 52,6 & 11,9 & 36,5 & 58,6 & 101,7 & 24,6 & 22,1 & 43,1 & 89,8 & 24,4 & 21,9 & 42,8 & 89,1 \\
\hline 11 & 45,9 & 93,5 & 103,2 & 20,0 & 47,6 & 9,7 & 57,3 & 47,2 & 9,6 & 56,9 & 11,9 & 36,5 & 58,7 & \begin{tabular}{|l|}
103,7 \\
\end{tabular} & 24,6 & 22,2 & 45,0 & 91,8 & 24,4 & 22,0 & 44,7 & 91,1 \\
\hline 12 & 45,9 & 97,6 & 108,1 & 20,0 & 51,7 & 10,5 & 62,2 & 51,3 & 10,4 & 61,7 & 11,9 & 37,1 & 59,9 & 107,3 & 25,2 & 22,8 & 47,4 & 95,4 & 25,0 & 22,6 & 47,0 & 94,7 \\
\hline 13 & 45,9 & 101,8 & 112,9 & 20,0 & 55,9 & 11,1 & 67,0 & 55,5 & 11,0 & 66,5 & 11,9 & 37,3 & 60,4 & 109,5 & 25,4 & 23,1 & 49,1 & 97,6 & 25,2 & 22,9 & 48,7 & 96,9 \\
\hline 14 & 45,9 & 106,4 & 118,6 & 20,0 & 60,5 & 12,2 & 72,7 & 60,0 & 12,1 & 72,2 & 11,9 & 37,3 & 60,4 & 110,7 & 25,4 & 23,1 & 50,3 & 98,8 & 25,2 & 22,9 & 49,9 & 98,1 \\
\hline 15 & 45,9 & 110,9 & 123,7 & 20,0 & 65,0 & 12,8 & 77,8 & 64,5 & 12,7 & 77,2 & 11,9 & 37,2 & 60,2 & 111,6 & 25,3 & 23,0 & 51,4 & 99,7 & 25,1 & 22,8 & 51,0 & 99,0 \\
\hline 16 & 45,9 & 114,3 & 127,7 & 21,5 & 68,4 & 13,4 & 81,8 & 70,4 & 13,8 & 84,2 & 11,9 & 36,6 & 59,2 & 111,2 & 24,7 & 22,6 & 52,0 & 99,3 & 25,4 & 23,3 & 53,5 & 102,2 \\
\hline 17 & 45,9 & 121,5 & 136,0 & 21,5 & 75,6 & 14,5 & 90,1 & 77,8 & 14,9 & 92,7 & 11,9 & 37,7 & 61,4 & 117,4 & 25,8 & 23,7 & 56,0 & 105,5 & 26,6 & 24,4 & 57,6 & 108,6 \\
\hline 18 & 46,0 & 126,4 & 141,5 & 22,0 & 80,4 & 15,1 & 95,5 & 83,8 & 15,7 & 99,5 & 12,0 & 37,5 & 61,3 & 121,9 & 25,5 & 23,8 & 60,6 & 109,9 & 26,6 & 24,8 & 63,1 & 114,5 \\
\hline 19 & 46,0 & 130,7 & 146,6 & 22,0 & 84,7 & 15,9 & 100,6 & 88,2 & 16,6 & 104,8 & 11,9 & 36,0 & 58,9 & 122,1 & 24,1 & 22,9 & 63,2 & 110,2 & 25,1 & 23,9 & 65,8 & 114,8 \\
\hline 20 & 46,0 & 135,0 & 151,9 & 22,5 & 89,0 & 16,9 & 105,9 & 93,8 & 17,8 & 111,7 & 11,9 & 36,6 & 61,7 & 132,6 & 24,7 & 25,1 & 70,9 & 120,7 & 26,0 & 26,5 & 74,8 & 127,3 \\
\hline 21 & 46,0 & 140,3 & 157,9 & 22,5 & 94,3 & 17,6 & 111,9 & 99,4 & 18,6 & 118,0 & 11,9 & 36,1 & 62,8 & 140,0 & 24,2 & 26,7 & 77,2 & 128,1 & 25,5 & 28,2 & 81,4 & 135,1 \\
\hline 22 & 46,0 & 145,0 & 163,4 & 23,0 & 99,0 & 18,4 & 117,4 & 105,7 & 19,6 & 125,3 & 11,9 & 36,3 & 64,8 & 148,4 & 24,4 & 28,5 & 83,6 & 136,5 & 26,0 & 30,4 & 89,2 & 145,7 \\
\hline 23 & 46,0 & 150,3 & 169,7 & 23,0 & 104,3 & 19,4 & 123,7 & 111,3 & 20,7 & 132,0 & 11,9 & 36,2 & 66,2 & 156,8 & 24,3 & 30,0 & 90,6 & 144,9 & 25,9 & 32,0 & 96,7 & 154,6 \\
\hline
\end{tabular}


(continuação)

\begin{tabular}{|c|c|c|c|c|c|c|c|c|c|c|c|c|c|c|c|c|c|c|c|c|c|c|}
\hline & & & & & & & & & & & & & & & & & & & & & & \\
\hline 24 & 46,0 & 155,7 & 176,2 & 23,0 & 109,7 & 20,5 & 130,2 & 17,1 & 21,9 & 139,0 & 11,9 & 36,7 & 68,2 & 166,3 & 24,8 & 31,5 & 98,1 & 154,4 & 26,5 & 33,6 & 104,7 & 164,8 \\
\hline 25 & 46,0 & 161,8 & 182,9 & 23,0 & 115,8 & 21,1 & 136,9 & 123,6 & 22,5 & 46,1 & 11,9 & 37,2 & 70,0 & 177,2 & 25,3 & 32,8 & 107,2 & 65,3 & 27,0 & \begin{tabular}{|l|}
35,0 \\
\end{tabular} & 14,4 & 176,4 \\
\hline 26 & 46,0 & 166,5 & 188,6 & 22,0 & 20,5 & 22,1 & 142,6 & 25,5 & 23,0 & 148,6 & 11,9 & 38,2 & 72,4 & 190,1 & 26,3 & \begin{tabular}{|l|}
34,2 \\
\end{tabular} & 17,7 & 78,2 & 27,4 & 35,6 & 22,6 & 185,6 \\
\hline 27 & 46,0 & 171,9 & 194,9 & 22,0 & 125,9 & 23,0 & 148,9 & 131,2 & 24,0 & 155,1 & 11,9 & 39,2 & 75,1 & 207,1 & 27,3 & 35,9 & 132,0 & 195,2 & 28,4 & \begin{tabular}{|l|}
37,4 \\
\end{tabular} & 137,5 & 203,3 \\
\hline 28 & 46,0 & 176,5 & 200,3 & 21,5 & 130,5 & 23,8 & 154,3 & 34,3 & 24,5 & 158,8 & 11,9 & 39,8 & 76,9 & 221,9 & 27,9 & 37,1 & 145,0 & 210,0 & 28,7 & 38,2 & 149,2 & 216,1 \\
\hline 29 & 46,0 & 182,1 & 207,1 & 21,5 & 136,1 & 25,0 & 100,1 & 140,1 & 25,7 & 165,8 & 12,0 & 32,8 & 52,7 & $J<, 4$ & 20,8 & 19,9 & , & 0,4 & 21,4 & 20,5 & 40,5 & 82,7 \\
\hline 30 & 46,0 & 187,3 & 213,3 & 21,0 & 141,3 & 26,0 & 167,3 & 143,7 & 26,4 & 170,1 & 12,0 & 33,7 & 55,5 & 133,5 & 21,7 & 21,8 & 78,0 & 121,5 & 22,1 & 22,2 & 79,3 & 123,5 \\
\hline 31 & 46,0 & 191,7 & 218,8 & 21,0 & 145,7 & 27,1 & 172,8 & 148,2 & 27,6 & 175,7 & 12,0 & 33,7 & 57,7 & 164,2 & 21,7 & 24,0 & 106,5 & 152,2 & 22,1 & \begin{tabular}{|l|}
24,4 \\
\end{tabular} & 108,3 & 154,8 \\
\hline 32 & 46,0 & 198,3 & 225,2 & 21,0 & 152,3 & 26,9 & 179,2 & 154,9 & 27,4 & 182,2 & 12,0 & 32,7 & 57,2 & 206,5 & 20,7 & 24,5 & 149,3 & 194,5 & 21,0 & 24,9 & 151,8 & 197,8 \\
\hline 32,2 & & & & 21,0 & \multicolumn{6}{|c|}{ Lavagem do FRD } & 12,0 & 33,0 & 58,0 & 222,0 & 21,0 & 25,0 & 164,0 & 210,0 & 21,4 & 25,4 & 166,8 & 213,5 \\
\hline 33 & 46,0 & 203,7 & 230,7 & 21,0 & 150,1 & 27,0 & 184,7 & 160,4 & 27,5 & 187,8 & 12,0 & 34,0 & 53,6 & 77,2 & 22,0 & 19,6 & 23,6 & 65,2 & 22,4 & 19,9 & 24,0 & 66,3 \\
\hline 34 & 46,0 & 207,8 & 237,0 & 21,0 & 161,8 & 29,2 & 191,0 & 164,5 & 29,7 & 194,2 & 12,0 & 34,4 & 55,1 & 103,8 & 22,4 & 20,7 & 48,7 & 91,8 & 22,8 & 21,0 & 49,5 & 93,3 \\
\hline 35 & 46,0 & 213,8 & 243,5 & 21,0 & 167,8 & 29,7 & 197,5 & 170,6 & 30,2 & 200,8 & 12,0 & 34,8 & 58,7 & 128,6 & 22,8 & 23,9 & 69,9 & 116,6 & 23,2 & 24,3 & 71,1 & 118,6 \\
\hline 36 & 46,0 & 219,5 & 250,4 & 21,0 & 173,5 & 30,9 & 204,4 & 176,4 & 31,4 & 207,8 & 12,0 & 35,6 & 63,4 & 152,9 & 23,6 & 27,8 & 89,5 & 140,9 & 24,0 & 28,3 & 91,0 & 143,3 \\
\hline
\end{tabular}
Média $\left({ }^{\circ} \mathrm{C}\right)=21,4$

$\mathrm{TF}=$ tempo de funcionamento; $\mathrm{T}$ = temperatura; Lavagem do FRD por perda de carga 


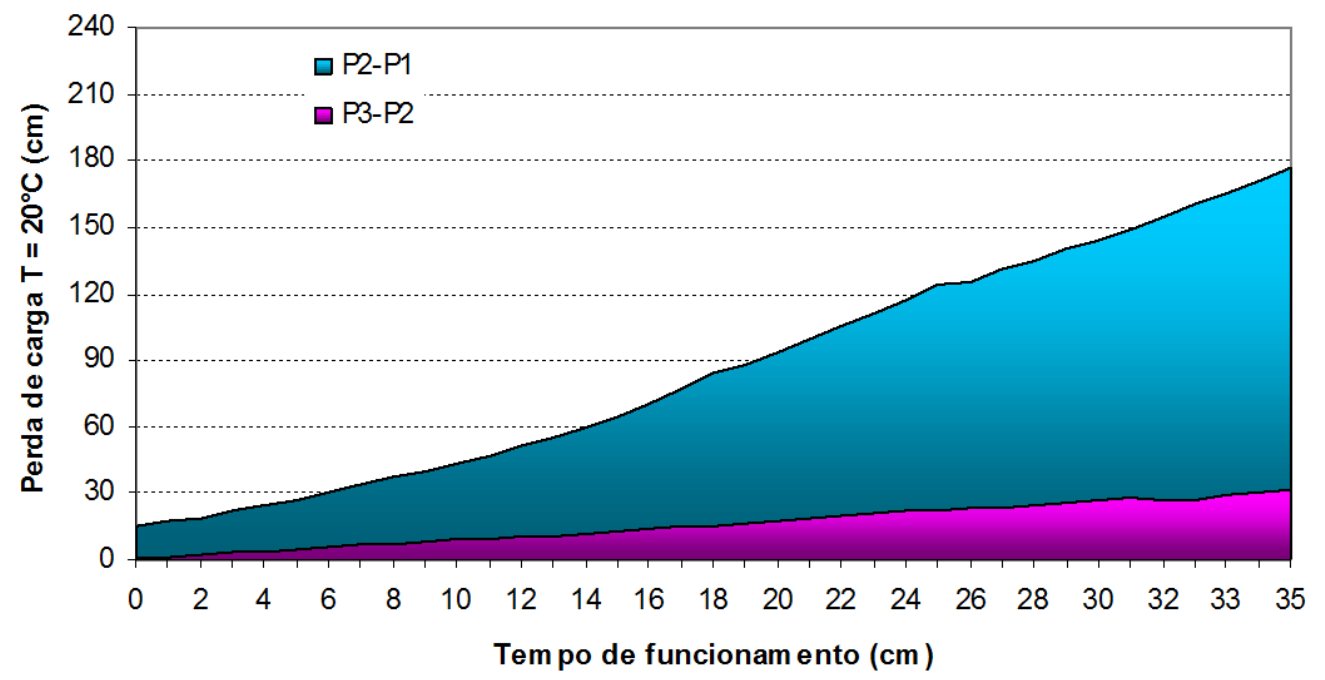

Figura C 1.1 - Perda de carga na camada suporte e camada de areia grossa no FAAG durante o ensaio $8-$ sem pré-oxidação ( $F A A G=180 \mathrm{~m}^{3} / \mathrm{m}^{2} \mathrm{~d}$ e $\mathrm{FRD}=280 \mathrm{~m}^{3} / \mathrm{m}^{2} \mathrm{~d}$ ). Fonte: Tabela C 1.3 - ANEXO C.

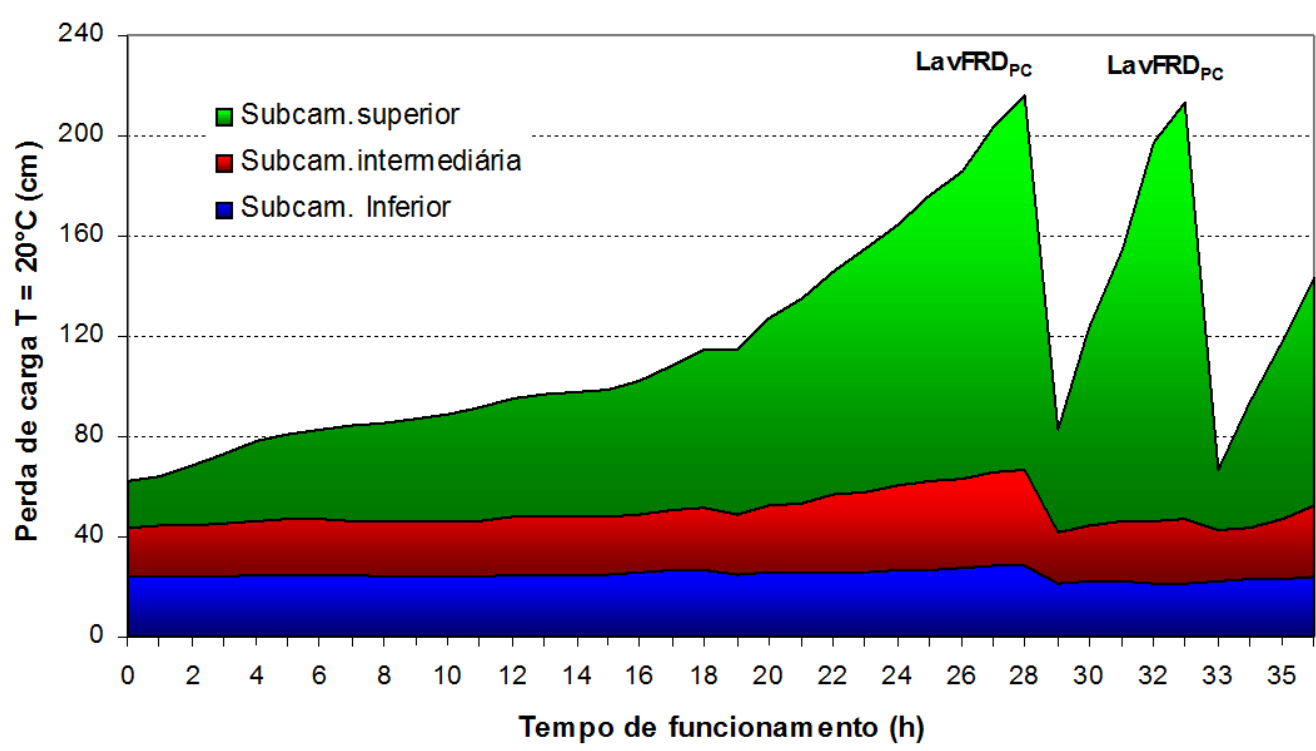

Figura C 1.2 - Perda de carga ao longo do meio filtrante do FRD durante o ensaio 8 - sem pré-oxidação $\left(F A A G=180 \mathrm{~m}^{3} / \mathrm{m}^{2} \mathrm{~d}\right.$ e $\left.\mathrm{FRD}=280 \mathrm{~m}^{3} / \mathrm{m}^{2} \mathrm{~d}\right)$. Fonte: Tabela C $1.3-$ ANEXO C. 
Tabela C 1.4 - Variação de vazões e taxas de filtração do FAAG e do FRD durante o ensaio 8 - sem pré-oxidação ( $F A A G=180 \mathrm{~m}^{3} / \mathrm{m}^{2} \mathrm{~d}$; $F R D=280 \mathrm{~m}^{3} / \mathrm{m}^{2} \mathrm{~d}$ ).

\begin{tabular}{|c|c|c|c|c|c|c|c|c|}
\hline \multirow{2}{*}{$\begin{array}{l}\text { TF } \\
\text { (h) } \\
\end{array}$} & \multicolumn{2}{|c|}{ descartes (L/h) } & \multicolumn{2}{|c|}{ turbidímetros (L/h) } & \multicolumn{2}{|c|}{ vazão total $(\mathrm{L} / \mathrm{h})$} & \multicolumn{2}{|c|}{ taxas de filtração $\left(\mathrm{m}^{3} / \mathrm{m}^{2} \mathrm{~d}\right)$} \\
\hline & FAAG & FRD & FAAG & FRD & FAAG & FRD & FAAG & FRD \\
\hline 0 & 6,58 & 54,65 & 35,50 & 24,37 & 121,10 & 79,02 & 186 & 289 \\
\hline 1 & 9,71 & 53,95 & 35,38 & 24,62 & 123,66 & 78,57 & 190 & 287 \\
\hline 2 & 10,75 & 51,66 & 35,91 & 24,00 & 122,32 & 75,66 & 188 & 277 \\
\hline 3 & 10,74 & 50,92 & 35,76 & 23,72 & 121,14 & 74,64 & 186 & 273 \\
\hline 4 & 9,42 & 53,50 & 35,46 & 23,52 & 121,90 & 77,02 & 187 & 282 \\
\hline 5 & 9,28 & 52,70 & 35,58 & 23,79 & 121,35 & 76,49 & 187 & 280 \\
\hline 6 & 9,40 & 54,00 & 34,89 & 23,76 & 122,05 & 77,76 & 188 & 284 \\
\hline 7 & 10,50 & 52,55 & 35,36 & 23,24 & 121,65 & 75,79 & 187 & 277 \\
\hline 8 & 10,29 & 51,56 & 35,19 & 23,92 & 120,96 & 75,48 & 186 & 276 \\
\hline 9 & 10,26 & 50,98 & 34,84 & 23,62 & 119,70 & 74,60 & 184 & 273 \\
\hline 10 & 8,73 & 53,70 & 34,99 & 23,62 & 121,04 & 77,32 & 186 & 283 \\
\hline 11 & 8,89 & 52,01 & 34,95 & 23,44 & 119,29 & 75,45 & 183 & 276 \\
\hline 12 & 6,79 & 53,27 & 33,95 & 23,67 & 117,68 & 76,94 & 181 & 281 \\
\hline 13 & 6,62 & 54,51 & 35,40 & 23,14 & 119,67 & 77,65 & 184 & 284 \\
\hline 14 & 6,49 & 52,59 & 35,28 & 23,67 & 118,03 & 76,26 & 181 & 279 \\
\hline 15 & 6,51 & 53,40 & 34,76 & 23,53 & 118,20 & 76,93 & 182 & 281 \\
\hline 16 & 6,52 & 54,12 & 34,49 & 23,61 & 118,74 & 77,73 & 183 & 284 \\
\hline 17 & 5,39 & 56,96 & 34,62 & 23,86 & 120,83 & 80,82 & 186 & 296 \\
\hline 18 & 9,15 & 57,03 & 31,69 & 23,15 & 121,02 & 80,18 & 186 & 293 \\
\hline 19 & 15,21 & 52,00 & 29,88 & 23,95 & 121,04 & 75,95 & 186 & 278 \\
\hline 20 & 15,05 & 54,76 & 26,21 & 23,76 & 119,78 & 78,52 & 184 & 287 \\
\hline 21 & 17,92 & 53,65 & 24,24 & 24,22 & 120,03 & 77,87 & 184 & 285 \\
\hline 22 & 20,57 & 54,50 & 24,83 & 24,24 & 124,14 & 78,74 & 191 & 288 \\
\hline 23 & 19,97 & 51,84 & 23,73 & 24,90 & 120,44 & 76,74 & 185 & 281 \\
\hline 24 & 20,95 & 53,73 & 23,67 & 24,67 & 123,02 & 78,40 & 189 & 287 \\
\hline 25 & 23,23 & 51,43 & 23,07 & 23,96 & 121,69 & 75,39 & 187 & 276 \\
\hline 26 & 22,11 & 51,57 & 22,78 & 23,89 & 120,35 & 75,46 & 185 & 276 \\
\hline 27 & 21,41 & 52,26 & 23,48 & 24,15 & 121,30 & 76,41 & 186 & 279 \\
\hline 28 & 20,55 & 53,54 & 23,01 & 23,64 & 120,74 & 77,18 & 186 & 282 \\
\hline 29 & 22,19 & 50,92 & 22,50 & 23,56 & 119,17 & 74,48 & 183 & 272 \\
\hline 30 & 19,94 & 51,54 & 22,37 & 24,67 & 118,52 & 76,21 & 182 & 279 \\
\hline 31 & 21,76 & 53,60 & 23,17 & 24,39 & 122,92 & 77,99 & 189 & 285 \\
\hline 32 & 23,67 & 47,24 & 22,46 & 23,42 & 116,79 & 70,66 & 180 & 258 \\
\hline 33 & 24,38 & 51,69 & 21,48 & 22,93 & 120,48 & 74,62 & 185 & 273 \\
\hline 34 & 23,97 & 51,67 & 20,36 & 23,13 & 119,13 & 74,80 & 183 & 274 \\
\hline 35 & 24,06 & 52,26 & 19,76 & 23,83 & 119,91 & 76,09 & 184 & 278 \\
\hline 36 & 24,32 & 53,25 & 19,12 & 22,83 & 119,52 & 76,08 & 184 & 278 \\
\hline & & & & Mínima & 116,79 & 70,66 & 180 & 258 \\
\hline & & & & Média & 120,52 & 76,65 & 185 & 280 \\
\hline & & & & Máxima & 124,14 & 80,82 & 191 & 296 \\
\hline & & & & DP & 1,65 & 1,85 & 2,53 & 6,77 \\
\hline
\end{tabular}

$\mathrm{TF}=$ tempo de funcionamento; FAAG = filtro ascendente de areia grossa; $F R D=$ filtro rápido descendente; $A C=$ água coagulada; $\mathrm{DP}=$ desvio padrão. 
Tabela C 2.1 - Características físicas da AB, AE, APO e efluentes do FAAG e do FRD durante o ensaio 9 - pré-oxidação com ozônio (FAAG $=180 \mathrm{~m}^{3} / \mathrm{m}^{2} \mathrm{~d} ; \mathrm{FRD}=280 \mathrm{~m}^{3} / \mathrm{m}^{2} \mathrm{~d}$ ).

\begin{tabular}{|c|c|c|c|c|c|c|c|c|c|}
\hline \multirow[b]{2}{*}{ TF (h) } & \multirow{2}{*}{\begin{tabular}{|c|}
$\begin{array}{c}\text { Temperatura } \\
\left({ }^{\circ} \mathrm{C}\right)\end{array}$ \\
$\mathrm{AE}$ \\
\end{tabular}} & \multicolumn{5}{|c|}{ Cor aparente (uH) } & \multicolumn{3}{|c|}{ Cor verdadeira (uH) } \\
\hline & & $\mathrm{AB}$ & $\mathrm{AE}$ & APO & FAAG & FRD & $\mathrm{AB}$ & $\mathrm{AE}$ & APO \\
\hline 0 & 25,0 & 155 & 213 & 135 & $<1,0$ & $<1,0$ & 14 & 97 & 23 \\
\hline 1 & 25,0 & & 228 & 133 & $<1,0$ & $<1,0$ & & 91 & 35 \\
\hline 2 & 23,0 & & 211 & 125 & $<1,0$ & $<1,0$ & & 83 & 23 \\
\hline 4 & 23,0 & & 231 & 135 & $<1,0$ & $<1,0$ & & 106 & 35 \\
\hline 6 & 22,5 & 149 & 223 & 138 & $<1,0$ & $<1,0$ & 28 & 90 & 28 \\
\hline 8 & 22,0 & & 219 & 130 & $<1,0$ & $<1,0$ & & 103 & 37 \\
\hline 10 & 22,0 & & 219 & 127 & $<1,0$ & $<1,0$ & & 102 & 31 \\
\hline 12 & 22,0 & 156 & 218 & 128 & $<1,0$ & $<1,0$ & 21 & 101 & 24 \\
\hline 14 & 23,0 & & 234 & 145 & 2,0 & $<1,0$ & & 104 & 40 \\
\hline 16 & 24,0 & & 240 & 161 & $<1,0$ & $<1,0$ & & 104 & 38 \\
\hline 18 & 25,0 & 165 & 228 & 146 & 13,0 & 1,0 & 22 & 102 & 39 \\
\hline 20 & 25,5 & & 223 & 139 & 32,0 & 1,0 & & 103 & 39 \\
\hline 22 & 25,0 & & 218 & 128 & 29,0 & $<1,0$ & & 103 & 32 \\
\hline 24 & 24,5 & 144 & 224 & 128 & 35,0 & 2,0 & 24 & 99 & 24 \\
\hline 26 & 23,5 & & 222 & 128 & 46,0 & $<1,0$ & & 101 & 36 \\
\hline 28 & 23,0 & & 214 & 118 & 47,0 & 2,0 & & 101 & 32 \\
\hline 30 & 22,5 & 146 & 234 & 141 & 55,0 & $<1,0$ & 22 & 102 & 32 \\
\hline 32 & 22,0 & & 230 & 138 & 57,0 & $<1,0$ & & 104 & 34 \\
\hline 34 & 22,0 & & 222 & 133 & 58,0 & $<1,0$ & & 103 & 36 \\
\hline 36 & 20,0 & 142 & 197 & 192 & 106,0 & $<1,0$ & 24 & 93 & 91 \\
\hline Média & 23,2 & 151 & 222 & 137 & 24,2 & 0,70 & 22 & 100 & 35 \\
\hline Mínimo & 20,0 & 142 & 197 & 118 & $<1,0$ & $<1,0$ & 14 & 83 & 23 \\
\hline Máximo & 25,5 & 165 & 240 & 192 & 106,0 & 2,00 & 28 & 106 & 91 \\
\hline DP & 1,44 & 8,12 & 9,66 & 15,87 & 29,67 & 0,47 & 4,26 & 5,90 & 14,19 \\
\hline
\end{tabular}

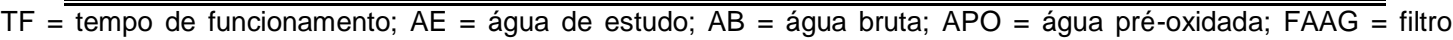
ascendente de areia grossa; $F R D$ = filtro rápido descendente; $\mathrm{DP}=$ desvio padrão. 
Tabela C 2.2 - Características químicas da AB, AE, APO e efluentes do FAAG e do FRD durante o ensaio 9 - pré-oxidação com ozônio (FAAG = 180 m³ $\mathrm{m}^{2} \mathrm{~d}$; $F R D=$ $280 \mathrm{~m}^{3} / \mathrm{m}^{2} \mathrm{~d}$ ).

\begin{tabular}{|c|c|c|c|c|c|c|c|c|c|c|c|c|c|c|c|c|c|c|c|c|c|}
\hline \multirow[b]{2}{*}{ TF (h) } & \multicolumn{4}{|c|}{$\mathrm{pH}$} & \multicolumn{3}{|c|}{ Alcalinidade $\left(\mathrm{mg} / \mathrm{L} \mathrm{CaCO}_{3}\right)$} & \multicolumn{5}{|c|}{ Absorvância 254 nm } & \multicolumn{5}{|c|}{$\operatorname{COD}(\mathrm{mg} / \mathrm{L})$} & \multicolumn{4}{|c|}{ Alumínio (mg/L) } \\
\hline & $A B$ & $\mathrm{AE}$ & APO & $\mathrm{AC}$ & AB & $\mathrm{AE}$ & APO & $\mathrm{AB}$ & $\mathrm{AE}$ & APO & FAAG & FRD & $\mathrm{AB}$ & $\mathrm{AE}$ & APO & FAAG & FRD & $A B$ & AE & FAAG & FRD \\
\hline 0 & 6,74 & 6,74 & 5,95 & 4,57 & 8,58 & 8,14 & 4,62 & 0,083 & 0,184 & 0,102 & 0,030 & 0,022 & - & - & $\begin{array}{lll}- & -\end{array}$ & $\begin{array}{lll}- & -\end{array}$ & $\begin{array}{lll}- & -\end{array}$ & 0,01 & ND & 0,02 & 0,02 \\
\hline 1 & & 6,61 & 5,91 & 4,57 & & & & & & & & & & & & & & & & & \\
\hline 2 & & 6,68 & - & 4,69 & & & & & & & & & & & & & & & & & \\
\hline 4 & & 6,68 & 5,92 & 4,65 & & & & & & & & & & & & & & & & & \\
\hline 6 & 6,66 & 6,72 & 5,96 & 4,66 & 8,14 & 9,46 & 5,28 & 0,086 & 0,201 & 0,102 & 0,013 & 0,013 & & & & & & & & & \\
\hline 8 & & 6,62 & 6,07 & 4,81 & & & & & & & & & & & & & & & & & \\
\hline 10 & & 6,67 & 6,09 & 4,86 & & & & & & & & & & & & & & & & & \\
\hline 12 & 6,67 & 6,62 & 6,04 & 4,96 & 8,58 & 10,78 & 5,06 & 0,076 & 0,192 & 0,099 & 0,012 & 0,017 & 1,975 & 2,474 & 2,473 & 2,338 & 2,181 & 0,03 & 0,01 & 0,90 & 0,85 \\
\hline 14 & & 6,63 & 6,12 & 4,91 & & & & & & & & & & & & & & & & & \\
\hline 16 & & 6,71 & 6,04 & 4,91 & & & & & & & & & & & & & & & & & \\
\hline 18 & 6,64 & 6,66 & 6,11 & 4,83 & 7,26 & 8,14 & 6,38 & 0,072 & 0,190 & 0,105 & 0,009 & 0,008 & & & & & & & & & \\
\hline 20 & & 6,68 & 5,96 & 4,82 & & & & & & & & & & & & & & & & & \\
\hline 22 & & 6,72 & 6,03 & 4,92 & & & & & & & & & & & & & & & & & \\
\hline 24 & 6,64 & 6,71 & 6,01 & 4,92 & 11,22 & 9,68 & 5,06 & 0,079 & 0,189 & 0,095 & 0,012 & 0,009 & 1,778 & 2,658 & 2,781 & 2,317 & 2,220 & ND & 0,01 & 0,34 & 0,34 \\
\hline 26 & & 6,71 & 6,09 & 4,98 & & & & & & & & & & & & & & & & & \\
\hline 28 & & 6,75 & 6,13 & 4,96 & & & & & & & & & & & & & & & & & \\
\hline 30 & 6,67 & 6,67 & 5,97 & 4,95 & 12,76 & 8,36 & 5,06 & 0,075 & 0,192 & 0,097 & 0,012 & 0,012 & & & & & & & & & \\
\hline 32 & & 6,64 & 6,02 & 5,22 & & & & & & & & & & & & & & & & & \\
\hline 34 & & 6,71 & 5,96 & 5,31 & & & & & & & & & & & & & & & & & \\
\hline 36 & 6,70 & 6,56 & 6,10 & 5,39 & 10,12 & 6,82 & 4,84 & 0,075 & 0,191 & 0,100 & 0,016 & 0,015 & 2,254 & 2,173 & 2,659 & 2,238 & 2,211 & ND & 0,05 & 0,10 & 0,08 \\
\hline Média & 6,67 & 6,67 & 6,03 & 4,89 & 9,52 & 8,77 & 5,19 & 0,078 & 0,191 & 0,100 & 0,015 & 0,014 & 2,002 & 2,435 & 2,638 & 2,298 & 2,204 & - & - & 0,34 & 0,32 \\
\hline Mínimo & 6,64 & 6,56 & 5,91 & 4,57 & 7,26 & 6,82 & 4,62 & 0,072 & 0,184 & 0,095 & 0,009 & 0,008 & 1,778 & 2,173 & 2,473 & 2,238 & 2,181 & - & - & 0,02 & 0,02 \\
\hline Máximo & 6,74 & 6,75 & 6,13 & 5,39 & 12,76 & 10,78 & 6,38 & 0,086 & 0,201 & 0,105 & 0,030 & 0,022 & 2,254 & 2,658 & 2,781 & 2,338 & 2,220 & - & - & 0,90 & 0,85 \\
\hline DP & 0,04 & 0,05 & 0,07 & 0,22 & 1,94 & 1,30 & 0,57 & 0,005 & 0,005 & 0,003 & 0,007 & 0,005 & 0,239 & 0,245 & 0,155 & 0,053 & 0,020 & - & - & 0,40 & 0,38 \\
\hline
\end{tabular}

$\mathrm{TF}=$ tempo de funcionamento; $\mathrm{AE}$ = água de estudo; $\mathrm{AB}$ = água bruta; $\mathrm{AC}$ = água coagulada; $\mathrm{APO}=$ água pré-oxidada; FAAG = filtro ascendente de areia grossa; $\mathrm{FRD}=$ filtro rápido descendente; $\mathrm{DP}=$ desvio padrão. 
Tabela C 2.3 - Perda de carga no FAAG $\left(180 \mathrm{~m}^{3} / \mathrm{m}^{2} \mathrm{~d}\right)$ e no FRD $\left(280 \mathrm{~m}^{3} / \mathrm{m}^{2} \mathrm{~d}\right)$ durante o ensaio 9, pré-oxidação com ozônio e sem DFls no FAAG para a temperatura T e para $\mathrm{T}=20^{\circ} \mathrm{C}$

\begin{tabular}{|c|c|c|c|c|c|c|c|c|c|c|c|c|c|c|c|c|c|c|c|c|c|c|}
\hline \multirow{3}{*}{$\begin{array}{l}\text { TF } \\
\text { (h) }\end{array}$} & \multicolumn{10}{|c|}{ FAAG } & \multicolumn{12}{|c|}{ FRD } \\
\hline & \multicolumn{3}{|c|}{$\begin{array}{c}\text { Leitura piezométrica } \\
(\mathrm{cm})\end{array}$} & \multirow{2}{*}{$\begin{array}{c}\mathrm{T} \\
\left({ }^{\circ} \mathrm{C}\right)\end{array}$} & \multicolumn{3}{|c|}{$\begin{array}{l}\text { Perda de carga } \\
\text { (cm) }\end{array}$} & \multicolumn{3}{|c|}{$\begin{array}{c}\text { Perda de carga }(\mathrm{cm}) \\
T=20^{\circ} \mathrm{C}\end{array}$} & \multicolumn{4}{|c|}{\begin{tabular}{|c} 
Leitura piezométrica \\
$(\mathbf{c m})$
\end{tabular}} & \multicolumn{4}{|c|}{$\begin{array}{l}\text { Perda de carga } \\
(\mathrm{cm})\end{array}$} & \multicolumn{4}{|c|}{$\begin{array}{c}\text { Perda de carga }(\mathrm{cm}) \\
T=20^{\circ} \mathrm{C}\end{array}$} \\
\hline & P1 & P2 & P3 & & P2-P1 & P3-P2 & P3-P1 & P2-P1 & P3-P2 & P3-P1 & P1 & $\mathrm{P} 2$ & P3 & P4 & P2-P1 & P3-P2 & P4-P3 & P4-P1 & P2-P1 & P3-P2 & P4-P3 & P4-P1 \\
\hline 0 & 46,0 & 59,8 & 60,6 & 25,0 & 13,8 & 0,8 & 14,6 & 15,5 & 0,9 & 16,4 & 12,1 & 34,8 & 51,3 & 64,3 & 22,7 & 16,5 & 13,0 & 52,2 & 25,4 & 18,5 & 14,6 & 58,5 \\
\hline 1 & 46,0 & 60,8 & 62,1 & 25,0 & 14,8 & 1,3 & 16,1 & 16,6 & 1,5 & 18,0 & 12,1 & 36,2 & 53,9 & 68,4 & 24,1 & 17,7 & 14,5 & 56,3 & 27,0 & 19,8 & 16,2 & 63,1 \\
\hline 2 & 46,0 & 61,5 & 63,2 & 25,0 & 15,5 & 1,7 & 17,2 & 17,4 & 1,9 & 19,3 & 12,1 & 35,9 & 53,5 & 68,0 & 23,8 & 17,6 & 14,5 & 55,9 & 26,7 & 19,7 & 16,2 & 62,6 \\
\hline 3 & 46,0 & 62,4 & 64,5 & 23,0 & 16,4 & 2,1 & 18,5 & 17,5 & 2,2 & 19,7 & 12,0 & 35,6 & 53,3 & 68,1 & 23,6 & 17,7 & 14,8 & 56,1 & 25,2 & 18,9 & 15,8 & 59,9 \\
\hline 4 & 46,0 & 63,3 & 65,7 & 23,0 & 17,3 & 2,4 & 19,7 & 18,5 & 2,6 & 21,0 & 12,0 & 34,9 & 53,7 & 69,0 & 22,9 & 18,8 & 15,3 & 57,0 & 24,4 & 20,1 & 16,3 & 60,8 \\
\hline 5 & 46,0 & 64,0 & 66,8 & 23,0 & 18,0 & 2,8 & 20,8 & 19,2 & 3,0 & 22,2 & 12,0 & 35,2 & 52,5 & 67,6 & 23,2 & 17,3 & 15,1 & 55,6 & 24,8 & 18,5 & 16,1 & 59,3 \\
\hline 6 & 46,0 & 65,0 & 68,3 & 23,0 & 19,0 & 3,3 & 22,3 & 20,3 & 3,5 & 23,8 & 12,0 & 36,2 & 54,3 & 70,2 & 24,2 & 18,1 & 15,9 & 58,2 & 25,8 & 19,3 & 17,0 & 62,1 \\
\hline 7 & 46,0 & 66,0 & 69,6 & 22,5 & 20,0 & 3,6 & 23,6 & 1 & 3,8 & 4,9 & 12,0 & 36,1 & 54,2 & 70,2 & 24,1 & 18,1 & 16,0 & 58,2 & 5,4 & 19,1 & 16,9 & 1,4 \\
\hline 8 & 46,0 & 67,0 & 70,9 & 22,5 & 21,0 & 3,9 & 24,9 & 22,1 & 4,1 & 26,3 & 12,0 & 35,8 & 53,5 & 69,6 & 23,8 & 17,7 & 16,1 & 58,2 & 25,1 & 18,7 & 17,0 & 61,4 \\
\hline 9 & 46,0 & 67,9 & 72,2 & 22,0 & 21,9 & 4,3 & 26,2 & 22,8 & 4,5 & 27,3 & 12,0 & 37,0 & 55,8 & 72,7 & 25,0 & 18,8 & 16,9 & 57,6 & 26,0 & 19,6 & 17,6 & 60,0 \\
\hline 10 & 46,0 & 69,2 & 74,0 & 22,0 & 23,2 & 4,8 & 28,0 & 24,2 & 5,0 & 29,2 & 12,0 & 36,7 & 55,1 & 71,8 & 24,7 & 18,4 & 16,7 & 60,7 & 25,7 & 19,2 & 17,4 & 63,2 \\
\hline 11 & 46,0 & 70,6 & 74,8 & 22,0 & 24,6 & 4,2 & 28,8 & 25,6 & 4,4 & 30,0 & 12,0 & 36,8 & 55,4 & 72,3 & 24,8 & 18,6 & 16,9 & 59,8 & 25,8 & 19,4 & 17,6 & 62,3 \\
\hline 12 & 46,0 & 71,5 & 77,0 & 22,0 & 25,5 & 5,5 & 31,0 & 26,6 & 5,7 & 32,3 & 12,0 & 36,8 & 55,5 & 72,5 & 24,8 & 18,7 & 17,0 & 60,3 & 25,8 & 19,5 & 17,7 & 62,8 \\
\hline 13 & 46,0 & 72,7 & 78,4 & 22,0 & 26,7 & 5,7 & 32,4 & 27,8 & 5,9 & 33,8 & 12,0 & 36,9 & 55,6 & 72,7 & 24,9 & 18,7 & 17,1 & 60,5 & 25,9 & 19,5 & 17,8 & 63,0 \\
\hline 14 & 46,0 & 74,0 & 80,1 & 22,0 & 28,0 & 6,1 & 34,1 & 29,2 & 6,4 & 35,5 & 12,0 & 36,9 & 55,6 & 72,7 & 24,9 & 18,7 & 17,1 & 60,7 & 25,9 & 19,5 & 17,8 & 63,2 \\
\hline 15 & 46,0 & 75,3 & 81,8 & 23,0 & 29,3 & 6,5 & 35,8 & 31,3 & 6,9 & 38,2 & 12,0 & 36,9 & 55,7 & 73,1 & 24,9 & 18,8 & 17,4 & 60,7 & 26,6 & 20,1 & 18,6 & 64,8 \\
\hline 16 & 46,0 & 76,5 & 83,5 & 23,0 & 30,5 & 7,0 & 37,5 & 32,6 & 7,5 & 40,0 & 12,0 & 36,3 & 54,4 & 71,4 & 24,3 & 18,1 & 17,0 & 61,1 & 25,9 & 19,3 & 18,1 & 65,2 \\
\hline 17 & 46,0 & 77,3 & 84,3 & 24,0 & 31,3 & 7,0 & 38,3 & 34,2 & 7,7 & 41,9 & 12,0 & 36,5 & 54,9 & 72,2 & 24,5 & 18,4 & 17,3 & 59,4 & 26,8 & 20,1 & 18,9 & 64,9 \\
\hline 18 & 46,0 & 78,4 & 85,7 & 24,0 & 32,4 & 7,3 & 39,7 & 35,4 & 8,0 & 43,4 & 12,0 & 36,3 & 54,5 & 71,7 & 24,3 & 18,2 & 17,2 & 60,2 & 26,6 & 19,9 & 18,8 & 65,8 \\
\hline 19 & 46,0 & 79,8 & 87,4 & 25,0 & 33,8 & 7,6 & 41,4 & 37,9 & 8,5 & 46,4 & 12,0 & 36,0 & 54,0 & 71,2 & 24,0 & 18,0 & 17,2 & 59,7 & 26,9 & 20,2 & 19,3 & 66,9 \\
\hline 20 & 46,0 & 81,0 & 88,9 & 25,0 & 35,0 & 7,9 & 42,9 & 39,2 & 8,8 & 48,0 & 12,0 & 36,7 & 55,3 & 73,1 & 24,7 & 18,6 & 17,8 & 59,2 & 27,7 & 20,8 & 19,9 & 66,3 \\
\hline 21 & 46,0 & 82,2 & 90,4 & 25,5 & 36,2 & 8,2 & 44,4 & 41,0 & 9,3 & 50,3 & 12,1 & 37,1 & 56,0 & 75,1 & 25,0 & 18,9 & 19,1 & 61,0 & 28,3 & 21,4 & 21,7 & 69,2 \\
\hline 22 & 46,0 & 83,7 & 92,3 & 25,5 & 37,7 & 8,6 & 46,3 & 42,7 & 9,7 & 52,5 & 12,0 & 35,6 & 53,5 & 73,0 & 23,6 & 17,9 & 19,5 & 63,1 & 26,8 & 20,3 & 22,1 & 71,5 \\
\hline 23 & 46,0 & 84,7 & 93,5 & 25,0 & 38,7 & 8,8 & 47,5 & 43,3 & 9,9 & 53,2 & 12,0 & 36,1 & 54,8 & 76,2 & 24,1 & 18,7 & 21,4 & 61,0 & 27,0 & 20,9 & 24,0 & 68,3 \\
\hline
\end{tabular}


(continuação)

\begin{tabular}{|c|c|c|c|c|c|c|c|c|c|c|c|c|c|c|c|c|c|c|c|c|c|c|}
\hline 24 & 46,0 & 86,1 & 95,3 & 25,0 & 40,1 & 9,2 & 49,3 & 44,9 & 10,3 & 55,2 & 12,0 & 35,7 & 54,4 & 77,4 & 23,7 & 18,7 & 23,0 & 64,2 & 26,5 & 20,9 & 25,8 & 71,9 \\
\hline 25 & 46,0 & 87,6 & 97,0 & 24,5 & 41,6 & 9,4 & 51,0 & 46,0 & 10,4 & 56,4 & 12,0 & 35,8 & 55,5 & 81,2 & 23,8 & 19,7 & 25,7 & 65,4 & 26,3 & 21,8 & 28,4 & 72,4 \\
\hline 26 & 46,0 & 88,5 & 98,4 & 24,5 & 42,5 & 9,9 & 52,4 & 47,0 & 11,0 & 58,0 & 11,9 & 35,6 & 55,1 & 82,4 & 23,7 & 19,5 & 27,3 & 69,3 & 26,2 & 21,6 & 30,2 & 76,7 \\
\hline 27 & 46,0 & 90,0 & 100,0 & 23,5 & 44,0 & 10,0 & 54,0 & 47,5 & 10,8 & 58,3 & 11,9 & 36,6 & 57,4 & 88,0 & 24,7 & 20,8 & 30,6 & 70,5 & 26,7 & 22,5 & 33,1 & 76,2 \\
\hline 28 & 46,0 & 91,3 & 101,5 & 23,5 & 45,3 & 10,2 & 55,5 & 48,9 & 11,0 & 60,0 & 11,9 & 37,3 & 59,0 & 92,2 & 25,4 & 21,7 & 33,2 & 76,1 & 27,4 & 23,4 & 35,9 & 82,2 \\
\hline 29 & 46,0 & 92,4 & 102,9 & 23,0 & 46,4 & 10,5 & 56,9 & 49,5 & 11,2 & 60,7 & 11,9 & 36,9 & 58,5 & 93,9 & 25,0 & 21,6 & 35,4 & 80,3 & 26,7 & 23,1 & 37,8 & 85,7 \\
\hline 30 & 46,0 & 93,7 & 104,6 & 23,0 & 47,7 & 10,9 & 58,6 & 50,9 & 11,6 & 62,5 & 11,9 & 37,4 & 59,7 & 98,2 & 25,5 & 22,3 & 8,5 & 82,0 & 27,2 & 3,8 & 1,1 & 87,5 \\
\hline 31 & 46,0 & 95,0 & 106,2 & 22,5 & 49,0 & 11,2 & 60,2 & 51,7 & 11,8 & 63,5 & 11,8 & 37,7 & 60,4 & 103,1 & 25,9 & 22,7 & 42,7 & 86,4 & 27,3 & 23,9 & 45,0 & 91,1 \\
\hline 32 & 46,0 & 96,5 & 107,9 & 22,5 & 50,5 & 11,4 & 61,9 & 53,2 & 12,0 & 65,3 & 11,8 & 38,3 & 61,9 & 108,5 & 26,5 & 23,6 & 46,6 & 91,3 & 27,9 & 24,9 & 49,1 & 96,3 \\
\hline 33 & 46,0 & 97,3 & 108,9 & 22,0 & 51,3 & 11,6 & 62,9 & 53,4 & 12,1 & 65,5 & 12,0 & 36,4 & 54,4 & 72,0 & 24,4 & 18,0 & 17,6 & 96,5 & 25,4 & 18,8 & 18,3 & 100,5 \\
\hline 34 & 46,0 & 98,4 & 110,2 & 22,0 & 52,4 & 11,8 & 64,2 & 54,6 & 12,3 & 66,9 & 12,0 & 36,4 & 55,4 & 76,6 & 24,4 & 19,0 & 21,2 & 60,0 & 25,4 & 19,8 & 22,1 & 62,5 \\
\hline 35 & 46,0 & 99,6 & 111,7 & 22,0 & 53,6 & 12,1 & 65,7 & 55,8 & 12,6 & 68,4 & 12,0 & 37,5 & 58,1 & 83,3 & 25,5 & 20,6 & 25,2 & 64,6 & 26,6 & 21,5 & 26,3 & 67,3 \\
\hline 36 & 46,0 & 100,9 & 113,2 & 22,0 & 54,9 & 12,3 & 67,2 & 57,2 & 12,8 & 70,0 & 12,0 & 37,5 & 58,5 & 86,8 & 25,5 & 21,0 & 28,3 & 71,3 & 26,6 & 21,9 & 29,5 & 74,3 \\
\hline
\end{tabular}

$\mathrm{FAAG}=$ filtro ascendente de areia grossa; $\mathrm{FRD}=$ filtro rápido descendente; $\mathrm{TF}=$ tempo de funcionamento; $\mathrm{T}=$ temperatura; Lavagem do FRD por transpasse. 


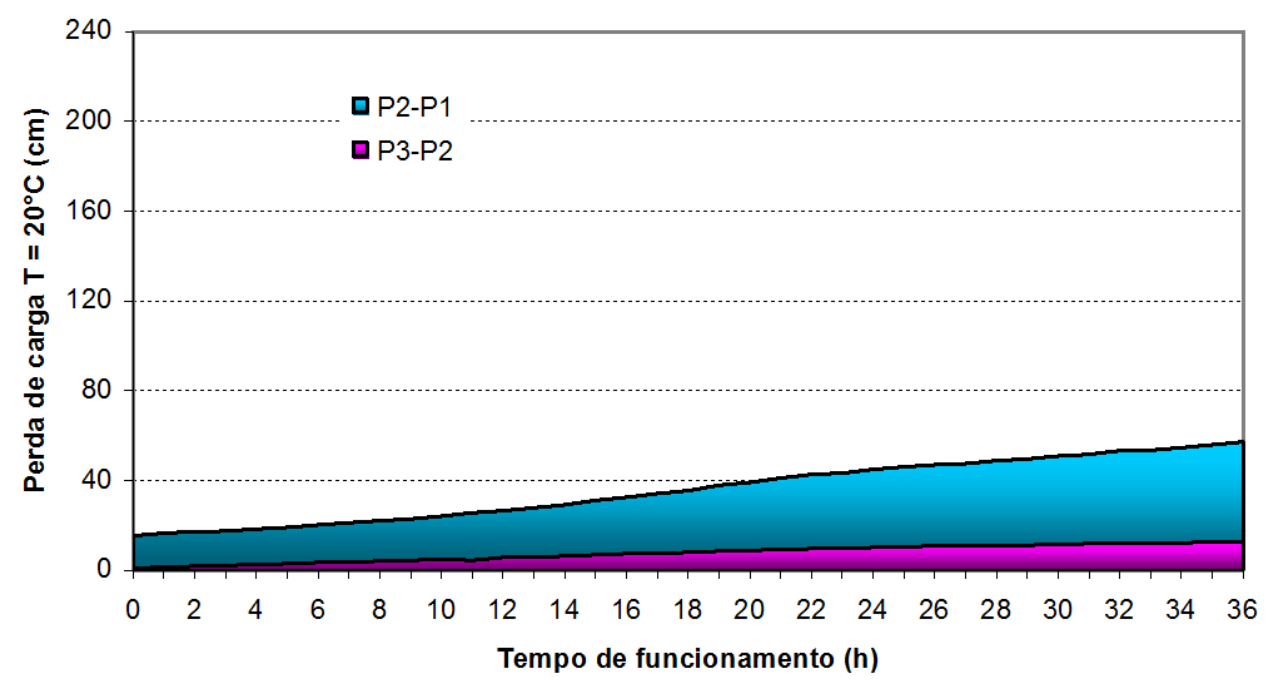

Figura C 2.1 - Perda de carga na camada suporte e camada de areia grossa no FAAG durante 0 ensaio 9 - pré-oxidação com ozônio ( $F A A G=180 \mathrm{~m}^{3} / \mathrm{m}^{2} \mathrm{~d}$ e $\mathrm{FRD}=280 \mathrm{~m}^{3} / \mathrm{m}^{2} \mathrm{~d}$ ). Fonte: Tabela C 2.3 - ANEXO C.

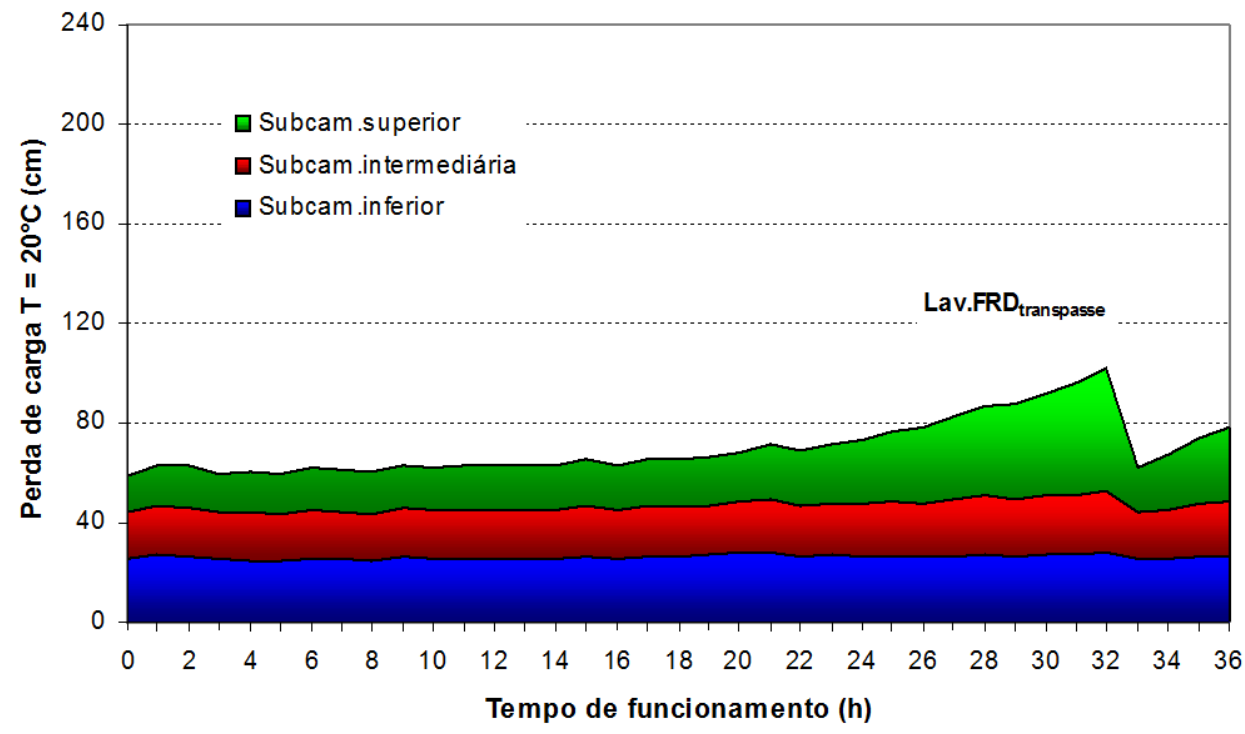

Figura C 2.2 - Perda de carga ao longo do meio filtrante do FRD durante o ensaio 9 - pré-oxidação com ozônio $\left(F A A G=180 \mathrm{~m}^{3} / \mathrm{m}^{2} \mathrm{~d}\right.$ e FRD $\left.=280 \mathrm{~m}^{3} / \mathrm{m}^{2} \mathrm{~d}\right)$. Fonte: Tabela C $2.3-$ ANEXO C. 
Tabela C 2.4 - Variação de vazões e taxas de filtração do FAAG e do FRD durante o ensaio 9 - préoxidação com ozônio ( $F A A G=180 \mathrm{~m}^{3} / \mathrm{m}^{2} \mathrm{~d} ; \mathrm{FRD}=280 \mathrm{~m}^{3} / \mathrm{m}^{2} \mathrm{~d}$ ).

\begin{tabular}{|c|c|c|c|c|c|c|c|c|c|}
\hline \multirow{2}{*}{$\begin{array}{l}\text { TF } \\
\text { (h) }\end{array}$} & \multicolumn{3}{|c|}{ descartes (L/h) } & \multicolumn{2}{|c|}{ turbidímetros (L/h) } & \multicolumn{2}{|c|}{ vazão total (L/h) } & \multicolumn{2}{|c|}{ taxas de filtração $\left(\mathrm{m}^{3} / \mathrm{m}^{2} \mathrm{~d}\right)$} \\
\hline & AC & FAAG & FRD & FAAG & FRD & FAAG & FRD & FAAG & FRD \\
\hline 0 & 52,68 & 18,61 & 53,13 & 22,94 & 24,85 & 119,53 & 77,98 & 184 & 285 \\
\hline 1 & 53,04 & 19,78 & 56,96 & 23,47 & 24,60 & 124,81 & 81,56 & 192 & 298 \\
\hline 2 & 56,65 & 21,53 & 54,70 & 22,03 & 24,53 & 122,79 & 79,23 & 189 & 290 \\
\hline 3 & 50,99 & 23,21 & 51,71 & 22,54 & 24,31 & 121,77 & 76,02 & 187 & 278 \\
\hline 4 & 50,82 & 23,45 & 53,65 & 22,26 & 24,00 & 123,36 & 77,65 & 190 & 284 \\
\hline 5 & 52,50 & 25,55 & 49,60 & 22,25 & 24,43 & 121,83 & 74,03 & 187 & 271 \\
\hline 6 & 53,07 & 23,34 & 53,02 & 22,65 & 23,92 & 122,93 & 76,94 & 189 & 281 \\
\hline 7 & 50,99 & 23,55 & 52,14 & 22,53 & 23,36 & 121,58 & 75,50 & 187 & 276 \\
\hline 8 & 54,70 & 23,57 & 52,21 & 22,53 & 22,30 & 120,61 & 74,51 & 185 & 273 \\
\hline 9 & 51,69 & 19,89 & 55,86 & 21,98 & 22,53 & 120,26 & 78,39 & 185 & 287 \\
\hline 10 & 55,13 & 321,48 & 54,32 & 22,70 & 21,64 & 120,14 & 75,96 & 185 & 278 \\
\hline 11 & 54,15 & 521,82 & 55,07 & 22,09 & 21,66 & 120,64 & 76,73 & 185 & 281 \\
\hline 12 & 67,75 & 21,94 & 54,38 & 23,34 & 21,77 & 121,43 & 76,15 & 187 & 279 \\
\hline 13 & 52,20 & 21,54 & 53,95 & 23,03 & 21,89 & 120,41 & 75,84 & 185 & 277 \\
\hline 14 & 53,78 & 21,20 & 54,52 & 22,69 & 22,46 & 120,87 & 76,98 & 186 & 282 \\
\hline 15 & 51,93 & 21,50 & 55,24 & 22,60 & 22,75 & 122,09 & 77,99 & 188 & 285 \\
\hline 16 & 54,28 & 322,42 & 51,84 & 22,77 & 22,53 & 119,56 & 74,37 & 184 & 272 \\
\hline 17 & 53,11 & 20,63 & 55,38 & 22,71 & 23,30 & 122,02 & 78,68 & 188 & 288 \\
\hline 18 & 53,85 & 20,40 & 56,13 & 22,38 & 22,56 & 121,47 & 78,69 & 187 & 288 \\
\hline 19 & 55,00 & 21,74 & 53,65 & 21,47 & 22,47 & 119,33 & 76,12 & 183 & 278 \\
\hline 20 & 53,25 & 20,78 & 58,80 & 18,79 & 21,99 & 120,36 & 80,79 & 185 & 296 \\
\hline 21 & 54,42 & 20,72 & 60,37 & 17,87 & 22,53 & 121,49 & 82,90 & 187 & 303 \\
\hline 22 & 56,33 & 25,06 & 53,78 & 16,58 & 22,82 & 118,24 & 76,60 & 182 & 280 \\
\hline 23 & 54,68 & 24,10 & 58,10 & 15,53 & 22,26 & 119,99 & 80,36 & 184 & 294 \\
\hline 24 & 54,98 & 327,21 & 55,80 & 14,23 & 22,46 & 119,70 & 78,26 & 184 & 286 \\
\hline 25 & 58,06 & 13,33 & 55,38 & 28,83 & 22,60 & 120,14 & 77,98 & 185 & 285 \\
\hline 26 & 57,14 & 419,39 & 53,68 & 23,85 & 22,57 & 119,49 & 76,25 & 184 & 279 \\
\hline 27 & 54,97 & 719,71 & 56,43 & 22,73 & 22,57 & 121,44 & 79,00 & 187 & 289 \\
\hline 28 & 55,38 & 319,95 & 55,84 & 22,30 & 22,93 & 121,02 & 78,77 & 186 & 288 \\
\hline 29 & 56,02 & 23,31 & 52,97 & 20,92 & 22,65 & 119,85 & 75,62 & 184 & 277 \\
\hline 30 & 53,23 & 23,31 & 53,80 & 21,69 & 22,81 & 121,61 & 76,61 & 187 & 280 \\
\hline 31 & 53,13 & 24,00 & 53,83 & 21,39 & 22,25 & 121,47 & 76,08 & 187 & 278 \\
\hline 33 & 57,23 & 30,68 & 56,05 & 15,48 & 24,06 & 126,27 & 80,11 & 194 & 293 \\
\hline 34 & 58,17 & 730,04 & 52,15 & 14,40 & 23,84 & 120,43 & 75,99 & 185 & 278 \\
\hline 35 & 50,78 & 28,13 & 54,63 & 13,85 & 23,15 & 119,76 & 77,78 & 184 & 285 \\
\hline \multirow[t]{5}{*}{36} & 54,78 & 29,73 & 53,17 & 13,68 & 24,15 & 120,73 & 77,32 & 186 & 283 \\
\hline & & & & & Mínima & 118,24 & 74,03 & 182 & 271 \\
\hline & & & & & Média & 121,10 & 77,49 & 186 & 283 \\
\hline & & & & & Máxima & 126,27 & 82,90 & 194 & 303 \\
\hline & & & & & DP & 1,56 & 2,01 & 2,41 & 7,35 \\
\hline
\end{tabular}

$\mathrm{TF}=$ tempo de funcionamento; FAAG = filtro ascendente de areia grossa; FRD = filtro rápido descendente; $\mathrm{AC}=$ água coagulada; $\mathrm{DP}=$ desvio padrão. 
Tabela C 3.1 - Características físicas da AB, AE, APO e efluentes do FAAG e do FRD durante o ensaio 10 - pré-oxidação com peróxido de hidrogênio (FAAG $=180 \mathrm{~m}^{3} / \mathrm{m}^{2} \mathrm{~d}$; $F R D=280 \mathrm{~m}^{3} / \mathrm{m}^{2} \mathrm{~d}$ ).

\begin{tabular}{c|c|c|c|c|c|c|c|c|c}
\hline \hline & $\begin{array}{c}\text { Temperatura } \\
\text { ('C) }\end{array}$ & \multicolumn{9}{|c|}{ Cor aparente (uH) } & \multicolumn{3}{|c}{ Cor verdadeira (uH) } \\
\cline { 2 - 10 } TF (h) & AE & AB & AE & APO & FAAG & FRD & AB & AE & APO \\
\hline \hline $\mathbf{0}$ & 21,0 & 184 & 258 & 259 & 9,0 & 2,0 & 31 & 116 & 117 \\
$\mathbf{1}$ & 21,5 & & 262 & 252 & 33,0 & 21,0 & & 121 & 112 \\
$\mathbf{2}$ & 22,0 & & 250 & 246 & 20,0 & 9,0 & & 92 & 100 \\
$\mathbf{4}$ & 22,0 & & 224 & 222 & 2,0 & $<1,0$ & & 90 & 91 \\
$\mathbf{6}$ & 22,0 & 156 & 227 & 223 & 4,0 & 2,0 & 24 & 98 & 98 \\
$\mathbf{8}$ & 22,0 & & 222 & 223 & 2,0 & $<1,0$ & & 101 & 99 \\
$\mathbf{1 0}$ & 20,5 & & 221 & 219 & 1,0 & $<1,0$ & & 97 & 95 \\
$\mathbf{1 2}$ & 20,0 & 149 & 217 & 215 & $<1,0$ & $<1,0$ & 18 & 99 & 95 \\
$\mathbf{1 4}$ & 20,0 & & 214 & 214 & 2,0 & 1,0 & & 96 & 96 \\
$\mathbf{1 6}$ & 20,0 & & 215 & 213 & 2,0 & 1,0 & & 100 & 99 \\
$\mathbf{1 8}$ & 19,5 & 146 & 214 & 213 & 28,0 & $<1,0$ & 22 & 94 & 96 \\
$\mathbf{2 0}$ & 19,5 & & 212 & 212 & 57,0 & $<1,0$ & & 98 & 98 \\
$\mathbf{2 2}$ & 20,0 & & 205 & 205 & 69,0 & 1,0 & & 95 & 94 \\
$\mathbf{2 4}$ & 21,0 & 140 & 210 & 211 & 75,0 & $<1,0$ & 24 & 104 & 97 \\
$\mathbf{2 6}$ & 22,0 & & 220 & 206 & 82,0 & 1,0 & & 100 & 102 \\
$\mathbf{2 8}$ & 22,0 & & 210 & 207 & 91,0 & 5,0 & & 100 & 98 \\
$\mathbf{3 0}$ & 22,0 & 134 & 202 & 201 & 94,0 & $<1,0$ & 27 & 96 & 99 \\
$\mathbf{3 2}$ & 21,0 & & 204 & 198 & 91,0 & 2,0 & & 98 & 96 \\
$\mathbf{3 4}$ & 20,0 & & 205 & 201 & 102,0 & 1,0 & & 97 & 95 \\
$\mathbf{3 6}$ & 20,0 & 130 & 197 & 192 & 106,0 & $<1,0$ & 18 & 93 & 91 \\
\hline \hline Média & 20,9 & 148 & 219 & 217 & 43,5 & 2,53 & 23 & 99 & 98 \\
Mínimo & 19,5 & 130 & 197 & 192 & $<1,0$ & $<1,0$ & 18 & 90 & 91 \\
Máximo & 22,0 & 184 & 262 & 259 & 106,0 & 21,00 & 31 & 121 & 117 \\
$\mathbf{D P}$ & 0,97 & 18,02 & 17,92 & 17,62 & 40,97 & 4,81 & 4,69 & 7,40 & 6,20 \\
\hline \hline
\end{tabular}

$\mathrm{TF}$ = tempo de funcionamento; $\mathrm{AE}$ = água de estudo; $\mathrm{AB}$ = água bruta; $\mathrm{APO}$ = água pré-oxidada; $\mathrm{FAAG}=$ filtro ascendente de areia grossa; $\mathrm{FRD}=$ filtro rápido descendente; $\mathrm{DP}=$ desvio padrão. 
Tabela C 3.2 - Características químicas da AB, AE, APO e efluentes do FAAG e do FRD durante o ensaio 10 - pré-oxidação com peróxido de hidrogênio (FAAG = 180 $\left.\mathrm{m}^{3} / \mathrm{m}^{2} \mathrm{~d} ; \mathrm{FRD}=280 \mathrm{~m}^{3} / \mathrm{m}^{2} \mathrm{~d}\right)$

\begin{tabular}{|c|c|c|c|c|c|c|c|c|c|c|c|c|c|c|c|c|c|c|c|c|c|}
\hline \multirow[b]{2}{*}{ TF (h) } & \multicolumn{4}{|c|}{ pH } & \multicolumn{3}{|c|}{ Alcalinidade $\left(\mathrm{mg} / \mathrm{L} \mathrm{CaCO}_{3}\right)$} & \multicolumn{5}{|c|}{ Absorvância 254 nm } & \multicolumn{5}{|c|}{$\operatorname{COD}(\mathrm{mg} / \mathrm{L})$} & \multicolumn{4}{|c|}{ Alumínio (mg/L) } \\
\hline & $\mathrm{AB}$ & $\mathrm{AE}$ & APO & $\mathrm{AC}$ & $\mathrm{AB}$ & $\mathrm{AE}$ & APO & $A B$ & $\mathrm{AE}$ & APO & FAAG & FRD & $A B$ & $\mathbf{A E}$ & APO & FAAG & FRD & $\mathrm{AB}$ & $\mathbf{A E}$ & FAAG & FRD \\
\hline 0 & 6,48 & 6,56 & 6,24 & 5,52 & 5,06 & 5,5 & 3,96 & 0,107 & 0,230 & 0,248 & 0,019 & 0,021 & 3,215 & 3,356 & 5,251 & 2,329 & 2,724 & - & - & - & - \\
\hline 1 & & 6,43 & 6,07 & 5,30 & & & & & & & & & & & & & & & & & \\
\hline 2 & & 6,43 & 5,99 & 5,18 & & & & & & & & & & & & & & & & & \\
\hline 4 & & 6,38 & 5,97 & 5,20 & & & & & & & & & & & & & & & & & \\
\hline 6 & 6,48 & 6,55 & 5,95 & 5,24 & 3,52 & 6,38 & 3,08 & 0,081 & 0,190 & 0,225 & 0,018 & 0,024 & & & & & & & & & \\
\hline 8 & & 6,56 & 6,11 & 5,23 & & & & & & & & & & & & & & & & & \\
\hline 10 & & 6,44 & 5,90 & 5,32 & & & & & & & & & & & & & & & & & \\
\hline 12 & 6,44 & 6,50 & 6,14 & 5,26 & 7,92 & 7,04 & 5,28 & 0,080 & 0,197 & 0,189 & 0,040 & 0,048 & 2,381 & 2,977 & 3,708 & 2,373 & 2,547 & ND & ND & 0,07 & 0,04 \\
\hline 14 & & 6,55 & 6,04 & 5,26 & & & & & & & & & & & & & & & & & \\
\hline 16 & & 6,44 & 6,03 & 5,24 & & & & & & & & & & & & & & & & & \\
\hline 18 & 6,49 & 6,51 & 5,93 & 5,32 & 6,38 & 5,94 & 4,84 & 0,079 & 0,190 & 0,188 & 0,018 & 0,024 & & & & & & & & & \\
\hline 20 & & 6,45 & 6,09 & 5,34 & & & & & & & & & & & & & & & & & \\
\hline 22 & & 6,46 & 5,94 & 5,28 & & & & & & & & & & & & & & & & & \\
\hline 24 & 6,46 & 6,60 & 6,11 & 5,26 & 5,94 & 7,48 & 4,40 & 0,080 & 0,195 & 0,186 & 0,019 & 0,024 & 2,429 & 4,410 & 3,602 & 2,108 & 2,094 & ND & 0,01 & 0,06 & 0,03 \\
\hline 26 & & 6,51 & 6,06 & 5,22 & & & & & & & & & & & & & & & & & \\
\hline 28 & & 6,50 & 6,03 & 5,28 & & & & & & & & & & & & & & & & & \\
\hline 30 & 6,56 & 6,58 & 6,08 & 5,28 & 6,60 & 7,48 & 4,62 & 0,077 & 0,184 & 0,188 & 0,018 & 0,022 & & & & & & & & & \\
\hline 32 & & 6,50 & 6,18 & 5,31 & & & & & & & & & & & & & & & & & \\
\hline 34 & & 6,56 & 6,07 & 5,33 & & & & & & & & & & & & & & & & & \\
\hline 36 & 6,60 & 6,56 & 6,12 & 5,39 & 7,26 & 8,36 & 5,72 & 0,075 & 0,176 & 0,241 & 0,079 & 0,083 & 2,563 & 4,133 & 3,820 & 2,504 & 2,865 & ND & ND & 0,11 & 0,07 \\
\hline Média & 6,50 & 6,50 & 6,05 & 5,29 & 6,10 & 6,88 & 4,56 & 0,083 & 0,195 & 0,209 & 0,030 & 0,035 & 2,647 & 3,719 & 4,095 & 2,329 & 2,558 & - & - & 0,08 & 0,05 \\
\hline Mínimo & 6,44 & 6,38 & 5,90 & 5,18 & 3,52 & 5,50 & 3,08 & 0,075 & 0,176 & 0,186 & 0,018 & 0,021 & 2,381 & 2,977 & 3,602 & 2,108 & 2,094 & - & - & 0,06 & 0,03 \\
\hline Máximo & 6,60 & 6,60 & 6,24 & 5,52 & 7,92 & 8,36 & 5,72 & 0,107 & 0,230 & 0,248 & 0,079 & 0,083 & 3,215 & 4,410 & 5,251 & 2,504 & 2,865 & - & - & 0,11 & 0,07 \\
\hline DP & 0,06 & 0,06 & 0,09 & 0,07 & 1,46 & 1,00 & 0,87 & 0,011 & 0,017 & 0,028 & 0,023 & 0,023 & 0,386 & 0,666 & 0,776 & 0,165 & 0,335 & - & - & 0,03 & 0,02 \\
\hline
\end{tabular}

$\mathrm{TF}=$ tempo de funcionamento; $\mathrm{AE}$ = água de estudo; $\mathrm{AB}$ = água bruta; $\mathrm{AC}=$ água coagulada; $\mathrm{APO}=$ água pré-oxidada; $\mathrm{FAAG}=$ filtro ascendente de areia grossa; $\mathrm{FRD}=$ filtro rápido descendente; $\mathrm{DP}=$ desvio padrão. 
Tabela C 3.3 - Perda de carga no FAAG $\left(180 \mathrm{~m}^{3} / \mathrm{m}^{2} \mathrm{~d}\right)$ e no FRD $\left(280 \mathrm{~m}^{3} / \mathrm{m}^{2}\right.$ d) durante o ensaio 10 , pré-oxidação com peróxido de hidrogênio e sem DFls no FAAG para a temperatura $\mathrm{T}$ e para $\mathrm{T}=20^{\circ} \mathrm{C}$.

\begin{tabular}{|c|c|c|c|c|c|c|c|c|c|c|c|c|c|c|c|c|c|c|c|c|c|c|}
\hline \multirow{3}{*}{$\begin{array}{l}\text { TF } \\
\text { (h) }\end{array}$} & \multicolumn{10}{|c|}{ FAAG } & \multicolumn{12}{|c|}{ FRD } \\
\hline & \multicolumn{3}{|c|}{\begin{tabular}{|c|} 
Leitura piezométrica \\
$(\mathrm{cm})$
\end{tabular}} & \multirow{2}{*}{$\begin{array}{c}\mathrm{T} \\
\left({ }^{\circ} \mathrm{C}\right)\end{array}$} & \multicolumn{3}{|c|}{$\begin{array}{l}\text { Perda de carga } \\
(\mathrm{cm})\end{array}$} & \multicolumn{3}{|c|}{$\begin{array}{c}\text { Perda de carga }(\mathrm{cm}) \\
T=20^{\circ} \mathrm{C}\end{array}$} & \multicolumn{4}{|c|}{$\begin{array}{l}\text { Leitura piezométrica } \\
(\mathbf{c m})\end{array}$} & \multicolumn{4}{|c|}{$\begin{array}{l}\text { Perda de carga } \\
\text { (cm) }\end{array}$} & \multicolumn{4}{|c|}{$\begin{array}{c}\text { Perda de carga }(\mathrm{cm}) \\
\mathrm{T}=20^{\circ} \mathrm{C}\end{array}$} \\
\hline & $\mathrm{P} 1$ & $\mathrm{P} 2$ & P3 & & 2-P1 & P3-P2 & P3-P1 & P2-P1 & P3-P2 & P3-P1 & $\mathrm{P} 1$ & P2 & P3 & P4 & P2-P1 & P3-P2 & P4-P3 & P4-P1 & P2-P1 & P3-P2 & P4-P3 & P4-P1 \\
\hline 0 & 45,8 & 6 & 6 & 21,0 & & & & & & & 12,1 & 35,8 & 57,9 & 74,9 & & & & 8 & 24,1 & D & 3 &, 9 \\
\hline 1 & 45,9 & 61,8 & 63,5 & 21,5 & 5,9 & & 6 & 16,4 &, 7 & 18,1 & 12,1 & 35,8 & 58,7 & 78,6 & 23,7 & 22,9 & 19,9 & 66,5 & 24,4 & 23,6 & 0,5 &, 4 \\
\hline 2 & 45,9 & & & 22,0 & & & & 18,2 & & & 12,1 & 35,9 & 59,7 & 85,0 & 23,8 & & & & & & & \\
\hline 3 & 45,9 & 65,1 & 68,7 & 22,0 & 19,2 & 3,6 & & 20,0 & 3,8 & & 12,1 & 35,9 & 60,4 & 88,9 & 3,8 & 24,5 & 8,5 & & & & & \\
\hline 4 & 45,8 & 67,0 & 71,5 & 22,0 & 21,2 & & 25,7 & 22,1 & 4,7 & 26,8 & 12,2 & 35,9 & 60,5 & 90,5 & 23,7 & 24,6 & 30,0 & 78,3 & 4,7 & 6 & 3 & 81,6 \\
\hline 5 & 45,8 & 69, & 74,2 & 22,0 & 3,2 & 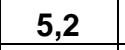 & 8,4 & 4,2 & 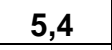 & 9,6 & 12,2 & 35,9 & 60,5 & 91,3 & 23,7 & 4,6 & 8 & 1 & 7 & 6 & 1 & \\
\hline 6 & 45,8 & 71,1 & 76,9 & 22,0 & & & & & & & 12,2 & 35,9 & 60,6 & 92,4 & & & & & & & & \\
\hline 8 & 45,9 & 76,0 & 83,1 & 22,0 & & & & & & & 12,2 & 36,0 & & & 23,8 & & & & & & & \\
\hline 9 & 45,9 & 79,3 & 87,2 & 22,0 & 33,4 & & & 3 & 8 , & 43,0 & 12,1 & 36,6 & 62,4 & 97,8 & 24,5 & 8 & 4 & 85,7 & 5 & 9 & 9 & 3 \\
\hline 10 & 45,9 & 81, & 89,8 & 22,0 & 35,6 & & & & & 45,7 & 12,1 & 37,1 & 63,4 & 100,0 & 25,0 & 26,3 & 6 & 87,9 & & 4 & 1 & \\
\hline 11 & 45,9 & & & 2 & & & & & & & 12,1 & & & & & & & & & & & \\
\hline 12 & 45,9 & 87,0 & 96,5 & 20,0 & & & & & & & 12,1 & 37,0 & 63,4 & 101,5 & 4,9 & & 38,1 & 89,4 & 4,7 & 2 & 37,8 & \\
\hline 13 & 45,9 & 89,7 & 99,7 & 20,0 & 43,8 & 10,0 & 53,8 & 43,5 & 9,9 & 53,4 & 12,1 & 37,1 & 63,7 & 102,4 & 25,0 & 26,6 & 38,7 & 90,3 & 24,8 & 26,4 & 38,4 & 89,6 \\
\hline 14 & 45,9 & 92,3 & 102,7 & 20,0 & 46,4 & 10,4 & 56,8 & 46,1 & 10,3 & 56,4 & 12,1 & 37,2 & 64,0 & 103,3 & 25,1 & 26,8 & 39,3 & 1,2 & 9 & 26,6 & 39,0 & 90,5 \\
\hline 15 & 45,9 & 95,6 & 106,5 & 20,0 & & 10,9 & & & & & 12,1 & 37,4 & 64,4 & 104,5 & 25,3 & & & 92,4 & & 26,8 & 39,8 & \\
\hline 16 & 45,9 & 98,7 & 110,0 & 20,0 & & & & & & & 12,0 & 37,5 & 64,6 & 105,3 & & & 40,7 & & & & 40,4 & \\
\hline 17 & 45,9 & 101,8 & 113,6 & 20,0 & 55,9 & 11,8 & 67,7 & 55,5 & 11,7 & 67,2 & 12,0 & 37,6 & 64,9 & 107,3 & 25,6 & 27,3 & 42,4 & 95,3 & 25,4 & 7,1 & 42,1 & 94,6 \\
\hline 18 & 45,8 & 105,0 & 117,2 & 19,5 & 59,2 & 12,2 & 71,4 & 58,1 & 12,0 & 70,0 & 12,0 & 38,5 & 66,8 & 115,2 & 26,5 & 28,3 & 48,4 & 103,2 & 26,0 & 27,8 & 47,5 & 101,2 \\
\hline 19 & 45,8 & 107,7 & 120,5 & 19,5 & & & & & & & 12,0 & 37,6 & 65,3 & 119,2 & 25,6 & 27,7 & 3,9 & 107,2 & 5,1 & 27,2 & 52,9 & 105,1 \\
\hline 20 & 45,8 & 110,4 & 123,3 & 19,5 & 64,6 & 12,9 & 77,5 & 63,3 & 12,6 & 76,0 & 12,0 & 37,7 & 67,3 & 128,5 & 25,7 & 29,6 & 61,2 & 116,5 & 25,2 & 29,0 & 60,0 & 114,2 \\
\hline 21 & 45,8 & 113,0 & 126,3 & 19,5 & 67,2 & 13,3 & 80,5 & 65,9 & 13,0 & 78,9 & 12,0 & 38,0 & 73,4 & 141,9 & 26,0 & 35,4 & 68,5 & 129,9 & 25,5 & 34,7 & 67,2 & 127,4 \\
\hline 22 & 45,8 & 115,6 & 129,4 & 20,0 & 69,8 & 13,8 & 83,6 & 69,3 & 13,7 & 83,0 & 12,0 & 38,0 & 77,9 & 151,4 & 26,0 & 39,9 & 73,5 & 139,4 & 25,8 & 39,6 & 73,0 & 138,4 \\
\hline 23 & 45,8 & 117,5 & 131,5 & 20,0 & 71,7 & 14,0 & 85,7 & 71,2 & 13,9 & 85,1 & 12,0 & 38,7 & 83,2 & 161,7 & 26,7 & 44,5 & 78,5 & 149,7 & 26,5 & 44,2 & 77,9 & 148,6 \\
\hline
\end{tabular}


(continuação)

\begin{tabular}{|c|c|c|c|c|c|c|c|c|c|c|c|c|c|c|c|c|c|c|c|c|c|c|}
\hline 24 & 45,9 & 119,1 & 33,5 & 21,0 & 73,2 & 14,4 & 87,6 & 74,4 & 14,6 & 89,1 & 12,0 & 38,1 & 84,3 & 164,6 & 26,1 & 46,2 & 80,3 & 152,6 & 26,5 & 47,0 & 81,7 & 155,2 \\
\hline 25 & 45,9 & 120,6 & 35,2 & 1,0 & 74,7 & 1,6 & 9,3 & 6,0 & 1 & 90,8 & 2,0 & 8,9 & 87,6 & 71,8 & 26,9 & 48,7 & 84,2 & 59,8 & 7,4 & 9,5 & 5,6 & 62,5 \\
\hline 26 & 45,9 & 122,6 & 37,4 & 2,0 & 76,7 & 14,8 & 91,5 & 79,9 & 15,4 & 95,3 & 2,0 & 0,1 & 91,9 & 181,0 & 8,1 & 51,8 & 89,1 & 69,0 & 9,3 & 4,0 & 2,8 & 76,1 \\
\hline 27 & 45,9 & 125,3 & 140,6 & 22,0 & 79,4 & 15,3 & 94,7 & 82,7 & 15,9 & 98,7 & 2,0 & 41,2 & 95,3 & 188,4 & 29,2 & 54,1 & 93,1 & 76,4 & 0,4 & 6,4 & 7,0 & 83,8 \\
\hline 28 & 5,9 & 8,3 & 4,1 & 2,0 & & 15,8 & J & 85,8 & 10,0 & 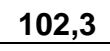 & 0 & 3,3 & 101,3 & 6 & 31,3 & 58,0 & 3 & 6 & 2,6 & 0,4 & 7 & 01,7 \\
\hline 28,4 & & & & 22,0 & \multicolumn{6}{|c|}{ Lavagem do FRD - transpasse } & 12,0 & 44,5 & 104,8 & 8 & 32,5 & 60,3 & 109,0 & 201,8 & 33,9 & 2,8 & 113,5 & 210,2 \\
\hline 29 & 46,0 & 130,4 & 146,4 & 22,0 & 84, & 16,0 & 100,4 & 87,9 & 16,7 & 104,6 & 12,0 & 32,6 & 50,8 & 70,2 & 20,6 & 18,2 & 19,4 & 58,2 & 21,5 & 19,0 & 20,2 & 60,6 \\
\hline 30 & 46,0 & 132,1 & 148,3 & 22,0 & 86,1 & 16,2 & 102,3 & 89,7 & 16,9 & 106,6 & 12,0 & 34,5 & 54,4 & 96,3 & 22,5 & 19,9 & 41,9 & 84,3 & 23,4 & 20,7 & 43,6 & 37,8 \\
\hline 31 & 46,0 & 135,0 & 151,6 & 22,0 & 89,0 & 16,6 & 105,6 & 92,7 & 17,3 & 110,0 & 12,0 & 35,0 & 58,2 & 123,0 & 23,0 & 23,2 & 64,8 & 111,0 & 24,0 & 24,2 & 67,5 & 115,6 \\
\hline 32 & 45,9 & 137,2 & 154,3 & 21,0 & 91,3 & 7,1 & 108,4 & 92,8 & 17 & 0,2 & 12,0 & 35,4 & 61,3 & 146,0 & 3,4 & 25,9 & 84,7 & 4,0 & 3,8 & 6,3 & 6,1 & 36,3 \\
\hline 33 & 45,9 & 40,0 & 157,0 & 1,0 & & & & & & & 12,0 & 35,8 & 63,8 & 181,5 & 23,8 & 28,0 & & 69,5 & 4,2 & 8,5 & 19,7 & 72,4 \\
\hline 34 & 45,9 & 141,7 & 59,7 & 20,0 & 5,8 & 18,0 & 113,8 & 95,1 & 17,9 & 113,0 & 11,9 & 36,5 & 65,8 & 214,4 & 24,6 & 29,3 & 148,6 & 02,5 & 24,4 & 9,1 & 47,5 & 201,0 \\
\hline 34,3 & & & & 20,0 & \multicolumn{6}{|c|}{ Lavagem do FRD - perda de carga } & 11,9 & 36,6 & 65,9 & 222,0 & 24,7 & 29,3 & 156,1 & 210,1 & 24,5 & 29,1 & 154,9 & 208,5 \\
\hline 35 & 45,9 & 143,8 & 162,1 & 20,0 & $91, y$ & 18,3 & 116,2 & 97,2 & 18,2 & 110,3 & 12,6 & 36,2 & 57,2 & 82,7 & 23,6 & 21,0 & 25,5 & 70,1 & 23,4 & 20,8 & 25,3 & 69,6 \\
\hline 36 & 45,9 & 146,3 & 164,9 & 20,0 & 100,4 & 18,6 & 119,0 & 99,7 & 18,5 & 118,1 & 12,7 & 36,8 & 60,7 & 109,6 & 24,1 & 23,9 & 48,9 & 96,9 & 23,9 & 23,7 & 48,5 & 96,2 \\
\hline
\end{tabular}

FAAG = filtro ascendente de areia grossa; FRD = filtro rápido descendente; TF = tempo de funcionamento; $T$ = temperatura. 


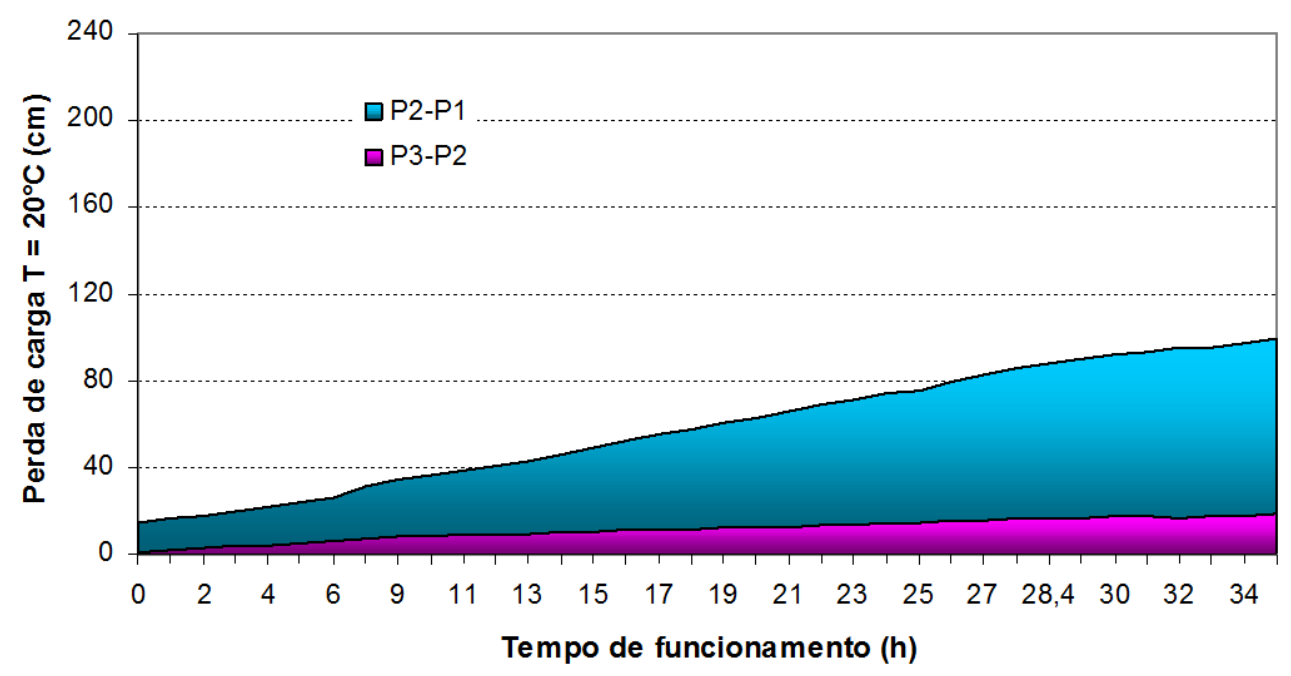

Figura C 3.1 - Perda de carga na camada suporte e camada de areia grossa no FAAG durante o ensaio 10 - pré-oxidação com peróxido de hidrogênio ( $F A A G=180 \mathrm{~m}^{3} / \mathrm{m}^{2} \mathrm{~d}$ e $\mathrm{FRD}=280 \mathrm{~m}^{3} / \mathrm{m}^{2} \mathrm{~d}$ ). Fonte: Tabela C 3.3 - ANEXO C.

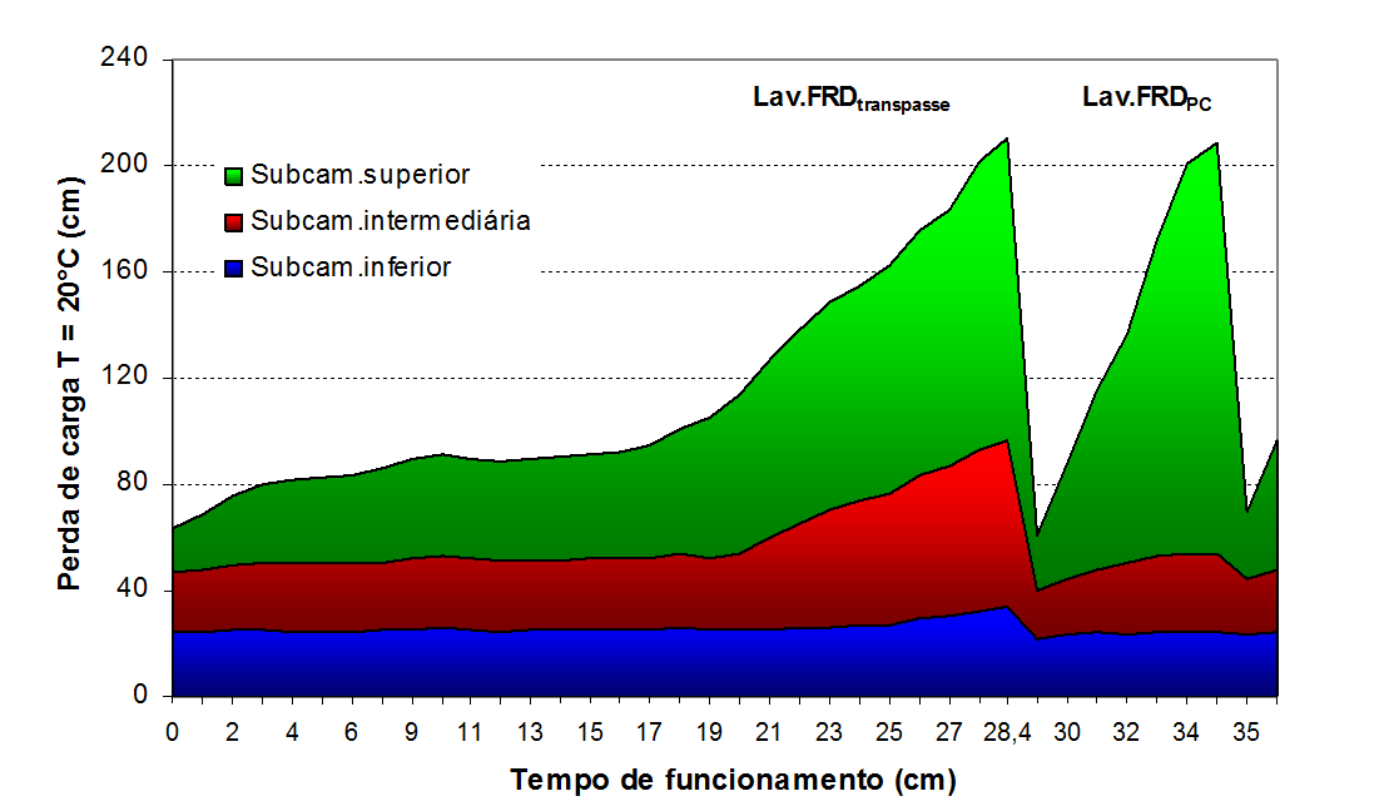

Figura C 3.2 - Perda de carga ao longo do meio filtrante do FRD durante o ensaio 10 - pré-oxidação com peróxido de hidrogênio (FAAG $=180 \mathrm{~m}^{3} / \mathrm{m}^{2} \mathrm{~d}$ e $\mathrm{FRD}=280 \mathrm{~m}^{3} / \mathrm{m}^{2} \mathrm{~d}$ ). Fonte: Tabela C $3.3-$ ANEXO C. 
Tabela C 3.4 - Variação de vazões e taxas de filtração do FAAG e do FRD durante o ensaio 10 - préoxidação com peróxido de hidrogênio ( $F A A G=180 \mathrm{~m}^{3} / \mathrm{m}^{2} \mathrm{~d} ; \mathrm{FRD}=280 \mathrm{~m}^{3} / \mathrm{m}^{2} \mathrm{~d}$ ).

\begin{tabular}{|c|c|c|c|c|c|c|c|c|}
\hline \multirow{2}{*}{$\begin{array}{l}\text { TF } \\
\text { (h) }\end{array}$} & \multicolumn{2}{|c|}{ descartes (L/h) } & \multicolumn{2}{|c|}{ turbidímetros (L/h) } & \multicolumn{2}{|c|}{ vazão total (L/h) } & \multicolumn{2}{|c|}{ taxas de filtração $\left(\mathrm{m}^{3} / \mathrm{m}^{2} \mathrm{~d}\right)$} \\
\hline & FAAG & FRD & FAAG & FRD & FAAG & FRD & FAAG & FRD \\
\hline 0 & 22,42 & 52,19 & 21,04 & 22,80 & 118,45 & 74,99 & 182 & 274 \\
\hline 1 & 22,30 & 54,49 & 21,47 & 22,83 & 121,09 & 77,32 & 186 & 283 \\
\hline 2 & 22,53 & 54,45 & 21,49 & 22,66 & 121,13 & 77,11 & 186 & 282 \\
\hline 3 & 21,78 & 53,88 & 21,03 & 22,79 & 119,48 & 76,67 & 184 & 280 \\
\hline 4 & 22,38 & 53,40 & 21,18 & 22,30 & 119,26 & 75,70 & 183 & 277 \\
\hline 5 & 22,29 & 53,96 & 20,75 & 23,24 & 120,24 & 77,20 & 185 & 282 \\
\hline 6 & 22,14 & 53,44 & 20,88 & 23,42 & 119,88 & 76,86 & 184 & 281 \\
\hline 8 & 22,08 & 55,75 & 20,23 & 22,65 & 120,71 & 78,40 & 186 & 287 \\
\hline 9 & 22,60 & 54,55 & 20,78 & 22,69 & 120,62 & 77,24 & 185 & 283 \\
\hline 10 & 22,01 & 55,32 & 20,64 & 22,60 & 120,57 & 77,92 & 185 & 285 \\
\hline 11 & 22,06 & 55,67 & 20,62 & 22,50 & 120,85 & 78,17 & 186 & 286 \\
\hline 12 & 23,81 & 54,57 & 20,45 & 22,38 & 121,21 & 76,95 & 186 & 281 \\
\hline 13 & 23,12 & 55,16 & 20,00 & 22,63 & 120,91 & 77,79 & 186 & 285 \\
\hline 14 & 23,02 & 54,44 & 19,94 & 22,21 & 119,61 & 76,65 & 184 & 280 \\
\hline 15 & 23,21 & 53,91 & 19,80 & 22,61 & 119,53 & 76,52 & 184 & 280 \\
\hline 16 & 24,22 & 53,86 & 19,96 & 22,50 & 120,54 & 76,36 & 185 & 279 \\
\hline 17 & 24,00 & 53,95 & 19,65 & 22,18 & 119,78 & 76,13 & 184 & 278 \\
\hline 18 & 21,96 & 54,53 & 19,28 & 22,84 & 118,61 & 77,37 & 182 & 283 \\
\hline 19 & 27,19 & 55,00 & 19,31 & 22,45 & 123,95 & 77,45 & 191 & 283 \\
\hline 20 & 27,44 & 53,20 & 19,05 & 22,21 & 121,90 & 75,41 & 187 & 276 \\
\hline 21 & 27,61 & 53,44 & 19,28 & 22,18 & 122,51 & 75,62 & 188 & 277 \\
\hline 22 & 29,59 & 53,88 & 19,89 & 22,90 & 126,26 & 76,78 & 194 & 281 \\
\hline 23 & 29,01 & 53,10 & 19,73 & 22,89 & 124,73 & 75,99 & 192 & 278 \\
\hline 24 & 29,07 & 53,38 & 19,08 & 22,63 & 124,16 & 76,01 & 191 & 278 \\
\hline 25 & 29,17 & 53,54 & 18,67 & 22,70 & 124,08 & 76,24 & 191 & 279 \\
\hline 26 & 29,54 & 53,82 & 19,43 & 23,03 & 125,82 & 76,85 & 193 & 281 \\
\hline 27 & 29,79 & 53,22 & 19,19 & 23,05 & 125,25 & 76,27 & 193 & 279 \\
\hline 28 & 29,27 & 53,74 & 19,14 & 23,31 & 125,46 & 77,05 & 193 & 282 \\
\hline 29 & 27,49 & 50,41 & 19,35 & 23,20 & 120,45 & 73,61 & 185 & 269 \\
\hline 30 & 29,15 & 53,10 & 18,76 & 23,73 & 124,74 & 76,83 & 192 & 281 \\
\hline 31 & 29,35 & 53,26 & 18,60 & 23,19 & 124,40 & 76,45 & 191 & 280 \\
\hline 32 & 29,12 & 53,20 & 18,86 & 23,27 & 124,45 & 76,47 & 191 & 280 \\
\hline 33 & 29,88 & 53,15 & 18,20 & 22,20 & 123,43 & 75,35 & 190 & 276 \\
\hline 34 & 29,42 & 52,41 & 18,13 & 22,70 & 122,66 & 75,11 & 189 & 275 \\
\hline 35 & 29,32 & 51,56 & 19,26 & 22,67 & 122,81 & 74,23 & 189 & 272 \\
\hline 36 & 29,12 & 52,73 & 18,35 & 22,45 & 122,65 & 75,18 & 189 & 275 \\
\hline & & & & Mínima & 118,45 & 73,61 & 182 & 269 \\
\hline & & & & Média & 122,01 & 76,45 & 188 & 280 \\
\hline & & & & Máxima & 126,26 & 78,40 & 194 & 287 \\
\hline & & & & DP & 2,24 & 1,05 & 3,44 & 3,86 \\
\hline
\end{tabular}

$\mathrm{TF}=$ tempo de funcionamento; FAAG = filtro ascendente de areia grossa; FRD = filtro rápido descendente; $A C=$ água coagulada; $\mathrm{DP}=$ desvio padrão. 
Tabela C 4.1 - Características físicas da AB, AE, APO e efluentes do FAAG e do FRD durante o ensaio 11 - pré-oxidação com tricloro-s-triazina-triona ( $F A A G=180 \mathrm{~m}^{3} / \mathrm{m}^{2} \mathrm{~d} ; \mathrm{FRD}=280 \mathrm{~m}^{3} / \mathrm{m}^{2} \mathrm{~d}$ ).

\begin{tabular}{|c|c|c|c|c|c|c|c|c|c|}
\hline \multirow[b]{2}{*}{ TF (h) } & \multirow{2}{*}{\begin{tabular}{|c|}
$\begin{array}{c}\text { Temperatura } \\
\left({ }^{\circ} \mathbf{C}\right)\end{array}$ \\
$\mathrm{AE}$ \\
\end{tabular}} & \multicolumn{5}{|c|}{ Cor aparente (uH) } & \multicolumn{3}{|c|}{ Cor verdadeira (uH) } \\
\hline & & $\mathrm{AB}$ & $\mathrm{AE}$ & APO & FAAG & FRD & $\mathrm{AB}$ & $\mathrm{AE}$ & APO \\
\hline 0 & 19,5 & 107 & 190 & 178 & $<1,0$ & $<1,0$ & 12 & 101 & 87 \\
\hline 1 & 19,0 & & 192 & 181 & 4,0 & 2,0 & & 102 & 94 \\
\hline 2 & 19,0 & & 193 & 183 & 2,0 & $<1,0$ & & 101 & 96 \\
\hline 4 & 19,0 & & 188 & 192 & $<1,0$ & $<1,0$ & & 93 & 89 \\
\hline 6 & 18,0 & 109 & 186 & 176 & $<1,0$ & $<1,0$ & 12 & 95 & 83 \\
\hline 8 & 18,0 & & 187 & 184 & $<1,0$ & $<1,0$ & & 96 & 91 \\
\hline 10 & 17,0 & & 181 & 177 & 1,0 & $<1,0$ & & 99 & 90 \\
\hline 12 & 17,0 & 97 & 172 & 168 & 1,0 & $<1,0$ & 14 & 92 & 84 \\
\hline 14 & 19,0 & & 177 & 174 & 14,0 & 5,0 & & 96 & 93 \\
\hline 16 & 21,0 & & 175 & 176 & $<1,0$ & $<1,0$ & & 92 & 89 \\
\hline 18 & 21,0 & 97 & 171 & 163 & 1,0 & $<1,0$ & 16 & 94 & 85 \\
\hline 20 & 21,0 & & 175 & 170 & 8,0 & $<1,0$ & & 98 & 92 \\
\hline 22 & 20,0 & & 175 & 171 & 28,0 & $<1,0$ & & 96 & 89 \\
\hline 24 & 19,0 & 96 & 175 & 169 & 41,0 & $<1,0$ & 15 & 102 & 93 \\
\hline 26 & 19,0 & & 181 & 170 & 53,0 & $<1,0$ & & 101 & 95 \\
\hline 28 & 18,5 & & 190 & 184 & 64,0 & 1,0 & & 100 & 93 \\
\hline 30 & 17,5 & 107 & 185 & 179 & 67,0 & 3,0 & 14 & 100 & 91 \\
\hline 32 & 17,0 & & 182 & 178 & 79,0 & $<1,0$ & & 95 & 93 \\
\hline 34 & 17,0 & & 178 & 176 & 81,0 & 2,0 & & 97 & 93 \\
\hline 36 & 17,0 & 98 & 178 & 175 & 81,0 & $<1,0$ & 15 & 99 & 94 \\
\hline Média & 18,7 & 102 & 182 & 176 & 26,4 & 1,03 & 14 & 97 & 91 \\
\hline Mínimo & 17,0 & 96 & 171 & 163 & $<1,0$ & $<1,0$ & 12 & 92 & 83 \\
\hline Máximo & 21,0 & 109 & 193 & 192 & 81,0 & 5,00 & 16 & 102 & 96 \\
\hline DP & 1,37 & 5,77 & 6,91 & 6,72 & 32,11 & 1,16 & 1,53 & 3,30 & 3,67 \\
\hline
\end{tabular}

$\mathrm{T} \overline{\bar{F}}=$ tempo de funcionamento; $\mathrm{AE}$ = água de estudo; $\mathrm{AB}$ = água bruta; $\mathrm{APO}=$ água pré-oxidada; $\mathrm{FAAG}=$ filtro ascendente de areia grossa; $F R D=$ filtro rápido descendente; $\mathrm{DP}=$ desvio padrão. 
Tabela C 4.2 - Características químicas da AB, AE, APO e efluentes do FAAG e do FRD durante o ensaio 11 - pré-oxidação com tricloro-s-trizina-triona (FAAG = 180 $\left.\mathrm{m}^{3} / \mathrm{m}^{2} \mathrm{~d} ; \mathrm{FRD}=280 \mathrm{~m}^{3} / \mathrm{m}^{2} \mathrm{~d}\right)$

\begin{tabular}{|c|c|c|c|c|c|c|c|c|c|c|c|c|c|c|c|c|c|c|c|c|c|}
\hline \multirow[b]{2}{*}{ TF (h) } & \multicolumn{4}{|c|}{$\mathrm{pH}$} & \multicolumn{3}{|c|}{ Alcalinidade $\left(\mathrm{mg} / \mathrm{L} \mathrm{CaCO}_{3}\right)$} & \multicolumn{5}{|c|}{ Absorvância 254 nm } & \multicolumn{5}{|c|}{$\operatorname{COD}(\mathrm{mg} / \mathrm{L})$} & \multicolumn{4}{|c|}{ Alumínio (mg/L) } \\
\hline & $A B$ & $\mathrm{AE}$ & APO & $A C$ & $\mathrm{AB}$ & $\mathrm{AE}$ & APO & $A B$ & $\mathrm{AE}$ & APO & FAAG & FRD & $A B$ & $\mathrm{AE}$ & APO & FAAG & FRD & $A B$ & $\mathrm{AE}$ & FAAG & FRD \\
\hline 0 & 6,74 & 6,80 & 5,73 & 4,95 & 7,70 & 5,50 & 3,96 & 0,052 & 0,188 & 0,173 & 0,021 & 0,018 & 2,987 & 5,595 & 5,533 & 3,328 & 3,131 & 0,04 & 0,01 & 0,10 & 0,15 \\
\hline 1 & & 6,69 & 5,90 & 5,19 & & & & & & & & & & & & & & & & & \\
\hline 2 & & 6,87 & 5,82 & 5,00 & & & & & & & & & & & & & & & & & \\
\hline 4 & & 6,73 & 5,74 & 4,99 & & & & & & & & & & & & & & & & & \\
\hline 6 & 6,63 & 6,71 & 5,73 & 4,99 & 5,06 & 6,16 & 3,52 & 0,050 & 0,172 & 0,171 & 0,018 & 0,025 & & & & & 3,985 & & & & \\
\hline 8 & & 6,72 & 5,96 & 5,04 & & & & & & & & & & & & & & & & & \\
\hline 10 & & 6,71 & 5,95 & 5,00 & & & & & & & & & & & & & & & & & \\
\hline 12 & 6,61 & 6,74 & 6,03 & 5,41 & 8,80 & 7,48 & 4,62 & 0,049 & 0,174 & 0,177 & 0,020 & 0,024 & 2,668 & 4,706 & 4,971 & 3,998 & 4,161 & 0,02 & ND & 0,11 & 0,10 \\
\hline 14 & & 6,74 & 6,04 & 5,59 & & & & & & & & & & & & & & & & & \\
\hline 16 & & 6,72 & 6,05 & 5,10 & & & & & & & & & & & & & & & & & \\
\hline 18 & 6,67 & 6,74 & 6,43 & 5,40 & 6,38 & 6,60 & 6,60 & 0,050 & 0,170 & 0,161 & 0,014 & 0,019 & & & & & & & & & \\
\hline 20 & & 6,70 & 6,40 & 5,42 & & & & & & & & & & & & & & & & & \\
\hline 22 & & 6,78 & 6,51 & 5,52 & & & & & & & & & & & & & & & & & \\
\hline 24 & 6,68 & 6,73 & 6,46 & 5,47 & 7,26 & 7,26 & 7,04 & 0,050 & 0,179 & 0,174 & 0,014 & 0,020 & 3,964 & 6,551 & 5,164 & 4,173 & 6,283 & ND & 0,01 & 0,10 & 0,07 \\
\hline 26 & & 6,72 & 6,34 & 5,43 & & & & & & & & & & & & & & & & & \\
\hline 28 & & 6,75 & 6,37 & 5,46 & & & & & & & & & & & & & & & & & \\
\hline 30 & 6,76 & 6,78 & 6,43 & 5,60 & 7,26 & 7,48 & 6,60 & 0,048 & 0,178 & 0,174 & 0,015 & 0,022 & & & & & & & & & \\
\hline 32 & & 6,64 & 6,37 & 5,60 & & & & & & & & & & & & & & & & & \\
\hline 34 & & 6,70 & 6,38 & 5,56 & & & & & & & & & & & & & & & & & \\
\hline 36 & 6,69 & 6,72 & 6,37 & 5,43 & 7,48 & 7,04 & 4,18 & 0,054 & 0,180 & 0,182 & 0,017 & 0,019 & 2,690 & 4,590 & 4,670 & 3,680 & 4,030 & 0,01 & 0,03 & 0,18 & 0,14 \\
\hline Média & 6,68 & 6,73 & 6,15 & 5,31 & 7,13 & 6,79 & 5,22 & 0,050 & 0,177 & 0,173 & 0,017 & $\mid 0,021$ & 3,077 & 5,361 & 5,085 & 3,795 & 4,318 & - & - & 0,12 & 0,12 \\
\hline Mínimo & 6,61 & 6,64 & 5,73 & 4,95 & 5,06 & 5,50 & 3,52 & 0,048 & 0,170 & 0,161 & 0,014 & 0,018 & 2,668 & 4,590 & 4,670 & 3,328 & 3,131 & - & - & 0,10 & 0,07 \\
\hline Máximo & 6,76 & 6,87 & 6,51 & 5,60 & 8,80 & 7,48 & 7,04 & 0,054 & 0,188 & 0,182 & 0,021 & 0,025 & 3,964 & 6,551 & 5,533 & 4,173 & 6,283 & - & - & 0,18 & 0,15 \\
\hline DP & 0,05 & 0,05 & 0,28 & 0,24 & 1,16 & 0,75 & 1,47 & 0,002 & 0,006 & 0,006 & 0,003 & 0,003 & 0,609 & 0,912 & 0,362 & 0,372 & 1,171 & - & - & 0,04 & 0,04 \\
\hline
\end{tabular}

$\mathrm{TF}=$ tempo de funcionamento; $\mathrm{AE}$ = água de estudo; $\mathrm{AB}$ = água bruta; $\mathrm{AC}=$ água coagulada; $\mathrm{APO}=$ água pré-oxidada; FAAG = filtro ascendente de areia grossa; $\mathrm{FRD}=$ filtro rápido descendente; $\mathrm{DP}=$ desvio padrão. 
Tabela C 4.3 - Perda de carga no FAAG $\left(180 \mathrm{~m}^{3} / \mathrm{m}^{2} \mathrm{~d}\right)$ e no FRD $\left(280 \mathrm{~m}^{3} / \mathrm{m}^{2} \mathrm{~d}\right)$ durante o ensaio 11 , pré-oxidação com tricloro-s-triazina-triona e sem DFls no FAAG para a temperatura $\mathrm{T}$ e para $\mathrm{T}=20^{\circ} \mathrm{C}$

\begin{tabular}{|c|c|c|c|c|c|c|c|c|c|c|c|c|c|c|c|c|c|c|c|c|c|c|}
\hline \multirow{3}{*}{$\begin{array}{l}\text { TF } \\
\text { (h) }\end{array}$} & \multicolumn{10}{|c|}{ FAAG } & \multicolumn{12}{|l|}{ FRD } \\
\hline & \multicolumn{3}{|c|}{\begin{tabular}{|c|} 
Leitura piezométrica \\
$(\mathbf{c m})$
\end{tabular}} & \multirow{2}{*}{$\begin{array}{c}\mathbf{T} \\
\left({ }^{\circ} \mathbf{C}\right)\end{array}$} & \multicolumn{3}{|c|}{$\begin{array}{c}\text { Perda de carga } \\
\text { (cm) }\end{array}$} & \multicolumn{3}{|c|}{$\begin{array}{c}\text { Perda de carga }(\mathrm{cm}) \\
\mathrm{T}=20^{\circ} \mathrm{C}\end{array}$} & \multicolumn{4}{|c|}{$\begin{array}{c}\text { Leitura piezométrica } \\
(\mathrm{cm})\end{array}$} & \multicolumn{4}{|c|}{$\begin{array}{l}\text { Perda de carga } \\
\text { (cm) }\end{array}$} & \multicolumn{4}{|c|}{$\begin{array}{c}\text { Perda de carga }(\mathrm{cm}) \\
\mathrm{T}=20^{\circ} \mathrm{C}\end{array}$} \\
\hline & $\mathrm{P} 1$ & $\mathrm{P} 2$ & P3 & & P2-P1 & P3-P2 & P3-P1 & P2-P1 & P3-P2 & P3-P1 & $\mathrm{P} 1$ & P2 & P3 & P4 & P2-P1 & P3-P2 & P4-P3 & P4-P1 & P2-P1 & P3-P2 & P4-P3 & P4-P1 \\
\hline 0 & 45,8 & 60,5 & 6 & 19,5 & & & & & & & 12,1 & 34,1 & 52,6 & 70,0 & 22,0 & & & 57,9 & - & & 1 & 56,8 \\
\hline 1 & 45,9 & 62,4 & 63,9 & 19,0 & 16,5 & 1,5 & 18,0 & 16,0 & 1,5 & 17,4 & 12,2 & 36,9 & 57,9 & 77,5 & 24,7 & 21,0 & 19,6 & 65,3 & 23,9 & 20,3 & 19,0 & 63,3 \\
\hline 2 & 45,9 & 63,8 & & 19,0 & 17,9 & & & & 2,1 & & 12,2 & 36,6 & 57,5 & 78,4 & 24,4 & & & & & & & \\
\hline 3 & 45,9 & 65,3 & 68,2 & 19,0 & 19,4 & 2,9 & & & 2,8 & & 12,2 & 36,8 & 57,9 & 80,0 & 24,6 & & & & & & & \\
\hline 4 & 45,9 & 66,8 & 70,0 & 19,0 & 20,9 & 3,2 & 24,1 & 20,2 & 31 & 23,3 & 12,2 & 37,1 & 58,5 & 81,2 & 24,9 & 21,4 & 22,7 & 69,0 & 4,1 & 0,7 & 0 & 8 \\
\hline 5 & 45,9 & 68,5 & 72,4 & 18,0 & 22,6 & 3,9 & & 21,4 & 3,7 & 5,1 & 12,2 & 36,7 & 57,9 & 80,7 & 24,5 & 21,2 & 22,8 & 5 & 2 & 0 & 6 & 8 \\
\hline 6 & 45,9 & 70,4 & 74,7 & 18,0 & & & & & & & 12,1 & 36,9 & 58,3 & 81,6 & & & & & & & & \\
\hline 7 & 45,9 & 72,4 & 77,1 & 18,0 & 26,5 & 4,7 & & & & & 12,0 & 36,7 & 58,1 & 81,6 & & & & & 4 & & & \\
\hline 8 & 45,9 & 73,8 & 79,0 & 18,0 & 27,9 & 5,2 & 1 & 26,4 & 4,9 & 31,3 & 12,0 & 36,9 & 58,4 & 82,4 & 9 & & 24,0 & 4 & 5 & 3 & 7 & 6 \\
\hline 9 & 45,9 & 75,8 & 81,5 & 17,0 & 29,9 & 5,7 & 35,6 & 27,6 & 0,0 & 32,9 & 12,0 & 37,3 & 59,2 & 83,5 & 25,3 & 21,9 & 24,3 & 71,5 & 23,4 & 0,2 & 2,4 & 0 \\
\hline 10 & 45,9 & & & & & & & & & & 12,0 & & 59,4 & 84,2 & & & & & & & & \\
\hline 11 & 45,9 & 80,0 & 86,7 & 17,0 & 34,1 & 6,7 & & & & & 12,0 & 37,7 & 59,9 & 85,0 & 25,7 & 22,2 & 25,1 & 73,0 & 3,7 & 0,5 & 3,2 & \\
\hline 12 & 45,9 & 82,1 & 88,9 & 17,0 & 36,2 & 6,8 & 43,0 & 33,4 & 6,3 & 39,7 & 12,0 & 38,1 & 60,6 & 86,1 & 26,1 & 22,5 & 25,5 & 74,1 & 24,1 & 20,8 & 3,5 & 4 \\
\hline 13 & 45,9 & 83,6 & 90,6 & 19,0 & 37,7 & 7,0 & 44,7 & 36,5 & 6,8 & 43,3 & 12,0 & 37,9 & 60,6 & 87,0 & 25,9 & 22,7 & 26,4 & 0 & 1 & 2,0 & 6 & 72,7 \\
\hline 14 & 45,9 & 84,5 & 91,5 & 19,0 & 38,6 & 7,0 & & & 6,8 & & 12,0 & 37,5 & 60,0 & 87,4 & 20,0 & 22,5 & & & 24,7 & 21,8 & 26,5 & \\
\hline 15 & 45,9 & 86,7 & 94,8 & 21,0 & 40,8 & & & & & & 12,0 & 36,8 & 58,6 & 85,6 & & & & & & 22,2 & 5 & \\
\hline 16 & 46,0 & 88,6 & 97,1 & 21,0 & 42,6 & 8,5 & 51,1 & 43,3 & 8,6 & 52,0 & 12,0 & 36,0 & 57,3 & 83,4 & 24,0 & 21,3 & 26,1 & 71,4 & 24,4 & 21,7 & 6,5 & 72,6 \\
\hline 17 & 46,0 & 91,2 & 100,2 & 21,0 & 45,2 & 9,0 & 54,2 & 46,0 & 9,2 & 55,1 & 12,0 & 35,7 & 56,5 & 82,0 & 23,7 & 20,8 & 25,5 & 70,0 & 24,1 & 21,2 & 25,9 & 71,2 \\
\hline 18 & 46,0 & 94,2 & 103,7 & 21,0 & 48,2 & 9,5 & & 49,0 & & 58,7 & 12,0 & 35,8 & 56,9 & 82,5 & 23,8 & & 25,6 & 70,5 & 24,2 & 21,5 & 26,0 & 71,7 \\
\hline 19 & 46,0 & 96,1 & 105,9 & 21,0 & 50,1 & 9,8 & 59,9 & 50,9 & 10,0 & 60,9 & 12,0 & 36,0 & 57,3 & 83,6 & 24,0 & 21,3 & 26,3 & 71,6 & 24,4 & 21,7 & 26,7 & 72,8 \\
\hline 20 & 46,0 & 98,9 & 109,1 & 21,0 & 52,9 & 10,2 & 63,1 & 53,8 & 10,4 & & 12,1 & 37,0 & 59,0 & 87,9 & 24,9 & 22,0 & 28,9 & 75,8 & 25,3 & 22,4 & 29,4 & 77,1 \\
\hline 21 & 46,0 & 101,0 & 111,5 & 20,0 & 55,0 & 10,5 & 65,5 & 54,6 & 10,4 & 65,0 & 12,0 & 35,8 & 56,9 & 87,8 & 23,8 & 21,1 & 30,9 & 75,8 & 23,6 & 20,9 & 30,7 & 75,2 \\
\hline 22 & 46,0 & 103,5 & 114,5 & 20,0 & 57,5 & 11,0 & 68,5 & 57,1 & 10,9 & 68,0 & 12,0 & 37,0 & 59,2 & 97,0 & 25,0 & 22,2 & 37,8 & 85,0 & 24,8 & 22,0 & 37,5 & 84,4 \\
\hline
\end{tabular}


(continuação)

\begin{tabular}{|c|c|c|c|c|c|c|c|c|c|c|c|c|c|c|c|c|c|c|c|c|c|c|}
\hline 23 & 46,0 & 106,0 & 117,2 & 19,0 & 60,0 & 11,2 & 71,2 & 58,1 & 10,9 & 69,0 & 12,1 & 38,7 & 62,8 & 109,6 & 26,6 & 24,1 & 46,8 & 97,5 & 25,8 & 23,3 & 45,3 & 94,5 \\
\hline 24 & 46,0 & 108,8 & 120,3 & 19,0 & 62,8 & 11,5 & 74,3 & 60,8 & 11,1 & 72,0 & 12,0 & 36,9 & 61,1 & 113,9 & 24,9 & 24,2 & 52,8 & 101,9 & 24,1 & 23,4 & 51,2 & 98,7 \\
\hline 25 & 46,0 & 110,6 & 122,2 & 19,0 & 64,6 & 11,6 & 76,2 & 62,6 & 11,2 & 73,8 & 12,0 & 37,8 & 64,7 & 124,0 & 25,8 & 26,9 & 59,3 & 112,0 & 25,0 & 26,1 & 57,5 & 108,5 \\
\hline 26 & 46,0 & 112,5 & 124,6 & 19,0 & 66,5 & 12,1 & 78,6 & 64,4 & 11,7 & 76,1 & 11,9 & 36,9 & 64,8 & 127,7 & 25,0 & 27,9 & 62,9 & 115,8 & 24,2 & 27,0 & 60,9 & 112,2 \\
\hline 27 & 46,0 & 114,7 & 127,1 & 18,5 & 68,7 & 12,4 & 81,1 & 65,8 & 11,9 & 77,6 & 11,9 & 38,1 & 68,4 & 139,0 & 26,2 & 30,3 & 70,6 & 127,1 & 25,1 & 29,0 & 67,6 & 121,7 \\
\hline 28 & 46,0 & 116,6 & 129,3 & 18,5 & 70,6 & 12,7 & 83,3 & 67,6 & 12,2 & 79,7 & 11,9 & 39,5 & 72,1 & 152,5 & 27,6 & 32,6 & 80,4 & 140,6 & 26,4 & 31,2 & 77,0 & 134,6 \\
\hline 29 & 46,0 & 118,4 & 131,5 & 17,5 & 72,4 & 13,1 & 85,5 & 67,6 & 12,2 & 79,9 & 11,8 & 37,2 & 69,8 & 155,5 & 25,4 & 32,6 & 85,7 & 143,7 & 23,7 & 30,5 & 80,1 & 134,3 \\
\hline 30 & 46,0 & 121,0 & 134,5 & 17,5 & 75,0 & 13,5 & 88,5 & 70,1 & 12,6 & 82,7 & 11,8 & 38,9 & 71,8 & 174,3 & 27,1 & 32,9 & 102,5 & 162,5 & 25,3 & 30,7 & 95,8 & 151,8 \\
\hline 31 & 46,0 & 123,3 & 137,0 & 17,0 & 77,3 & 13,7 & 91,0 & 71,3 & 12,6 & 84,0 & 11,8 & 37,7 & 59,8 & 81,2 & 25,9 & 22,1 & 21,4 & 69,4 & 23,9 & 20,4 & 19,8 & 64,1 \\
\hline 32 & 45,9 & 125,4 & 139,5 & 17,0 & 79,5 & 14,1 & 93,6 & 73,4 & 13,0 & 86,4 & 11,9 & 39,2 & 64,4 & 100,4 & 27,3 & 25,2 & 36,0 & 88,5 & 25,2 & 23,3 & 33,2 & 81,7 \\
\hline 33 & 45,9 & 127,2 & 141,5 & 17,0 & 81,3 & 14,3 & 95,6 & 75,0 & 13,2 & 88,2 & 11,8 & 38,0 & 64,3 & 109,2 & 26,2 & 26,3 & 44,9 & 97,4 & 24,2 & 24,3 & 41,4 & 89,9 \\
\hline 34 & 45,9 & 129,0 & 143,8 & 17,0 & 83,1 & 14,8 & 97,9 & 76,7 & 13,7 & 90,4 & 11,8 & 39,1 & 68,0 & 124,0 & 27,3 & 28,9 & 56,0 & 112,2 & 25,2 & 26,7 & 51,7 & 103,6 \\
\hline 35 & 45,9 & 130,7 & 146,0 & 17,0 & 84,8 & 15,3 & 100,1 & 78,3 & 14,1 & 92,4 & 11,8 & 42,0 & 71,0 & 138,4 & 30,2 & 29,0 & 67,4 & 126,6 & 27,9 & 26,8 & 62,2 & 116,9 \\
\hline 36 & 45,9 & 132,3 & 147,8 & 17,0 & 86,4 & 15,5 & 101,9 & 79,7 & 14,3 & 94,1 & 12,1 & 39,5 & 62,0 & 86,2 & 27,4 & 22,5 & 24,2 & 74,1 & 25,3 & 20,8 & 22,3 & 68,4 \\
\hline
\end{tabular}

FAAG = filtro ascendente de areia grossa; FRD = filtro rápido descendente; TF = tempo de funcionamento; $T$ = temperatura; Lavagem do FRD por transpasse 


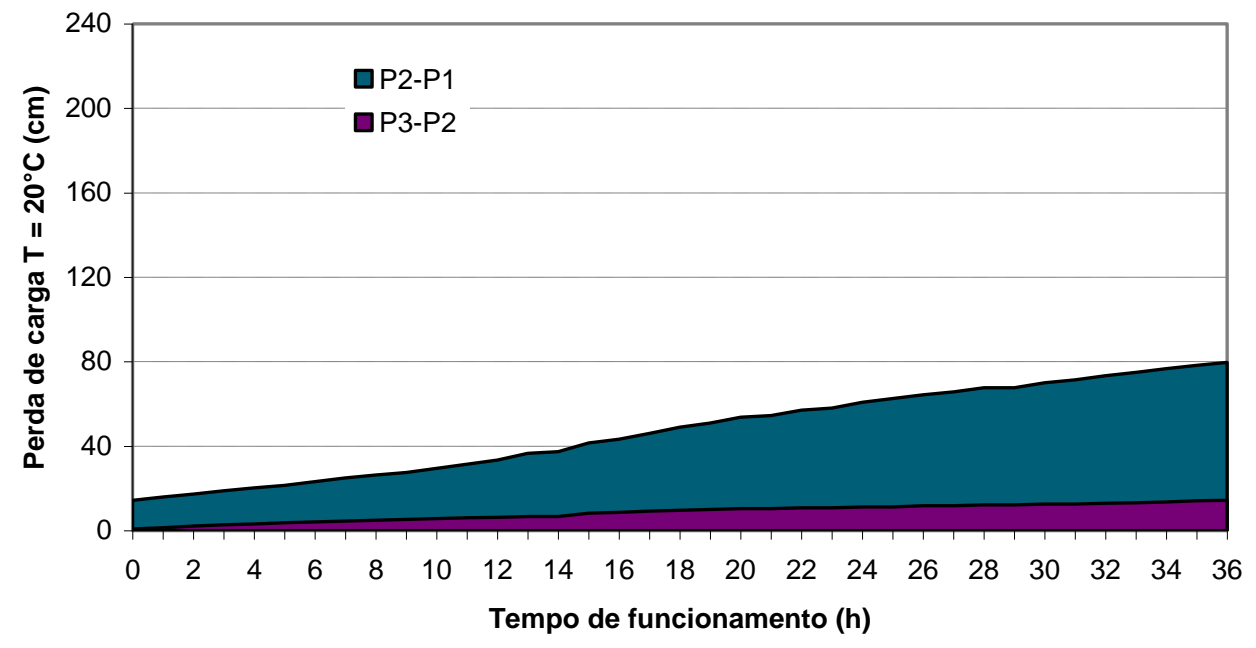

Figura C 4.1 - Perda de carga na camada suporte e camada de areia grossa no FAAG durante o ensaio 11 - pré-oxidação com tricloro-s-triazina-triona (FAAG $=180 \mathrm{~m}^{3} / \mathrm{m}^{2} \mathrm{~d}$ e FRD $=280 \mathrm{~m}^{3} / \mathrm{m}^{2} \mathrm{~d}$ ). Fonte: Tabela C 4.3 - ANEXO C.

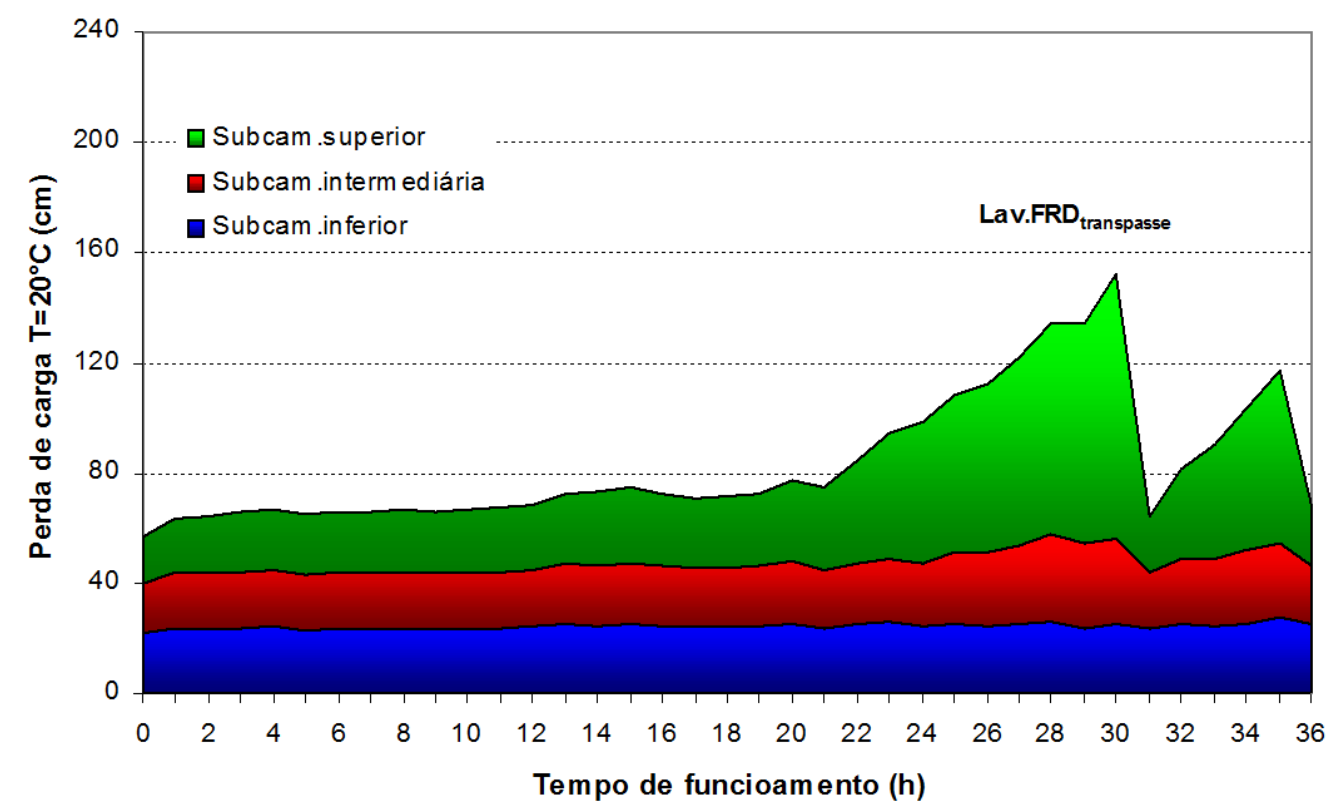

Figura C 4.2 - Perda de carga ao longo do meio filtrante do FRD durante o ensaio 11 - pré-oxidação com tricloro-s-triazina-triona (FAAG $=180 \mathrm{~m}^{3} / \mathrm{m}^{2} \mathrm{~d}$ e $\mathrm{FRD}=280 \mathrm{~m}^{3} / \mathrm{m}^{2} \mathrm{~d}$ ). Fonte: Tabela C $4.3-$ ANEXO C. 
Tabela C 4.4 - Variação de vazões e taxas de filtração do FAAG e do FRD durante o ensaio 11 - préoxidação com tricloro-s-triazina-triona (FAAG $=180 \mathrm{~m}^{3} / \mathrm{m}^{2} \mathrm{~d} ; \mathrm{FRD}=280 \mathrm{~m}^{3} / \mathrm{m}^{2} \mathrm{~d}$ ).

\begin{tabular}{|c|c|c|c|c|c|c|c|c|}
\hline \multirow{2}{*}{$\begin{array}{l}\text { TF } \\
\text { (h) }\end{array}$} & \multicolumn{2}{|c|}{ descartes (L/h) } & \multicolumn{2}{|c|}{ turbidímetros (L/h) } & \multicolumn{2}{|c|}{ vazão total (L/h) } & \multicolumn{2}{|c|}{ taxas de filtração $\left(\mathrm{m}^{3} / \mathrm{m}^{2} \mathrm{~d}\right)$} \\
\hline & FAAG & FRD & FAAG & FRD & FAAG & FRD & FAAG & FRD \\
\hline 0 & 24,65 & 59,03 & 13,70 & 23,07 & 120,45 & 82,10 & 185 & 300 \\
\hline 1 & 30,78 & 56,22 & 13,45 & 22,08 & 122,53 & 78,30 & 188 & 286 \\
\hline 2 & 33,72 & 55,62 & 12,19 & 21,55 & 123,08 & 77,17 & 189 & 282 \\
\hline 3 & 33,77 & 54,96 & 11,80 & 21,62 & 122,15 & 76,58 & 188 & 280 \\
\hline 4 & 13,21 & 54,49 & 31,40 & 22,67 & 121,77 & 77,16 & 187 & 282 \\
\hline 5 & 14,52 & 54,10 & 32,54 & 21,50 & 122,66 & 75,60 & 189 & 277 \\
\hline 6 & 14,29 & 55,16 & 32,26 & 21,58 & 123,29 & 76,74 & 190 & 281 \\
\hline 7 & 14,40 & 54,82 & 32,37 & 21,41 & 123,00 & 76,23 & 189 & 279 \\
\hline 8 & 14,19 & 53,68 & 32,36 & 21,06 & 121,29 & 74,74 & 186 & 273 \\
\hline 9 & 13,33 & 54,13 & 32,34 & 21,48 & 121,28 & 75,61 & 186 & 277 \\
\hline 10 & 14,06 & 54,25 & 32,37 & 21,54 & 122,22 & 75,79 & 188 & 277 \\
\hline 11 & 13,35 & 55,54 & 32,73 & 21,88 & 123,50 & 77,42 & 190 & 283 \\
\hline 12 & 13,47 & 55,72 & 31,33 & 21,23 & 121,75 & 76,95 & 187 & 281 \\
\hline 13 & 13,74 & 57,11 & 31,40 & 21,11 & 123,36 & 78,22 & 190 & 286 \\
\hline 14 & 13,69 & 52,80 & 32,56 & 22,25 & 121,30 & 75,05 & 186 & 275 \\
\hline 15 & 13,49 & 54,92 & 32,08 & 22,25 & 122,89 & 77,32 & 189 & 283 \\
\hline 16 & 13,38 & 53,43 & 31,36 & 22,40 & 120,64 & 75,90 & 185 & 278 \\
\hline 17 & 13,58 & 53,10 & 31,53 & 22,47 & 120,74 & 75,63 & 186 & 277 \\
\hline 18 & 13,62 & 55,45 & 30,61 & 22,53 & 122,44 & 78,21 & 188 & 286 \\
\hline 19 & 12,80 & 55,69 & 30,74 & 22,76 & 121,33 & 77,79 & 186 & 285 \\
\hline 20 & 12,41 & 57,06 & 28,52 & 22,10 & 120,32 & 79,39 & 185 & 290 \\
\hline 21 & 16,78 & 55,92 & 27,75 & 22,33 & 122,33 & 77,80 & 188 & 285 \\
\hline 22 & 15,22 & 55,88 & 25,37 & 21,88 & 118,34 & 77,75 & 182 & 284 \\
\hline 23 & 12,80 & 61,21 & 24,41 & 21,87 & 120,28 & 83,07 & 185 & 304 \\
\hline 24 & 19,76 & 53,66 & 23,05 & 21,86 & 118,80 & 75,99 & 183 & 278 \\
\hline 25 & 18,80 & 56,75 & 21,71 & 22,33 & 119,14 & 78,63 & 183 & 288 \\
\hline 26 & 22,93 & 53,60 & 21,30 & 21,88 & 119,70 & 75,47 & 184 & 276 \\
\hline 27 & 21,52 & 54,19 & 21,21 & 21,87 & 118,64 & 75,91 & 182 & 278 \\
\hline 28 & 20,68 & 56,22 & 21,14 & 21,72 & 119,89 & 78,07 & 184 & 286 \\
\hline 29 & 25,89 & 51,59 & 20,66 & 21,85 & 119,34 & 72,79 & 183 & 266 \\
\hline 30 & 25,77 & 50,88 & 20,16 & 21,20 & 117,17 & 71,24 & 180 & 261 \\
\hline 31 & 23,94 & 55,61 & 18,25 & 20,36 & 118,35 & 76,16 & 182 & 279 \\
\hline 32 & 23,16 & 60,00 & 16,94 & 20,55 & 120,34 & 80,24 & 185 & 294 \\
\hline 33 & 26,96 & 55,24 & 16,33 & 20,24 & 118,87 & 75,58 & 183 & 276 \\
\hline 34 & 28,22 & 56,39 & 16,24 & 20,34 & 121,25 & 76,79 & 186 & 281 \\
\hline 35 & 27,73 & 56,09 & 14,92 & 20,40 & 121,05 & 78,40 & 186 & 287 \\
\hline 36 & 26,34 & 53,13 & 17,06 & 22,31 & 118,84 & 75,44 & 183 & 276 \\
\hline & & & & Mínima & 117,17 & 71,24 & 180 & 261 \\
\hline & & & & Média & 120,93 & 76,95 & 186 & 281 \\
\hline & & & & Máxima & 123,50 & 83,07 & 190 & 304 \\
\hline & & & & DP & 1,68 & 2,18 & 2,58 & 7,96 \\
\hline
\end{tabular}

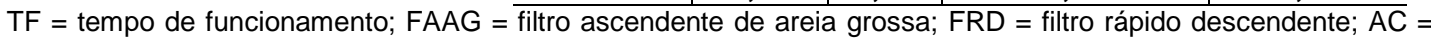
água coagulada; $\mathrm{DP}=$ desvio padrão. 
Tabela C 5.1 - Características físicas da AB, AE, APO e efluentes do FAAG e do FRD durante o ensaio 12 - pré-oxidação com dióxido de cloro (FAAG $=180 \mathrm{~m}^{3} / \mathrm{m}^{2} \mathrm{~d} ; \mathrm{FRD}=280 \mathrm{~m}^{3} / \mathrm{m}^{2} \mathrm{~d}$ ).

\begin{tabular}{|c|c|c|c|c|c|c|c|c|c|}
\hline \multirow[b]{2}{*}{ TF (h) } & \multirow{2}{*}{\begin{tabular}{|c|}
$\begin{array}{c}\text { Temperatura } \\
\left({ }^{\circ} \mathrm{C}\right)\end{array}$ \\
$\mathrm{AE}$ \\
\end{tabular}} & \multicolumn{5}{|c|}{ Cor aparente (uH) } & \multicolumn{3}{|c|}{ Cor verdadeira (uH) } \\
\hline & & $\mathrm{AB}$ & $\mathbf{A E}$ & APO & FAAG & FRD & $\mathrm{AB}$ & $\mathrm{AE}$ & APO \\
\hline 0 & 18,0 & 89 & 167 & 166 & 4,0 & 1,0 & 16 & 95 & 88 \\
\hline 1 & 19,0 & & 167 & 161 & $<1,0$ & $<1,0$ & & 96 & 88 \\
\hline 2 & 20,0 & & 174 & 164 & 1,0 & $<1,0$ & & 94 & 92 \\
\hline 4 & 20,5 & & 182 & 179 & $<1,0$ & $<1,0$ & & 104 & 93 \\
\hline 6 & 22,0 & 90 & 170 & 164 & $<1,0$ & $<1,0$ & 12 & 100 & 95 \\
\hline 8 & 20,0 & & 172 & 172 & $<1,0$ & $<1,0$ & & 105 & 99 \\
\hline 10 & 19,0 & & 170 & 168 & $<1,0$ & $<1,0$ & & 103 & 100 \\
\hline 12 & 18,5 & 93 & 171 & 163 & $<1,0$ & $<1,0$ & 14 & 102 & 99 \\
\hline 14 & 18,0 & & 184 & 178 & $<1,0$ & $<1,0$ & & 103 & 97 \\
\hline 16 & 17,5 & & 183 & 177 & 16,0 & $<1,0$ & & 102 & 96 \\
\hline 18 & 17,0 & 100 & 178 & 170 & 37,0 & $<1,0$ & 14 & 103 & 93 \\
\hline 20 & 16,0 & & 171 & 174 & 48,0 & $<1,0$ & & 98 & 98 \\
\hline 22 & 17,0 & & 172 & 167 & 55,0 & $<1,0$ & & 98 & 95 \\
\hline 24 & 20,0 & 103 & 181 & 176 & 58,0 & 3,0 & 16 & 101 & 96 \\
\hline 26 & 21,0 & & 182 & 176 & 63,0 & 6,0 & & 104 & 99 \\
\hline 28 & 22,0 & & 179 & 176 & 72,0 & $<1,0$ & & 107 & 102 \\
\hline 30 & 21,0 & 95 & 176 & 172 & 73,0 & $<1,0$ & 14 & 107 & 99 \\
\hline 32 & 20,0 & & 176 & 172 & 83,0 & 2,0 & & 105 & 101 \\
\hline 34 & 19,0 & & 175 & 170 & 83,0 & 10,0 & & 106 & 101 \\
\hline 36 & 18,0 & 88 & 172 & 168 & 88,0 & $<1,0$ & 14 & 105 & 100 \\
\hline Média & 19,2 & 94 & 175 & 171 & 34,2 & 1,48 & 14 & 102 & 97 \\
\hline Mínimo & 16,0 & 88 & 167 & 161 & $<1,0$ & $<1,0$ & 12 & 94 & 88 \\
\hline Máximo & 22,0 & 103 & 184 & 179 & 88,0 & 10,00 & 16 & 107 & 102 \\
\hline DP & 1,69 & 5,72 & 5,35 & 5,41 & 34,73 & 2,41 & 1,38 & 3,91 & 4,08 \\
\hline
\end{tabular}

$\mathrm{TF}=$ tempo de funcionamento; $\mathrm{AE}$ = água de estudo; $\mathrm{AB}$ = água bruta; $\mathrm{APO}$ = água pré-oxidada; $\mathrm{FAAG}$ = filtro ascendente de areia grossa; $F R D=$ filtro rápido descendente; $D P=$ desvio padrão. 
Tabela C 5.2 - Características químicas da AB, AE, APO e efluentes do FAAG e do FRD durante o ensaio 12 - pré-oxidação com dióxido de cloro (FAAG = 180 $\left.\mathrm{m}^{3} / \mathrm{m}^{2} \mathrm{~d} ; \mathrm{FRD}=280 \mathrm{~m}^{3} / \mathrm{m}^{2} \mathrm{~d}\right)$

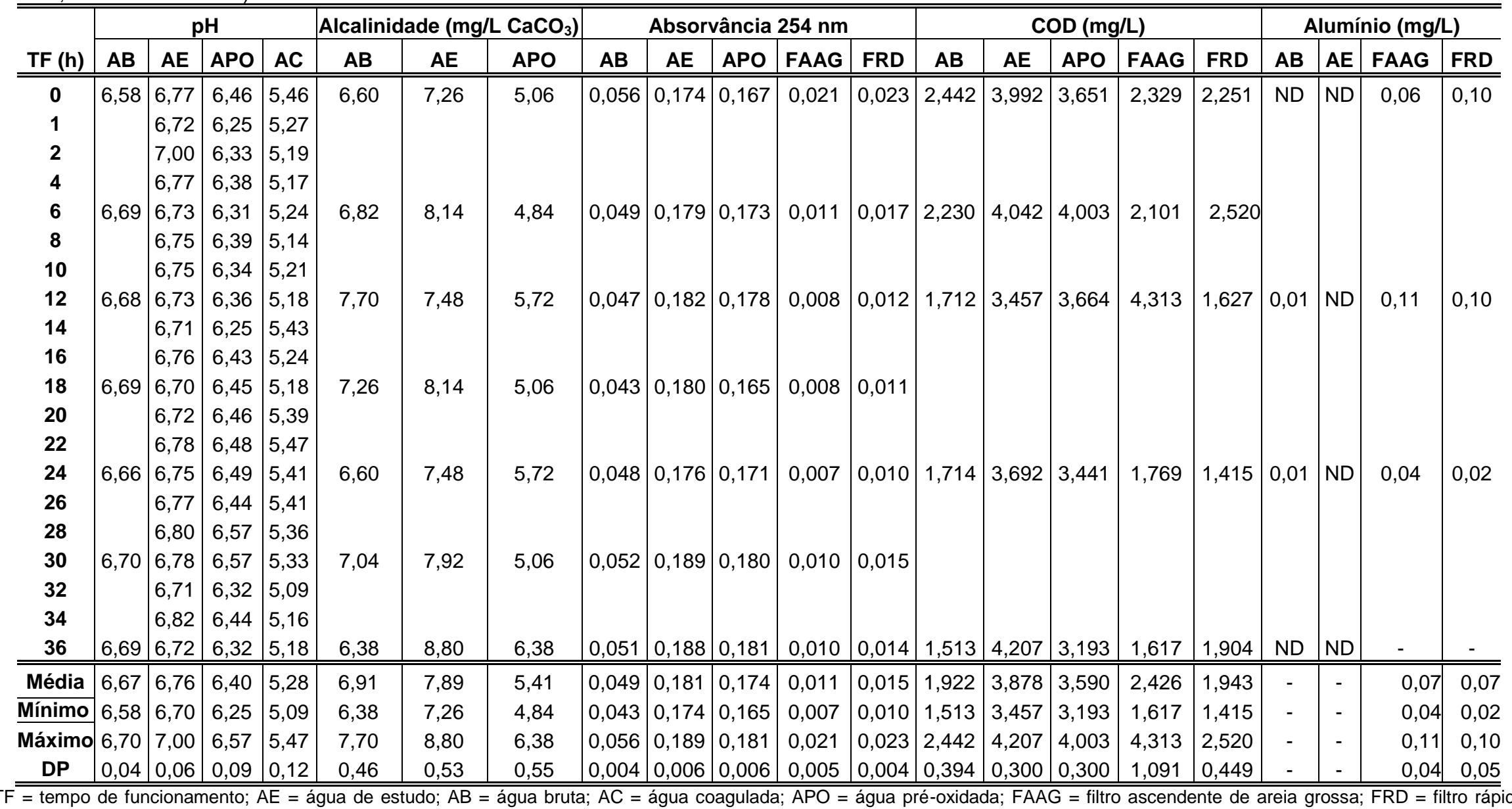
descendente; $\mathrm{DP}=$ desvio padrão. 
Tabela C 5.3 - Perda de carga no FAAG $\left(180 \mathrm{~m}^{3} / \mathrm{m}^{2} \mathrm{~d}\right)$ e no FRD $\left(280 \mathrm{~m}^{3} / \mathrm{m}^{2} \mathrm{~d}\right)$ durante o ensaio 12, pré-oxidação com dióxido de cloro e sem DFls no FAAG para a temperatura $\mathrm{T}$ e para $\mathrm{T}=20^{\circ} \mathrm{C}$

\begin{tabular}{|c|c|c|c|c|c|c|c|c|c|c|c|c|c|c|c|c|c|c|c|c|c|c|}
\hline \multirow{3}{*}{$\begin{array}{l}\text { TF } \\
\text { (h) }\end{array}$} & \multicolumn{10}{|c|}{ FAAG } & \multicolumn{12}{|l|}{ FRD } \\
\hline & \multicolumn{3}{|c|}{$\begin{array}{c}\text { Leitura piezométrica } \\
\text { (cm) }\end{array}$} & \multirow{2}{*}{$\begin{array}{c}\mathrm{T} \\
\left({ }^{\circ} \mathrm{C}\right)\end{array}$} & \multicolumn{3}{|c|}{$\begin{array}{c}\text { Perda de carga } \\
(\mathbf{c m})\end{array}$} & \multicolumn{3}{|c|}{$\begin{array}{c}\text { Perda de carga }(\mathrm{cm}) \\
\mathrm{T}=20^{\circ} \mathrm{C}\end{array}$} & \multicolumn{4}{|c|}{\begin{tabular}{|c} 
Leitura piezométrica \\
$(\mathrm{cm})$
\end{tabular}} & \multicolumn{4}{|c|}{$\begin{array}{l}\text { Perda de carga } \\
\text { (cm) }\end{array}$} & \multicolumn{4}{|c|}{$\begin{array}{c}\text { Perda de carga }(\mathrm{cm}) \\
T=20^{\circ} \mathrm{C}\end{array}$} \\
\hline & $\mathrm{P} 1$ & $\mathrm{P} 2$ & P3 & & P2-P1 & P3-P2 & P3-P1 & P2-P1 & P3-P2 & P3-P1 & $\mathrm{P} 1$ & P2 & P3 & P4 & P2-P1 & P3-P2 & P4-P3 & P4-P1 & P2-P1 & P3-P2 & P4-P3 & P4-P1 \\
\hline 0 & 45,9 & 62,5 & 63,5 & 18,0 & 16,6 & 1,0 & 17,6 & 15,7 & 0,9 & 16,6 & 11,9 & 35,2 & 55,5 & 73,0 & 23,3 & 20,3 & 17,5 & 61,1 & 22,0 & 19,2 & 16,5 & 57,8 \\
\hline 1 & 45,9 & 62,8 & 64,3 & 19,0 & 16,9 & 1,5 & 18,4 & 16,4 & 1,5 & 17,8 & 12,1 & 37,8 & 59,9 & 79,1 & 25,7 & 22,1 & 19,2 & 67,0 & 24,9 & 21,4 & 18,6 & 64,9 \\
\hline 2 & 45,9 & 63,8 & 65,9 & 20,0 & 17,9 & 2,1 & 20,0 & 17,8 & 2,1 & 19,9 & 12,1 & 36,9 & 58,4 & 77,4 & 24,8 & 21,5 & 19,0 & 65,3 & 24,6 & 21,3 & 18,9 & 64,8 \\
\hline 3 & 45,9 & 65,0 & 67,6 & 20,0 & 19,1 & 2,6 & 21,7 & 19,0 & 2,6 & 21,5 & 12,1 & 36,6 & 57,9 & 77,0 & 24,5 & 21,3 & 19,1 & 64,9 & 24,3 & 21,1 & 19,0 & 64,4 \\
\hline 4 & 45,9 & 66,5 & 69,8 & 20,5 & 20,6 & 3,3 & 23,9 & 20,7 & 3,3 & 24,0 & 12,1 & 36,4 & 57,4 & 76,7 & 24,3 & 21,0 & 19,3 & 64,6 & 24,4 & 21,1 & 19,4 & 64,9 \\
\hline 5 & 45,9 & 68,0 & 71,8 & 22,0 & 22,1 & 3,8 & 25,9 & 23,0 & 4,0 & 27,0 & 12,1 & 36,2 & 57,2 & 76,7 & 24,1 & 21,0 & 19,5 & 64,6 & 25,1 & 21,9 & 20,3 & 67,3 \\
\hline 6 & 45,9 & 69,9 & 74,2 & 22,0 & 24,0 & 4,3 & 28,3 & 25,0 & 4,5 & 29,5 & 12,1 & 36,1 & 57,0 & 76,5 & 24,0 & 20,9 & 19,5 & 64,4 & 25,0 & 21,8 & 20,3 & 67,1 \\
\hline 7 & 46,0 & 71,6 & 76,3 & 20,0 & 25,6 & 4,7 & 30,3 & 25,4 & 4,7 & 30,1 & 12,1 & 36,1 & 57,0 & 76,6 & 24,0 & 20,9 & 19,6 & 64,5 & 23,8 & 20,7 & 19,5 & 64,0 \\
\hline 8 & 46,0 & 73,5 & 78,8 & 20,0 & 27,5 & 5,3 & 32,8 & 27,3 & 5,3 & 32,6 & 12,1 & 36,2 & 57,3 & 77,2 & 24,1 & 21,1 & 19,9 & 65,1 & 23,9 & 20,9 & 19,8 & 64,6 \\
\hline 9 & 45,9 & 75,8 & 81,5 & 19,0 & 29,9 & 5,7 & 35,6 & 29,0 & 5,5 & 34,5 & 12,0 & 36,8 & 58,4 & 79,0 & 24,8 & 21,6 & 20,6 & 67,0 & 24,0 & 20,9 & 20,0 & 64,9 \\
\hline 10 & 45,9 & 78,3 & 84,5 & 19,0 & 32,4 & 6,2 & 38,6 & 31,4 & 6,0 & 37,4 & 12,0 & 37,3 & 59,5 & 80,6 & 25,3 & 22,2 & 21,1 & 68,6 & 24,5 & 21,5 & 20,4 & 66,5 \\
\hline 11 & 45,9 & 80,6 & 87,2 & 18,5 & 34,7 & 6,6 & 41,3 & 33,2 & 6,3 & 39,5 & 12,0 & 37,6 & 60,0 & 81,4 & 25,6 & 22,4 & 21,4 & 69,4 & 24,5 & 21,4 & 20,5 & 66,4 \\
\hline 12 & 45,9 & 82,9 & 89,9 & 18,5 & 37,0 & 7,0 & 44,0 & 35,4 & & & 12,0 & 37,8 & 60,4 & 82,1 & 25,8 & 22,6 & 21,7 & 70,1 & 24,7 & 21,6 & 20,8 & 67,1 \\
\hline 13 & 45,9 & 85,3 & 93,0 & 18,0 & 39,4 & 7,7 & 47,1 & 37,3 & 7,3 & 44,5 & 12,0 & 37,9 & 60,6 & 82,5 & 25,9 & 22,7 & 21,9 & 70,5 & 24,5 & 21,5 & 20,7 & 66,7 \\
\hline 14 & 45,9 & 87,7 & 95,5 & 18,0 & 41,8 & 7,8 & 49,6 & 39,5 & 7,4 & 46,9 & 12,0 & 38,1 & 60,9 & 83,1 & 26,1 & 22,8 & 22,2 & 71,1 & 24,7 & 21,6 & 21,0 & 67,2 \\
\hline 15 & 45,9 & 89,8 & 98,3 & 17,5 & 43,9 & 8,5 & 52,4 & 41,0 & 7,9 & 49,0 & 12,0 & 38,1 & 61,0 & 83,7 & 26,1 & 22,9 & 22,7 & 71,7 & 24,4 & 21,4 & 21,2 & 67,0 \\
\hline 16 & 45,9 & 92,5 & 101,4 & 17,5 & 46,6 & 8,9 & 55,5 & 43,5 & 8,3 & 51,9 & 12,0 & 38,5 & 61,6 & 86,6 & 26,5 & 23,1 & 25,0 & 74,6 & 24,8 & 21,6 & 23,4 & 69,7 \\
\hline 17 & 45,9 & 95,3 & 104,9 & 17,0 & 49,4 & 9,6 & 59,0 & 45,6 & 8,9 & 54,5 & 12,0 & 38,9 & 62,4 & 90,8 & 26,9 & 23,5 & 28,4 & 78,8 & 24,8 & 21,7 & 26,2 & 72,7 \\
\hline 18 & 45,9 & 98,3 & 108,1 & 17,0 & 52,4 & 9,8 & 62,2 & 48,4 & 9,0 & 57,4 & 12,0 & 39,8 & 64,9 & 98,4 & 27,8 & 25,1 & 33,5 & 86,4 & 25,7 & 23,2 & 30,9 & 79,7 \\
\hline 19 & 45,9 & 99,7 & 110,0 & 16,0 & 53,8 & 10,3 & 64,1 & 48,5 & 9,3 & 57,7 & 11,9 & 38,5 & 63,5 & 99,6 & 26,6 & 25,0 & 36,1 & 87,7 & 24,0 & 22,5 & 32,5 & 79,0 \\
\hline 20 & 45,9 & 102,3 & 113,1 & 16,0 & 56,4 & 10,8 & 67,2 & 50,8 & 9,7 & 60,5 & 11,9 & 38,9 & 65,8 & 107,1 & 27,0 & 26,9 & 41,3 & 95,2 & 24,3 & 24,2 & 37,2 & 85,8 \\
\hline 21 & 45,9 & 104,7 & 115,7 & 17,0 & 58,8 & 11,0 & 69,8 & 54,3 & 10,2 & 64,4 & 11,9 & 39,5 & 68,0 & 114,1 & 27,6 & 28,5 & 46,1 & 102,2 & 25,5 & 26,3 & 42,6 & 94,3 \\
\hline 22 & 45,9 & 106,2 & 117,7 & 17,0 & 60,3 & 11,5 & 71,8 & 55,7 & 10,6 & 66,3 & 11,9 & 40,0 & 69,8 & 120,5 & 28,1 & 29,8 & 50,7 & 108,6 & 25,9 & 27,5 & 46,8 & 100,2 \\
\hline
\end{tabular}


(continuação)

\begin{tabular}{|c|c|c|c|c|c|c|c|c|c|c|c|c|c|c|c|c|c|c|c|c|c|c|}
\hline 23 & 45,9 & 107,8 & 119,6 & 20,0 & 1,9 & 11,8 & 73,7 & 61,4 & 11,7 & 73,2 & 11,9 & 38,9 & 8,4 & 121,2 & 27,0 & 29,5 & 52,8 & 109,3 & 26,8 & 29,3 & 52,4 & 108,5 \\
\hline 24 & 45,9 & 109,3 & 21,5 & 0,0 & 3,4 & 2,2 & 75,6 & 2,9 & 2,1 & 75,0 & 1,9 & 39,5 & 0,5 & 128,4 & 7,6 & 1,0 & 7,9 & 16,5 & 7,4 & 0,8 & 7,5 & 15,6 \\
\hline 25 & 46,0 & 111,0 & 3,7 &, 0 & 5,0 & ,7 & 77,7 & 0,1 & 9 & 9,0 &, 9 & 39,7 & 1,7 & 35,6 & 7,8 & 2,0 & 3,9 & 3,7 & 8,3 & 2,5 & 5,0 & 5,8 \\
\hline 26 & 46,0 & 112,8 & 125,7 & 21,0 & 66,8 & 12,9 & 79,7 & 67,9 & 13,1 & 81,0 & 1,9 & 39,3 & 71,4 & 141,3 & 27,4 & 32,1 & 99,9 & 129,4 & 27,9 & 2,6 & 71,1 & 31,6 \\
\hline 27 & 45,9 & 3 & 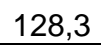 & 22,0 & 9,4 & 13,0 & 82,4 & 72,3 & 10,0 & 85,8 & 12,0 & 40,1 & 73,9 & 156,3 & 28,1 & 33,8 & 82,4 & 144,3 &, 3 & 5,2 & 5,8 & 150,3 \\
\hline 27,5 & & & & 22,0 & \multicolumn{6}{|c|}{ Lavagem do FRD - transpasse } & 12,0 & 40,4 & 74,7 & 163,5 & 28,4 & 34,3 & 88,8 & 151,5 & 29,6 & 5,7 & 92,5 & 157,8 \\
\hline 28 & 45,9 & 117,8 & 131,3 & 22,0 & 71,9 & 13,5 & 85,4 & 74,9 & 14,1 & 89,0 & 12,2 & 36,4 & 55,5 & 74,8 & 24,2 & 19,1 & 19,3 & 62,6 & 25,2 & 19,9 & 20,1 & 65,2 \\
\hline 29 & 45,9 & 119,3 & 133,2 & 21,0 & 73,4 & 13,9 & 87,3 & 74,6 & 14,1 & 88,8 & 12,2 & 37,1 & 56,4 & 89,6 & 24,9 & 19,3 & 33,2 & 77,4 & 25,3 & 19,6 & 33,8 & 78,7 \\
\hline 30 & 45,9 & 121,7 & 136,1 & 21,0 & 75,8 & 14,4 & 90,2 & 77,1 & 14,6 & 91,7 & 12,2 & 37,8 & 61,2 & 106,6 & 25,6 & 23,4 & 45,4 & 94,4 & 26,0 & 23,8 & 46,2 & 96,0 \\
\hline 31 & 45, & 12 & & $\angle 0,0$ & 78 & & & 7 & & 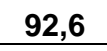 & & & 6 & 120,5 & 25,6 & 25,8 & 9 & &, 4 & 5,6 &, 5 & \\
\hline 32 & 45,9 & 126,3 & 141,8 & 20,0 & 80,4 & 15,5 & & & & & 12,1 & 39,4 & 67,8 & 136,1 & 27,3 & 28,4 & 88,3 & & 27,1 & 8,2 & 7,8 & 3,1 \\
\hline 33 & 45,9 & 128,4 & 144,5 & 19,0 & 82,5 & 16,1 & 98,6 & 79,9 & 15,6 & 95,5 & 12,1 & 40,0 & 69,9 & 149,9 & 27,9 & 29,9 & 80,0 & 137,8 & 27,0 & 29,0 & 77,5 & 133,5 \\
\hline 34 & 45,9 & 130,9 & 147,8 & 19,0 & 85,0 & 16,9 & 101,9 & 82,3 & 16,4 & 98,7 & 12,1 & 41,6 & 73,7 & 173,1 & 29,5 & 32,1 & 99,4 & 161,0 & 28,6 & 1,1 & 96,3 & 156,0 \\
\hline 35 & 45,9 & 132,9 & 149,7 & 18,0 & 87,0 & 16,8 & 103,8 & 82,3 & 15,9 & 98,2 & 12,1 & 37,2 & 59,0 & 82,9 & 25,1 & 21,8 & 23,9 & 70,8 & 23,7 & 20,6 & 22,6 & 67,0 \\
\hline 36 & 45,9 & 135,2 & 152,5 & 18,0 & 89,3 & 17,3 & 106,6 & 84,4 & 16,4 & 100,8 & 12,1 & 37,4 & 63,3 & 106,4 & 25,3 & 25,9 & 43,1 & 94,3 & 23,9 & 24,5 & 40,8 & 89,2 \\
\hline
\end{tabular}

FAAG = filtro ascendente de areia grossa; $F R D$ = filtro rápido descendente; TF = tempo de funcionamento; $T$ = temperatura; Lavagem do FRD por transpasse 


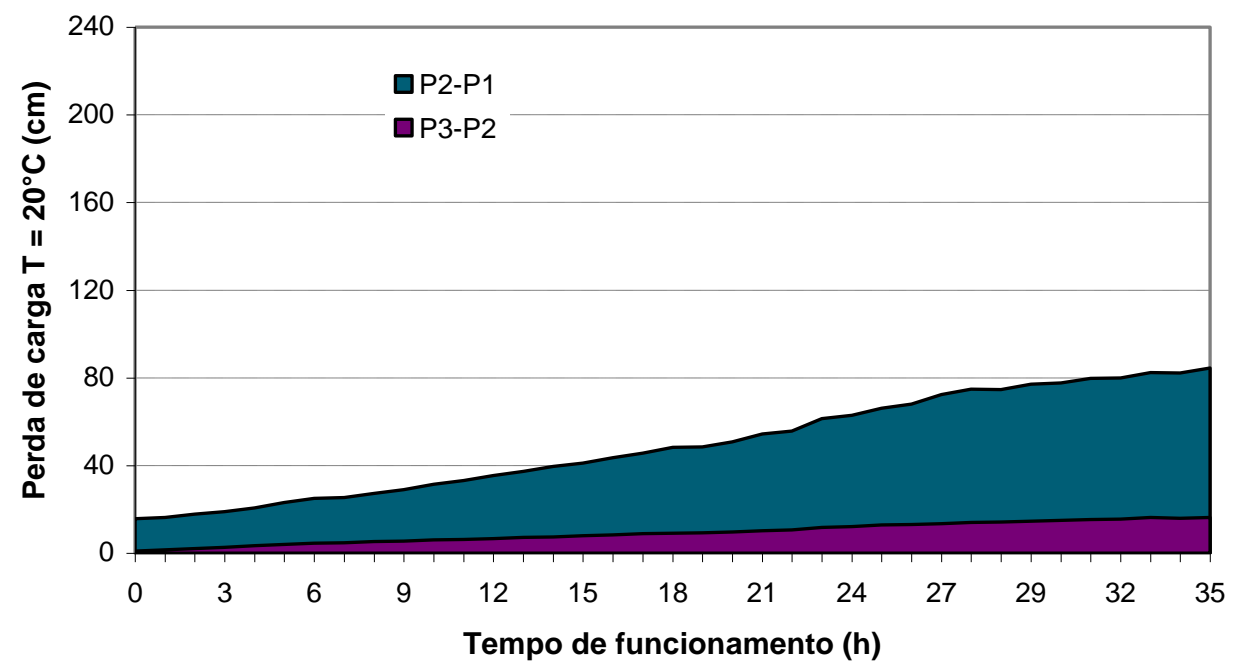

Figura C 5.1 - Perda de carga na camada suporte e camada de areia grossa no FAAG durante o ensaio 12 - pré-oxidação com dióxido de cloro (FAAG $=180 \mathrm{~m}^{3} / \mathrm{m}^{2} \mathrm{~d}$ e $\mathrm{FRD}=280 \mathrm{~m}^{3} / \mathrm{m}^{2} \mathrm{~d}$ ). Fonte: Tabela C 5.3 - ANEXO C.

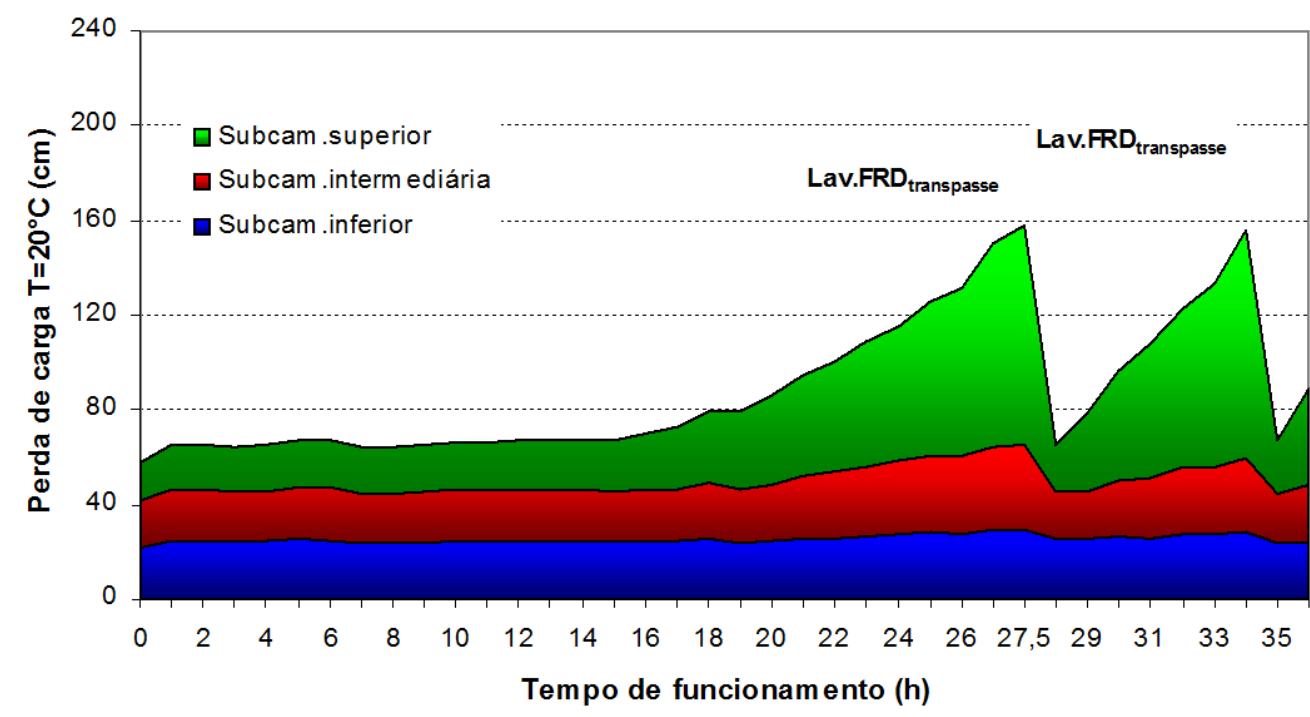

Figura C 5.2 - Perda de carga ao longo do meio filtrante do FRD durante o ensaio 12 - pré-oxidação com dióxido de cloro (FAAG $=180 \mathrm{~m}^{3} / \mathrm{m}^{2} \mathrm{~d}$ e FRD $=280 \mathrm{~m}^{3} / \mathrm{m}^{2} \mathrm{~d}$ ). Fonte: Tabela C $5.3-$ ANEXO C. 
Tabela C 5.4 - Variação de vazões e taxas de filtração do FAAG e do FRD durante o ensaio 12 - préoxidação com dióxido de cloro (FAAG $=180 \mathrm{~m}^{3} / \mathrm{m}^{2} \mathrm{~d} ; \mathrm{FRD}=280 \mathrm{~m}^{3} / \mathrm{m}^{2} \mathrm{~d}$ ).

\begin{tabular}{|c|c|c|c|c|c|c|c|c|}
\hline \multirow{2}{*}{$\begin{array}{l}\text { TF } \\
\text { (h) }\end{array}$} & \multicolumn{2}{|c|}{ descartes (L/h) } & \multicolumn{2}{|c|}{ turbidímetros $(\mathrm{L} / \mathrm{h})$} & \multicolumn{2}{|c|}{ vazão total (L/h) } & \multicolumn{2}{|c|}{ taxas de filtração $\left(\mathrm{m}^{3} / \mathrm{m}^{2} \mathrm{~d}\right)$} \\
\hline & FAAG & FRD & FAAG & FRD & FAAG & FRD & FAAG & FRD \\
\hline 0 & 27,87 & 50,12 & 18,30 & 22,10 & 118,39 & 72,22 & 182 & 264 \\
\hline 1 & 26,61 & 55,98 & 17,28 & 21,90 & 121,77 & 77,88 & 187 & 285 \\
\hline 2 & 26,62 & 54,15 & 18,23 & 22,35 & 121,35 & 76,50 & 187 & 280 \\
\hline 3 & 26,94 & 55,15 & 18,06 & 22,26 & 122,41 & 77,41 & 188 & 283 \\
\hline 4 & 26,88 & 54,90 & 18,09 & 22,79 & 122,66 & 77,69 & 189 & 284 \\
\hline 5 & 26,69 & 53,74 & 18,34 & 22,68 & 121,45 & 76,42 & 187 & 280 \\
\hline 6 & 26,82 & 53,86 & 18,21 & 23,12 & 122,01 & 76,98 & 188 & 282 \\
\hline 7 & 26,97 & 53,44 & 18,28 & 22,89 & 121,58 & 76,33 & 187 & 279 \\
\hline 8 & 27,28 & 52,20 & 17,92 & 23,04 & 120,44 & 75,24 & 185 & 275 \\
\hline 9 & 26,61 & 53,23 & 18,16 & 22,08 & 120,08 & 75,31 & 185 & 275 \\
\hline 10 & 26,89 & 52,21 & 18,00 & 22,20 & 119,30 & 74,41 & 183 & 272 \\
\hline 11 & 27,12 & 53,49 & 18,95 & 22,76 & 122,32 & 76,25 & 188 & 279 \\
\hline 12 & 26,71 & 52,73 & 17,90 & 22,63 & 119,97 & 75,36 & 184 & 276 \\
\hline 13 & 26,37 & 53,60 & 18,00 & 21,96 & 119,93 & 75,56 & 184 & 276 \\
\hline 14 & 26,65 & 54,38 & 17,80 & 21,98 & 120,99 & 76,54 & 186 & 280 \\
\hline 15 & 26,98 & 55,47 & 17,90 & 22,16 & 122,65 & 77,77 & 189 & 284 \\
\hline 16 & 26,50 & 54,14 & 17,12 & 22,30 & 119,26 & 75,64 & 183 & 277 \\
\hline 17 & 27,11 & 55,07 & 16,87 & 21,50 & 120,65 & 76,67 & 185 & 280 \\
\hline 18 & 27,10 & 55,69 & 16,39 & 21,60 & 120,98 & 77,49 & 186 & 283 \\
\hline 19 & 29,34 & 53,04 & 15,99 & 21,80 & 120,10 & 74,77 & 185 & 273 \\
\hline 20 & 28,66 & 55,74 & 16,17 & 21,73 & 122,70 & 77,87 & 189 & 285 \\
\hline 21 & 28,39 & 54,81 & 15,84 & 22,13 & 120,29 & 76,06 & 185 & 278 \\
\hline 22 & 28,30 & 54,55 & 16,10 & 21,25 & 121,27 & 76,87 & 186 & 281 \\
\hline 23 & 30,21 & 52,65 & 18,77 & 22,32 & 123,76 & 74,78 & 190 & 274 \\
\hline 24 & 31,25 & 53,84 & 13,83 & 22,13 & 121,42 & 76,34 & 187 & 279 \\
\hline 25 & 28,59 & 55,31 & 16,74 & 22,50 & 123,50 & 78,17 & 190 & 286 \\
\hline 26 & 28,12 & 53,13 & 15,72 & 22,86 & 120,13 & 76,29 & 185 & 279 \\
\hline 27 & 26,98 & 54,22 & 15,35 & 23,16 & 119,89 & 77,56 & 184 & 284 \\
\hline 28 & 24,92 & 53,33 & 19,76 & 23,34 & 120,39 & 75,71 & 185 & 277 \\
\hline 29 & 23,57 & 55,24 & 19,09 & 22,38 & 121,13 & 78,47 & 186 & 287 \\
\hline 30 & 21,85 & 56,33 & 18,13 & 23,23 & 119,38 & 79,40 & 183 & 290 \\
\hline 31 & 26,24 & 53,50 & 17,65 & 23,07 & 119,79 & 75,90 & 184 & 278 \\
\hline 32 & 25,23 & 55,24 & 16,39 & 22,40 & 119,31 & 77,69 & 183 & 284 \\
\hline 33 & 27,19 & 53,29 & 16,97 & 22,45 & 119,49 & 75,33 & 184 & 276 \\
\hline 34 & 26,69 & 53,55 & 16,78 & 22,04 & 119,39 & 75,92 & 184 & 278 \\
\hline 35 & 21,65 & 53,00 & 22,32 & 22,37 & 118,60 & 74,63 & 182 & 273 \\
\hline \multirow[t]{5}{*}{36} & 22,31 & 54,17 & 21,41 & 21,63 & 119,52 & 75,80 & 184 & 277 \\
\hline & & & & Mínima & 118,39 & 72,22 & 182 & 264 \\
\hline & & & & Média & 120,76 & 76,36 & 186 & 279 \\
\hline & & & & Máxima & 123,76 & 79,40 & 190 & 290 \\
\hline & & & & DP & 1,36 & 1,37 & 2,08 & 5,01 \\
\hline
\end{tabular}

$\mathrm{TF}=$ tempo de funcionamento; $\mathrm{FAAG}=\overline{\text { filtro ascendente de areia grossa; } \mathrm{FRD}=\text { filtro rápido descendente; } \mathrm{AC}}=$ água coagulada; $\mathrm{DP}=$ desvio padrão. 
Tabela C 6.1 - Características físicas da AB, AE, APO e efluentes do FAAG e do FRD durante o ensaio 13 - pré-oxidação com permanganato de potássio ( $F A A G=180 \mathrm{~m}^{3} / \mathrm{m}^{2} \mathrm{~d} ; \mathrm{FRD}=280 \mathrm{~m}^{3} / \mathrm{m}^{2} \mathrm{~d}$ ).

\begin{tabular}{|c|c|c|c|c|c|c|c|c|c|}
\hline \multirow[b]{2}{*}{ TF (h) } & \multirow{2}{*}{\begin{tabular}{|c|}
$\begin{array}{c}\text { Temperatura } \\
\left({ }^{\circ} \mathrm{C}\right)\end{array}$ \\
$\mathrm{AE}$ \\
\end{tabular}} & \multicolumn{5}{|c|}{ Cor aparente (uH) } & \multicolumn{3}{|c|}{ Cor verdadeira (uH) } \\
\hline & & $\mathrm{AB}$ & $\mathrm{AE}$ & APO & FAAG & FRD & AB & $\mathbf{A E}$ & APO \\
\hline 0 & 20,0 & 78 & 160 & 252 & 8,0 & 1,0 & 13 & 96 & 144 \\
\hline 1 & 20,5 & & 177 & 237 & 2,0 & $<1,0$ & & 105 & 130 \\
\hline 2 & 21,0 & & 175 & 244 & 1,0 & $<1,0$ & & 106 & 126 \\
\hline 4 & 21,0 & & 171 & 236 & $<1,0$ & $<1,0$ & & 104 & 127 \\
\hline 6 & 21,5 & 84 & 165 & 241 & $<1,0$ & $<1,0$ & 14 & 98 & 129 \\
\hline 8 & 21,0 & & 164 & 235 & $<1,0$ & $<1,0$ & & 103 & 131 \\
\hline 10 & 19,5 & & 164 & 228 & $<1,0$ & $<1,0$ & & 102 & 128 \\
\hline 12 & 19,0 & 79 & 161 & 233 & $<1,0$ & $<1,0$ & 12 & 99 & 137 \\
\hline 14 & 19,0 & & 155 & 220 & $<1,0$ & $<1,0$ & & 100 & 124 \\
\hline 16 & 18,0 & & 157 & 220 & 9,0 & $<1,0$ & & 102 & 125 \\
\hline 18 & 18,0 & 73 & 155 & 228 & 30,0 & $<1,0$ & 14 & 96 & 129 \\
\hline 20 & 18,0 & & 155 & 224 & 46,0 & $<1,0$ & & 103 & 130 \\
\hline 22 & 18,0 & & 165 & 225 & 61,0 & $<1,0$ & & 111 & 125 \\
\hline 24 & 20,0 & 74 & 163 & 236 & 60,0 & $<1,0$ & 14 & 101 & 135 \\
\hline 26 & 21,0 & & 181 & 244 & 78,0 & 4,0 & & 106 & 135 \\
\hline 28 & 22,0 & & 186 & 251 & 84,0 & 10,0 & & 108 & 134 \\
\hline 30 & 22,0 & 85 & 166 & 246 & 88,0 & $<1,0$ & 13 & 100 & 139 \\
\hline 32 & 22,0 & & 175 & 241 & 94,0 & $<1,0$ & & 106 & 135 \\
\hline 34 & 20,0 & & 172 & 243 & 115,0 & 6,0 & & 109 & 134 \\
\hline 36 & 19,5 & 82 & 164 & 243 & 111,0 & $<1,0$ & 14 & 99 & 131 \\
\hline Média & 20,1 & 79 & 167 & 236 & 39,5 & 1,45 & 13 & 103 & 131 \\
\hline Mínimo & 18,0 & 73 & 155 & 220 & $<1,0$ & $<1,0$ & 12 & 96 & 124 \\
\hline Máximo & 22,0 & 85 & 186 & 252 & 115,0 & 10,00 & 14 & 111 & 144 \\
\hline DP & 1,39 & 4,68 & 8,86 & 9,65 & 42,64 & 2,46 & 0,79 & 4,19 & 5,20 \\
\hline
\end{tabular}

TF = tempo de funcionamento; $\mathrm{AE}$ = água de estudo; $\mathrm{AB}$ = água bruta; $\mathrm{APO}=$ água pré-oxidada; $\mathrm{FAAG}=$ filtro ascendente de areia grossa; $F R D=$ filtro rápido descendente; $\mathrm{DP}=$ desvio padrão. 
Tabela C 6.2 - Características químicas da AB, AE, APO e efluentes do FAAG e do FRD durante o ensaio 13 - pré-oxidação com permanganato de potássio (FAAG = $\left.180 \mathrm{~m}^{3} / \mathrm{m}^{2} \mathrm{~d} ; \mathrm{FRD}=280 \mathrm{~m}^{3} / \mathrm{m}^{2} \mathrm{~d}\right)$

\begin{tabular}{|c|c|c|c|c|c|c|c|c|c|c|c|c|c|c|c|c|c|c|c|c|c|}
\hline \multirow[b]{2}{*}{ TF (h) } & \multicolumn{4}{|c|}{$\mathrm{pH}$} & \multicolumn{3}{|c|}{ Alcalinidade $\left(\mathrm{mg} / \mathrm{L} \mathrm{CaCO}_{3}\right)$} & \multicolumn{5}{|c|}{ Absorvância 254 nm } & \multicolumn{5}{|c|}{ COD (mg/L) } & \multicolumn{4}{|c|}{ Alumínio (mg/L) } \\
\hline & $\mathrm{AB}$ & $\mathrm{AE}$ & APO & AC & $\mathrm{AB}$ & $\mathbf{A E}$ & APO & $\mathrm{AB}$ & $\mathrm{AE}$ & APO & FAAG & FRD & AB & $\mathrm{AE}$ & APO & FAAG & FRD & $\mathrm{AB}$ & $\mathrm{AE}$ & FAAG & FRD \\
\hline 0 & 6,48 & 6,57 & 6,50 & 5,51 & 5,72 & 6,82 & 5,94 & 0,045 & 0,167 & 0,198 & 0,008 & 0,015 & 2,578 & 4,272 & 4,010 & 2,346 & 2,922 & ND & 0,01 & 0,17 & 0,15 \\
\hline 1 & & 6,52 & 6,23 & 5,20 & & & & & & & & & & & & & & & & & \\
\hline 2 & & 6,63 & 6,37 & 5,29 & & & & & & & & & & & & & & & & & \\
\hline 4 & & 6,59 & 6,35 & 5,37 & & & & & & & & & & & & & & & & & \\
\hline 6 & 6,55 & 6,60 & 6,40 & 5,28 & 6,16 & 7,26 & 6,38 & 0,044 & 0,169 & 0,183 & 0,006 & 0,007 & 2,161 & 3,510 & 3,725 & 2,200 & 2,082 & & & & \\
\hline 8 & & 6,62 & 6,44 & 5,34 & & & & & & & & & & & & & & & & & \\
\hline 10 & & 6,53 & 6,29 & 5,52 & & & & & & & & & & & & & & & & & \\
\hline 12 & 6,53 & 6,68 & 6,37 & 5,61 & 6,60 & 7,92 & 7,48 & 0,042 & 0,171 & 0,193 & 0,003 & 0,016 & 2,084 & 3,583 & 3,713 & 2,048 & 1,986 & 0,01 & 0,01 & ND & ND \\
\hline 14 & & 6,58 & 6,28 & 5,54 & & & & & & & & & & & & & & & & & \\
\hline 16 & & 6,53 & 6,37 & 5,53 & & & & & & & & & & & & & & & & & \\
\hline 18 & 6,34 & 6,54 & 6,29 & 5,48 & 4,84 & 7,70 & 7,04 & 0,047 & 0,166 & 0,187 & 0,013 & 0,014 & & & & & & & & & \\
\hline 20 & & 6,62 & 6,30 & 5,47 & & & & & & & & & & & & & & & & & \\
\hline 22 & & 6,68 & 6,39 & 5,47 & & & & & & & & & & & & & & & & & \\
\hline 24 & 6,56 & 6,60 & 6,37 & 5,31 & 5,50 & 8,80 & 6,82 & 0,046 & 0,180 & 0,190 & 0,009 & 0,015 & 3,079 & 4,254 & 3,473 & 1,910 & 2,000 & 0,01 & ND & 0,04 & 0,03 \\
\hline 26 & & 6,56 & 6,30 & 5,37 & & & & & & & & & & & & & & & & & \\
\hline 28 & & 6,57 & 6,28 & 5,23 & & & & & & & & & & & & & & & & & \\
\hline 30 & 6,46 & 6,53 & 6,29 & 5,25 & 6,82 & 7,92 & 5,50 & 0,051 & 0,183 & 0,192 & 0,012 & 0,016 & & & & & & & & & \\
\hline 32 & & 6,57 & 6,23 & 5,27 & & & & & & & & & & & & & & & & & \\
\hline 34 & & 6,64 & 6,31 & 5,45 & & & & & & & & & & & & & & & & & \\
\hline 36 & 6,51 & 6,64 & 6,25 & 5,35 & 7,26 & 7,70 & 5,72 & 0,045 & 0,173 & 0,188 & \begin{tabular}{|l|}
0,009 \\
\end{tabular} & 0,014 & 2,796 & 3,694 & 3,237 & 2,942 & 2,471 & ND & 0,01 & 0,04 & 0,03 \\
\hline Média & 6,49 & 6,59 & 6,33 & 5,39 & 6,13 & 7,73 & 6,41 & 0,046 & 0,173 & 0,190 & 0,009 & 0,014 & 2,540 & 3,863 & 3,632 & 2,289 & 2,292 & - & - & & \\
\hline Mínimo & 6,34 & 6,52 & 6,23 & 5,20 & 4,84 & 6,82 & 5,50 & 0,042 & 0,166 & 0,183 & 0,003 & 0,007 & 2,084 & 3,510 & 3,237 & 1,910 & 1,986 & - & - & & \\
\hline Máximo & 6,56 & 6,68 & 6,50 & 5,61 & 7,26 & 8,80 & 7,48 & 0,051 & 0,183 & 0,198 & 0,013 & 0,016 & 3,079 & 4,272 & 4,010 & 2,942 & 2,922 & - & - & & \\
\hline DP & 0,08 & 0,05 & 0,07 & 0,12 & 0,84 & 0,61 & 0,73 & 0,003 & 0,006 & 0,005 & 0,003 & 0,003 & 0,421 & 0,371 & 0,291 & 0,400 & 0,404 & - & - & & \\
\hline
\end{tabular}

$\mathrm{TF}=$ tempo de funcionamento; $\mathrm{AE}$ = água de estudo; $\mathrm{AB}$ = água bruta; $\mathrm{AC}=$ água coagulada; $\mathrm{APO}=$ água pré-oxidada; $\mathrm{FAAG}=$ filtro ascendente de areia grossa; $\mathrm{FRD}=$ filtro rápido descendente; $\mathrm{DP}=$ desvio padrão. 
Tabela C 6.3 - Perda de carga no FAAG $\left(180 \mathrm{~m}^{3} / \mathrm{m}^{2} \mathrm{~d}\right)$ e no FRD $\left(280 \mathrm{~m}^{3} / \mathrm{m}^{2} \mathrm{~d}\right)$ durante o ensaio 13, pré-oxidação com permanganato de potássio e sem DFIs no FAAG para a temperatura $\mathrm{T}$ e para $\mathrm{T}=20^{\circ} \mathrm{C}$

\begin{tabular}{|c|c|c|c|c|c|c|c|c|c|c|c|c|c|c|c|c|c|c|c|c|c|c|}
\hline \multirow{3}{*}{$\begin{array}{l}\text { TF } \\
\text { (h) }\end{array}$} & \multicolumn{10}{|c|}{ FAAG } & \multicolumn{12}{|l|}{ FRD } \\
\hline & \multicolumn{3}{|c|}{$\begin{array}{c}\text { Leitura piezométrica } \\
(\mathbf{c m})\end{array}$} & \multirow{2}{*}{$\mid \begin{array}{c}\mathrm{T} \\
\left({ }^{\circ} \mathrm{C}\right)\end{array}$} & \multicolumn{3}{|c|}{$\begin{array}{l}\text { Perda de carga } \\
\text { (cm) }\end{array}$} & \multicolumn{3}{|c|}{$\begin{array}{c}\text { Perda de carga }(\mathrm{cm}) \\
\mathrm{T}=20^{\circ} \mathrm{C}\end{array}$} & \multicolumn{4}{|c|}{$\begin{array}{c}\text { Leitura piezométrica } \\
\text { (cm) }\end{array}$} & \multicolumn{4}{|c|}{$\begin{array}{l}\text { Perda de carga } \\
(\mathrm{cm})\end{array}$} & \multicolumn{4}{|c|}{$\begin{array}{c}\text { Perda de carga }(\mathrm{cm}) \\
\mathrm{T}=20^{\circ} \mathrm{C}\end{array}$} \\
\hline & P1 & $\mathrm{P} 2$ & P3 & & P2-P1 & P3-P2 & P3-P1 & P2-P1 & P3-P2 & P3-P1 & P1 & P2 & P3 & P4 & P2-P1 & P3-P2 & P4-P3 & P4-P1 & P2-P1 & P3-P2 & P4-P3 & P4-P1 \\
\hline 0 & 46,0 & 61,7 & 62,6 & 20,0 & 15,7 & 0,9 & 16,6 & 5,6 & 0,9 & 16,5 & 12,2 & 35,8 & 56,8 & 72,3 & 23,6 & 21,0 & 15,5 & 60,1 & 23,4 & 20,8 & 15,4 & 59,7 \\
\hline 1 & 46,0 & 62,6 & 64,3 & 20,5 & 16,6 & 1,7 & 18,3 & 16,7 & 1,7 & 18,4 & 12,3 & 37,8 & 60,4 & 78,2 & 25,5 & 22,6 & 17,8 & 65,9 & 25,6 & 22,7 & 17,9 & 66,2 \\
\hline 2 & 46,0 & 64,3 & 66,6 & 21,0 & 18,3 & 2,3 & 20,6 & 18,6 & 2,3 & 20,9 & 12,3 & 37,5 & 59,9 & 78,2 & 25,2 & 22,4 & 18,3 & 65,9 & 25,6 & 22,8 & 18,6 & 67,0 \\
\hline 3 & 46,0 & 65,9 & 68,8 & 21,0 & 19,9 & 2,9 & 22,8 & 20,2 & 2,9 & 23,2 & 12,3 & 38,0 & 61,0 & 80,0 & 25,7 & 23,0 & 10,0 & 67,7 & 26,1 & 23,4 & & 68,8 \\
\hline 4 & 46,0 & 67,6 & 71,1 & 21,0 & 21,6 & 3,5 & 25,1 & 22,0 & 36 & 5,5 & 12,3 & 38,0 & 61,1 & 80,5 & 5,7 & 23,1 & 19,4 & 68,2 & 26,1 & 23,5 & 19,7 & 69,3 \\
\hline 5 & 46,0 & 69,4 & 73,5 & 21,0 & 23,4 & 4,1 & 27,5 & 23,8 & 4,2 & 28,0 & 12,3 & 38,0 & 61,1 & 80,9 & 25,7 & 23,1 & 19,8 & 68,6 & 26,1 & 23,5 & 20,1 & 69,8 \\
\hline 6 & 46,1 & 71,3 & 76,0 & 21,5 & 25,2 & 4,7 & 29, & 20 & 4, & 30,8 & 12,3 & 37,9 & 61,0 & 81,0 & 25,6 & 23,1 & 0 & 68,7 & 3 & 23,8 & 6 & 70,7 \\
\hline 7 & 46,0 & 73,2 & 78,4 & 21,5 & 27,2 & 5,2 & 3 & & & 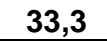 & 12,3 & 37,9 & 60,9 & 81,1 & 25,6 & 23,0 & 2 & 68,8 & , & 3,7 & 8 & 70,8 \\
\hline 8 & 46,0 & 75,2 & 81,0 & 21,0 & 29,2 & 5,8 & 35,0 & 29,7 & 5,9 & 35,6 & 12,2 & 37,6 & 60,5 & 80,7 & 25,4 & 22,9 & 20,2 & 68,5 & 25,8 & 23,3 & 20,5 & 69,7 \\
\hline 9 & 46,0 & 77,5 & 83,9 & 21,0 & 31,5 & 6,4 & 37,9 & 32,0 & 6,5 & 38,5 & 12,1 & 36,6 & 58,8 & 78,6 & 24,5 & 22,2 & 19,8 & 66,5 & 24,9 & 22,6 & 20,1 & 67,6 \\
\hline 10 & 46,0 & 79,6 & 86,3 & 19,5 & 33,6 & 6,7 & 40,3 & 32,9 & 6,6 & 39,5 & 12,2 & 38,7 & 62,7 & 84,0 & 26,5 & 24,0 & 21,3 & 71,8 & 26,0 & 23,5 & 20,9 & 70,4 \\
\hline 11 & 46,0 & 81,8 & 89,0 & 19,5 & 35,8 & 7,2 & 43,0 & 35,1 & 7, & 72,2 & 12,1 & 38,9 & 62,9 & 84,8 & 26,8 & 24,0 & 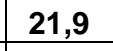 & 72,7 & 26,3 & 23,5 & 5 & 71,3 \\
\hline 12 & 46,0 & 83,9 & 91,5 & 19,0 & 37,9 & 7,6 & 45,5 & 36,7 & 7,4 & 44,1 & 12,1 & 38,7 & 62,6 & 84,8 & 26,6 & 23,9 & 22,2 & 72,7 & 25,8 & 23,2 & 21,5 & 70,4 \\
\hline 13 & 46,0 & 86,1 & 94,1 & 19,0 & 40,1 & 8,0 & 48,1 & 38,8 & 7,8 & 46,6 & 12,1 & 38,7 & 62,7 & 84,9 & 26,6 & 24,0 & 22,2 & 72,8 & 25,8 & 23,3 & 21,5 & 70,5 \\
\hline 14 & 46,0 & 88,5 & 97,1 & 19,0 & 42,5 & 8,6 & 51,1 & 41,2 & 8,3 & 49,5 & 12,1 & 38,7 & 62,8 & 84,9 & 26,6 & 24,1 & 22,1 & 72,8 & 25,8 & 23,3 & 21,4 & 70,5 \\
\hline 15 & 46,0 & 91,0 & 100,0 & 19,0 & 45,0 & 9,0 & 54,0 & 43,6 & 8,7 & 52,3 & 12,1 & 38,8 & 63,0 & 85,0 & 26,7 & 24,2 & 22,0 & 72,9 & 25,9 & 23,4 & ,3 & 70,6 \\
\hline 16 & 46,0 & 93,9 & 103,3 & 18,0 & 47,9 & 9,4 & 57,3 & 45,3 & 8,9 & 54,2 & 12,1 & 39,3 & 63,8 & 86,8 & 27,2 & 24,5 & 23,0 & 74,7 & 25,7 & 23,2 & 21,7 & 70,6 \\
\hline 17 & 46,0 & 96,5 & 106,4 & 18,0 & 50,5 & 9,9 & 60,4 & 47,8 & 9,4 & 57,1 & 12,1 & 39,5 & 64,4 & 89,2 & 27,4 & 24,9 & 24,8 & 77,1 & 25,9 & 23,5 & 23,5 & 72,9 \\
\hline 18 & 46,0 & 99,0 & 109,4 & 18,0 & 53,0 & 10,4 & 63,4 & 50,1 & 9,8 & 60,0 & 12,1 & 39,8 & 65,0 & 93,4 & 27,7 & 25,2 & 28,4 & 81,3 & 26,2 & 23,8 & 26,9 & 76,9 \\
\hline 19 & 46,0 & 101,5 & 112,4 & 18,0 & 55,5 & 10,9 & 66,4 & 52,5 & 10,3 & 62,8 & 12,0 & 39,2 & 64,6 & 96,8 & 27,2 & 25,4 & 32,2 & 84,8 & 25,7 & 24,0 & 30,4 & 80,2 \\
\hline 20 & 46,0 & 103,7 & 115,2 & 18,0 & 57,7 & 11,5 & 69,2 & 54,6 & 10,9 & 65,4 & 12,0 & 39,3 & 66,4 & 103,9 & 27,3 & 27,1 & 37,5 & 91,9 & 25,8 & 25,6 & 35,5 & 86,9 \\
\hline 21 & 46,0 & 106,4 & 118,2 & 18,0 & 60,4 & 11,8 & 72,2 & 57,1 & 11,2 & 68,3 & 12,0 & 39,6 & 68,9 & 111,5 & 27,6 & 29,3 & 42,6 & 99,5 & 26,1 & 27,7 & 40,3 & 94,1 \\
\hline 22 & 45,9 & 108,2 & 120,4 & 18,0 & 62,3 & 12,2 & 74,5 & 58,9 & 11,5 & 70,5 & 12,0 & 40,2 & 72,5 & 120,4 & 28,2 & 32,3 & 47,9 & \begin{tabular}{|l|}
108,4 \\
\end{tabular} & 26,7 & 30,5 & 45,3 & 102,5 \\
\hline
\end{tabular}


(continuação)

\begin{tabular}{|c|c|c|c|c|c|c|c|c|c|c|c|c|c|c|c|c|c|c|c|c|c|c|}
\hline 23 & 45,9 & 109,6 & 122,1 & 18,0 & 63,7 & 12,5 & 76,2 & 60,2 & 11,8 & 72,1 & 12,0 & 40,2 & 74,4 & 125,5 & 28,2 & 34,2 & 51,1 & 113,5 & 26,7 & 32,3 & 48,3 & 107,3 \\
\hline 24 & 45,9 & 111,4 & 124,3 & 20,0 & 65,5 & 12,9 & 78,4 & 65,0 & 12,8 & 77,8 & 12,0 & 40,2 & 75,6 & 129,7 & 28,2 & 35,4 & 54,1 & 117,7 & 28,0 & 35,1 & 53,7 & 116,8 \\
\hline 25 & 46,0 & 112,8 & 126,0 & 20,0 & 66,8 & 13,2 & 80,0 & 66,3 & 13,1 & 79,4 & 12,0 & 40,0 & 76,7 & 133,8 & 28,0 & 36,7 & 57,1 & 121,8 & 27,8 & 36,4 & 56,7 & 120,9 \\
\hline 26 & 46,0 & 115,9 & 129,6 & 21,0 & 69,9 & 13,7 & 83,6 & 71,1 & 13,9 & 85,0 & 12,0 & 40,5 & 79,0 & 140,6 & 28,5 & 38,5 & 61,6 & 128,6 & 29,0 & 39,1 & 62,6 & 130,8 \\
\hline 27 & 46,0 & 118,5 & 132,6 & 21,0 & 72,5 & 14,1 & 86,6 & 73,7 & 14,3 & 88,1 & 12,1 & 42,2 & 83,9 & 153,8 & 30,1 & 41,7 & 69,9 & 141,7 & 30,6 & 42,4 & 71,1 & 144,1 \\
\hline 28 & 46,0 & 120,5 & 135,3 & 22,0 & 74,5 & 14,8 & 89,3 & 77,6 & 15,4 & 93,0 & 12,0 & 41,2 & 82,7 & 158,8 & 29,2 & 41,5 & 76,1 & 146,8 & 30,4 & 43,2 & 79,3 & 152,9 \\
\hline 29 & 46,0 & 122,2 & 137,2 & 22,0 & 76,2 & 15,0 & 91,2 & 79,4 & 15,6 & 95,0 & 12,2 & 35,5 & 54,6 & 80,6 & 23,3 & 19,1 & 26,0 & 68,4 & 24,3 & 19,9 & 27,1 & 71,3 \\
\hline 30 & 46,0 & 124,1 & 139,3 & 22,0 & 78,1 & 15,2 & 93,3 & 81,4 & 15,8 & 97,2 & 12,2 & 35,5 & 55,7 & 102,5 & 23,3 & 20,2 & 46,8 & 90,3 & 24,3 & 21,0 & 48,8 & 94,1 \\
\hline 31 & 46,0 & 126,8 & 142,7 & 22,0 & 80,8 & 15,9 & 96,7 & 84,2 & 16,6 & 100,7 & 12,2 & 35,2 & 57,5 & 119,9 & 23,0 & 22,3 & 62,4 & 107,7 & 24,0 & 23,2 & 65,0 & 112,2 \\
\hline 32 & 46,0 & 128,5 & 145,0 & 22,0 & 82,5 & 16,5 & 99,0 & 85,9 & 17,2 & 103,1 & 12,1 & 35,6 & 59,9 & 133,8 & 23,5 & 24,3 & 73,9 & 121,7 & 24,5 & 25,3 & 77,0 & 126,8 \\
\hline 33 & 46,0 & 131,0 & 147,9 & 22,0 & 85,0 & 16,9 & 101,9 & 88,5 & 17,6 & 106,2 & 12,1 & 36,3 & 62,4 & 150,9 & 24,2 & 26,1 & 88,5 & 138,8 & 25,2 & 27,2 & 92,2 & 144,6 \\
\hline 34 & 46,0 & 132,9 & 150,2 & 20,0 & 86,9 & 17,3 & 104,2 & 86,3 & 17,2 & 103,4 & 12,1 & 37,1 & 65,7 & 171,8 & 25,0 & 28,6 & 106,1 & 159,7 & 24,8 & 28,4 & 105,3 & 158,5 \\
\hline 35 & 46,0 & 135,5 & 153,2 & 20,0 & 89,5 & 17,7 & 107,2 & 88,8 & 17,6 & 106,4 & 11,8 & 36,9 & 56,7 & 77,6 & 25,1 & 19,8 & 20,9 & 65,8 & 24,9 & 19,7 & 20,7 & 65,3 \\
\hline 36 & 46,0 & 137,7 & 155,8 & 19,5 & 91,7 & 18,1 & 109,8 & 89,9 & 17,7 & 107,7 & 11,9 & 37,4 & 58,2 & 92,8 & 25,5 & 20,8 & 34,6 & 80,9 & 25,0 & 20,4 & 33,9 & 79,3 \\
\hline
\end{tabular}

Média $\left({ }^{\circ} \mathrm{C}\right)=\quad 20,1$

FAAG $=$ filtro ascendente de areia grossa; $F R D=$ filtro rápido descendente $; \mathrm{TF}=$ tempo de funcionamento; $\mathrm{T}=$ temperatura; Lavagem do $\mathrm{FRD}$ por transpasse 


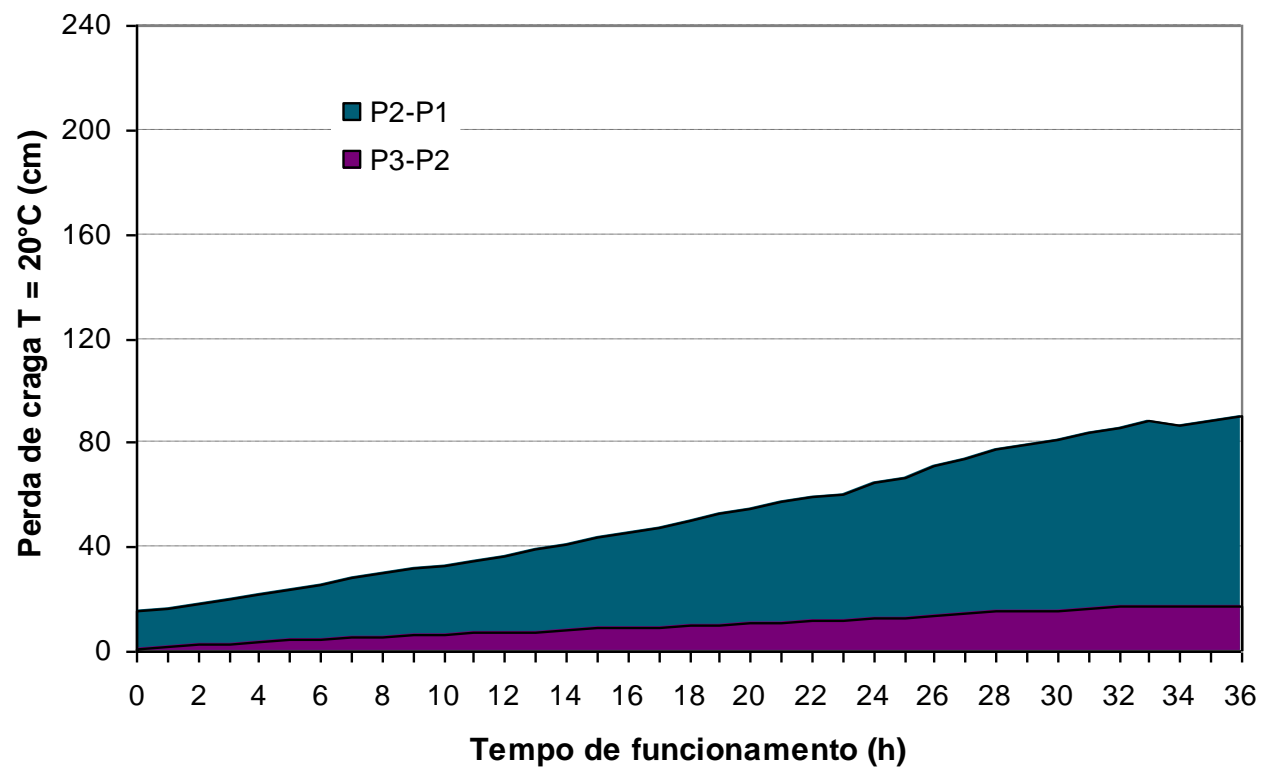

Figura C 6.1 - Perda de carga na camada suporte e camada de areia grossa no FAAG durante 0 ensaio 13 - pré-oxidação com permanganato de potássio ( $F A A G=180 \mathrm{~m}^{3} / \mathrm{m}^{2} \mathrm{~d}$ e $\mathrm{FRD}=280 \mathrm{~m}^{3} / \mathrm{m}^{2} \mathrm{~d}$ ). Fonte: Tabela C 6.3 - ANEXO C.

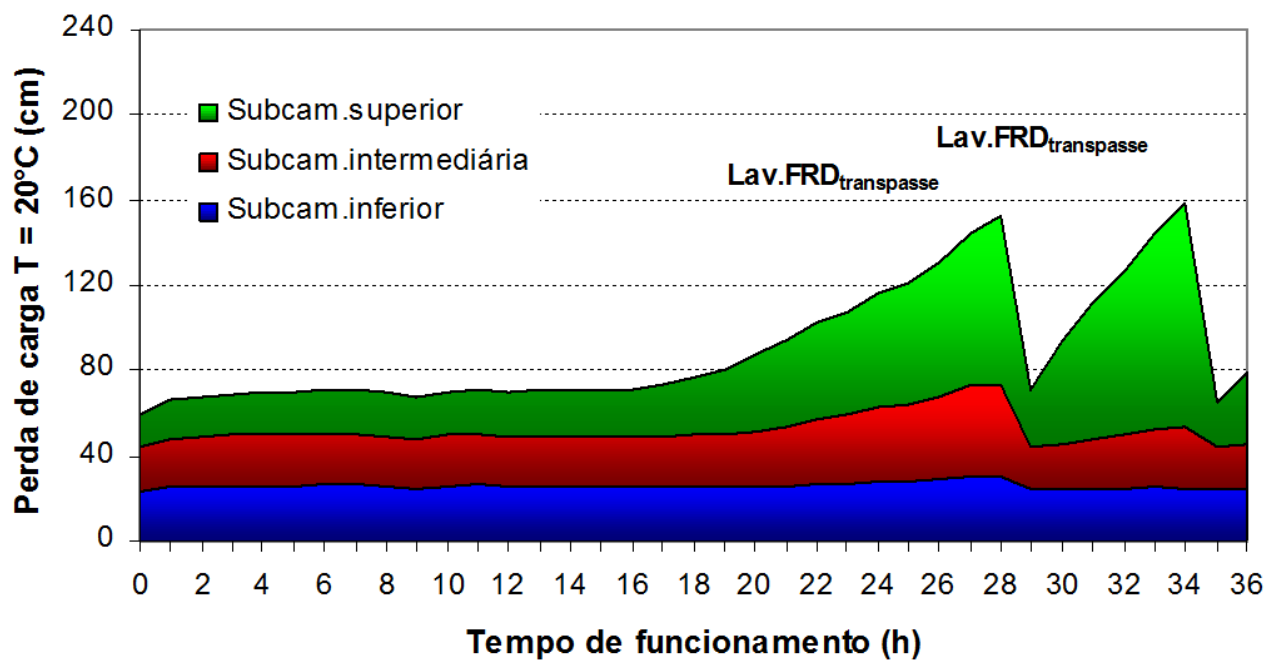

Figura C 6.2 - Perda de carga ao longo do meio filtrante do FRD durante o ensaio 13 - pré-oxidação com permanganato de potássio ( $F A A G=180 \mathrm{~m}^{3} / \mathrm{m}^{2} \mathrm{~d}$ e $\mathrm{FRD}=280 \mathrm{~m}^{3} / \mathrm{m}^{2} \mathrm{~d}$ ). Fonte: Tabela C $6.3-$ ANEXO C. 
Tabela C 6.4 - Variação de vazões e taxas de filtração do FAAG e do FRD durante o ensaio 13 - préoxidação com permanganato de potássio ( $F A A G=180 \mathrm{~m}^{3} / \mathrm{m}^{2} \mathrm{~d} ; \mathrm{FRD}=280 \mathrm{~m}^{3} / \mathrm{m}^{2} \mathrm{~d}$ ).

\begin{tabular}{|c|c|c|c|c|c|c|c|c|}
\hline \multirow{2}{*}{$\begin{array}{l}\text { TF } \\
\text { (h) }\end{array}$} & \multicolumn{2}{|c|}{ descartes $(\mathrm{L} / \mathrm{h})$} & \multicolumn{2}{|c|}{ turbidímetros $(\mathrm{L} / \mathrm{h})$} & \multicolumn{2}{|c|}{ vazão total (L/h) } & \multicolumn{2}{|c|}{ taxas de filtração $\left(\mathrm{m}^{3} / \mathrm{m}^{2} \mathrm{~d}\right)$} \\
\hline & FAAG & FRD & FAAG & FRD & FAAG & FRD & FAAG & FRD \\
\hline 0 & 21,31 & 51,67 & 24,72 & 22,74 & 120,44 & 74,41 & 185 & 272 \\
\hline 1 & 20,26 & 52,58 & 24,47 & 22,44 & 119,75 & 75,02 & 184 & 274 \\
\hline 2 & 20,36 & 53,03 & 24,42 & 23,24 & 121,05 & 76,27 & 186 & 279 \\
\hline 3 & 20,64 & 53,70 & 24,36 & 22,03 & 120,73 & 75,73 & 186 & 277 \\
\hline 4 & 20,81 & 53,44 & 24,12 & 22,56 & 120,93 & 76,00 & 186 & 278 \\
\hline 5 & 20,75 & 54,05 & 24,36 & 22,69 & 121,85 & 76,74 & 187 & 281 \\
\hline 6 & 20,64 & 54,88 & 23,96 & 22,88 & 122,36 & 77,76 & 188 & 284 \\
\hline 7 & 20,62 & 55,54 & 24,12 & 23,04 & 123,32 & 78,58 & 190 & 287 \\
\hline 8 & 20,94 & 54,51 & 23,29 & 23,03 & 121,77 & 77,54 & 187 & 284 \\
\hline 9 & 23,04 & 50,33 & 23,84 & 22,47 & 119,68 & 72,80 & 184 & 266 \\
\hline 10 & 19,87 & 55,62 & 23,69 & 22,35 & 121,53 & 77,97 & 187 & 285 \\
\hline 11 & 21,48 & 53,33 & 23,92 & 22,20 & 120,93 & 75,53 & 186 & 276 \\
\hline 12 & 21,29 & 53,17 & 23,86 & 21,99 & 120,31 & 75,16 & 185 & 275 \\
\hline 13 & 21,68 & 53,03 & 24,00 & 21,98 & 120,69 & 75,01 & 186 & 274 \\
\hline 14 & 22,01 & 54,68 & 23,27 & 22,09 & 122,17 & 76,89 & 188 & 281 \\
\hline 15 & 21,23 & 52,68 & 24,04 & 22,21 & 120,28 & 75,01 & 185 & 274 \\
\hline 16 & 20,72 & 54,19 & 22,91 & 22,33 & 119,90 & 76,27 & 184 & 279 \\
\hline 17 & 20,99 & 54,00 & 22,31 & 22,08 & 118,98 & 75,68 & 183 & 277 \\
\hline 18 & 20,68 & 54,72 & 21,99 & 21,68 & 119,21 & 76,54 & 183 & 280 \\
\hline 19 & 22,84 & 53,26 & 20,86 & 21,82 & 118,72 & 75,02 & 182 & 274 \\
\hline 20 & 22,18 & 53,81 & 20,46 & 21,76 & 118,05 & 75,41 & 181 & 276 \\
\hline 21 & 22,15 & 54,55 & 21,42 & 21,60 & 120,07 & 76,50 & 185 & 280 \\
\hline 22 & 21,62 & 55,07 & 21,43 & 21,95 & 120,05 & 77,00 & 185 & 282 \\
\hline 23 & 21,03 & 54,98 & 21,39 & 21,93 & 120,57 & 78,15 & 185 & 286 \\
\hline 24 & 20,88 & 54,51 & 21,14 & 23,17 & 119,44 & 77,42 & 184 & 283 \\
\hline 25 & 20,99 & 54,19 & 21,48 & 22,91 & 119,33 & 76,86 & 183 & 281 \\
\hline 26 & 20,61 & 54,49 & 20,41 & 22,67 & 118,55 & 77,53 & 182 & 284 \\
\hline 27 & 20,57 & 57,06 & 20,03 & 23,04 & 120,73 & 80,13 & 186 & 293 \\
\hline 28 & 23,43 & 51,68 & 20,63 & 23,07 & 118,43 & 74,37 & 182 & 272 \\
\hline 29 & 16,82 & 54,15 & 25,23 & 22,69 & 119,34 & 77,29 & 183 & 283 \\
\hline 30 & 17,70 & 54,41 & 24,04 & 23,14 & 119,33 & 77,59 & 183 & 284 \\
\hline 31 & 20,03 & 53,09 & 22,91 & 23,18 & 118,49 & 75,55 & 182 & 276 \\
\hline 32 & 21,15 & 51,57 & 22,54 & 22,46 & 117,80 & 74,11 & 181 & 271 \\
\hline 33 & 21,66 & 50,69 & 23,08 & 22,54 & 117,89 & 73,15 & 181 & 268 \\
\hline 34 & 20,92 & 53,40 & 22,50 & 22,46 & 119,49 & 76,07 & 184 & 278 \\
\hline 35 & 22,03 & 52,24 & 20,97 & 22,67 & 117,55 & 74,55 & 181 & 273 \\
\hline 36 & 24,64 & 54,99 & 18,63 & 22,31 & 120,57 & 77,30 & 185 & 283 \\
\hline & & & & Mínima & 117,55 & 72,80 & 181 & 266 \\
\hline & & & & Média & 120,01 & 76,19 & 184 & 279 \\
\hline & & & & Máxima & 123,32 & 80,13 & 190 & 293 \\
\hline & & & & DP & 1,36 & 1,54 & 2,10 & 5,63 \\
\hline
\end{tabular}

$\mathrm{TF}=$ tempo de funcionamento; FAAG = filtro ascendente de areia grossa; $\mathrm{FRD}=$ filtro rápido descendente; $\mathrm{AC}=$ água coagulada; $\mathrm{DP}$ = desvio padrão. 
Tabela C 7.1 - Características físicas da $A B, A E, A P O$ e efluentes do FAAG e do FRD durante 0 ensaio 14 - pré-oxidação com peroxônio (FAAG $=180 \mathrm{~m}^{3} / \mathrm{m}^{2} \mathrm{~d}$; FRD $=280 \mathrm{~m}^{3} / \mathrm{m}^{2} \mathrm{~d}$ ).

\begin{tabular}{|c|c|c|c|c|c|c|c|c|c|}
\hline \multirow[b]{2}{*}{ TF (h) } & \multirow{2}{*}{\begin{tabular}{|c|}
$\begin{array}{c}\text { Temperatura } \\
\left({ }^{\circ} \mathrm{C}\right)\end{array}$ \\
$\mathrm{AE}$ \\
\end{tabular}} & \multicolumn{5}{|c|}{ Cor aparente (uH) } & \multicolumn{3}{|c|}{ Cor verdadeira (uH) } \\
\hline & & $\mathrm{AB}$ & $\mathbf{A E}$ & APO & FAAG & FRD & $A B$ & $\mathbf{A E}$ & APO \\
\hline 0 & 22,0 & 108 & 179 & 134 & 9,0 & 6,0 & 22 & 94 & 56 \\
\hline 1 & 22,5 & & 196 & 144 & 1,0 & $<1,0$ & & 103 & 63 \\
\hline 2 & 23,0 & & 198 & 145 & 1,0 & $<1,0$ & & 106 & 65 \\
\hline 4 & 24,0 & & 197 & 148 & $<1,0$ & $<1,0$ & & 109 & 71 \\
\hline 6 & 24,0 & 106 & 184 & 134 & $<1,0$ & $<1,0$ & 21 & 104 & 61 \\
\hline 8 & 23,5 & & 193 & 137 & $<1,0$ & $<1,0$ & & 104 & 62 \\
\hline 10 & 22,5 & & 192 & 133 & $<1,0$ & $<1,0$ & & 103 & 54 \\
\hline 12 & 22,0 & 113 & 188 & 129 & $<1,0$ & $<1,0$ & 17 & 100 & 51 \\
\hline 14 & 22,0 & & 201 & 145 & $<1,0$ & $<1,0$ & & 102 & 63 \\
\hline 16 & 22,0 & & 196 & 143 & $<1,0$ & $<1,0$ & & 103 & 61 \\
\hline 18 & 22,0 & 117 & 189 & 140 & $<1,0$ & $<1,0$ & 20 & 103 & 59 \\
\hline 20 & 21,0 & & 182 & 134 & $<1,0$ & $<1,0$ & & 100 & 61 \\
\hline 22 & 21,0 & & 183 & 137 & 1,0 & $<1,0$ & & 102 & 64 \\
\hline 24 & 22,5 & 109 & 186 & 135 & 12,0 & $<1,0$ & 21 & 107 & 61 \\
\hline 26 & 23,5 & & 194 & 138 & 21,0 & $<1,0$ & & 104 & 64 \\
\hline 28 & 24,0 & & 193 & 143 & 32,0 & $<1,0$ & & 106 & 67 \\
\hline 30 & 25,0 & 118 & 193 & 140 & 43,0 & $<1,0$ & 21 & 107 & 63 \\
\hline 32 & 24,0 & & 190 & 137 & 45,0 & $<1,0$ & & 104 & 63 \\
\hline 34 & 23,0 & & 187 & 134 & 49,0 & $<1,0$ & & 104 & 60 \\
\hline 36 & 22,0 & 108 & 187 & 126 & 45,0 & $<1,0$ & 21 & 105 & 58 \\
\hline Média & 22,8 & 111 & 190 & 138 & 13,2 & 0,78 & 20 & 104 & 61 \\
\hline Mínimo & 21,0 & 106 & 179 & 126 & $<1,0$ & $<1,0$ & 17 & 94 & 51 \\
\hline Máximo & 25,0 & 118 & 201 & 148 & 49,0 & 6,00 & 22 & 109 & 71 \\
\hline DP & 1,08 & 4,75 & 5,89 & 5,70 & 18,53 & 1,23 & 1,62 & 3,17 & 4,43 \\
\hline
\end{tabular}

TF = tempo de funcionamento; $\mathrm{AE}$ = água de estudo; $\mathrm{AB}$ = água bruta; $\mathrm{APO}=$ água pré-oxidada; $\mathrm{FAAG}=$ filtro ascendente de areia grossa; $F R D=$ filtro rápido descendente; $\mathrm{DP}=$ desvio padrão. 
Tabela C 7.2 - Características químicas da AB, AE, APO e efluentes do FAAG e do FRD durante o ensaio 14 - pré-oxidação com peroxônio (FAAG = 180 m ${ }^{3} / \mathrm{m}^{2} \mathrm{~d}$; $\mathrm{FRD}$ $\left.=280 \mathrm{~m}^{3} / \mathrm{m}^{2} \mathrm{~d}\right)$.

\begin{tabular}{|c|c|c|c|c|c|c|c|c|c|c|c|c|c|c|c|c|c|c|c|c|c|}
\hline \multirow[b]{2}{*}{ TF (h) } & \multicolumn{4}{|c|}{$\mathrm{pH}$} & \multicolumn{3}{|c|}{ Alcalinidade $\left(\mathrm{mg} / \mathrm{L} \mathrm{CaCO}_{3}\right)$} & \multicolumn{5}{|c|}{ Absorvância 254 nm } & \multicolumn{5}{|c|}{ COD (mg/L) } & \multicolumn{4}{|c|}{ Alumínio (mg/L) } \\
\hline & AB & $\mathrm{AE}$ & APO & AC & $A B$ & $\mathrm{AE}$ & APO & AB & $\mathrm{AE}$ & APO & FAAG & FRD & $\mathrm{AB}$ & $\mathrm{AE}$ & APO & FAAG & FRD & $\mathrm{AB}$ & AE & FAAG & FRD \\
\hline 0 & 7,41 & 6,88 & 6,38 & 5,51 & 11,52 & 10,32 & 6,48 & 0,069 & 0,183 & 0,126 & 0,026 & 0,030 & 2,637 & 4,032 & 3,674 & 2,990 & 2,808 & ND & ND & 0,23 & 0,20 \\
\hline 1 & & 6,87 & 6,15 & 5,12 & & & & & & & & & & & & & & & & & \\
\hline 2 & & 7,04 & 6,50 & 5,23 & & & & & & & & & & & & & & & & & \\
\hline 4 & & 7,00 & 6,51 & 5,27 & & & & & & & & & & & & & & & & & \\
\hline 6 & 6,94 & 6,98 & 6,53 & 5,30 & 8,40 & 10,80 & 7,44 & 0,070 & 0,193 & 0,130 & 0,010 & 0,011 & 2,419 & 4,483 & 3,967 & 2,546 & 2,471 & & & & \\
\hline 8 & & 6,99 & 6,36 & 5,22 & & & & & & & & & & & & & & & & & \\
\hline 10 & & 7,05 & 6,59 & 5,36 & & & & & & & & & & & & & & & & & \\
\hline 12 & 6,84 & 6,85 & 6,43 & 5,39 & 10,32 & 11,04 & 6,96 & 0,073 & 0,192 & 0,118 & 0,014 & 0,023 & 2,553 & 3,723 & 3,405 & 2,702 & 2,460 & ND & ND & 0,20 & 0,18 \\
\hline 14 & & 6,87 & 6,48 & 5,44 & & & & & & & & & & & & & & & & & \\
\hline 16 & & 6,97 & 6,40 & 5,49 & & & & & & & & & & & & & & & & & \\
\hline 18 & 6,80 & 6,81 & 6,39 & 5,51 & 10,56 & 11,28 & 8,40 & 0,065 & 0,187 & 0,127 & 0,008 & 0,017 & & & & & & & & & \\
\hline 20 & & 6,90 & 6,47 & 5,51 & & & & & & & & & & & & & & & & & \\
\hline 22 & & 6,77 & 6,38 & 5,51 & & & & & & & & & & & & & & & & & \\
\hline 24 & 6,89 & 7,03 & 6,48 & 5,51 & 11,28 & 11,04 & 7,20 & 0,069 & 0,195 & 0,129 & 0,013 & 0,020 & 2,300 & 3,921 & 3,824 & 2,731 & 2,514 & ND & ND & 0,15 & 0,13 \\
\hline 26 & & 7,08 & 6,61 & 5,45 & & & & & & & & & & & & & & & & & \\
\hline 28 & & 6,97 & 6,42 & 5,39 & & & & & & & & & & & & & & & & & \\
\hline 30 & 6,93 & 7,05 & 6,53 & 5,28 & 9,60 & 9,60 & 6,72 & 0,072 & 0,197 & 0,137 & 0,016 & 0,022 & & & & & & & & & \\
\hline 32 & & 6,89 & 6,34 & 5,32 & & & & & & & & & & & & & & & & & \\
\hline 34 & & 6,96 & 6,33 & 5,30 & & & & & & & & & & & & & & & & & \\
\hline 36 & 6,96 & 7,07 & 6,48 & 5,32 & 10,56 & 9,36 & 7,44 & 0,070 & 0,192 & 0,113 & 0,013 & 0,019 & 2,486 & 3,859 & 3,827 & 2,479 & 2,240 & 0,01 & ND & 0,18 & 0,17 \\
\hline Média & 6,97 & 6,95 & 6,44 & 5,37 & 10,32 & 10,49 & 7,23 & 0,070 & 0,191 & 0,126 & 0,014 & 0,020 & 2,479 & 4,004 & 3,739 & 2,690 & 2,499 & - & - & 0,19 & 0,17 \\
\hline Mínimo & 6,80 & 6,77 & 6,15 & 5,12 & 8,40 & 9,36 & 6,48 & 0,065 & 0,183 & 0,113 & 0,008 & 0,011 & 2,300 & 3,723 & 3,405 & 2,479 & 2,240 & - & - & 0,15 & 0,13 \\
\hline Máximo & 7,41 & 7,08 & 6,61 & 5,51 & 11,52 & 11,28 & 8,40 & 0,073 & 0,197 & 0,137 & 0,026 & 0,030 & 2,637 & 4,483 & 3,967 & 2,990 & 2,808 & - & - & 0,23 & 0,20 \\
\hline DP & 0,20 & 0,09 & 0,10 & 0,12 & 1,06 & 0,76 & 0,63 & 0,003 & 0,005 & 0,008 & 0,006 & 0,006 & 0,129 & 0,290 & 0,214 & 0,198 & 0,203 & - & - & 0,03 & 0,03 \\
\hline
\end{tabular}


Tabela C 7.3 - Perda de carga no FAAG $\left(180 \mathrm{~m}^{3} / \mathrm{m}^{2} \mathrm{~d}\right)$ e no FRD $\left(280 \mathrm{~m}^{3} / \mathrm{m}^{2} \mathrm{~d}\right)$ durante o ensaio 14 , pré-oxidação com peroxônio e sem DFls no FAAG para a temperatura $\mathrm{T}$ e para $\mathrm{T}=20^{\circ} \mathrm{C}$.

\begin{tabular}{|c|c|c|c|c|c|c|c|c|c|c|c|c|c|c|c|c|c|c|c|c|c|c|}
\hline \multirow{3}{*}{$\begin{array}{l}\text { TF } \\
\text { (h) }\end{array}$} & \multicolumn{10}{|c|}{ FAAG } & \multicolumn{12}{|l|}{ FRD } \\
\hline & \multicolumn{3}{|c|}{$\begin{array}{c}\text { Leitura piezométrica } \\
(\mathbf{c m})\end{array}$} & \multirow{2}{*}{$\begin{array}{c}\mathrm{T} \\
\left({ }^{\circ} \mathbf{C}\right)\end{array}$} & \multicolumn{3}{|c|}{$\begin{array}{l}\text { Perda de carga } \\
\text { (cm) }\end{array}$} & \multicolumn{3}{|c|}{$\begin{array}{c}\text { Perda de carga }(\mathrm{cm}) \\
\mathrm{T}=20^{\circ} \mathrm{C}\end{array}$} & \multicolumn{4}{|c|}{$\begin{array}{c}\text { Leitura piezométrica } \\
(\mathrm{cm})\end{array}$} & \multicolumn{4}{|c|}{$\begin{array}{l}\text { Perda de carga } \\
\text { (cm) }\end{array}$} & \multicolumn{4}{|c|}{$\begin{array}{c}\text { Perda de carga }(\mathrm{cm}) \\
T=20^{\circ} \mathrm{C}\end{array}$} \\
\hline & $\mathrm{P} 1$ & $\mathrm{P} 2$ & P3 & & P2-P1 & P3-P2 & P3-P1 & P2-P1 & P3-P2 & P3-P1 & P1 & $\mathrm{P} 2$ & P3 & P4 & P2-P1 & P3-P2 & P4-P3 & P4-P1 & P2-P1 & P3-P2 & P4-P3 & P4-P1 \\
\hline 0 & 45,7 & 60,2 & 1,0 & 22,0 & 14,5 & 8 & 15,3 & 1 & 0,8 & 15,9 & 11,9 & 33,6 & 53,4 & 70,0 & 21,7 & 19,8 & 16,6 & 58,1 & 22,6 & 20,6 &, 3 & 60,5 \\
\hline 1 & 45,8 & 61,1 & 62,5 & 22,5 & 15,3 & 1,4 & 16,7 & 16,1 & 1,5 & 17,6 & 12,0 & 35,2 & 56,7 & 75,2 & 23,2 & 21,5 & 18,5 & 63,2 & 24,5 & 22,7 & 19,5 & 66,6 \\
\hline 2 & 45,8 & 62,0 & 64,0 & 23,0 & 16,2 & 0 & 8,2 & 17,3 & 2,1 & 19,4 & 12,0 & 34,8 & 56,1 & 75,3 & 22,8 & 1,3 & 19,2 & 3, & 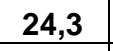 & 2,7 & 0,5 & 6 \\
\hline 3 & 5,8 & 62,9 & & 24,0 & 17,1 & 2,6 & & & & & 12,0 & 34,5 & 55,6 & 75,2 & 22,5 & & & & & & & \\
\hline 4 & 45,8 & 63,9 & 67,1 & 24,0 & 181 & 3,2 & 21,3 & 19,8 & 3 & 33 & 12,0 & 34,2 & 54,9 & 74,8 & 2,2 & 7 & 19,9 & 8 & 24,3 & 2.6 & 8 & 3,7 \\
\hline 5 & 45,8 & 64,8 & 68,5 & 24,0 & 19,0 & 3,7 & 22,7 & 20,8 & 4,0 & 24,8 & 12,0 & 34,2 & 55,0 & 74,9 & 22,2 & 20,8 & 19,9 & 62,9 & 24,3 & 22,7 & 21,8 & 68,8 \\
\hline 6 & 45 , & 66,6 & 70,8 & 24,0 & 2 & 4 & 25,0 & 26 & 4,6 & 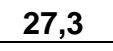 & 12,0 & 34,2 & 55,0 & 75,1 & 22,2 & 20,8 & 20,1 & 0. & 24,3 & 7 & 0 & 0 \\
\hline 7 & 3 & 67,7 & 72,3 & 23,5 & & & & & & & 12,0 & 34,2 & 55,0 & 75,5 & 28 & & & & & & & \\
\hline 8 & 45,8 & 69,5 & 74,5 & 23,5 & 23,7 & 5,0 & 28,7 & 25,6 & 5,4 & 31,0 & 12,0 & 34,5 & 55,8 & 76,8 & 22,5 & 1,3 &,- 0 & 64 , & 24,3 & 23,0 & 22,7 & 70,0 \\
\hline 9 & 45,8 & 71,4 & 76,9 & 22,5 & 25,6 & 5,5 & 31,1 & 27,0 & 5,8 & 32,8 & 12,0 & 34,9 & 56,7 & 78,4 & 22,9 & 21,8 & 21,7 & 66,4 & 24,1 & 23,0 & 22,9 & 70,0 \\
\hline 10 & 45,8 & 73,1 & 78,9 & 22,5 & 27,3 & 5,8 & 3 & 28 & 6,1 & 34,9 & 12,0 & 35,2 & 57,0 & 79,3 & 3,2 & 8 & 22,3 & $6 /, 3$ & 5 & 3,0 & 3,5 & 71,0 \\
\hline 11 & 45,8 & 74,9 & 81,2 & 22,0 & 29,1 & 6,3 & & & & 36,9 & 12,0 & 35,3 & 57,5 & 80,3 & 3,3 & 22,2 & 22, & 68 , & & & 3,8 & \\
\hline 12 & 45,8 & 76,7 & 83,3 & 22,0 & 30,9 & 66 & 37 & 32,2 & 60 & 39,1 & 12,0 & 35,4 & 57,6 & 80,9 & 3,4 & 22,2 & 23,3 & 68,9 & 4 & 1 & 24,3 & 71,8 \\
\hline 13 & 45,8 & 78,4 & 85,2 & 22,0 & 32,6 & 6,8 & 39,4 & 34,0 & 7,1 & 41,0 & 12,0 & 35,4 & 57,8 & 81,6 & 23,4 & 22,4 & 23,8 & 69,6 & 24,4 & 23,3 & 24,8 & 72,5 \\
\hline 14 & 45,8 & 80,7 & 88,1 & 22,0 & 34,9 & 7,4 & 42,3 & 36,4 & & 44,1 & 12,0 & 35,5 & 58,3 & 84,8 & 3,5 & 22,8 & 26,5 & 72,8 & 5 & 23,8 & 27,6 & 75,8 \\
\hline 15 & 45,8 & 82,6 & 90,6 & 22,0 & 36,8 & & & & & 46,7 & 11,9 & 35,5 & 58,4 & 84,8 & 3,6 & 22,9 & 26,4 & & 24,6 & & & 75,9 \\
\hline 16 & 45,8 & 84,7 & 93,2 & 22,0 & 38,9 & 8,5 & 47,4 & 40,5 & 8,9 & 49,4 & 11,9 & 35,5 & 58,4 & 85,1 & 23,6 & 22,9 & 26,7 & 73,2 & 24,6 & 23,9 & 27,8 & 76,3 \\
\hline 17 & 45,8 & 86,8 & 95,6 & 22,0 & 41,0 & 8,8 & 49,8 & 42,7 & 9,2 & 51,9 & 11,9 & 35,5 & 58,5 & 85,5 & 23,6 & 23,0 & 27,0 & 73,6 & 24,6 & 24,0 & 28,1 & 76,7 \\
\hline 18 & 45,8 & 88,9 & 98,1 & 22,0 & 43,1 & 9,2 & 52,3 & 44,9 & 9,6 & 54,5 & 11,9 & 35,6 & 58,6 & 85,8 & 23,7 & 23,0 & 27,2 & 73,9 & 24,7 & 24,0 & 28,3 & 77,0 \\
\hline 19 & 45,8 & 90,8 & 100,5 & 21,0 & 45,0 & 9,7 & & 45,8 & & & 11,9 & 35,6 & 58,7 & 86,2 & 23,7 & 23,1 & 27,5 & 74,3 & 24,1 & 23,5 & 28,0 & 75,6 \\
\hline 20 & 45,8 & 93,7 & 103,6 & 21,0 & 47,9 & 9,9 & 57,8 & 48,7 & 10,1 & 58,8 & 11,9 & 35,8 & 59,1 & 87,0 & 23,9 & 23,3 & 27,9 & 75,1 & 24,3 & 23,7 & 28,4 & 76,4 \\
\hline 22 & 45,8 & 99,5 & 110,3 & 21,0 & 53,7 & 10,8 & 64,5 & 54,6 & 11,0 & 65,6 & 11,9 & 36,1 & 59,8 & 88,5 & 24,2 & 23,7 & 28,7 & 76,6 & 24,6 & 24,1 & 29,2 & 77,9 \\
\hline 23 & 45,9 & 100,6 & 111,6 & 21,0 & 54,7 & 11,0 & 65,7 & 55,6 & 11,2 & 66,8 & 11,9 & 36,1 & 59,9 & 89,5 & 24,2 & 23,8 & 29,6 & 77,6 & 24,6 & 24,2 & 30,1 & 78,9 \\
\hline
\end{tabular}


(continuação)

\begin{tabular}{|c|c|c|c|c|c|c|c|c|c|c|c|c|c|c|c|c|c|c|c|c|c|c|}
\hline 24 & 45,9 & 101,8 & 113,1 & 22,5 & 55,9 & 11,3 & 67,2 & 58,9 & 11,9 & 70,9 & 11,9 & 35,8 & 59,1 & 90,7 & 23,9 & 23,3 & 31,6 & 78,8 & 25,2 & 24,6 & 33,3 & 83,1 \\
\hline 25 & 45,9 & 103,4 & 115,0 & 22,5 & 57,5 & 11,6 & 69,1 & 60,6 & 12,2 & 72,9 & 11,9 & 35,2 & 58,1 & 92,2 & 23,3 & 22,9 & 34,1 & 80,3 & 24,6 & 24,1 & 36,0 & 84,7 \\
\hline 26 & 45,9 & 105,3 & 117,2 & 23,5 & 59,4 & 11,9 & 71,3 & 64,2 & 12,9 & 77,0 & 11,9 & 34,3 & 56,4 & 94,2 & 22,4 & 22,1 & 37,8 & 82,3 & 24,2 & 23,9 & 40,8 & 88,9 \\
\hline 27 & 45,9 & 107,4 & 119,9 & 23,5 & 61,5 & 12,5 & 74,0 & 66,4 & 13,5 & 79,9 & 11,9 & 34,5 & 56,9 & 100,0 & 22,6 & 22,4 & 43,1 & 88,1 & 24,4 & 24,2 & 46,6 & 95,2 \\
\hline 28 & 45,9 & 109,4 & 122,3 & 24,0 & 63,5 & 12,9 & 76,4 & 69,4 & 14,1 & 83,5 & 11,9 & 34,5 & 58,3 & 107,7 & 22,6 & 23,8 & 49,4 & 95,8 & 24,7 & 26,0 & 54,0 & 104,7 \\
\hline 29 & 45,9 & 111,1 & 124,3 & 24,0 & 65,2 & 13,2 & 78,4 & 71,3 & 14,4 & 85,7 & 11,9 & 34,2 & 60,0 & 114,7 & 22,3 & 25,8 & 54,7 & 102,8 & 24,4 & 28,2 & 59,8 & 112,4 \\
\hline 30 & 45,9 & 113,0 & 126,6 & 25,0 & 67,1 & 13,6 & 80,7 & 75,2 & 15,2 & 90,4 & 11,9 & 34,8 & 64,1 &, 8 & 22,9 & 29,3 & 62,7 & 114,9 & 25,6 & 32,8 & 70,2 & 128,7 \\
\hline 31 & 46,0 & 115,2 & 129,1 & 25,0 & 69,2 & 13,9 & 83,1 & 77,5 & 15,6 & 93,1 & 11,9 & 35,1 & 67,3 & 138,2 & 23,2 & 32,2 & 70,9 & 126,3 & 26,0 & 36,1 & 79,4 & 141,5 \\
\hline 32 & 46,0 & 117,9 & 132,1 & 24,0 & 71,9 & 14,2 & 86,1 & 78,6 & 15,5 & 94,1 & 11,9 & 35,0 & 69,0 & 149,0 & 23,1 & 34,0 & 80,0 & 137,1 & 25,3 & 37,2 & 87,5 & 149,9 \\
\hline 33 & 46,0 & 119,6 & 134,2 & 24,0 & 73,6 & 14,6 & 88,2 & 80,5 & 16,0 & 96,4 & 11,9 & 35,7 & 71,4 & 162,5 & 23,8 & 35,7 & 91,1 & 150,6 & 26,0 & 39,0 & 99,6 & 164,7 \\
\hline 34 & 46,0 & 121,7 & 136,7 & 23,0 & 75,7 & 15,0 & 90,7 & 80,8 & 16,0 & 96,8 & 11,9 & 36,0 & 73,0 & 177,2 & 24,1 & 37,0 & 104,2 & 165,3 & 25,7 & 39,5 & 111,2 & 176,4 \\
\hline 35 & 46,0 & 124,0 & 139,4 & 23,0 & 78,0 & 15,4 & 93,4 & 83,2 & 16,4 & 99,7 & 11,9 & 36,6 & 75,4 & 196,8 & 24,7 & 38,8 & 121,4 & 184,9 & 26,4 & 41,4 & 129,6 & 197,3 \\
\hline 36 & 46,0 & 126,6 & 142,3 & 22,0 & 80,6 & 15,7 & 96,3 & 84,0 & 16,4 & 100,3 & 11,9 & 37,2 & 77,5 & 219,0 & 25,3 & 40,3 & 141,5 & 207,1 & 26,4 & 42,0 & 147,4 & 215,7 \\
\hline
\end{tabular}

FAAG = filtro ascendente de areia grossa; $F R D$ = filtro rápido descendente; $T F$ = tempo de funcionamento; $T$ = temperatura. 


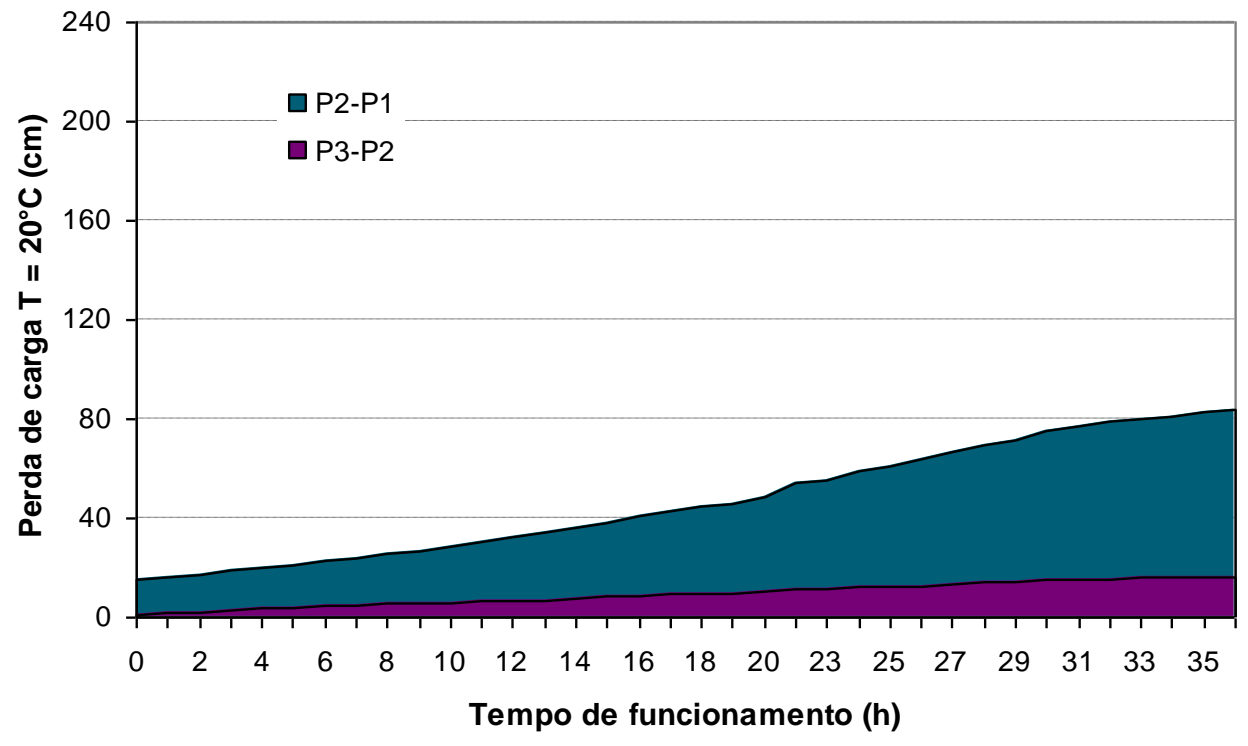

Figura C 7.1 - Perda de carga na camada suporte e camada de areia grossa no FAAG durante o ensaio 14 - pré-oxidação com peroxônio (FAAG $=180 \mathrm{~m}^{3} / \mathrm{m}^{2} \mathrm{~d}$ e FRD $=280 \mathrm{~m}^{3} / \mathrm{m}^{2} \mathrm{~d}$ ). Fonte: Tabela C 7.3 - ANEXO C.

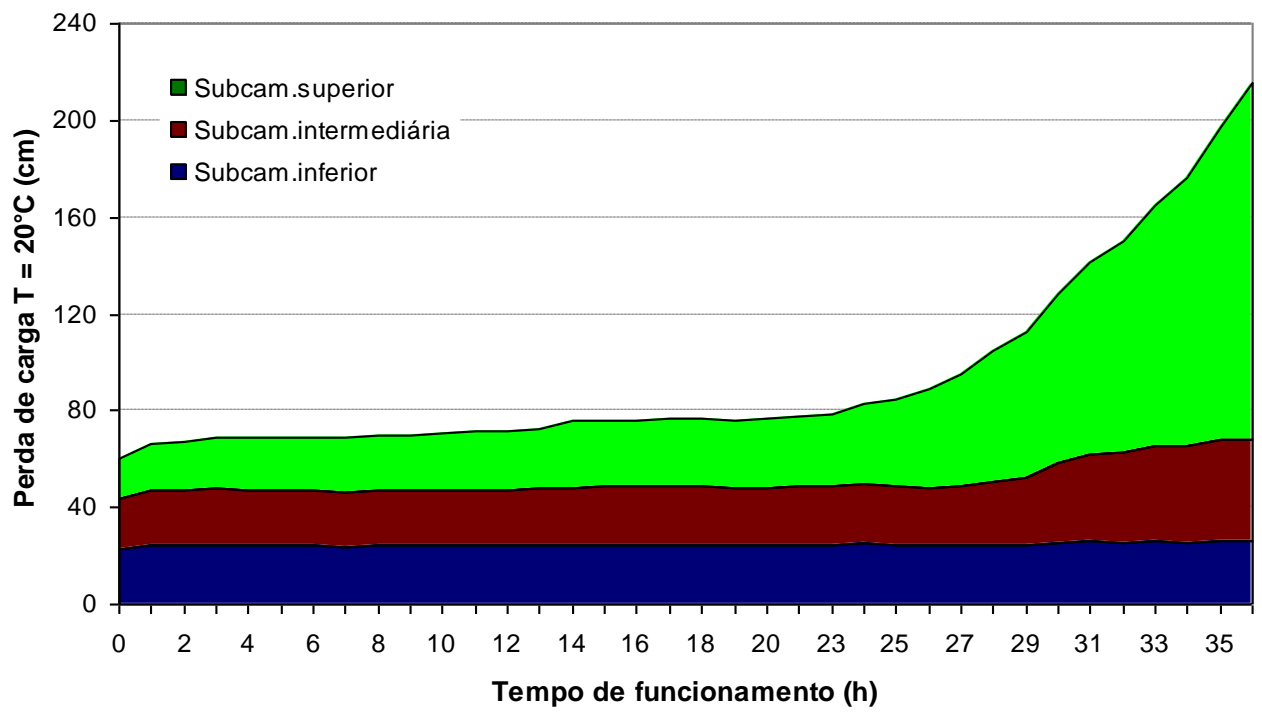

Figura C 7.2 - Perda de carga ao longo do meio filtrante do FRD durante o ensaio 14 - pré-oxidação com peroxônio (FAAG $=180 \mathrm{~m}^{3} / \mathrm{m}^{2} \mathrm{~d}$ e FRD $=280 \mathrm{~m}^{3} / \mathrm{m}^{2} \mathrm{~d}$ ). Fonte: Tabela C $7.3-$ ANEXO C. 
Tabela C 7.4 - Variação de vazões e taxas de filtração do FAAG e do FRD durante o ensaio 14 - préoxidação com peroxônio ( $F A A G=180 \mathrm{~m}^{3} / \mathrm{m}^{2} \mathrm{~d} ; \mathrm{FRD}=280 \mathrm{~m}^{3} / \mathrm{m}^{2} \mathrm{~d}$ ).

\begin{tabular}{|c|c|c|c|c|c|c|c|c|}
\hline \multirow{2}{*}{$\begin{array}{l}\text { TF } \\
\text { (h) }\end{array}$} & \multicolumn{2}{|c|}{ descartes (L/h) } & \multicolumn{2}{|c|}{ turbidímetros $(\mathrm{L} / \mathrm{h})$} & \multicolumn{2}{|c|}{ vazão total (L/h) } & \multicolumn{2}{|c|}{ taxas de filtração $\left(\mathrm{m}^{3} / \mathrm{m}^{2} \mathrm{~d}\right)$} \\
\hline & FAAG & FRD & FAAG & FRD & FAAG & FRD & FAAG & FRD \\
\hline 0 & 19,21 & 52,50 & 22,03 & 23,84 & 117,58 & 76,34 & 181 & 279 \\
\hline 1 & 20,20 & 53,50 & 21,78 & 24,12 & 119,60 & 77,62 & 184 & 284 \\
\hline 2 & 20,91 & 52,70 & 21,38 & 23,41 & 118,40 & 76,11 & 182 & 278 \\
\hline 3 & 21,05 & 52,99 & 21,77 & 24,14 & 119,95 & 77,13 & 184 & 282 \\
\hline 4 & 20,55 & 53,55 & 21,28 & 24,75 & 120,13 & 78,30 & 185 & 286 \\
\hline 5 & 20,51 & 52,79 & 21,94 & 24,38 & 119,62 & 77,17 & 184 & 282 \\
\hline 6 & 20,60 & 52,81 & 21,99 & 24,08 & 119,48 & 76,89 & 184 & 281 \\
\hline 7 & 20,63 & 52,45 & 21,35 & 24,35 & 118,78 & 76,80 & 183 & 281 \\
\hline 8 & 20,87 & 52,59 & 21,44 & 24,20 & 119,10 & 76,79 & 183 & 281 \\
\hline 9 & 20,40 & 53,76 & 21,18 & 24,00 & 119,34 & 77,76 & 183 & 284 \\
\hline 10 & 20,91 & 53,76 & 20,86 & 23,76 & 119,29 & 77,52 & 183 & 284 \\
\hline 11 & 20,28 & 54,00 & 21,13 & 23,52 & 118,93 & 77,52 & 183 & 284 \\
\hline 12 & 20,28 & 53,95 & 20,76 & 23,62 & 118,61 & 77,57 & 182 & 284 \\
\hline 13 & 20,52 & 54,15 & 21,09 & 23,92 & 119,68 & 78,07 & 184 & 286 \\
\hline 14 & 21,30 & 53,73 & 21,60 & 24,08 & 120,71 & 77,81 & 186 & 285 \\
\hline 15 & 21,36 & 54,80 & 21,18 & 24,41 & 121,75 & 79,21 & 187 & 290 \\
\hline 16 & 20,95 & 53,37 & 20,10 & 23,20 & 117,62 & 76,57 & 181 & 280 \\
\hline 17 & 21,50 & 53,60 & 21,00 & 24,00 & 120,10 & 77,60 & 185 & 284 \\
\hline 18 & 21,25 & 52,89 & 21,08 & 23,96 & 119,18 & 76,85 & 183 & 281 \\
\hline 19 & 21,13 & 53,11 & 21,18 & 23,62 & 119,04 & 76,73 & 183 & 281 \\
\hline 20 & 21,52 & 53,54 & 20,85 & 23,52 & 119,43 & 77,06 & 184 & 282 \\
\hline 22 & 21,65 & 53,81 & 21,09 & 23,59 & 120,14 & 77,40 & 185 & 283 \\
\hline 23 & 20,99 & 53,74 & 20,66 & 23,62 & 119,01 & 77,36 & 183 & 283 \\
\hline 24 & 21,67 & 53,60 & 19,90 & 23,96 & 119,13 & 77,56 & 183 & 284 \\
\hline 25 & 21,69 & 54,00 & 19,83 & 23,88 & 119,40 & 77,88 & 184 & 285 \\
\hline 26 & 23,67 & 52,52 & 20,08 & 23,84 & 120,11 & 76,36 & 185 & 279 \\
\hline 27 & 23,79 & 52,20 & 19,83 & 24,22 & 120,04 & 76,42 & 185 & 280 \\
\hline 28 & 23,47 & 52,79 & 18,56 & 24,08 & 118,90 & 76,87 & 183 & 281 \\
\hline 29 & 23,51 & 52,38 & 18,92 & 24,22 & 119,03 & 76,60 & 183 & 280 \\
\hline 30 & 22,26 & 53,72 & 18,59 & 23,69 & 118,26 & 77,41 & 182 & 283 \\
\hline 31 & 22,21 & 54,63 & 17,34 & 24,15 & 118,33 & 78,78 & 182 & 288 \\
\hline 32 & 24,23 & 51,53 & 17,01 & 24,42 & 117,19 & 75,95 & 180 & 278 \\
\hline 33 & 24,12 & 52,46 & 16,69 & 24,16 & 117,43 & 76,62 & 180 & 280 \\
\hline 34 & 24,09 & 52,30 & 17,36 & 24,04 & 117,79 & 76,34 & 181 & 279 \\
\hline 35 & 23,52 & 53,33 & 17,28 & 24,15 & 118,28 & 77,48 & 182 & 283 \\
\hline 36 & 24,00 & 52,44 & 17,39 & 23,89 & 117,72 & 76,33 & 181 & 279 \\
\hline & & & & Mínima & 117,19 & 75,95 & 180 & 278 \\
\hline & & & & Média & 119,09 & 77,19 & 183 & 282 \\
\hline & & & & Máxima & 121,75 & 79,21 & 187 & 290 \\
\hline & & & & DP & 0,99 & 0,74 & 1,52 & 2,69 \\
\hline
\end{tabular}

$\mathrm{TF}=$ tempo de funcionamento; $\mathrm{FAAG}=$ filtro ascendente de areia grossa; $\mathrm{FRD}$ = filtro rápido descendente; $\mathrm{AC}=$ água coagulada; $\mathrm{DP}$ = desvio padrão. 
Tabela C 8.1 - Características físicas da AB, AE, APO e efluentes do FAAG e do FRD durante o ensaio 15 - pré-oxidação com hipoclorito de sódio (FAAG $=180 \mathrm{~m}^{3} / \mathrm{m}^{2} \mathrm{~d}$; FRD $=280 \mathrm{~m}^{3} / \mathrm{m}^{2} \mathrm{~d}$ ).

\begin{tabular}{|c|c|c|c|c|c|c|c|c|c|}
\hline \multirow[b]{2}{*}{ TF (h) } & \multirow{2}{*}{$\begin{array}{c}\begin{array}{c}\text { Temperatura } \\
\left({ }^{\circ} \mathrm{C}\right)\end{array} \\
\mathrm{AE} \\
\end{array}$} & \multicolumn{5}{|c|}{ Cor aparente (uH) } & \multicolumn{3}{|c|}{ Cor verdadeira (uH) } \\
\hline & & $\mathrm{AB}$ & $\mathbf{A E}$ & APO & FAAG & FRD & $A B$ & $\mathbf{A E}$ & APO \\
\hline 0 & 23,0 & 118 & 191 & 189 & 19,0 & 12,0 & 23 & 99 & 91 \\
\hline 1 & 23,0 & & 202 & 190 & 4,0 & 1,0 & & 106 & 93 \\
\hline 2 & 23,0 & & 203 & 192 & 1,0 & $<1,0$ & & 109 & 101 \\
\hline 4 & 22,0 & & 198 & 188 & $<1,0$ & $<1,0$ & & 105 & 96 \\
\hline 6 & 22,0 & 121 & 192 & 189 & $<1,0$ & $<1,0$ & 22 & 99 & 91 \\
\hline 8 & 21,5 & & 186 & 182 & $<1,0$ & $<1,0$ & & 98 & 90 \\
\hline 10 & 21,0 & & 185 & 182 & 2,0 & 1,0 & & 98 & 91 \\
\hline 12 & 21,0 & 107 & 184 & 178 & $<1,0$ & $<1,0$ & 20 & 98 & 90 \\
\hline 14 & 21,0 & & 220 & 217 & $<1,0$ & 5,0 & & 113 & 108 \\
\hline 16 & 21,0 & & 155 & 205 & $<1,0$ & $<1,0$ & & 42 & 101 \\
\hline Média & 21,9 & 115 & 192 & 191 & 2,9 & 2,20 & 22 & 97 & 95 \\
\hline Mínimo & 21,0 & 107 & 155 & 178 & $<1,0$ & $<1,0$ & 20 & 42 & 90 \\
\hline Máximo & 23,0 & 121 & 220 & 217 & 19,0 & 12,00 & 23 & 113 & 108 \\
\hline DP & 0,88 & 7,37 & 16,86 & 11,65 & 5,77 & 3,71 & 1,53 & 19,94 & 6,18 \\
\hline
\end{tabular}

$T F=$ tempo de funcionamento; $A E$ = água de estudo; $A B$ = água bruta; $A P O=$ água pré-oxidada; $F A A G=$ filtro ascendente de areia grossa; $F R D=$ filtro rápido descendente; $D P=$ desvio padrão. 
Tabela C 8.2 - Características químicas da AB, AE, APO e efluentes do FAAG e do FRD durante o ensaio 15 - pré-oxidação com hipoclorito de sódio (FAAG = 180 $\left.\mathrm{m}^{3} / \mathrm{m}^{2} \mathrm{~d} ; \mathrm{FRD}=280 \mathrm{~m}^{3} / \mathrm{m}^{2} \mathrm{~d}\right)$

\begin{tabular}{|c|c|c|c|c|c|c|c|c|c|c|c|c|c|c|c|c|c|c|c|c|c|}
\hline \multirow[b]{2}{*}{ TF $(\mathrm{h})$} & \multicolumn{4}{|c|}{$\mathrm{pH}$} & \multicolumn{3}{|c|}{ Alcalinidade $\left(\mathrm{mg} / \mathrm{L} \mathrm{CaCO}_{3}\right)$} & \multicolumn{5}{|c|}{ Absorvância 254 nm } & \multicolumn{5}{|c|}{ COD (mg/L) } & \multicolumn{4}{|c|}{ Alumínio (mg/L) } \\
\hline & $A B$ & $\mathrm{AE}$ & APO & $\mathrm{AC}$ & $\mathrm{AB}$ & $\mathrm{AE}$ & APO & $\mathrm{AB}$ & $\mathrm{AE}$ & APO & FAAG & FRD & $\mathrm{AB}$ & $\mathbf{A E}$ & APO & FAAG & FRD & $A B$ & $\mathbf{A E}$ & FAAG & FRD \\
\hline 0 & 6,68 & 6,74 & 6,47 & 5,67 & 9,36 & 9,12 & 7,68 & 0,081 & 0,195 & 0,187 & 0,028 & 0,031 & 2,483 & 3,987 & 3,776 & 2,418 & 2,745 & 0,01 & 0,01 & 0,20 & 0,10 \\
\hline 1 & & 6,67 & 5,96 & 5,13 & & & & & & & & & & & & & & & & & \\
\hline 2 & & 6,74 & 5,96 & 5,08 & & & & & & & & & & & & & & & & & \\
\hline 4 & & 6,71 & 6,06 & 5,10 & & & & & & & & & & & & & & & & & \\
\hline 6 & 6,86 & 6,81 & 6,24 & 5,17 & 10,56 & 11,28 & 5,28 & 0,079 & 0,192 & 0,184 & 0,014 & 0,025 & 2,495 & 4,009 & 4,230 & 2,014 & 2,121 & & & & \\
\hline 8 & & 7,04 & 6,34 & 5,65 & & & & & & & & & & & & & & & & & \\
\hline 10 & & 7,25 & 5,30 & 4,88 & & & & & & & & & & & & & & & & & \\
\hline 12 & 7,36 & 7,27 & 6,12 & 5,35 & 16,32 & 16,56 & 6,72 & 0,079 & 0,200 & 0,190 & 0,024 & 0,034 & 2,670 & 4,191 & 3,915 & 2,313 & 2,321 & 0,01 & 0,01 & 0,25 & 0,10 \\
\hline 14 & & 6,70 & 5,76 & 4,88 & & & & & & & & & & & & & & & & & \\
\hline 16 & & 6,74 & 6,00 & 4,98 & & & & & & & & & & & & & & & & & \\
\hline Média & 6,97 & 6,87 & 6,02 & 5,19 & 12,08 & 12,32 & 6,56 & 0,080 & 0,196 & 0,187 & 0,022 & 0,030 & 2,549 & 4,062 & 3,974 & 2,248 & 2,396 & - & - & - & - \\
\hline Mínimo & 6,68 & 6,67 & 5,30 & 4,88 & 9,36 & 9,12 & 5,28 & 0,079 & 0,192 & 0,184 & 0,014 & 0,025 & 2,483 & 3,987 & 3,776 & 2,014 & 2,121 & - & - & - & - \\
\hline Máximo & 7,36 & 7,27 & 6,47 & 5,67 & 16,32 & 16,56 & 7,68 & 0,081 & 0,200 & 0,190 & 0,028 & 0,034 & 2,670 & 4,191 & 4,230 & 2,418 & 2,745 & - & - & - & - \\
\hline DP & 0,35 & 0,23 & 0,33 & 0,28 & 3,72 & 3,83 & 1,21 & 0,001 & 0,004 & 0,003 & 0,007 & 0,005 & 0,105 & 0,112 & 0,233 & 0,210 & 0,319 & - & - & - & - \\
\hline
\end{tabular}

$\mathrm{TF}=$ tempo de funcionamento; $\mathrm{AE}=$ água de estudo; $\mathrm{AB}=$ água bruta; $\mathrm{AC}=$ água coagulada; $\mathrm{APO}=$ água pré-oxidada; $\mathrm{FAAG}=$ filtro ascendente de areia grossa; $\mathrm{FRD}=$ filtro rápido descendente; $\mathrm{DP}=$ desvio padrão. 
Tabela C 8.3 - Perda de carga no FAAG $\left(180 \mathrm{~m}^{3} / \mathrm{m}^{2} \mathrm{~d}\right)$ e no FRD $\left(280 \mathrm{~m}^{3} / \mathrm{m}^{2} \mathrm{~d}\right)$ durante o ensaio 15, pré-oxidação com cloro (hipoclorito de sódio) e sem DFls no FAAG para a temperatura $\mathrm{T}$ e para $\mathrm{T}=20^{\circ} \mathrm{C}$

\begin{tabular}{|c|c|c|c|c|c|c|c|c|c|c|c|c|c|c|c|c|c|c|c|c|c|c|}
\hline \multirow{3}{*}{$\begin{array}{l}\text { TF } \\
\text { (h) }\end{array}$} & \multicolumn{10}{|c|}{ FAAG } & \multicolumn{12}{|l|}{ FRD } \\
\hline & \multicolumn{3}{|c|}{\begin{tabular}{|c|} 
Leitura piezométrica \\
(cm)
\end{tabular}} & \multirow{2}{*}{$\begin{array}{c}\mathbf{T} \\
\left({ }^{\circ} \mathrm{C}\right)\end{array}$} & \multicolumn{3}{|c|}{$\begin{array}{l}\text { Perda de carga } \\
\text { (cm) }\end{array}$} & \multicolumn{3}{|c|}{$\begin{array}{c}\text { Perda de carga }(\mathrm{cm}) \\
T=20^{\circ} \mathrm{C}\end{array}$} & \multicolumn{4}{|c|}{$\begin{array}{c}\text { Leitura piezométrica } \\
(\mathrm{cm})\end{array}$} & \multicolumn{4}{|c|}{$\begin{array}{l}\text { Perda de carga } \\
\text { (cm) }\end{array}$} & \multicolumn{4}{|c|}{$\begin{array}{c}\text { Perda de carga }(\mathrm{cm}) \\
\qquad T=20^{\circ} \mathrm{C}\end{array}$} \\
\hline & $\mathrm{P} 1$ & P2 & P3 & & P2-P1 & P3-P2 & P3-P1 & P2-P1 & P3-P2 & P3-P1 & $\mathrm{P} 1$ & P2 & P3 & P4 & P2-P1 & P3-P2 & P4-P3 & P4-P1 & P2-P1 & P3-P2 & P4-P3 & P4-P1 \\
\hline 0 & 45,9 & 60,2 & 61,3 & 23,0 & 14,3 & 1,1 & 15,4 & 15,3 & 1,2 & 16,4 & 12,2 & 33,6 & 53,5 & 72,7 & 21,4 & 19,9 & 19,2 & 60,5 & 22,8 & 1,2 & 20,5 & 64,6 \\
\hline 1 & 45,9 & 61,3 & 63,0 & 23,0 & 15,4 & 1,7 & 17,1 & 16,4 & 1,8 & 18,2 & 12,1 & 33,6 & 53,9 & 73,8 & 21,5 & 20,3 & 19,9 & 61,7 & 22,9 & 21,7 & 21,2 & 65,8 \\
\hline 2 & 45,9 & 62,6 & 65,0 & 23,0 & 16,7 & 2,4 & 19,1 & 17,8 & 2,6 & 20,4 & 12,1 & 34,1 & 54,9 & 76,0 & 22,0 & 20,8 & 21,1 & 63,9 & 23,5 & 22,2 & 22,5 & 68,2 \\
\hline 3 & 45,9 & 64,2 & 67,5 & 23,0 & 18,3 & 3,3 & 21,6 & 19,5 & 3,5 & 23,1 & 12,0 & 33,7 & 54,3 & 75,8 & 21,7 & 20,6 & 21,5 & 63,8 & 3,2 & 22,0 & 22,9 & 68,1 \\
\hline 4 & 45,9 & 65,9 & 70,0 & 22,0 & 20,0 & 4,1 & 24,1 & 20,8 & 4,3 & 25,1 & 12,0 & 34,0 & 54,9 & 76,9 & 22,0 & 20,9 & 22,0 & 64,9 & 22,9 & 21,8 & 22,9 & 67,6 \\
\hline 5 & 45,9 & 67,9 & 72,6 & 22,0 & 22,0 & 4,7 & 26,7 & 22,9 & 4,9 & 27,8 & 12,0 & 33,9 & 54,7 & 77,0 & 21,9 & 20,8 & 22,3 & 65,0 & 22,8 & 21,7 & 23,2 & 67,7 \\
\hline 6 & 45,9 & 70,0 & 75,5 & 22,0 & 24,1 & 5,5 & 29,6 & 25,1 & 5,7 & 30,8 & 12,0 & 33,8 & 54,7 & 77,2 & 21,8 & 20,9 & 22,5 & 65,2 & 22,7 & 21,8 & 23,4 & 67,9 \\
\hline 7 & 45,9 & 72,2 & 78,2 & 22,0 & 26,3 & 6,0 & 32,3 & 27,4 & 6,3 & 33,6 & 12,0 & 33,9 & 54,9 & 77,7 & 21,9 & 21,0 & 22,8 & 65,7 & 22,8 & 21,9 & 23,8 & 68,4 \\
\hline 8 & 45,9 & 74,2 & 80,5 & 21,5 & 28,3 & 6,3 & 34,6 & 29,1 & 6,5 & 35,6 & 12,0 & 34,1 & 55,2 & 78,4 & 22,1 & 21,1 & 23,2 & 66,4 & 22,7 & 21,7 & 23,9 & 68,3 \\
\hline 9 & 45,9 & 76,3 & 82,8 & 21,5 & 30,4 & 6,5 & 36,9 & 31,3 & 6,7 & 38,0 & 12,0 & 34,5 & 56,3 & 81,1 & 22,5 & 21,8 & 24,8 & 69,1 & 23,2 & 22,4 & 25,5 & 71,1 \\
\hline 10 & 45,9 & 79,1 & 86,9 & 21,0 & 33,2 & 7,8 & 41,0 & 33,8 & 7,9 & 41,7 & 12,0 & 34,6 & 56,6 & 82,6 & 22,6 & 22,0 & 26,0 & 70,6 & 23,0 & 22,4 & 26,4 & 71,8 \\
\hline 11 & 45,9 & 83,0 & 92,0 & 21,0 & 37,1 & 9,0 & 46,1 & 37,7 & 9,2 & 46,9 & 12,0 & 34,0 & 55,5 & 81,4 & 22,0 & 21,5 & 25,9 & 69,4 & 22,4 & 21,9 & 26,3 & 70,6 \\
\hline 12 & 45,9 & 85,0 & 94,2 & 21,0 & 39,1 & 9,2 & 48,3 & 39,8 & 9,4 & 49,1 & 11,9 & 33,9 & 55,3 & 81,1 & 22,0 & 21,4 & 25,8 & 69,2 & 22,4 & 21,8 & 26,2 & 70,4 \\
\hline 13 & 45,9 & 87,6 & 97,9 & 21,0 & 41,7 & 10,3 & 52,0 & 42,4 & 10,5 & 52,9 & 11,9 & 34,3 & 56,0 & 82,3 & 22,4 & 21,7 & 26,3 & 70,4 & 22,8 & 22,1 & 26,7 & 71,6 \\
\hline 14 & 45,9 & 92,0 & 103,3 & 21,0 & 46,1 & 11,3 & 57,4 & 46,9 & 11,5 & 58,4 & 11,9 & 34,3 & 56,2 & 82,7 & 22,4 & 21,9 & 26,5 & 70,8 & 22,8 & 22,3 & 26,9 & 72,0 \\
\hline 15 & 45,9 & 95,8 & 107,7 & 21,0 & 49,9 & 11,9 & 61,8 & 50,7 & 12,1 & 62,8 & 11,9 & 34,5 & 56,5 & 83,2 & 22,6 & 22,0 & 26,7 & 71,3 & 23,0 & 22,4 & 27,1 & 72,5 \\
\hline 16 & 45,9 & 99,5 & 112,0 & 21,0 & 53,6 & 12,5 & 66,1 & 54,5 & 12,7 & 67,2 & 11,9 & 34,5 & 56,7 & 83,5 & 22,6 & 22,2 & 26,8 & 71,6 & 23,0 & 22,6 & 27,3 & 72,8 \\
\hline
\end{tabular}

FAAG = filtro ascendente de areia grossa; $F R D=$ filtro rápido descendente; $T F=$ tempo de funcionamento; $T$ = temperatura. 


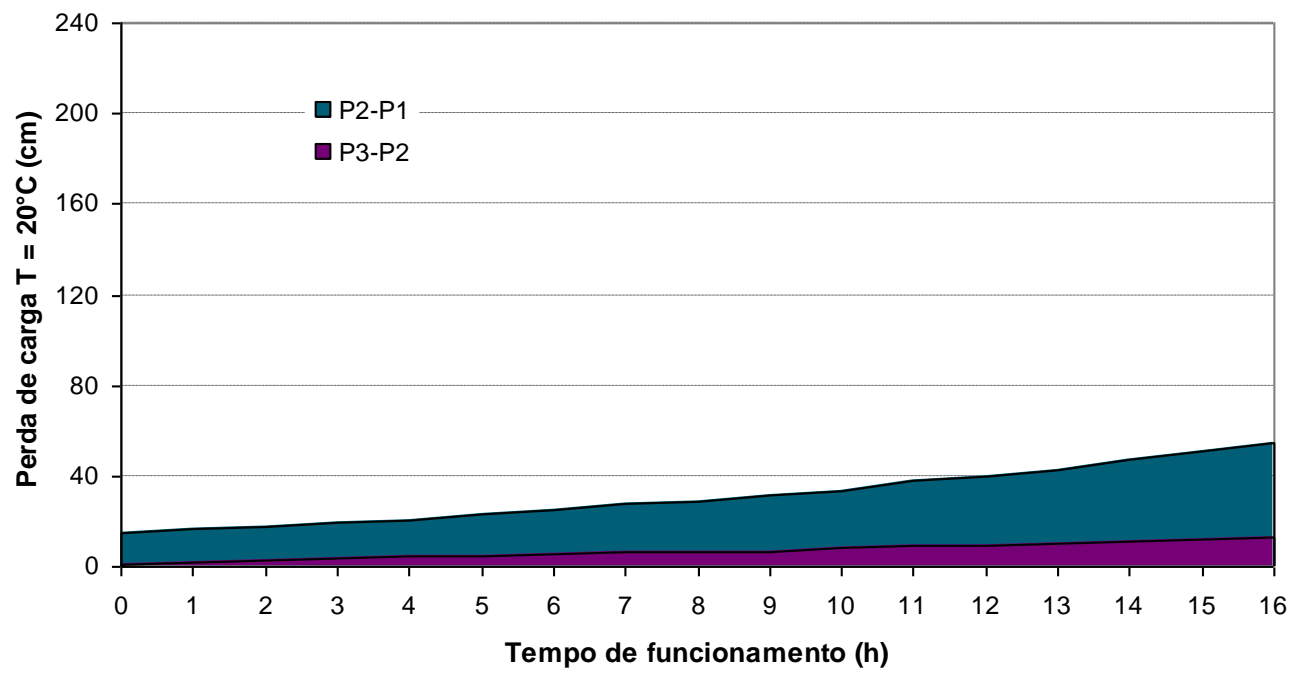

Figura C 8.1 - Perda de carga na camada suporte e camada de areia grossa no FAAG durante 0 ensaio 15 - pré-oxidação com hipoclorito de sódio ( $F A A G=180 \mathrm{~m}^{3} / \mathrm{m}^{2} \mathrm{~d}$ e $\mathrm{FRD}=280 \mathrm{~m}^{3} / \mathrm{m}^{2} \mathrm{~d}$ ). Fonte: Tabela C 8.3 - ANEXO C.

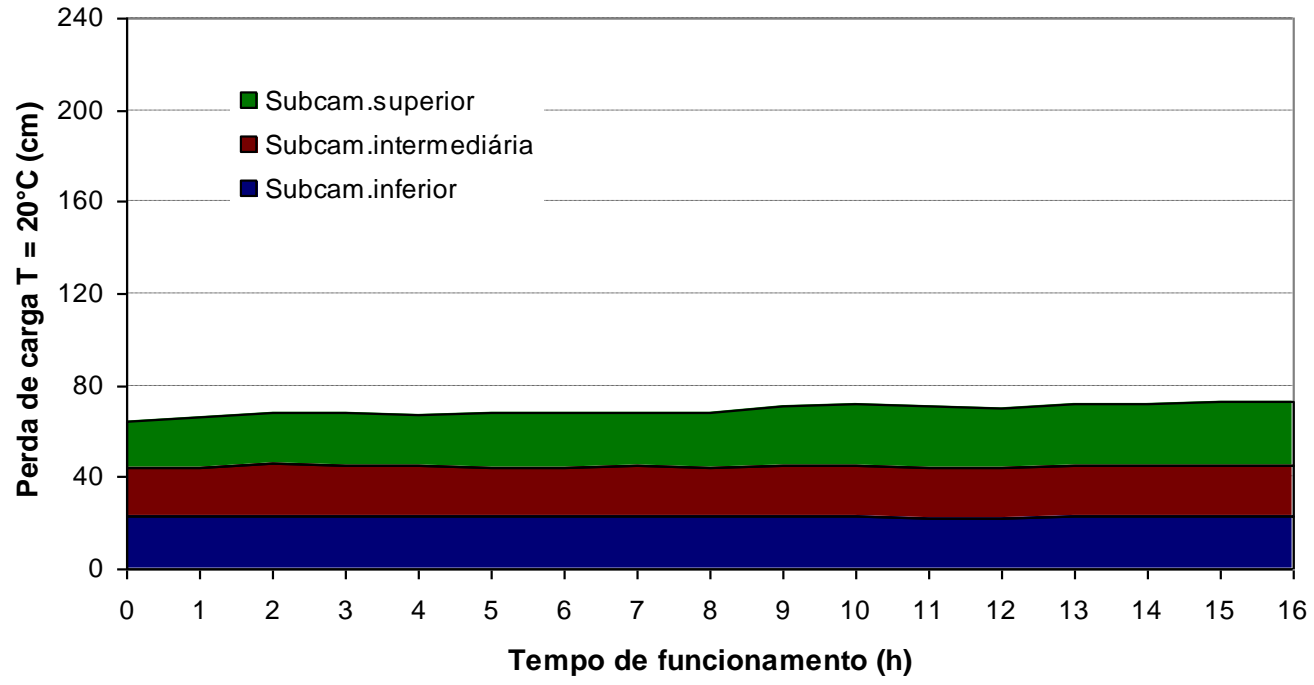

Figura C 8.2 - Perda de carga ao longo do meio filtrante do FRD durante o ensaio 15 - pré-oxidação com hipoclorito de sódio ( $F A A G=180 \mathrm{~m}^{3} / \mathrm{m}^{2} \mathrm{~d}$ e FRD $=280 \mathrm{~m}^{3} / \mathrm{m}^{2} \mathrm{~d}$ ). Fonte: Tabela C $8.3-$ ANEXO C. 


\section{ANEXO D}

Resultados da Formação de Subprodutos da Pré-oxidação e Pós-cloração - Fase 2 
Tabela D 1.1 - Resumo dos resultados da formação de subprodutos das amostras de APO utilizando diferentes oxidantes e pós-cloração com dosagem de 4 a $6 \mathrm{mg} / \mathrm{L}$ e tempo de contato de $24 \mathrm{~h}$, e das amostras do efluente do FRD com variação do pH - ENSAIOS 8 e 9.

\begin{tabular}{|c|c|c|c|c|c|c|c|}
\hline \multirow{3}{*}{$\begin{array}{l}\text { Condições de pré-oxidação } \\
\text { Trialometanos ( } \mu \mathrm{g} / \mathrm{L})\end{array}$} & \multicolumn{3}{|c|}{ ENSAIO 8 - sem pré-oxidação } & \multicolumn{4}{|c|}{ ENSAIO 9 - pré-oxidação com $\mathrm{O}_{3}$} \\
\hline & \multicolumn{3}{|c|}{-} & \multicolumn{4}{|c|}{ Dosagem aplicada de $\mathrm{O}_{3} \cong 6 \mathrm{mg} / \mathrm{L}$} \\
\hline & $\begin{array}{c}\text { Efluente FRD } \\
(\mathrm{pH}=5,0)\end{array}$ & $\begin{array}{c}\text { Efluente FRD } \\
(\mathrm{pH}=7,1)\end{array}$ & $\begin{array}{c}\text { Efluente FRD } \\
(\mathrm{pH}=9,0)\end{array}$ & $\begin{array}{c}\text { APO } \\
(\mathrm{pH}=6,0) \\
\end{array}$ & $\begin{array}{c}\text { Efluente FRD } \\
(\mathrm{pH}=5,2)\end{array}$ & $\begin{array}{c}\text { Efluente FRD } \\
(\mathrm{pH}=7,0)\end{array}$ & $\begin{array}{c}\text { Efluente FRD } \\
(\mathrm{pH}=9,0) \\
\end{array}$ \\
\hline Clorofórmio & NR & NR & NR & 4,33 & NR & NR & NR \\
\hline Bromodiclorometano & NR & NR & NR & 1,45 & NR & NR & NR \\
\hline Dibromoclorometano & NR & NR & NR & ND & NR & NR & NR \\
\hline Bromofórmio & NR & NR & NR & ND & NR & NR & NR \\
\hline $\begin{array}{l}\text { Haloacetonitrilas, Halocetonas e } \\
\text { Halopicrinas }(\mu \mathrm{g} / \mathrm{L})\end{array}$ & $\begin{array}{l}\text { Efluente FRD } \\
(\mathrm{pH}=5,0)\end{array}$ & $\begin{array}{c}\text { Efluente FRD } \\
(\mathrm{pH}=7,1)\end{array}$ & $\begin{array}{l}\text { Efluente FRD } \\
(\mathrm{pH}=9,0)\end{array}$ & $\begin{array}{c}\text { APO } \\
(\mathrm{pH}=6,0)\end{array}$ & $\begin{array}{l}\text { Efluente FRD } \\
(\mathrm{pH}=5,2)\end{array}$ & $\begin{array}{l}\text { Efluente FRD } \\
(\mathrm{pH}=7,0)\end{array}$ & $\begin{array}{l}\text { Efluente FRD } \\
(\mathrm{pH}=9,0)\end{array}$ \\
\hline Tricloroacetonitrila & NR & NR & NR & ND & NR & NR & NR \\
\hline Dicloroacetonitrila & NR & NR & NR & 1,86 & NR & NR & NR \\
\hline 1,1-dicloropropanona & NR & NR & NR & 3,14 & NR & NR & NR \\
\hline Cloropicrina & NR & NR & NR & $<1,00$ & NR & NR & NR \\
\hline 1,1,1-tricloropropanona & NR & NR & NR & 1,69 & NR & NR & NR \\
\hline bromocloroacetonitrila & NR & NR & NR & 4,36 & NR & NR & NR \\
\hline Dibromoacetonitrila & NR & NR & NR & ND & NR & NR & NR \\
\hline Ácidos Haloacéticos ( $\mu \mathrm{g} / \mathrm{L})$ & $\begin{array}{l}\text { Efluente FRD } \\
(\mathrm{pH}=5,0)\end{array}$ & $\begin{array}{c}\text { Efluente FRD } \\
(\mathrm{pH}=7,1)\end{array}$ & $\begin{array}{c}\text { Efluente FRD } \\
(\mathrm{pH}=9,0)\end{array}$ & $\begin{array}{c}\text { APO } \\
(\mathrm{pH}=6,0)\end{array}$ & $\begin{array}{c}\text { Efluente FRD } \\
(\mathrm{pH}=5,2)\end{array}$ & $\begin{array}{c}\text { Efluente FRD } \\
(\mathrm{pH}=7,0)\end{array}$ & $\begin{array}{l}\text { Efluente FRD } \\
(\mathrm{pH}=9,0)\end{array}$ \\
\hline Ácido cloroacético & NR & NR & NR & 223,47 & NR & NR & NR \\
\hline Ácido bromoacético & NR & NR & NR & ND & NR & NR & NR \\
\hline Ácido dicloroacético & NR & NR & NR & 207,78 & NR & NR & NR \\
\hline Dalapon & NR & NR & NR & ND & NR & NR & NR \\
\hline Ácido tricloroacético & NR & NR & NR & 13,89 & NR & NR & NR \\
\hline Ácido bromocloroacético & NR & NR & NR & ND & NR & NR & NR \\
\hline Ácido bromodicloroacético & NR & NR & NR & ND & NR & NR & NR \\
\hline Ácido dibromoacético & NR & NR & NR & ND & NR & NR & NR \\
\hline Ácido clorodibromoacético & NR & NR & NR & ND & NR & NR & NR \\
\hline Ácido tribromoacético & NR & NR & NR & ND & NR & NR & NR \\
\hline
\end{tabular}

ND = não detectado; $\mathrm{NR}$ = não realizado. 
Tabela D 1.2 - Resumo dos resultados da formação de subprodutos das amostras de APO utilizando diferentes oxidantes e pós-cloração com dosagem de 4 a 6 mg/L e tempo de contato de $24 \mathrm{~h}$, e das amostras do efluente do FRD com variação do $\mathrm{pH}-$ ENSAIOS 10 e 11.

\begin{tabular}{|c|c|c|c|c|c|c|c|c|}
\hline & \multicolumn{4}{|c|}{ ENSAIO 10 - pré-oxidação com $\mathrm{H}_{2} \mathrm{O}_{2}$} & \multicolumn{4}{|c|}{ ENSAIO 11 - pré-oxidação com $\mathrm{Cl}_{2}$ (tricloro-s-triazina-triona) } \\
\hline Condições de pré-oxidação & \multicolumn{4}{|c|}{ Dosagem aplicada de $\mathrm{H}_{2} \mathrm{O}_{2} \cong 35 \mathrm{mg} / \mathrm{L}$} & \multicolumn{4}{|c|}{ Dosagem aplicada de cloro $\cong 4 \mathrm{mg} / \mathrm{L}$} \\
\hline Trialometanos $(\mu \mathrm{g} / \mathrm{L})$ & $\begin{array}{c}\mathrm{APO} \\
(\mathrm{pH}=6,0)\end{array}$ & $\begin{array}{c}\text { Efluente FRD } \\
(\mathrm{pH}=5,2)\end{array}$ & $\begin{array}{c}\text { Efluente FRD } \\
(\mathrm{pH}=7,6)\end{array}$ & $\begin{array}{c}\text { Efluente FRD } \\
(\mathrm{pH}=9,3) \\
\end{array}$ & $\begin{array}{c}\text { APO } \\
(\mathrm{pH}=5,7) \\
\end{array}$ & $\begin{array}{c}\text { Efluente FRD } \\
(\mathrm{pH}=4,9)\end{array}$ & $\begin{array}{c}\text { Efluente FRD } \\
(\mathrm{pH}=8,4) \\
\end{array}$ & $\begin{array}{c}\text { Efluente FRD } \\
(\mathrm{pH}=11,2)\end{array}$ \\
\hline Clorofórmio & 3,94 & NR & NR & NR & 14,92 & ND & 17,33 & 26,58 \\
\hline Bromodiclorometano & 7,01 & NR & NR & NR & 5,92 & ND & 2,35 & 3,44 \\
\hline Dibromoclorometano & ND & NR & NR & NR & ND & ND & ND & ND \\
\hline Bromofórmio & ND & NR & NR & NR & ND & ND & ND & ND \\
\hline $\begin{array}{l}\text { Haloacetonitrilas, Halocetonas } \\
\text { e Halopicrinas }(\mu \mathrm{g} / \mathrm{L})\end{array}$ & $\begin{array}{c}\mathrm{APO} \\
(\mathrm{pH}=6,0)\end{array}$ & $\begin{array}{c}\text { Efluente FRD } \\
(\mathrm{pH}=5,2)\end{array}$ & $\begin{array}{l}\text { Efluente FRD } \\
(\mathrm{pH}=7,6)\end{array}$ & $\begin{array}{c}\text { Efluente FRD } \\
(\mathrm{pH}=9,3)\end{array}$ & $\begin{array}{c}\text { APO } \\
(\mathrm{pH}=5,7)\end{array}$ & $\begin{array}{c}\text { Efluente FRD } \\
(\mathrm{pH}=4,9)\end{array}$ & $\begin{array}{l}\text { Efluente FRD } \\
(\mathrm{pH}=8,4)\end{array}$ & $\begin{array}{l}\text { Efluente FRD } \\
(\mathrm{pH}=11,2)\end{array}$ \\
\hline Tricloroacetonitrila & ND & NR & NR & NR & ND & ND & ND & ND \\
\hline Dicloroacetonitrila & 2,76 & NR & NR & NR & 6,39 & ND & ND & ND \\
\hline 1,1-dicloropropanona & 2,76 & NR & NR & NR & $<1,00$ & ND & ND & ND \\
\hline Cloropicrina & ND & NR & NR & NR & ND & ND & ND & ND \\
\hline 1,1,1-tricloropropanona & ND & NR & NR & NR & ND & ND & ND & ND \\
\hline bromocloroacetonitrila & 2,87 & NR & NR & NR & 6,72 & ND & ND & ND \\
\hline Dibromoacetonitrila & ND & NR & NR & NR & ND & ND & ND & ND \\
\hline Ácidos Haloacéticos ( $\mu \mathrm{g} / \mathrm{L})$ & $\begin{array}{c}\mathrm{APO} \\
(\mathrm{pH}=6,0)\end{array}$ & $\begin{array}{c}\text { Efluente FRD } \\
(\mathrm{pH}=5,2)\end{array}$ & $\begin{array}{c}\text { Efluente FRD } \\
(\mathrm{pH}=7,6)\end{array}$ & $\begin{array}{c}\text { Efluente FRD } \\
(\mathrm{pH}=9,3)\end{array}$ & $\begin{array}{c}\mathrm{APO} \\
(\mathrm{pH}=5,7)\end{array}$ & $\begin{array}{c}\text { Efluente FRD } \\
(\mathrm{pH}=4,9)\end{array}$ & $\begin{array}{c}\text { Efluente FRD } \\
(\mathrm{pH}=8,4)\end{array}$ & $\begin{array}{c}\text { Efluente FRD } \\
(\mathrm{pH}=11,2)\end{array}$ \\
\hline Ácido cloroacético & 120,82 & NR & NR & NR & NR & NR & NR & NR \\
\hline Ácido bromoacético & ND & NR & NR & NR & NR & NR & NR & NR \\
\hline Ácido dicloroacético & 73,25 & NR & NR & NR & NR & NR & NR & NR \\
\hline Dalapon & ND & NR & NR & NR & NR & NR & NR & NR \\
\hline Ácido tricloroacético & 10,14 & NR & NR & NR & NR & NR & NR & NR \\
\hline Ácido bromocloroacético & ND & NR & NR & NR & NR & NR & NR & NR \\
\hline Ácido bromodicloroacético & ND & NR & NR & NR & NR & NR & NR & NR \\
\hline Ácido dibromoacético & ND & NR & NR & NR & NR & NR & NR & NR \\
\hline Ácido clorodibromoacético & ND & NR & NR & NR & NR & NR & NR & NR \\
\hline Ácido tribromoacético & ND & NR & NR & NR & NR & NR & NR & NR \\
\hline
\end{tabular}

ND = não detectado; NR = não realizado. 
Tabela D 1.3 - Resumo dos resultados da formação de subprodutos das amostras de APO utilizando diferentes oxidantes e pós-cloração com dosagem de 4 a 6 mg/L e tempo de contato de $24 \mathrm{~h}$, e das amostras do efluente do FRD com variação do $\mathrm{pH}-$ ENSAIOS 12 e 13.

\begin{tabular}{|c|c|c|c|c|c|c|c|c|}
\hline & \multicolumn{4}{|c|}{ ENSAIO 12 - pré-oxidação com $\mathrm{ClO}_{2}$} & \multicolumn{4}{|c|}{ ENSAIO 13 - pré-oxidação com $\mathrm{KMnO}_{4}$} \\
\hline Condições de pré-oxidação & \multicolumn{4}{|c|}{ Dosagem aplicada de $\mathrm{ClO}_{2} \cong 0,4 \mathrm{mg} / \mathrm{L}$} & \multicolumn{4}{|c|}{ Dosagem aplicada de $\mathrm{KMnO}_{4} \cong 1 \mathrm{mg} / \mathrm{L}$} \\
\hline Trialometanos $(\mu \mathrm{g} / \mathrm{L})$ & $\begin{array}{c}\text { APO } \\
(\mathrm{pH}=6,3)\end{array}$ & $\begin{array}{c}\text { Efluente FRD } \\
(\mathrm{pH}=5,1)\end{array}$ & $\begin{array}{l}\text { Efluente FRD } \\
(\mathrm{pH}=8,1)\end{array}$ & $\begin{array}{l}\text { Efluente FRD } \\
(\mathrm{pH}=10,5)\end{array}$ & $\begin{array}{c}\text { APO } \\
(\mathrm{pH}=6,4)\end{array}$ & $\begin{array}{c}\text { Efluente FRD } \\
(\mathrm{pH}=5,2)\end{array}$ & $\begin{array}{l}\text { Efluente FRD } \\
\quad(\mathrm{pH}=8,6)\end{array}$ & $\begin{array}{c}\text { Efluente FRD } \\
(\mathrm{pH}=10,3)\end{array}$ \\
\hline Clorofórmio & 5,27 & 3,22 & 3,65 & 12,60 & 4,66 & 3,00 & 1,54 & 1,62 \\
\hline Bromodiclorometano & 1,88 & 1,48 & 1,92 & 2,67 & 1,47 & 1,64 & 4,83 & 1,24 \\
\hline Dibromoclorometano & ND & $<1,00$ & ND & ND & $<1,00$ & ND & ND & ND \\
\hline Bromofórmio & ND & ND & ND & ND & ND & ND & ND & ND \\
\hline $\begin{array}{l}\text { Haloacetonitrilas,Halocetonas } \\
\text { e Halopicrinas }(\mu \mathrm{g} / \mathrm{L})\end{array}$ & $\begin{array}{c}\text { APO } \\
(\mathrm{pH}=6,3)\end{array}$ & $\begin{array}{c}\text { Efluente FRD } \\
(\mathrm{pH}=5,1)\end{array}$ & $\begin{array}{c}\text { Efluente FRD } \\
(\mathrm{pH}=\mathbf{8 , 1})\end{array}$ & $\begin{array}{c}\text { Efluente FRD } \\
(\mathrm{pH}=10,5)\end{array}$ & $\begin{array}{c}\text { APO } \\
(\mathrm{pH}=6,4)\end{array}$ & $\begin{array}{c}\text { Efluente FRD } \\
(\mathrm{pH}=5,2)\end{array}$ & $\begin{array}{l}\text { Efluente FRD } \\
(\mathrm{pH}=8,6)\end{array}$ & $\begin{array}{c}\text { Efluente FRD } \\
(\mathrm{pH}=10,3)\end{array}$ \\
\hline Tricloroacetonitrila & ND & ND & ND & $<1,00$ & ND & ND & ND & ND \\
\hline Dicloroacetonitrila & 1,58 & $<1,00$ & ND & ND & $<1,00$ & $<1,00$ & $<1,00$ & $<1,00$ \\
\hline 1,1-dicloropropanona & $<1,00$ & $<1,00$ & ND & ND & $<1,00$ & $<1,00$ & ND & $<1,00$ \\
\hline Cloropicrina & ND & ND & ND & $<1,00$ & ND & ND & ND & ND \\
\hline 1,1,1-tricloropropanona & ND & ND & ND & ND & ND & ND & 1,33 & 1,17 \\
\hline bromocloroacetonitrila & 1,42 & $<1,00$ & ND & ND & $<1,00$ & $<1,00$ & $<1,00$ & $<1,00$ \\
\hline Dibromoacetonitrila & ND & ND & ND & ND & ND & ND & ND & ND \\
\hline $\begin{array}{ll}\text { Ácidos } & \text { Haloacéticos } \\
(\mu \mathrm{g} / \mathrm{L}) & \\
\end{array}$ & $\begin{array}{c}\text { APO } \\
(\mathrm{pH}=6,3) \\
\end{array}$ & $\begin{array}{c}\text { Efluente FRD } \\
(\mathrm{pH}=5,1)\end{array}$ & $\begin{array}{c}\text { Efluente FRD } \\
(\mathrm{pH}=8,1)\end{array}$ & $\begin{array}{c}\text { Efluente FRD } \\
(\mathrm{pH}=10,5)\end{array}$ & $\begin{array}{c}\text { APO } \\
(\mathrm{pH}=6,4)\end{array}$ & $\begin{array}{c}\text { Efluente FRD } \\
(\mathrm{pH}=5,2)\end{array}$ & $\begin{array}{c}\text { Efluente FRD } \\
(\mathrm{pH}=8,6)\end{array}$ & $\begin{array}{c}\text { Efluente FRD } \\
(\mathrm{pH}=10,3)\end{array}$ \\
\hline Ácido cloroacético & 52,37 & ND & ND & ND & 50,59 & 18,50 & 24,27 & 30,20 \\
\hline Ácido bromoacético & ND & ND & ND & ND & ND & ND & ND & ND \\
\hline Ácido dicloroacético & 44,56 & 6,14 & 6,76 & 13,45 & 25,06 & 4,62 & 5,41 & 5,94 \\
\hline Dalapon & ND & ND & ND & ND & ND & ND & ND & ND \\
\hline Ácido tricloroacético & 15,74 & 1,50 & $<1,00$ & $<1,00$ & 6,41 & $<1,00$ & $<1,00$ & 1,04 \\
\hline Ácido bromocloroacético & ND & ND & ND & ND & ND & ND & ND & ND \\
\hline Ácido bromodicloroacético & ND & ND & ND & 3,18 & ND & ND & ND & ND \\
\hline Ácido dibromoacético & ND & ND & ND & 1,09 & ND & ND & $<1,00$ & ND \\
\hline Ácido clorodibromoacético & ND & ND & ND & ND & ND & ND & ND & ND \\
\hline Ácido tribromoacético & ND & ND & ND & ND & ND & ND & 13,46 & ND \\
\hline
\end{tabular}

ND = não detectado. 
Tabela D 1.4 - Resumo dos resultados da formação de subprodutos das amostras de APO utilizando diferentes oxidantes e pós-cloração com dosagem de 4 a 6 mg/L e tempo de contato de $24 \mathrm{~h}$, e das amostras do efluente do FRD com variação do pH - ENSAIOS 14 e 15.

\begin{tabular}{|c|c|c|c|c|c|c|c|c|}
\hline & \multicolumn{4}{|c|}{ ENSAIO 14 - pré-oxidação com Peroxônio } & \multicolumn{4}{|c|}{ ENSAIO 15 - pré-oxidação com $\mathrm{Cl}_{2}$ ( $\mathrm{NaClO}$ ) } \\
\hline Condições de pré-oxidação & \multicolumn{4}{|c|}{$\begin{array}{c}\text { Dosagem aplicada de } \mathrm{H}_{2} \mathrm{O}_{2} \cong 1,3 \mathrm{mg} / \mathrm{L} \mathrm{e} \\
\mathrm{O}_{3} \cong 2,6 \mathrm{mg} / \mathrm{L}\left(\mathrm{H}_{2} \mathrm{O}_{2}: \mathrm{O}_{3}=0,5\right) \\
\end{array}$} & \multicolumn{4}{|c|}{ Dosagem aplicada de $\mathrm{NaClO} \cong 2,0 \mathrm{mg} / \mathrm{L}$} \\
\hline Trialometanos $(\mu \mathrm{g} / \mathrm{L})$ & $\begin{array}{c}\mathrm{APO} \\
(\mathrm{pH}=6,5)\end{array}$ & $\begin{array}{l}\text { Efluente FRD } \\
(\mathrm{pH}=5,2)\end{array}$ & $\begin{array}{l}\text { Efluente FRD } \\
(\mathrm{pH}=7,9)\end{array}$ & $\begin{array}{l}\text { Efluente FRD } \\
(\mathrm{pH}=10,5)\end{array}$ & $\begin{array}{c}\mathrm{APO} \\
(\mathrm{pH}=6,2)\end{array}$ & $\begin{array}{l}\text { Efluente FRD } \\
(\mathrm{pH}=5,0)\end{array}$ & $\begin{array}{l}\text { Efluente FRD } \\
(\mathrm{pH}=8,5)\end{array}$ & $\begin{array}{c}\text { Efluente FRD } \\
(\mathrm{pH}=10,2)\end{array}$ \\
\hline Clorofórmio & 12,08 & 6,04 & 2,38 & 2,84 & 12,37 & 5,48 & 1,14 & 12,65 \\
\hline Bromodiclorometano & 6,78 & 4,97 & 2,23 & 2,65 & 5,74 & 2,91 & ND & 5,14 \\
\hline Dibromoclorometano & $<1,00$ & $<1,00$ & ND & ND & $<1,00$ & ND & ND & ND \\
\hline Bromofórmio & $<1,00$ & $<1,00$ & ND & ND & ND & ND & ND & ND \\
\hline $\begin{array}{l}\text { Haloacetonitrilas, Halocetonas } \\
\text { e Halopicrinas }(\mu \mathrm{g} / \mathrm{L})\end{array}$ & $\begin{array}{c}\mathrm{APO} \\
(\mathrm{pH}=6,5) \\
\end{array}$ & $\begin{array}{c}\text { Efluente FRD } \\
(\mathrm{pH}=5,2) \\
\end{array}$ & $\begin{array}{c}\text { Efluente FRD } \\
(\mathrm{pH}=7,9) \\
\end{array}$ & $\begin{array}{c}\text { Efluente FRD } \\
(\mathrm{pH}=10,5) \\
\end{array}$ & $\begin{array}{c}\mathrm{APO} \\
(\mathrm{pH}=6,2) \\
\end{array}$ & $\begin{array}{c}\text { Efluente FRD } \\
(\mathrm{pH}=5,0) \\
\end{array}$ & $\begin{array}{c}\text { Efluente FRD } \\
(\mathrm{pH}=8,5) \\
\end{array}$ & $\begin{array}{c}\text { Efluente FRD } \\
(\mathrm{pH}=10,2) \\
\end{array}$ \\
\hline Tricloroacetonitrila & 3,89 & $<1,00$ & $<1,00$ & ND & $<1,00$ & $<1,00$ & ND & $<1,00$ \\
\hline Dicloroacetonitrila & 4,80 & 1,46 & $<1,00$ & $<1,00$ & 8,29 & 1,31 & ND & 2,48 \\
\hline 1,1-dicloropropanona & 4,75 & 2,64 & 1,62 & 1,97 & $<1,00$ & $<1,00$ & ND & $<1,00$ \\
\hline Cloropicrina & $<1,00$ & $<1,00$ & ND & ND & $<1,00$ & $<1,00$ & ND & ND \\
\hline 1,1,1-tricloropropanona & 8,15 & 1,25 & ND & 4,55 & ND & ND & ND & ND \\
\hline bromocloroacetonitrila & 8,17 & 4,86 & 2,02 & 2,41 & 39,01 & 1,26 & ND & 2,19 \\
\hline Dibromoacetonitrila & ND & ND & ND & ND & ND & ND & ND & ND \\
\hline Ácidos Haloacéticos ( $\mu \mathrm{g} / \mathrm{L})$ & $\begin{array}{c}\mathrm{APO} \\
(\mathrm{pH}=6,5) \\
\end{array}$ & $\begin{array}{c}\text { Efluente FRD } \\
(\mathrm{pH}=5,2) \\
\end{array}$ & $\begin{array}{c}\text { Efluente FRD } \\
(\mathrm{pH}=7,9) \\
\end{array}$ & $\begin{array}{c}\text { Efluente FRD } \\
(\mathrm{pH}=10,5) \\
\end{array}$ & $\begin{array}{c}\mathrm{APO} \\
(\mathrm{pH}=6,2) \\
\end{array}$ & $\begin{array}{c}\text { Efluente FRD } \\
(\mathrm{pH}=5,0) \\
\end{array}$ & $\begin{array}{c}\text { Efluente FRD } \\
(\mathrm{pH}=8,5) \\
\end{array}$ & $\begin{array}{c}\text { Efluente FRD } \\
(\mathrm{pH}=10,2) \\
\end{array}$ \\
\hline Ácido cloroacético & 65,51 & 11,38 & 11,68 & 9,27 & 87,74 & 15,81 & 23,99 & 47,45 \\
\hline Ácido bromoacético & 6,93 & 1,72 & 2,42 & 1,29 & ND & ND & ND & ND \\
\hline Ácido dicloroacético & 58,86 & 22,26 & 19,02 & 8,47 & 18,46 & 7,60 & 10,54 & 22,85 \\
\hline Dalapon & ND & ND & ND & $<1,00$ & ND & ND & $<1,00$ & ND \\
\hline Ácido tricloroacético & 18,05 & 1,21 & 1,01 & 1,75 & 26,43 & 5,12 & 6,31 & 9,91 \\
\hline Ácido bromocloroacético & $<1,00$ & ND & ND & $<1,00$ & $<1,00$ & $<1,00$ & $<1,00$ & $<1,00$ \\
\hline Ácido bromodicloroacético & $<1,00$ & ND & ND & $<1,00$ & $<1,00$ & $<1,00$ & $<1,00$ & ND \\
\hline Ácido dibromoacético & ND & ND & ND & ND & ND & ND & ND & ND \\
\hline Ácido clorodibromoacético & 6,77 & 1,40 & 1,45 & $<1,00$ & $<1,00$ & $<1,00$ & ND & ND \\
\hline Ácido tribromoacético & ND & ND & 5,35 & 10,30 & 8,46 & 4,92 & 7,58 & 11,78 \\
\hline
\end{tabular}

ND = não detectado. 


\section{REFERÊNCIAS BIBLIOGRÁFICAS}

APHA, AWWA, WPCF (1998). Standard Methods for the Examination of Water and

Wastewater. $19^{\text {th }}$ edition, Washington, USA.

AMERICAN WATER WORKS ASSOCIATION (1990). Water Quality and Treatment:

A Handbook of Community Water Supplies. $4^{\text {th }}$ edition, McGraw-Hill, USA, 1194

p.

AMIRTHARAJAH, A. \& MILLS, K. M. (1982). Rapid-mix Design for Mechanisms of Alum Coagulation. Journal American Water Works Association, Vol. 74, $n^{\circ} 4$, p. $210-216$.

BECKER, W. C.; AU, K-K; CHEVALLIER, M. W.; O'MELIA, C. R.; YOUNG, J. S. (2001). The Effects of Oxidation on the Performance of Granular Media Filters: The Role of Natural Organic Matter. In Advances in Rapid Granular Filtration in Water Treatment. International Conference, London, p. 47 - 57.

BENINI, B. D. S. (2003). Remoção de Substâncias Húmicas na Dupla Filtração com

Filtro Ascendente de Pedregulho. São Carlos. 147 p. Dissertação (Mestrado) -

Escola de Engenharia de São Carlos, Universidade de São Paulo.

BOLTO, B.; ABBT-BRAUN; G.; DIXON, D.; ELDRIDGE, R.; FRIMMEL, F.; HESSE,

S.; KING, S.; TOIFL, M. (1999). Experimental Evaluation of Cationic

Polyelectrolytes for Removing Natural Organic Matter from Water. Water Science

\& Technology: Removal of Humic Substances from Water. Vol 40, n. 9. International Association on Water Quality, p. 71-79.

BRASIL, Leis etc. (2004). Ministério da Saúde. Portaria $n^{\circ} 518$ de abril de 2004:

Aprova o Controle e Vigilância da Qualidade da Água para o Consumo Humano e seu Padrão de Potabilidade, Brasília.

CAMPOS, S. X. (2004). Influência das Substâncias Húmicas de Diferentes Massas Molares na Coagulação, Floculação e Sedimentação no Tratamento de Água. São Carlos. Tese (Doutorado) - Instituto de Química de São Carlos, Universidade de São Paulo.

CANELLAS, L. P.; GURIDI, F.; SANTOS, G. A.; RUMJANEK, V. M.; BRAZ-FILHO, R. (2001). Aumento da Resolução de Espectros de RMN ${ }^{13} \mathrm{C}$ de Ácidos Húmicos 
em Solução através do Tratamento Prévio com KCl 0,03 mol L-1. Química Nova, vol. 24, n. 1, p. 131-132.

CASTILLA MIRANDA, S. J. (1997). Influência da Mistura dos Grãos de Areia no Desempenho da Filtração Direta Ascendente. São Carlos. 154 p. Dissertação (Mestrado) - Escola de Engenharia de São Carlos, Universidade de São Paulo.

COELHO, E. R. C. (2002). Influência da Pré-oxidação com Ozônio e Peróxido de Hidrogênio na Remoção de Atrazina em Filtros Lentos de Areia e Carvão Ativado Granular. São Carlos. 248 p. Tese (Doutorado) - Escola de Engenharia de São Carlos, Universidade de São Paulo.

CROZES, G.; WHITE, P. \& MARSHALL, M. (1995). Enhanced Coagulation: Its Effect on NOM Removal and Chemical Costs. Journal American Water Works Association, Vol. 87, $\mathrm{n}^{0} 1$, p. 78 - 89.

CRUZ VELLEZ, C. H. (1993). Filtração Direta Ascendente com Alta Taxa. São Carlos. 220 p. Dissertação (Mestrado) - Escola de Engenharia de São Carlos, Universidade de São Paulo.

DALSASSO, R. L. (1999). Pré-Ozonização de Águas Contendo Agrotóxico, Seguida de Filtração Direta. Florianópolis. 135p. Dissertação (Mestrado) - Universidade Federal de Santa Catarina.

DE PAULA, D. (2003). Avaliação da Dupla Filtração para Tratamento de Água Superficial Utilizando Filtração Ascendente em Areia Grossa. São Carlos. 110 p. Dissertação (Mestrado) - Escola de Engenharia de São Carlos, Universidade de São Paulo.

DI BERNARDO, A. S. (2004). Desempenho de Sistemas de Dupla Filtração no Tratamento de Água com Turbidez Elevada. São Carlos, 2004, 281 p. Tese (Doutorado) - Escola de Engenharia de São Carlos, Universidade de São Paulo.

DI BERNARDO, L. (1993). Métodos e Técnicas de Tratamento de Água. Rio de Janeiro, ABES. vol II, p. 216-280: Filtração direta ascendente.

DI BERNARDO, L. \& ISAAC, R. L. (2001). Direct Upflow Filtration - A Review. In: Advances in Rapid Granular Filtration in Water Treatment. International Conference, London, p. 251-268.

DI BERNARDO, L.; DI BERNARDO, A.; CENTURIONE FILHO, P. L. (2002). Ensaios de Tratabilidade de Água e dos Resíduos Gerados em Estações de Tratamento de Água. São Carlos, Editora RiMa, 237 p.

DI BERNARDO, L., coord. (2003). Tratamento de Água por Filtração Direta. Rio de Janeiro, ABES, Editora RiMa, 498 p, Projeto PROSAB. 
EIKEBROKK, B. (1999). Coagulation-Direct Filtration of Soft, Low Alkalinity Humic Waters. Water Science \& Technology: Removal of Humic Substances from Water, vol 40, n. 9. International Association on Water Quality, p. 55-62.

FERGUSON, D. W.; McGUIRE, M. J.; KOCH, B.; WOLFE, R. L.; AIETA, E. M. (1990). Comparing Peroxone and Ozone for Controlling Taste and Odor Compounds, Disinfection Byproducts and Microorganisms. Journal American Water Works Association, vol. 82, n.4. AWWA, p. 181.

FREEZE, S.D.; NOZAIC, D.; PRYOR, M.J.; TROLLIP, D.L.; SMITH, R.A. (1999). Comparison of Ozone and Hydrogen Peroxide/Ozone for the Treatment of Eutrophic Water. Water Science \& Technology, vol. 39, n. 10-11, p. 325-328.

GATES, D. J. (1998). The Chlorine Dioxide Handbook. Water Disinfection Series, AWWA, USA, $186 \mathrm{p}$.

GOEL, S.; HOZALSKI, R. M.; BOUWER, E. J. (1995). Biodegradation of NOM:

Effect of NOM Source and Ozone Dose. Journal American Water Works Association, vol. 87, n.1. AWWA, p. 90-105.

GREGOR, J. E.; NOKES, C.J.; FENTON, E. (1997). Optimising Natural Organic Matter Removal from Low Turbidity Waters by Controlled $\mathrm{pH}$ Adjustment of Aluminium Coagulation. Water Research, vol. 31, no 12, p. 2949-2958.

GUSMÃO, P. T. (2001). Utilização de Filtração Direta Ascendente como Pré-

Tratamento à Filtração Rápida Descendente para Tratamento de Água para Abastecimento. São Carlos. 335 p.Tese (Doutorado) - Escola de Engenharia de São Carlos, Universidade de São Paulo.

HESPANHOL, I. (1999). Água e Saneamento Básico In: REBOUÇAS, A. C; BRAGA, B.; TUNDISI, J. G. Uma Visão Realista em Águas Doces do Brasil Capital Ecológico. Uso e Conservação. São Paulo, Escrituras Editora, p. 249 304.

HOIGNÉ, J. \& BADER, H. (1976). Role of Hydroxyl Radical Reactions in Ozonation Processes in Aqueous Solutions. Water Resource, n. 10, p. 377.

INOUE, M. R. (2001). Caracterização Hidrodinâmica de Colunas de Ozonização Operando em Regime de Escoamento em Contra-Corrente. São Paulo. 150 p. Dissertação (Mestrado) - Escola Politécnica da Universidade de São Paulo.

ISAAC, R. L. (1997). Influência da Disposição dos Grãos de Areia na Eficiência da Filtração Direta Ascendente. São Carlos. 74 p. Tese (Doutorado) - Escola de Engenharia de São Carlos, Universidade de São Paulo. 
KURODA, E. K. (2002) Avaliação da Filtração Direta Ascendente em Pedregulho como Pré-Tratamento em Sistemas de Dupla Filtração. São Carlos, 217 p. Dissertação (Mestrado) - Escola de Engenharia de São Carlos, Universidade de São Paulo.

LANGLAIS, B.; RECKHOW, D. A.; BRINK, D. R. (1991). Ozone in Water Treatment: Application and Engineering. AWWA Research Foundation and Lewis Publishers, USA, $569 \mathrm{p}$.

LARA PINTO, D. M. C. (1994). Influência das Descargas de Fundo Intermediárias na Filtração Direta Ascendente de Alta Taxa. São Carlos. 194 p. Dissertação (Mestrado) - Escola de Engenharia de São Carlos, Universidade de São Paulo.

LU, X.; CHEN, Z.; YANG, X. (1999). Spectroscopic Study of Aluminium Speciation in Removing Humic Substances by Al Coagulation. Water Research, vol. 33, no 15 , p. $3271-3280$.

MASSCHELEN, W. (1977). Spectrophotometric Determination of Residual Hydrogen Peroxide. Water and Sewerage Works, p.69.

MEGDA, C. R. (1999). Filtração Direta Ascendente em Pedregulho como PréTratamento à Filtração Rápida Descendente. São Carlos. 167 p. Dissertação (Mestrado) - Escola de Engenharia de São Carlos, Universidade de São Paulo.

MENDES, C. G. N. (1985). Estudo das Influências das Dosagens de Produtos Químicos na Filtração Direta Ascendente. São Carlos. 117 p. Dissertação (Mestrado) - Escola de Engenharia de São Carlos, Universidade de São Paulo.

ODEGAARD, H.; EIKEBROKK, B.; STORHAUG, R. (1999). Processes for the Removal of Humic Substances from Water - an Overview Based on Norwegian Experiences. Water Science \& Technology: Removal of Humic Substances from Water, vol 40, n. 9. International Association on Water Quality, p. 37-46.

O'MELIA, C. R., BECKER, W. C., AU, K. -K. (1999). Removal of Humic Substances by Coagulation. Water Science \& Technology: Removal of Humic Substances from Water, vol 40, n. 9. International Association on Water Quality, p. 47-54.

OWEN, D. M.; AMY, G. L.; CHOWDHURY, Z. K.; PAODE, R.; McCOY, G.; VISCOSIL, K. (1995). NOM - Characterization and Treatability. Journal American Water Works Association, vol. 87, n.1. AWWA, p. 46-63.

PASCHOALATO, C. F. P. R.; FERREIRA, J. F.; TROFINO, J.; LATANZE, R.; OLIVEIRA JÚNIOR, M.; DI BERNARDO, L. Avaliação do Potencial de Formação de Subprodutos Orgânicos Halogenados com Uso de Cloro e Dióxido de Cloro Aplicado em Água Contendo Substâncias Húmicas. (CD ROM) XXIX Congreso 
Interamericano de Ingenieria Sanitaria y Ambiental. San Juan, Puerto Rico, agosto 2004.

PATERNIANI, J. E. S. (1986). Estudo da Influência de Descargas de Fundo na Eficiência da Remoção de Microrganismos em Sistemas de Filtração Direta Ascendente. São Carlos, 139 p. Dissertação (Mestrado) - Escola de Engenharia de São Carlos, Universidade de São Paulo.

RAUEN, T. G.; DEBACHER, N. A.; SIERRA, M. M. S.; SIERRA, E. J. S. (2002). Tensoatividade de Ácidos Húmicos de Procedências Distintas. Química Nova, vol. 25, n. 6, p. 909-913.

ROCHA, J. C. \& ROSA, A. H. (2003). Substâncias Húmicas Aquáticas: Interação com Espécies Metálicas. São Paulo, Editora UNESP, 120 p.

ROSA, A. H., ROCHA, J. C.; FURLAN, M. (2000). Substâncias Húmicas de Turfa:

Estudo dos Parâmetros que Influenciam no Processo de Extração Alcalina. Química Nova, vol. 23, n. 4., p. 472-476.

SALDANHA, J. R. (2002). Avaliação do Desempenho de uma Estação de Tratamento de Água com Sistema de Dupla Filtração, em Escala Real. São Carlos. 214 p. Dissertação (Mestrado) - Escola de Engenharia de São Carlos, Universidade de São Paulo.

SARGENTINI JÚNIOR, E.; ROCHA, J.C.; ROSA, A. H.; ZARA, L. F.; SANTOS, A. (2001). Substâncias Húmicas Aquáticas: Fracionamento Molecular e Caracterização de Rearranjos Internos após Complexação com ĺons Metálicos. Química Nova, vol. 24, n. 3, p. 339-344.

SINGER, P.C. (1999). Humic Substances as Precursors for Potentially Harmful Disinfection By-products. Water Science \& Technology: Removal of Humic Substances from Water, vol 40, n. 9. International Association on Water Quality, p. 25-30.

STEVENS, A. A.; MOORE, L. A.; MILTNER, R. J. (1989). Formation and Control of Non-Trihalomethane Disinfection By-products. Journal American Water Works Association, vol. 81, n.8. AWWA, p. 54-60.

TANGERINO, E. P. (2003). Remoção de Substâncias Húmicas por meio de Oxidação com Ozônio e Peróxido de Hidrogênio e Filtração Lenta. São Carlos. 265 p. Tese (Doutorado) - Escola de Engenharia de São Carlos, Universidade de São Paulo.

TEIXEIRA, B. A. N. (1986). Influência das Características da Camada Suporte e da Areia na Eficiência da Filtração Direta Ascendente. São Carlos. 194 p. 
Dissertação (Mestrado) - Escola de Engenharia de São Carlos, Universidade de São Paulo.

THURMAN, E. M. \& MALCOLM, R. L. (1981). Preparative Isolation of Aquatic Humic Substances. American Chemical Society, vol. 15, n. 4, p. 463 - 466.

UNITED STATES ENVIRONMENTAL PROTECTION AGENCY - USEPA. (1995). Method 551.1 - Determination of chlorination disinfection byproducts, chlorinated solvents, and halogenated pesticides/herbicides in drinking water by liquid-liquid extraction and gas chromatografhy with electron-capture detection. CD-ROM, USA.

UNITED STATES ENVIRONMENTAL PROTECTION AGENCY - USEPA (1995). Method 552.2 - Determination of haloacetic acids and dalapon in drinking water by liquid-liquid extraction, derivatization and gas chromatografhy with electroncapture detection. CD-ROM, USA.

UNITED STATES ENVIRONMENTAL PROTECTION AGENCY - USEPA (1999). Alternative Disinfectants and Oxidants Guidance Manual. USA.

WERDEHOFF, K. S. \& SINGER, P. C. (1987). Chlorine Dioxide Effects on THMFP, TOXFP and the Formation of Inorganic By-products. Journal American Water Works Association, vol. 79, n.9. AWWA, p. 107.

WIECHETECK, G. K. ; BENINI, B. D. S.; DI BERNARDO, L. (2004). Remoção de Substâncias Húmicas Utilizando Dupla Filtração com Filtro Ascendente de Areia Grossa ou de Pedregulho. Revista Engenharia Sanitária e Ambiental, p. 156 164, Vol. 9, $\mathrm{n}^{\circ} 2$. 